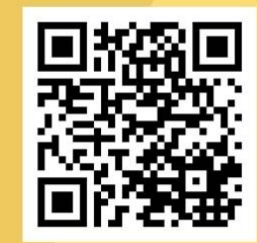

Tópicos em

\title{
Administração
}
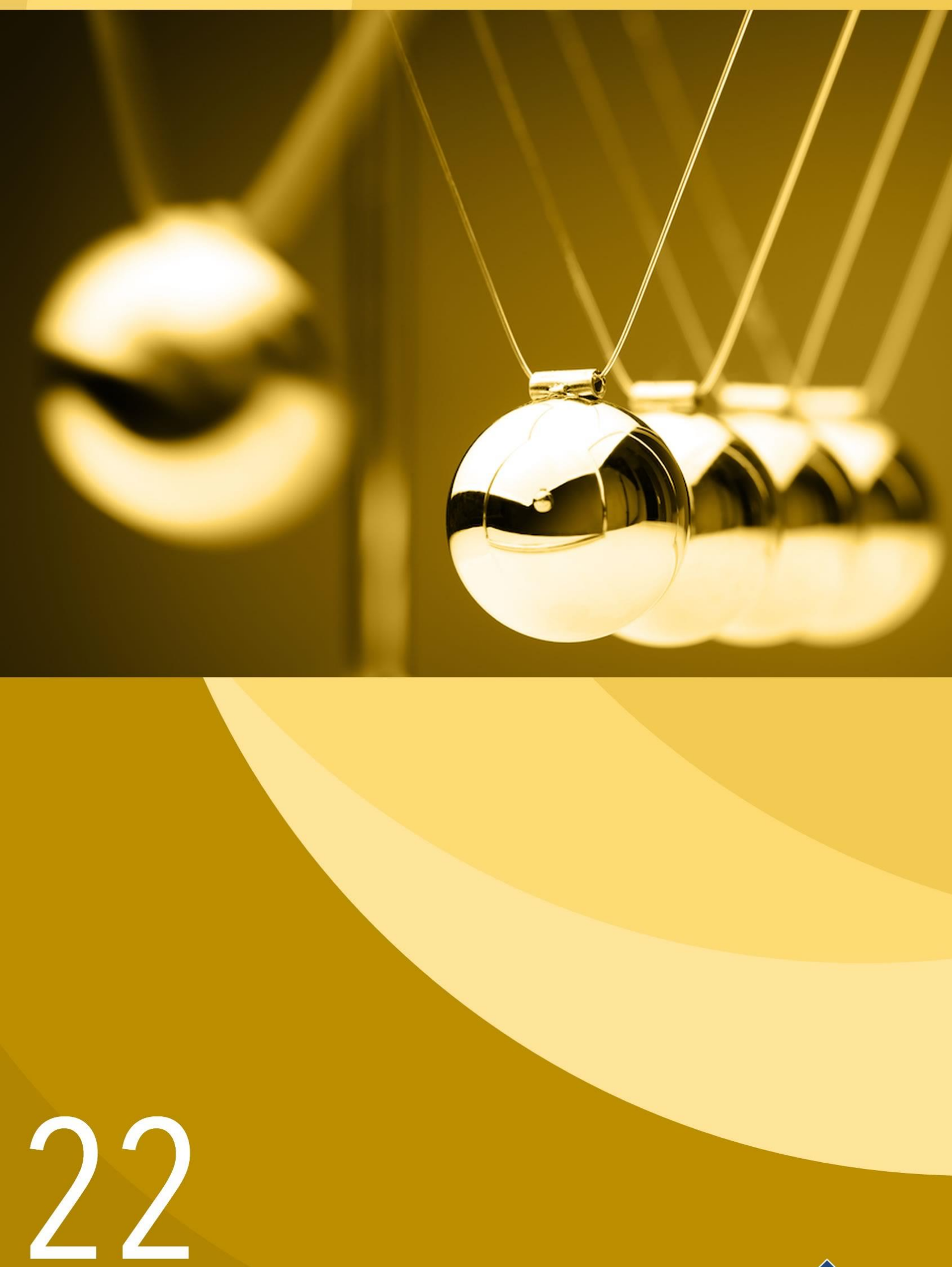

VOLUME 
Editora Poisson

\section{Tópicos em Administração Volume 22}

1a Edição

Belo Horizonte

Poisson

2019 
Editor Chefe: Dr. Darly Fernando Andrade

\section{Conselho Editorial}

Dr. Antônio Artur de Souza - Universidade Federal de Minas Gerais

Ms. Davilson Eduardo Andrade

Msc. Fabiane dos Santos Toledo

Dr. José Eduardo Ferreira Lopes - Universidade Federal de Uberlândia Dr. Otaviano Francisco Neves - Pontifícia Universidade Católica de Minas Gerais

Dr. Luiz Cláudio de Lima - Universidade FUMEC

Dr. Nelson Ferreira Filho - Faculdades Kennedy

Ms. Valdiney Alves de Oliveira - Universidade Federal de Uberlândia

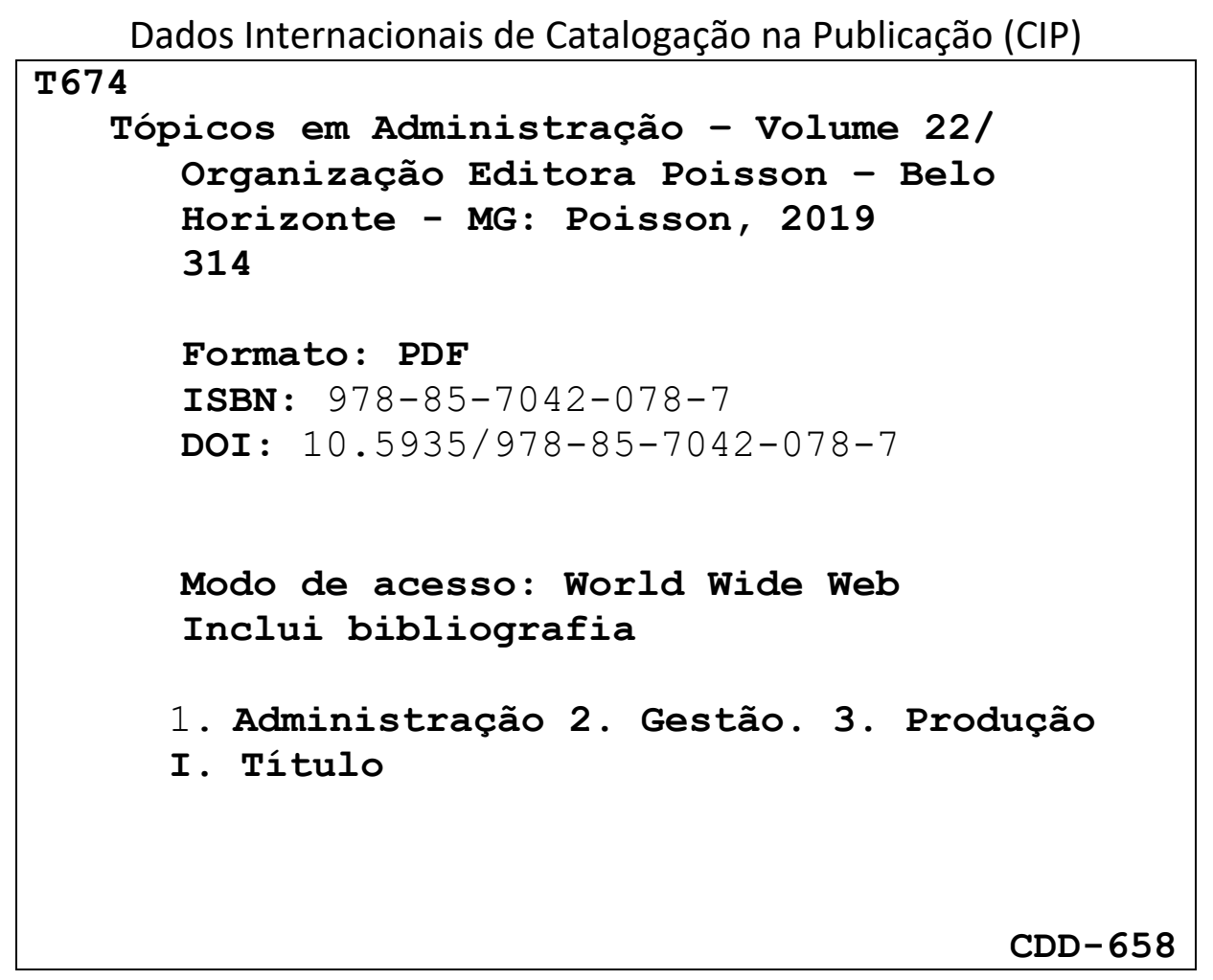

O conteúdo dos artigos e seus dados em sua forma, correção e confiabilidade são de responsabilidade exclusiva dos seus respectivos autores.

www.poisson.com.br

contato@poisson.com.br 


\section{SUMÁRIO}

Capítulo 1: VERIFICAÇÃO DA APLICABILIDADE DE UMA ESTRUTURA COMPUTACIONAL DE INTERVENÇÕES PROGRAMADAS PARA REALIZAÇÃO DE ATIVIDADES EDUCACIONAIS VIA SMARTPHONES 7

Joab Cavalcante da Silva, Laurentino Augusto Dantas, Giselle Giovanna do Couto de Oliveira

Capítulo 2: EXECUÇÃO DO PNAE: UM CONTEXTO DE PROBLEMAS RELATADOS PELA MIDIA BRASILEIRA. 16

Paulo César Schotten, Maria Valdilene dos Santos Schotten, Solange Fachin, Rodrigo Santolini Soares

Capítulo 3: EQUILÍBRIO DAS DIMENSÕES DE ACOMPANHAMENTO E DO CONTROLE DAS OPERAÇÕES: ESTUDO DE CASO EM UMA REDE DE ENSINO 25

Regina Ferreira da Rocha, José Paulo Alves Fusco, Otávio José de Oliveira

Capítulo 4: ANÁLISE DO DESEMPENHO ECONÔMICO-FINANCEIRO UMA COOPERATIVA DE PLANOS E ASSISTÊNCIA À SAÚDE DA CIDADE DE DOURADOS/MS. 37

Kely da Silva Rodrigues, Reginaldo José da Silva, Gisele Alves Soares Rocha

Capítulo 5: IMPLEMENTAÇÃO DE INDICADORES DE DESEMPENHO DA QUALIDADE EM UMA FABRICANTE DE EMBALAGENS PARA ALCANCE DAS METAS ORGANIZACIONAIS 46

Silvana Ribeiro Cobé

Capítulo 6: SANTOS MELHOR IDADE: SITE DE PROGRAMAÇÃO CULTURAL E RECREATIVA PARA IDOSOS. 62

Cauê Bongiovanni Sobral Sousa, Henry Hiraki, Rodrigo Ribeiro da Costa, Vanina Carrara Sigrist

Capítulo 7: CARACTERÍSTICAS E VALORES PREDOMINANTES DOS ALUNOS DE CIÊNCIAS CONTÁBEIS DA FACE/UFGD EM CONSONÂNCIA COM AS PRERROGATIVAS TEÓRICAS SOBRE GERAÇÕES 72

Cezar Eduardo Soares Cordeiro, Cristiane Mallmann Huppes

Capítulo 8: FATORES INTRÍNSECOS E EXTRÍNSECOS: UM ESTUDO DA MOTIVAÇ̃̃O E SATISFAÇÃO DOS COLABORADORES DE UMA INDÚSTRIA DE COMPENSADOS NO SUDESTE DO PARÁ. 86

Rosangela Sarmento Silva, Gellena Tayná Silva Souza, Mônica Ribeiro Gama, Kezia Souza Silva, Bárbara Ádria Oliveira Farias Fernandes 


\section{SUMÁRIO}

Capítulo 9: PLANO DE CARGO E SALÁRIOS: UM ESTUDO SOBRE A APLICAÇÃO EM UMA INDÚSTRIA DE MÁQUINAS ÓTICAS.. 100

Paulo César Schotten, Solange Fachin, Rodrigo Santolini Soares, Norah Patricia Panozo Rivero

Capítulo 10: PROJETO DE LEI 9.960/2018 UMA OPORTUNIDADE PARA O AUTISTA OU DESVIO DA MÃO DE OBRA? 113

Rose Kelly I. S. da Conceição Melicio, Oduvaldo Vendrametto

Capítulo 11: O MERCADO DE TRABALHO PARA FORMAÇÃO SUPERIOR: ANÁLISE DO PERFIL ACADÊMICO E SUA ADEQUAÇÃO AOS REQUISITOS PROFISSIONAIS. 123

Dayan Rios Pereira

Capítulo 12: ANÁLISE DE PROCESSO DE RECRUTAMENTO E SELEÇÃO, COM BASE NAS COMPETENCIAS REQUERIDAS PARA OS CARGOS.

Paulo Cesar Schotten, Rodrigo Santolini Soares, Solange Fachin

Capítulo 13: TENDÊNCIA EMPREENDEDORA: UMA ANÁLISE COMPARATIVA ENTRE OS ACADÊMICOS DOS CURSOS DE ADMINISTRAÇÃO E CIÊNCIAS CONTÁBEIS DO CAMPUS PANTANAL DA UNIVERSIDADE FEDERAL DE MATO GROSSO DO SUL 147

Rafaela Esmorges Assad, Roosiley dos Santos Souza, Valdir da Costa Pereira

Capítulo 14: O MICROEMPREENDEDOR INDIVIDUAL NO ESTADO DE MATO GROSSO DO SUL 161

Raíssa de Melo Morinigo, Roosiley dos Santos Souza, Eva Carina Martins Aldrigue

Capítulo 15: SUCESSÃO GERACIONAL FAMILIAR EM PROPRIEDADES RURAIS DE AGRICULTORES ASSOCIADOS EM COOPERATIVA DE CRÉDITO 174

Geneci da Silva Ribeiro Rocha, Maielen Lambrecht Kuchak, Patricio Duarte Rocha, Adriano Lago

Capítulo 16: PERCEPÇÃO DE IMPORTÂNCIA DA CONTABILIDADE DE CUSTOS NA PRODUÇÃO DE LEITE: UM ESTUDO COM PRODUTORES RURAIS DE ALFREDO CHAVESE.S. 192

Miguel Carlos Ramos Dumer, Mark Miranda De Mendonça, Wando Belffi da Costa, Alcinete Aparecida Basso Favero Da Silva, Ana Carolina Júlio, Ariana Marchezi de Souza 


\section{SUMÁRIO}

Capítulo 17: DEMANDA POR CONSULTORIA AGRÍCOLA DOS CAFEICULTORES DO CÓRREGO CACHOEIRÃO, NO MUNICÍPIO DE SIMONÉSIA - MG 202

Maxwell Pacelli de Souza Marcial, José Carlos de Souza, Rock Kleyber Silva Brandão, Rosane Aparecida Moreira, Marluci Moraes Pereira

Capítulo 18: AS FERRAMENTAS DE GESTÃO DA QUALIDADE NAS AGROINDÚSTRIAS DE ARROZ, NA REGIÃO DA CAMPANHA DO RS: UM ESTUDO MULTICASO. 215

Thaís Arrué Melo Gonçalves, Tatielle Belem Langbecker, Fernando Zocche, Janaína Wohlenberg

Capítulo 19: MANUTENÇÃO PREVENTIVA NO SETOR SUCROALCOOLEIRO - ESTUDO DE CASO EM UMA USINA NO VALE DO RIO IVINHEMA 227

Willer Rodrigues da Costa, Antonio Sérgio Eduardo, Thaís Nogueira da Silva

Capítulo 20: A EVOLUÇÃO DO COMPLEXO AGROINDUSTRIAL CITRÍCOLA PAULISTA NA DINÂMICA DOS CONTRATOS . 239

Murilo Secchieri de Carvalho, Luiz Fernando de Oriani e Paulillo, Paulo Henrique Palota, Elson Avallone, Paulo Cesar Mioralli

Capítulo 21: MENSURAÇÃO DA DESIGUALDADE DE RENDA E POBREZA NO ESTADO DO PARÁ E SUAS MESORREGIÕES ENTRE OS ANOS DE 2000 E 2009. 256

Jorge Eduardo Macedo Simões, Clayton Douglas Chagas de Oliveira, David Costa Correia Silva, Hayatahandeson Borges de Caldas

Capítulo 22: AS EXPORTAÇÕES DOS PRODUTOS AGRÍCOLAS DA FRUTICULTURA NO VALE DO SÃO FRANCISCO (PETROLINA): UMA ANÁLISE DAS VANTAGENS COMPARATIVAS REVELADAS. 272

Sourou Gautier Goussi, Lilian Aldina Pereira Mendonça e Mendonça

Capítulo 23: BIODIGESTORES NA SUINOCULTURA CATARINENSE: RELATO DE EXPERIÊNCIAS DE IMPLANTAÇÃO... 281

Francisco Gelinski Neto, Eduardo Gelinski Junior, Nédio Rogério Rogoski

Capítulo 24: COMO A PERCEPÇÃO DO SABOR E O CONHECIMENTO INFLUENCIAM O CONSUMIDOR NA DECISÃO DE COMPRA DE AZEITE DE OLIVA 294

Larissa Bueno Ambrosini, Roni Blume, Suzimary Specht, Paulo Lipp João 


\section{Capítulo 1}

VERIFICAÇÃO DA APLICABILIDADE DE UMA ESTRUTURA COMPUTACIONAL DE INTERVENÇÕES PROGRAMADAS PARA REALIZACÃO DE ATIVIDADES EDUCACIONAIS VIA SMARTPHONES

Joab Cavalcante da Silva

Laurentino Augusto Dantas

Giselle Giovanna do Couto de Oliveira

Resumo: A presença massiva dos dispositivos móveis na sociedade tem possibilitado transformações nas ofertas de serviços virtuais e possibilitado muitas facilidades no acesso à informação. Os smartphones atuais são equipamentos que possuem grande quantidade de recursos e a cada dia são capazes de realizar maior quantidade de atividades. 0 uso de dispositivos móveis em atividades educacionais é, atualmente, um assunto expressivamente debatido e investigado por pesquisadores. Porém, até o momento, pouco tem sido explorado o potencial desses equipamentos no contexto da educação. Essa pesquisa investiga a aplicabilidade de uma estrutura computacional de intervenções programadas para a realização de atividades educacionais por parte dos alunos, em seus próprios dispositivos móveis. Os resultados obtidos sugerem que: o ferramental utilizado tem grande potencial para despertar interesse dos alunos pelo conteúdo estudado. E o smartphone pode ser um grande aliado do professor para promover o conhecimento.

Palavras-chave: Educação; Smartphone; Tecnologia; Notificação. 


\section{INTRODUÇÃO}

A crescente popularização dos dispositivos móveis, em particular dos smartphones, tem sido percebida em todas as faixas sociais e já está presente em parcela significativa da população (FELIZOLA, 2017). Este fato posiciona esses dispositivos como ferramentas disponíveis para apoio à atividades de vários seguimentos da sociedade, dentre elas, a educação.

Considerando a possibilidade de problemas com distrações e também os atrativos dos recursos oferecidos, o uso do celular no contexto educacional divide opiniões, especialmente quando ocorrido em sala de aula. 0 uso desses dispositivos, geralmente pode ocasionar distrações prejudiciais ao aprendizado, apesar disso, esses problemas são percebidos também em outros ambientes, por exemplo, trânsito ou trabalho. Nesse sentido, vantagens e desvantagens têm sido estudadas por pesquisadores com o propósito de discutir alternativas de uso adequado dos dispositivos móveis no contexto da educação, tendo em vista o potencial que as múltiplas funções desses aparelhos podem oferecer aos usuários (BATISTA; BARCELOS; 2017).

Nos níveis de ensino fundamental, médio e superior, os alunos pertencem a uma faixa etária média na qual os indivíduos estão cada vez mais familiarizados com as tecnologias e ainda apresentam ótimos índices de inclusão digital (WAISELFISZ, 2007). Essa percepção favorece iniciativas que têm sido pensadas como soluções para problemas antigos da educação, por exemplo, o abandono escolar e o insucesso educativo (BENTO et al, 2017).

Os recursos oferecidos por smartphones, tablets e outros dispositivos móveis apresentam potenciais atrativos para auxiliar no contexto da educacional, tanto na ambiente presencial como à distância, incluindo educação especial.

Esta pesquisa apresenta uma proposta de aplicabilidade de um estrutura computacional de intervenções programadas para realização de atividades educacionais via smartphones. 0 experimentos apresentados neste artigo foram realizados no ensino presencial. Foram desenvolvidas atividades extras àquelas desenvolvidas em sala de aula, porém versando sobre os mesmos conteúdos, com o objetivo de reforçar o aprendizado e despertar maior interesse nos alunos pelo conteúdo. As atividades foram enviadas para os smartphones dos alunos em horários programados fora dos horários de aula. Alguns detalhes sobre os experimentos estão descritos na Seção 4.

\section{REVISÃO DA LITERATURA}

\subsection{COMPUTAÇÃO UBÍQUA}

Computação ubíqua é um termo que se refere à visão de Mark Weiser (1991) de um mundo onde, computadores "invisíveis" iriam apoiar pessoas em atividades cotidianas, oferecendo acesso ilimitado a recursos de informação a qualquer hora e em qualquer lugar. Atualmente entende-se a computação ubíqua como uma computação onipresente, as pessoas possuem recursos computacionais a qualquer hora e em qualquer lugar.

Para a área da educação, Marinagi et al. (2013) dizem que em um ambiente educacional, professores e alunos podem aproveitar as novas tendências em computação onipresente, empregando dispositivos e tecnologias onipresentes na sala de aula.

Na verdade, atualmente, os jovens carregam dispositivos móveis em qualquer lugar e a qualquer momento. Divertem-se jogando com novos gadgets. Educadores e desenvolvedores de currículos precisam reconhecer essa realidade e adotar "ferramentas móveis do século 21 para aprendizes do século XXI" (Norris e Soloway, 2008).

Zaharakis et al. (2016) apresentaram o Projeto UMI-Sci-Ed que tem como objetivo investigar a introdução das tecnologias ubíqua e móvel na ciência, tecnologia, educação em engenharia e matemática. Os autores acreditavam que os avanços em áreas como velocidade computacional, redes de alta largura de banda, desenvolvimento de software, bancos de dados, ferramentas de visualização e plataformas de colaboração estão reformulando práticas de aprendizagem e estão começando a transformar o ensino.

O uso da computação Ubíqua na educação, faz com a tornemos mais ampla, acessível e de certo modo aberto. Conforme Mccarty (2013) com o uso dos smartphones e computação ubíqua, o acesso à educação on-line não significa apenas cursos mistos (presencial e on-line), mas em um sentido mais amplo, a Internet pode servir para fins educacionais de diversas maneiras através dos seus múltiplos recursos. 
Pode-se conectar pessoas para trocar informações, permitir a interação, fazer com que os professores e estudantes utilizem os diversos sensores do smartphone, pode-se coletar vídeos, imagens e sons em tempo real.

De certo modo a computação ubíqua trás a outro nível o termo educação em tempo integral, o uso do smartphone de modo correto, amplia o espaço de interação com o aluno, permite que experiências educacionais que antes só poderiam ser imaginadas.

Entretanto, aqui cabe uma ressalva, conforme observam Jeong e Joo (2015), o serviço é fornecido sem limitação de tempo ou local e é constituído dinamicamente. Acima de tudo, em termos de sistema de apoio à educação, é necessária uma tecnologia de fornecimento de informação para oferecer um serviço de suporte educacional correto e adaptável a contextos diferentes.

É evidente que a computação ubíqua, a partir do usos dos smartphones, tem o potencial de criar uma nova dimensão no ambiente de ensino e aprendizagem, a relação dos estudantes com professores e outros estudantes, neste novo modelo pode-se sem dúvida ser implementada a educação em tempo integral. 0 professor sempre terá acesso aos estudantes.

Mas é evidente a necessidade da criação de ferramentas computacionais que consigam fazer com que o professor crie novos modelos de atividades, bem como que os alunos sejam acessados de forma consciente, de modo que eles não se sintam presos e permanentemente sob a tutela dos professores e das atividades.

\subsection{MÉTODO DE AMOSTRAGEM POR EXPERIÊNCIA}

O Método de Amostragem por Experiência, do inglês Experience-Sampling Method (ESM) tenta fornecer instrumentos válidos para descrever as variações nos auto relatos dos processos mentais, em contextos reais, na realização de atividades rotineiras. Conforme Csikszentmihalyi e Larson (2014) coletas de dados baseados em técnicas de ESM podem ser usado para obter dados empíricos sobre os seguintes tipos de variáveis: (a) frequência e padronização da atividade diária, interação social e mudanças na localização; (b) frequência, intensidade e padronização dos estados psicológicos, isto é, dimensões emocionais, cognitivas e conativas da experiência; (c) frequência e padronização de pensamentos, incluindo qualidade e intensidade do distúrbio do pensamento.

O método de amostragem por experiência (ESM), permite aos pesquisadores/observadores aprender sobre as vidas dos indivíduos em um determinado contexto, dando a oportunidade da "captura" dos sentimentos, pensamentos, ações, contexto e atividades durante o dia a dia.

As abordagens ESM permitem que os pesquisadores tenham acesso para expandir as áreas e aspectos das experiências dos participantes, eles podem investigar e descrever e entender como as pessoas e os contextos se relacionam e muitas vezes moldar essas experiências.melhor

Conforme Zirkel et al. (2015) abordagens através de métodos ESM podem ser enriquecedoras para a pesquisa em educação, permitindo aos pesquisadores fazer perguntas novas e interessantes sobre como os alunos, professores e líderes escolares se envolvem com a educação como eles são vivendo suas vidas e, assim, ajudar a entender melhor como os contextos educacionais moldam a aprendizagem e outros resultados.

Uma das principais vantagens do ESM explicitadas por Beal (2015), é a capacidade de examinar a influência mais imediata dos eventos diários em estados emocionais das pessoas, fazendo com que, na maioria das vezes, o sentimento experimento já seja registrado no momento de sua ocorrência.

Além disso, conforme Hoffman e Pattel (2015), o método é capaz de capturar variações situacionais, como acontecem em "tempo real", e com a onipresença do smartphone, seus sensores e os recentes avanços técnicos, estudos de amostragem de experiência a partir dos próprios dispositivos dos observados tornaram-se extremamente simples de serem realizados.

O uso de sistemas ESM para experiências com alunos vêm sendo amplamente utilizados, Broda (2017) realizou um estudo no sentido de tentar definir padrões para a não resposta de alunos do ensino médio a um sistema que ficava fazendo interações agendadas, através de um aplicativo para celular em horários aleatórios. 0 estudo verificou que os alunos não estavam muito suscetíveis a responder às interações quando estavam fora do horário escolar. 
É muito relevante compreender que os jovens, na maioria da vezes, não querem continuar com as atividades escolares quando não estão na escola, e que experiências utilizando ESM necessitam ser elaboradas com cuidados adicionais quando direcionadas a estudantes.

Por ser uma área relativamente nova, mas com um imenso potencial de apoio e ajuda no entendimento dos estudantes, pesquisas que envolvam alunos e ESM se mostram de grande valia.

Entender como o aluno deve ser abordado e como utilizar método ESM a serviço do processo ensino/aprendizagem, mostra-se uma tarefa de relativa importância, para que novas metodologias de ensino possam ser desenvolvidas, de modo a serem melhores aproveitadas pelos estudantes.

\subsection{USO DE TECNOLOGIAS NA EDUCAÇÃO}

As tecnologias digitais de comunicação presente no cotidiano das pessoas, vêm, de modo significativo, alterando os modos como as pessoas se comunicam. Entretanto, o impacto que os meios de comunicação digital causam na sociedade como o todo não é observado de modo similar na educação, conforme descrito por Valente (2014).

A evolução das tecnologias vêm acompanhadas por mudanças significativas no comportamento dos estudantes, segundo Barbosa (2015), novas tecnologias causam impactos tanto nos hábitos sociais como na educação, as tecnologias móveis, atualmente, rompem os limites de lugar e tempo, consolidando um paradigma de produção e acesso ao conhecimento de forma colaborativa e ubíqua. Deve-se atentar ao fato que os estudantes, através dos seus dispositivos eletrônicos, em especial smartphones se tornam permanentemente "conectados".

Seguindo as palavras de Baran (2014), dispositivos móveis, tais como tablets e smartphones, são extremamente atrativos para os jovens, o seu uso apresentam novas oportunidades no contexto educacional, fazendo surgir o Mobile Learning (Nichele e Schlemmer, 2013).

Os profissionais envolvidos no ensino precisam enxergar nos tablets e smartphones novas ferramentas de comunicação com os estudantes, o mobile learning é o campo de estudo que busca analisar como os dispositivos móveis podem colaborar para a aprendizagem, segundo Batista e Barcelo (2017), o uso do celular é, em particular, uma questão que ainda apresenta dificuldades diversas, que devem ser discutidas.

Nas palavras de Tori (2016), um jovem acostumado a interagir o tempo todo, e a procurar na internet as informações e conteúdo que deseja, certamente terá dificuldade em aceitar aulas meramente expositivas, além disso, atualmente os smartphones oferecem, além de recursos de comunicação e acesso à internet, câmeras de vídeo, tocadores de mídia, possibilidade de acesso a inúmeros aplicativos, conteúdo multimídia e diversos sensores.

0 uso de smartphones para ensino está dentro da prática de mobile learning, que permite ao aluno a qualquer hora e em qualquer lugar através do uso de multimídia e comunicação, tal modo de ensinar e aprender fornece interação on-line em tempo real em uma série de atividades de curto prazo (Guy, 2010).

Sharples et al. (2005), antes da popularização dos smartphones, publicaram um trabalho onde definiram uma estrutura inicial para teorizar sobre a aprendizagem móvel, visando complementar as teorias de aprendizagem infantil, de sala de aula, de trabalho e informal. No mesmo trabalho os autores definiram o que o mobile learning representava de novo em relação às demais tecnologias educacionais existentes.

Atualmente o mobile learning é um assunto de grande interesse para os pesquisadores, uma consulta pelo tema no scholar google, buscando artigos entre os anos 2017 e 2018 obtém-se um total de 12.600 trabalhos publicados.

Dessa forma, entende-se que o uso de smartphones como ferramenta de ensino/aprendizado, não deve ser descartado. Deve-se oferecer aos professores recursos para que possam utilizá-los, principalmente por ser um recurso que está disponível para grande parcela da população brasileira.

Conforme dados da 29a pesquisa anual de uso de TI, da Fundação Getúlio Vargas, em maio de 2018 o Brasil passou a ter uma média de mais de um smartphone por habitante, o que torna comum que os jovens que cursam o ensino médio possuam o seu próprio aparelho.

Olhando a situação pelo lado tecnológico, pode-se visualizar que cada aluno possui a sua própria ferramenta de aprendizado, inclusive o uso de dispositivos pessoais para a execução de tarefas corporativas já é uma realidade com o BYOD (bring your own device), que numa tradução literal quer dizer "traga seu próprio dispositivo". 
Conforme Afreen (2014), BYOD é um conceito que permite que os funcionários utilizem seus dispositivos pessoais para acessar dados ou concluir tarefas para suas organizações, o autor pontua que essa ideia é atraente, pois proporciona um maior nível de conforto no uso de tecnologia de escolha do próprio funcionário para fazer o trabalho de escritório

Pelo lado educacional Bruder (2014) diz que, teoricamente, permitir aos alunos usar a tecnologia que eles estão familiarizados, incentiva a sua participação na sala de aula, o uso dos dispositivos por parte dos alunos, permite ao professores, entre outras coisas, criar atividades mais interativas visando uma maior participação dos alunos.

\section{METODOLOGIA}

Esta é uma pesquisa exploratória (Gil, 1999), uma vez que objetiva investigar os potenciais do uso de ferramentas computacionais de intervenção programada no contexto da educação e também levantar requisitos para modelar recursos que ampliem as possibilidades dessas ferramentas para o uso na educação. Essa investigação envolve aspectos quantitativos, já que analisa questões relacionadas à representatividade de participação dos alunos nas atividades, e também envolve aspectos qualitativos, avaliando o nível de envolvimento e interesse dos mesmos e mensurando a aplicabilidade das tecnologias utilizadas durante os experimentos.

A pesquisa foi realizada no município de Naviraí-MS, envolvendo um profissional de educação e um grupo de alunos divididos em duas turmas de ensino ensino superior presencial e os detalhes estão descritos na Seção 4.

Para a realização do experimento foram utilizadas os seguintes recursos tecnológicos:

1) Uma interface de autoria de rotinas interventivas: uma plataforma Web que permite a criação de atividades que podem ser personalizadas com diferentes componentes multimídia (e. g., textos, imagens, questões). As atividades são distribuídas em forma cronológicas em um calendário personalizado pelo especialista, podendo este determinar o dia e a hora que cada atividade será apresentada para os participantes. Neste ambiente o profissional de educação criou atividades distribuídas por um período de 10 dias e cadastrou os alunos como participantes, utilizando o e-mail pessoal. Tornando possível que os alunos recebessem os disparos nas datas e horas programadas. Ao cadastrar cada aluno, o sistema gera uma chave (senha) de acesso para autenticação.

2) Um aplicativo para smartphone (Resolve Notification): um aplicativo que se conecta à plataforma de autoria e dispara notificações nos horários programados pelo professor, linkando para as respectivas atividades. Ao clicar na notificação recebida, o sistema abre o navegador do dispositivo contendo a atividade definida pelo professor. 0 usuário visualiza e pode confirmar ou responder eventuais questões contidas na atividade. Caso o aluno não possa resolver a atividade no momento do disparo ou descarte involuntariamente a notificação, o aplicativo permite a recuperação de todas as atividades disparadas anteriormente e permite identificar se foram realizadas ou não, possibilita também a realização de qualquer uma das tarefas a qualquer momento, desde que permitida pelo profissional.

3) Smartphones dos alunos: o aplicativo foi instalado nos próprios dispositivos pessoais dos alunos. Por questões de limitações técnicas do aplicativo, apenas os alunos tinham smatphones com sistema Android puderam participar. A Figura 1 mostra as telas iniciais do aplicativo, a tela de primeiro acesso quando o usuário precisa cadastrar uma conexão com o sistema a partir dos dados cadastrados (à esquerda), e a tela principal do aplicativo exibindo as atividades disponíveis (à direita). A Figura 2 exibe a imagem da barra de notificações do dispositivo no momento que recebeu a atividade (à esquerda), e exibe a atividade sendo exibida no navegador do dispositivo (à direita), na ilustração a atividade oferece um vídeo para ser assistido.

As atividades utilizadas no experimento foram planejadas contendo conteúdo complementar ao abordado em sala de aula. Foram usados textos, imagens ilustrativas e questões com o propósito de reforçar o conteúdo e despertar o interesse do aluno. 
Figura 1: telas iniciais do aplicativo Resolve

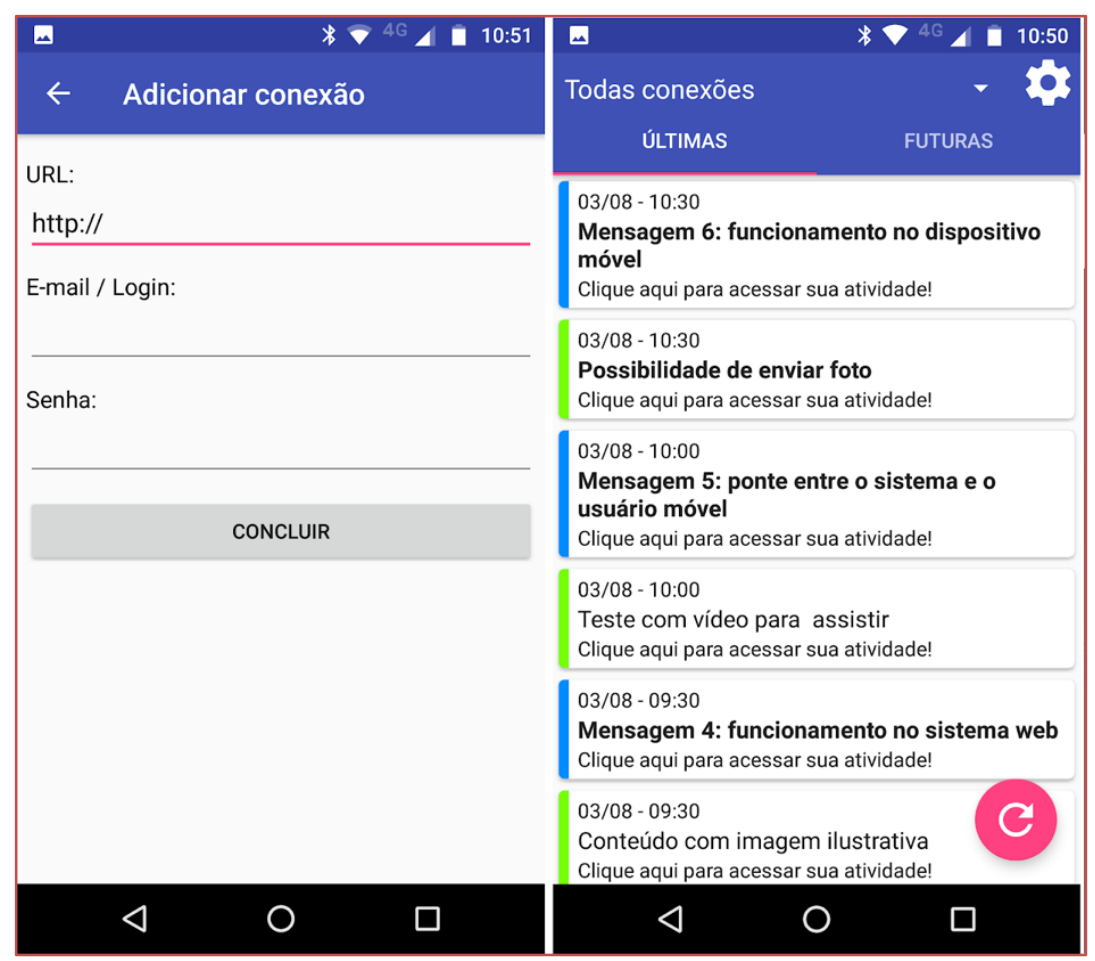

Fonte: captura de tela de conexão de teste do aplicativo.

Figura 2: telas da execução de atividades em dispositivo móvel

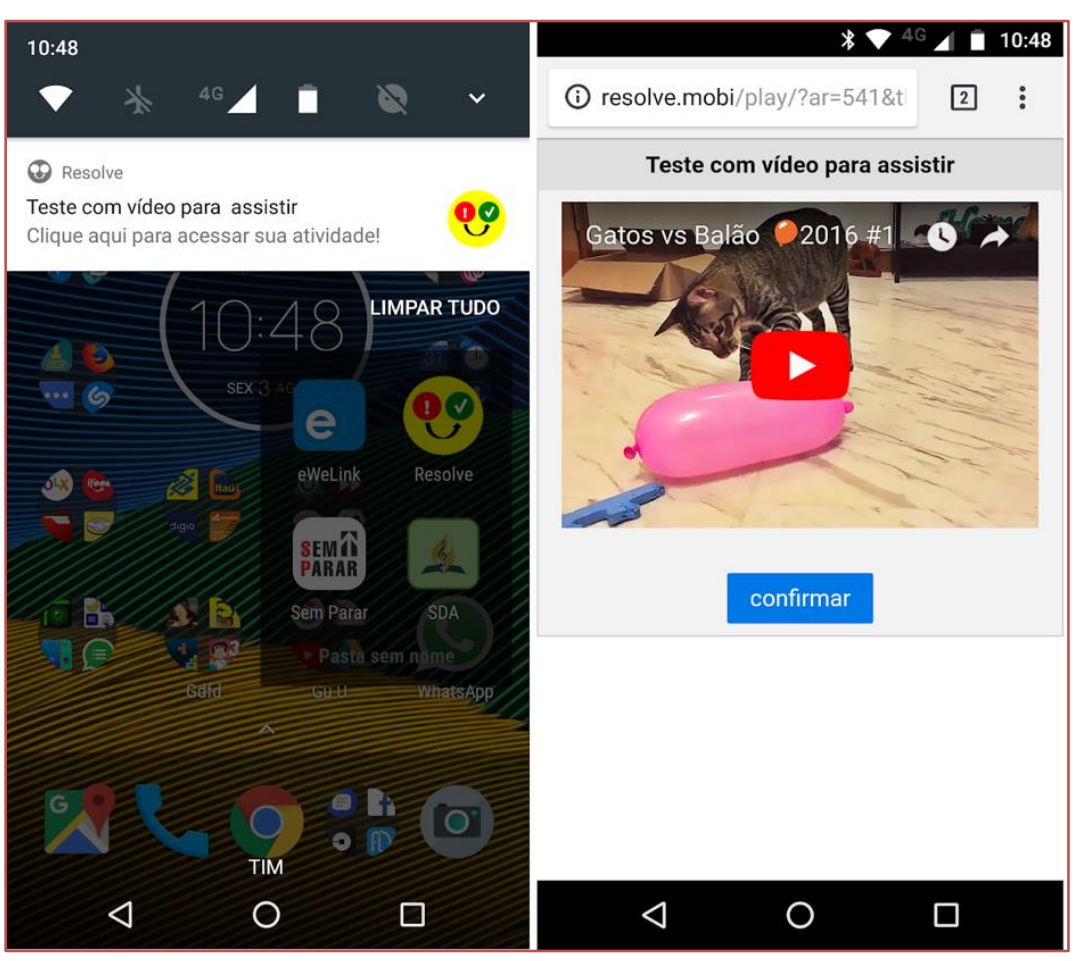

Fonte: captura de tela da barra de notificação e da execução de tarefa no navegador. 


\section{DISCUSSÃO E ANÁLISE DOS DADOS}

\subsection{DESCRIÇÃO DO CENÁRIO E LIMITAÇõES}

Os experimentos foram realizados em duas etapas, em duas turmas totalizando 70 alunos, particularmente matriculados em disciplina de química. A primeira etapa foi planejada com objetivo de oferecer reforço do conteúdo passado em sala de aula, os alunos recebiam frações de conteúdo relativo ao assunto transmitido presencialmente, recebiam também exercícios e desafios com objetivo de despertar curiosidade pelos temas. A segunda etapa foi aplicada uma avaliação aos alunos utilizando o aplicativo.

Para participar do experimento, os alunos precisavam ter dispositivo (smartphone ou tablet) com sistema operacional Android. Considerando a impossibilidade de fornecer dispositivos móveis aos participantes, na realização dos experimentos, os alunos utilizaram seus próprios aparelhos (prática de BYOD). Dadas essas circunstâncias, surgiram algumas limitações: dos 70 alunos, apenas 53 alunos possuíam dispositivos móveis compatíveis. Assim, alunos portadores de dispositivos com sistema iOS não puderam participar por restrições tecnológicas.

Em razão do número restrito de participantes, o professor restringiu os incentivos dados para quem realizasse as atividades, de forma a não prejudicar os que não participaram do experimento. Os alunos concordaram em participar voluntariamente da pesquisa, foram pré-cadastrados no sistema, instalaram o aplicativo e receberam instruções para estabelecer conexão com a plataforma.

A primeira etapa do experimento ocorreu durante duas semanas do mês de julho de 2018, que representavam 10 dias úteis no calendário de ensino, nesse período foram disparadas 15 notificações para cada participante, as notificações remetiam os alunos a atividades que continham: textos explicativos referentes ao conteúdo em questão, imagens ilustrativas, perguntas objetivas e perguntas abertas. As atividades tiveram seus disparos agendados para horários diferentes dos horários das aulas presenciais, já que um dos propósitos era conduzir o aluno ao estudo fora da sala de aula.

Na interface do professor foram montadas as atividades. O conteúdo escolhido foi "Ligações químicas". Nesta primeira etapa as turmas escolhidas para o estudo foram as de Química 1 do Curso Técnico Integrado em Internet para a Informática.

\subsection{ALGUNS RESULTADOS}

Na avaliação do professor, a interface de autoria se mostrou bem flexível quanto às possibilidades de criação de atividades e rotinas interventivas, oferecendo recursos que tornaram possível a personalização de atividades em vários contextos e de forma muito fácil. Dentro da aba atividade, existe a área "cadastrar nova atividade". Dentro dessa aba outras abas que permite ver o nome da atividade, quais componentes tem a atividade e qual o tipo de atividade. Além disso, ainda é possível ver como a atividade vai ser visto no aplicativo instalado no celular do aluno.

A plataforma oferece um controle completo das interações dos usuários. 0 professor pode acompanhar individualmente, quais atividades foram visualizadas e quais foram respondidas, pode ainda determinar se permite mais de uma resposta para a atividade, bem como visualizar todas as respostas para cada atividade.

Conforme relato do professor participante: "As ferramentas utilizadas têm significativo potencial para propor desafios para os alunos, o professor pode, por exemplo, propor incentivos para quem primeiro enviar respostas das atividades. A possibilidade de escolher o exato momento que o aluno receberá atividade é muito útil. E por parte dos alunos, cria-se uma expectativa e curiosidade pela chegada da tarefa que acaba refletindo positivamente no interesse do aluno pelo conteúdo".

Mesmo não podendo haver incentivos pontuais para os alunos participantes, foi percebido grande interesse por parte deles na participação das atividades. Limitações ocasionadas por falta de conexão foi uma dificuldade relatada por alguns alunos. Dos 53 alunos participantes, 39 participaram efetivamente das atividades.

Do total de notificações que foram acessadas, 59\% foram clicadas até os primeiros 10 minutos posteriores ao momento programado para a notificação, e $84 \%$ das atividades tinham sido clicadas em até uma hora após o horário agendado e apenas $16 \%$ acessou a notificação com mais de uma hora de atraso. Esses números podem refletir a curiosidade e interesse dos alunos por realizar as atividades. Para avaliar a 
possibilidade de continuidade desse interesse será necessário um acompanhamento continuado por um período de tempo maior.

Os recursos multimídia oferecidos pelas tecnologias podem despertar maior interesse nos alunos por conteúdos científicos, conforme relato do professor: "mesmo os alunos que geralmente demonstram menor interesse em sala de aula, se apresentaram desafiados e dispostos com a experiência".

Na visão do professor, de forma geral os alunos gostaram da experiência. Ao finalizar as atividades, os alunos foram convidados a escrever sugestões e relatar a experiência, segue alguns relatos: "O aplicativo é simples e prático. É uma ferramenta ótima e muito útil para o ensino", disse um. "É legal, é pratico e bem fácil, gostamos de usar este aplicativo e recomendamos para que outros professores também utilizem", relatou outro; e ainda: "A usabilidade é bem simples, porém atende as necessidades e a contribuição do aprendizado, ótima ferramenta de ensino", relato outro.

As ferramentas utilizadas para realizar as interações agendadas com os alunos são de uso genérico, ou seja, a arquitetura foi projetada para uso em diferentes cenários e aplicações e não exatamente na educação. Dessa forma, surgiram também algumas sugestões de recursos que seriam especificamente úteis no contexto da educação como: "feedback de resposta certa ou errada" e "correção automática de resposta dos alunos para cálculo de pontuação". A construção de uma versão especializada da ferramenta para o contexto educacional facilitaria o trabalho do aluno e do professor, sendo esta uma sugestão para trabalhos futuros.

\section{CONCLUSÕES}

Os resultados obtidos com o experimento indicam que o uso de intervenções programadas pode ser muito promissor no contexto da educação. A facilidade para personalizar atividades e personalizar diferentes formas de interações podem se bons incentivos para os professores; e o apelo tecnológico, bem como recursos multimídias oferecidos pelos dispositivos móveis poder ser atrativos significativos para os alunos.

Existem ainda algumas barreiras a serem superadas, como disponibilidade de internet para todos os alunos e uma estrutura multiplataforma para permitir a participação de todos.

Os dispositivos móveis atuais são equipamentos capazes de realizar enorme quantidade de tarefas e está nas mãos na maioria absoluta dos alunos, é necessário usar esses recursos em favor da educação, planejando, construindo, usando e aperfeiçoando novos sistemas computacionais para este fim.

\section{REFERÊNCIAS}

[1] AFREEN, Rahat. Bring your own device (BYOD) in higher education: opportunities and challenges. International Journal of Emerging Trends \& Technology in Computer Science, v. 3, n. 1, p. 233-236, 2014.

[2] BARAN, Evrim. A review of research on mobile learning in teacher education. Journal of Educational Technology \& Society, v. 17, n. 4, p. 17, 2014.

[3] BARBOSA, Débora Nice Ferrari et al. Experiências com o uso de Tablets no contexto da Educação escolar e não escolar. Revista Prâksis, v. 2, p. 67-80, 2015.

[4] BATISTA, Silvia Cristina Freitas; BARCELOS, Gilmara Teixeira. Análise do uso do celular no contexto educacional. RENOTE, v. 11, n. 1, 2017.

[5] BEAL, Daniel J. ESM 2.0: State of the art and future potential of experience sampling methods in organizational research. Annu. Rev. Organ. Psychol. Organ. Behav., v. 2, n. 1, p. 383-407, 2015.

[6] BENTO, M., Silva, B. D. D., Osório, A. J., Lencastre, J. A., \& Pereira, M. B. (2017). Trazer vida à sala de aula: utilização inovadora de dispositivos móveis no processo educativo.

[7] BRODA, Michael. Using Multilevel Models to Explore Predictors of High School Students' Nonresponse in Experience Sampling Method (ESM) Studies. Social Science Computer Review, v. 35, n. 6, p. 733-750, 2017.

[8] BRUDER, Patricia. Gadgets go to school: The benefits and risks of BYOD (bring your own device). The Education Digest, v. 80, n. 3, p. 15, 2014.

[9] CSIKSZENTMIHALYI, Mihaly; LARSON, Reed. Validity and reliability of the experience-sampling method. In: Flow and the foundations of positive psychology. Springer, Dordrecht, 2014. p. 35-54. 
[10] FELIZOLA, M. P. M., Araújo, N. A., de Souza Nunes, M. C., Gomes, V. J. B. M., \& Menezes, M. W. M. (2017). 0 nordeste conectado: Um quadro do acesso às tecnologias digitais de comunicação pelos jovens. Fronteiras-estudos midiáticos, 19(1), 120-128.

[11] GIL, Antonio Carlos. Métodos e técnicas de pesquisa social. 6. ed. Editora Atlas SA, 2008.

[12] GUY, Retta. Mobile learning defined. Mobile learning: pilot projects and initiatives, 2010.

[13] HOFMANN, Wilhelm; PATEL, Paresh V. SurveySignal: A convenient solution for experience sampling research using participants' own smartphones. Social Science Computer Review, v. 33, n. 2, p. 235-253, 2015.

[14] KUKULSKA-HULME, Agnes; TRAXLER, John. Mobile teaching and learning. In: Mobile learning. Routledge, 2007. p. 41-60.

[15] JEONG, Chang Won; JO0, Su Chong. The Implementation of Context-based Multi-agent Education Supporting System in Ubiquitous Computing Environments. KIPS Transactions on Computer and Communication Systems, v. 4, n. 4, p. 117-124, 2015.

[16] LIMA, E.R; MOITA, F.M. A tecnologia no ensino de química: jogos digitais como interface metodológica. 1 ed. Campina Grande: Eduepb, 2011.

[17] MARINAGI, Catherine; SKOURLAS, Christos; BELSIS, Petros. Employing ubiquitous computing devices and technologies in the higher education classroom of the future. Procedia-Social and Behavioral Sciences, v. 73, p. 487494, 2013.

[18] MCCARTY, Steve. Ubiquitous computing and online collaboration for open education. 2013.

[19] MORÁN, José. "Mudando a educação com metodologias ativas." Coleção Mídias Contemporâneas. Convergências Midiáticas, Educação e Cidadania: aproximações jovens 2 (2015): 15-33.

[20] NICHELE, A.G; SCHLEMMER, E. Mobile Learning em Química: uma análise acerca dos aplicativos disponíveis para tablets. Anais do 33o Encontro de Debates sobre Ensino de Química, 2013.

[21] NORRIS, Cathleen; SOLOWAY, Elliot. Handhelds: Getting mobile. District Administration, v. 44, n. 8, p. 20-24, 2008.

[22] SHARPLES, Mike; TAYLOR, Josie; VAVOULA, Giasemi. Towards a theory of mobile learning. In: Proceedings of mLearn. 2005. p. 1-9.

[23] SILVA, P. F.; SILVA, T. P.; SILVA, G. N. StudyLab: Construção e Avaliação de um aplicativo para auxiliar o Ensino de Química por professores da Educação Básica. Revista Tecnologias na Educação, v. 13, p. 1-12, 2015.

[24] TORI, Romero. Tecnologia e metodologia para uma educação sem distância. Em Rede-Revista de Educação a Distância, v. 2, n. 2, p. 44-55, 2016.

[25] VALENTE, José Armando. A comunicação e a educação baseada no uso das tecnologias digitais de informação e comunicação. UNIFESO-Humanas e Sociais, v. 1, n. 01, p. 141-166, 2014

[26] WAISELFISZ, Julio Jacobo; LÁPIS, Borracha. Mapa das desigualdades digitais no Brasil. UNESCO Brasil, 2007.

[27] WISER, M. The Computer for the 21st Century-Scientific American Special Issue on Communications. Computers, and Networks, p. 94-104, 1991.

[28] ZAHARAKIS, Ioannis D.; SKLAVOS, Nicolas; KAMEAS, Achilles. Exploiting Ubiquitous Computing, Mobile Computing and the Internet of Things to Promote Science Education. In: New Technologies, Mobility and Security (NTMS), 2016 8th IFIP International Conference on. IEEE, 2016. p. 1-2.

[29] ZIRKEL, Sabrina; GARCIA, Julie A.; MURPHY, Mary C. Experience-sampling research methods and their potential for education research. Educational Researcher, v. 44, n. 1, p. 7-16, 2015. 


\section{Capítulo 2}

\section{Execução do PNAE: Um contexto de problemas relatados pela midia brasileira}

\section{Paulo César Schotten \\ Maria Valdilene dos Santos Schotten \\ Solange Fachin \\ Rodrigo Santolini Soares}

Resumo: 0 estudo sobre o Programa Nacional de Alimentação Escolar (PNAE) é de profunda relevância e está voltada a preocupação na aplicação de recursos na merenda escolar em busca de garantir pelo menos uma refeição digna no dia, atendendo alunos de escolas públicas e garantindo o mínimo necessário de nutrientes para seu desenvolvimento. A partir dessa preocupação surge o problema de pesquisa adotado para esse estudo que era responder se o programa PNAE tem conseguido atingir completamente seu objetivo de oferecer alimentação saudável e têm atingido satisfatoriamente seu público alvo? Bibliograficamente foram apresentados os conceitos básicos do programa, legislação e operacionalidade além de apresentar a evolução histórica dos programas de merenda escolar. Para efeito de estudo foram pesquisados sete casos de má aplicação desses recursos e apresentados, demonstrando que nem tudo está perfeito e que problemas acabam por prejudicar o bom andamento do programa. Conclui que o programa é satisfatório, embora na sua operacionalidade problemas explícitos de corrupção, má gestão, incompetência e roubos são detectados. Apresentamse algumas soluções para o caso e pede-se a discussão do assunto de maneira mais ampla em busca de uma eficiência e satisfação geral da população quanto a aplicação visando atingimento dos objetivos do programa.

Palavras-chave: PNAE; Educação Básica; Alimentação Escolar. 


\section{INTRODUÇÃO}

O programa Nacional de Alimentação Escolar tem por objetivo oferecer alimentação escolar saudável e fomentar ações de educação alimentar e nutricional para estudantes da educação básica pública. É uma iniciativa governamental que vem de encontro às necessidades da população, principalmente as menos desprovidas de recursos que por muitas vezes não tem condições de manter uma alimentação digna, tornando-se então a alimentação escolar a principal refeição para as crianças atendidas.

O programa consiste no repasse de recursos da União para os Estados e Municípios que por sua vez tem o papel de adquirir os insumos necessários, montar estrutura para preparo e servir cumprindo então com a finalidade do programa. Como esse processo envolve muitos níveis e atores, a pergunta de pesquisa que fica e é razão desse estudo é: 0 programa PNAE tem conseguido atingir completamente seu objetivo de oferecer alimentação saudável e têm atingido satisfatoriamente seu público alvo?

Para responder a essa pergunta esse trabalho será direcionado metodologicamente pela explicação teórica / bibliográfica do processo e principais regulamentações e especificações do Programa PNAE. Em seguida, descritivamente serão relatados casos apresentados na mídia nacional que configuram violações dos objetivos do programa e em seguida procurar-se-á estudar onde foi violado e espera-se, a partir dessa análise apontar ações que poderiam ter sido tomadas que coibiram tais ações irregulares.

Estudos relacionados ao tema são importantes e justificam pela finalidade de apresentar a população em geral quais ações vêm de encontro aos anseios da sociedade e buscam auxiliar na formação da pessoa e na sua manutenção, bem como destacar o papel de cada um na cadeia que forma esse projeto, identificando elos fracos e apontando soluções. Outro ponto que justifica esse estudo é demonstrar principalmente às pessoas beneficiadas a importância de sua participação no processo, fiscalizando e fazendo cumprir os objetivos do programa.

0 objetivo geral desta pesquisa é então apresentado como descrever o Programa PNAE e violações apresentadas pela mídia com relação ao objetivo do programa, tendo como objetivos específicos: a) apresentar o programa PNAE; b) apresentar casos apresentados pela mídia nacional que configurem violação das regras do programa e; c) apresentar ações que, se tomadas poderiam intervir no processo evitando a violação das regras do programa.

Esse artigo está apresentado nas seguintes partes: Na parte introdutória apresenta os objetivos e justificase a necessidade do estudo. Na parte II, apresenta os principais conceitos, normas e objetivos do programa PNAE. Na parte III são apresentados os aspectos metodológicos que norteiam a pesquisa. Na parte IV são apresentados casos divulgados na mídia nacional que violam as regras do programa, bem como ações que poderiam ser tomadas para coibir tais ações e por fim, na parte V são apresentadas as considerações finais com relação ao estudo realizado.

\section{PNAE (PROGRAMA NACIONAL DE ALIMENTAÇÃO ESCOLAR)}

Conforme apresentado pelo Site do FNDE (2018) o Programa Nacional de Alimentação Escolar (PNAE) oferece alimentação escolar e ações de educação alimentar e nutricional a estudantes de todas as etapas da educação básica pública. 0 governo federal repassa, a estados, municípios e escolas federais, valores financeiros de caráter suplementar efetuados em 10 parcelas mensais (de fevereiro a novembro) para a cobertura de 200 dias letivos, conforme o número de matriculados em cada rede de ensino. 0 site aponta ainda que o PNAE é acompanhado e fiscalizado diretamente pela sociedade, por meio dos Conselhos de Alimentação Escolar (CAE), e também pelo FNDE, pelo Tribunal de Contas da União (TCU), pela Controladoria Geral da União (CGU) e pelo Ministério Público.

Tratando do assunto o site portal da transparência (2018) define que o Programa Nacional de Alimentação Escolar - PNAE, conhecido como Merenda Escolar, consiste na transferência de recursos financeiros do Governo Federal, em caráter suplementar, aos estados, Distrito Federal e municípios, para a aquisição de gêneros alimentícios destinados à merenda escolar.

Historicamente, o site afirma ainda que 0 PNAE teve sua origem na década de 40. Mas foi em 1988, com a promulgação da nova Constituição Federal, que o direito à alimentação escolar para todos os alunos do Ensino Fundamental foi assegurado, sendo beneficiários do programa alunos da educação infantil (creches e pré-escolas), do ensino fundamental, da educação indígena, das áreas remanescentes de quilombos e os alunos da educação especial, matriculados em escolas públicas dos estados, do Distrito Federal e dos municípios, ou em estabelecimentos mantidos pela União, bem como os alunos de escolas filantrópicas, em conformidade com o Censo Escolar realizado pelo INEP no ano anterior ao do atendimento. 
Considerando o histórico e evolução da alimentação escolar Santos, Costa e Bandeira (2016) apresentaram:

a) Na década de 1940, as escolas públicas utilizavam as "caixas escolares", para arrecadar recursos para a compra da alimentação dos seus alunos. Nesse período, o Governo Federal passou a se preocupar com a permanência dos alunos nas escolas, assim como em reduzir a desnutrição infantil no Brasil.

b) Na década de 1950 foi promulgado o Decreto-Lei no. 37.106, que criou a Campanha da Merenda Escolar (CME). Desde então, os escolares passaram a receber alimentação no período em que estavam nas escolas, porém no começo o Governo Federal ainda não comprava os gêneros alimentícios, apenas recebia doações de Órgãos internacionais e repassava aos Municípios, que apresentassem maior prevalência de desnutrição infantil. Nesse sentido, o Brasil recebeu uma doação proveniente dos Estados Unidos da América, que foi o excedente de sua produção alimentícia. Aliás, a região Nordeste foi privilegiada com essa ação em virtude da maioria dos escolares apresentarem desnutrição.

c) Na década de 1960, no entanto, com a redução do número de doações, fez-se necessário a manutenção do programa pelo governo brasileiro. Teve início a compra de produtos nacionais para a alimentação escolar. E, em 1979, foi instituído o "Programa Nacional de Alimentação Escolar" (PNAE), conhecido popularmente por "merenda escolar", cujo nome permanece até os dias atuais.

d) A partir de 1998, o PNAE foi gerenciado pelo Fundo Nacional de Desenvolvimento da Educação (FNDE), que é uma autarquia do Ministério da Educação com o intuito de contribuir para o crescimento, desenvolvimento, aprendizagem e rendimento escolar.

e) Década de 2000. O maior avanço do programa veio com a publicação da Lei no 11.947/2009 que universalizou o PNAE para toda educação básica, ou seja, da educação infantil ao ensino médio, além dos jovens e adultos; define a educação alimentar e nutricional como eixo prioritário para o alcance dos objetivos do programa; fortalece a participação da comunidade no controle social; formaliza a garantia da alimentação aos alunos mesmo quando houver suspensão do repasse dos recursos por eventuais irregularidades constatadas

Ressalta-se que o site da Secretaria da Educação do Estado do Paraná afirma que o Programa Nacional de Alimentação Escolar representa a maior e mais abrangente experiência em programas de alimentação e nutrição na América do Sul. A clientela atendida atualmente no país ultrapassa 37 milhões de alunos, com um investimento superior a 1,025 bilhão de reais ao ano.

Os objetivos principais do programa também são apresentados pelo governo do Paraná no site da Secretaria da Educação (2018), onde esclarece que o objetivo principal do PNAE é suprir parcialmente as necessidades nutricionais dos alunos beneficiários, através da oferta de no mínimo uma refeição diária, visando atender os requisitos nutricionais referentes ao período em que este se encontra na escola, tendo como objetivos secundários: a) Melhorar as condições fisiológicas do aluno, de forma a contribuir para a melhoria do desempenho escolar; b) Promover a educação nutricional no âmbito da escola, de forma a reforçar a aquisição de bons hábitos alimentares; c) Reduzir a evasão e a repetência escolar.

As metas do programa são apresentadas pelo referido site que a tem descrito como garantir uma refeição diária com aproximadamente 350 quilocalorias (Kcal) e 9 gramas de proteínas. Desta forma, a alimentação escolar deve possibilitar a cobertura de no mínimo $15 \%$ das necessidades diárias do aluno. 0 gerenciamento do programa é bastante complexo em virtude de estarem envolvidos diretamente no processo, União, Estados, Municípios, Conselhos e estabelecimentos de ensino. No entanto, o compromisso de gerenciar este recurso de forma transparente e eficaz deve ser uma constante, uma vez que o programa apresenta grande impacto social. Segundo FNDE (2018) o PNAE é acompanhado e fiscalizado diretamente pela sociedade, por meio dos Conselhos de Alimentação Escolar (CAE), e também pelo FNDE, pelo Tribunal de Contas da União (TCU), pela Controladoria Geral da União (CGU) e pelo Ministério Público.

O Governo do Paraná através da Secretaria da Educação afirma que o repasse é feito diretamente aos estados e municípios, com base no Censo Escolar realizado no ano anterior ao do atendimento. 0 Programa é acompanhado e fiscalizado diretamente pela sociedade, por meio dos Conselhos de Alimentação Escolar (CAE), pelo FNDE, pelo Tribunal de Contas da União (TCU), pela Controladoria Geral da União (CGU) e pelo Ministério Público.

Comentando sobre a origem dos recursos Santos, Costa e Bandeira (2016) afirma que programa é financiado pelo Tesouro Nacional e os recursos estão assegurados no Orçamento da União. O Fundo 
Nacional de Desenvolvimento da Educação (FNDE) transfere a verba às entidades executoras (Estados, Distrito Federal e Municípios), em conta corrente exclusiva para este fim, sem necessidade de formalizar convênio, ajuste, acordo, contrato ou qualquer outro instrumento. Segundo (FNDE 2018) é a origem dos recursos é a União e o valor repassado pela União a estados e municípios por dia letivo para cada aluno é definido de acordo com a etapa e modalidade de ensino:

- $\quad$ Creches: $\mathrm{R} \$ 1,07$

- $\quad$ Pré-escola: R\$0,53

- Escolas indígenas e quilombolas: $\mathrm{R} \$ 0,64$

- $\quad$ Ensino fundamental e médio: $\mathrm{R} \$ 0,36$

- $\quad$ Educação de jovens e adultos: R\$0,32

- Ensino integral: $\mathrm{R} \$ 1,07$

- Programa de Fomento às Escolas de Ensino Médio em Tempo Integral: R\$2,00

- Alunos que frequentam o Atendimento Educacional Especializado no contra turno: R\$ 0,53

A transferência dos recursos financeiros dá-se de acordo com Santos, Costa e Bandeira (2016) em dez parcelas mensais, a partir do mês de fevereiro de cada ano, para a cobertura de 200 dias letivos. Apenas $70 \%$ dos recursos são destinados à compra de produtos alimentícios básicos, ou seja, semielaborados e in natura. Os 30 \% restantes são destinados a produtos da agricultura familiar. 0 valor a ser repassado para a entidade executora é calculado da seguinte forma: TR=Número de alunos x Número de dias x Valor per capita, onde TR é o total de recursos a serem recebidos.

Por fim, vale ressaltar que vários órgãos são responsáveis pela gestão do PNAE. Saõ apresentados como órgãos participantes e responsáveis pelo PNAE, estabelecido no site do FNDE (2018):

Do ponto de vista operacional, participam do PNAE:

- Governo Federal, por meio do FNDE - Responsável pela definição das regras do programa. É aqui que se inicia o processo de financiamento e execução da alimentação escolar.

- Entidades Executoras (EEx) - Secretarias de Educação dos Estados, do Distrito Federal e dos Municípios e as escolas federais, que se responsabilizam pelo desenvolvimento de todas as condições para que o PNAE seja executado de acordo com o que a legislação determina.

- Unidade Executora (UEx) - Sociedade civil com personalidade jurídica de direito privado, vinculada à escola, sem fins lucrativos, que pode ser instituída por iniciativa da escola, da comunidade ou de ambas. As Unidades Executoras podem ser chamadas de "Caixa Escolar", "Associação de Pais e Mestres", 'Círculo de Pais e Mestres" ou “Unidade Executora”. Representam a comunidade educativa.

- Conselho de Alimentação Escolar - Responsável pelo controle social do PNAE, isto é, por acompanhar a aquisição dos produtos, a qualidade da alimentação ofertada aos alunos, as condições higiênico-sanitárias em que os alimentos são armazenados, preparados e servidos, a distribuição e o consumo, a execução financeira e a tarefa de avaliação da prestação de contas das EEx e emissão do Parecer Conclusivo.

Existem outras instituições que apoiam o PNAE (FNDE, 2018):

- Tribunal de Contas da União e Ministério da Transparência, Fiscalização e ControladoriaGeral da União - Órgãos de fiscalização do governo federal.

- Ministério Público Federal - Em parceria com o FNDE, recebe e investiga as denúncias de má gestão do programa.

- Secretarias de Saúde e de Agricultura dos Estados, do Distrito Federal e dos Municípios Responsáveis pela inspeção sanitária, por atestar a qualidade dos produtos utilizados na alimentação ofertada e por articular a produção da agricultura familiar com o PNAE.

- Conselho Federal e Conselhos Regionais de Nutricionistas - Fiscalizam a atuação desses profissionais. 


\section{Atuação (FNDE,2018):}

- FNDE - Responsável pela assistência financeira em caráter complementar, normatização, coordenação, acompanhamento, monitoramento e fiscalização da execução do programa, além da avaliação da sua efetividade e eficácia.

Por fim, vale apresentar que conforme preconiza o FNDE e o programa PNAE. Embora cada um dos programas seja regido por leis, portarias e resoluções específicas, os executores locais devem observar determinadas normas, tais como:

- Lei n 8.666, de 21 de junho de 1993, que trata de licitações e contratos na administração pública;

- Lei n ${ }^{\circ} 12.527$, de 18 de novembro de 2011, que regula o acesso à informação;

- Lei no 10.520, de 17 de julho de 2002; que instituiu a modalidade de licitação pregão, para aquisição de bens e serviços comuns;

- Decreto no 5.450, de 31 de maio de 2005; que regulamenta o pregão eletrônico;

- Decreto $\mathrm{n}^{\circ} 7.507$, de 27 de junho de 2011, que determina a obrigatoriedade de movimentação dos recursos por meio eletrônico;

- Resolução ${ }^{\circ} 2$, de 18 de janeiro de 2012, que dispõe sobre a prestação de contas por meio do Sistema de Gestão de Prestação de Contas (SiGPC);

- Resolução $\mathrm{n}^{\circ} 21$, de 13 de outubro de 2014, que dispensa a autorização prévia do FNDE para a reprogramação de saldos.

\section{METODOLOGIA}

Método na visão de Souza (2018) é um conjunto de regras básicas para desenvolver uma experiência a fim de produzir novos conceitos, também corrigir e integrar conhecimentos já existentes. Afirma ainda que entende-se por Método científico a metodologia usada por cientistas na busca do conhecimento, em uma definição mais precisa: um conjunto de regras básicas para desenvolver uma experiência a fim de produzir novos conceitos, bem como corrigir e integrar conhecimentos pré-existentes.

Quanto a classificação dessa pesquisa, em relação ao seu objetivo essa pesquisa é descritiva. Cervo e Bervian (1983) definem que Pesquisa descritiva é aquela que analisa, observa, registra e correlaciona aspectos (variáveis) que envolvem fatos ou fenômenos, sem manipulá-los. Os fenômenos humanos ou naturais são investigados sem a interferência do pesquisador que apenas "procura descobrir, com a precisão possível, a frequência com que um fenômeno ocorre, sua relação e conexão com outros, sua natureza e características.

Voltado ao método de análise essa pesquisa é documental. Gil (2008) afirma que a pesquisa documental é muito parecida com a bibliográfica. A diferença está na natureza das fontes, pois esta forma vale-se de materiais que não receberam ainda um tratamento analítico, ou que ainda podem ser reelaborados de acordo com os objetos da pesquisa. Além de analisar os documentos de "primeira mão" (documentos de arquivos, igrejas, sindicatos, instituições etc.), existem também aqueles que já foram processados, mas podem receber outras interpretações, como relatórios de empresas, tabelas etc.

Operacionalmente essa pesquisa desenvolveu-se a partir de um levantamento de informações contidas na mídia e disponíveis na internet. Buscou-se na ferramenta de procura do Google no mês junho de 2018 informações referentes à corrupção e desvios na aplicação da verba destinada merenda escolar e, com base em sete casos selecionados aleatoriamente entre os diversos disponíveis fez-se um cruzamento dos objetivos do programa e a forma de execução. Dessa analise fez-se uma descrição dos casos provando que os objetivos do programa não são totalmente atingidos por problemas que são relatados na pesquisa.

\section{CASOS DE VIOLAÇÃO DO PROGRAMA PNAE}

Como visto, o programa possui regras e normas bastante definidas. Possui toda uma estrutura de objetivos claros e uma escala de atuação de vários membros e órgãos que tem por finalidade o cumprimento do estabelecido na lei. As leis são claras e punitivas em caso de desvio, há órgãos fiscalizadores e comitês de acompanhamento. Com tudo isso, será possível que no Brasil ainda há ações que violem esse programa? 
Em busca dessa resposta foram levantados através da plataforma web casos divulgados na mídia que apresentem sinais de violação dos objetivos do programa e que configurem alguma forma de violação do processo e descreve-se para conhecimento e posterior análise.

Em uma breve busca na ferramenta de procura do site Google na data de 01 de junho de 2018, ás 11:49 minutos, é espantoso a quantidade de informações relativas a corrupção na merenda escolar. Há uma quantidade infinita de desvios de recursos na área da merenda tanto que, em um breve trabalho do assunto seria inviável a exploração de todos os casos, razão essa que remete a autora desse estudo a uma limitação da pesquisa, sendo, portanto, escolhido aleatoriamente sete casos para demonstrar essa realidade. Sabe-se que esse procedimento de escolha limita o aprofundamento do assunto, mas não inviabiliza o estudo visto que abre espaços para novas discussões, novos trabalhos e aprofundamentos quanto ao tema. Vale destacar que outros casos são apresentados na mídia, principalmente desvios de merenda, roubos em escolas, falta de fornecimento, fornecimento de alimentos com data de validade vencida e assim sucessivamente

Outro ponto que vale destacar que esse trabalho não tem cunho político logo, legendas e partidos serão suprimidos das informações, destacando-se e descrevendo-se apenas o caso apresentado.

Caso 1: Quebra de cooperativa de agricultores em São Paulo.

Em notícia veiculada pelo Portal G1 no ano de 2016 é apresentado um caso ocorrido no Estado de São Paulo onde um esquema de corrupção na merenda escolar levou a quebra de uma cooperativa de agricultores. Veicula a notícia que nomes de agricultores eram usados para desviar recursos do fundo Nacional de Desenvolvimento da Educação através da falsificação de notas fiscais.

Caso 2: Desvio de Recursos da União destinado à merenda escolar em municípios de São Paulo, Paraná, Bahia e Distrito Federal.

Nesse caso 65 contratos na área da educação somam segundo o site $R$ \$ 1,6 bilhão de reais sendo cinco núcleos empresarias investigados ligados à chamada "máfia da merenda" onde um cartel direcionava licitações e superfaturava contratos. É apresentado na notícia que segundo a Policia Federal, os grupos criminosos agiam entrando em contato com prefeituras por meio de lobistas, para direcionar licitações que usavam recursos federais para fornecimento de merenda escolar, uniformes, material didático e outros serviços à escolas municipais. Os responsáveis deveriam responder por crime de fraude a licitações, associação criminosa, corrupção ativa e passiva.

\section{Caso 3: Superfaturamento em ovos de galinha para merenda escolar}

Neste caso apresentado pelo site Carta Campinas também em 2018, apresenta que a corrupção faz um único ovo da merenda escolar custar R $\$ 12,15$ (doze reais e quinze centavos) para os cofres públicos. Afirma a notícia que o superfaturamento não acontecia apenas no ovo, mas também com os demais produtos da merenda escolar, uniforme, material e até limpeza de escolas gerando um superfaturamento mínimo de $\mathrm{R} \$ 366.000,00$ (trezentos e sessenta e seis mil reais) somente naquele município.

\section{Caso 4: Crianças recebem meio milho na merenda escolar}

Notícia veiculada em 2018 no portal G1 demonstra que estudante de uma escola tem recebido apenas a metade de uma espiga de milho na merenda escolar e, pasmem, Secretário de Educação diz que a merenda é nutritiva e que os recursos não são para uma refeição. Essa alimentação contraria o pressuposto na legislação do PNAE onde preconiza que a merenda na educação básica deve suprir pelo menos $20 \%$ das necessidades nutricionais da criança.

\section{Caso 5: Pipoca como prato principal nas escolas públicas do Distrito Federal}

Notícia veiculada pelo Jornal de Brasília no ano de 2017 afirma que nas escolas públicas do Distrito Federal o milho é integrante oficial e que segundo a Secretaria de Educação a intenção é melhorar a variedade e qualidade nutricional. Os pais dos alunos contrariam a afirmação ao apontarem que o lanche composto apenas por pipoca e suco não seria suficiente para satisfazer os alunos. Alertam também que muitos alunos só tem acesso as refeições no colégio em virtude das dificuldades financeiras em casa e, por isso, a pipoca não seria suficiente para sanar a necessidade alimentar. Há afirmações que de que havia escassez de outros produtos como óleo e sal. A notícia informa ainda que A previsão orçamentária para 2017 com a merenda escolar é de R \$ 61 milhões. Parte do montante vem do Governo Federal, por meio do Fundo Nacional de Desenvolvimento da Educação (FNDE) - R\$35 milhões, e o restante do executivo local - R\$ 25 milhões. 


\section{Caso 6: Paçoca e doces como merenda escolar}

Uma reportagem apresentada pelo site Bahia Notícias em 2015 destaca que em um município do Estado comporá a merenda escolar chocolate sonho de valsa, pipoca doce, jujuba, paçoca e pirulito. A mercadoria seria fornecida pela empresa vencedora de processo licitatório. Esse processo, segundo o Ministério Público e apresentado na reportagem contraria os parâmetros e regras da legislação da merenda escolar citando que o MEC recomenda que a merenda escolar seja composta por alimentos saudáveis e que contribuam para o crescimento, desenvolvimento, aprendizagem e a formação de hábitos alimentares saudáveis, com ações de educação alimentar e nutricional.

\section{Caso 7: Falta de merenda escolar}

Notícia veiculada pelo site São Gonçalo news em 2018 denunciou falta de fornecimento de merenda escolar em colégio do povoado no município de São Gonçalo de Campos. Informa também a dispensa de aulas por falta de merendo escolar no município.

\subsection{ANÁLISES DOS CASOS APRESENTADOS}

Como visto, muitos casos são apresentados que desviam a finalidade e objetivos do Programa Nacional de Alimentação Escolar. Problemas de todos os tipos são encontrados como desvio de dinheiro, corrupção, falta de profissionalismo, não preocupação com o desenvolvimento da criança e com a saúde pública, roubo de merenda por ações internas ou externas e assim sucessivamente.

Grande preocupação deve existir por parte da sociedade visto que o programa tem finalidade pública e busca o desenvolvimento da criança. Tem caráter social. Desta forma ações apresentadas contrariam a razão do bom senso e remete ao pensamento de que temos sérios problemas comportamentais e de moral com relação ao processo e ao programa, vindo de pessoas que tinham por função proteger e desenvolver o projeto.

De maneira geral vale ressaltar que bem ou mal o programa tem atingido seus objetivos, embora não satisfaça plenamente seus objetivos e analisando e buscando as razões, pode-se afirmar que o Governo Federal está fazendo sua parte ao empreender e desenvolver o programa. Temos então problemas no sistema operacional que carece de algumas ações que possam ajudar e diminuir ou eliminar pontos que possam abrir possibilidades de ações de corrupção ou minimizar os efeitos da incompetência dos gestores. Sugere-se, a partir do estudo realizado:

a) Reestudar a operacionalidade do sistema com controle efetivo de aplicação dos recursos;

b) Engajamento da sociedade como órgão fiscalizador, quer seja formando comitês de acompanhamento com pessoas não comprometidas no processo ou mesmo criação de observatórios sociais em cada município para acompanhamento da gestão.

c) Cobrança, especialização e autonomia para as Nutricionistas que, através dessa independência possa exercer papel fiscalizador da gestão municipal.

d) Endurecimento de penas tornando o desvio da finalidade ou má gestão deste recurso como crime hediondo, inafiançável, com penas duras, visando inibir ações.

e) Cobrança e retorno de recursos desviados independentemente do meio em que tenham ocorrido.

Essas são algumas sugestões que podem ser adotadas mas vale dizer que um estudo aprofundado do tema deverá ser desenvolvido em busca de soluções definitivas e, a partir desse estudo, adotar essas soluções fazendo com que os recursos atinjam realmente seus objetivos e façam o que a população realmente espera das ações governamentais.

\section{CONSIDERAÇõES FINAIS}

Esse estudo teve como objetivo descrever o Programa Nacional de Alimentação Escolar (PNAE) e para tanto buscou conhecê-lo através de estudos da legislação e artigos sobre o tema bem como buscou através de casos divulgados pela mídia nacional apresentar casos em que problemas se apresentam no cumprimento do objetivo. 
Vários problemas foram detectados como falta de profissionalização dos gestores dos recursos do programa, corrupção, desvios de merenda ou mesmo de recursos, atividades operacionais que não condizem com o proposto no programa além de outros problemas detectados e não descritos nessa pesquisa. Esses problemas não inviabilizam ou desvalorizam o projeto, muito pelo contrário, a pesquisa apresenta a importância do programa e demonstra que está atingindo aos objetivos propostos, não em sua totalidade em virtude dos problemas apresentados, mas é relevante e importante.

Vale ressaltar que essa pesquisa não tinha como objetivo final encerrar discussão com relação ao tema, mas buscava identificar um ponto de início de discussão o qual se espera seja relevante e promova uma preocupação na sociedade de debater, encontrar soluções e implantá-las em busca do bem comum da sociedade. Recomenda-se então estudos futuros com relação ao tema, aprofundamento das causas de desvio de recursos, de erros operacionais e proposição de soluções para os problemas.

Como limitação da pesquisa aponta-se o não aprofundamento do tema e a não ampliação a todos os casos apresentados na pesquisa com relação a problemas no sistema, mas fica como ponto de partida para novas discussões relacionadas ao tema.

\section{REFERÊNCIAS}

[1] BAHIA NOTÍCIAS. Notícia: Sonho de Valsa, pirulito e paçoca compõem a merenda escolar de Livramento de Nossa Senhora (2015). Disponível em https://www.bahianotícias.com.br/municipios/notícia/942-sonho-de-valsapirulito-e-pacoca-compoem-a-merenda-escolar-de-livramento-de-nossa-senhora.html. Acesso em 01 de junho de 2018, às 12:57.

[2] CARTA CAMPINAS. Notícia: Corrupção faz um único ovo da merenda de escola governada pelo PSDB custar $\mathrm{R} \$ 12,15$ (2018). Disponível em http://cartacampinas.com.br/2018/05/corrupcao-faz-um-unico-ovo-da-merenda-deescola-governada-pelo-psdb-custar-r-1215/. Acesso em 01 de junho de 2018, às 12:36.

[3] CERVo, Amado Luiz; BERVIAN, Pedro Alcino. Metodologia Científica. 3 ed. São Paulo: McGraw-Hill do Brasil, 1983

[4] FNDE. Programa Nacional de Alimentação Escolar. 0 que é? Disponível em http://www.fnde.gov.br/programas/programas-suplementares/pnae-sobre-o-programa/pnae-sobre-o-pnae. Acesso em 01 de junho de 2018, às 10:55.

[5] G1. Notícia: Corrupção na merenda escolar em SP quebra cooperativa de agricultores (2016). Disponível em http://g1.globo.com/jornal-nacional/notícia/2016/02/corrupcao-na-merenda-escolar-em-sp-quebra-cooperativade-agricultores.html. Acesso em 01 de junho de 2018, às 12:19.

[6] G1. Notícia: Crianças recebem meio milho na merenda escolar e secretário diz que comida é elogiada (2018). Disponível em https://g1.globo.com/ma/maranhao/notícia/criancas-recebem-meio-milho-na-merenda-escolar-esecretario-diz-que-comida-e-elogiada.ghtml. Acesso em 01 de junho de 2018, às 12:43.

[7] G1. Notícia: Polícia Federal faz operação contra desvios de recursos da União para a merenda em três Estados e no Distrito Federal (2018). Disponível em https://g1.globo.com/sp/sao-paulo/notícia/policia-federal-fazoperacao-contra-desvio-de-dinheiro-publico.ghtml. Acesso em 01 de junho de 2018, às 12:28.

[8] GIL, Antonio Carlos. Como elaborar projetos de pesquisa. 4. ed. São Paulo: Atlas, 2008.

[9] GOOGLE. Ferramentas de busca. Assunto: Corrupção na merenda escolar. https://www.google.com/search?source=hp\&ei=Pm8RW_HGCoGBwgSV_LeoCg\&q=corrup\%C3\%A7a\%C3\%B5+na+m erenda+escolar\&oq=corrup $\% \mathrm{C} 3 \% \mathrm{~A} 7 \mathrm{a} \% \mathrm{C} 3 \% \mathrm{~B} 5+$ na+merenda+escolar\&gs_l=psyab.3..0i22i30k1.1761.6119.0.6408.28.25.0.0.0.0.245.3167.0j17j3.20.0...0...1.1.64.psyab..8.20.3157...0j0i131k1j0i30k1.0.17_qChPZYVA. Pesquisa em 01 de junho de 2018, às 10:03.

[10] GOVERNO DO PARANÁ (SECRETARIA DA EDUCAÇÃO). Informativo: Programas e Projetos - PNAE -

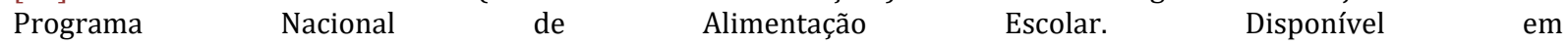
http://www.gestaoescolar.diaadia.pr.gov.br/modules/conteudo/conteudo.php?conteudo=156. Acesso em 01 de junho de 2018, às 11:08.

[11] PORTAL DA TRANSPARÊNCIA. Merenda Escolar: Programa Nacional de Alimentação Escolar (PNAE). Disponível em http://www.portaldatransparencia.gov.br/aprendaMais/documentos/curso_PNAE.pdf, Acesso em 01 de junho de 2018, às 11:00.

[12] SANTOS, Sérgio Ribeiro dos. COSTA, Maria Bernadete de Souza Costa. BANDEIRA, Geovanna Torres de Paiva. Ensaio: As formas de gestão do programa nacional de alimentação escolar (PNAE). Publicado em Rev. salud pública. 18 (2): 311-322, 2016. Disponível em

https://www.scielosp.org/article/ssm/content/raw/?resource_ssm_path=/media/assets/rsap/v18n2/v18n2a14.pdf. Acesso em 01 de junho de 2018, às 11:16. 
[13] SÃo GONÇALO NEWS. Notícia: Absurdo: Falta merenda escolar nas escolas da zona rural de São Gonçalo dos Campos (2018). Disponível em http://www.saogoncalonews.com.br/2018/03/absurdo-falta-merenda-escolar-nasescolas-da-zona-rural-de-sao-goncalo-dos-campos.html. Acesso em 01 de junho de 2018, às 13:02.

[14] SOUZA, Líria Alves de. Informativo: Método científico. Disponível em https://mundoeducacao.bol.uol.com.br/quimica/metodo-cientifico.htm. Acesso em 11 de junho de 2018, às 16:11. 


\section{Capítulo 3}

EQUILÍBRIO DAS DIMENSÕES DE ACOMPANHAMENTO E DO CONTROLE DAS OPERAÇÕES: ESTUDO DE CASO EM UMA REDE DE ENSINO

\section{Regina Ferreira da Rocha \\ José Paulo Alves Fusco \\ Otávio José de Oliveira}

Resumo: Ao considerar o cenário mercadológico, em virtude da globalização e dos avanços tecnológicos, as Intituições de Ensino Superior (IES) bem como as outras organizações procuram sua estabilidade competitiva. Por essa razão, cabe às organizações adotarem modelos inovadores de gestão de suas operações, visando à melhoria dos resultados. Redes de empresas podem ser um modelo perfeito para unir esforços por meio da cooperação entre os parceiros de um determinado negócio, envolvendo laços de diferentes naturezas. Este estudo mostra o desenvolvimento e a aplicação de uma técnica auxiliar para analisar a intensidade, a natureza e a importância das relações internas e externas na obtenção de resultados para uma rede da empresa. Para tal, um estudo de caso foi realizado em uma IES do Estado de São Paulo e sua rede de parceiros, a fim de observar suas especificidades e estratégias organizacionais. Demonstrou-se a existência de critérios de desempenho específicos (pilares) da IES que podem refletir em sua realidade competitiva. São reveladas evidências de que o pilar da educação é reforçado, que o pilar pesquisa está crescendo, embora seja o mais fraco. Quanto ao pilar extensão, tem-se que é o segundo mais robusto na IES pública.

Palavras-chave: Redes de empresas, Instituição de Ensino Superior, Intensidade de relacionamentos, Natureza das operações, Critérios de Desempenho. 


\section{INTRODUÇÃO}

0 mundo contemporâneo apresenta constantes desafios às nações e exige uma postura vigorosa frente a questões inerentes aos âmbitos econômico, político, social, entre outros. Em decorrência do cenário ora apresentado, a educação é um setor relevante para o desenvolvimento de um povo. Sob essa perspectiva, cabe à educação superior formar profissionais aptos a atuarem em organizações que são desafiadas a permanecerem ativas em mercados ávidos por novos produtos e serviços. Assim, adaptações nas esferas curriculares e metodológicas são estudadas no sentido de aprimorar a qualificação de mão de obra capaz de desenvolver pesquisas inovadoras e contribuir para o crescimento tecnológico.

A sustentação das Instituições de Ensino Superior (IES) se dá pelo poder público ou pelo capital privado. Dessa forma, as IES públicas apresentam uma ampla gama de estratégias que envolvem pesquisas e desenvolvimento de pessoal e de tecnologia e, por outro lado, as privadas, além de preparar pessoas capacitadas, buscam também o retorno financeiro para suas atividades. No Brasil, há diversidade de estruturas de ensino que contemplam as exigências do mercado, caracterizando, então, a concorrência entre essas organizações.

Segundo o Censo da Educação Superior de 2013, divulgado pelo Instituto de Estudos e Pesquisas Educacionais Anísio Teixeira (INEP), no Brasil existiam 2.391 instituições de educação superior; dessas, 301 públicas e 2.090 particulares. Essas IES atendem a uma clientela de 7.305 .977 alunos, dos quais 1.932.527 são alunos de instituições públicas e 5.373 .450 estão regularmente matriculados em IES privadas. Neste contexto, há evidências de que as IES possuem expectativas diferenciadas e são altamente competitivas.

Porter (1989) postula que toda organização deve definir sua estratégia, visando a uma posição competitiva diante da concorrência, e Christopher (2007), por sua vez, afirma que a filosofia que versa sobre a "sobrevivência do mais forte" está vinculada à estratégia corporativa. Por essa razão, a subsistência das organizações está atrelada à adoção de novos modelos de gestão que viabilizem a obtenção de resultados satisfatórios em suas dimensões competitivas.

Este estudo pretende mostrar o desenvolvimento e a aplicação de uma técnica auxiliar para analisar a intensidade, a natureza e a importância das relações internas e externas na formação de resultados para uma rede de empresa. A hipótese que o norteia é que a sustentabilidade de uma IES está condicionada ao alinhamento de suas operações em relação às suas orientações estratégicas. Destarte, seu intuito consiste em mostrar o desenvolvimento e a aplicação de uma técnica auxiliar para analisar a intensidade, a natureza e a importância das relações internas e externas para o alcance de resultados para uma rede de empresas.

Ao longo do estudo são discutidos os pilares de gestão propostos para estabelecer a ligação entre os aspectos competitivos da IES e sua realidade. Trata-se, então, de um estudo de caso em uma IES de Tecnologia, situada no interior do Estado de São Paulo, para entender a dinâmica do negócio explorado pela rede. Assim, pelo recorte avaliado, as informações obtidas na rede fornecem evidências da existência do excesso de preocupação com os aspectos didático-pedagógicos, o que reforça o pilar educação. Em relação ao pilar pesquisa, a intensidade da força é relativamente baixa quando comparada à educação e extensão. No que diz respeito ao pilar de extensão, em razão dos objetivos institucionais, há maior robustez do pilar quando comparado ao pilar pesquisa. Como tal, a IES pesquisada atribui importância adequada a cada pilar, considerando sua natureza e demais variáveis que podem alterar o cenário mercadológico.

\section{COMPETITIVIDADE E ESTRATÉGIA COMPETITIVA}

A concorrência está no âmago do sucesso ou fracasso das empresas, determinando a adequação das atividades que podem contribuir para seu desempenho, como inovações, uma cultura coesa ou uma boa implementação (PORTER, 1989, p. 1). Diante desse pressuposto, a mudança de paradigma é inevitável, razão pela qual Christopher (2007) menciona que é inadmissível supor que bons produtos se vendam por si mesmos. Segundo ele, cabe ao administrador buscar uma vantagem competitiva sustentável e defensável diante da realidade do mercado.

Jarillo (1998) apregoa que as organizações necessitam obter vantagem competitiva, definindo sua própria estratégia, de acordo com as características próprias e a natureza de seu "core business" (negócios), patrimônio, cultura, sociedade, ou seja, valorizando a coordenação e a motivação suficientes para atravessar fronteiras. 
A estratégia, na visão de Teixeira et al. (2007, p. 191) e de Slack et al. (2007, p. 74), é o padrão, modelo ou plano que integra as principais metas, as políticas e as sequências de ações que posicionam a organização em seu ambiente e buscam atingir seus objetivos de longo prazo. Na acepção de Teixeira Filho (2000, p. 33), estratégia significa um padrão de comportamento a ser implementado na organização, de modo a agir e reagir perante as situações; trata-se, portanto, de educar a organização a comportar-se conforme determinadas diretrizes. Gattorna e Walters (1996) mencionam que um aspecto importante da estratégia diz respeito a seu papel na construção de relacionamentos com fornecedores e clientes.

\section{REDES DE EMPRESAS}

Outrora, as estratégias gerenciais e a política governamental focavam o âmbito organizacional (AMATO NETO, 2008). Contudo, ao considerar o cenário exposto, torna-se imprescindível responder rapidamente ao mercado, dificultando a atuação isolada das empresas. Por esta razão, um novo modelo de cooperação entre as empresas surge para melhorar seu desempenho competitivo. Segundo Porter (1999), o conceito de redes de empresas deve ser encarado como um método ou uma forma de organizar as atividades econômicas por meio da coordenação e/ou cooperação interfirmas.

Sob a ótica de Britto (2013, p. 347), as redes são arranjos interorganizacionais baseados em vínculos sistemáticos, que, por vezes, ocorrem entre empresas formalmente independentes, dando origem a uma forma particular de coordenação das atividades econômicas.

As redes interfirmas tiveram sua origem no norte da Itália, ocasião em que as empresas familiares e manufatureiras apostaram em melhorias dos resultados associando seus negócios. Trata-se de uma visão coletiva e interdependente. Esta estrutura organizacional foi adotada por outros países, como Portugal, Reino Unido, Espanha, EUA e Canadá. Salientando a relevância das experiências mencionadas, Castells (1999) corrobora a prosperidade das empresas em rede do Leste Asiático, em vários contextos institucionais e culturais da Europa e dos Estados Unidos. Para o referido autor, as grandes empresas, que são organizadas hierarquicamente de forma vertical, encontram dificuldades para sobreviver à economia global.

Há que se destacar que as redes de empresas possuem elementos morfológicos conhecidos por nós, ligações, posições e fluxos. Os nós podem ser descritos como empresas ou atividades entre empresas. As posições definem as localizações das empresas ou atividades na estrutura de divisão de trabalho dos diferentes agentes, necessárias à produção de bens, envolvendo a integração de capacidades operacionais, competências e tecnologias. As ligações, conexões ou linkages, determinam o relacionamento entre empresas em aspectos qualitativos, o grau de densidade ou a qualidade do relacionamento dos agentes de uma rede. Os fluxos tangíveis, ou de bens (insumos e produtos) e intangíveis, ou de informações, fluem pelas ligações (BRITTO, 2013; SACOMANO NETO, 2004).

\subsection{RELACIONAMENTOS COM LAÇOS FORTES E FRACOS}

Pela teoria de rede, apresentada por Granovetter (1983) na abordagem de rede social, os amigos são denominados laços fortes, ao passo que os conhecidos são designados de laços fracos. Uma rede é considerada de baixa densidade quando há relacionamentos com laços fracos, e é densa quando ocorre o relacionamento com laços fortes. As pessoas com poucos laços fracos são privadas de informações de partes distantes do seu sistema social, captando somente as notícias e pontos de vista de seus amigos. Essa concepção no ambiente organizacional significa que a privação de informações pode representar uma ameaça à responsividade da organização frente ao mercado.

Os laços fracos, na visão de Granovetter (1983), proporcionam acesso a informações e recursos além dos disponíveis no próprio círculo social. Por outro lado, os laços fortes têm maior motivação para serem úteis, estão mais disponíveis, sobretudo se os laços fracos representarem uma parcela muito pequena do total de contatos. Em outro estudo, Granovetter (1973) menciona ser possível atribuir intensidade ou força aos relacionamentos e, para Lazzarini (2008), essa intensidade pode ser mensurada ao se considerar o número de vezes que duas pessoas se encontram para trocar ideias. Quanto maior for a frequência dos encontros, maior será a intensidade dos relacionamentos. 


\subsection{TIPOLOGIA}

Grandori e Soda (1995) apresentam uma tipologia de redes interorganizacionais a partir dos critérios: tipos de mecanismos de coordenação utilizados, grau de centralidade e grau de formalização da rede. $\mathrm{Na}$ classificação, três tipos básicos de redes são subdivididos em simétricos e assimétricos.

Nas Redes Sociais (social network), a característica fundamental é a informalidade nas relações interempresariais, ou seja, não existem acordos ou contratos formais (AMATO NETO, 2008). Nas Redes Sociais Simétricas todos os participantes possuem contatos pessoais e compartilham a mesma influência. Nas Redes Sociais Assimétricas ou Centralizadas há um agente central que coordena os contratos formais de fornecimento (produtos/serviços) entre as empresas que participam da rede (GRANDORI; SODA, 1995; AMATO NETO, 2008).

As Redes Burocráticas possuem uma formalização contratual. Nas Redes Burocráticas Simétricas, os relacionamentos são baseados na igualdade de direitos e deveres entre as empresas dos mesmos setores (GRANDORI; SODA, 1995; AMATO NETO, 2008; FUSCO; SACOMANO, 2009). Nas Redes Burocráticas Assimétricas há uma empresa coordenadora central que estabelece as regras da rede (GRANDORI; SODA, 1995).

Nas Redes Proprietárias, a formalização de acordos estabelece o direito de propriedade entre os acionistas das empresas (GRANDORI; SODA, 1995; AMATO NETO, 2008). As Redes Proprietárias Simétricas são representadas pelas joint-venture (união de duas ou mais empresas proprietárias e gestoras de uma terceira). As Redes Proprietárias Assimétricas são formadas pelas associações capital ventures, em que um investidor financia o outro da rede (AMATO NETO, 2008).

\subsection{EQUILÍBRIO DOS RELACIONAMENTOS}

As organizações unem-se em rede, visando alcançar vantagens, aumentar a competitividade, estimular oportunidades de empreendimentos, aumentar exportações, formar novas bases de capital, criar alternativas de investimentos e reduzir custos (FUSCO; SACOMANO, 2009).

Gattorna e Walters (1996) sugerem uma tipologia para mapeamento e avaliação do nível dos relacionamentos existentes entre os atores de uma rede, independente de eles serem de caráter vertical ou horizontal. No modelo de mapeamento há quatro níveis principais que classificam os relacionamentos existentes nas redes por grau de importância das transações operacionais de quem presta o serviço e de quem o recebe (GATTORNA; WALTERS, 1996). Os referidos autores denominam como 'fornecedor' os extremos de um relacionamento, ou seja, altamente conectados e, por outro lado, o 'comprador' por haver uma forte probabilidade de existir conflito e abuso de poder no mercado, representando assim diferentes graus de dependência entre os atores envolvidos. 0 mapeamento dos relacionamentos entre os atores de uma rede possibilita a mensuração das interações e, quando confrontado com indicadores de desempenho, a execução das atividades ocorre de acordo com objetivos estratégicos da rede.

\section{ENSINO SUPERIOR}

Um dos desafios do ensino superior é conviver com o moderno, que integra o avanço tecnológico à educação, sem prescindir da qualidade exigida pela competitividade mundial (VILELA, 2007). Sob essa ótica, Martins (2000, p. 42) defende que o caminho da política educacional promissora deve estar pautado na heterogeneidade institucional do sistema, sendo necessário reconhecer a existência de uma multiplicidade de instituições com perfis organizacionais e vocações acadêmicas distintas, além de evitar tratamentos homogêneos para realidades acadêmicas marcadas pela disparidade.

No Brasil, o Decreto no 2.306/97, com base na LBD/96, estabelece a organização acadêmica das Instituições de Ensino Superior (Universidade, Centro Universitário, Faculdades e Institutos, Escolas Superiores ou Faculdades), além de destacar suas peculiaridades. Assim, há que se considerar que cada IES, dada a sua organização acadêmica, deverá empenhar seus esforços na tríade ensino, pesquisa e extensão, ponderando suas ações no foco a ser perseguido.

\section{MÉTODO DE PESQUISA}

Esta pesquisa parte de três procedimentos técnicos: a pesquisa referencial, a pesquisa documental e, por fim, o estudo de caso. 
Na pesquisa referencial busca-se explicar um problema por meio de referências teóricas já publicadas (GIL, 2010). Assim, foram utilizados livros e materiais de cunho científico com a finalidade de colher informações e conhecimentos acerca do assunto a ser tratado. A pesquisa documental deve ser fundamentada em materiais que não sofreram tratamento analítico (GIL, 2010). No que tange ao estudo de caso, para Yin (2010) e Miguel (2010), este procedimento torna-se mais relevante à medida que a pesquisa almeja explicar como ou por que algum fenômeno social funciona, de modo a exigir sua análise profunda. Esta pesquisa busca analisar, portanto, como a aplicação do conceito de rede de empresas, em um contexto real, uma IES, pode beneficiar a execução dos processos operacionais que possibilitem o alcance dos resultados almejados.

$\mathrm{Na}$ definição da estrutura conceitual-teórica foram considerados assuntos como o panorama das IES no Brasil, a importância de formular estratégias para a competitividade e o conceito de rede de empresas aplicado à área da educação. Na sequência, as etapas foram definidas para propor uma abordagem que analisa as dimensões de controle e monitoramento (pilares) das operações de uma IES. Salienta-se que o grupo NETPRO explora a aplicação do conceito de redes de empresas em IES e tenta compreender se atividades que compõem os relacionamentos de uma IES refletem os critérios de desempenho adotados pela Instituição.

A princípio, o grupo NETPRO, com base na legislação pertinente, define os pilares ensino, pesquisa e extensão, comuns a todas as instituições, podendo, no entanto, apresentar outro pilar específico para sua realidade.

O levantamento dos dados deu-se por meio de entrevistas semiestruturadas e observação direta, com a adequação do questionário, seguindo a proposta de Miguel (2010), Figura 1. Houve ainda a precaução de validar o conteúdo obtido junto aos entrevistados de forma a evitar a interpretação equivocada dos dados obtidos.

Figura 1 - Aplicação do método e da técnica propostos por Miguel (2010)

\begin{tabular}{|c|c|}
\hline $\begin{array}{l}\text { - Coletar o material científico e } \\
\text { elaborar o embasamento teórico da } \\
\text { pesquisa }\end{array}$ & $\begin{array}{l}\text { - Solicitar autorização para a realização da } \\
\text { pesquisa } \\
\text { - Agendar as entrevistas } \\
\text { - Registrar as entrevistas em áudio }\end{array}$ \\
\hline $\begin{array}{l}\text { - Definir as dimensões de uma IES } \\
\text { - Levantar as atividades }\end{array}$ & $\begin{array}{l}\text { desempenho } \\
\text { - Validar o conteúdo junto aos entrevistados }\end{array}$ \\
\hline $\begin{array}{l}\text { desempenho para cada dimensão da } \\
\text { IES } \\
\text { - Verificar se as atividades } \\
\text { desenvolvidas pelos atores } \\
\text { fortalecem a(s) dimensão(ões) }\end{array}$ & $\begin{array}{l}\text { - Analisar o fluxo das atividades entre os } \\
\text { entrevistados } \\
\text { - Analisar os relacionamentos entre os } \\
\text { entrevistados } \\
\text { - Mapear a rede }\end{array}$ \\
\hline $\begin{array}{l}\text { - Estudo de caso único } \\
\text { - Pesquisa documental, observação }\end{array}$ & $\begin{array}{l}\text { - Analisar o mapeamento da rede } \\
\text { - Analisar o equilíbrio das atividades } \\
\text { desenvolvidas pelos atores e os critérios de } \\
\text { desempenho adotados pela IES }\end{array}$ \\
\hline $\begin{array}{l}\text { - Realizar o teste piloto } \\
\text { - Adequar o questionário }\end{array}$ & $\begin{array}{l}\text { - Elaborar o trabalho relacionando os } \\
\text { resultados obtidos na pesquisa ao } \\
\text { referencial conceitual-teórico }\end{array}$ \\
\hline
\end{tabular}

Fonte: Elaborada pelos autores.

A etapa de coleta de dados permitiu, além do levantamento geral dos dados apresentados, o delineamento das dimensões de monitoramento e controle das operações adotadas pela IES estudada para galgar melhor posicionamento frente às demais unidades de ensino. Assim, a Figura 2 apresenta uma síntese da dinâmica explorada no estudo. 
Figura 2. Base norteadora da pesquisa.

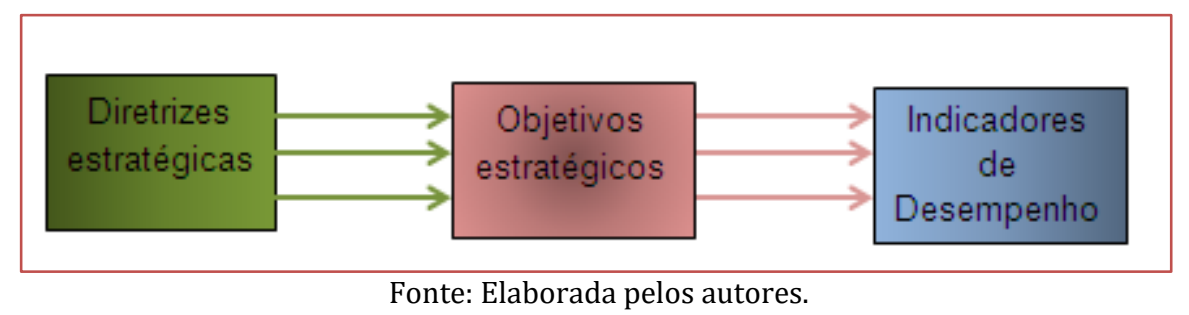

Para mapear a rede de empresas, utilizou-se o software Ucinet(C) 6.408, a partir dos dados coletados. 0 recorte foi restrito aos atores com maior visualização na rede de Ensino, que compreende os mais citados nas entrevistas iniciais, sendo constatada a importância da inserção de novos atores detectados no transcorrer da pesquisa ou necessários para a conclusão do estudo proposto.

\section{ABORDAGEM PROPOSTA}

Parte-se do pressuposto que as IES públicas ou privadas possuem as dimensões de controle (pilares) ensino, pesquisa e extensão, com outras variáveis específicas à instituição. Estes pilares devem estar em equilíbrio, em termos de interesse entre as partes envolvidas e em relação aos critérios de desempenho estabelecidos para garantir a obtenção de resultados estratégicos. Com esse objetivo, propõe-se uma abordagem que permite avaliar a simetria do poder e o grau em que as atividades desenvolvidas na IES pública estão relacionadas com os critérios de desempenho estabelecidos pela referida instituição. Tornase, assim, possível distinguir a pertinência estratégica dessas atividades desenvolvidas como resultado de tais relações.

A etapa da análise documental possibilitou o levantamento da missão, dos objetivos e das diretrizes traçadas pela IES a ser estudada. A definição do recorte analítico foi delineada nesta etapa, durante a qual foram inseridos os atores adicionais que poderiam ajudar a melhorar a caracterização de cada operação da IES.

A coleta de dados com os atores do recorte da IES deu-se via entrevistas semiestruturadas, cujo teor está organizado em quadros e consiste em conhecer as principais atividades desempenhadas por eles e o destinatário ou o ator que depende da atividade. Vale salientar que o destinatário é fundamental para mensurar a intensidade e o equílibrio dos relacionamentos.

Granovetter (1983) propõe que a intensidade dos relacionamentos entre os atores do recorte avaliado da rede deve ser mensurada de acordo com a frequência de cada relacionamento, mostrada na Tabela 1.

Tabela 1 -Intensidade dos relacionamentos

\begin{tabular}{|c|c|c|}
\hline \multirow{2}{*}{ Ator } & Destinatário & Periodicidade \\
\hline \multirow{3}{*}{ AAA } & ZCA & 7 \\
\cline { 2 - 3 } & ADC & 3 \\
\cline { 2 - 3 } & ABA & 2 \\
\hline \multirow{2}{*}{ ABA } & ADC & 5 \\
\cline { 2 - 3 } & JJA & 3 \\
\hline ADC & ZCA & 4 \\
\hline
\end{tabular}

Fonte: Elaborada pelos autores.

Um exemplo hipotético de relacionamentos exibido, na Tabela 1; o destinatário "ZCA" pode ser mencionado 7 vezes nas principais atividades relatadas pelo ator "AAA", ao passo que o ator "ADC" pode ser citado 3 vezes pelo mesmo ator. Assim, o destinatário "ZCA" será considerado mais importante que o destinatário "ADC", menos referenciado, evidenciando que a intensidade do relacionamento com "ZCA" é 
maior que o estabelecido com "ADC". 0 resultado obtido permitiu a representação gráfica da rede pelo software Ucinet.

Ao ponderar sobre a organização acadêmica da instituição, conforme determina o Decreto no 2.306/97, baseado na a LDB 96, cada IES apresenta suas dimensões de monitoramento e controle, denominados de pilares. Então, fez-se o levantamento dos pilares adotados pela instituição pesquisada, com a definição dos indicadores de desempenho de cada pilar estabelecido.

De posse das principais atividades desenvolvidas pelos atores do recorte analítico e dos indicadores de desempenho adotados pela IES, foram levantados os dados correspondentes à natureza de cada atividade.

Os atores foram orientados a explicitar que (e como) as atividades se relacionam com os indicadores de desempenho da instituição, Quadro 1. De acordo com as instruções, cada ator marcou com a letra " $\mathrm{X}$ " a intersecção da linha e coluna, caso julgasse que a atividade por ele desenvolvida influenciava no critério de desempenho de um ou mais pilares que sustentam a IES.

Quadro 1- Proposta de relacionamento das atividades desenvolvidas com os indicadores

\begin{tabular}{|c|c|c|c|c|c|c|c|c|c|c|c|c|}
\hline ATOR & \multicolumn{12}{|c|}{ PILARES } \\
\hline $\begin{array}{c}\text { Nome do } \\
\text { ATOR }\end{array}$ & 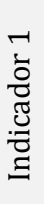 & 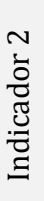 & $\vdots$ & 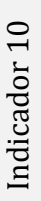 & 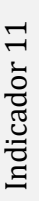 & 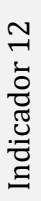 & $\vdots$ & 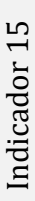 & 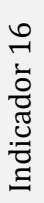 & 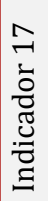 & $\vdots$ & 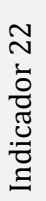 \\
\hline Atividade 1 & $\mathrm{x}$ & $\mathrm{x}$ & & & & $\mathrm{x}$ & & & & & $\mathrm{x}$ & \\
\hline Atividade 2 & $\mathrm{x}$ & & & $\mathrm{X}$ & $\mathrm{X}$ & & & $\mathrm{X}$ & & & $\mathrm{x}$ & \\
\hline$\ldots$ & & & $\mathrm{X}$ & & & & $\mathrm{x}$ & & $\mathrm{x}$ & & & $\mathrm{x}$ \\
\hline Atividade $\mathrm{N}$ & $\mathrm{x}$ & & & & & $\mathrm{X}$ & & & & & & \\
\hline
\end{tabular}

A análise da natureza, ou pertinência estratégica de atividades, pode ser viabilizada ao comparar as principais atividades mencionadas pelos entrevistados da IES pesquisada com os indicadores de desempenho de cada pilar. Reforça-se, aqui, a possibilidade de vislumbrar quais atividades desenvolvidas pelos atores podem contribuir positivamente para os resultados da rede e fortalecer a sustentabilidade das operações.

A somatória das atividades desenvolvidas pelos atores e relacionadas aos pilares, seguida da mesma operação matemática relativa às demarcações efetuadas pelos entrevistados, viabiliza constatar se as atividades por eles desenvolvidas influenciam os pilares com a mesma intensidade. A diferenciação dos valores obtidos nos cálculos pode caracterizar o equilíbrio entre os pilares, ou não.

\section{INSTITUIÇÃO ESTUDADA}

0 pressuposto de que as IES possuem diferenças quanto à sua organização acadêmica, a seus próprios critérios de desempenho e aos meios de busca de sobrevivência competitiva determinou a escolha da Instituição a ser pesquisada pelo Grupo NETPRO.

A Faculdade de Tecnologia de Garça (Fatec) oferece 3 cursos de graduação tecnológica e atende a 1069 alunos. A Fatec Garça é uma das unidades de ensino do Centro Estadual de Educação Tecnológica Paula Souza (CEETEPS), entidade autárquica, presente em 300 municípios do Estado de São Paulo, com 66 Fatec e 220 Escolas Técnicas Estaduais (ETEC) (CEETEPS, 2016).

A princípio, as entrevistas foram realizadas com enfoque no nível estratégico da instituição. Houve a participação de alguns atores para compreender o quanto as atividades por eles desenvolvidas influenciavam as tomadas de decisões da instituição estudada. 
Na rede da Fatec Garça, existe o relacionamento entre os atores envolvidos, que pode ser visualizado na Figura 3. Os atores que compreendem o recorte analítico são apontados na figura. Neste estudo, a FATEC Garça é rotulada como uma rede burocrática assimétrica, por existir contratos que regulam os relacionamentos entre os atores. O Centro Estadual de Educação Tecnológica Paula Souza (CEETEPS) estabelece a legislação norteadora das atividades desenvolvidas no âmbito local e dispõe sobre as atribuições dos cargos ocupados pelos atores entrevistados. Trata-se do Regimento Geral das Fatec.

No recorte da rede da FATEC Garça, apurou-se a existência de 167 atores, sendo 9 entrevistados, 10 internos e 148 externos, os dois últimos não entrevistados. No mapeamento do recorte supracitado, constatou-se que no centro a rede é densa (muitas ligações) e, na periferia, é difusa (poucas ligações). Percebeu-se que o ator central da rede é a Diretoria Geral, por haver maior incidência de relacionamentos apontados a ela.

Figura 3 - Atores internos do recorte da Fatec Garça

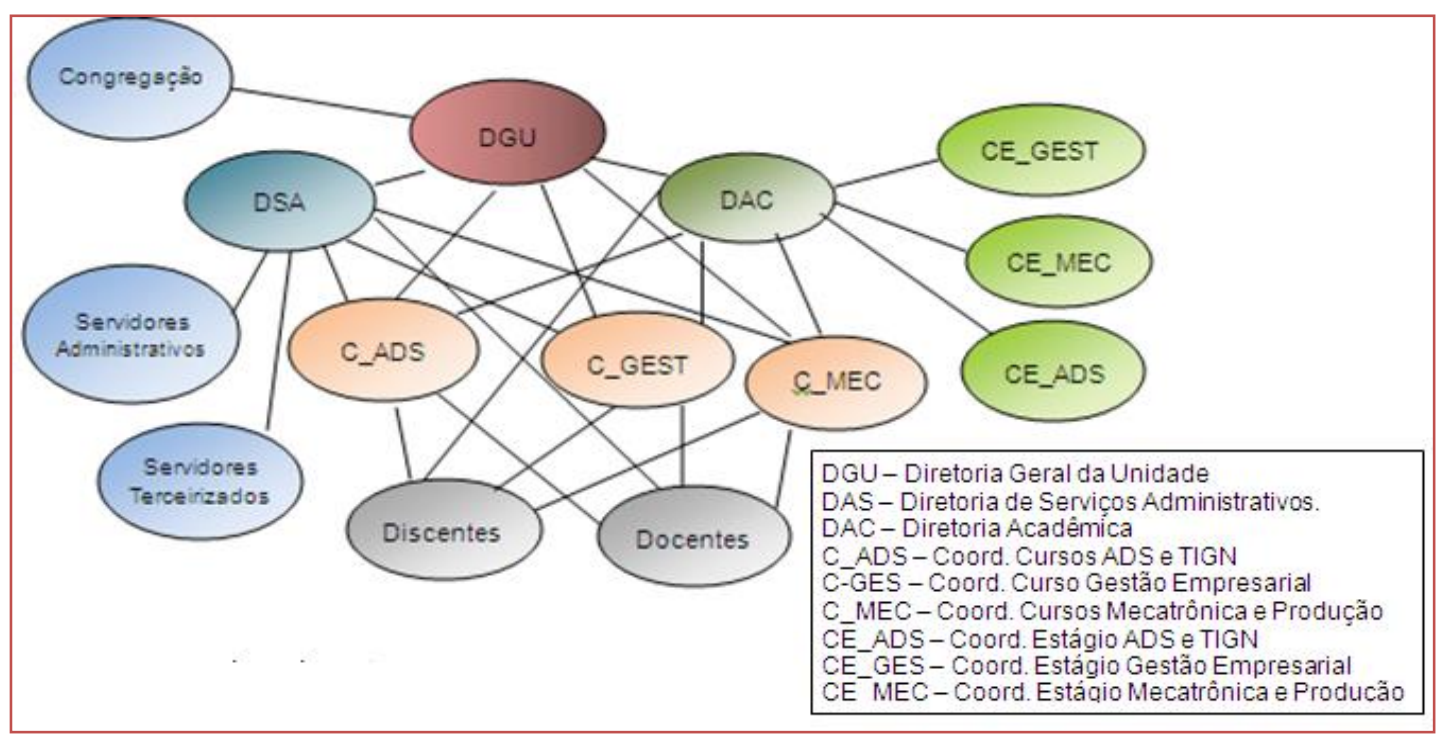

Fonte: Elaborada pelos atores.

Ao delinear os pilares da Fatec Garça, os três pilares (ensino, pesquisa e extensão) foram evidenciados, conforme mostra a Figura 4. Inicialmente, em razão da preocupação da IES com demanda social, houve a suspeita da existência de outro pilar, atividades incorporadas ao pilar extensão. A Figura 4 explicita os pilares com os indicadores de desempenho definidos pela Diretoria Geral. 
Figura 4 - Relação dos Pilares com os indicadores de desempenho da FATEC Garça

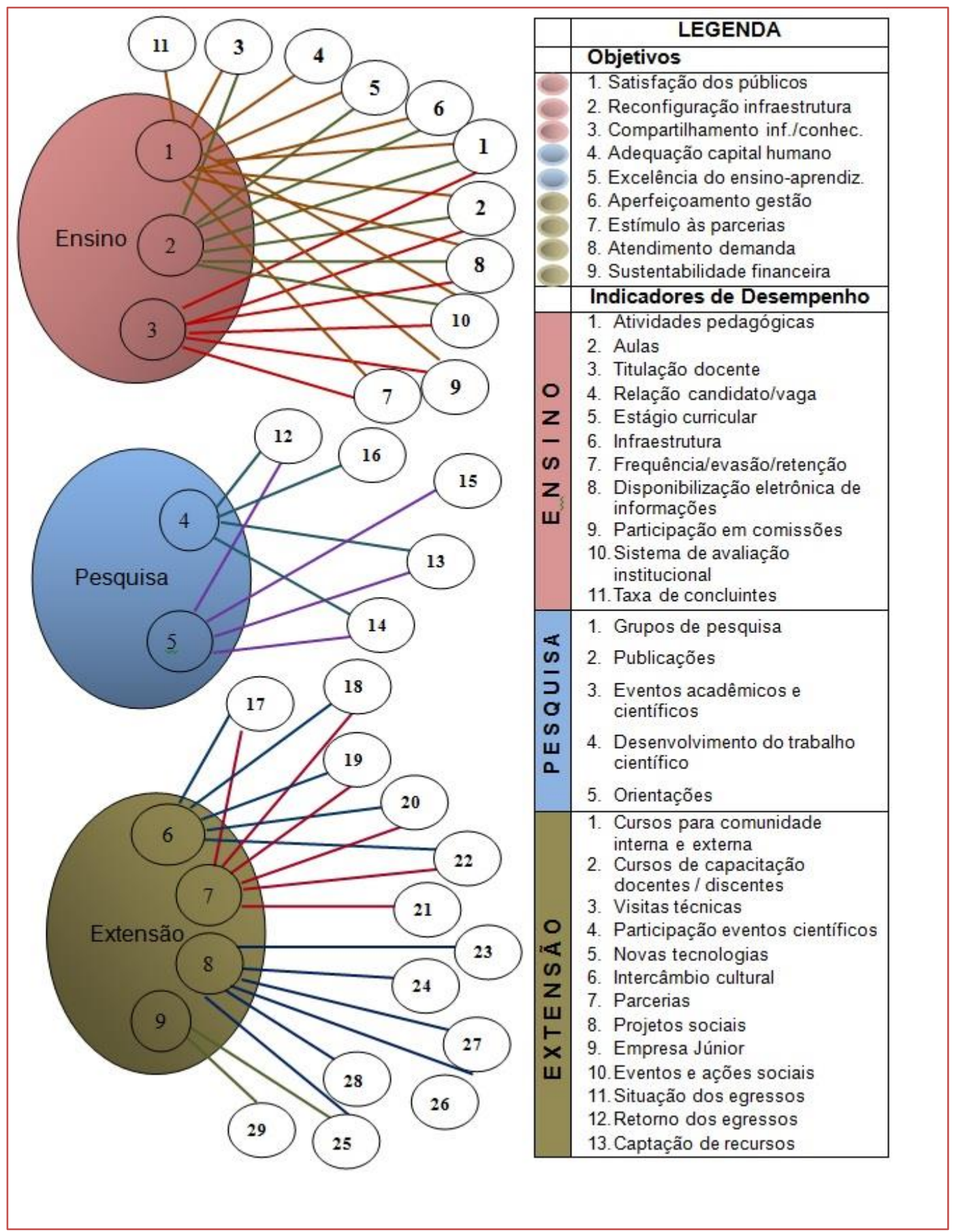

Fonte: Elaborada pelos autores.

\section{ANÁLISE DO ESTUDO DE CASO}

Ao analisar os resultados obtidos na aplicação Gráfico 1, considerando os pilares específicos da IES, é possível observar a força de cada um, bem como avaliar a representatividade desses pilares, e, portanto, cada atividade desenvolvida por eles (Tabela 2). 
Tabela 2- Representatividade dos pilares da IES

\begin{tabular}{|c|c|}
\hline Pilares & $\begin{array}{l}\text { Somatória dos relacionamentos entre Atividades e } \\
\text { Indicadores de Desempenho }\end{array}$ \\
\hline & FATEC \\
\hline Ensino & 380 \\
\hline Pesquisa & 124 \\
\hline Extensão & 289 \\
\hline Total & 793 \\
\hline
\end{tabular}

A soma das indicações dos atores entrevistados para cada pilar detectado na IES estudada é exibida na Tabela 2, o que possibilita a análise do fortalecimento dos pilares. A análise das indicações dos atores entrevistados permite converter os valores expressos na Tabela 2 em percentagens, como mostrado no Gráfico 1.

Gráfico 1 - Atividades desenvolvidas X critérios de desempenho (\%)

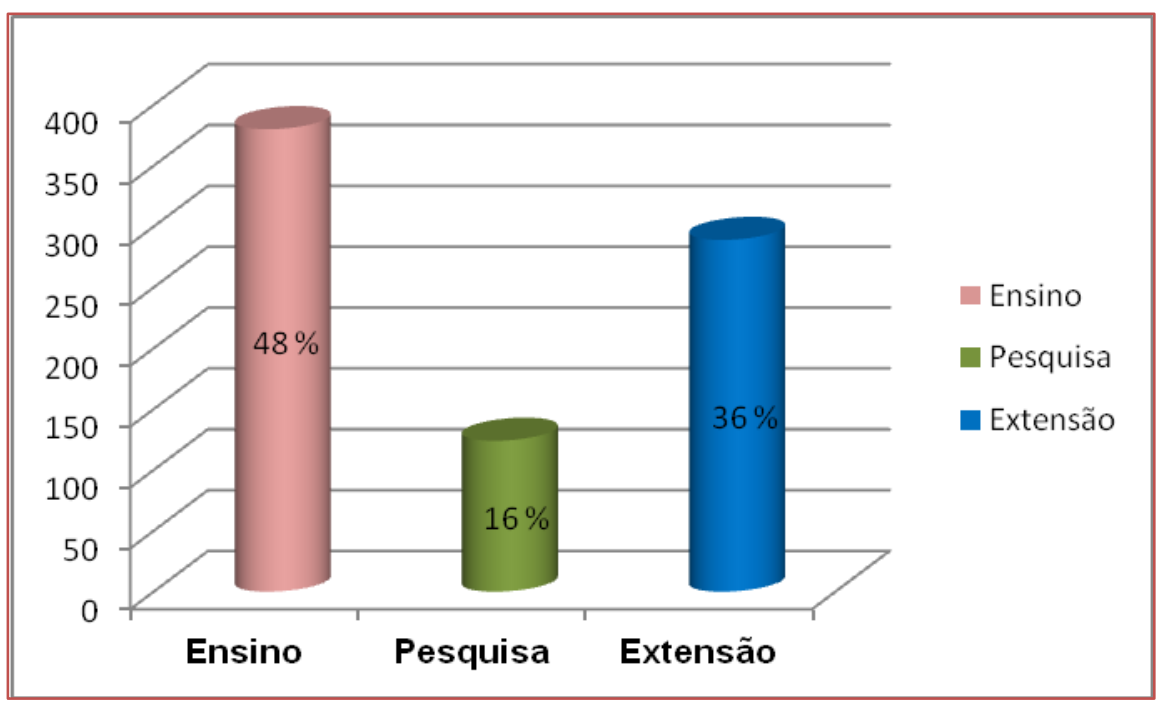

Fonte: Elaborado pelos autores.

As informações levantadas no Gráfico 1 apontam alguns aspectos da abordagem avaliada na instituição estudada. Devido à natureza das atividades operacionais nesta IES, algumas observações podem ser tecidas. Ressalta-se que a natureza dos relacionamentos permite efetuar uma avaliação, considerando as variáveis de competitividade adotadas pela IES. Os relacionamentos são explicitados no mapeamento da rede, conforme ROCHA (2015).

No que tange ao pilar ensino, a IES aparenta zelo no aspecto didático-pedagógico, por haver intenso relacionamento entre as Diretorias e as coordenações dos cursos de graduação, fato sedimentado no mapeamento do recorte da rede. 0 estágio curricular e a infraestrutura são aspectos relevantes a uma IES tecnológica. A qualidade de ensino torna-se fator preponderante para a unidade, sendo viabilizada pelo comprometimento do corpo docente e pela infraestrutura oferecida pela Instituição.

Ao analisar o pilar pesquisa, é possível observar que a IES adota indicadores de desempenho específicos ao pilar, mesmo considerando ser uma instituição pública, com a sua fundamentação exposta na LDB/96.

No tocante ao pilar extensão, algumas variáveis são tratadas com empenho, tais como cursos para a comunidade interna e externa, parcerias, intercâmbio cultural e captação de recursos devido a seu caráter público. Ao expressar o foco do CEETEPS na demanda social, a IES apresenta visível preocupação quanto à intensidade de seus relacionamentos envolvendo a comunidade. A pesquisa revelou que o indicador de 
desempenho "cursos e treinamentos" compõe o pilar extensão e o indicador "evasão" pertence ao pilar ensino.

A análise de critérios de desempenho adotados e o modo como as ações são executadas no âmbito interno da IES fornecem evidências que permitem avaliar a robustez de cada pilar ou as deficiências da IES analisada, observadas na relação dos seus aspectos competitivos que são traduzidos em critérios de desempenho. A partir da mesma perspectiva, outro estudo, conduzido por Macedo e Barbosa (2013), usa variáveis diferentes para verificar o potencial da IES e as dificuldades enfrentadas para melhorar a sua atuação no mercado.

O relacionamento mais próximo com as empresas torna-se possível por meio da participação em redes que possibilita aos envolvidos desfrutar dos benefícios do capital social (LAZZARINI, 2008). Outro aspecto a ser mencionado é que o conceito de capital social está associado a uma diversidade de elementos que envolvem algumas perspectivas da estrutura social e propicia a ação dos atores nessas estruturas (COLLEMAN, 1988; LAZZARINI, 2008).

\section{CONSIDERAÇÕES FINAIS}

Este estudo mostra o desenvolvimento e a aplicação de uma abordagem auxiliar ou técnica para subsidiar a análise da intensidade estratégica e pertinência das relações internas e externas à rede de uma IES. Optou-se por efetuar o estudo de caso em uma IES pública e de tecnologia para conhecer o tipo de negócio explorado pela rede e as suas condições de sucesso. 0 estudo realizado levantou os objetivos da IES, os indicadores de desempenho adotados e as atividades desenvolvidas pelos atores, relacionando-os com os critérios estabelecidos. Assim, as informações obtidas demonstram o grau de fortalecimento de cada pilar estratégico da Instituição. Verifica-se, então, que o gestor, de acordo com um ranking dos potenciais impactos sobre os resultados da instituição, analisa e toma decisões sobre as ações a serem adotadas.

É importante mencionar, todavia, que, embora o resultado obtido no caso apresentado possa, numa primeira vista, sugerir alguma falta de equilíbrio entre as ações, torna-se necessário proceder a uma avaliação mais ampla e precisa dessa IES, focando a diversidade dos objetivos estratégicos e do negócio explorado em si.

Por fim, quando se considera o ensino superior com suas variáveis numa perspectiva de redes de empresas, novos estudos podem ser elaborados com vista a melhorar a proposta apresentada e incorporar outros aspectos relevantes para a competitividade não abrangidos por este estudo.

\section{REFERÊNCIAS}

[1] AMATO NETO, J. Redes de cooperação produtiva e clusters regionais: oportunidades para as pequenas e médias empresas. São Paulo: Atlas: Fundação Vanzolini, 2008.

[2] BRASIL. Estabelece as diretrizes e bases da educação nacional - Lei no 9.394, de 20 de dezembro de 1996. Disponível em: < http://www.planalto.gov.br/ccivil_03/Leis/L9394.htm> . Acesso em: 20 maio 2016.

[3] BRITTO, J. N. P. Cooperação interindustrial e redes de empresas. In: KUPFER, David; HASENCLEVER, Lia (Org.). Economia industrial: fundamentos teóricos e práticos no Brasil. 2. ed. Rio de Janeiro: Campus, 2013.

[4] CASTELLS, M. A sociedade em rede. Tradução Roneide Venancio Majer. São Paulo: Paz e Terra, 1999.

[5] CEETEPS. Centro Estadual de Educação tecnológica Paula Souza. Perfil e histórico. Disponível em: <http://www.cps.sp.gov.br/quem-somos/perfil-historico/>. Acesso em: 20 jun. 2016.

[6] CHRISTOPHER, M. Logística e gerenciamento da cadeia de suprimentos: criando redes que agregam valor. Tradução: Mauro de Campos Silva. São Paulo: Thomson Learning, 2007.

[7] COLLEMAN, J. S. Social capital in creation of human capital. The American Journal of Sociology, Chicago, v. 94, p. 95-120, 1988. Disponível em: <http://www.jstor.org>..Acesso em: 15 set. 2008.

[8] FUSCO, J. P.; SACOMANO, J. B. Alianças em redes de empresas. São Paulo: Arte \& Ciência, 2009.

[9] GATTORNA, J. L.; WALTERS, D. W. Managing the supply chain: a strategic perspective. London: MacMillan Press, 1996.

[10] GIL, A. C. Como elaborar projetos de pesquisa. 5. ed. São Paulo: Atlas, 2010.

[11] GRANDORI, A.; SODA, G. Inter-firm networks: antecedents, mechanisms and forms. Organization studies, v.16, n. 2, p.1-19, 1995. 
[12] GRANOVETTER, M. The strength of weak ties. American Journal of Sociology, Chicago,v. 78, n. 6, p. 13601380, maio 1973.

[13] __ The strength of weak ties: a network theory reviseted. Sociological Theory, John Wiley \& Sons, v.1, p. 201-233, 1983.

[14] INEP - Instituto Nacional de Estudos e Pesquisas Educacionais Anísio Teixeira (Brasil). Disponível em: <http://portal.inep.gov.br/superior-censosuperior-sinopse>. Acesso em: 10 jun. 2016.

[15] JARILLO, J. C. Strategic networks: creating the borderless organization. Oxford: Butterworth - Heinemann, 1998.

[16] LAZZARINI, S.G. Empresas em rede. São Paulo: Cengage Learning, 2008.

[17] MACEDO, S. M. S.; BARBOSA, R. R. Information Management, information technology and behavior and value relation to information in higher education institutions (HEI) of Belo Horizonte. Brazilian Journal, v. 7, Special Number, p. 129-143, 2013.

[18] MARTINS, C. B. O ensino superior brasileiro nos anos 90. Revista São Paulo em Perspectiva, São Paulo, v. 1, n. 14 , p. 41-60, 2000.

[19] MIGUEL, P. A. C. Adoção do estudo de caso na engenharia de produção. In: MIGUEL, Paulo A. Cauchick (Org.). Metodologia de pesquisa em engenharia de produção e gestão de operações. Rio de Janeiro: Elsevier, 2010.

[20] PORTER, M. E. Vantagem competitiva: Criando e sustentando um desempenho superior. Trad. Elisabeth Maria de Pinho Braga. Rio de Janeiro: Elsevier, 1989.

[21] ___. Competição: estratégias competitivas essenciais. Rio de Janeiro: Campus, 1999.

[22] ROCHA, R. F. Análise dos relacionamentos em redes de ensino: Faculdade de Tecnologia de Garça/SP. Saarbrücken, Deutscland: Novas Editoras Acadêmicas, 2015.

[23] SACOMANO NETO, M. Redes: difusão de conhecimento e controle - um estudo de caso na indústria brasileira de caminhões. 2004. Tese (Doutorado em Engenharia de Produção) - Programa de Pós-Graduação em Engenharia de Produção, Universidade Federal de São Carlos, São Paulo.

[24] TEIXEIRA, E. B. et al. Cooperação estratégica, redes de cooperação e desenvolvimento regional: o caso Unijui. Desenvolvimento em Questão. v. 5, n. 10, p. 187-210, 2007. Disponível em: <http://redalyc.uaemex.mx/redalyc/pdf/752/75251008.pdf >. Acesso em: 12 dez. 2013.

[25] TEIXEIRA FILHO, J. Gerenciando conhecimento: como a empresa pode usar a memória organizacional e a inteligência competitiva no desenvolvimento dos negócios. Rio de Janeiro: Senac, 2000.

[26] VILELA, S. O ensino superior no estado de São Paulo: contribuição das universidades públicas paulistas. Revista Educação Brasileira, Brasília, DF, v. 29, n. 58-59, p. 15-28, jan./dez. 2007.

[27] YIN, R. K. Estudo de caso - planejamento e métodos. 4. ed. São Paulo: Bookman, 2010. 


\section{Capítulo 4}

ANÁLISE DO DESEMPENHO ECONÔMICOFINANCEIRO UMA COOPERATIVA DE PLANOS E ASSISTÊNCIA Aे SAÚDE DA CIDADE DE DOURADOS/MS

Kely da Silva Rodrigues

Reginaldo José da Silva

Gisele Alves Soares Rocha

Resumo: 0 segmento de plano e assistência à saúde enfrenta grandes dificuldades econômico- financeiras nos últimos anos, ocasionando a intervenção da agência reguladora Agência Nacional de Saúde Suplementar - ANS. O presente estudo de caso em uma cooperativa de trabalho médico de médio porte, da cidade de Dourados/MS, tem como objetivo, averiguar o desempenho econômico-financeiro de uma cooperativa de trabalho médico de médio porte, da cidade de Dourados/MS nos exercícios financeiros de 2014 a 2015. Os resultados obtidos, evidenciaram que os índices de rentabilidade do ativo e do patrimônio líquido tiveram taxas menores que o ideal para ser positiva, apesar disso a margem líquida apresentou resultados favoráveis e apontam para se a necessidade dos atentar-se quanto à busca por outras formas de geração de recursos.

Palavras-chave: Cooperativa médica, Agência Reguladora, Indicadores econômicos. 


\section{INTRODUÇÃO}

O cooperativismo é compreendido como um sistema onde um grupo de pessoas reciprocamente se obriga a contribuir com bens e serviços para o exercício de uma atividade econômica, de interesse comum, sem objetivo de lucro.

Em 1844, foi criada por tecelões na Inglaterra, a primeira cooperativa que se tem conhecimento no mundo: a "Sociedade dos Probos Pioneiros de Rochdale", eles montaram um armazém - a cooperativa de consumo - que teve destaque na época, tornando-se alternativa viável ao novo modelo econômico do século XIX: o capitalismo (OCB, 2004).

Segundo a Organização das Cooperativas Brasileiras - OCB, no Brasil, o cooperativismo se concretizou em 1889, nas Minas Gerais, com a fundação da Sociedade Cooperativa Econômica dos Funcionários Públicos de Ouro Preto.

Em 2013, ainda de acordo com o referido órgão, no Brasil o número desse tipo de sociedade chegava a 6.827, distribuídos nos mais diversos ramos de atividades: agropecuário, consumo, crédito, educacional, especial, habitacional, infraestrutura, mineral, produção, saúde, trabalho e transporte, turismo e lazer. 0 setor reuniu mais de 9 milhões de associados e gerou 300 mil empregos diretos.

A atividade econômica explorada nesta pesquisa será a de cooperativa do bem estar humano, segmento voltado para a área da saúde, mais especificamente plano de saúde.

Conforme dados da Agencia Nacional de Saúde - ANS

As cooperativas têm $32 \%$ de participação no mercado nacional de plano de saúde, atendendo 15,1 milhões de clientes. São 377 cooperativas médicas com abrangência em 74,9\% do território nacional, nas quais 106 mil médicos desenvolvem suas atividades. Até o final do exercício de 2014, o faturamento dessa atividade econômica somava $\mathrm{R} \$ 43.931 .353 .892,00$.

As cooperativas médicas são subordinadas à ANS e obedecem às legislações específicas, Resoluç̧ões Normativas, Resoluções da Diretoria Colegiada e Resoluções Operacionais.

A Agência Nacional de Saúde Suplementar (ANS) foi criada pela Lei 9.961 de janeiro de 2000 (Brasil 2000) e tem por objetivo "... promover a defesa do interesse público na assistência suplementar a saúde, regulando as operadoras setoriais, inclusive quanto as relações com prestadores e consumidores, contribuindo para o desenvolvimento das ações de saúde no país."

Nesse sentido, a ANS faz o acompanhamento da solvência desse mercado de saúde suplementar, pois esse é um fator fundamental quando se gerencia risco social envolvido - a vida humana e capital de terceiros (NOGUEIRA, 2004).

Segundo Câmara, Maia Sobrinho e Lima (2008), o segmento de saúde suplementar, no Brasil, enfrenta sérios problemas como baixos índices de liquidez e alta sinistralidade, ficando suscetível de sofrer intervenções por parte a ANS.

Pinheiro (2014) explica que o "desempenho econômico-financeiro das operadoras está ligado à forma com que elas têm sido geridas e refletem a pressão governamental exercida por conta do setor.".

Diante do cenário apresentado, este estudo propõe-se, através de um estudo de caso, mediante analise dos índices econômico-financeiro, responder ao seguinte questionamento:

qual o desempenho econômico-financeiro de uma cooperativa de trabalho médico de médio porte, da cidade de Dourados/MS. 0 período analisado para o estudo compreende os exercícios financeiros de 2014 a 2015.

Neste contexto, o presente estudo tem como objetivo, averiguar o desempenho econômico-financeiro de uma cooperativa de trabalho médico de médio porte, da cidade de Dourados/MS nos exercícios financeiros de 2014 a 2015.

\section{METODOLOGIA}

O presente estudo pode ser considerado como o estudo de caso que, conforme Gressler (2007) trata se um tipo de pesquisa que se dedica a estudos intensivos do passado, presente e de interações ambientais 
(socioeconômica, política, cultural) de uma unidade: indivíduo, grupo, instituição ou comunidade, selecionada por sua especificidade. Para Vedovatto, (2009), complementa que o estudo de caso é a pesquisa sobre determinado indivíduo, família, grupo ou comunidade que seja representativo do seu universo, para examinar aspectos variados de sua vida.

A fim de alcançar o objetivo proposto e de responder a questão de pesquisa estabelecida para este estudo foram utilizadas: informações contábeis disponibilizadas pela internet da cooperativa estudada. E ainda: livros, teses e dissertações, revistas especializadas para isso, realizou-se uma pesquisa quantitativa, descritiva e documental, construindo uma base com os dados contábeis da operadora com propósito de mensurar o desempenho por meio dos índices econômico-financeiros, posterior análise e interpretação dos dados.

A pesquisa teve como foco, uma cooperativa de trabalho médico de médio porte, da cidade de Dourados/MS nos exercícios financeiros de 2014 a 2015.

\section{REVISÃO DA LITERATURA}

A revisão de literatura Segundo Gil (2006) tem por finalidade, dentre outras, destacar e resumir as ideias já formuladas por outras pessoas, compará-las com alguns autores, descrever a evolução de conhecimentos sobre o tema, mostrar as contradições, reafirmar comportamentos ou interpretações.

Assim as seções seguintes abordam os aspectos conceituais de Instituições Cooperativas, Cooperativas Médicas e Índices Econômicos Financeiros.

\subsection{INSTITUIÇÕES COOPERATIVAS}

De acordo com Bialoskorski Neto (2000), o cooperativismo foi concebido em Rochdale em 1844, na Inglaterra e estava baseado nos princípios de solidariedade, igualdade, democracia e fraternidade.

No Brasil, o cooperativismo surgiu oficialmente em 1847, através do médico francês, Jean Maurice Faivre, que fundou a colônia Santa Tereza Cristina do Sertão do Paraná, durou pouco tempo, mas foi importante para o surgimento das cooperativas brasileiras. A colônia não era uma cooperativa, e sim uma organização que seguia os fundamentos cooperativistas (KREUTZ, 2004).

Sobre o aspecto da estrutura cooperativista, Bialoskorski Neto (2000) cita que pode ser visualizada através de seu organograma, por meio do qual se pode identificar a sua organização e composição administrativa, o seu funcionamento, e as atribuições de proceder à gestão do empreendimento cooperativista, conforme Figura 01.

Figura 01 - Organograma básico de uma cooperativa

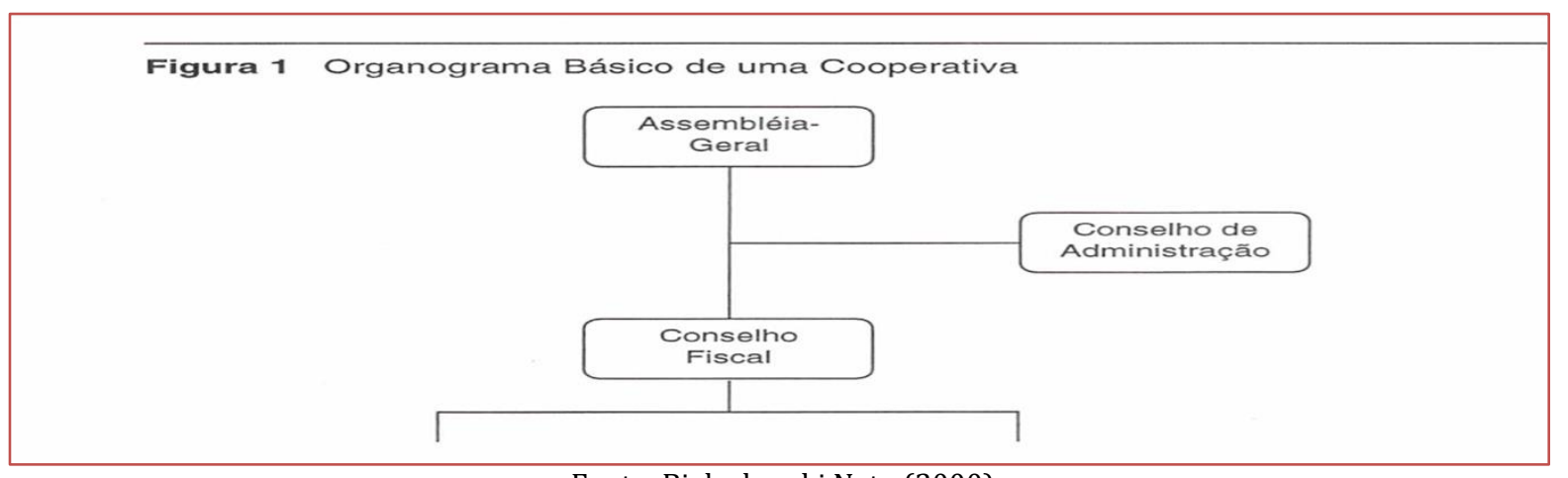

Fonte: Bialoskorski Neto (2000)

Segundo Pinheiro (2006), sociedades cooperativas são sociedades de pessoas, com forma e natureza jurídica próprias, constituída para prestar serviços aos associados, cujo regime jurídico, atualmente, é instituído pela Lei 5.764/ 1971. 


\subsection{COOPERATIVAS MÉDICAS}

Segundo a OCB, (2013), no Brasil o numero de cooperativas com ramo de atividade voltado à saúde, as cooperativas médicas, reporta se a 849.

De acordo com Almeida e Sant'anna, ( 2010) as cooperativas médicas constituem a modalidade em que os médicos são ao mesmo tempo sócios e prestadores de serviços e recebem pagamento de forma proporcional a produção de cada um, isto é, por tipo e quantidade de atendimento, rateando o resultado final obtido.

De acordo com Seibel (2003, apud Pinheiro, 2014), os cooperados devem se preocupar com sua eficiência e gestão, isto é, devem estar capacitados para a adequada gestão de custos gerados por si próprios no exercício de suas atividades, nos consultórios, clinicas e hospitais, conhecendo e vivenciando a dinâmica da organização, com a consciência de que são donos do negócio e precisam garantir a sobrevivência da operadora.

No âmbito do setor de saúde suplementar, as empresas são reguladas pelo Governo Federal, por meio da Agência Nacional de Saúde Suplementar (ANS), que busca promover segurança ao setor, por meio da defesa do interesse público na assistência à saúde e do monitoramento das empresas atuantes nesse setor (ANS, 2014).

Segundo a ANS, (2014), o segmento de plano e assistência à saúde enfrenta grandes dificuldades econômico-financeiras nos últimos anos, ocasionando a intervenção da agência reguladora, ANS, que tem como preocupação garantir a solvência das operadoras, exigindo cada vez mais, e buscando formas de melhorar a eficiência na aplicação dos recursos.

Dentre as preocupações da ANS, estão os aspectos financeiros das empresas do setor de saúde suplementar, e, dessas empresas, a agência reguladora vem exigindo capital mínimo, reservas técnicas e provisões de risco, como forma de assegurar a oferta e a assistência à saúde aos beneficiários dos planos privados de saúde.

No que se refere às garantias do equilíbrio financeiro e anormalidades econômico- financeiras a Lei 9656/98 que dispõe sobre os planos e seguros privados de assistência à saúde no artigo no 24 determina:

Sempre que detectadas nas operadoras sujeitas à disciplina desta Lei insuficiência das garantias do equilíbrio financeiro, anormalidades econômico-financeiras ou administrativas graves que coloquem em risco a continuidade ou a qualidade do atendimento à saúde, a ANS poderá determinar a alienação da carteira, o regime de direção fiscal ou técnica, por prazo não superior a trezentos e sessenta e cinco dias, ou a liquidação extrajudicial, conforme a gravidade do caso.

As operadoras de plano e assistência à saúde remetem a ANS informações trimestrais através do Documento de Informações Periódicas - DIOPS, para que possa ser feito o acompanhamento da situação econômico-financeira da organização.

Nogueira (2004) relata que o DIOPS é uma ferramenta que permite definir indicadores de desempenho, avaliar tendências, entre outras ações regulatórias, que é fundamental para que o órgão regulador possa atuar de maneira preventiva, com o objetivo de preservar o equilíbrio do mercado e assim, garantir a manutenção da assistência à saúde prestada.

A ANS utiliza vários indicadores para o monitoramento da solvência das operadoras: indicadores na avalição dos custos, do endividamento, da liquidez, entre outros.

\section{3 ÍNDICES ECONÔMICOS FINANCEIROS}

De acordo com Medeiros, (1994) os índices são as relações que se estabelecem entre duas grandezas, como por exemplo, entre contas ou grupo de contas das demonstrações contábeis, de forma a evidenciar aspectos da situação econômica da empresa.

Corroborando esta ideia, Matarazzo (2010), afirma que os índices consistem na relação entre contas ou grupo de contas do Balanço Patrimonial ou da Demonstração de Resultado do Exercício da empresa. Esses índices podem evidenciar a situação econômica ou uma situação financeira da empresa. 
Ainda segundo o autor os índices que evidenciam a situação econômica da empresa são chamados de Índices de Rentabilidade e avaliam o rendimento da empresa em relação às vendas e aos investimentos.

No que se refere aos índices que evidenciam a situação financeira da empresa são divididos em dois grupos, sendo eles: Índices de Estrutura de Capital, que indicam o grau de comprometimento financeiro da empresa perante seus credores e Índices de Liquidez procuram medir quão sólida é a base financeira da empresa, indicando a capacidade de pagamento da empresa com terceiros.

De acordo com Coelho (2005), a definição dos índices a ser utilizada numa análise depende exclusivamente da profundidade que se deseja assim, o presente estudo de caso utilizou se de uma análise das demonstrações financeiras de uma cooperativa de trabalho médico, a partir dos aspectos contidos nas estruturas patrimoniais, econômicas e financeiras, trabalhando com os índices de rentabilidade.

\section{ANÁLISE E DISCUSSÃO DOS RESULTADOS}

0 objeto dessa pesquisa é uma cooperativa de plano e assistência à saúde, de médio porte, com aproximadamente 50.000 (cinquenta mil) beneficiários em sua carteira, localizada na cidade de Dourados, atuando em 22 municípios de Mato Grosso do Sul.

Os dados foram obtidos através do cálculo dos indicadores econômicos: rentabilidade do ativo, rentabilidade do patrimônio líquido, margem líquida e giro do ativo.

0 índice de rentabilidade do ativo é obtido dividindo-se o lucro líquido pelo total do ativo. Conforme Ribeiro (2011), "esse quociente evidencia o potencial de geração de lucros por parte da empresa, isto é, quanto à empresa obteve de lucro líquido para cada \$ 1 de Investimentos totais.”.

Os dados acima evidenciam que houve diferenças significativas referentes à variação entre os períodos. A Tabela 1 Rentabilidade do ativo abaixo apresenta os índices de rentabilidade do ativo obtidos ao longo dos anos de 2014 e 2015.

Tabela 1 - Rentabilidade do ativo

\begin{tabular}{|c|c|c|c|}
\hline & 2014 & 2015 & VARIAÇÃ \\
\hline JAN & $3,15 \%$ & $1,62 \%$ & $-1,53 \%$ \\
\hline FEV & $0,77 \%$ & $0,59 \%$ & $-0,18 \%$ \\
\hline MAR & $-2,25 \%$ & $3,18 \%$ & $0,94 \%$ \\
\hline ABR & $1,93 \%$ & $0,60 \%$ & $-1,33 \%$ \\
\hline MAI & $-4,71 \%$ & $0,69 \%$ & $-4,02 \%$ \\
\hline JUN & $0,74 \%$ & $0,04 \%$ & $-0,70 \%$ \\
\hline JUL & $0,75 \%$ & $0,65 \%$ & $-0,10 \%$ \\
\hline AGO & $-5,94 \%$ & $0,63 \%$ & $-5,30 \%$ \\
\hline SET & $1,20 \%$ & $0,48 \%$ & $-0,71 \%$ \\
\hline OUT & $0,37 \%$ & $0,82 \%$ & $0,45 \%$ \\
\hline NOV & $3,00 \%$ & $0,22 \%$ & $-2,78 \%$ \\
\hline DEZ & $1,41 \%$ & $-3,88 \%$ & $-2,48 \%$ \\
\hline
\end{tabular}

Fonte: Dados da Pesquisa - Coop. Médica (2017)

Ao analisar a tabela Rentabilidade do ativo verifica se que em 2014, nos meses de março, maio e agosto a cooperativa obteve taxas negativas de rentabilidade do ativo, $-2,25 \%$,

$-4,71 \%$ e 5,94\% respectivamente, o que representa que sua operação não resultou em lucro e sim em prejuízo, assim como ocorre em dezembro de 2015, com uma taxa de $-3,88 \%$. Tal constatação, indica a necessidade de buscar outras fontes para gerar recursos, aumentando o endividamento da empresa.

Ainda de acordo com a tabela 1, percebe se que o melhor desempenho com relação ao índice em questão, ocorreu nos meses de janeiro de 2014, com uma taxa de 3,18\% e março de 2015, com 3,15\%.

No que se refere ao índice de rentabilidade do patrimônio líquido o mesmo é obtido através da divisão entre o lucro líquido e o patrimônio líquido. De acordo com Ribeiro (2011), tal indicador revela qual a taxa 
de rentabilidade obtida pelo Capital Próprio investido na empresa, isto é, quanto a empresa ganhou de Lucro Líquido para cada \$1 de Capital Próprio investido.

A Tabela 2 Rentabilidade do patrimônio líquido apresenta o calculo dos índices de rentabilidade do patrimônio líquido do período.

Tabela 2 - Rentabilidade do patrimônio líquido

\begin{tabular}{|c|c|c|c|}
\hline & 2014 & 2015 & VARIAÇÃO \\
\hline JAN & $7,91 \%$ & $4,39 \%$ & $-3,51 \%$ \\
\hline FEV & $2,03 \%$ & $1,64 \%$ & $-0,39 \%$ \\
\hline MAR & $-6,38 \%$ & $8,39 \%$ & $2,01 \%$ \\
\hline ABR & $5,44 \%$ & $1,63 \%$ & $-3,81 \%$ \\
\hline MAI & $-12,83 \%$ & $1,86 \%$ & $-10,97 \%$ \\
\hline JUN & $2,06 \%$ & $0,10 \%$ & $-1,96 \%$ \\
\hline JUL & $2,06 \%$ & $1,75 \%$ & $-0,32 \%$ \\
\hline AGO & $-19,26 \%$ & $1,67 \%$ & $-17,59 \%$ \\
\hline SET & $3,80 \%$ & $1,27 \%$ & $-2,52 \%$ \\
\hline OUT & $1,14 \%$ & $2,14 \%$ & $1,00 \%$ \\
\hline NOV & $8,40 \%$ & $0,59 \%$ & $-7,81 \%$ \\
\hline DEZ & $3,75 \%$ & $-10,94 \%$ & $-7,19 \%$ \\
\hline
\end{tabular}

Fonte: Dados da Pesquisa - Coop. Médica (2017)

Pôde-se observar que em de março, maio e agosto de 2014 obteve-se taxas negativas de rentabilidade do patrimônio líquido, $-6,38 \%,-12,83 \%$ e $-19,26 \%$ respectivamente, pois conforme visto na tabela anterior, nos referidos meses houve prejuízo, assim como em dezembro de 2015, com taxa de -10,94\%.

Sobre este contexto, Ribeiro (2011) explica que quanto maior for tal quociente, maior será o grau de lucratividade apurado pela empresa em relação ao Capital Próprio investido. E complementa que o resultado obtido pode ser comparado com outras formas de aplicações existentes no mercado financeiros como aplicações em poupança, ações, aluguéis, fundos de investimentos, etc.

No que tange o giro do ativo o índice é obtido através da divisão entre as vendas líquidas e o ativo total. Sobre esta analise, Ribeiro (2011) explica que esse quociente evidencia a proporção existente entre o volume de vendas e os Investimentos totais efetuados na empresa, isto é, quanto a empresa vendeu para cada \$ 1 de investimento total.".

A Tabela 3- Giro do ativo mostra a análise do giro do ativo do período de 2014 a 2015.

Tabela 3 - Giro do ativo

\begin{tabular}{|c|c|c|c|}
\hline & 2014 & 2015 & $-0,01$ \\
\hline JAN & 0,22 & 0,21 & $-0,02$ \\
\hline FEV & 0,21 & 0,19 & $-0,01$ \\
\hline MAR & 0,21 & 0,20 & $-0,01$ \\
\hline ABR & 0,20 & 0,19 & $-0,02$ \\
\hline MAI & 0,20 & 0,18 & $-0,03$ \\
\hline JUN & 0,20 & 0,17 & $-0,02$ \\
\hline JUL & 0,21 & 0,19 & 0,00 \\
\hline AGO & 0,19 & 0,19 & $-0,01$ \\
\hline SET & 0,20 & 0,19 & $-0,01$ \\
\hline OUT & 0,19 & 0,18 & $-0,03$ \\
\hline NOV & 0,21 & 0,18 & $-0,02$ \\
\hline DEZ & 0,21 & 0,19 & VARIAC̃O \\
\hline
\end{tabular}


Observa-se que em ambos os períodos o ativo não girou na totalidade, uma só vez, isso significa que o volume de vendas realizadas não foi adequado em relação ao Capital Total investido na empresa. Sobre este aspecto Ribeiro, (2011),menciona sobre a importância de se analisar o índice de margem líquida. A mesma é obtida mediante a divisão entre o lucro líquido e as vendas líquidas. Tal indicador revela a margem de lucratividade obtida pela empresa em relação ao seu faturamento, ou seja, quanto a empresa conseguiu de lucro líquido para cada $\$ 1$.

A Tabela 4 demonstra o resultado conseguido do cálculo da margem líquida do período de 2014 a 2015.

Tabela 4 - Margem líquida

\begin{tabular}{|c|c|c|c|}
\hline & 2014 & 2015 & VARIAÇÃO \\
\hline JAN & $14,33 \%$ & $7,90 \%$ & $-6,43 \%$ \\
\hline FEV & $3,73 \%$ & $3,13 \%$ & $-0,59 \%$ \\
\hline MAR & $-11,02 \%$ & $16,18 \%$ & $5,15 \%$ \\
\hline ABR & $10,25 \%$ & $3,18 \%$ & $-7,07 \%$ \\
\hline MAI & $-23,51 \%$ & $3,87 \%$ & $-19,64 \%$ \\
\hline JUN & $3,91 \%$ & $0,23 \%$ & $-3,68 \%$ \\
\hline JUL & $3,77 \%$ & $3,57 \%$ & $-0,20 \%$ \\
\hline AGO & $-31,38 \%$ & $3,38 \%$ & $-27,99 \%$ \\
\hline SET & $6,25 \%$ & $2,60 \%$ & $-3,65 \%$ \\
\hline OUT & $1,92 \%$ & $4,63 \%$ & $2,71 \%$ \\
\hline NOV & $14,93 \%$ & $1,31 \%$ & $-13,62 \%$ \\
\hline DEZ & $6,75 \%$ & $-21,13 \%$ & $-14,39 \%$ \\
\hline
\end{tabular}

Fonte: elaborada pelo autor

Observando a tabela 4, percebe se que houve prejuízo nos meses de março, maio e agosto de 2014, apresentando taxas negativas, $-11,02 \%,-23,51 \%$ e $-31,38 \%$ respectivamente, assim como em dezembro de 2015 , com taxa de $-21,13 \%$. Os períodos que tiveram maior margem líquida foi novembro de 2014, com $14,93 \%$ e março de 2015 , com $16,18 \%$.

Conforme mencionado anteriormente, é importante analisar a relação entre o quociente de margem líquida e o quociente do giro do ativo. Assim, se o índice do giro do ativo for inferior a 1 e o índice da margem líquida for superior a 1, poderá não corresponder a realidade da empresa.

\section{CONSIDERAÇÕES FINAIS}

No cenário que se exibe na atualidade, marcado pela competitividade entre as empresas, o desempenho econômico-financeiro apresenta se de extrema relevância aos diversos públicos de interesse, acadêmicos ou gerenciais, pois, pelo seu conhecimento, é possível avaliar as decisões acordadas, e, também, auxiliar nas futuras decisões.

A ANS, órgão regulador do segmento de plano e assistência à saúde, tem como preocupação garantir a solvência das operadoras, exigindo cada vez mais, e buscando formas de melhorar a eficiência na aplicação dos recursos.

Dentre as preocupações da ANS, estão os aspectos financeiros das empresas do setor de saúde suplementar, e, dessas empresas, a agência reguladora vem exigindo capital mínimo, reservas técnicas e provisões de risco, como forma de assegurar a oferta e a assistência à saúde aos beneficiários dos planos privados de saúde.

Neste contexto, o presente artigo que teve por objetivo: Averiguar o desempenho econômico-financeiro de uma cooperativa de trabalho médico de médio porte, da cidade de Dourados/MS nos exercícios financeiros de 2014 a 2015, analisou os indicadores de rentabilidade da cooperativa médica e os índices que apontam a situação financeira da empresa e concluiu-se a partir dos resultados obtidos: 
As variações apuradas no período analisado, referentes à rentabilidade do ativo e do patrimônio líquido, foram significativas por conta do prejuízo ocorrido em alguns dos meses investigados.

Diante de tal fato, verificou-se que cooperativa necessita de mais tempo para dobrar os investimentos efetuados no seu ativo, bem como o retorno do capital próprio investido pelos cooperados.

Constatou se também que mediante os índices apresentados, considera se a necessidade dos atentar-se quanto à busca por outras formas de geração de recursos, o aumento do endividamento, tende ao afastamento das metas da ANS em manter a solvência da operadora.

No entanto, apesar do resultado negativo em alguns períodos, a cooperativa conseguiu obter margem líquida positiva nos demais meses, o que demonstra que suas vendas foram suficientes para cobrir seus custos.

De modo geral, os autores deste estudo, afirma que o objetivo pretendido foi alcançado e, ressalvadas as limitações, a pesquisa contribui para ampliação da discussão acerca do tema. Os resultados obtidos sugerem futuras pesquisas de análise de outros indicadores econômicos e ainda os índices de outras operadoras de plano e assistência à saúde que possibilite a identificação e a comparação dos resultados do desempenho das operadoras,

\section{REFERÊNCIAS}

[1] ALMEIDA, R.G.; SANT“ANNA, A.P. Composição probabilística na avaliação do risco de operadoras de planos de assistência à saúde. R. Bras. Risco e Seg., Rio de Janeiro, v. 6, n. 11, p. 1-34, abr./set. 2010. Disponível em: < http://docvirt.com/docreader.net/DocReader.aspx?bib=funenseg2_wi\&pagfis=21470\&pesq=> Acesso em: 21 de agosto de 2016.

[2] ANS TABNET. Informações em Saúde Suplementar. Disponível em: < http://www.ans.gov.br/anstabnet/cgibin/dh?dados/tabnet_rc.def> Acesso em: 02 de abril de 2016.

[3] BIALOSKORSKI NETO, S. Agroindústria Cooperativa: Um Ensaio Sobre Crescimento E Estrutura De Capital, Gestão \& Produção v.5, n.1, p. 60-68, Acesso 22 de Agosto 2016

[4] BRASIL. Lei $\mathrm{n}^{\circ}$ 9.961, de 28 de janeiro de 2000. Disponível em: < http://www.planalto.gov.br/ccivil_03/leis/L9961.htm > Acesso em: 22 de agosto de 2016.

[5] BRASIL. Lei $\mathrm{n}^{\circ}$ 9656, de 3 de junho de 1998 . Disponível em: < http://www.planalto.gov.br/ccivil_03/leis/L9656.htm> Acesso em: 28 de agosto de 2016.

[6] CÂMARA, R.P.B.; MAIA SOBRINHO, M.R.; LIMA, L.S. Análise financeira nas operadoras de planos de saúde. Rev. Ciênc. Admin., Fortaleza, v. 14, n.1 , p. 105-121, ago. 2008. Disponível em: < http://ojs.unifor.br/index.php/rca/article/view/252> Acesso em: 21 agosto de 2016.

[7] CERVO E BERVIAN apud VEDOVATTO, Eliana. A auditoria interna como ferramenta de gestão nas cooperativas de crédito. Disponível em: <http://www.cresol.com.br/site/upload/_downloads/54.pdf> Acesso em: 15 de agosto de 2016.

[8] COELHO, Ediomar César. Análise econômico-financeira de empresas de revestimento cerâmico. Florianópolis, 2005. Disponível em: < http://tcc.bu.ufsc.br/Contabeis294339> Acesso em: 21 de agosto de 2016.

[9] Fernandes, F., Ferreira, M. E., \& Rodrigues, E. R. (2014). Análise de Rentabilidade utilizando o Modelo Dupont: estudo de caso em uma operadora de planos de saúde. Revista de Gestão em Sistemas de Saúde, 3(2), 30-44.

[10] GRESSLER, Lori Alice. Introdução a pesquisa - projetos e relatórios. 3. ed. São Paulo: Loyola, 2007.

[11] MATARAZZO apud PINHEIRO, Isabel Cristina Barbosa. Efeitos da regulação econômico- financeira nas estratégias de financiamento das operadoras de plano de saúde: cooperativas médicas versus medicinas de grupo. São Paulo, $2014 . \quad$ Disponível em: < http://tede.fecap.br:8080/jspui/bitstream/tede/526/1/Isabel_Cristina_Barbosa_Pinheiro.pdf> Acesso em: 21 de agosto de 2016.

[12] MEDEIROS, L.E. Análise Econômico-Financeira. 2. ed. Porto Alegre: Ortiz, 1994.

[13] NOGUEIRA, Carlos Alexandre Lima. Análise da estrutura econômica da saúde suplementar: em busca de uma estrutura eficiente de mercado. Rio de Janeiro, 2004. Dissertação de Mestrado apresentada à Escola Nacional de Saúde Pública.

[14] OCB - ORGANIZAÇÃO DAS COOPERATIVAS BRASILEIRAS. Cooperativismo Brasileiro: uma história. Ribeirão Preto, SP. Versão Br Comunicação e Marketing, 2004. 
[15] PINHEIRO, Isabel Cristina Barbosa. Efeitos da regulação econômico-financeira nas estratégias de financiamento das operadoras de plano de saúde: cooperativas médicas versus medicinas de grupo. São Paulo, 2014. Disponível em: <http://tede.fecap.br:8080/jspui/bitstream/tede/526/1/Isabel_Cristina_Barbosa_Pinheiro.pdf> Acesso em: 21 de agosto de 2016.

[16] RIBEIRO, Osni Moura. Estrutura e análise de balanços fácil. 9 ed. São Paulo: Saraiva, 2011.

[17] SAMPAIO, L.M.D.; IGNACIO, A.A.V.; OLIVEIRA, M.J.F. Análise econômico financeira das operadoras de saúde suplementar através da DEA - $\quad$ Não Arquimediano. Disponível em: http://www.din.uem.br/sbpo/sbpo2010/pdf/72643.pdf> Acesso em: 21 de agosto de 2016.

[18] SEIBEL apud PINHEIRO, Isabel Cristina Barbosa. Efeitos da regulação econômico- financeira nas estratégias de financiamento das operadoras de plano de saúde: cooperativas médicas versus medicinas de grupo. São Paulo, 2014. Disponível em:

http://tede.fecap.br:8080/jspui/bitstream/tede/526/1/Isabel_Cristina_Barbosa_Pinheiro.pdf> Acesso em: 21 de agosto de 2016. 


\section{Capítulo 5}

\section{IMPLEMENTAÇÃO DE INDICADORES DE DESEMPENHO DA QUALIDADE EM UMA FABRICANTE DE EMBALAGENS PARA ALCANCE DAS METAS ORGANIZACIONAIS}

\section{Silvana Ribeiro Cobé}

Resumo: A melhoria contínua da qualidade faz parte do plano de negócios de muitas empresas como força competitiva no mercado. Dessa forma, busca-se a soma de esforços para implementar medidas que promovam o aperfeiçoamento da qualidade de seus produtos/serviços. Esse estudo trata-se do desenvolvimento de um conjunto de indicadores da qualidade em uma empresa fabricante de embalagens para óleos lubrificantes automotivos, para aferir a capabilidade de seus processos e proporcionar a melhoria contínua da qualidade de seus produtos. 0 objetivo desse trabalho é realizar a análise da implementação desses indicadores e como contribuíram para a melhoria do Sistema de Gestão da Qualidade da empresa em questão, assim como para seus processos e produtos. Vale ressaltar que os mesmos foram criados a fim de contribuir na realização de tratativas corretivas e preventivas com o objetivo de reduzir as não conformidades, retenções internas e custos gerados pelas mesmas. Assim como reduzir as situações de riscos diárias de defeitos, tornando o processo mais estável e confiável. Os resultados mostraram que os planos de ação, resultantes da implementação dos indicadores, contribuíram para um crescimento no percentual de produtos aprovados nas linhas que receberam tratativas, além de trazer melhorias qualitativas para a cultura organizacional da empresa.

Palavras-chaves: Indicador de desempenho, Qualidade, Melhoria contínua. 


\section{INTRODUÇÃO}

A busca pela qualidade tanto dos processos produtivos como do produto final tem sido cada vez mais almejada pelas empresas. Essa demanda tem sido uma exigência dos clientes, bem como, uma alternativa para melhorar o desempenho dos processos e reduzir os custos com desperdícios e retrabalhos.

A Qualidade passou a ser vista como uma estratégia de negócios dentro das organizações e servem como suporte para o crescimento e desenvolvimento das mesmas (LIMA, 2006).

A chave para a qualidade é a mensuração precisa da performance dos processos, visando identificar o atual posicionamento das operações para então desenvolver estratégias capazes de reverter esse nível e alcançar o desempenho ideal.

Existem diversas maneiras de medir o progresso das atividades de rotina de uma organização, entre elas, podemos citar, devido à facilidade de implementação e desenvolvimento estruturado, os indicadores de desempenho ou KPI's (Key Performance Indicator).

Para uma empresa que pretenda ter uma cultura de excelência, necessita ter um pensamento sistêmico, medindo tanto os processos organizacionais, como os operacionais. 0 desempenho deve ser analisado e controlado para constatar se os objetivos e metas estão sendo atingidos e para definir as ações a serem tomadas e decidir as prioridades a serem traçadas (FNQ, 2010).

Segundo a NBR ISO 9001:2015, no item 4.4.1, diz que a organização deve estabelecer, implementar, manter e melhorar continuamente seu sistema de gestão da qualidade, incluindo os processos necessários e suas interações. A organização deve determinar os processos necessários para o sistema de gestão da qualidade e sua aplicação na organização, e deve determinar e aplicar os critérios e métodos (incluindo monitoramento, medições dos indicadores de desempenho relacionados) necessários para assegurar a operação e o controle eficazes desses processos.

Em suma, a qualidade está diretamente relacionada com a capacidade de identificar as características que afetam a qualidade dos processos, sua mensuração e monitoramento. Sendo necessária a criação e análise de indicadores de desempenho, para então ser possível melhorar e alcançar as metas definidas da organização.

\section{OBJETIVO GERAL}

O objetivo desta pesquisa consiste em analisar o processo de implementação de um conjunto de indicadores de desempenho da qualidade em uma empresa fabricante de embalagens. E verificar se, após o processo de implementação, o modelo de sistema de medição desses indicadores auxiliaram na melhoria contínua da qualidade, e consequentemente, no alcance das metas da organização.

\subsection{OBJETIVOS ESPECÍFICOS}

Para o alcance do objetivo geral, serão considerados os seguintes objetivos específicos:

a) Criar um indicador interno da qualidade na empresa de embalagens, de forma a coletar dados verídicos e consistentes, com uma plataforma de fácil utilização dos usuários para input dos dados.

b) Alinhar de forma clara e objetiva o método de avaliação para apontar as ocorrências diárias de produtos não conformes, situações de risco de envio de produtos não conformes para o cliente e o levantamento dos defeitos mais recorrentes.

c) Analisar os dados e usar método de priorização para as tratativas através dos cinco maiores problemas da linha de produção escolhida.

d) Utilizar ferramentas da qualidade para análise de causa raiz e plano de ação para as tratativas para a melhoria da qualidade dos produtos e ocorrências diárias.

e) Verificar a contribuição na melhoria do processo produtivo a partir do levantamento de dados e aplicação de possíveis soluções para os problemas identificados, assim como o atendimento das metas organizacionais. 
Desta forma, pretende-se demonstrar a importância da utilização de um sistema de medição como ferramenta para controlar os processos operacionais e melhorar o nível de qualidade dos produtos, contribuindo para a gestão estratégica da organização em questão e proporcionando uma forma de gerenciamento mais estruturada e fundamentada em dados, técnicas específicas e visão sistêmica.

\section{SITUAÇÃO PROBLEMA}

0 presente trabalho trata-se de uma pesquisa exploratória, de caráter quantitativo e qualitativo. 0 estudo de caso foi voltado para a implementação e análise de indicadores internos de desempenho utilizados no setor de qualidade de uma empresa localizada no Rio de Janeiro, que fabrica embalagens para envase de óleos lubrificantes automotivos. Tais indicadores foram desenvolvidos para sinalizar as principais causas de reprovação de produtos de cada linha de produção, antes de se tornar uma não conformidade de cliente, bem como contribuir para possíveis propostas de solução.

A empresa sofria com altos índices de não conformidades de clientes e devoluções constantes resultantes de produtos defeituosos e sem o nível de qualidade esperado. 0 único indicador da qualidade era o corporativo chamado "Number of Complaints per 10MM sold" que apresentava dados referentes ao número de não conformidades em relação ao número de produtos vendidos, como mostra na figura 1, este indicador estava muito acima do target máximo no ano de 2016, ano anterior ao da implementação dos indicadores internos de controle e início do estudo que foi realizado em 2017. 0 target máximo em 2016 era de 3.660 per 10MM vendidos e o resultado das não conformidades ao final do ano de 2016 ficou em 5.372 per 10MM, ou seja, 1.712 per 10MM acima da meta máxima estipulada pela alta direção.

Figura 1- Indicador corporativo - 2016

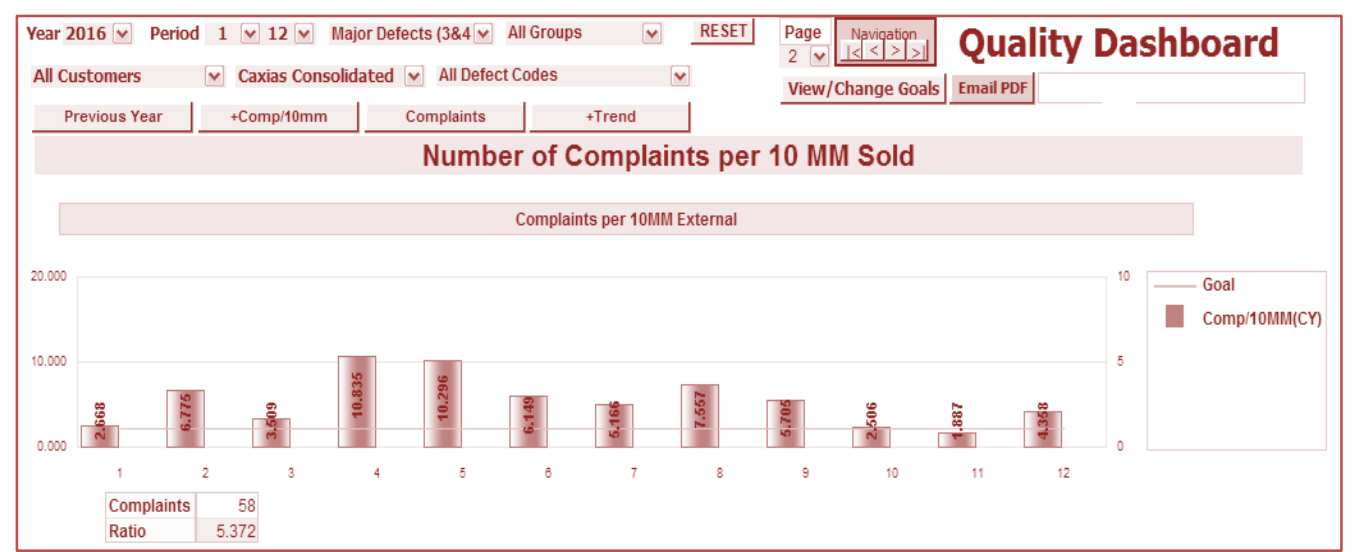

Fonte: Empresa

A relevância do uso dos indicadores internos de desempenho no setor da qualidade é de promover a melhoria proativa, que consiste em utilizar os indicadores de desempenho como parte da informação necessária para propor ações que previnam problemas futuros ou atinjam desempenho nunca antes imaginado. Com este controle interno, análise e proposta de ações previamente identificadas, são esperadas que o impacto final fosse de diminuir o índice de não conformidades do cliente e por consequência diminuir sua insatisfação. Ações de melhoria reativa ou proativa, feita com base na informação contida nos indicadores, tem grande chance de contribuir com o objetivo da organização e atendimento de suas metas.

Sistema de indicadores de desempenho é um tema muito estudado e discutido em diferentes tipos de setores tanto fabril quanto de serviços e por diversos autores, tais como Kaplan, Norton, entre outros. Estes autores justificam a importância dos sistemas de indicadores de desempenho como um elemento essencial para o gerenciamento e monitoramento do desempenho da empresa, pois, os indicadores fornecem informações que ajudam o planejamento, o controle de processos gerenciais e monitoramento das metas estratégicas (COSTA, 2003).

Por isso foi elaborada uma questão de pesquisa referente ao objetivo geral proposto:

Qual a relação entre indicadores de desempenho e o alcance das metas organizacionais? 
Além disso, foi realizada uma revisão bibliográfica, a fim de compreender termos chaves relativa aos Indicadores de Desempenho (KPI's), bem como, a análise da autora e analista da qualidade, responsável pela implementação do indicador. Além disso, a empresa forneceu dados quantitativos do acompanhamento contínuo de cada linha produtiva, necessários para as análises realizadas.

\section{REVISÃO DA LITERATURA}

Os indicadores de desempenho, também chamados de KPI (Key Performance Indicators) são métricas que quantificam o nível de desempenho de processos e são úteis na comparação do desempenho real e o estimado.

Segundo Machado (2014), a utilização desses indicadores fornece às empresas um conjunto de benefícios, tais como: a possibilidade de providenciar dados oportunos, ou seja, significantes para um dado processo, formalizar o estado atual de uma organização, antecipar as mudanças drásticas que poderão ocorrer, ajudar na tomada de decisão e na compreensão e/ou verificação dos objetivos definidos, entre outros.

A aplicação dos indicadores surge após a organização ter definido a missão, as partes interessadas do negócio (stakeholders) e os objetivos a serem alcançados. A partir de então são desenvolvidos indicadores capazes de medir o progresso dos viabilizadores dos objetivos definidos. Em termos práticos, esses objetivos serão mais facilmente alcançados através da criação, implementação e controle dos indicadores de desempenho (MACHADO, 2014).

Os indicadores são ferramentas chave, pois a partir deles pode-se identificar se a empresa está seguindo no rumo planejado e se estão em busca do atendimento dos objetivos estratégicos traçados (KAPLAN; NORTON, 1997).

De acordo com Fischmann e Zilber (1999), os indicadores auxiliam os gestores a identificar a performance de seu negócio para então tomar decisões mais assertivas, além de permitir que os problemas sejam mais facilmente identificáveis e que o alinhamento estratégico da empresa seja validado. Entretanto, é necessário definir os KPI's corretamente, pois medições erradas podem levar o negócio a um retrocesso, ocasionar perdas e levar a empresa a tomar decisões equivocadas. Além disso, é necessário que os KPI's estejam alinhados com os objetivos organizacionais, caso contrário, serão apenas medições irrelevantes para as atividades de análise desempenho dos objetivos (MACHADO, 2014).

Segundo Slack et al. (2006), há cinco objetivos gerais de desempenho: qualidade, velocidade, flexibilidade, confiabilidade e custo. No entanto, para este trabalho, teremos foco no desempenho da qualidade, que diz respeito ao nível de reclamação do consumidor, tempo médio entre falhas, número de defeitos por unidade, ou seja, informações capazes de identificar possíveis melhorias dentro da empresa, tornando-a mais competitiva perante o mercado que atua. Além disso, um bom desempenho na qualidade dos produtos também facilita a vida das pessoas envolvidas na operação, que também é tão importante quanto satisfazer os clientes externos, pois, qualidade reduz custos e aumenta a confiabilidade. Quanto menos erro em cada linha de produção menos tempo será desperdiçado para a correção e, consequentemente, menos confusão e irritação dos envolvidos.

De acordo com Dornier et al. (2000, p.629), os indicadores de desempenho são peças chave do sistema de controle e análise, e permitem que ações e decisões sejam tomadas de forma coerentes e vislumbrando a estratégia da empresa. Na Figura 2 é demonstrada a relação dos indicadores nos resultados das ações geradas pela organização em relação a sua estratégia. 
Figura 2 - Relacionamento entre medidas e estratégia

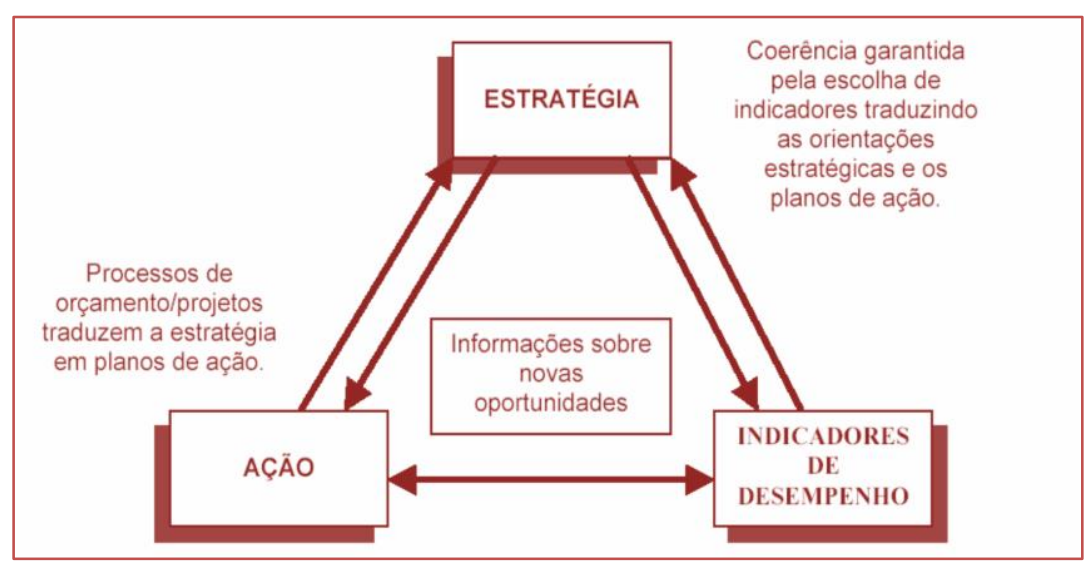

Fonte: Dornier et al, 2000, p.630.

Através da coleta de dados para os indicadores, classificações corretas, análises e interpretação dos resultados, a medição de desempenho quantifica a eficiência dos processos com resultados relacionados à utilização de recursos e a eficácia dos processos com resultados relacionados ao cliente, direcionando as tratativas a serem tomadas (CARPINETTI, 2012).

Segundo o FPNQ (2004) as principais funções de um sistema de medição de desempenho são: comunicar a estratégia da organização; comunicar as prioridades da alta direção e dos gestores; reconhecer a dedicação coletiva; analisar os problemas de forma proativa; incentivar a tomada de decisão; colaborar com a busca de novos caminhos estratégicos; e corroborar com o aprendizado da organização.

Partindo dos princípios apresentados que a implementação e utilização dos indicadores de desempenho são ferramentas chaves para o sucesso da empresa, o presente trabalho implementará e analisará a contribuição dos indicadores de desempenho como viabilizadores para melhoria contínua da qualidade dos produtos da empresa em questão e alcance das metas organizacionais.

\section{METODOLOGIA}

\subsection{A ORGANIZAÇÃO ESTUDADA E O PROCESSO PRODUTIVO}

A empresa é uma das líderes mundiais no desenvolvimento, manufatura e venda de embalagens plásticas. Atualmente, participa em quatro mercados globais: América do Norte, América Latina, Ásia e Europa e em quatro linhas de produtos principais: Automotivo, Alimentício, Químico e Produtos de Limpeza e Higiene. Suas embalagens são fabricadas principalmente com Polietileno de Alta Densidade (PEAD), Polietileno Tereftalato (PET) e Polipropileno (PP).

A unidade fabril foco deste estudo localiza-se no Rio de Janeiro, com tecnologias voltadas para conformação de polímeros, principalmente Polietileno de Alta Densidade (PEAD) através de processos de extrusão e sopro, a fábrica opera de segunda a sábado em três turnos rotativos (manhã, tarde e noite). Seu portfólio de produtos é dedicado apenas a dois clientes voltados para a produção de frascos de óleo lubrificante automotivo, tendo um total de sete linhas produtivas com sku's de 0,5 L, $1 \mathrm{~L}, 3 \mathrm{~L}$ e $20 \mathrm{~L}$.

Os frascos são compostos basicamente de resina virgem (PEAD), de grânulos responsáveis pela coloração das embalagens (máster) e de material moído resultante de rebarbas e de frascos não conformes (regrind). A resina é transportada de silos que a armazenam, até os alimentadores da máquina (funil de alimentação), que são os equipamentos onde ocorre a dosagem e a mistura da matéria-prima (resina, máster e regrind) ainda em grânulos ou pelletes como são chamados, como podemos ver na figura ilustrativa 3. Em seguida, os grânulos são transportados até a extrusora que é onde ocorre a homogeneização e fundição deste material, formando um melt. A extrusora é composta de três seções: seção de alimentação, seção de compressão e seção de dosagem, como podemos observar na figura 3.

Posteriormente, esse melt segue em direção a uma parte da máquina chamada de cabeçote também ilustrado na figura 3, onde é realizada a distribuição de massa e sai em um formato denominado parison, como podemos ver na figura 4. 
Figura 3 - Vista de corte de uma extrusora de rosca utilizada para o processamento de materiais poliméricos

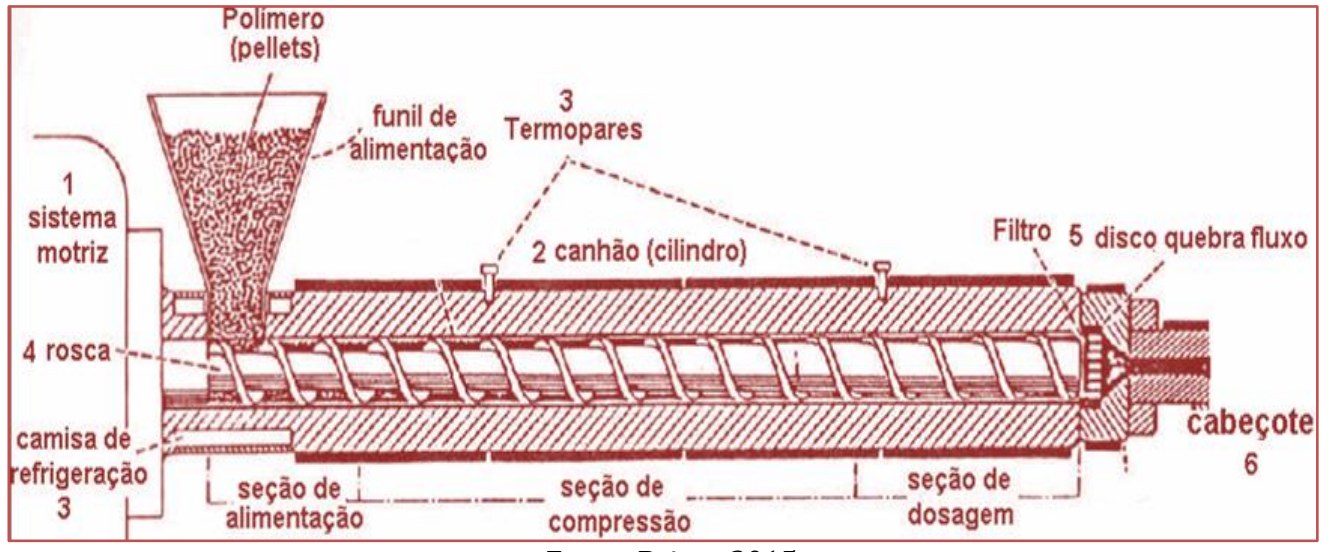

Fonte: Britto, 2015.

O material dimensionado segue para as cavidades da máquina, que são moldes no formato da embalagem a ser produzida. No interior do molde acontece o sopro aquecido contra as cavidades, através de um pino introduzido no mesmo (pino de sopro), fazendo com que o parison seja inflado e assume o formato imposto pela cavidade. Ainda no interior do molde, ocorre um processo de resfriamento do frasco recémformado, por canais de água gelada, cuja função é causar um choque térmico de modo a fornecer rigidez ao produto antes de sua extração.

Figura 4 - Moldagem por extrusão e sopro

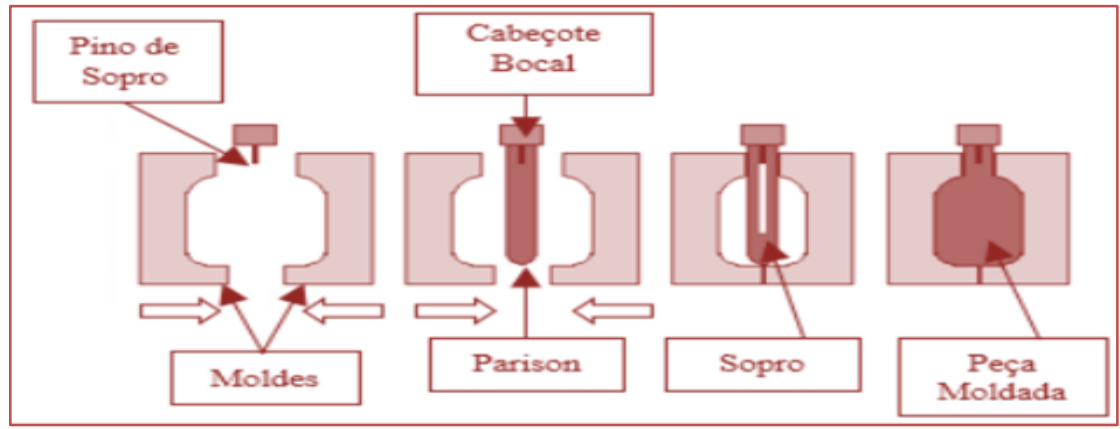

Fonte: Paula, 2016.

Após esse processo, cada molde expele o frasco formado, ainda com suas rebarbas inferior e superior. Esse conjunto segue pela esteira até a mesa de rebarbação, onde ocorre a separação do frasco e a retirada de suas rebarbas.

Após a retirada do material sobressalente, as garrafas passam por um sistema poka-yoke na linha produtiva, que é composto por sensores e câmeras cuja função é identificar algumas não conformidades no produto, como, por exemplo: gargalos prolongados, bocais amassados e furos. Em seguida, dependendo da unidade produtiva, os frascos são encaminhados ao estoque ou seguem direto para linha de envase do cliente.

\subsection{A CRIAÇÃO E IMPLEMENTAÇÃO DE UM NOVO INDICADOR}

Antes da implementação dos indicadores, o registro dos produtos defeituosos era realizado pelos inspetores da qualidade de cada turno em formato de planilha denominado Relatórios Diários da Qualidade (RDQ's). Os mesmos continham a descrição breve das ocorrências do turno, assim como os problemas identificados e as ações imediatas, e eram enviados apenas via e-mail. Os RDQ's serviam para 
comunicar os inspetores de outros turnos, líderes e gerência sobre o desempenho produtivo e também evidenciar os principais problemas ocorridos no turno.

No entanto, a emissão desses dados não era padronizada, nem guardadas em um banco de dados de forma fácil a resgatar as informações e verificar o histórico, também não eram tratados de modo a fornecer um estudo mais profundo que permitisse, por exemplo, verificar os defeitos de maior frequência em cada linha, os tipos de defeitos, quais as máquinas com maiores problemas, dentre outros fatores que inviabilizam uma avaliação do nível de qualidade requerido. Diante disso, surgiu a necessidade da elaboração de alguma estratégia que fosse capaz de fornecer dados que auxiliem nesse processo de gestão, tornando-o mais eficaz e eficiente.

Observou-se que havia uma lacuna sistêmica, que deveria ser desenvolvida para atender o sistema de gestão e melhoria da qualidade dos produtos fornecidos, visando atender a demanda anteriormente citada, foi criado um conjunto de indicadores internos, apresentados graficamente, que mensuram a variabilidade e tendência dos produtos de cada linha produtiva. 0 mesmo teve como base de dados a própria planilha do RDQ’s dos inspetores, pois já possuía uma interface familiar que seria de fácil adaptação dos usuários, esta planilha foi reestruturada no software Excel através da linguagem VBA, nela foi inserido uma coluna de notas que avaliam o produto em relação as análises dimensionais e visuais, e uma coluna com uma lista padronizada dos defeitos que tenham ocorrido durante o turno, como mostra a figura 5 .

Figura 5 - Relatório Diário da Qualidade (RDQ)

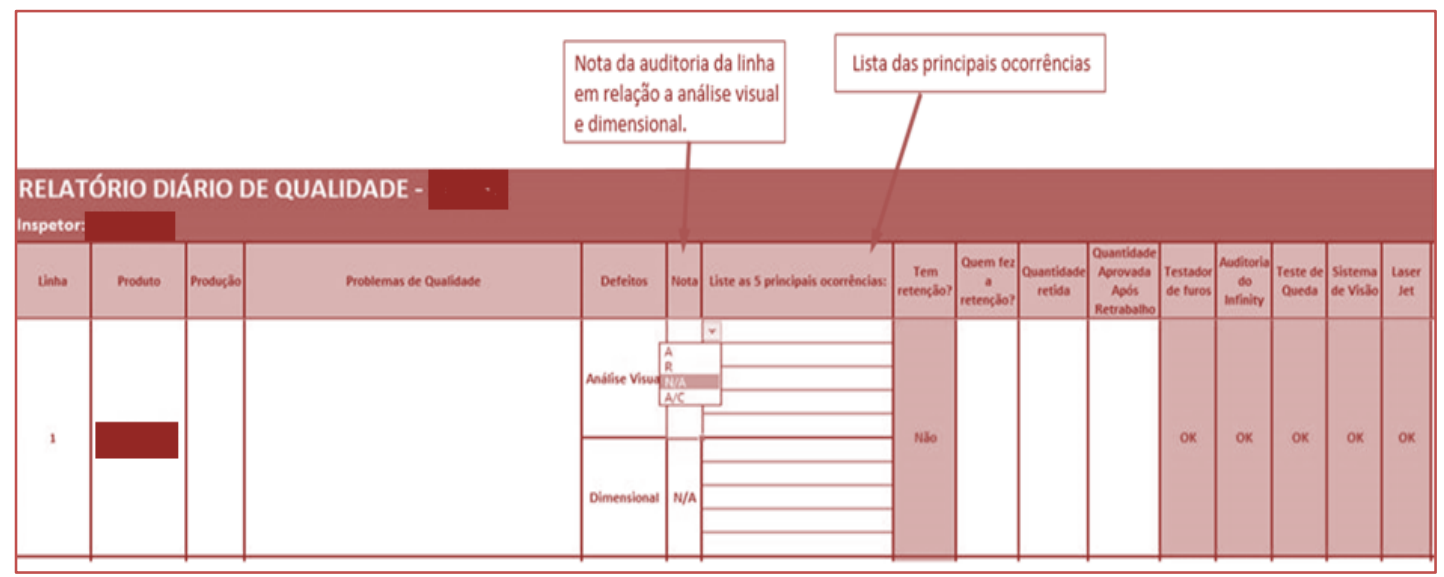

Fonte: Empresa

Segundo a NBR ISO 9001:2015, um produto não conforme é aquele que não atende algum requisito préestabelecido. Na empresa estudada, os problemas identificados em produtos não conformes são classificados em dois tipos: dimensionais e visuais. Defeitos dimensionais são referentes a problemas que não atendem as especificações definidas no projeto do produto: peso, alturas, espessuras e diâmetro do bocal. E são aferidos através de instrumentos de medição como balanças e paquímetros. Em contrapartida, um defeito visual diz respeito a questões estéticas que podem ou não influenciar no aspecto funcional do produto. Por isso, a nota a ser inserida deve ser dada aos dois tipos de defeitos por linha produtiva, dimensional e visual.

Para a empresa em questão, o critério de avaliação adotado para a coluna de notas foi:

- "A" de aprovado - Os produtos aprovados são aqueles que cumpriram todas as especificidades técnicas do cliente.

- "R" de reprovado - Por outro lado os reprovados são os que não cumpriram as especificidades e por isso não seguem para o cliente e devem ser tomadas ações imediatas, como a parada do envio e retenção do produto.

- “A/C" de condições aceitáveis - Já os produtos em condições aceitáveis, são os que apresentam algum tipo de não conformidade, dimensional ou visual, mas em um nível mínimo aceitável, que não compromete a funcionalidade dos produtos e não geram não conformidades do cliente. 
- "N/A" de não se aplica - Neste caso é utilizado o não se aplica se a unidade produtiva estiver inoperante e desprogramada, não contando positivamente nem negativamente para o cálculo do indicador.

Já a coluna que deve ser inserido as cinco principais ocorrências do turno, deve ser preenchida apenas em caso de produtos reprovados ou em condições aceitáveis. Na tabela 1 consta a listagem padronizada com todas as possíveis não conformidades identificadas pela empresa. Nessa tabela, a seguir, entende-se como LIE o limite inferior especificado e LSE significa limite superior especificado (tratam-se do range préestabelecido de cada parâmetro desejado).

Tabela 1 - Lista de defeitos das embalagens

\begin{tabular}{|c|c|c|c|c|}
\hline \multicolumn{3}{|c|}{ DEFEITOS VISUAIS } & \multicolumn{2}{|c|}{ DEFEITOS DIMENSIONAIS } \\
\hline Acúmulo de massa no bocal & Fraqueza na costura do fundo & Marca de ar & Altura total até a alça abaixo do LIE & Largura acima do LSE \\
\hline Acúmulo de massa no fundo & Fraqueza no interior do bocal & Marca de ferramenta & Altura total até a alça acima do LSE & Largura da base abaixo do LIE \\
\hline Acúmulo de massa no ombro & Fraqueza sob a alça & Marca de fluxo & Altura total até o bocal abaixo do LIE & Largura da base acima do LSE \\
\hline Acúmulo de massa no pamel & Frasco amassado & Marca de óleo & Altura total até 0 bocal acima do LSE & Largura do ombro abaixo do LIE \\
\hline Arranhões no painel & Frasco com agressão & Olho de peixe & Cota $\mathrm{H}$ abaixo do LIE & Largura do ombro acima doLSE \\
\hline Bocal amassado & Frasco fora de fase & Painel empenado & Cota $\mathrm{H}$ acima do LSE & Overflow abaixo do LIE \\
\hline Bocal chanfrado & Frasco furado & Porosidade no frasco & Cota T abaixo do LIE & Overflow acima do LIE \\
\hline Bocal furado & Frasco mal formado & Rebarba na alça & Cota T acima do LSE & Peso abaixo do LIE \\
\hline Bocal mal faceado & Fratura de fundido & Rebarba na pista de selagem & Cota T de ovalização acima do LSE & Peso acima do LSE \\
\hline Bocal mal formado & Fuga de massa na pista de selagem & Rebarba no bocal & Cota $Z$ abaixo do LIE & Profundidade abaixo do LIE \\
\hline Bocal quebrado & Fuga de massa no filete da rosca & Rebarba no fundo & Cota $Z$ acima do LSE & Profundidade acma do LSE \\
\hline Bocal rasgado & Fuga de massa no part line do bocal & Rebarba no part line & Diâmetro da catraca abaixo do LIE & Profundidade da base abaixo do LIE \\
\hline Bollhas no fundo & Fundo abaulado & Rebarba no stripe & Diâmetro da catraca acima do LSE & Profundidade da base acima do LSE \\
\hline Contaminação & Furo na alça & Refilo & Espessura da alça abaixo do LIE & Profundidade do ombro abaixo do LIE \\
\hline Costura aberta & Furo sob a alça & Risco de material & Espessura da alça acima do LSE & Profundidade do ombro acima do LSE \\
\hline Fallha na pista de selagem & Gargalo cortado & Rompimento na solda & Espessura de parede abaixo do LIE & Stripe abaixo do LIE \\
\hline Fallha no stripe & Gargalo prolongado & Rosca danificada & Head space abaixo do LIE & Stripe acima do LSE \\
\hline Fora de tonalidade & Má distribuição de massa & Saboneteira presa & Inclinação do bocal acima do LSE & Top load abaixo do LIE \\
\hline Fraqueza na alça & Marca d'água & Stripe desalinhado & Largura abaixo do LIE & \\
\hline
\end{tabular}

Fonte: Empresa

Vale ressaltar, que o processo de implementação dos indicadores requereu um treinamento da equipe envolvida. Foi necessário um treinamento dos inspetores para o preenchimento adequado da base de alimentação, e alinhamento do método de avaliação dos defeitos e linhas produtivas, para adquirir dados confiáveis e com o mesmo critério adotado entre os três turnos. Em seguida, houve uma etapa de testes para assegurar a adaptação dos mesmos ao novo formato RDQ, bem como verificar possíveis pontos de melhoria no framework dos KPI's.

\subsection{RESULTADOS GRÁFICOS E FERRAMENTAS DA QUALIDADE}

A partir das coletas de dados diárias, são gerados três resultados gráficos, o primeiro é o novo indicador interno chamado "Auditoria de linha" que contabiliza as notas anteriormente explicitadas, dadas as linhas produtivas durante as inspeções diárias, que tem como meta da fábrica e individual por linha, 70\% de aprovação dos produtos.

O segundo resultado gráfico é os cinco maiores defeitos oriundos de reprovações relatados em cada linha chamado "Top 5 de defeitos" e o terceiro resultado gráfico é os cinco maiores problemas relatados como condições aceitáveis chamado "Top 5 de aceites condicionais", que também não podem sair do radar, pois condições aceitáveis se extrapolar os limites pode se tornar uma não conformidade de cliente. A tabela 2, apresenta a descrição resumida de cada indicador gerado a partir dos dados coletados.

Nas figuras 6, 7 e 8 pode-se ilustrar a apresentação gráfica dos indicadores de Auditoria de linha, Top 5 de defeitos e Top 5 de Aceites condicionais, respectivamente. 
Tabela 2 - Indicadores

\begin{tabular}{|clll|}
\hline NOME DO INDICADOR & \multicolumn{1}{c|}{ DESCRIÇÃO } & \multicolumn{1}{c|}{ FUNÇÃO } & META \\
\hline Auditoria de linha & $\begin{array}{l}\text { Contabiliza a quantidade de produtos } \\
\text { aprovados, reprovados e aceites condicionais } \\
\text { de cada linha }\end{array}$ & $\begin{array}{l}\text { Mensurar o percentual de produtos } \\
\text { aprovados da fábrica e por cada linha } \\
\text { produtiva }\end{array}$ & $70 \%$ \\
\hline Top 5 de defeitos & $\begin{array}{l}\text { Contabiliza a frequência da ocorrência de } \\
\text { cada defeito apontado em cada linha } \\
\text { produtiva }\end{array}$ & $\begin{array}{l}\text { Destacar os cinco principais defeitos de } \\
\text { cada linha produtiva }\end{array}$ \\
\hline & $\begin{array}{l}\text { Contabiliza a frequência da ocorrência de } \\
\text { Top 5 de Aceites Condicionais condicionais apontado em cada linha } \\
\text { produtiva }\end{array}$ & $\begin{array}{l}\text { Destacar os cinco principais aceites } \\
\text { condicionais de cada linha produtiva }\end{array}$ \\
\hline
\end{tabular}

Fonte: Autora

Figura 6 - Indicador de Auditoria de linha

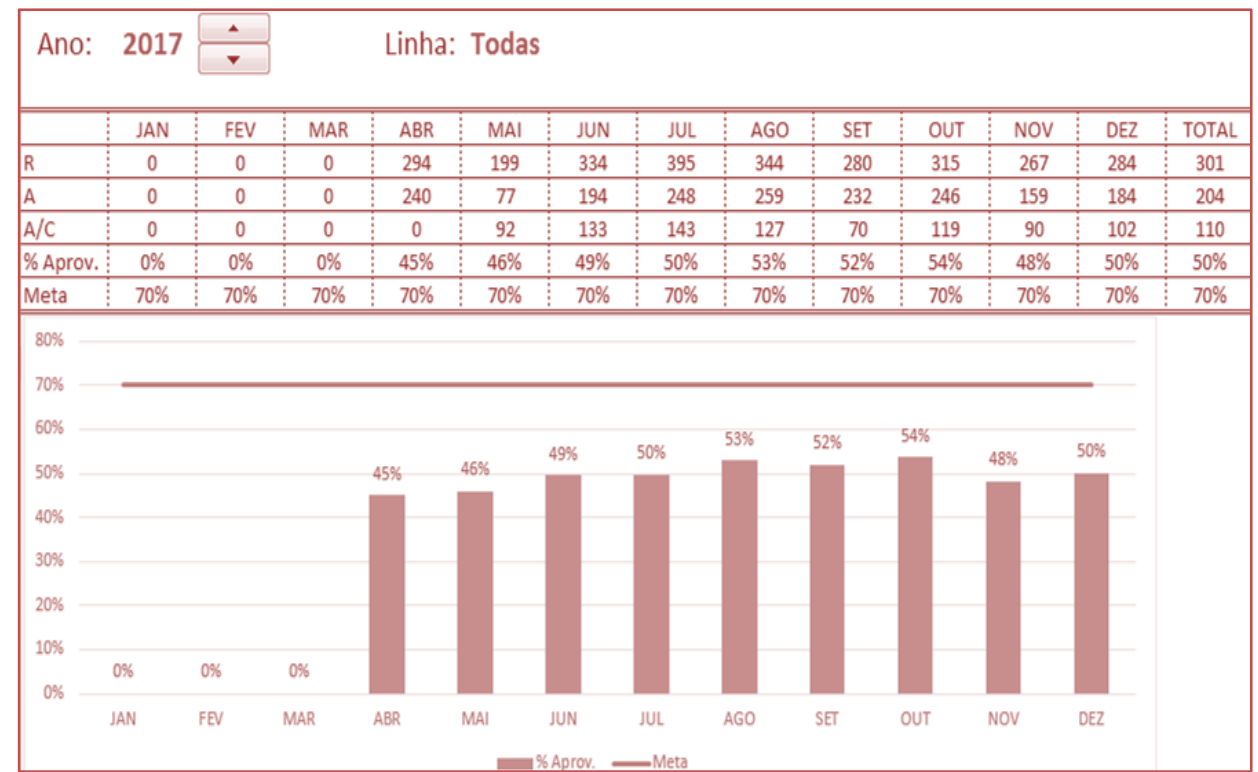

Fonte: Empresa

Figura 7 - Indicador Top 5 de defeitos

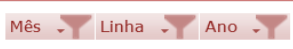

Top 5 de defeitos - Linha 17

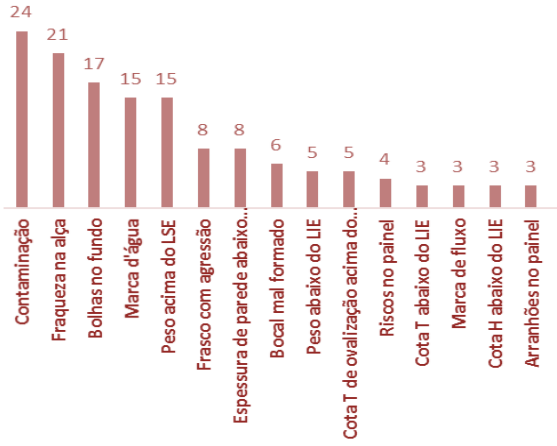

Maiores Problemas -

Fonte: Empresa 
Figura 8 - Indicador Top 5 de Aceites condicionais

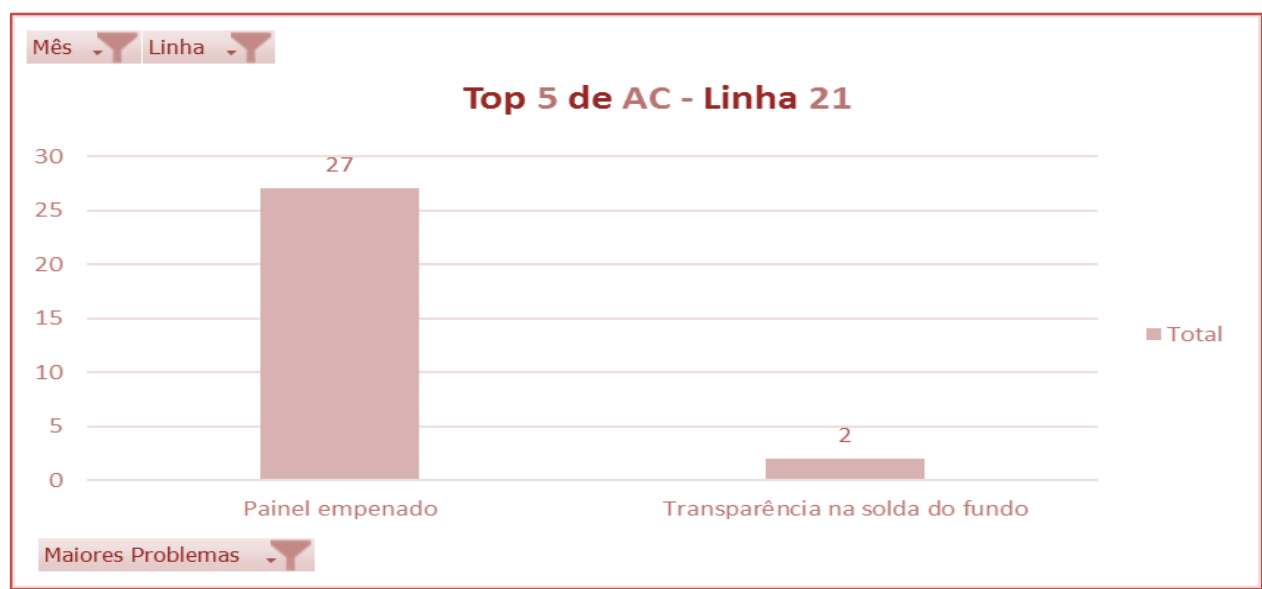

Fonte: Empresa

Com a implementação definitiva desses indicadores, passaram a ser feitas reuniões com a equipe multifuncional, a fim de tratar os maiores problemas relatados, resultando em um documento denominado A3, exemplificado na figura 9. Nele definem-se os principais problemas de um dado mês e junto aos gestores é realizada uma análise de causa a partir de ferramentas da qualidade como Ishikawa e cinco porquês, exemplificados nas figuras 10 e 11 respectivamente. Além disso, indica qual situação se deseja alcançar, mostrando os planos de ações e os responsáveis pelas mesmas. Um fator relevante é que essas reuniões são sempre realizadas com os representantes da produção, qualidade, logística, processos, manutenção e gerência da planta visando a participação e colaboração de toda a equipe.

Figura 9 - Modelo de Relatório A3

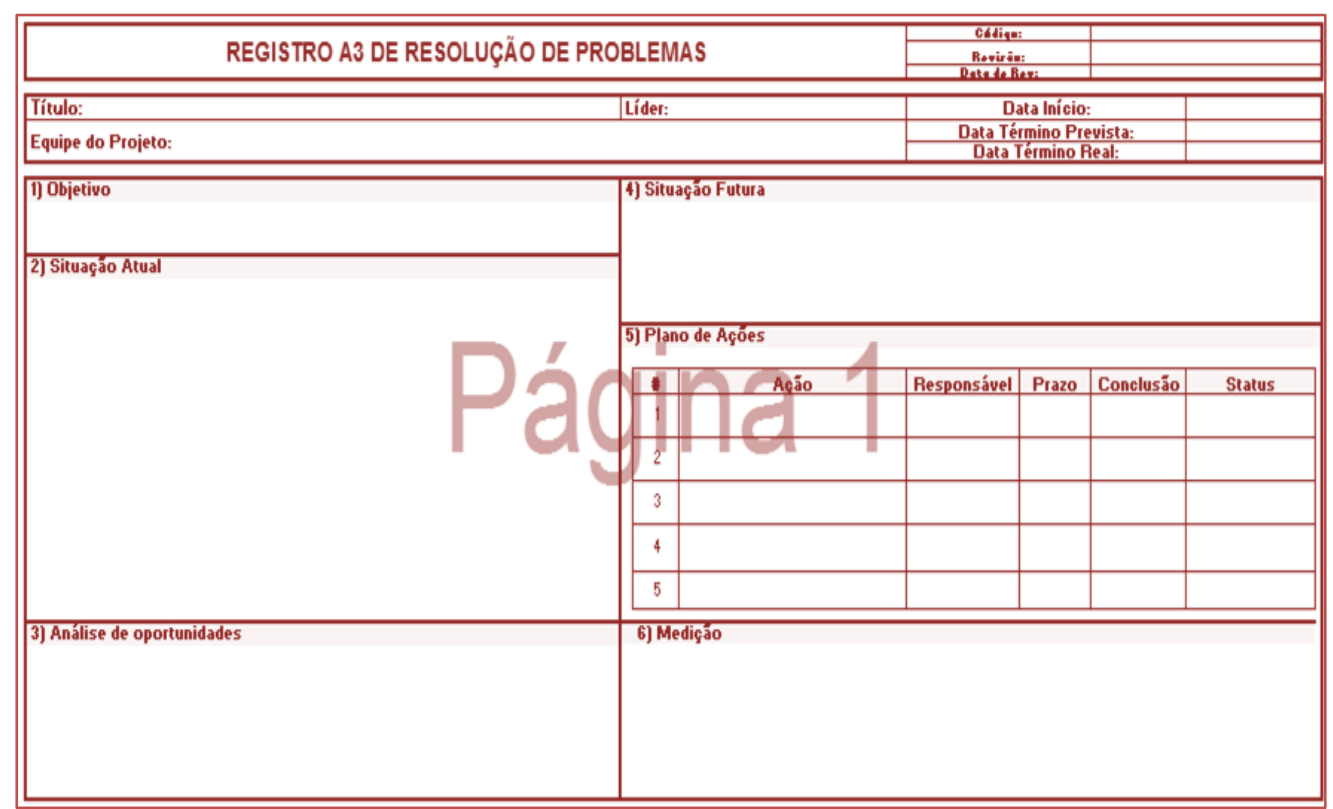

Fonte: Empresa 
Figura 10 - Ferramenta Ishikawa

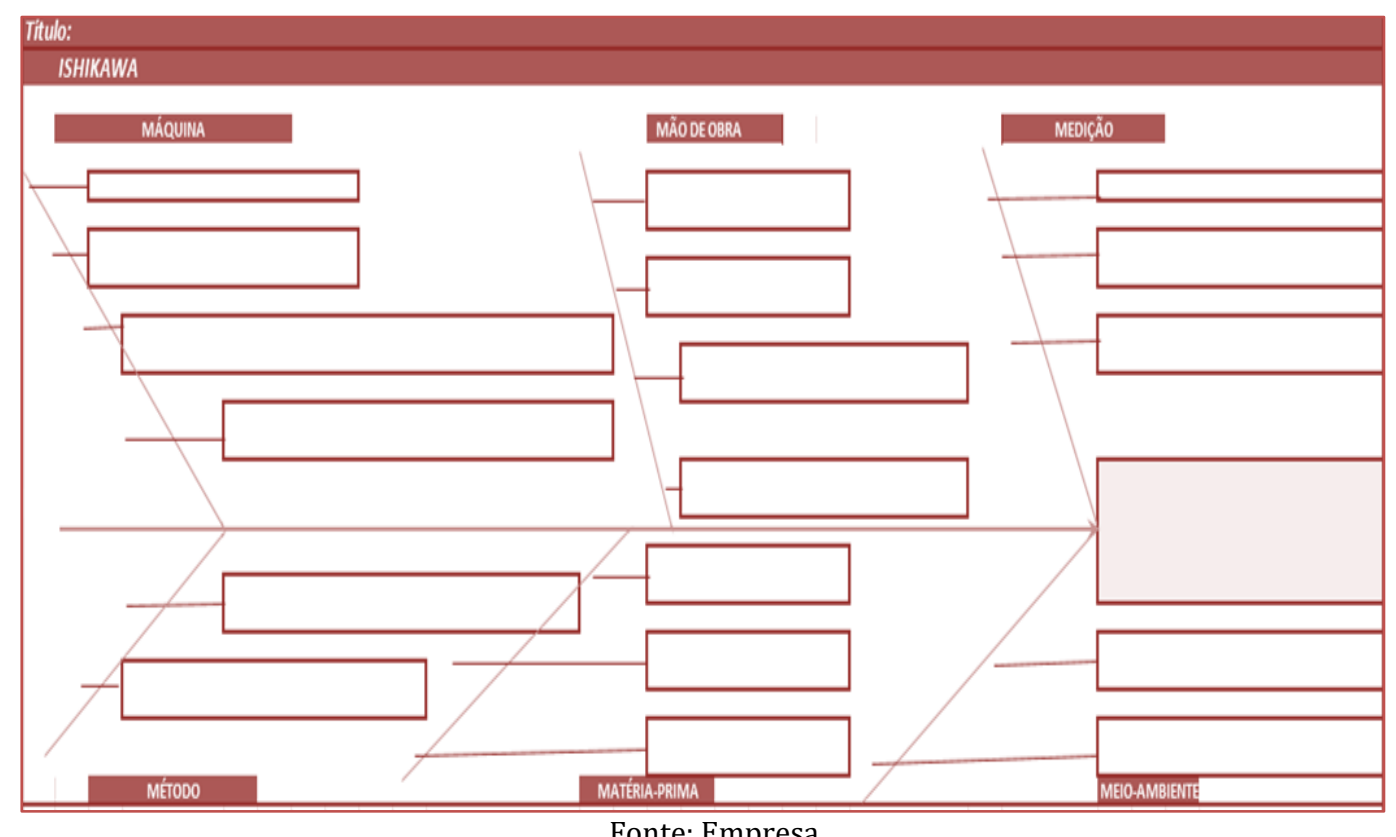

Figura 11 - Ferramenta 5 Porquês

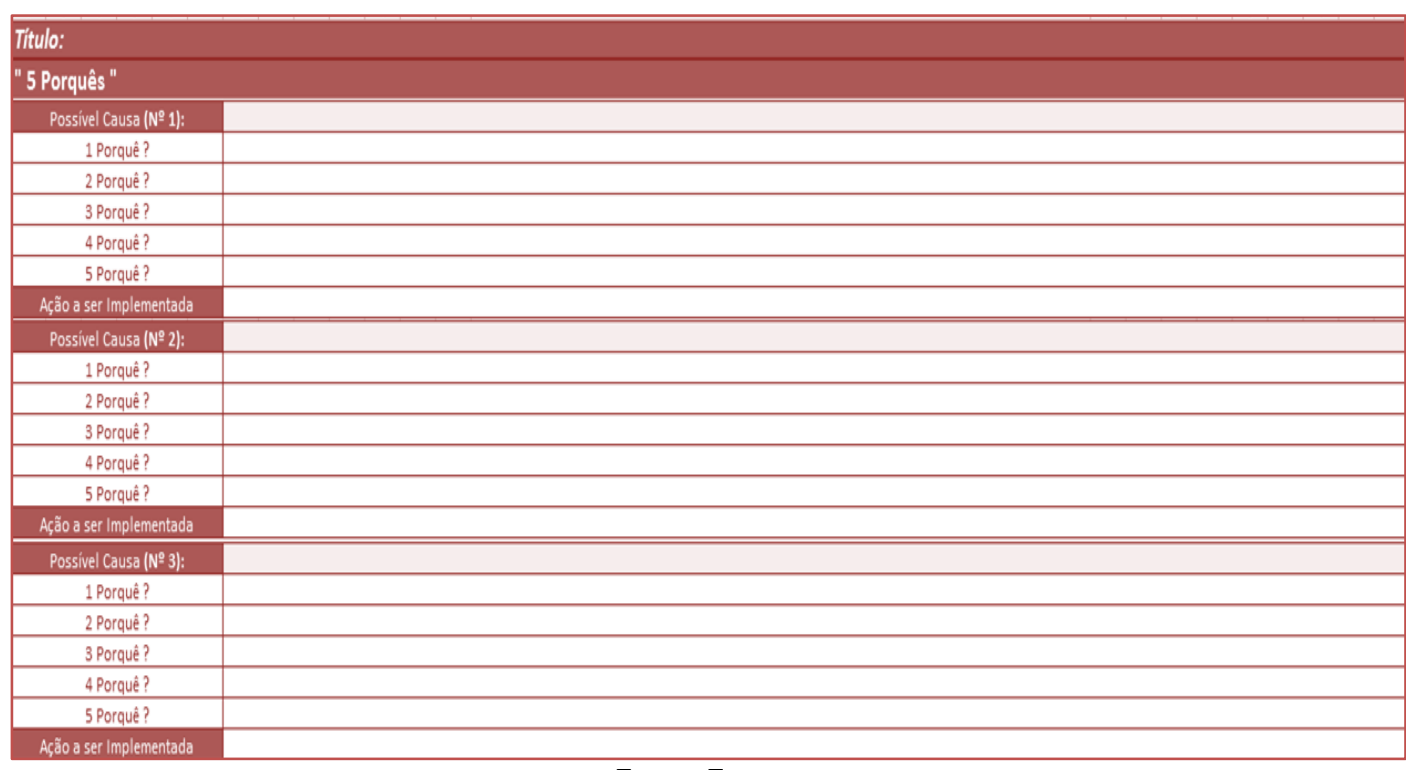

Fonte: Empresa

\section{ANÁLISE DOS RESULTADOS}

Os resultados deste trabalho foram segmentados em duas seções, a primeira de viés quantitativo e a segunda, qualitativo. Para elaboração das análises foi utilizado como referência o ano de 2017, ano cujo foi implementado o indicador de desempenho. É importante ressaltar que o conjunto de indicadores foi proposto no início do ano de 2017 para elaboração, em abril de 2017 foram realizados os primeiros testes de coleta de dados e treinamentos, e teve sua implementação efetiva em maio de 2017.

\subsection{ANÁLISE QUANTITATIVA}

No indicador de auditoria de linha observa-se que ao longo do ano estudado, os resultados ainda permanecem abaixo da meta de $70 \%$, estipulado no projeto inicial junto a gerência, figura 12 . No entanto, identificamos uma tendência de crescimento do percentual de aprovações, um pequeno acréscimo em torno de 5\%. Aumento este relativamente pequeno em relação ao percentual de aprovação dos produtos 
da planta, porém quando estratificado a análise para as linhas que sofreram tratativas, pôde-se observar números mais significativos. Em contrapartida, uma análise mais crítica, a partir da estratificação dos dados, permitiu também compreender que o desempenho global do indicador é impactado pela performance individual de cada linha de produção. Uma linha que teve um desempenho acima do esperado em determinado mês impulsiona o resultado geral do indicador para cima ainda que as demais não tenham tido um resultado tão bom assim, por exemplo, na figura 13 mostra a linha 21 que teve um aumento de $15 \%$ do mês de julho para agosto de 2017. 0 mesmo pode acontecer caso uma linha tenha o desempenho muito abaixo do seu histórico.

Figura 12 - Indicador de auditoria de linha da planta

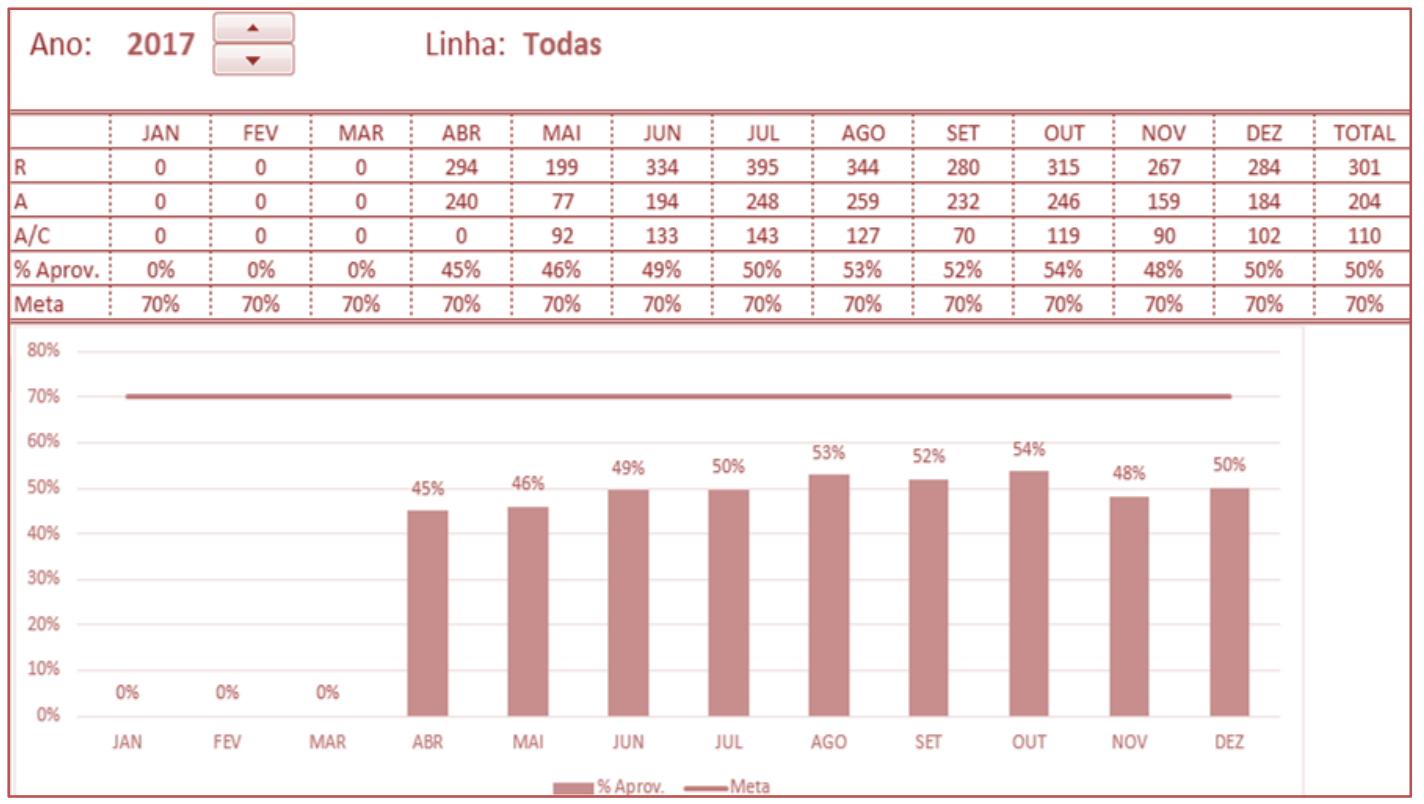

Fonte: Empresa

Figura 13 - Indicador da linha 21

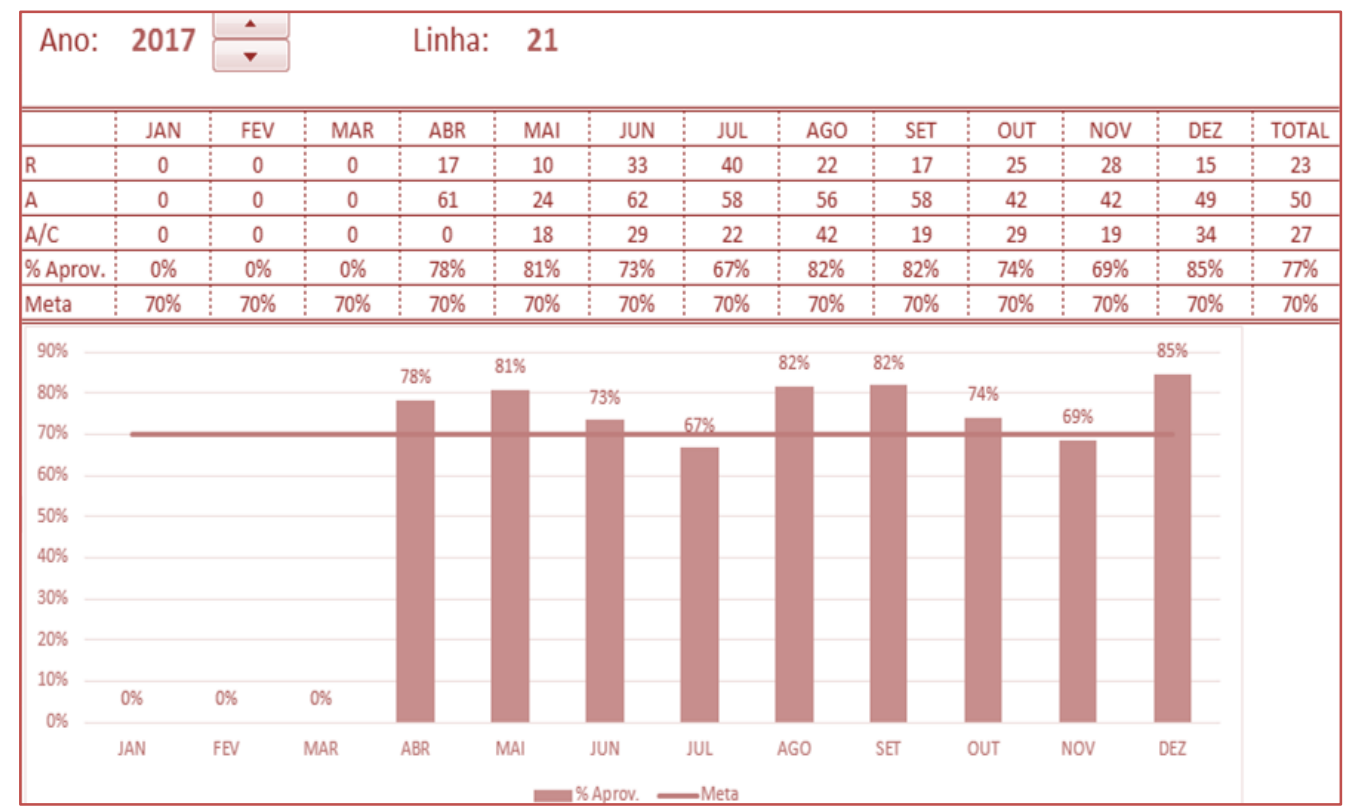

Fonte: Empresa

As primeiras três reuniões realizadas para análise das causas dos defeitos a partir dos dados gerados dos indicadores, e registrados em documento A3, foram: 
A linha 17 foi a primeira a ser tratada no mês de maio, pois apresentou seu percentual individual mais baixo em relação às outras linhas. Para a linha 17, foram propostas quatorze ações, das quais três foram canceladas ou inviabilizadas, a última ação concluída foi no mês de julho. Na figura 14, podemos observar um aumento de 16\% no percentual de aprovação do mês de junho para o mês de julho, cujo mês foi de conclusão das ações propostas. Após esta tratativa pôde-se observar uma oscilação do indicador ficando com uma média de 32,5\% de aprovação ao longo do ano após tratativas. Apesar deste índice ainda estar abaixo da meta, ele se comportou de maneira satisfatória após análise de causa e tratativas realizadas em reunião e executadas conforme alinhado. E demonstra que necessita que mais tratativas e ações sejam traçadas para alcançar percentuais ainda maiores.

Figura 14 - Indicador da linha 17

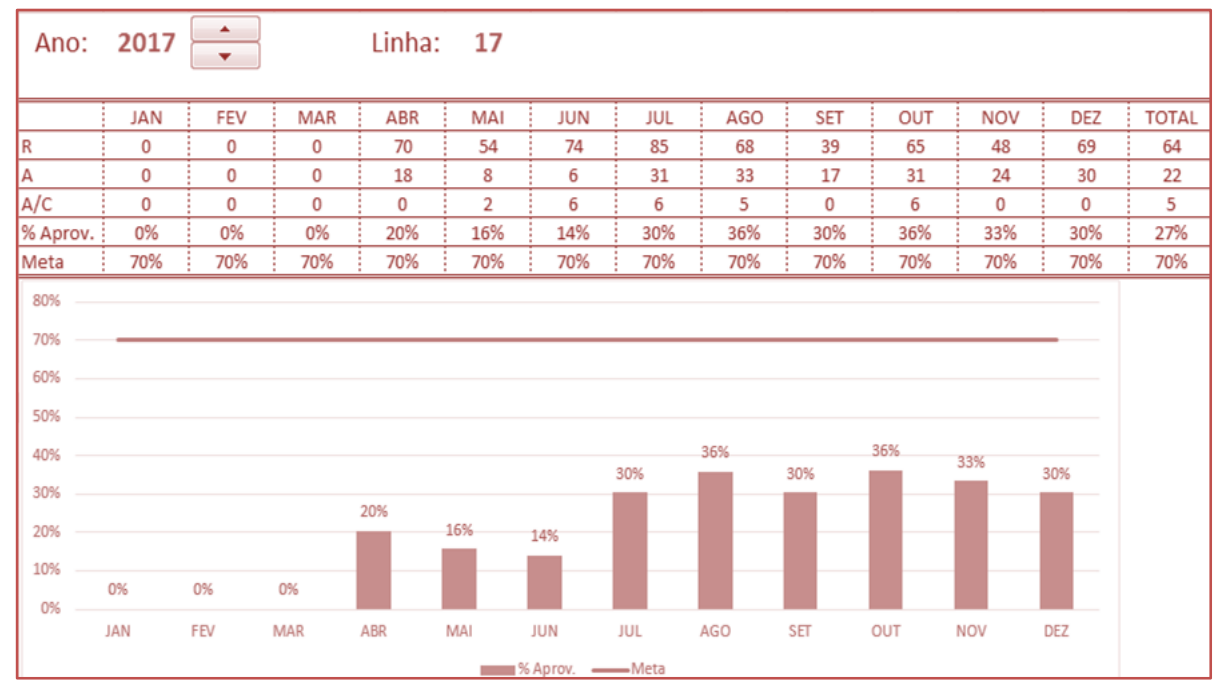

Fonte: Empresa

A linha 15 foi a segunda a ser tratada a partir dos dados dos indicadores, em reunião foram propostas cinco ações, das quais uma foi cancelada ou inviabilizada, sendo a última ação concluída em setembro. Na figura 15, podemos observar o indicador da linha 15, onde demonstra um acréscimo de $20 \%$ no índice de aprovação desta linha, do mês analisado em junho para o mês de conclusão das ações em setembro. Mantendo-se ao longo do ano com uma média de 33,5\% de aprovação. Foi evidenciado aumento no percentual de aprovação de produtos desta linha após as tratativas traçadas, porém o percentual de aprovação ainda se encontra muito abaixo da meta e necessita de nova análise e ações.

Figura 15 - Indicador da linha 15

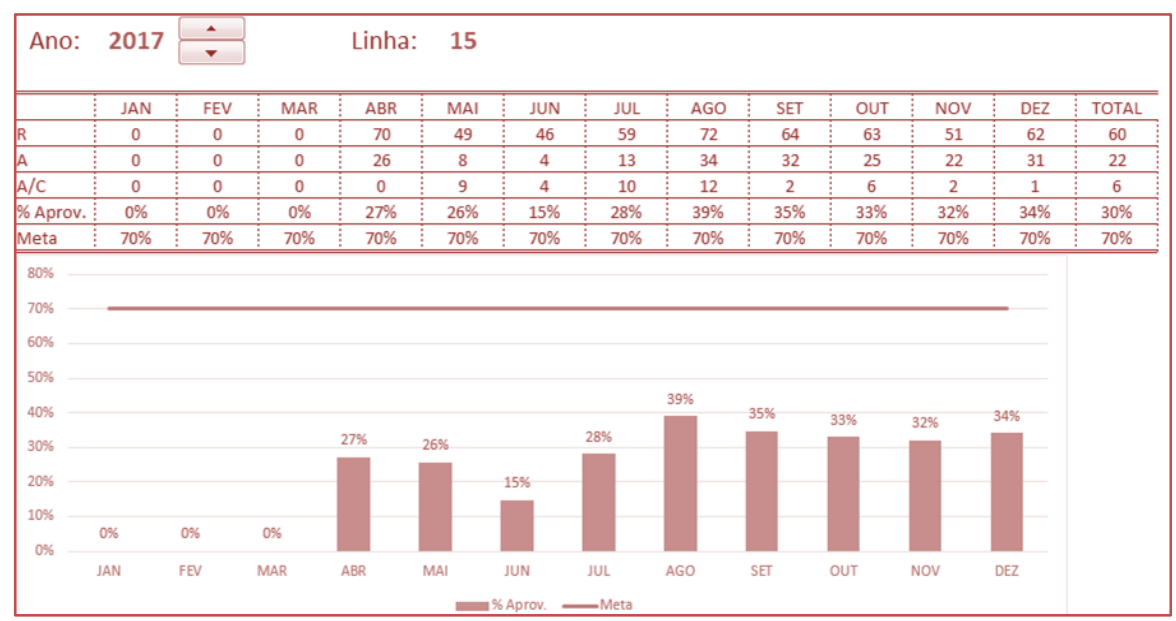

Fonte: Empresa 
Já a linha 02, foi a terceira linha que apresentou percentuais baixos e necessidade de melhorias, foram propostas quatro ações e nenhuma cancelada, da qual a última ação foi executada em agosto. Na figura 16, pode-se observar que o indicador da linha 2 apresentou um acréscimo de $20 \%$ do mês de julho, onde foi realizada as análises, para o mês de agosto, mês de conclusão das ações propostas. E apresentou ao longo do ano, após ações concluídas, o percentual de aprovação em média de 31,2\%. Uma melhoria significante frente aos problemas apresentados na máquina, apesar de ainda estar abaixo da meta estipulada.

Figura 16 - Indicadores da linha 2

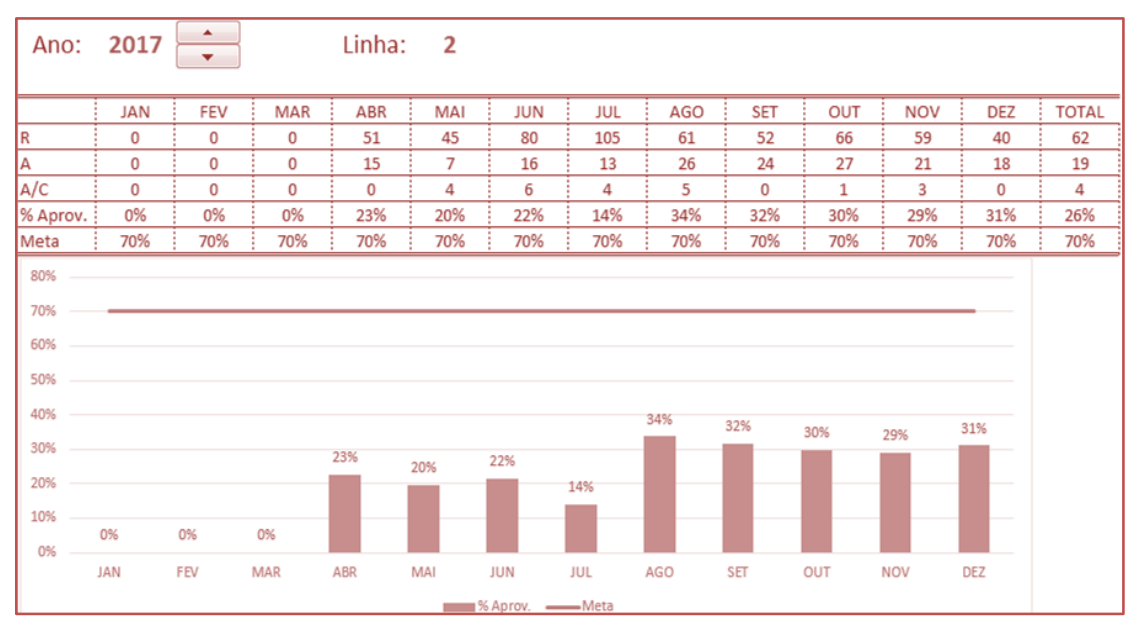

Fonte: Empresa

Além de evidenciar o aumento percentual da porcentagem de aprovação de todas as linhas tratadas, foi possível atingir ao final do ano de 2017 o target esperado do indicador corporativo com o resultado de 3.490 por $10 \mathrm{MM}$ vendidos. Ficando dentro do target de 3.927 per $10 \mathrm{MM}$ vendidos, definido para este ano pela alta direção, como podemos ver na figura 17.

Figura 17 - Indicador corporativo - 2017

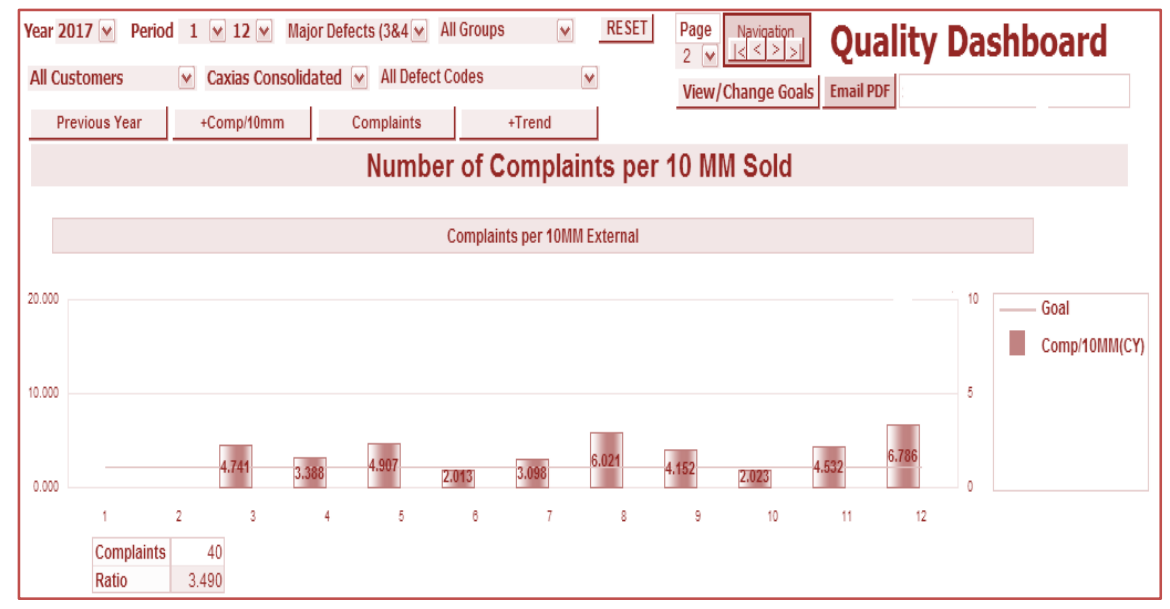

Fonte: Empresa

\subsection{ANÁLISE QUALITATIVA}

O conjunto de indicadores, juntamente com as reuniões com foco na elaboração do A3 para os principais problemas identificados constituíram-se como boas práticas para a organização, pois trouxeram não apenas resultados quantitativos como também benefícios relativos à cultura organizacional. Dentre eles, após a criação dos indicadores foi possível perceber que houve um maior engajamento dos colaboradores 
de cada setor, principalmente pelo fato de que as soluções dos problemas passaram a serem definidas em conjunto, fazendo com que fosse necessária a interação dos funcionários.

Outra melhoria identificada foi que o processo decisório passou a ser pautado em evidências, uma vez que, o indicador mensura, com dados estatísticos, os reais problemas que devem ser tratados e não com base em especulações. Essa nova forma de abordagem permite também a soma de esforços em ações preventivas que são muito mais eficientes que as corretivas, visto que reduz impactos financeiros de custos com devoluções, retrabalhos e insumos descartados.

Todas essas melhorias foram viabilizadoras para atender a política da qualidade da empresa que destaca a busca pela melhoria contínua da capacidade dos processos para garantir a superação das expectativas dos clientes, fornecendo produtos de alta qualidade, de melhor valor e serviços em tempo hábil.

\section{CONCLUSÃO}

A empresa estudada entende que melhorar a qualidade, além de reduzir as não conformidades e custos gerados, aumenta também consequentemente o grau de satisfação do cliente externo e interno. E com a implementação do indicador interno de desempenho da qualidade, pôde-se evidenciar a necessidade de projetos de melhoria e verificar se as ações implementadas produziram os efeitos desejados, ações estas baseadas em dados e informações quantitativas, sempre visando a melhoria contínua dos processos.

Ao fim do estudo além do ganho percentual nas aprovações de produtos, houve por consequência a queda de situações de riscos diárias na rotina das unidades de produção e o atingimento das metas do indicador corporativo, assim como o engajamento de todas as partes para o alcance das metas da organização.

Considerando os objetivos traçados pelo estudo e a questão formulada na situação problema, pode-se inferir que o modelo apresentado utiliza a estruturação do sistema de medição de desempenho como forma de garantir resultados consistentes e alinhados as metas da organização. Destaca-se a importância da conexão entre os indicadores, a melhoria contínua da qualidade e o alcance das metas organizacionais, e constata-se que elas possuem relação estreitas. Medir os resultados de uma forma estruturada é fundamental para gestão de uma organização uma vez que possibilita o planejamento, a análise, a comparação dos resultados, a avaliação em relação à concretização dos objetivos estratégicos, o direcionamento para obtenção de melhores resultados e a promoção de uma cultura para excelência.

0 estudo demonstra que as análises de causa e ações proposta, pautadas por evidências bem construídas, são eficientes e podem melhorar a performance não só do setor da qualidade, mas de todos os outros setores de organização, e devem ser replicados o conceito, como por exemplo para o setor de produção, manutenção, logística entre outros.

\section{BIBLIOGRAFIA}

[1] ABNT NBR ISO 9001:2015 - Sistema de Gestão da Qualidade - Requisitos. Disponível em: <https://files.comunidades.net/lodineimarchini/iso2015_versao_completa.pdf>. Acesso em: 23 de março de 2018.

[2] BRITTO, Hamilton. Extrusão plástica. $2015 . \quad$ Disponível em: <http://mecanicadefabricar.blogspot.com/2015/10/extrusao-plastica.html>. Acesso em: 27 de maio de 2018.

[3] CARPINETTI, L.C.R. Gestão da qualidade: conceitos e técnicas. 2 ed. São Paulo: Atlas, 2012.

[4] COSTA, Dayana Bastos. Diretrizes para concepção, implantação e uso de sistemas de indicadores de desempenho para empresas da construção civil. Universidade Federal do Rio Grande do Sul (2003).

[5] DORNIER, Philippe Pierre et al. Logística e Operações Globais: textos e casos. São Paulo: Atlas, 2000.

[6] FISCHMANN, A.; ZILBER, M. A. Utilização de indicadores de desempenho como instrumento de suporte à gestão estratégica. Encontro da ANPAD, 23., Anais.., 1999.

[7] FPNQ. FUNDAÇÃO PRÊMIO NACIONAL DA QUALIDADE. Relatório do Comitê Temático: Planejamento do sistema de medição do desempenho global. São Paulo, 2004.

[8] FNQ. FUNDAÇÃO NACIONAL DA QUALIDADE. Critérios de Excelência em Gestão: Avaliação e diagnóstico da gestão organizacional. São Paulo, 2010

[9] KAPLAN, R.S.; NORTON, D.P. A estratégia em ação: Balanced Scorecard. 10 ed. Rio de janeiro: Campus, 1997. 
[10] LIMA, Maria Bernadete Barros Piazzon Barbosa. A Gestão da Qualidade e o Redesenho de Processos como Modelo de Desenvolvimento Organizacional em Hospitais Públicos Universitários: O Caso do Hospital de Clínicas da UNICAMP. Universidade Estadual de Campinas, Faculdade de Engenharia Mecânica. Campinas, 2006.

[11] MACHADO, Luís André Pinto. Definição de indicadores de desempenho e construção de um Data Mart para a ADIRA. SA. 2014.

[12] PAULA, Willian Rodrigues; STEVAN JUNIOR, Sergio Luiz; Monitoramento microcontrolado do estado das resistências de aquecimento de injetoras por moldagem; Revista brasileira de instrumentação e controle, 2016. Disponível em: <https://www.researchgate.net/profile/Sergio_Stevan_Jr/publication/312545616_Monitoramento_microcontrolado_ do_estado_das_resistencias_de_aquecimento_de_injetoras_por_moldagem/links/58ad72e892851c3cfda24ac1/Monito ramento-microcontrolado-do-estado-das-resistencias-de-aquecimento-de-injetoras-por-moldagem.pdf $>$. Acesso em: 27 de maio de 2018.

[13] RIBEIRO FILHO, José. Definição e implantação de KPIs para auxiliar a gestão de uma empresa de softwares. Universidade Federal de Uberlândia, 2017.

[14] SLACK, N.; CHAMBERS, S.; JOHNSTON, R. Administração da Produção: Edição Compacta. São Paulo: Atlas, 2006 


\section{Capítulo 6}

\section{SANTOS MELHOR IDADE: SITE DE PROGRAMAÇÃO CULTURAL E RECREATIVA PARA IDOSOS}

\section{Cauê Bongiovanni Sobral Sousa \\ Henry Hiraki \\ Rodrigo Ribeiro da Costa \\ Vanina Carrara Sigrist}

Resumo: A cidade de Santos é um polo turístico importante na região da Baixada Santista (SP), onde existem muitos locais que costumam atrair visitantes o ano todo; porém, muitos deles possuem seus próprios sites, nos quais podem ser encontradas informações sobre data de inauguração, acervo existente, horários de funcionamento e valores das entradas para visitação, que acabam por ficar dispersas, em meio a outras tantas referentes a exposições, atividades de cultura e lazer, sessões recreativas, programações turísticas, que também compõem o conjunto de possibilidades de entretenimento de que moradores e turistas podem usufruir semanalmente. Diante desse cenário, o objetivo aqui é desenvolver um website responsivo (Santos Melhor Idade) destinado a facilitar a aproximação entre as pessoas de terceira idade (índice populacional considerável da cidade) e as programações culturais e de lazer voltadas a esse público que ocorrem em Santos. 0 site realizará levantamentos sobre os destinos, recomendações de passeios e atividades, acesso, localização e preços. A natureza desta pesquisa é aplicada, com abordagem exploratória e qualitativa, incluindo revisão bibliográfica. Para o desenvolvimento do sítio web, foi utilizado um conjunto de tecnologias focadas em performance e sutileza, para que, dessa forma, gerasse a rapidez e estabilidade necessárias para o bom funcionamento: na camada front-end, HTML; CSS; MATERIALIZE; JAVASCRIPT; JQUERY; na back-end, PHP, no que tange à persistência de dados, e o sistema gerenciável de banco de dados MYSQL. Os resultados do desenvolvimento permitem afirmar que as funcionalidades de Santos Melhor Idade foram todas cumpridas.

Palavras-chave: Santos Melhor Idade. Website responsivo. Programação para Terceira Idade. 


\section{INTRODUÇÃO}

A cidade de Santos é um polo turístico importante na região da Baixada Santista (SP), para onde aflui um número considerável de turistas e moradores da capital do Estado em datas festivas, feriados prolongados e períodos de férias, tornando o município ainda mais populoso. Existem muitos locais que costumam atrair visitantes o ano todo, como o Aquário Municipal, localizado na Ponta da Praia e subordinado à Secretaria Municipal do Meio Ambiente, o Orquidário, parque zoobotânico que abriga mais de 3.500 orquídeas, a Pinacoteca Benedito Calixto, que possui acervo pictórico próprio e onde sempre acontecem exposições e apresentações musicais e teatrais itinerantes, dentre outros.

Muitos desses locais possuem seus próprios sítios eletrônicos, nos quais podem ser encontradas informações sobre data de inauguração, o acervo existente, os horários de funcionamento e os valores das entradas para visitação. Essas informações, porém, pelo que se vê, ficam dispersas, em meio a outras tantas referentes a exposições, atividades de cultura e lazer, sessões recreativas, programações turísticas, que também compõem o conjunto de possibilidades de entretenimento de que moradores e turistas podem usufruir semanalmente. 0 interessado deve, nesse caso, visitar cada sítio individualmente, para poder conhecer sobre o ponto e poder visitá-lo, ou deve acessar alguns sítios que buscam abrigar as informações turísticas mais relevantes sobre a cidade, mas que, ainda assim, são incompletos ou apresentam programação destinada a todo e qualquer público.

Além disso, sabe-se que a população santista é bastante envelhecida: "Atualmente, entre os 434.359 habitantes de Santos, 80.353 têm mais de 60 anos, segundo o Instituto Brasileiro de Geografia e Estatística (IBGE)" (VENTURA, 2017, s/p). Isso significa que há um público frequentador de pontos culturais e de lazer muito amplo, com disponibilidade de tempo, recursos financeiros (muitos já aposentados e beneficiados pelo pagamento da meia entrada garantido por lei) e cercado por condições de vida e de vivência da cidade muito propícias, já que Santos foi considerada, seguindo o Índice de Desenvolvimento Urbano para Longevidade (IDL), a melhor cidade no Brasil para se viver após os 60 anos, segundo uma pesquisa até então inédita, de iniciativa do Instituto de Longevidade Mongeral Aegon e da Escola de Administração de Empresas de São Paulo da Fundação Getúlio Vargas (FGV/EAESP) (VENTURA, 2017). Santos, nesse estudo, está à frente de Florianópolis, Porto Alegre, Niterói, São José do Rio Preto, Ribeirão Preto, Jundiaí, Americana, Vitória e Campinas, cidades que também estão na lista. Foram cruzados 63 indicadores divididos em sete variáveis (indicadores gerais, cuidados de saúde, bem-estar, finanças, habitação, educação e trabalho, cultura e engajamento), incluindo o clima, tido como bastante benéfico em municípios litorâneos.

Diante desse cenário, surge o questionamento sobre como atingir esse público, oferecendo-lhe notícias e dicas de programação de lazer de modo mais acurado e eficiente. 0 problema que se configura é a inexistência de opções na web que centralizem as informações de interesse dos idosos.

A proposta aqui é desenvolver um sítio web responsivo destinado a facilitar a aproximação entre as pessoas de terceira idade e as programações culturais e de lazer voltadas a esse público que ocorrem em Santos. 0 site realizará levantamentos sobre os destinos, recomendações de passeios e atividades, acesso, localização e preços, centralizando-os. Não existem ainda no mercado muitas aplicações que levantem tais informações específicas ao público idoso. Este projeto assume um tema de extrema relevância para o atendimento dos anseios de grande parte da população santista, na tentativa de buscar suprir uma carência na área sociotecnológica: como facilitar o acesso à programação destinada ao público idoso e quais recursos poderiam parecer mais atraentes a esse público num website que busque se diferenciar daqueles já disponíveis, voltados ao público em geral?

Para cumprir tal propósito, foram coletados alguns dados sobre os principais pontos turísticos da cidade de Santos, sobre os principais passeios voltados a pessoas com mais de 60 anos de idade, foram centralizadas as informações obtidas e disponibilizadas em um website responsivo.

Há de se levar em consideração que esse público não necessariamente tem acesso irrestrito a equipamentos ou dispositivos em rede, tampouco familiaridade com o uso de sites ou aplicativos. Assim, um desafio central desta pesquisa é derrubar tais barreiras de acessibilidade, na tentativa de conectar pessoas menos conectadas ao mundo digital e suas oportunidades de crescimento e entretenimento.

A natureza desta pesquisa é aplicada, com abordagem exploratória e qualitativa, incluindo revisão bibliográfica. Para o desenvolvimento do sítio web, foi utilizado um conjunto de tecnologias focadas em performance e sutileza, para que, dessa forma, gerasse a rapidez e estabilidade necessárias para o bom funcionamento. Sendo assim, na camada front-end, HTML; CSS; MATERIALIZE; JAVASCRIPT; JQUERY; na back-end, $P H P$, no que tange à persistência de dados, e o sistema gerenciável de banco de dados MYSQL. 


\section{EMBASAMENTO TEÓRICO}

Dalla Vecchia et al. (2005, p.247) especificam que "o conceito de qualidade de vida está relacionado à autoestima [sic] e ao bem-estar pessoal e abrange uma série de aspectos como a capacidade funcional, (...) a atividade intelectual, (...) os valores culturais", dentre outros. Os autores focaram, nessa pesquisa, o público da terceira idade, com o intuito de perscrutar sua própria visão sobre estilo e qualidade de vida, compondo uma amostra de habitantes de uma cidade do interior de São Paulo.

Já Barros (1998) discorre sobre o tema de um ponto de vista antropológico e no âmbito nacional, acenando para certo confronto entre a imagem do Brasil como nação jovem e população festeira e os idosos, não mais considerados "velhos", porém ainda vulneráveis perante problemas profissionais, de saúde e de assistência social, por exemplo.

Os indivíduos pertencentes ao grupo da terceira idade, ou seja, aqueles com 60 anos de idade ou mais, segundo categoria estipulada pela Organização Mundial de Saúde (OMS) para países em desenvolvimento, requerem consideração e cuidados especiais, e, no entanto, têm, ao mesmo tempo, demonstrado vitalidade e disposição para continuar trabalhando, praticando esportes, aproveitando passeios culturais ou recreativos, viajando, e assim por diante.

O lazer, de uma forma geral, apresenta-se como instrumento importante para a ocupação do tempo disponível, oportunizando novas experiências, conhecimentos, socialização e autorrealização. Para Dumazedier (1974, p.34), lazer é:

[...] um conjunto de ocupações, às quais o individuo pode entregar-se de livre vontade, seja para repousar, seja para divertir-se, recrear-se e entreter-se ou, ainda, para desenvolver sua informação ou formação desinteressada, sua livre capacidade criadora, após livrar-se ou desembarcar-se das obrigações profissionais, familiares e sociais.

Assim, enfatiza-se que é necessário facilitar o acesso do idoso a informação clara, gratuita e fácil, com o intuito de garantir que essa parcela da população possa aproveitar seu tempo livre em atividades de lazer, como turismo em lugares ainda desconhecidos, passeios recreativos, práticas de exercício físico, cursos de variados gêneros, dentre outros, com prioridade do bem-estar.

Embora essas considerações reforcem o nosso interesse em compreender o significado da concepção de lazer para essa população, sabemos que, a questão do lazer, é apenas uma parte dentre vários outros aspectos relacionados à vida das pessoas da terceira idade, o qual deve ser considerado e cada vez mais, merecedor de novos estudos e pesquisas que resulte em melhorias na qualidade de vida dessa população. (MARCELLINO, 2000, p.23).

De fato, como aponta Marcellino (2000), nos últimos anos tem-se visto a publicação de inúmeros trabalhos focados no estudo da população idosa e suas características, em vários aspectos. Mais entidades de atendimento têm surgido, mais iniciativas de integração dessa parcela da população ainda ativa têm sido pensadas, mais formulações, inclusive jurídicas, que atendam às suas necessidades têm sido forjadas para que se entenda e se aprenda a lidar com indivíduos mais envelhecidos e, nem por isso, senis ou inválidos, como outrora considerados.

Inclusive, fazendo jus ao escopo deste projeto, o setor do lazer voltado ao público da terceira idade, ou "melhor idade", como se tornou de praxe dizer, é um dos que têm sido estudados, tendo em vista a potencialidade econômica do turismo praticado pelos idosos. A pesquisa executada por Mota e Babinski (2012), no esteio dessa produção acadêmica, objetiva discutir o aumento da expectativa de vida da população em relação ao aumento no número de pessoas com mais tempo disponível, podendo utilizá-lo para o turismo, amplo nicho de mercado na terceira idade.

Dois importantes portais que fornecem esse tipo de informação para a população da cidade de Santos, em particular, são Juicy Santos e o da Prefeitura Municipal. 0 primeiro é um grande portal de entretenimento na Baixada Santista, no qual constam diversas informações sobre eventos, atividades, turismo, disponíveis de forma clara para o público em geral, sendo grande parte desse conteúdo direcionado a eventos e publicidade paga. Já a Prefeitura Municipal oferece um portal para a terceira idade, o \#Espaço Do Idoso guia exclusivo de atividades e eventos voltados para esse público, principalmente aos que frequentam a entidade Espaço do Idoso, onde são realizadas diversas atividades gratuitas de saúde e bem-estar. 
Quadro 1 - Comparações entre as aplicações investigadas

\begin{tabular}{|c|c|c|c|}
\hline Tópicos & Santos Melhor Idade & Juicy Santos & $\begin{array}{c}\text { Prefeitura } \\
\text { Santos } \\
\text { (\#Espaço do } \\
\text { Idoso) }\end{array}$ \\
\hline Público Alvo & Idosos & Todos & Todos \\
\hline Rede Social & & & \\
\hline Multiplataforma & & & \\
\hline Lazer & & & \\
\hline Contato & & & \\
\hline $\begin{array}{c}\text { Fácil acesso a } \\
\text { informações sobre } \\
\text { programação para } \\
\text { idosos }\end{array}$ & & & \\
\hline
\end{tabular}

Através do quadro, constata-se mais facilmente que o recurso principal de Santos Melhor Idade é a facilidade de localização de conteúdo de interesse do público da terceira idade, e dividido em categorias práticas e intuitivas.

\section{PROCEDIMENTOS METODOLÓGICOS}

Nesta seção, abordam-se os padrões necessários, ferramentas e linguagens para o desenvolvimento do site em questão.

De acordo com Sommerville (2011, p.59):

Os requisitos funcionais de um sistema descrevem o que ele deve fazer. Eles dependem do tipo de software a ser desenvolvido, de quem são seus possíveis usuários e da abordagem geral adotada pela organização ao escrever os requisitos. Quando expressos como requisitos de usuário, os requisitos funcionais são normalmente descritos de forma abstrata, para serem compreendidos pelos usuários do sistema.

Como, segundo Guedes (2011, p.30), o diagrama de casos de uso é mais informal e geral, "embora venha a ser consultado durante todo o processo de modelagem e possa servir de base para outros diagramas", reproduziu-se na Figura 1 tal diagrama: 
Figura 1 - Diagrama de casos de uso

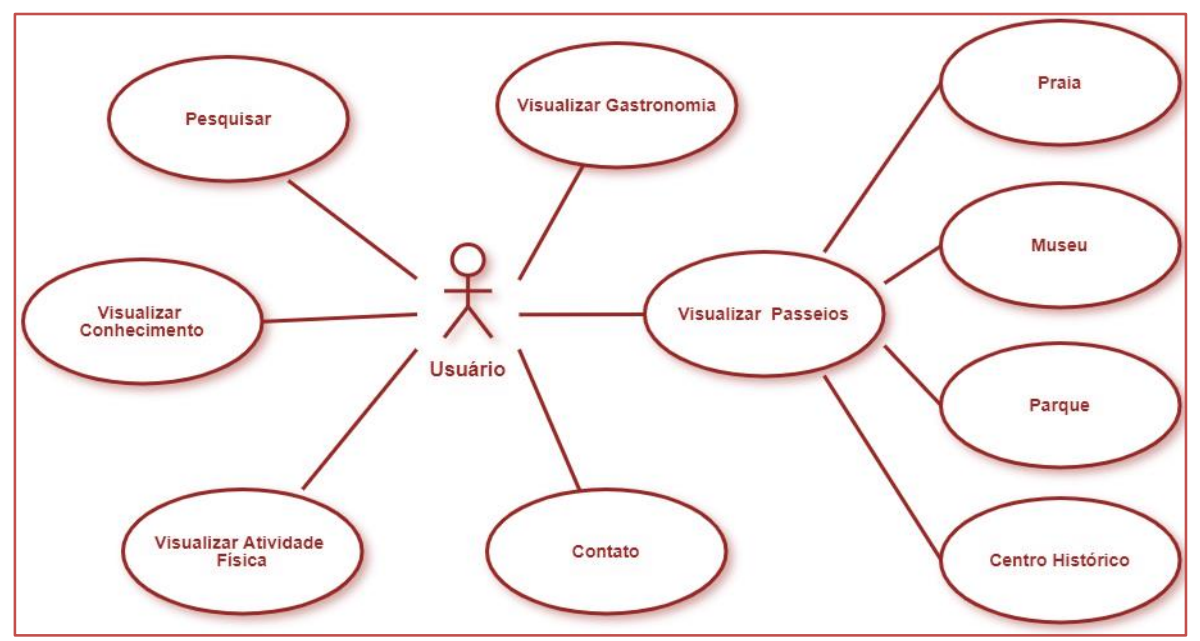

Fonte: Autores (2018)

Na Figura 2, por sua vez, optou-se pela apresentação do Mapa do site Santos Melhor Idade:

Figura 2 - Mapa do site Santos Melhor Idade

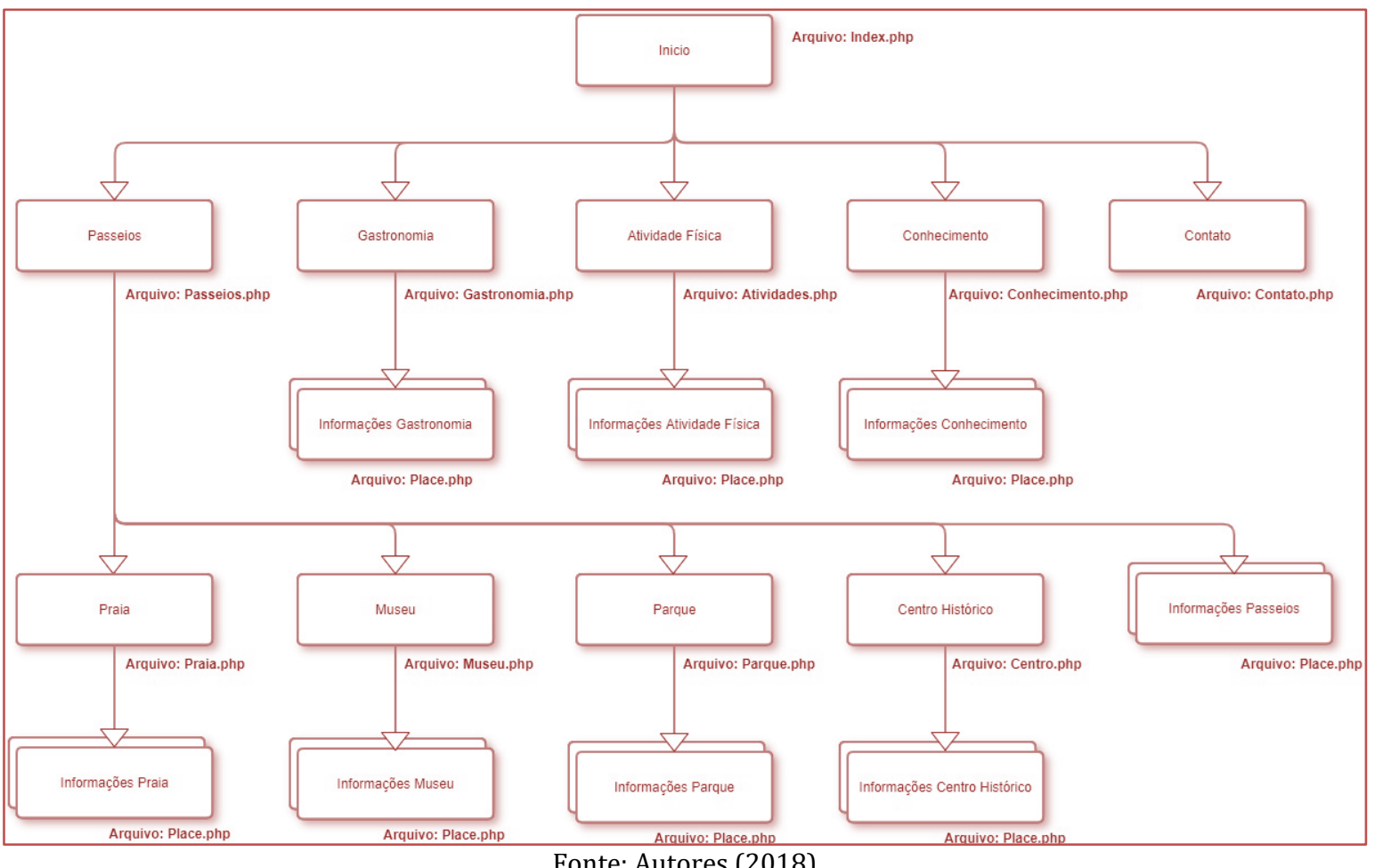

Em relação às linguagens usadas nas camadas front-end e back-end, tem-se:

HTML5: evolução das versões anteriores do HTML, mostra-se importante na implementação do website para que gere "códigos" para o browser conseguir fazer a interpretação e seu conteúdo.

CSS3 (Cascading Style Sheet ou, em português, folha de estilo em cascata), que, conforme Silva (2015, p.129), prevê "várias funcionalidades destinadas a manipular e definir o posicionamento dos boxes da marcação HTML em uma página". Portanto, com o CSS3 é possível modificar visualmente os estilos, tornando, assim, a aplicação mais amigável para o usuário final. 
JAVASCRIPT: Crockford (2008, p. 1, tradução livre) afirma que "Javascript é (...) uma das linguagens mais populares do mundo", enquanto Prescott (2016, p.15) ressalta:

O Javascript também pode ser usado para controlar o navegador, comunicar-se de forma assíncrona com o servidor, alterar de forma dinâmica o conteúdo de uma página web e para desenvolver jogos e aplicações móveis e de desktop.

JQUERY: De acordo com Rockford (2003, apud SILVA, 2018, p.13), “é uma biblioteca JavaScript criada por John Resig e disponibilizada como software livre e aberto (...) conforme as regras estabelecidas pelo MIT(Massachussets Institute of technology) e pelo GLP(GNU General Public License).

MATERIALIZE: Sua definição, conforme Prabhu e Shenoy (2016, p.1, tradução livre):

Materialize é uma framework intuitiva ao longo das linhas do Bootstrap and Foundation. E ela se adere ao Material Design, linguagem que foi lançada pela Google. Materialize possui UI (User Interface), componentes introduzidas, de fácil uso e implementação, e fornece estilo e animações para a construção de sites estéticos e responsivos.

PHP: De acordo com Moraz (2005, p.14):

PHP (Hipertext PreProcessor) é uma linguagem de programação utilizada para criar sites dinâmicos. Esses sites são os que permitem uma interação com o usuário mediante formulários, parâmetros de URL, links e etc. E que retornam páginas criadas em tempo real. Aplicações em PHP são geradas em excelente performance, e automaticamente pelo servidor.

MYSQL: De acordo com Milani (2006, p.22):

O MySQL é um servidor e gerenciador de banco de dados (SGBD) relacional, de licença dupla (sendo uma delas de software livre), projetado inicialmente para trabalhar com aplicações de pequeno e médio portes, mas hoje atendendo a aplicações de grande porte e com mais vantagens do que seus concorrentes. Possui todas as características que um banco de dados de grande porte precisa, sendo reconhecido por algumas entidades como o banco de dados open source com maior capacidade para concorrer com programas similares de código fechado, tais como SQLServer, e Oracle.

CLOUD9: Na página oficial do serviço (AWS, 2018, s/p), menciona-se que “0 AWS Cloud9 é um ambiente de desenvolvimento integrado (IDE) que permite escrever, executar e depurar código usando apenas um navegador". 0 ambiente inclui um editor de código, um depurador e um terminal. Portanto, optou-se por utilizá-lo, já que está na nuvem e permitee atualizar o código fonte de maneira mais prática.

GITHUB: Segundo Schmitz (2015, s/p):

O Github é um serviço web que oferece diversas funcionalidades extras aplicadas ao git. Resumindo, você poderá usar gratuitamente o github para hospedar seus projetos pessoais. Além disso, quase todos os projetos/frameworks/bibliotecas sobre desenvolvimento open source estão no github, e você pode acompanhá-los através de novas versões, contribuir informando bugs ou até mesmo enviando código e correções.

PHPMYADMIN: Delisle (2012, p.8, tradução livre) cita que “O phpMyAdmin é uma aplicação web escrita em PHP, que contém (como a maioria das aplicações web) XHTM, CSS e JavaScript. Essa aplicação fornece uma completa interface web para administrar base de dados MySQL".

Photoshop: Johnson (2012, p.1, tradução livre) define que "Adobe Photoshop é um design gráfico e realiza melhoria nas imagens, esse programa roda tanto em plataforma Windows e Macintosh". E ainda complementa, exemplificando que artistas de Hollywood, designers e usuários casuais utilizam Photoshop para criar efeitos desejados em imagens e fotos. Dessa forma, as imagens do site Santos Melhor Idade também serão tratadas. 


\section{RESULTADOS E DISCUSSÃO}

Depois da apresentação dessa seção metodológica, apresentam-se os resultados finais da pesquisa, com a conclusão do desenvolvimento do site, mediante a análise de algumas de suas telas. A primeira, ilustrada na Figura 3, é a Tela de Início, na qual se vê o título e o logotipo do site e as abas ou categorias de divisão do conteúdo:

Figura 3 - Tela inicial de Santos Melhor Idade

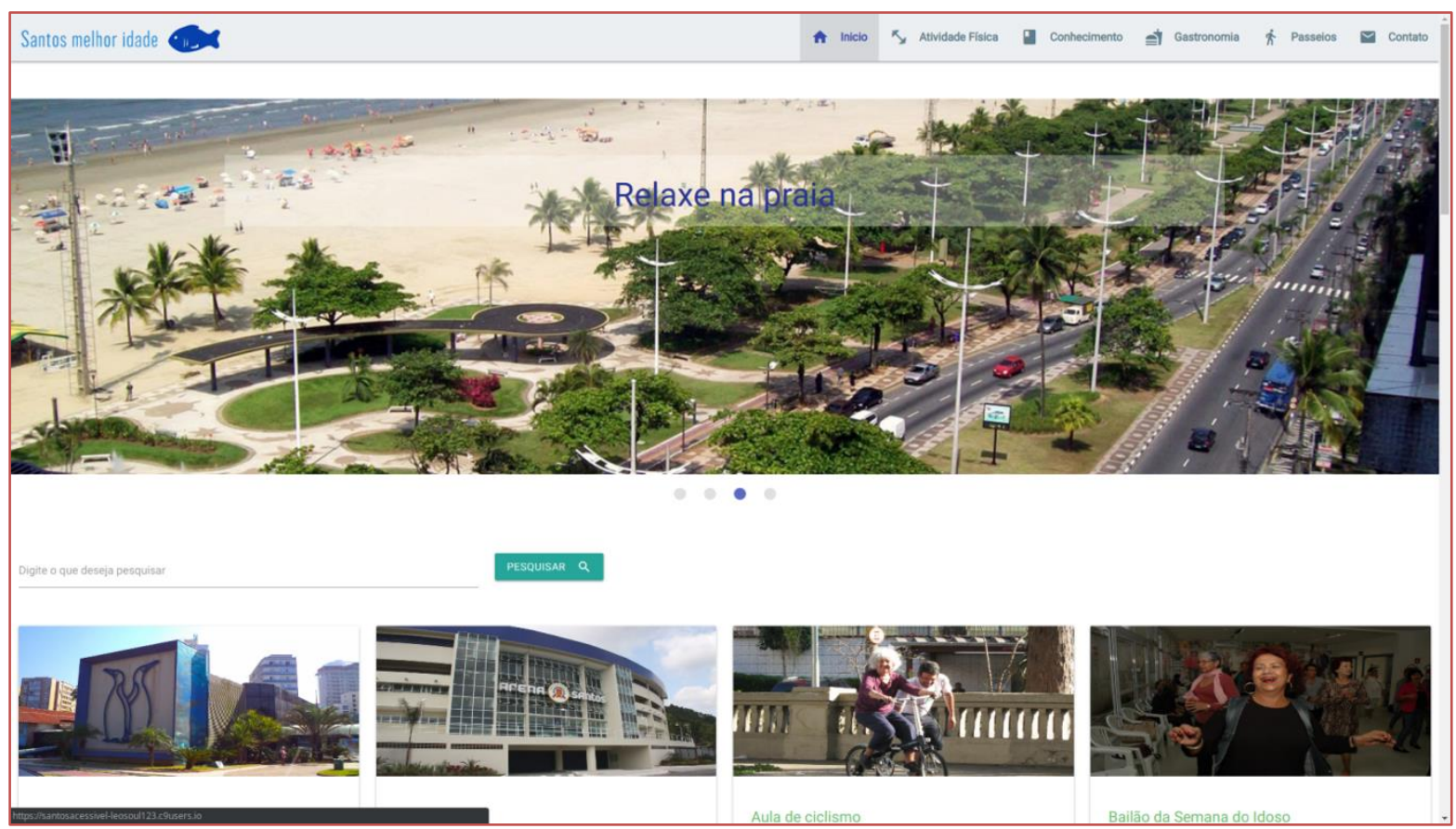

Fonte: Autores (2018)

A decisão pelo título se deu principalmente pela necessidade de desmistificar a faixa etária em questão, retirando-lhe o estigma de "terceira" idade como "avançada" ou "derradeira". Buscou-se, assim, uma conotação mais leve e positiva à aplicação. 0 logotipo remete diretamente à natureza litorânea, praiana, da cidade atendida pelo site, com a representação do peixe e a cor azulada.

Além disso, na figura acima também se vê, após "Início", as quatro principais guias destinadas à classificação da programação cultural e recreativa disponibilizada, organizadas por ordem alfabética.

Em "Atividade Física", serão destacados os locais em Santos onde os idosos podem se exercitar gratuitamente, como as praças próximas à praia em que estão instalados aparelhos de ginástica, ou o espaço Arena Santos, ginásio poliesportivo (ilustrado na Figura 4): 
Figura 4 - Tela “Atividade Física” de Santos Melhor Idade

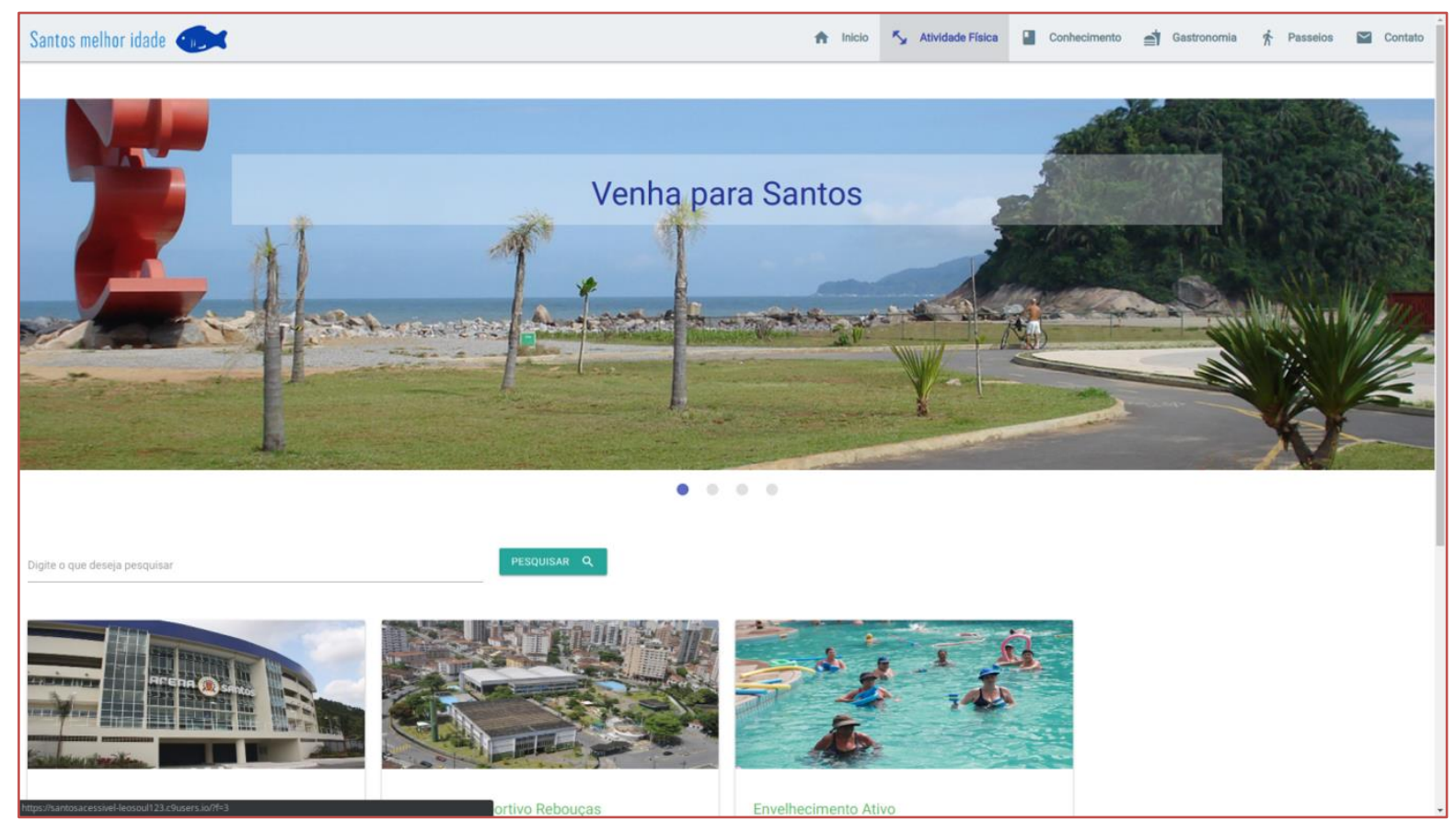

Fonte: Autores (2018)

"Conhecimento" traz dicas interessantes de cursos de extensão universitários e palestras ou minicursos esporádicos sobre temas ligados a esse público. Destacam-se nessa guia os cursos oferecidos pelas universidades públicas e privadas da cidade, como a Unifesp, com seu projeto de Universidade Aberta à Terceira Idade (UATI), e a própria FATEC Baixada Santista, onde esta pesquisa se desenvolveu, com o Projeto Nova Era - Melhor Idade, que oferece gratuitamente cursos de informática e de língua espanhola aos inscritos.

E, finalmente, "Passeios" apresenta opções de turismo e entretenimento tanto permanentes quanto itinerantes. Os principais pontos de visitação de Santos, como o Aquário Municipal e a Pinacoteca Benedito Calixto, mesclam-se com programas reservados a datas comemorativas específicas (como o Bailão da Semana do Idoso) ou a apresentações culturais temporárias, como peças de teatro e atividades circenses. Algumas das opções aparecem na Figura 5: 
Figura 5 - Tela "Passeios" de Santos Melhor Idade

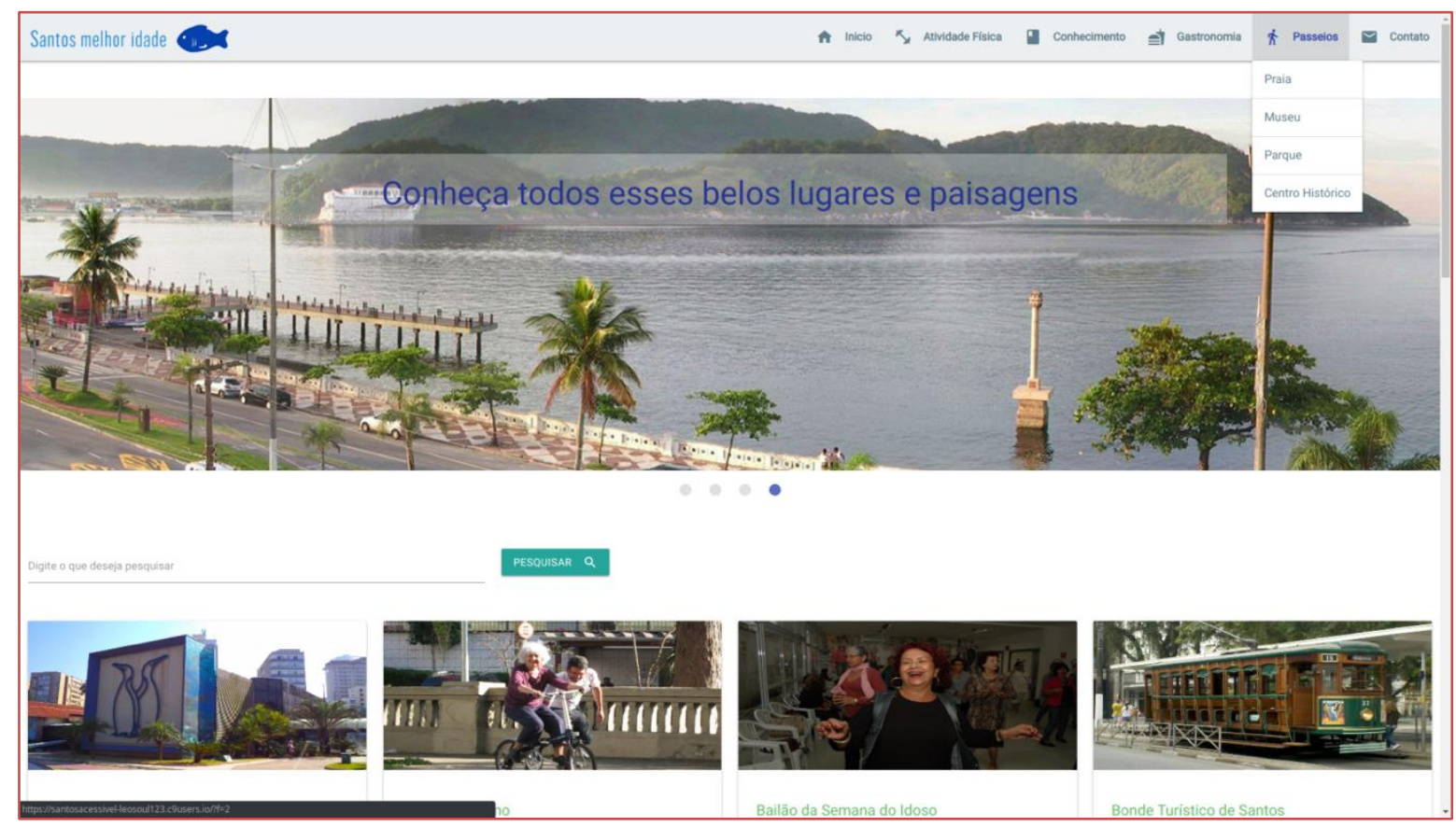

Fonte: Autores (2018)

Na imagem acima, vê-se que a grande variedade de passeios possíveis foi subdividida para facilitar a escolha por parte do usuário, de acordo com suas preferências ou intenções. Desse modo, tem-se "Praia", "Museu", "Parque" e "Centro histórico", para que opções tão distintas não estivessem misturadas e pudessem atrasar a interação do usuário com a programação oferecida.

Optou-se também por oferecer um espaço de contato com o usuário. Ao clicar em "Contato", uma janela se abre solicitando informações pessoais básicas, como nome e email, para que alguma crítica, sugestão ou contribuição possa ser enviada. Esse canal de comunicação é de extrema importância para a manutenção e atualização constante do site, por tomar como base de referência os comentários de quem navega.

\section{CONSIDERAÇõES FINAIS}

Conforme mencionado na literatura, os indivíduos pertencentes ao grupo da terceira idade, aqui denominada "melhor idade", ou simplesmente idosos, formam um contingente significativo para a vida cultural, social e recreativa de qualquer cidade atualmente. No caso de Santos, isso é ainda mais evidente, pela parcela da população com mais de 60 anos ser maior do que em outras regiões, e pelo município ser turístico, com oferta deliberada de opções de lazer para moradores, visitantes assíduos da capital paulista ou mesmo viajantes de passagem, mais numerosos em alta temporada. Um objetivo inicial do projeto foi identificar uma solução para divulgar passeios, palestras, encontros, atividades, de modo fácil e organizado, ao público da terceira idade, e esse objetivo foi cumprido, já que o site Santos Melhor Idade categoriza programas culturais e recreativos que interessariam a esses usuários, alguns, aliás, exclusivos.

Agora é possível afirmar que as funcionalidades previstas foram atendidas, dentro do escopo geral de desenvolvimento, com auxílio das tecnologias e ferramentas descritas (que se mostraram mais apropriadas em comparação com outras anteriormente definidas e depois substituídas, como é natural em qualquer processo de desenvolvimento tecnológico).

Os resultados deste estudo indicam que é plenamente viável oferecer serviços práticos e de qualidade àqueles que têm buscado sua inserção digital no mundo das novas tecnologias de informação. Mais capacitados e ativos do que há algumas décadas, os idosos devem ser vistos como usuários frequentes e exigentes, que demandam produtos específicos.

Tais resultados visam a alcançar um público que frequenta menos o ciberespaço e pode ser considerado "imigrante digital", cuja formação se deu anteriormente ao fortalecimento de tantos sistemas e redes sociais, mas que se mostra muito atuante no cenário sociocultural na região da Baixada Santista. 
Espera-se que esta pesquisa sirva de base para futuros estudos nessa área, que se dediquem a pensar soluções técnicas inovadoras para atender aos anseios de um público em rede cada vez mais crescente. A limitação aqui de não ter conseguido realizar testes de usabilidade com usuários potenciais em tempo hábil ao término da pesquisa, nem focado em estabelecer parcerias com estabelecimentos que oferecem os serviços divulgados no site, poderia ser resolvida com a continuidade do projeto, assim como pesquisas semelhantes na região de toda a Baixada Santista, da qual Santos faz parte, seriam bem-vindas.

\section{REFERÊNCIAS}

[1] AWS Cloud9. Disponível em: https://aws.amazon.com/pt/cloud9/. Acesso em: 10 jan. 2018.

[2] BARROS, M. M. L. (org.). Velhice ou terceira idade? Estudos antropológicos sobre identidade, memória e política. São Paulo: Fundação Getúlio Vargas, 1998.

[3] CROCKFORD, D. JavaScript: The Good Parts. O'Reilly, 2008. Disponível em: https://www.amazon.com.br/JavaScript-Good-Parts-Douglas- Crockford/dp/0596517742. Acesso em 02 fev. 2018.

[4] DALLA VECCHIA, R.; RUIZ, T.; BOCCHI, S. C. M.; CORRENTE, J. E. Qualidade de vida na terceira idade: um conceito subjetivo. Revista Brasileira de Epidemiologia. v.8, n.3, 246-52, 2005. Disponível em: https://www.scielosp.org/pdf/rbepid/2005.v8n3/. Acesso em: 10 nov. 2018.

[5] DELISLE, M. Mastering Phpmyadmin 3.4 For Effective Mysql Management.

[6] 2012. Disponível em: https://www.amazon.com.br/Mastering-Phpmyadmin-Effective-MySQLManagement/dp/1849517789. Acesso em: 10 abr. 2018.

[7] DUMAZEDIER, J. Lazer e cultura popular. São Paulo: Perspectiva, 1974.

[8] GUEDES, G. UML - Uma abordagem prática. São Paulo: Novatec, 2011.

[9] JOHNSON, S. Adobe Photoshop CS6 on Demand. Perspection Inc., 2012. Disponível em: https://books.google.com.br/books?id=IW89ijmKzhsC\&hl=pt-BR. Acesso em: 22 fev. 2018.

[10] MARCELlinO, N.C. Estudos do lazer: Uma introdução. 2 ed. Campinas, São Paulo: Autores Associados, 2000.

[11] MILANI, A. Mysql Guia do Programador. São Paulo: Novatec, 2006. Disponível em: https://www.estantevirtual.com.br/livros/andre-milani/mysql-guia-do-programador/1424800269. Acesso em: 05 mai. 2018.

[12] MORAZ, E. Treinamento Prático em PHP. Universo dos Livros Editora, 2005. Disponível em: https://books.google.com.br/books/about/Treinamento_Pr\%C3\%A1tico_em_PHP.html?id=RDCxxaLUrKAC\&redir_esc =y. Acesso em: 10 abr. 2018 .

[13] MOTA, K. M.; BABINSKI, L. R. Lazer na Terceira Idade: o Turismo como opção. GT 11 - Universidade de Caxias do Sul. 2012. Disponível em: https://www.ucs.br/site/midia/arquivos/gt11-lazer-na-terceira-idade.PDF. Acesso em: 12 set. 2018.

[14] PRABHU, A.; SHENOY, A. Introducing Materialize. Apress, 2016. Disponível em: https://www.apress.com/br/book/9781484223482. Acesso em: 12 abr. 2018.

[15] PRESCOTT, P. Programação em JavaScript. 2016. Disponível em: https://www.amazon.com.br/Programa\%C3\%A7\%C3\%A3o-em-JavaScript-Preston-Prescottebook/dp/B01BHQ0510. Acesso em: 12 jan. 2018.

[16] SCHMIDT, D. Tudo que você queria saber sobre Git e GitHub, mas tinha vergonha de perguntar. Tableless. 2015. Disponível em: https://tableless.com.br/tudo-que-voce-queria-saber-sobre-git-e-github-mas-tinha-vergonhade-perguntar/. Acesso em: 15 abr. 2018.

[17] SILVA, M. S. Fundamentos de HTML5 e CSS3. São Paulo: Novatec, 2015. Disponível em: https://novatec.com.br/livros/fundamentos-html5-css3/. Acesso em: 30 jan. 2018.

[18] JQuery - A Biblioteca do Programador JavaScript. São Paulo: Novatec, 2018. Disponível em: https://s3.novatec.com.br/capitulos/capitulo-9788575222379.pdf. Acesso em: 03 mar. 2018.

[19] SOMMERVILLE, I. Engenharia de Software. Trad. Ivan Bosnic e Kalinka G. de O. Gonçalves. São Paulo: Pearson $\begin{array}{llll}\text { Prentice } & \text { Hall, } & 2011 . & \text { Disponível: }\end{array}$ ftp://ftpaluno.umc.br/Aluno/Daisy/Engenharia\%20de\%20Software/Engenharia_Software_3Edicao\%20sommerville. pdf. Acesso em: 11 fev. 2018.

[20] VENTURA, L. A. S. Santos, a cidade no 1 na melhor idade. Jornal Estadão. 18 Março 2017. Disponível em: http://sao-paulo.estadao.com.br/noticias/geral,santos-a-cidade-n-1-na-melhor-idade,70001704589. Acesso em: 11 mai. 2018. 


\section{Capítulo 7}

Características e valores predominantes dos alunos de ciências contábeis da FACE/UFGD em consonância com as prerrogativas teóricas sobre gerações

\section{Cezar Eduardo Soares Cordeiro}

\section{Cristiane Mallmann Huppes}

Resumo: A sociedade atual apresenta quatro gerações convivendo nos diversos meios: os Veteranos, os Baby Boomers, a geração X e a geração Y. Este trabalho objetivou estudar as principais características teóricas das gerações atuais e confrontá-las com 0 comportamento da amostra analisada, a fim de se determinar ou não a predominância de tais prerrogativas teóricas a ela. Para tanto, foi aplicado um questionário aos discentes do curso de graduação em Ciências Contábeis da FACE/UFGD, e os respondentes representaram $41,4 \%$ da população estudada. Para a análise, os dados foram tratados no software Excel. Os resultados da pesquisa indicaram que assim como menciona a teoria, somente a idade não é suficiente para categorizar determinado grupo de pessoas à determinada geração. 0 grupo analisado foi categorizado como predominantemente pertencente à geração $\mathrm{Y}$, pela idade cronológica e porque a maioria das características Y foram compatíveis, mas pela análise de todas as características predominantes, a amostra pode ser classificada gradativamente em menor grau como também pertencente à Geração $\mathrm{X}$, aos Veteranos, e ainda aos Baby Boomers.

Palavras Chave: Ciências Contábeis; Perfil de alunos; Teoria das Gerações. 


\section{INTRODUÇÃO}

As interações entre indivíduos dentro das organizações têm despertado o interesse dos gestores, que hoje estão preocupados com o desenvolvimento social e emocional dos colaboradores, revelando assim que, gerir pessoas e estabelecer um relacionamento no ambiente empresarial, são condições influenciadas também por aspectos como: a natureza do trabalho e os elementos emocionais do comportamento humano (NORO et al., 2012). Exposto isso, reconhecer que as empresas funcionam através do capital humano e compreender as interações entre os indivíduos nas organizações, se torna necessário para os gestores, pois os reflexos disso são positivos ao desempenho geral das organizações.

A globalização tende a tornar as empresas competitivas, pois a tecnologia e as mudanças geram grandes desafios. Deste modo, é primordial utilizar o conhecimento das pessoas de maneira veloz e eficaz para atingir resultados desejados, como novos produtos e serviços inovadores. Além disso, é necessário que elas trabalhem de forma integrada, em sistemas interdependentes e colaborativos (PEREIRA, TREML e RANK, 2012).

Ainda de acordo aos autores, esse cenário exige que as organizações estejam cientes das diferentes gerações de pessoas atuando juntas no ambiente laboral, por meio de profissionais capazes de reconhecer cada uma dessas gerações, sua formação, suas influências sócio-históricas, suas capacidades, suas falhas, pois cada uma reage de um modo diferente ao meio em que estão inseridas. Não se resume apenas a comparar, mas admitir e reconhecer suas diferenças, desenvolvendo assim suas potencialidades.

Atualmente entre os autores do tema, a maioria tende a categorizar as gerações existentes em quatro: geração dos Veteranos, geração dos Baby Boomers, geração X e geração Y. Essa última vem sendo foco da maioria das pesquisas, por ser a geração mais recente e menos conhecida e também por apresentar características bem diferentes das anteriores.

Não existe um consenso definitivo entre os literários que estudam o tema. Como expõe Lima (2012), as gerações não têm uma data-limite precisa. Vários estudos, linhas de pensamento, ideologias, e pesquisadores consideram datas diferentes para início e término das mesmas, não existindo uma classificação definitiva e incontestável. 0 que há é um sentido de adequação referente a cada cultura ou contexto social. Oliveira (2012) menciona que é necessário considerar os vários fatores que ajudam a entender o tema, principalmente o conceito que é mais aceito pelos estudiosos - a separação da sociedade pela idade cronológica.

Em seu estudo sobre o choque das gerações no ambiente organizacional, Zemke, Raines e Filipczak (2000, p. 1), afirmam:

Há um problema comum a todas as empresas de qualquer parte do mundo. Não se trata da mudança, da tecnologia, da concorrência, dos clientes, dos chefes autoritários, dos colegas invejosos ou de jogos de bastidores. É um problema de diferenças de valores, de ambições, de pontos de vista. É, em suma, um problema de gerações. De gerações em conflito.

Diante do exposto sobre o tema e considerando o contexto atual das organizações, nota-se que administrar a convivência entre as diferentes gerações pede conhecimentos sobre o conjunto de características e valores que compõem o perfil de cada uma. Nesta perspectiva, esta pesquisa problematiza: quais as características e os valores predominantes dos alunos de Ciências Contábeis da FACE/UFGD em consonância com as prerrogativas teóricas sobre Gerações?

\section{REVISÃO DA LITERATURA}

Um grande marco nos estudos sobre a importância dos aspectos psicológicos e sociais dentro das organizações, determinando o começo de uma nova teoria baseada em valores humanos, foi a experiência de Hawthorne. Coordenada por Elton Mayo em 1927, o Conselho Nacional de Pesquisas dos Estados Unidos iniciou a experiência na fábrica de Hawthorne da Western Eletric Company, Chicago. No intuito de verificar a correlação entre iluminação e eficiência dos operários, medida por meio da produção, a pesquisa envolveu os aspectos fadiga, acidentes no trabalho, rotatividade de pessoal e efeito das condições de trabalho sobre a produtividade.

Os resultados da experiência, segundo os pesquisadores, eram prejudicados por variáveis de natureza psicológica. Inicialmente numa tentativa de eliminar ou neutralizar os fatores psicológicos, por os reconhecerem apenas quanto sua influência negativa, a pesquisa durou até 1932 (CHIAVENATO, 2003). Dividida em quatro fases, cada fase reunia grupos de operários a fim de testá-los e/ou conhecê-los. Tais 
resultados representaram um grande marco no reconhecimento e valorização do aspecto humano dentro das empresas, direcionando a ênfase na estrutura e nas tarefas para o foco nas pessoas (CHIAVENATO, 2003).

Hoje, as empresas e os profissionais têm se remodelado pelas transformações provocadas pela globalização da economia e novas tendências produtivas, como uma necessidade de sobreviver e crescer em um ambiente altamente competitivo e de competências mais complexas. A capacidade de lidar com a diferença e conviver com grupos de diferentes faixas etárias e características é uma destas competências (PEREIRA et al., 2012). Para administrar essa convivência é preciso conhecer as motivações e valores de cada um desses diferentes grupos, ou melhor, gerações. Neste sentido Ribeiro (2005, apud NORO, 2012) destaca que o profissional de recursos humanos deve obter meios de avaliar pessoas em todos os sentidos, diferenciando as pessoas com as quais lida diariamente e observando que cada pessoa tem sua própria personalidade, possuem conhecimentos, habilidades e atitudes peculiares.

Logo, antes de tudo, se torna necessário definir a palavra geração. Segundo o Dicionário Aurélio da língua portuguesa (FERREIRA, 2008, p. 432):

Geração sf. 1. Ato ou efeito de gerar. 2. Cada grau de filiação de pai a filho. 3. Conjunto de pessoas nascidas pela mesma época. 4. 0 espaço de tempo (aproximadamente 25 anos) que vai de uma geração (3) a outra. 5. Rád. Telev. Transmissão em circuito fechado de sinais de áudio ou vídeo para um ou mais pontos. [Pl.: ções.]

Kupperschimdt (2000, apud PEREIRA et al., 2012, p. 3), define geração como um "grupo identificável de pessoas nascidas em um mesmo período que compartilha experiências ao longo de suas vidas, influenciando e sendo influenciadas por uma variedade de fatores que incluem troca de atitudes da sociedade, mudanças sociais, políticas e econômicas. " Já de acordo com Oliveira (2010, apud SILVA et al., 2012, p. 3), "o conceito de geração reconhecido e aceito pela sociedade moderna estabelece o período de vinte anos como marco de separação entre as gerações".

Para Santos et al. (2011), de acordo com a história e os vários estudos que contemplam a trajetória do trabalho pode-se entender sobre os diversos aspectos sociais, humanos, políticos e funcionais que compõem as organizações. As atividades desenvolvidas e as ações projetadas oportunizaram uma ampliação da visão geral que envolve os contextos e culturas empresariais no que se refere à constituição do quadro funcional. Assim sendo, ocorrem inúmeras mudanças e pessoas de diferentes gerações são selecionadas para compor os organogramas das empresas.

Diante disso, Lombardia, Stein e Pin (2008, apud PEREIRA et al., 2012), salientam que esse novo contexto de diversidade presente nas organizações atuais, resulta em uma atuação simultânea e forçada de diferentes gerações de colaboradores. Ainda segundo os autores, para administrar essa convivência e conhecer as motivações e capacidades de cada geração é necessário compreender o contexto em que cresceram, as tendências culturais às quais foram expostos e as transformações políticas e sociais que viveram.

Todavia, considerar somente a idade de cada pessoa não é o suficiente para definir a geração a qual pertence. Mais que isso, é preciso identificar um conjunto de convívios históricos partilhados que definam princípios de visão de vida, contexto e valores iguais. Além disso, deve-se considerar a classe social, a educação e o acesso a inovações tecnológicas; então nesse conjunto de dados, teremos informações satisfatórias para adequar cada pessoa a sua geração (TEIXEIRA; JAESCHKE, 2012).

Santos et al. (2011, p. 2), comenta que por causa do processo de globalização e da ocorrência de mudanças rápidas, é essencial conhecer como cada uma dessas gerações se formou numa construção de cenário mundial, mapeando quais influências sócio históricas as constituíram. Argumentam ainda: "não se trata apenas de fazer comparações, visto que cada uma se prende com diferentes circunstâncias e contextos e são derivadas de diferentes tempos e sociedades, mas de concebê-las num processo de reconhecimento das diferenças".

Uma geração tem sua história baseada em um conjunto de vivências comuns, valores, visão de vida, cenário sociopolítico e aproximação de idades. Compreender e adaptar-se às diferentes gerações não é um desafio apenas dos gestores dentro das organizações, mas um desafio também da sociedade, pois o conjunto de comportamentos e valores das várias gerações influenciam o modo de ser e de viver das pessoas em sociedade (LOMBARDIA; STEIN; PIN, 2008 apud VASCONCELOS et al., 2010). 
Ao encontro disso, Bauman (2009, apud CHIUZI; PEIXOTO; FUSARI, 2011) explica que traçar o perfil de diferentes gerações é uma tarefa muito arriscada, pois inevitavelmente pode-se fazer generalizações indevidas, resultando na extração da historicidade e culturalidade do indivíduo.

Na literatura sobre o tema, não há consenso entre os autores sobre quantas gerações existam, como também há variação quanto às datas de nascimento e limite das gerações, e ainda quanto às suas denominações. Vasconcelos et al. (2010) argumentam que nas pesquisas sobre o tema identifica-se uma convergência nas características das gerações, assim como um foco de estudo voltado para as três últimas gerações. Alguns autores consideram períodos ligeiramente diferentes, começando alguns anos antes ou depois e/ou terminando anos mais cedo ou mais tarde. Neste raciocínio, Chiuzi, Peixoto e Fusari (2011, p. 581) mencionam:

Independente da nomenclatura, algumas características comuns são compartilhadas em função precisamente de eventos históricos que moldaram padrões socioculturais dos indivíduos. 0 que se percebe é que a maioria dos estudos e registros históricos (senão todos) é oriunda da cultura norteamericana, realizados a partir de registros históricos especialmente em função da história de participação em guerras que, definitivamente geraram verdadeiras cicatrizes sociais em determinadas gerações, marcando-as de maneira bastante significativa.

Silva, Silva e Santos (2012), afirmam que embora haja o convívio social de cinco gerações diferentes, três delas destacam-se numericamente no ambiente organizacional: os Baby Boomers, a Geração X e a Geração Y. Também, Veloso et al. (2008, apud VASCONCELOS et al., 2010), propõem a existência de três gerações: (a) Baby Boomers (nascidos até 1964); (b) Geração X (nascidos ente 1965 e 1977); (c) Geração Y (nascidos a partir de 1978). Na concepção de Engelmann (2009, apud SANTOS et al., 2011), que também divide as gerações em três, existe uma ligeira diferença quanto às datas: os Baby Boomers são as pessoas nascidas entre 1948 e 1963; a geração X, pessoas nascidas entre 1964 e 1977; a geração Y aquelas que nasceram entre 1978 e 1994.

Diante de tantas classificações quanto a nomenclaturas e datas, neste trabalho adotou-se a classificação apresentada por Teixeira e Jaeschke (2012), que tem por base a dimensão exposta na Tabela 1.

Tabela 1 - As quatro gerações presentes no ambiente de trabalho

\begin{tabular}{|c|c|c|c|c|}
\hline & Veteranos & Baby Boomers & Geração X & Geração Y \\
\hline Ano Nasc. & $1925-1945$ & $1946-1964$ & $1965-1979$ & $1980-2001$ \\
\hline $\begin{array}{l}\text { Eventos } \\
\text { históricos } \\
\text { chaves }\end{array}$ & $\begin{array}{l}2^{\mathrm{a}} \text { Guerra } \\
\text { Mundial. }\end{array}$ & $\begin{array}{c}1^{\circ} \text { homem na lua; Guerra } \\
\text { do Vietnã. }\end{array}$ & $\begin{array}{l}\text { Epidemia da AIDS; queda } \\
\text { do muro de Berlim. }\end{array}$ & $\begin{array}{c}\text { Ataque } 11 \text { de setembro; } \\
\text { Guerras do Afeganistão } \\
\text { e do Iraque; furacão } \\
\text { Katrina. }\end{array}$ \\
\hline $\begin{array}{l}\text { Traços } \\
\text { marcantes }\end{array}$ & $\begin{array}{l}\text { Patriotas rígidos, } \\
\text { práticos, } \\
\text { valorizam o } \\
\text { respeito, as } \\
\text { hierarquias e o } \\
\text { sacrifício. }\end{array}$ & $\begin{array}{c}\text { Workaholic, } \\
\text { competitivos, leais, } \\
\text { materialistas, otimistas, } \\
\text { focados, lideram por } \\
\text { consenso, automotivação } \\
\text { presente em suas } \\
\text { carreiras. }\end{array}$ & $\begin{array}{l}\text { Céticos, equilibrados, } \\
\text { valorizam a liderança por } \\
\text { competência e tem } \\
\text { espírito de } \\
\text { anticompromisso. }\end{array}$ & $\begin{array}{c}\text { Equilíbrio entre vida } \\
\text { pessoal e profissional, } \\
\text { otimistas e } \\
\text { esperançosos, decididos, } \\
\text { visam a inclusão e o } \\
\text { coletivismo. }\end{array}$ \\
\hline
\end{tabular}

Fonte: Teixeira e Jaeschke (2012, p. 6).

A Tabela 1 apresenta um resumo das quatro gerações existentes hoje, seu período cronológico, os eventos históricos marcantes e principais traços comportamentais. Uma vez definidas as gerações e sua delimitação no tempo histórico, a seguir são tratados aspectos característicos de cada geração.

\subsection{CARACTERÍSTICAS, CONTEXTO HISTÓRICO, COMPORTAMENTO E VALORES}

Nos próximos tópicos serão apresentadas especificidades de cada uma das Gerações que serão objeto de observação, a saber: Veteranos; Baby Boomers; Geração X; e, Geração Y. 


\subsubsection{VETERANOS}

Nascidas entre 1925 e 1945, a Segunda Guerra Mundial foi um evento que marcou profundamente essa geração. De acordo com Teixeira e Jaeschke (2012), as crianças desta geração cresceram vendo o mundo submerso na depressão econômica, e suas famílias imigrando em busca de trabalho ou fugindo da intolerância política causada pelas duas Guerras Mundiais. As destruições provocadas por elas separam suas famílias, desenvolvendo nessas crianças e os fazendo seguir mais tarde valores como compaixão, solidariedade, lealdade, a família, a lealdade, os direitos civis, o respeito pela autoridade e moralidade. Oliveira (2010, p.48 apud TEIXEIRA; JAESCHKE, 2012) lembra que a grande motivação e missão destes jovens foi a de reconstruir a sociedade.

É a geração mais antiga dentro das organizações. No ambiente organizacional prezam pelos princípios éticos e da memória coletiva da empresa, o que, por vezes, é rejeitado pelos Boomers, orientados para a ação, e pelos X, entusiastas da tecnologia. Possuem muita sabedoria e astúcia em relação ao ambiente de trabalho, além de terem uma rede de contatos valiosa para a organização.

Segundo Zemke, Raines e Filipczak (2000), profissionalmente esta geração apresenta os seguintes pontos fortes: são trabalhadores esforçados, estáveis, minuciosos, éticos, consistentes e leais; já os pontos fracos apontam para o receio a ambiguidade e a mudança e o desconforto com o conflito e as novas tecnologias.

\subsubsection{BABY BOOMERS}

Esta geração refere-se às pessoas nascidas entre 1946 e 1964, durante o período Baby Boom, definição genérica para crianças nascidas durante uma explosão populacional (grande número de nascimentos de crianças) - Baby Boom em inglês, pode ser traduzido como Explosão de Bebês. Em geral, sua atual definição se refere aos filhos da Segunda Guerra Mundial, já que logo após a guerra houve uma explosão populacional. Os nascidos nesta época são hoje os indivíduos que foram jovens durante as décadas de 60 e 70 e acompanharam de perto as mudanças culturais e sociais dessas duas décadas (SERRANO, 2010).

De acordo com Oliveira (2009, apud SANTOS et al., 2011), os pertencentes a esta geração são considerados motivados, otimistas e workaholies (viciados em trabalho). Todavia Conger (1998, apud SANTOS et al., 2011) menciona que essas qualidades não foram muito consideradas nos anos seguintes, tendo em vista fatos como a Guerra do Vietnã, o surgimento dos anticoncepcionais e os movimentos feministas. Pela rigidez da disciplina que recebiam, a tendência natural a rebeldia refletia na música, momento que surge o Rock and Roll e grandes nomes da música como Elvis Presley, Bob Dylan, Beatles e Rolling Stones.

Hoje, tem-se uma geração resistente às mudanças, pois devido à bagagem e vivência de experiências relevantes demonstram resistência em aliar ações em um ambiente cooperativo. Todavia essa geração tornou-se mais saudável e instruída que sua antecessora, uma vez que a motivação favorece uma aposentadoria mais tardia, por exemplos como a necessidade de complementar a renda familiar, a vitalidade que sentem ou a necessidade de continuar produzindo (KANNAME, 1999, apud SANTOS et al., 2011).

\subsubsection{GERAÇÃO X}

Compreende os que nasceram de 1965 a 1979. Como aponta Oliveira (2009, apud SANTOS et al., 2011), as inovações tecnológicas avançaram consideravelmente, deixando grandes marcas nos jovens dessa geração, influenciando a aceleração das atividades diárias, provocando manifestações revolucionárias e criando diferentes estilos de viver entre eles. Os revolucionários assumidos organizavam manifestações em movimentos estudantis como os "Hippies" que buscavam direitos iguais para todos. A música servia para representar os valores e posições políticas, que em um outro momento eram marcadas pela censura de imprensa. Além do que a liberdade de escolha passou a ser característica marcante dessa geração. No Brasil tivemos várias revoluções políticas que resultaram em perseguições a líderes políticos, professores, jornalistas, artistas e religiosos (SILVA, 2010).

Em relação à estrutura familiar, o casamento deixou de ser uma condição de permanência eterna. As crianças passaram a ter pais separados e mães que trabalhavam fora, o que começou a provocar um imenso sentimento de culpa nas mulheres, pela ausência em seus lares, o que gerou dificuldade de se colocar limites e estruturar a disciplina. Essas mudanças na estrutura familiar provocaram a quebra dos padrões aceitos como arcaicos social e moralmente (Oliveira, 2009 apud SANTOS et al., 2011). 
Essa geração teve grande contato com as inovações tecnológicas, assistiram ao surgimento do vídeo cassete, do computador pessoal e da internet e várias outras novidades que começaram a surgir na juventude e continuam num ritmo acelerado hoje (SILVA, 2010).

Outras características observadas são a valorização ao trabalho e a estabilidade financeira, uma vez que a carreira, por proporcionar sucesso na vida profissional, permanece como foco central. Questões como a busca pelo sucesso na vida pessoal, constituição de família e preocupação com a qualidade de vida são efetivadas. As pessoas da geração "X" são egoístas e autossuficientes, e buscaram através do trabalho a realização dos desejos materiais e pessoais, além de serem marcadas pelo pragmatismo e autoconfiança nas escolhas, buscando promover a igualdade de direitos e de justiça em suas decisões (OLIVEIRA, 2008, apud SILVA, 2010; OLIVEIRA, 2009, apud SANTOS et al., 2011).

Ainda sobre os X, Zemke, Raines e Filipczak (2000) expõem que enquanto os veteranos sobreviveram à Segunda Guerra Mundial e os Boomers à guerra fria e ao pânico nuclear, os X não encararam uma verdadeira guerra. Sobreviveram como puderam aos choques econômicos dos anos 70 e 80 . Isso ajuda a explicar o seu aparente alienamento, cinismo, ceticismo e materialismo. Eles são uma geração profundamente dividida.

\subsubsection{GERAÇÃO Y}

Nascida entre 1980 e 2001, a geração Y é formada por indivíduos filhos da geração Baby Boomers e dos primeiros membros da geração X. É conhecida como a geração dos resultados, tendo em vista que nasceu na época das tecnologias, da Internet e do excesso de segurança, pois não viveu nenhuma grande ruptura social, vive a democracia, a liberdade política e a prosperidade econômica.

Em relação às características, os indivíduos dessa geração são ambiciosos, individualistas, instáveis, pouco preconceituosos, curiosos e comunicativos, além do que são preocupados com o meio ambiente e com os direitos humanos. São pessoas também definidas como esperançosas, decididas, coletivas e com um bom nível de formação geralmente agindo sem autorização. Tendem a fazer várias coisas simultaneamente, gostam de variedade, desafios e oportunidades. Outra característica presente nas pessoas da geração Y é que elas convivem muito bem com as diferenças de etnia, sexo, religião ou nação em seus relacionamentos, pois aceitam bem a diversidade (LOIOLA, 2009, apud SANTOS et al., 2011).

As pessoas dessa geração valorizam mais a lealdade a si mesmos, por isso prezam menos pela permanência em uma única empresa. Embora dominem a tecnologia, estão sempre buscando novos desafios, novas oportunidades de emprego. Todavia são recrutadas com facilidade, porque no trabalho buscam liberdade, flexibilidade e criatividade (SANTOS et al., 2011).

\section{METODOLOGIA}

A metodologia responde, simultaneamente, às perguntas como? com o que? onde? e quanto? Isto é, a metodologia esclarece como a pesquisa será desenvolvida, o que utilizar para fazê-la e onde o estudo será aplicado (LAKATOS; MARCONI, 1991). Com base no referencial teórico, este estudo, quanto à metodologia, apresenta a divisão a seguir.

\subsection{DELINEAMENTO DA PESQUISA}

De acordo com os objetivos estabelecidos, este trabalho se caracteriza como uma pesquisa descritiva. Segundo Marion et al. (2010), a pesquisa descritiva busca descrever determinado fenômeno ou população. Nos estudos descritivos de natureza quantitativa, busca-se quantificar as variáveis selecionadas como sendo as mais importantes para descrever as características da população. Nesta linha, Beuren (2010) menciona que a pesquisa descritiva é intermediária entre a pesquisa exploratória e a pesquisa explicativa, isto é, nem tão prévia como a primeira nem tão profunda quanto a segunda, e seu objetivo é identificar, relatar, comparar, entre outros aspectos. Andrade (2002, apud BEUREN, 2010) enfatiza que o estudo descritivo foca em observar, registrar, analisar, classificar e interpretar os fatos, sem o pesquisador interferir neles.

Em relação aos procedimentos adotados para se obter os dados, o estudo é classificado como um levantamento. Beuren (2010) menciona que os procedimentos refletem o modo como o estudo será conduzido. As pesquisas de levantamento se caracterizam pela indagação direta das pessoas cujo 
comportamento se deseja esclarecer (GIL, 1999 apud BEUREN, 2010). Nesta tipologia de pesquisa os dados são coletados com base em uma amostra recortada de uma população ou universo que se deseja conhecer, possibilitando variação no grau de erro, pois nenhuma amostra é perfeita (BEUREN, 2010).

Quanto à abordagem do problema, este estudo é quantitativo, caracterizando-se pelo uso de instrumentos estatísticos na coleta e no tratamento dos dados. Esta tipologia não é tão profunda na busca do conhecimento sobre a realidade dos fenômenos, porque se volta para o comportamento geral dos fatos. A utilização da pesquisa quantitativa é comum em pesquisas de levantamento, para se compreender o comportamento de uma população através da amostra. A utilização desta abordagem se torna mais relevante à medida que se utiliza instrumentos estatísticos desde a coleta, até a análise e tratamento dos dados (BEUREN, 2010).

O instrumento de pesquisa a ser utilizado será o questionário. Ele é um instrumento de coleta de dados constituído por uma série ordenada de perguntas que devem ser respondidas por escrito pelos informantes que compõem a amostra, sem a presença do pesquisador (BEUREN, 2010). Ainda segundo Beuren (2010, p. 131), “o questionário precisa ser claro e limitado em sua extensão e estar acompanhado de notas que expliquem a natureza da pesquisa e ressaltem a importância e necessidade das respostas, a fim de motivar o informante. " Para Oliveira et al (2003), ele é um dos meios mais usados para se obter os dados desejados, pois permiti uma mensuração mais exata destes dados, além disso, trata-se de uma técnica impessoal entre pesquisador e entrevistados, já que a entrevista se dá por meio de um documento com perguntas dirigidas, aguardando resposta do entrevistado.

\subsection{DEFINIÇÃO DA POPULAÇÃO E AMOSTRA}

População ou universo da pesquisa é a totalidade de elementos diferentes que têm alguma igualdade nas características definidas para determinado estudo (BEUREN, 2010). Contandriopoulos et al (1994, apud BEUREN, 2013) afirmam que a população ou universo é composto por elementos distintos que possuem determinado número de características comuns. Esses elementos são as unidades de análise sobre as quais serão recolhidas as informações.

Amostra é uma pequena parte da população ou do universo, selecionada seguindo determinadas regras. É um subconjunto da população, por meio do qual se estabelecem ou se estimam as características desse universo ou população (GIL, 1999, apud BEUREN, 2010).

A população objeto de estudo desta pesquisa é composta por todos os 244 alunos regularmente matriculados no curso de graduação em Ciências Contábeis da FACE - Faculdade de Administração, Ciências Contábeis e Economia da UFGD - Universidade Federal da Grande Dourados, Dourados - MS. 0 questionário foi aplicado em todas as salas de aulas do curso, no dia 16/02/2017, abrangendo diretamente os alunos presentes em sala no dia da aplicação, o que representa a amostra da pesquisa. Optou-se pelo questionário impresso e aplicação in loco porque o feedback de respostas é maior em quantidade e também mais veloz quando comparado à uma aplicação em plataforma eletrônica. Totalizando 105 questionários distribuídos, quatro foram invalidados por motivos de erros de impressão, rasuras por parte dos respondentes entre outros motivos, perfazendo um total de 101 questionários válidos para análise. Logo, verifica-se que a amostra analisada representa 41,4\% da população questionada.

\subsection{TÉCNICAS DE COLETA E ANÁLISE DOS DADOS}

Para coletar os dados da pesquisa, foi desenvolvido um questionário dividido em 2 blocos. 0 primeiro bloco foi baseado nas características teóricas das 4 gerações apresentadas no trabalho, misturadas entre 32 afirmativas fechadas em primeira pessoa, cuja avaliação foi medida em escala Likert de quatro pontos, gradativamente de 1 a 4, sendo que 1 significa "Discordo Totalmente", 2 "Discordo", 3 "Concordo" e 4, "Concordo Totalmente", buscando-se obter por meio desta escala o grau ou intensidade de discordância/concordância para cada característica analisada. 0 questionário também possibilita resposta "Sem Opinião", representada por 0.0 bloco 2 refere-se ao perfil dos respondentes, com questões de ordem econômica, social e educacional, totalizando 13 perguntas, algumas abertas e outras de múltipla escolha.

Para análise dos dados, será utilizada a abordagem quantitativa, por meio da codificação e tabulação dos resultados no software Excel, para que possam ser tabelados e contados, permitindo a descrição, interpretação e compreensão dos resultados de forma rápida e objetiva. 


\section{DISCUSSÃO E ANÁLISE DOS DADOS}

Os resultados desta pesquisa são apresentados a seguir, iniciando com a descrição do perfil dos respondentes, seguido da discussão das características encontradas na amostra, segundo as prerrogativas das quatro gerações analisadas, a saber: características da geração "Veteranos", geração "Baby Boomers", geração " $\mathrm{X}$ " e geração "Y". Por fim, é apresentado um resumo das características predominantes dos alunos de Ciências Contábeis da FACE/UFGD.

\subsection{PERFIL DOS RESPONDENTES}

Os respondentes do questionário desta pesquisa são, em maior índice, do gênero masculino (50,5\%), com idade entre 17 e 37 anos (99\%), predominantemente solteiros $(77,2 \%)$ e estão alunos matriculados no primeiro ano do curso $(32,7 \%)$. Em sua maioria possuem independência financeira $(53,5 \%)$, com renda familiar total de $\mathrm{R} \$ 1.903,99$ até $2.826,65(23,8 \%)$ e possuem 1 dependente para esta renda. Questionados sobre onde cursaram ensinos fundamental e médio, 89,1\% dos respondentes estudaram o ensino fundamental em escola pública, assim como a maioria também cursou o ensino médio em escolas públicas $(82,2 \%)$. Nasceram predominantemente no MS $(87,1 \%)$ e se consideram brancos $(54,5 \%)$. Sobre o nível de escolaridade dos pais, 39,6\% responderam que as mães possuem ensino fundamental, já para os pais este percentual aumentou para 52,5\% que também possuem ensino fundamental.

Como a idade prevalecente dos respondentes está entre 17 e 37 anos (99\%), infere-se que a amostra corresponde majoritariamente à geração $\mathrm{Y}$, isso de acordo com o critério "Ano de Nascimento". Porém, se as características marcantes encontradas nesta amostra majoritariamente geração Y, correspondem ou não às elencadas pela teoria dos " $Y$ 's", ou ainda correspondem a qualquer característica teórica das outras 3 gerações em questão, é o que veremos a seguir.

\subsection{SOBRE AS CARACTERÍSTICAS DA GERAÇÃO VETERANOS}

Nascidos entre 1925 e 1945 (idade hoje entre 72 e 92 anos) os Veteranos foram significativamente marcados pela Segunda Guerra Mundial, crescendo em meio à depressão econômica e social da época. Este contexto de destruição despertou mais tarde nestas crianças valores como compaixão, solidariedade, lealdade e família (TEIXEIRA e JAESCHKE, 2012). Para Zemke, Raines e Filipczak (2000), os Veteranos acreditam no trabalho em equipe, embora o encarem segundo o modelo militar; esperam dos seus colaboradores, acima de tudo, lealdade e dedicação; e são atraídos pela segurança e estabilidade.

TABELA 2 - CARACTERÍSTICAS DA GERAÇÃO VETERANOS

\begin{tabular}{|c|c|c|c|c|c|c|c|c|}
\hline & & & & POS & FRE & ENCI & ELAT & \\
\hline & PERGUNTA / AFIRMATIVA & Não & $(0)$ & & ordo & & ordo & \\
\hline & & & $\begin{array}{l}\text { sem } \\
\text { opin. }\end{array}$ & (1) & (2) & (3) & (4) & Total \\
\hline 1.2 & Acredito na lógica e não na magia. & 0,0 & 2,0 & 4,0 & 13,9 & 23,7 & 56,4 & 100 \\
\hline 1.5 & Acredito sempre na lei e na ordem. & 1,0 & 2,0 & 4,0 & 23,7 & 47,5 & 21,8 & 100 \\
\hline 1.13 & $\begin{array}{l}\text { Eu aprecio coisas grandes e em } \\
\text { escala. }\end{array}$ & 0,0 & 8,8 & 5,0 & 23,8 & 40,6 & 21,8 & 100 \\
\hline 1.14 & $\begin{array}{l}\text { Gosto de aprender com as lições do } \\
\text { passado. }\end{array}$ & 0,0 & 2,0 & 2,0 & 7,9 & 37,6 & 50,5 & 100 \\
\hline 1.15 & $\begin{array}{l}\text { Gosto de consistência e } \\
\text { uniformidade. }\end{array}$ & 1,0 & 2,0 & 5,0 & 16,8 & 41,6 & 33,7 & 100 \\
\hline 1.23 & Possuo forte sentido do dever. & 1,0 & 2,0 & 0,0 & 12,9 & 46,5 & 37,6 & 100 \\
\hline 1.26 & $\begin{array}{c}\text { Sou conservador (a) com meus } \\
\text { investimentos. }\end{array}$ & 0,0 & 3,0 & 2,0 & 16,8 & 35,6 & 42,6 & 100 \\
\hline 1.29 & Sou disciplinado (a) e leal. & 1,0 & 1,0 & 5,0 & 7,8 & 41,6 & 43,6 & 100 \\
\hline
\end{tabular}


A Tabela 2 apresenta um corte do questionário aplicado, que corresponde à algumas das principais características elencadas pela teoria da Geração Veteranos. Observa-se que quando indagados em relação à tais afirmativas, a frequência de suas respostas prevalece entre concordo (3) e concordo totalmente (4). Logo, percebe-se que embora na idade cronológica a amostra analisada corresponda à Geração Y, ela tende a concordar com todas as características aqui analisadas da Geração Veteranos, sem exceções. Dentre elas, a crença na lógica e não na magia e a preferência por consistência e uniformidade, são as 2 características encontradas com maior intensidade aqui, ambas com mais de $50 \%$ de frequência das respostas dentro da escala (4) concordo totalmente.

\subsection{SOBRE AS CARACTERÍSTICAS DA GERAÇÃO BABY BOOMERS}

Os Baby Boomers compreendem as pessoas nascidas entre 1946 e 1964 (idade atual de 53 a 71 anos), período chamado de Baby Boom por conta do grande número de nascimentos da época. Enquanto os Veteranos viveram a Segunda Guerra Mundial, os Boomers são referenciados como filhos dela, pois logo após a guerra houve uma explosão populacional (SERRANO, 2010). São considerados motivados, otimistas e viciados em trabalho (OLIVEIRA, 2009 apud SANTOS e al., 2011). Profissionalmente possuem foco nos resultados, valorizam a missão da empresa, seu status e ascensão profissional. 0 emprego é uma afirmação de identidade. Sua ética refere-se mais à vida pessoal do que à vida profissional e preferem gerir por consensos (ZEMKE, RAINES e FILIPCZAK, 2000).

TABELA 3 - CARACTERÍSTICAS DA GERAÇÃO BABY BOOMERS

\begin{tabular}{|c|c|c|c|c|c|c|c|c|}
\hline & & & & POSTA & FREQ & NCIA & LATIV & \\
\hline & PERGUNTA / AFIRMATIVA & Não & $(0)$ & Dis & rdo & Con & rdo & \\
\hline & & & $\begin{array}{l}\text { sem } \\
\text { opin. }\end{array}$ & (1) & $(2)$ & (3) & (4) & Total \\
\hline 1.4 & $\begin{array}{c}\text { Acredito no progresso econômico e } \\
\text { social. }\end{array}$ & 0,0 & 0,0 & 1,0 & 16,8 & 41,6 & 40,6 & 100 \\
\hline 1.7 & $\begin{array}{l}\text { Aprendi o que é o trabalho em equipe } \\
\text { na escola. }\end{array}$ & 2,0 & 3,0 & 15,8 & 24,7 & 33,7 & 20,8 & 100 \\
\hline 1.8 & $\begin{array}{l}\text { Aprendi o que é o trabalho em equipe } \\
\text { no local onde trabalho. }\end{array}$ & 1,0 & 2,0 & 12,8 & 20,8 & 31,7 & 31,7 & 100 \\
\hline 1.17 & $\begin{array}{c}\text { Gosto de ser a (o) estrela do } \\
\text { espetáculo. }\end{array}$ & 1,0 & 4,0 & 39,6 & 32,7 & 12,8 & 9,9 & 100 \\
\hline 1.18 & $\begin{array}{c}\text { Minha gratificação pessoal possui um } \\
\text { custo elevado para mim e para os } \\
\text { outros. }\end{array}$ & 0,0 & 6,9 & 27,7 & 23,8 & 20,8 & 20,8 & 100 \\
\hline 1.24 & $\begin{array}{l}\text { Procuro a essência e o sentido da vida } \\
\text { de forma repetida e obsessiva. }\end{array}$ & 0,0 & 7,9 & 23,8 & 38,6 & 20,8 & 8,9 & 100 \\
\hline 1.32 & Sou otimista. & 0,0 & 0,0 & 3,0 & 17,8 & 37,6 & 41,6 & 100 \\
\hline
\end{tabular}

De forma análoga à Tabela 2, a Tabela 3 mostra algumas das características mais relevantes da geração Baby Boomers e o comportamento dos respondentes em relação à elas. Percebe-se certa dispersão nas maiores freqüências relativas para cada característica, indicando discordância para 3 das 7 prerrogativas analisadas, porém ainda as 4 demais indicam concordância, revelando novamente que embora a amostra seja predominantemente $\mathrm{Y}$, ela tende a concordar com a maioria das características dos Baby Boomers aqui analisadas. Com 39,6\%, a característica “Gosto de ser a estrela do espetáculo" obteve o maior nível de discordância. Por outro lado, o maior grau de concordância foi de 41,6\% para a característica "Sou otimista". 


\subsection{SOBRE AS CARACTERÍSTICAS DA GERAÇÃO "X"}

Os indivíduos da geração X nasceram de 1965 até 1979 (atualmente com idade entre 38 e 52 anos). Vivenciaram um cenário de revolução e luta política e social. Progredindo significativamente, as inovações tecnológicas marcaram os jovens dessa geração, incitando a aceleração de seu ritmo de vida, o que resultou em manifestações revolucionárias. A música na época representava valores e posições políticas (SILVA, 2010). A sua estrutura familiar sofreu rupturas, tornando-se comum pais separados e mães que trabalhavam fora. Influenciada pela TV, os apelos consumistas aumentaram, reordenando o modo de viver e agir das pessoas (OLIVEIRA, 2009 apud SANTOS et al., 2011). Os X valorizam o trabalho e a estabilidade financeira, embora para eles emprego não garanta sobrevivência. São egoístas e auto-suficientes. Possuem traços de cinismo, ceticismo e materialismo. Dominam a tecnologia, desconfiam da hierarquia e das verdades absolutas (ZEMKE; RAINES; FILIPCZAK, 2000).

\section{TABELA 4 - CARACTERÍSTICAS DA GERAÇ̃̃O “X”}

\begin{tabular}{|c|c|c|c|c|c|c|c|c|}
\hline \multirow{3}{*}{\multicolumn{2}{|c|}{ PERGUNTA / AFIRMATIVA }} & \multirow{4}{*}{$\begin{array}{l}\text { Não } \\
\text { resp. } \\
2,0\end{array}$} & \multicolumn{5}{|c|}{ RESPOSTAS FREQUENCIA RELATIVA } & \multirow{3}{*}{ Total } \\
\hline & & & \multirow{2}{*}{$\begin{array}{l}\text { (0) sem } \\
\text { opin. }\end{array}$} & \multicolumn{2}{|c|}{ Discordo } & \multicolumn{2}{|c|}{ Concordo } & \\
\hline & & & & (1) & (2) & (3) & (4) & \\
\hline 1.9 & Busco um sentido de família. & & 4,0 & 6,9 & 8,9 & 30,7 & 47,5 & 100 \\
\hline 1.10 & $\begin{array}{l}\text { Concilio minha vida pessoal e } \\
\text { profissional. }\end{array}$ & 0,0 & 3,0 & 4,0 & 11,9 & 28,6 & 52,5 & 100 \\
\hline 1.11 & Domino as tecnologias. & 0,0 & 2,0 & 4,0 & 20,7 & 59,4 & 13,9 & 100 \\
\hline 1.16 & Gosto de correr riscos. & 1,0 & 3,0 & 25,7 & 34,7 & 25,7 & 9,9 & 100 \\
\hline 1.21 & Normalmente cumpro objetivos. & 0,0 & 0,0 & 1,0 & 6,9 & 40,6 & 51,5 & 100 \\
\hline 1.22 & $\begin{array}{l}\text { Normalmente } \mathrm{NÃO} \text { cumpro } \\
\text { prazos. }\end{array}$ & 0,0 & 5,9 & 55,4 & 29,7 & 5,0 & 4,0 & 100 \\
\hline 1.25 & Sou autoconfiante. & 0,0 & 1,0 & 9,8 & 19,8 & 54,5 & 14,9 & 100 \\
\hline 1.27 & Sou criativo (a). & 0,0 & 3,0 & 6,9 & 36,6 & 33,7 & 19,8 & 100 \\
\hline 1.28 & Sou desconfiado e descrente. & 0,0 & 5,9 & 19,8 & 25,8 & 38,6 & 9,9 & 100 \\
\hline 1.30 & Sou indiferente a autoridades. & 0,0 & 7,9 & 35,6 & 32,7 & 16,9 & 6,9 & 100 \\
\hline 1.31 & Sou informal no meu trabalho. & 1,0 & 6,9 & 39,6 & 34,6 & 12,9 & 5,0 & 100 \\
\hline
\end{tabular}

Fonte: dados da pesquisa.

A Tabela 4 refere-se às características dos X encontradas na amostra. Observa-se novamente uma dispersão em relação às maiores frequências de respostas. Aqui foram identificadas e analisadas 11 prerrogativas da geração $X$, sendo que 5 delas obtiveram maior frequência em tender a discordar, mostrando que tais características não representam a amostra, com destaque em não concordância para a afirmativa "Normalmente NÃO cumpro prazos", que obteve 55,4\% das respostas em nível máximo de discordância. Por outro lado, 6 dessas prerrogativas apresentam frequências maiores tendendo a concordar, indicando que tais prerrogativas representam a amostra aqui estudada, com ênfase para a característica "Concilio minha vida pessoal e profissional", que obteve uma frequência relativa de 52,5 \% das respostas em grau máximo de concordância.

\subsection{SOBRE AS CARACTERÍSTICAS DA GERAÇÃO Y}

Nascidos entre 1980 e 2001 (idade hoje de 16 até 37 anos), época das tecnologias, Internet e excesso de segurança, esta geração também é chamada de geração dos resultados. Não vivenciou nenhuma grande ruptura social. OS Y são ambiciosos, individualistas, instáveis, pouco preconceituosos, curiosos e comunicativos. Convivem de forma agradável com as diferenças e aceitam bem a diversidade (LOIOLA, 2009, apud SANTOS et al., 2011). Sua estrutura familiar é flexível, com pais separados e convívio com 
irmãos de pais diferentes; adendo para as mães dessa geração, que predominantemente são mulheres independentes com vida profissional ativa. Outros traços marcantes a esta geração dizem respeito à autoconfiança, inteligência, informalidade e imediatismo. 0 trabalho é visto como fonte de satisfação e aprendizado. Contudo, por serem leais mais a si próprios, não prezam pela permanência em uma única empresa.

TABELA 5 - CARACTERÍSTICAS DA GERAÇÃO Y

\begin{tabular}{|c|c|c|c|c|c|c|c|c|}
\hline \multirow{3}{*}{\multicolumn{2}{|c|}{ PERGUNTA / AFIRMATIVA }} & \multirow{3}{*}{$\begin{array}{l}\text { Não } \\
\text { resp. }\end{array}$} & \multicolumn{6}{|c|}{ RESPOSTAS FREQUENCIA RELATIVA } \\
\hline & & & \multirow{2}{*}{$\begin{array}{c}(0) \text { sem } \\
\text { opin. }\end{array}$} & \multicolumn{2}{|c|}{ Discordo } & \multicolumn{2}{|c|}{ Concordo } & \multirow{2}{*}{ Total } \\
\hline & & & & (1) & $(2)$ & (3) & $(4)$ & \\
\hline 1.1 & $\begin{array}{l}\text { Aceito de forma natural a diversidade } \\
\text { social (raças, religiões, gênero) }\end{array}$ & 0,0 & 0,0 & 1,0 & 1,0 & 31,7 & 66,3 & 100 \\
\hline 1.3 & Acredito no meu futuro. & 0,0 & 0,0 & 2,0 & 0,0 & 14,8 & 83,2 & 100 \\
\hline 1.6 & Aprecio a maneira de ser dos meus pais. & 0,0 & 0,0 & 3,0 & 15,9 & 25,7 & 55,4 & 100 \\
\hline 1.12 & $\begin{array}{l}\text { Enquanto criança (bebê) freqüentei } \\
\text { infantário (escolinha, creche). }\end{array}$ & 1,0 & 11,9 & 40,6 & 8,9 & 9,9 & 27,7 & 100 \\
\hline 1.19 & $\begin{array}{l}\text { Minha mãe sempre teve vida profissional } \\
\text { (trabalhou fora de casa). }\end{array}$ & 1,0 & 1,0 & 23,8 & 15,8 & 18,8 & 39,6 & 100 \\
\hline 1.20 & $\begin{array}{l}\text { No meu emprego sou desejoso por } \\
\text { trabalhar e aprender. }\end{array}$ & 1,0 & 5,9 & 7,9 & 7,9 & 24,8 & 52,5 & 100 \\
\hline
\end{tabular}

Fonte: dados da pesquisa.

A Tabela 5 apresenta as prerrogativas teóricas dos $\mathrm{Y}$ e o comportamento da amostra em relação a elas. Infere-se que a maioria dessas características representam fortemente a amostra estudada, ou seja, reafirmam os principais traços comportamentais elencados pela teoria, pois quase todas apontam a maioria das respostas para o grau (4) "Concordo Totalmente", principalmente no que se refere à crença no futuro $(83,2 \%)$ e a aceitação da diversidade social $(66,3 \%)$, seguidas pela admiração ao modo de ser dos pais $(55,4 \%)$. A exceção foi para a característica "Enquanto criança (bebê) frequentei infantário (escolinha, creche)", em que 40,6\% dos entrevistados responderam negativamente a ela, comportamento amostral que contradiz a teoria, uma vez que as mães dessa geração foram mulheres independentes financeira e emocionalmente, tendo que trabalhar fora deixavam os filhos em creches, e quando perguntados se a mães possuíam vida profissional, 39,6 \% responderam positivamente, o que reforça a contradição, revelando aqui uma falha na interpretação da pergunta ou na forma como foi questionada.

\subsection{CARACTERÍSTICAS PREDOMINANTES DA AMOSTRA}

A Tabela 6 mostra as prerrogativas teóricas que mais marcaram a amostra estudada, em grau máximo de concordância, independentemente a qual geração tal prerrogativa se refira. 
TABELA 6 - CARACTERÍSTICAS PRODOMINANTES DA AMOSTRA

\begin{tabular}{|c|c|c|c|c|c|c|c|c|c|}
\hline & & & & & OSTA & FREC & ENCI & ELAT & \\
\hline & PERGUNTA / AFIRMATIVA & Geraç. & Não & $(0)$ & Disc & rdo & Col & ordo & \\
\hline & & & & $\begin{array}{l}\text { sem } \\
\text { opin. }\end{array}$ & (1) & (2) & (3) & $(4)$ & Total \\
\hline 1.1 & $\begin{array}{l}\text { Aceito de forma natural a diversidade } \\
\text { social (raças, religiões, gênero) }\end{array}$ & Y & 0,0 & 0,0 & 1,0 & 1,0 & 31,7 & 66,3 & 100 \\
\hline 1.2 & Acredito na lógica e não na magia. & V & 0,0 & 2,0 & 4,0 & 13,9 & 23,7 & 56,4 & 100 \\
\hline 1.3 & Acredito no meu futuro. & Y & 0,0 & 0,0 & 2,0 & 0,0 & 14,8 & 83,2 & 100 \\
\hline 1.6 & $\begin{array}{l}\text { Aprecio a maneira de ser dos meus } \\
\text { pais. }\end{array}$ & Y & 0,0 & 0,0 & 3,0 & 15,9 & 25,7 & 55,4 & 100 \\
\hline 1.8 & $\begin{array}{c}\text { Aprendi o que é o trabalho em equipe } \\
\text { no local onde trabalho. }\end{array}$ & $\mathrm{BB}$ & 1,0 & 2,0 & 12,8 & 20,8 & 31,7 & 31,7 & 100 \\
\hline 1.9 & Busco um sentido de família. & $\mathrm{X}$ & 2,0 & 4,0 & 6,9 & 8,9 & 30,7 & 47,5 & 100 \\
\hline 1.10 & $\begin{array}{l}\text { Concilio minha vida pessoal e } \\
\text { profissional. }\end{array}$ & $\mathrm{X}$ & 0,0 & 3,0 & 4,0 & 11,9 & 28,6 & 52,5 & 100 \\
\hline 1.14 & $\begin{array}{c}\text { Gosto de aprender com as lições do } \\
\text { passado. }\end{array}$ & V & 0,0 & 2,0 & 2,0 & 7,9 & 37,6 & 50,5 & 100 \\
\hline 1.19 & $\begin{array}{l}\text { Minha mãe sempre teve vida } \\
\text { profissional (trabalhou fora de casa). }\end{array}$ & Y & 1,0 & 1,0 & 23,8 & 15,8 & 18,8 & 39,6 & 100 \\
\hline 1.20 & $\begin{array}{l}\text { No meu emprego sou desejoso por } \\
\text { trabalhar e aprender. }\end{array}$ & Y & 1,0 & 5,9 & 7,9 & 7,9 & 24,8 & 52,5 & 100 \\
\hline 1.21 & Normalmente cumpro objetivos. & $\mathrm{X}$ & 0,0 & 0,0 & 1,0 & 6,9 & 40,6 & 51,5 & 100 \\
\hline 1.26 & $\begin{array}{l}\text { Sou conservador (a) com meus } \\
\text { investimentos. }\end{array}$ & V & 0,0 & 3,0 & 2,0 & 16,8 & 35,6 & 42,6 & 100 \\
\hline 1.29 & Sou disciplinado (a) e leal. & V & 1,0 & 1,0 & 5,0 & 7,8 & 41,6 & 43,6 & 100 \\
\hline 1.32 & Sou otimista. & $\mathrm{BB}$ & 0,0 & 0,0 & 3,0 & 17,8 & 37,6 & 41,6 & 100 \\
\hline
\end{tabular}

Fonte: dados da pesquisa.

Primeiramente, cabe ressaltar que para as prerrogativas da Geração Y, a amostra revela as maiores frequências de respostas afirmativas, corroborando com os aspectos elencados pela teoria da geração $\mathrm{Y}$. Características como a aceitação da diversidade cultural $(66,3 \%)$, a crença no futuro $(83,2 \%)$ e admiração pelo modo de ser dos pais $(55,4 \%)$ predominaram sobre as demais em termos de frequência relativa, mostrando que a amostra tende a se identificar mais com os aspectos comportamentais de sua respectiva idade cronológica, ou seja, geração Y. Também marcaram fortemente a amostra os aspectos Y como a vontade por trabalhar e aprender (52,5\%) e o fato das mães terem vida profissional ativa (39,6\%).

Em segundo lugar vale destacar que o comportamento amostral também revelou uma forte identificação com as características teóricas da geração X. Quando questionados sobre o equilíbrio entre vida pessoal e profissional, $52,5 \%$ responderam positivamente. Também representaram fortemente a amostra aspectos quanto ao cumprimento de objetivos $(51,5 \%)$ e a busca por um sentido de família $(47,5 \%)$.

Ainda analisando a Tabela 6, também infere-se que a amostra possui fortemente traços comportamentais da geração dos Veteranos. Destacaram-se as características: crença na lógica e não na magia (56,4\%); o gosto em aprender com o passado (50,5\%); a disciplina e lealdade $(43,6 \%)$ e o conservadorismo para investir $(42,6 \%)$.

Por último e com menor representatividade da amostra, destacam-se as características dos Baby Boomers. Apenas duas delas apresentaram grau máximo de concordância: o otimismo $(41,6 \%)$ e o aprendizado de trabalho em equipe no trabalho e não na escola $(31,7 \%)$.

Considerando que a idade cronológica aponte para a Geração Y, de 17 a 37 anos, pela análise dos dados obtidos nota-se uma identificação forte não apenas com as características da Geração Y, mas também com 
aspectos teóricos das outras três gerações em questão. Logo, a amostra não se comporta exclusivamente como Y, incorporando aspectos das demais gerações.

\section{CONCLUSÕES}

Com a presença de quatro gerações nos diversos meios sociais, saber administrar os conflitos dessa convivência é indispensável. Para isso é necessário identificar e entender cada geração. Identificar uma geração requer considerar, além do período de nascimento, variáveis que interferem na formação de um ser humano, por exemplo, a cultura, família, educação, padrão econômico e localização. Por isso, a categorização geracional tem considerado acontecimentos sociais e culturais coletivos, assim como aspectos comportamentais facilmente identificáveis.

A análise dos dados colhidos permitiu verificar que assim como menciona a teoria, somente a idade não é suficiente para categorizar determinado grupo de pessoas à determinada geração. Adotando somente o critério idade cronológica, a amostra analisada é pertencente à geração Y, pois possui idade entre 17 e 37 anos, como apontou o perfil dos respondentes. Porém, submetendo esta amostra ao questionamento sobre diversas características das quatro gerações, ela apresentou fortemente traços comportamentais não só de sua categoria pela idade, mas também aspectos dos Boomers, dos Veteranos e dos X. Logo, o grupo analisado pode ser categorizado como predominantemente pertencente à geração Y, pela idade cronológica ser compatível, assim como a maioria das características analisadas, mas pela análise de suas características pode ser classificado como Geração X, Veteranos, ou em menor grau, até como Baby Boomer.

Conclui-se que as características Y encontradas na amostra corroboram com as elencadas pela teoria, uma vez que a maioria delas apresentou alto grau de concordância por parte dos respondentes. Entretanto, o grupo analisado apresentou a predominância de valores e características em acordo às prerrogativas teóricas de outros grupos de gerações, o que contradiz a teoria, e gera dificuldade em atribuir o grupo à apenas uma geração específica.

Independentemente da geração ao qual pertença, o trabalho de identificação deve ir além de comparar, devendo-se compreender as diferenças como características complementares umas às outras, de forma a amenizar os conflitos entre as gerações.

Fatores limitantes como a região de moradia ou a classe social podem influenciar os resultados, ficando como sugestão a serem considerados em pesquisas futuras de forma mais expansiva. Outras limitações podem ter afetado as respostas dos entrevistados, como: falta de motivação do entrevistado ao responder, fornecimento de respostas falsas, ou ainda compreensão incorreta do significado de algumas perguntas.

\section{REFERÊNCIAS}

[1] BEUREN, Ilse Maria et al. (Org.). Como elaborar trabalhos monográficos em contabilidade. 3. ed. São Paulo: Atlas, 2010.

[2] CERETTA, Simone Beatriz; FROEMMING, Lurdes Marlene. Geração Z: Compreendendo os hábitos de consumo da geração emergente. Revista Eletrônica do Mestrado Profissional em Administração, Lagoa Nova, v. 3, n. 02, p.15-24, 2011.

[3] CERVO, Amado Luiz; BERVIAN, Pedro Alcino; SILVA, Roberto da. Metodologia científica. 6. ed. São Paulo: Pearson Prentice Hall, 2007.

[4] CHIAVENATO, Idalberto. Introdução à Teoria Geral da Administração. 7. ed. Rio de Janeiro: Elsevier, 2003.

[5] CHIUZI, Rafael Marcus; PEIXOTO, Bruna Ribeiro Gonçalves; FUSARI, Giovana Lorenzini. Conflito de gerações nas organizações; um fenômeno social interpretado a partir da teoria de Erik Erikson. Temas Em Psicologia, São Bernardo do Campo, v. 19, n. 2, p. 579-590, 2011.

[6] FERrEIRA, Aurélio Buarque de Holanda. MINIAURÉLIO: O DICIONÁRIO DA LÍNGUA PORTUGUESA. 7. ed. Curitiba: Positivo, 2008.

[7] LAKATOS, Eva Maria; MARCONI, Marina de Andrade. Fundamentos de metodologia científica. 3. ed. São Paulo: Atlas, 1991.

[8] LIMA, Ranieri. Perfil das gerações no Brasil: As gerações X, Y e Z e seus perfis políticos. São Paulo: Baraúna, 
[9] MARION, José Carlos et al. Monografia para os Cursos de Administração, Contabilidade e Economia. 2. ed. São Paulo: Atlas, 2010.

[10] NORO, Greice de Bem et al. A gestão da geração Y nas empresas filiadas à AJESM da cidade de Santa Maria RS. Gestão Estratégica, Empreendedorismo e Sustentabilidade, Santa Maria, set. 2012.

[11] OLIVEIRA, Antonio Benedito Silva et al (Org.). Métodos e técnicas de pesquisa em contabilidade. São Paulo: Saraiva, 2003.

[12] OLIVEIRA, Sidnei. Jovens para sempre: Como entender os conflitos de gerações. São Paulo: Integrare Editora,

2012.

[13] PEREIRA, Liandra; TREML, Édna E. Z. Fietz; RANK, Sueli M. W. Perfil profissional da geração Y: um estudo exploratório em cursos da área de ciências sociais aplicadas em universidades do interior de Santa Catarina. Gestão Estratégica: Empreendedorismo e Sustentabilidade, Santa Maria, set. 2012.

[14] RUDIO, Franz Victor. Introdução ao projeto de pesquisa científica. 12 ed. Petrópolis: Vozes, 1995.

[15] SANTOS, Cristiane Ferreira dos et al. O processo evolutivo entre as gerações X, Y e Baby Boomers. Seminários em Administração, Limeira, 2011.

[16] SERRANO, Daniel Portillo. Geração Baby Boomer. 2010. Disponível em: <http://www.portaldomarketing.com.br/Artigos/Geracao_Baby_Boomer.htm>. Acesso em: 25 jun. 2013.

[17] SILVA, Soraya Juliane da; SILVA, Francine Candatten Soares e; SANTOS, Daniel Ferreira dos. Técnicas da liderança situacional como mecanismos para a promoção do amadurecimento profissional da geração Y. Gestão Estratégica, Empreendedorismo e Sustentabilidade, São Bernardo do Campo, set. 2012.

[18] SILVA, Viviane Ferreira da; STRUCKEL, Antonio Carlos. Perfil da geração Y que trabalha no comércio da cidade de Maringá. Caderno de Administração, Maringá, v. 21, n. 01, p.01-16, 2013.

[19] TEIXEIRA, Esnice Barth; JAESCHKE, Juliana. Mentoring e geração Y: uma metodologia para o desenvolvimento pessoal e profissional. Gestão Estratégica; Empreendedorismo e Sustentabilidade, São Bernardo do Campo, set. 2012.

[20] VASCONCELOS, Katia C. de Araujo et al. A geração Y e suas âncoras de carreira. Revista Eletrônica de Gestão Organizacional, Vitória, p.1-16, 2010.

[21] ZEMKE, Ron; RAINES, Claire; FILIPCZAK, Bob. Choque de gerações. Carreira \& Família, São Paulo, n. 65, 2000. 


\section{Capítulo 8}

FATORES INTRINNSECOS E EXTRÍNSECOS: UM ESTUDO DA MOTIVAÇÃO E SATISFAÇÃO DOS COLABORADORES DE UMA INDÚSTRIA DE COMPENSADOS NO SUDESTE DO PARÁ

Rosangela Sarmento Silva

Gellena Tayná Silva Souza

Mônica Ribeiro Gama

Kezia Souza Silva

Bárbara Ádria Oliveira Farias Fernandes

Resumo: 0 objetivo dessa pesquisa foi identificar os fatores presentes na satisfação e motivação dos colaboradores de uma indústria de compensados situada na região sudeste do Pará, com base nas teorias das necessidades básicas de Maslow (1970) e motivação de Herzberg (1986). Para tanto, esta pesquisa descritiva de natureza quantitativa aplicou questionário estruturado baseado nos modelos proposto por Meliá; Peiró; Calatayd (1986) e Meliá; Peiró (1998) junto a 67 funcionários de uma indústria de compensados no Sudeste do Pará. 0 método de tratamento empregado foi à análise fatorial exploratória buscando-se assim, auferir os fatores motivacionais. Os resultados evidenciam os, os fatores identificados no construto satisfação foram: Estabilidade na Empresa (EE), Ideias Organizacionais (IO) e Responsabilidade (RSP), em relação ao construto motivação, os fatores identificados foram: Participação (PRT), Estabilidade (EST) e Desafios Organizacionais (DO). A partir dos resultados encontrados para cada fator analisado, pode-se concluir que os fatores identificados na AFE estão em consonância com a teoria bifatorial de Herzberg $(1968,1986)$, como também na teoria de Maslow (1970) estabelecidas para compreender a satisfação dos empregados e sua relação com a motivação.

Palavras chave: Fatores Intrínsecos e Extrínsecos. Satisfação. Motivação. 


\section{INTRODUÇÃO}

A gestão de recursos humanos (GRH), como peça-chave no processo de criação e de desenvolvimento de uma força de trabalho altamente produtiva, encontra-se no centro do debate sobre a competitividade das organizações (BRITO; OLIVEIRA, 2016, p. 95). Nesse feito, Jiang et al., (2012) assevera que os métodos que geram a motivação, empenho, a capacitação e a criação de um espaço apropriado para melhor atuação do colaborador, determinam condições adequadas ao crescimento de recursos e de aprimoramento que promovem a criação de valor para as organizações, contribuindo assim para o desenvolvimento de vantagens competitivas (WRIGHT; MCMAHAN; MCWILLIAMS, 1994; HUSELID, 1995; BARNEY; WRIGHT, 1998).

De acordo com Moscovici (1985), o capital humano é a maior riqueza das organizações. Por isso, é viável o equilíbrio entre o investimento em tecnologia e o aprimoramento dos conhecimentos das pessoas proporcionando a atualização da potencialização do corpo coorporativo. Além disso, Motta (1995, p.192) afirma que a vontade e dedicação passado por uma pessoa com a finalidade de executar bem uma atividade é visto como motivação. Nesse ponto Bredan e Oliveira (2009) colocam que ocorre um aumento do grau de comprometimento de pessoas motivadas em seus trabalhos, influenciando assim na satisfação dos colaboradores, corroborando com a teoria de Maslow (1954) que deixa claro em suas pesquisas que a satisfação em relação aos colaboradores no ambiente de trabalho pode ser descrita como sentimentos, atitudes e preferências dos colaboradores em relação ao seu trabalho, colaborando com resultados positivos, bem como no alcance de metas e desempenho organizacional.

Teorias foram estabelecidas a fim de compreender a satisfação dos empregados e sua relação com a motivação, dentre as quais está a teoria bifatorial de Herzberg. Segundo esta teoria, os fatores motivacionais estariam atrelados à satisfação dos funcionários, quando existentes, e os fatores higiênicos relacionar-se à insatisfação, quando ausentes (BRANDÃO, et al., 2014 p.92). Pesquisas de autores tais como, Gondin e Silva (2004); Maciel e Sá (2007); Brandão et al. (2014) e Silva et al., (2016) aplicadas em empresas para identificar e entender a motivação e a satisfação dos colaboradores e ajudar a gestão a lidar com problemas correlatos visando o desenvolvimento organizacional, têm demonstrado que essa temática ainda é um fator desafiador no âmbito organizacional, pois foi identificado um elevado número de colaboradores desmotivados e insatisfeitos em relação ao ambiente de trabalho, em vários campos de atuação, o que pode gerar problemas, tais como: redução nos padrões de qualidade, intervenção na produtividade dos serviços prestados e aumento no absenteísmo e na rotatividade entre outros (HERZBERG, 1968; JESUS; SANTOS, 2004; BATISTA et al., 2005; BEALE, 2007; BEDRAN JUNIOR; OLIVEIRA, 2009; AFONSO; ROCHA, 2010; BRANDÃO, et al. 2014).

Herzberg (1986, p.12), assevera que "os fatores motivacionais são intrínsecos ao trabalho e derivam do conteúdo do cargo e do seu nível de enriquecimento, diferente dos fatores higiênicos que são periféricos ao trabalho". Herzberg (1986, p.4) ainda ressalta que, somente os "sistemas de necessidades que correspondem aos níveis de estima e auto realização de Maslow (1970), convêm de fontes diretas de motivação para se trabalhar com eficiência". Essas necessidades foram chamadas de fatores de motivação ou satisfação que devem ser promovidas pelas organizações para manter, equipes e funcionários motivados.

Assim, com base ao exposto, esta pesquisa tem como objetivo identificar os fatores presentes na satisfação e motivação dos colaboradores de uma indústria de compensados situada na região sudeste do Pará, com base nas teorias das necessidades básicas de Maslow (1970) e motivação de Herzberg (1986).

O que justifica esta pesquisa, é que mesmo a teoria de Maslow (1970) e Herzberg (1986) deixar claro da importância da satisfação e motivação dos colaboradores de uma organização, como também pesquisas de Meliá; Peiró e Calatayud (1986) e Meliá e Peiró (1998) também têm identificado que o processo motivacional do indivíduo se dá de forma intrínseca, em que cada um desenvolve impulsos motivacionais distintos em momentos diferentes, reconhecendo que estas forças afetam diretamente a maneira de encarar o trabalho e suas próprias vidas, ainda existem organizações que não reconhecem da importância da satisfação e motivação dos colaboradores, o extrínseco, e pensando nessa ótica que esta pesquisa poderá contribuir para área de Recursos Humanos. 


\section{REFERENCIAL TEÓRICO}

\subsection{SATISFAÇÃO}

A satisfação no trabalho é um dos maiores desafios que os gestores encontram no seu contexto de atuação, devido à subjetividade do construto que depende da avaliação que o trabalhador tem sobre o seu trabalho ou da realização de seus valores por meio dessa atividade, sendo uma emoção positiva de bem-estar, conforme pode ser observado no Quadro 01 na visão de diversos autores. Enfatiza-se que há dicotomia entre valores e necessidades, sendo que necessidades se referem à sobrevivência e ao bem-estar do indivíduo e essas são inatas e comuns a todos, já os valores diferem de pessoa para pessoa, pois estão em consonância com o que o indivíduo deseja ou percebe como favorável (LOCKE,1969 apud FERREIRA, 2016 p.6).

Quadro 1: Satisfação na visão de diversos autores.

\begin{tabular}{|c|c|}
\hline Autores & $\begin{array}{c}\text { Satisfação } \\
\text { Locke (1969) }\end{array}$ \\
\hline Harris (1989) & Influenciado pela competencional. \\
\hline Bergamini (1997); & $\begin{array}{c}\text { Salário e benefícios. } \\
\text { Pinder (1998) } \\
\text { organizacional. }\end{array}$ \\
\hline Lawer (2000) & Comportamento individual comprometimento \\
\hline Lopes (2005) & Ambiente de trabalho. \\
\hline $\begin{array}{c}\text { Gomes e Quelhas (2003); } \\
\text { Lopes e Regis Filho (2005); } \\
\text { Oliveira et al. (2009); Nunes } \\
\text { e Rodrigues (2011); }\end{array}$ & Realização. \\
\hline
\end{tabular}

Fonte: Autores conforme dados da pesquisa.

Locke (1969) apud Ferreira, (2016 p.6), ressalta ainda que o trabalho é resultante da avaliação que o trabalhador tem sobre o seu trabalho ou a realização de seus valores por meio dessa atividade, sendo uma emoção positiva de bem-estar. Portanto, a satisfação no trabalho é um estado emocional, cuja emoção procede da avaliação dos valores do indivíduo e possui dois fenômenos: o de alegria (satisfação) e o de sofrimento, desprazer (insatisfação).

Herzberg (1971), afirma que a satisfação e insatisfação estão diretamente envolvidas com os fatores relacionados ao do ambiente de trabalho, recompensas e chefia. Com base nessa ótica de Herzberg (1971), é necessário haver um equilíbrio entre organização e chefia, haja vista que de nada adianta uma empresa ter uma gestão estratégica de RH para satisfazer e motivar seus funcionários, se a chefia não pratica os valores que a empresa preconiza.

Para Harris (1989), a satisfação é influenciada pela competência em enfrentar as adversidades no trabalho, podendo o processo de satisfação ser dinâmico ou não, e abrange contextos variados, características da personalidade, condições de trabalho, expectativas, motivações e necessidades.Em complemento, Chen (2008) ressalta que satisfação no trabalho pode ser entendida por meio de sentimentos, atitudes e preferências dos funcionários em relação ao trabalho. Na visão de Hollenbeck (2009) existem três fatores primordiais a serem considerados em relação a satisfação, a saber: os valores, sua importância e sua percepção.

Em suma, compreende-se então que, o contrário de satisfação não é necessariamente insatisfação, mas sim, ausência de satisfação ou não satisfação. Do mesmo modo que o contrário de insatisfação não é satisfação, mas sim ausência de insatisfação ou não insatisfação (HERZBERG, 1986; GOMES; QUELHAS, 2003; BERGAMINI, 2005).

\subsection{MOTIVAÇÃO}

Atualmente a motivação vem sendo relacionada a vontade de envolver níveis elevados de esforço em direção a metas organizacionais, condicionada pela capacidade do esforço de satisfazer alguma 
necessidade do indivíduo, sendo esta necessidade destacada por Lütz et al., (2012 p.166), como três fatores fundamentais para a compreensão da motivação, a saber: esforço, metas organizacionais e necessidades.

Conforme Herzberg (1997); Gondim; Silva (2004) e Freitas (2006) os funcionários e suas atividades são o foco central dos fatores motivacionais gerando satisfação. Compreendendo assim, a realização, a valorização, a execução do trabalho, o compromisso e desenvolvimento do indivíduo. Em relação a insatisfação, aplica-se os fatores higiênicos relacionado ao ambiente de trabalho em que a pessoa está inserida, envolvendo a cultura da empresa, a remuneração, o cargo e a seguridade. A satisfação e insatisfação são correlacionadas as necessidades diferentes do homem (PUGH; HICHSON, 2004). Assim, quando ocorre a inexistência de fatores higiênicos ocorre uma elevada insatisfação, no entanto sua falta não causa o mesmo grau de satisfação (MACIEL; SÁ, 2007).

Os fatores motivacionais centram-se no funcionário e em suas atividades conforme pode ser visto no Quadro 02 na ótica de diversos autores, ou seja, no conteúdo do trabalho, produzindo satisfação. Abrangem a realização, o reconhecimento, o trabalho em si, a responsabilidade e o crescimento ou progresso. Os fatores higiênicos referem-se aos que levam os empregados à insatisfação, e encontram-se no contexto do trabalho, ou seja, nos aspectos externos à pessoa, compreendendo a política e administração da empresa, a supervisão, as relações interpessoais, as condições de trabalho, o salário, o status e a segurança, (HERZBERG, 1997; GONDIM; SILVA, 2004; FREITAS, 2006). Desta forma, satisfação e insatisfação não são compreendidas como sensações opostas, pois estão associadas a necessidades distintas do ser humano (PUGH; HICHSON, 2004).

Quadro 2: Motivação na visão de diversos autores.

\begin{tabular}{|l|l|}
\hline Autor & \multicolumn{1}{|l|}{ Motivação } \\
\hline $\begin{array}{l}\text { Adams, (1965); Rodrigues, } \\
\text { 1973). }\end{array}$ & $\begin{array}{l}\text { O indivíduo depende da comparação que ele faz entre o } \\
\text { seu próprio comportamento e os resultados que obtém; } \\
\text { Teoria da equidade. }\end{array}$ \\
\hline $\begin{array}{l}\text { Maslow, (1954, 1970); } \\
\text { McGregor, (1999) }\end{array}$ & As necessidades. \\
\hline Bergamini, (1982). & Origina dentro da própria vida psíquica do indivíduo. \\
\hline Deci e Ryan, (1985). & Energia e Força. \\
\hline $\begin{array}{l}\text { Gomes e Quelhas, (2003); } \\
\text { Frohman, (1996) }\end{array}$ & Fatores externos. \\
\hline $\begin{array}{l}\text { Handy e Thomas Jr. (1997, } \\
\text { 1998). }\end{array}$ & Atendimento às suas expectativas. \\
\hline $\begin{array}{l}\text { Bergamini, (1998); Gomes e } \\
\text { Quelhas, (2003). }\end{array}$ & Psicossocial. \\
\hline $\begin{array}{l}\text { Marrero, (2000); Lawer, } \\
\text { rnnn) }\end{array}$ & Recompensa. \\
$\begin{array}{l}\text { Bagozzi, Bergami e Leone, } \\
\text { (2003). }\end{array}$ & Liderança. \\
\hline Lutz et al., (2012). & Impulso e Motivo. \\
\hline
\end{tabular}

\section{PROCEDIMENTOS METODOLÓGICOS}

Para atingir o objetivo proposto na pesquisa foi realizado um estudo de natureza descritiva,

valendo-se de levantamento quantitativo realizado junto a 67 colaboradores de uma indústria de compensados situada na região sudeste do Pará, especificamente no município de Rondon do Pará. 0 nome da empresa foi preservado a pedido do gestor da empresa. Para a análise dos dados coletados foi utilizada a Análise Fatorial Exploratória (AFE). 


\subsection{OBJETO DE ESTUDO E UNIDADE DE ANÁLISE}

O objeto de estudo foram os colaboradores e a unidade de pesquisa foi uma indústria de compensados situada na região sudeste do Pará, em outras palavras, no município de Rondon do Pará. Para identificar o total de colaborares da empresa foco desse estudo, foi pesquisado junto ao Recursos Humanos-RH da empresa, sendo um total de 142, sendo que 10 estão afastados, sendo os mesmos retirados como desta pesquisa. Assim, o total de colaboradores foram 132 colaboradores.

\subsection{UNIVERSO, AMOSTRAGEM E AMOSTRA DA PESQUISA}

A partir do levantamento da quantidade de colaboradores, chegou-se ao universo da pesquisa,

composto por 132. Para o cálculo da amostra foi utilizada a fórmula estatística de frequência amostral desconhecida abaixo exposta, em virtude de se tratar de uma população finita, consoante com o que preconizam Bussab e Morettin (1986).

Figura 1: Fórmula para o cálculo da amostra

$$
n=\frac{z^{2} * f(1-f) * N}{e^{2} *(N-1)+z^{2} * f *(1-f)}
$$

Fonte: autores da pesquisa.

Nota: $f=$ frequência amostral desconhecida, no valor de $(0,5) ; Z$ = intervalo de confiança de $95 \%$, o que equivale a 1,96; $\mathrm{N}=$ universo de lojas em cada aglomerado; $\mathrm{e}=$ erro de $5 \%$.

Com o cálculo estimou-se a amostra necessária. Portanto, a amostra desta pesquisa foi determinada em 99 colaboradores da indústria de compensados foco desta pesquisa. Entretanto, em virtude de alguns colaboradores sentirem medo de responder a pesquisa, foi pesquisado somente 67.

O método de seleção dos entrevistados empregado foi a amostragem aleatória simples. É um método direto de amostragem que atribui a cada elemento da população igual probabilidade de ser selecionado (HAIR et al., 2005).

\subsection{INSTRUMENTO DE PESQUISA E COLETA DE DADOS}

Para identificar os fatores presentes na satisfação e motivação dos colaboradores, optou-se por

um instrumento validado por (MELIÁ; PEIRÓ CALATAYUD, 1986; MELIÁ; PEIRÓ, 1998) da Universidade de Valência. Para elaboração desse instrumento os autores tomaram como base as teorias das necessidades básicas de Maslow (1970) e motivação de Herzberg (1986). O Quadro 3 ilustra o instrumento que é composto por 30 variáveis, sendo dividido dois construtos, satisfação e motivação. As variáveis do construtos satisfação são da V1 a V14 e as variáveis que compõem o construto motivação são da V15 a V30. 
Quadro 01: Instrumento de Pesquisa

\section{VARIÁVEIS - SATISFAÇÃO}

V1- Percebo que tenho autonomia para propor melhorias na execução do meu trabalho.

V2- Realizo-me pessoalmente e profissionalmente com o trabalho que executo.

V3- Sinto que minhas ideias de inovação e sugestões para criação são ouvidas.

V4- Sinto-me reconhecido pelo trabalho que executo.

V5- Tenho responsabilidade com o trabalho que realizo.

V6- Sou chamado a participar das decisões do meu setor.

V7- Tenho me desenvolvido profissionalmente.

V8- 0 relacionamento entre as pessoas da equipe que faço parte é bom.

V9- Considero bom o relacionamento com a chefia.

V10- Concordo com as decisões organizacionais da empresa.

V11- Estou satisfeito com minha remuneração.

V12- Meu trabalho me proporciona status.

V13- Confio que continuarei trabalhando na empresa.

V14- Quanto à questão comunicação, acho adequada a divulgação de informações na empresa.

\section{VARIÁVEIS - MOTIVAÇÃO}

V15- Instalações físicas

V16- Poder usar as instalações

V17- Promover o desenvolvimento

V18- Integração da equipe de trabalho

V19- Oportunidade de crescimento

V20- Autonomia

V21- Estabilidade no emprego

V22- Gostar do que faz

V23- Salário somado a benefícios

V24- Sentir-se desafiado a comprovar a eficiência

V25- Desafios existentes no trabalho

V26- Relação com os colegas

V27- Participação das decisões

V28- Relação com a liderança da equipe

V29- Ser valorizado e reconhecido pelo trabalho que faz

V30- Ser ouvido

Fonte: Meliá; Peiró Calatayud, (1986) e Meliá; Peiró, (1998).

Conforme pode ser observado no Quadro 03, o construto satisfação é formado por 14 variáveis e construto motivação é formado por 16 variáveis. A escalas para marcação das respostas foram uma escala tipo likert de zero a dez. Quanto menor a nota menor a satisfação e motivação e quanto maior a nota maior a satisfação e motivação. Nesta pesquisa, não foi possível elaborar um preste haja vista que o número de funcionários é pequeno. 


\subsection{MÉTODO DE TRATAMENTO E ANÁLISE DOS DADOS}

O modelo proposto efetuou o tratamento dos dados coletados por meio da Análise Fatorial Exploratória para verificar a unidimensionalidade dos construtos satisfação e motivação, além de identificar quais indicadores são representativos desses construtos. Na Análise Fatorial Exploratória, foram analisadas as premissas, tais como tamanho da amostra (acima de 20 casos por variável), normalidade multivariada, multicolinearidade por meio dos testes de Esfericidade de Bartlett, Kaiser Meyer Olkin - KMO, Measure of Sampling Adequacy - MSA e matriz de correlação, conforme apregoado por Hair et al. (2009).

\subsection{MODELO TEÓRICO-EMPÍRICO DA PESQUISA}

O modelo teórico-empírico da pesquisa associa os dois construtos (satisfação e motivação) do estudo em questão na percepção dos colaboradores da indústria de compensados, empresa foco desse estudo, conforme exposto na Figura 1.

Figura 1: Modelo teórico da pesquisa.

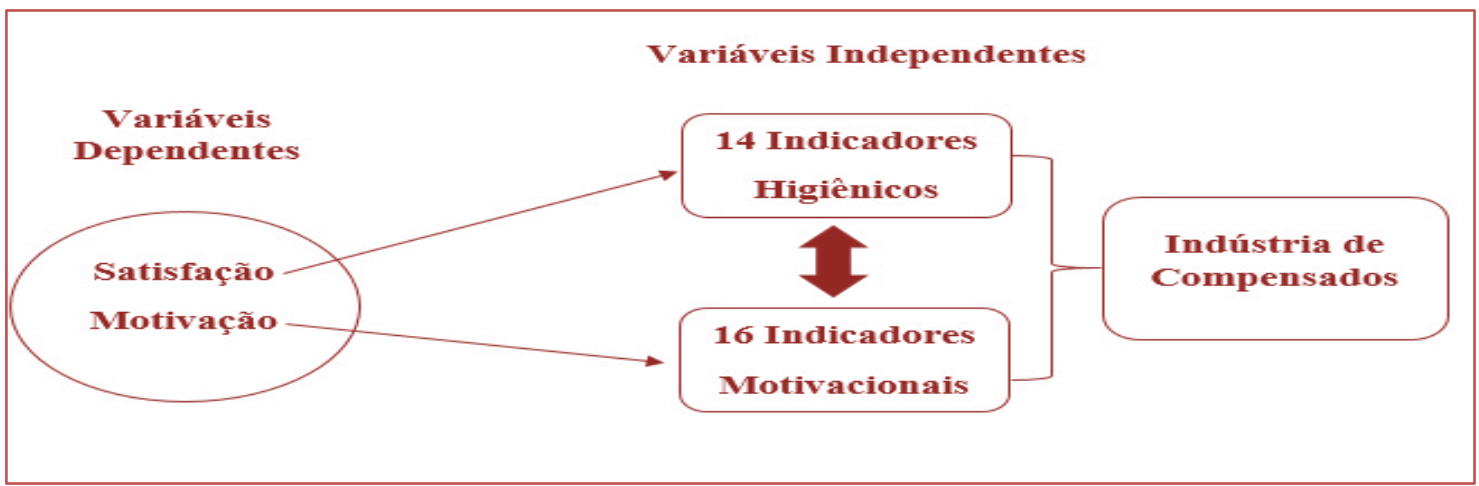

Fonte: Elaborado pelos autores com base em Meliá; Peiró Calatayud, (1986) e Meliá; Peiró, (1998).

\subsection{ANÁLISE DAS PREMISSAS DA ANÁLISE FATORIAL EXPLORATÓRIA (AFE)}

Antes de se analisarem os resultados da AFE, é necessário primeiro verificar suas premissas, conforme determinam Prearo et al. (2011), tais como tamanho da amostra, normalidade multivariada e multicolinearidade por meio dos testes de Esfericidade de Bartlett, Kaiser Meyer Olkin - KMO, Measure of Sampling Adequacy - MSA e matriz de correlação, conforme Quadro 4.

Quadro 04: Premissas subjacentes ao uso da Análise Fatorial Exploratória

\begin{tabular}{|c|c|c|}
\hline Premissas Subjacentes & Considerações & Autores \\
\hline \multirow{3}{*}{ Tamanho da amostra } & 5 a 20 casos por variável & Stevans (1996) \\
\hline & 5 casos por variável & Pestana e Gageiro (2000) \\
\hline & 20 casos por variável & Hair (2005) \\
\hline \multirow{2}{*}{ Multicolinearidade } & $\begin{array}{l}\text { MAS (Meassure of Sampling } \\
\text { Adequacy) }>0,5\end{array}$ & $\begin{array}{c}\text { Pestana e Gageiro (2000); } \\
\text { Tabachnik e Fidell (1996); } \\
\text { Garson (2007) }\end{array}$ \\
\hline & KMO (Kaiser-Meyer-Olkin) $>0,5$ & $\begin{array}{l}\text { Pestana e Gageiro (2000); } \\
\text { Tabachnik e Fidell (1996); } \\
\text { Garson (2007) }\end{array}$ \\
\hline Normalidade multivariada & $\begin{array}{l}\text { Condição para os testes de } \\
\text { significância }\end{array}$ & Hair (2005); Garson (2007) \\
\hline
\end{tabular}

Fonte: adaptado de Prearo et al. (2011, p. 628).

A presente pesquisa atende as premissas do método, tais como: (testes MSA- Measure of Sampling Adequacy e KMO - Kaiser-Meyer-Olkin) foram também atendidas neste estudo. Em relação à normalidade 
multivariada, cumpre salientar que Eisenbeis (1977) e Huberty (1994) apud Prearo et al., (2011, p.628) assinalam que, para dados reais, a presença de variáveis com distribuição normal multivariada exata dificilmente ocorre. Nesses casos, a densidade normal é frequentemente uma aproximação útil à verdadeira distribuição da população.

\section{APRESENTAÇÃO E ANÁLISE DOS RESULTADOS}

\subsection{ANÁLISE DOS RESULTADOS DA AFE DO CONSTRUTO SATISFAÇÃO}

0 construto Satisfação foi formado por quatorze variáveis, conforme demonstrado no Quadro 03 do capítulo dos procedimentos metodológicos. No entanto, para atender às premissas da AFE foi necessário realizar duas tentativas, o que resultou na retirada da variável V06. Em sequência, com o propósito de validar a AFE, medida pelos testes KMO e MSA. Para Prearo et al., (2011), o KMO informa a medida de adequação dos dados e analisa o ajuste desses dados, adotando todas as variáveis simultaneamente.

Segundo os autores relacionados no Quadro 04 , indicam que se as correlações parciais forem pequenas, o teste KMO terá valor entre 1,0 e 0,9 , ou seja, quanto mais próximo a 1,0, há a indicação de melhor adequação dos dados para a AFE, valores entre 0,8 e 0,9 indicam boa adequação; valores entre 0,7 e 0,8 indicam média adequação; valores entre 0,6 e 0,7 indicam razoável adequação; valores entre 0,5 e 0,6 indicam má adequação e, por fim, valores $<0,5$ são inaceitáveis. Para esta pesquisa, o KMO obteve um valor de 0,819 , o que indica uma boa adequação dos dados para a AFE.

0 teste de esfericidade de Bartlett's é indicado para ser feito antes da AFE, tendo como objetivo testar a correlação entre as variáveis (PREARO et al., 2011). Para esta pesquisa, o nível de significância empregado foi sig $<0,05$. Logo, aceitou-se a hipótese de que as correlações entre as variáveis são significativamente diferentes de zero, ou seja, são suficientes para se continuar a AFE do construto satisfação.

Segundo Prearo et al. (2011 p.627), o MSA indica a multicolinearidade entre as variáveis, o que significa uma perfeita ou exata relação linear entre algumas ou todas as variáveis explicativas de um modelo de regressão. Dessa forma, MSA $\geq 0,80$ atesta multicolinearidade admirável; $\geq 0,70$ - mediana; $\geq 0,60$ medíocre e $<0,50$ - inaceitável. Verificou-se que a matriz anti-imagem apresentou um nível de MSA na maioria das variáveis, com valores entre 0,7 e 0,9 . Esses resultados indicam que os fatores do construto satisfação conseguem descrever satisfatoriamente as variações dos dados.

Com o objetivo de avaliar a proporção da variância total em cada variável, foi analisada a comunalidade, que expressa quanto das variações da variável é explicada pelo conjunto de fatores, sendo que seus valores necessitam ser maiores que 0,50 , segundo Hair et al. (2009). Nesta pesquisa essa premissa foi atendida. Quanto à variância total explicada pelo modelo fatorial obtido, Hair et al. (2009) e Prearo et al. (2011) asseveram ser a soma do quadrado das cargas fatoriais, dividida pelo número de variáveis. Para esses autores, a variância total explicada precisa ser $>60 \%$. Neste caso, a variância total explicada dos dois fatores foi $67,25 \%$. Por meio da matriz de componentes, rotacionados pelo método de Rotação Ortogonal Varimax, verifica-se a composição de cada um dos três fatores identificados na análise. Objetiva-se, conforme Hair et al. (2009, p. 119), a "simplificação das linhas e colunas da matriz fatorial, facilitando, então, sua interpretação". Segundo esses autores, o intuito é maximizar a soma de variâncias das cargas exigidas da matriz fatorial. Com isso, tenta-se carregar os pesos para que cada variável possa estar relacionada a apenas um fator.

Após a rotação pelo método Varimax, obteve-se uma classificação mais precisa das variáveis em cada um dos fatores. Dessa forma, pode-se concluir a formação dos fatores do construto satisfação, que é composto por três fatores, conforme exposto na Tabela 1. 
Tabela 01: Nomeação dos fatores do construto satisfação

\begin{tabular}{|c|c|c|}
\hline \multirow{5}{*}{$\begin{array}{l}\text { FATOR } 01 \text { ESTABILIDADE NA } \\
\text { EMPRESA - EE }\end{array}$} & VARIÁVEIS - SATISFAÇÃO & $\begin{array}{l}\text { CARGA } \\
\text { FATORIAL }\end{array}$ \\
\hline & V13- Confio que continuarei trabalhando na empresa. & 0,822 \\
\hline & $\begin{array}{l}\text { V14- Quanto à questão comunicação, acho adequada a } \\
\text { divulgação de informações na empresa. }\end{array}$ & 0,807 \\
\hline & V9- Considero bom o relacionamento com a chefia. & 0,702 \\
\hline & $\begin{array}{l}\text { V10- Concordo com as decisões organizacionais da } \\
\text { empresa. }\end{array}$ & 0,593 \\
\hline \multirow{5}{*}{$\begin{array}{c}\text { FATOR } 02 \text { - IDEIAS } \\
\text { ORGANIZACIONAIS - IO }\end{array}$} & $\begin{array}{l}\text { V3- Sinto que minhas ideias de inovação e sugestões } \\
\text { para criação são ouvidas. }\end{array}$ & 0,837 \\
\hline & $\begin{array}{l}\text { V1- Percebo que tenho autonomia para propor } \\
\text { melhorias na execução do meu trabalho. }\end{array}$ & 0,804 \\
\hline & V12- Meu trabalho me proporciona status. & 0,560 \\
\hline & V11- Estou satisfeito com minha remuneração. & 0,552 \\
\hline & V4- Sinto-me reconhecido pelo trabalho que executo. & 0,525 \\
\hline \multirow{4}{*}{$\begin{array}{c}\text { FATOR 03- } \\
\text { RESPONSABILIDADE - RSP }\end{array}$} & V5- Tenho responsabilidade com o trabalho que realizo. & 0,800 \\
\hline & $\begin{array}{l}\text { V8- O relacionamento entre as pessoas da equipe que } \\
\text { faço parte é bom. }\end{array}$ & 0,766 \\
\hline & V7- Tenho me desenvolvido profissionalmente. & 0,751 \\
\hline & $\begin{array}{l}\text { V2- Realizo-me pessoalmente e profissionalmente com o } \\
\text { trabalho que executo. }\end{array}$ & 0,708 \\
\hline
\end{tabular}

Fonte: Autores conforme dados da pesquisa.

A classificação dos fatores ocorreu por meio da maior carga fatorial, conforme indicações de Hair et al. (2009). Assim, a ordem das variáveis estão descritas conforme seu poder de explicação, sendo que a variável V13 apresenta a maior carga fatorial $(0,822)$ do fator um - Estabilidade na Empresa-(EE). 0 segundo fator foi denominado Ideias Organizacionais (IO), pois a variável V3 foi a que obteve maior carga fatorial $(0,857)$. Por fim o terceiro fator ficou denominado Responsabilidade - (RSP), sendo a variável V5 com maior carga fatorial $(0,800)$.

\subsubsection{CONSIDERAÇÕES TEÓRICAS ACERCA DO CONSTRUTO SATISFAÇÃO}

O Fator um, Estabilidade na Empresa- (EE), como resultado da AFE, está em consonância com a teoria existência, relacionamento e crescimento, no qual autores tais como: Alderfer; Schneider (1973), Maslow (1970), Gomes e Quelhas (2003), Lopes; Regis Filho (2005), Oliveira et al. (2009), Ferreira; Demutti; Gimeniz (2010), Nunes; Rodrigues (2011) e Lutz et al. (2012) fundamentam a intenção de tornar-se tudo aquilo que a pessoa é capaz de ser; inclui crescimento, autodesenvolvimento e alcance do próprio potencial, ou seja, Herzberg (2003) assevera que os fatores de crescimento ou motivadores que são intrínsecos ao trabalho estão relacionados as execuções, reconhecimento pelas execuções, o trabalho em si, responsabilidade, crescimento e progresso organizacional. Esse resultado foi maior na carga fatorial da variável "V13" $(0,822)$, pela qual se verifica que os colaboradores confiam que continuarão trabalhando na empresa. Percebe-se então que a confiança de estabilidade organizacional, é um fator que motiva os colaboradores pesquisados na indústria de compensados.

Os autores supracitados ressaltam ainda que as necessidades de crescimento incluem o desejo de ter uma influência criativa e produtiva sobre si mesmo e sobre o ambiente em que vive. A satisfação da necessidade de crescimento ocorre quando uma pessoa engaja em problemas para os quais necessita utilizar plenamente suas capacidades e desenvolver novas capacidades, surgindo assim, as Ideias Organizacionais - (IO) fator dois da AFE, representado pela variável "V3 Sinto que minhas ideias de inovação e sugestões para criação são ouvidas", que para Herzberg (1973), contribui muito para a satisfação profissional, corroborando com os colaboradores pesquisados, pois tais fatores constituem importantes fontes de satisfação no trabalho para os mesmos (PINDER,1998; ALDERFER; SCHNEIDER, 1973; FERREIRA; DEMUTTI; GIMENIZ, 2010, SILVA et al., 2016).

Bergamini (2008), afirma que quando recompensas extrínsecas são dadas a alguém por desempenhar uma tarefa interessante, elas fazem o interesse intrínseco na tarefa diminuir. A autora ainda destaca que o modelo de Maslow propõe a noção de necessidade como fonte de energia das motivações existente no interior das pessoas. É importante ressaltar que Bergamini (2008), assevera que os fatores higiênicos não fazem as pessoas produzirem mais, sua presença garante apenas que esteja conseguindo manter o nível de 
insatisfação delas em grau mínimo". Para a autora, a organização tem uma espécie de obrigação em assegurar política administrativa adequada, cumprir com justiça e igualdade os seus compromissos salariais e cuidar para que as condições de trabalho sejam adequadas, o que influencia os colaboradores a terem responsabilidades - (RSP), fator três identificado na AFE respaldado pela variável "V5 Tenho responsabilidade com o trabalho que realizo".

\subsection{ANÁLISE DOS RESULTADOS DA AFE DO CONSTRUTO MOTIVAÇÃO}

O construto motivação foi formado por dezesseis variáveis (V15 a V30), conforme pode ser visto no Quadro 1 do capítulo de procedimentos metodológicos. No entanto, para atender as premissas da AFE, foram necessárias realizar cinco tentativas, por meio das quais foram retiradas as variáveis V18, V22, V26 e V16, restando um modelo satisfatório com onze variáveis.

Nessa quinta tentativa, o teste KMO obteve como resultado o valor de 0,847. 0 teste de esfericidade de Bartlett's teve significância de sig<0,00. 0 poder de explicação com três fatores da AFE explica 78\% das variações das variáveis do construto motivação. Dessa forma, acredita-se ter chegado a um grau de relacionamento e explicação das variáveis capaz de ser útil na avaliação desse construto, haja vista que, segundo Hair et al. (2009) e Prearo et al. (2011), a variância total explicada precisa ser >60\%.

Quanto à comunalidade, as onze variáveis obtiveram seus valores entre 0,60 a 0,90 , ou sejam todas acima de 0,50, o que atende as indicações da teoria, que ressaltam ser esses valores $>0,50$. Os valores do MSA obtiveram valores entre 0,70 a 0,90, também atendendo às premissas asseveradas pelos autores a saber: Tabachnik; Fidell, (1996); Pestana; Gageiro, (2000); Garson, (2007) apud Prearo et al. (2011) e Hair et al. (2009).

Com a rotação das variáveis, por meio do método Varimax, o construto se dividiu em três fatores. Ficando mais clara a distribuição das variáveis em cada fator, tais como: os fatores 1 e 2 com cinco variáveis e o fator 2 com duas variáveis. Dessa forma, a composição dos fatores pode ser visto na Tabela 2, com um total de onze variáveis.

Tabela 02: Nomeação dos fatores do construto motivação.

\begin{tabular}{|c|c|c|}
\hline FATORES & VARIÁVEIS - MOTIVAÇÃO & $\begin{array}{l}\text { CARGA } \\
\text { FATORIAL }\end{array}$ \\
\hline \multirow{5}{*}{$\begin{array}{c}\text { FATOR } 01 \text { - } \\
\text { PARTICIPAÇÃO - PRT }\end{array}$} & V27- Participação das decisões & 0,798 \\
\hline & V20- Autonomia & 0,789 \\
\hline & V30- Ser ouvido & 0,773 \\
\hline & V29- Ser valorizado e reconhecido pelo trabalho que faz & 0,701 \\
\hline & V19- Oportunidade de crescimento & 0,675 \\
\hline \multirow{5}{*}{$\begin{array}{c}\text { FATOR } 02- \\
\text { ESTABILIDADE - EST }\end{array}$} & V21- Estabilidade no emprego & 0,865 \\
\hline & V17- Promover o desenvolvimento & 0,786 \\
\hline & V15- Instalações físicas & 0,744 \\
\hline & V23- Salário somado a benefícios & 0,619 \\
\hline & V28- Relação com a liderança da equipe & 0,607 \\
\hline \multirow{2}{*}{$\begin{array}{l}\text { FATOR } 03 \text { - DESAFIOS } \\
\text { ORGANIZACIONAIS - DO }\end{array}$} & V24- Sentir-se desafiado a comprovar a eficiência & 0,916 \\
\hline & V25- Desafios existentes no trabalho & 0,857 \\
\hline
\end{tabular}

Fonte: Autores conforme dados da pesquisa.

É importante ressaltar que o fator três foi composto somente por duas variáveis, mas segundo Hair et. al., (2005) e Prearo et. al., (2011), quanto um fator é composto somente por duas 
variáveis e estas são importantes para a pesquisa, deve considera-las. Nesse caso, as variáveis "V24 Sentirse desafiado a comprovar a eficiência" e "V25 Desafios existentes no trabalho" são de grande importância quando se trata motivação, pois segundo Herzberg (2003 p.87-96); Meliá; Peiró Calatayud, (1986) e Meliá; Peiró, (1998) os fatores de crescimento ou motivadores que são intrínsecos ao trabalho são: execuções, reconhecimento pelas execuções, o trabalho em si, responsabilidade e crescimento e progresso. Estes estão sob o controle do indivíduo, pois são relacionados com aquilo que ele faz e desempenha, o que respalda o fator três "Desafios Organizacionais".

\subsubsection{CONSIDERAÇÕES TEÓRICAS ACERCA DO CONSTRUTO MOTIVAÇÃO}

O fator um identificado na AFE, Participação- (PRT) do construto motivação, sendo a variável "V27Participação das decisões" que subsidia a nomeação desse fator, estar em consonância com a teoria motivacional, pois segundo Junior et al. (2013 p.93), a motivação é um determinante direto do desempenho. Os autores ainda ressaltam a influência direta que as características individuais exercem sobre o desempenho no trabalho, com destaque para os aspectos motivacionais e cognitivos, ou seja, as pessoas apresentarão melhores desempenhos se o trabalho for significativo para elas e (o indivíduo atribuir alto valor de motivação ao trabalho) e sentir que suas ideias são importantes para desenvolvimento da organização (MASLOW, 1954, 1970; ADAMS, 1965; RODRIGUES, 1973; BERGAMINI, 1998; MCGREGOR, 1999; LUTZ et al., 2012).

Em relação ao fator dois Estabilidade - (EST), no qual a variável "V21- Estabilidade no emprego" respalda a nomeação desse fator. A teoria aponta que a estabilidade é com certeza uma das maiores ambições do trabalhador, pois funciona a partir do envolvimento do ego, da necessidade de autoestima. A estabilidade é considerada um dos fatores motivacionais extrínsecos mais importante no trabalho (CHANG, 2003). Uma vez que a estabilidade dar garantia ao colaborador que o mesmo pode construir uma carreira na organização sem medo de a qualquer momento ser desligado, principalmente em cargos operacionais, como é o caso dos colaboradores pesquisados nessa pesquisa (MARRERO, 2000). É importante ressaltar que na análise do construto satisfação, o fator um (EE) foi de grande importância para os colaboradores pesquisados, na visão de Lutz et. al., (2012) na iniciativa privada não há uma garantia de estabilidade no trabalho como nas empresas públicas, pois nas empresas privadas os direitos que regem são as consolidações das leis trabalhistas- CLT, ou seja, nas empresas privadas essa estabilidade depende da cultura e diretrizes de cada organização.

Observa-se então, que a necessidade de crescimento - o desejo constante de crescimento e desenvolvimento pessoal motiva os colaboradores (ALDERFER, 1969 p.75), o que impulsiona os colaborares a sentir desafiados pela organização para comprovar suas eficiências, fator três identificado na AFE, no qual a variável "V24- Sentir-se desafiado a comprovar a eficiência" nomeou esse fator. A competência aliada a necessidade de eficácia, relacionada a um sentimento de eficiência sobre o ambiente de trabalho é um dos fatores que mais motiva os colaboradores.

Segundo Bergamini (2008), os desafios também podem estar ligados ao oferecer incentivos financeiros a motivação das pessoas. Entretanto, a ligação entre esses dois fatores, no entanto, não é tão fácil, como acreditava Taylor da Administração Cientifica. Se os funcionários são bem remunerados, realizam tarefas que os motivam e tem o reconhecimento da gerência, vão realizar suas tarefas com eficiência e bom desempenho, mesmo que a empresa ofereça novos incentivos. Além disso, a remuneração com excelentes ganhos financeiros, conforme a Teoria de Herzberg, não é o bastante para motivar os funcionários. Sendo assim, é necessário saber se os funcionários estão satisfeitos com seus salários para que outros motivos possam levá-los à satisfação.

\section{CONSIDERAÇÕES FINAIS}

O objetivo dessa pesquisa foi identificar os fatores presentes na satisfação e motivação dos colaboradores de uma indústria de compensados situada na região sudeste do Pará, com base nas teorias das necessidades básicas de Maslow (1970) e motivação de Herzberg (1986). Assim por meio dos resultados da AFE, os fatores identificados no construto satisfação foram: Estabilidade na Empresa (EE), Ideias Organizacionais (IO) e Responsabilidade (RSP), em relação ao construto motivação, os fatores identificados foram: Participação (PRT), Estabilidade (EST) e Desafios Organizacionais (DO).

A partir dos resultados encontrados para cada fator analisado, pode-se concluir que os fatores identificados na AFE estão em consonância com a teoria bifatorial de Herzberg $(1968,1986)$, como 
também na teoria de Maslow (1970) estabelecidas para compreender a satisfação dos empregados e sua relação com a motivação. Assim, pode-se identificar nos resultados da pesquisa que os colaboradores da empresa pesquisada reconhecem a importância da motivação e satisfação na execução do trabalho.

Os achados da pesquisa também permitiram identificar que as recompensas extrínsecas são dadas a alguém por desempenhar uma tarefa interessante, elas fazem o interesse intrínseco na tarefa diminuir. Assim, o modelo de Maslow propõe a noção de necessidade como fonte de energia das motivações existente no interior das pessoas, ou seja, os fatores higiênicos não fazem as pessoas produzirem mais, sua presença garante apenas que esteja conseguindo manter o nível de insatisfação delas em grau mínimo. Em suma, a organização tem uma espécie de obrigação em assegurar política administrativa adequada, cumprir com justiça e igualdade os seus compromissos salariais e cuidar para que as condições de trabalho sejam adequadas, o que influencia os colaboradores a terem responsabilidades (MASLOW, 1954, 1970; ADAMS, 1965; RODRIGUES, 1973; BERGAMINI, 1998, 2008; MCGREGOR, 1999; LUTZ et al., 2012; SILVA et al., 2016).

Assim, os desafios também podem estar ligados ao oferecer incentivos financeiros a motivação das pessoas. Entretanto, a ligação entre esses dois fatores, no entanto, não é tão fácil, como acreditava Taylor da Administração Cientifica. Se os funcionários são bem remunerados, realizam tarefas que os motivam e tem o reconhecimento da gerência, vão realizar suas tarefas com eficiência e bom desempenho, mesmo que a empresa ofereça novos incentivos. Além disso, a remuneração com excelentes ganhos financeiros, conforme a Teoria de Herzberg, não é o bastante para motivar os funcionários. Sendo assim, é necessário saber se os funcionários estão satisfeitos com seus salários para que outros motivos possam levá-los à satisfação (BERGAMINI, 2008; MCGREGOR, 1999; LUTZ et al., 2012; SILVA et al., 2016).

Os resultados também permitiram identificar que, a motivação dos colaboradores está relacionada tantos a fatores intrínsecos, inerentes à pessoa, como a fatores extrínsecos, presentes no ambiente, dessa forma, as organizações podem influenciar determinados comportamentos para o trabalho. Conclui-se então, que os resultados ora explicitados trazem um campo de estudos a ser ampliado, tanto em termos teóricos, quanto em termos práticos para área de Recursos Humanos. Para os membros da Academia, os resultados expostos são uma contribuição para estudos futuros acerca do conjunto das necessidades humanas básicas quanto ao conjunto dos fatores higiênicos e motivadores, haja vista que por meio dos resultados exploratórios identificados nessa pesquisa, podem servir de base para um estudo confirmatório, como também em outros segmentos de mercado.

\section{REFERÊNCIAS}

[1] ADANS, J. Stacy, Inequity in social exchanges, in BERKOWITZ L. (ed.) Advances

[2] inexperimental social psychology, New York: Academic Press, 1965.

[3] ALDERFER, C. P. An empirical test of a new theory of humans needs. Organizational behavior and human performance, Burlington, v.4, n.2, p. 142-176,1969.

[4] ALDERFER, C. P.; SCHNEIDER, B. Three Studies of Measures of Need Satisfaction in Organizations. Administrative Science Quarterly, Ithaca, Vol. 18, n. 4, pp 489-505, Dezembro 1973.

[5] AFFONSO, L. M. F.; ROCHA, H. M. Fatores organizacionais que geram insatisfação no servidor público e comprometem a qualidade dos serviços prestados. In: SIMPÓSIO DE EXCELÊNCIA EM GESTÃO E TECNOLOGIA, 7, 2010, Rio de Janeiro. Anais... Rio de Janeiro, 2010.

[6] BAGOZZI, R.P.; BERGAMI; M.; LEONE, L. Hierarchical representation of motives in goal setting. Journal of Applied Psychology, v. 88, n. 5, p. 915-943, 2003.

[7] BATISTA, A. A. V. et al. Fatores de motivação e insatisfação no trabalho do enfermeiro. 2005.

[8] Revista da Escola de Enfermagem da USP, v. 39, n. 1, p. 85-91. Disponível em: <http://www.scielo.br/pdf/reeusp/v39n1/a11v39n1.pdf>. Acesso em: 10 jan. 2017.

[9] BARNEY, J. B.; WRIGHT, P. M. On becmoming a strategic partner: the role of human resources in gaining competitive advantage. Human Resource Management, v. 37, n. 1, p. 31, 1998.

[10] BEALE, J. Motivação entre funcionários na adoção de comportamentos desestimuladores: antecedentes de nível individual. Revista de Administração FACES Journal, Belo Horizonte, v. 6, n. 2, p. 11-31, mai./ago. 2007.

[11] BEDRAN JUNIOR, P. E.; OLIVEIRA, J. L. C. Motivação no trabalho: avaliando o ambiente organizacional. In: CONGRESSO NACIONAL DE EXCELÊNCIA EM GESTÃO, 5, 2009, Niterói. Anais... Niterói: UFF, 2009. 
[13] . A difícil Administração das Motivações. Organização, Recursos Humanos e Planejamento. Revista de Administração de Empresas. São Paulo, v. 38, n.1, p.6- 17, 1998.

[14] . Psicologia aplicada à administração de empresas: psicologia do comportamento organizacional. 3. ed. São Paulo: Atlas, 1982.

[15] . Psicologia aplicada à administração de empresas: psicologia do comportamento organizacional. 4. ed. São Paulo: Atlas, 2005.

[16] BUSSAB, W. O.; MORETTIN, P. A. Estatística básica. 3 ed. São Paulo: Atual, 1986. CHANG, E. Composite effects of extrinsic motivation on work effort: case of Korean employees. Journal of World Business, v.38, p.70-79, 2003.

[17] CHEN, L.H. Job satisfaction among information system (IS) personnel. Computers in Human Behavior, v. 24, p.105-118, 2008.

[18] DE BRITO, Renata Peregrino; DE OLIVEIRA, Lucia Barbosa. A relação entre gestão de recursos humanos e desempenho organizacional. Brazilian Business Review, v. 13, n. 3, p. 94, 2016.

[19] DECI, E.L.; RYAN, R.M. Intrinsic motivation and self-determination in human behavior. New York: Plenum Press, 1985.

[20] FERREIRA, Cláudia Aparecida Avelar. Percepção da motivação e satisfação no trabalho pelos trabalhadores de uma instituição psiquiátrica no Brasil. Revista Capital Científico-Eletrônica (RCCe)-ISSN 2177-4153, v. 14, n. 2, p. 25-41, 2016

[21] DE FREITAS BRANDÃO, Isac et al. Satisfação no serviço público: um estudo na Superintendência Regional do Trabalho e Emprego no Ceará. REAd-Revista Eletrônica de Administração, v. 20, n. 1, 2014.

[22] FREITAS, C. M. F. Estudo da motivação e da liderança na indústria hoteleira da RAM.

[23] 2006. 141 fls Dissertação. (Mestrado em Gestão Estratégica e Desenvolvimento do Turismo), Funchal, 2006.

[24] GOMES, A. A. E.; QUELHAS, O. L. G. Motivação dos recursos humanos no serviço público: um estudo de caso sob dois ângulos teóricos. Revista Eletrônica de Administração, Porto Alegre, ed. 35, v. 9, n. 5, set./out. 2003.

[25] GONDIM, S. M. G.; SILVA, N. Motivação no trabalho. In: ZANELLI, J. C.; BORGES

[26] ANDRADE, J. E.; BASTOS, A. V. B. Psicologia, organizações e trabalho no Brasil. Porto Alegre: Artmed, , p. 357 379,2004

[27] HAIR, J. F.; ANDERSON, R. E.; TATHAM, R. L.; BLACK, W. C.; BABIN, B. J. Análise multivariada de dados. 6 ed. Porto Alegre: Bookman, 2009.

[28] HAIR, J. F.; BABIN, B.; MONEY, A. H.; SAMOUEL, P. Fundamentos de métodos de pesquisa em administração. Porto Alegre: Bookman, 2005.

[29] HAIR, J. F.; ANDERSON, R. E.; TATHAM, R. L.; BLACK, W. C.; BABIN, B. J. Análise multivariada de dados. 6 ed. Porto Alegre: Bookman, 2009.

[30] HARRIS, R. B. Reviewing nursing stress according to a proposed coping-adaption framework. Advances in Nursing Science. v. 11, n. 2, p.12-28, 1989.

[31] HERZBERG, F. Mais uma vez: como motivar seus funcionários. In: VROOM, V. Gestão de pessoas, não de pessoal: os melhores métodos de motivação e avaliação de desempenho. Tradução de Ana Beatriz Rodrigues e Priscilla Martins Celeste. Rio de Janeiro: Campus, 1997. 273p. Tradução de: Manage people, not personnel.

[32] HERZBERG, F. Work and the nature of man. 4. ed. Cleveland: World Publishing, 1971.

[33] . One more time: How do you motivate employees. Harvard Business Review-Business Classics, p.13-22, 1986.

[34] . "One more time: how do you motivate employees?" Harvard Business Review, Boston, v. 46, n. 1, p. 53-62, 1968.

[35] HUSELID, M. A. The impact of human resource management practices on turnover, productivity, and corporate financial performance. Academy of Management Journal, v. 38, n. 3, p. 635-672, 1995.

[36] JESUS, S. N.; SANTOS, J. C. V. Desenvolvimento profissional e motivação dos professores. Educação: Revista da Faculdade de Educação, Porto Alegre: PUCRS, v. 27, n. 52, p. 39-58, 2004.

[37] JIANG, K. et al. How does human resource management influence organizational outcomes? A meta-analytic investigation of mediating mechanisms. Academy of Management Journal, v. 55, n. 6, p. 1264-1294, 2012.

[38] JUNIOR, S. S. B. et al. Possibilidades entre Motivação e Produtividade: Um Estudo de Caso no Alto Tietê. Sociedade, Contabilidade e Gestão, Rio de Janeiro, v. 8, n. 3, p.90-104, 2013. LAWLER III, Edward. E. Rewarding excellence: paying strategies for the new economy. San Francisco: Jossey-Brass, 2000. 
[39] LOPES, A. L. V. Satisfação e insatisfação no ambiente de trabalho e sua forma de expressão: o caso dos servidores técnico-administrativos da Universidade Federal do Ceará. 2005. (Mestrado Profissional em Administração) - Faculdade de Economia, Administração, Atuária e Contabilidade, Universidade Federal do Ceará, Fortaleza, 2005. LOPES, M. C.; REGIS FILHO, G. I. A motivação humana no trabalho: o desafio da gestão em serviços de saúde pública. Revista de Administração, v. 39, n. 1, p. 62-75, jan/fev/mar. 2005. São Paulo: EAD/FEA/USP, 2005.

[40] LOCKE, E. A. What is job satisfaction? Organizational Behaviour Human Performance. v. 4, n. 4, p. 309-336, 1969.

[41] LÜTZ, C.; CANES, R.; BEURON, T. A.; GROHMANN, M. Z. Fatores motivacionais extrínsecos para a profissão militar. Revista de Administração da UNIMEP - v.10, n.1, p. 164-188, 2012.

[42] MACIEL, S. E. V; SÁ, M. A. D. Motivação no trabalho: uma aplicação do modelo dos dois fatores de Herzberg. Studia Diversa, CCAE-UFPB, v. 1, n. 1, p. 62-86, out. 2007. MASLOW, A. H. Motivation and personality. New York: Harper, 1954.

[43] . Motivation and personality. 2. ed. New York: Harper \& Row, 1970. MARRERO, J.M. Managing and motivating by rewards. Military Review, v.80, p.72-73, 2000. McGREGOR, Douglas. O lado humano da empresa. Tradução: Margarida Maria C. Costa. 3. ed. São Paulo: Martins Fontes, 1999.

[44] MELIÁ, J. L.; PEIRÓ, J. M.; CALATAYUD, C. El. Cuestionario General de Satisfacciónen Organizaciones Laborales: Estudios factoriales, fiabilidad y validez. (Presentacióndel Cuestionario S4/82). Rev. de Filosofía, Psicología y Ciencias de la Educación, [S.l.], v. 11, n. 3-4, pp.43-78, 1986.

[45] MELIÁ, J. L.; PEIRÓ, J. M. Cuestionario de satisfacción laboral S4/82, 1998. Universitat de València: [Valência, Espanha].

[46] MELIÁ, J. L.; PEIRÓ, J. M.; CALATAYUD, C. El. Cuestionario General de Satisfacciónen Organizaciones Laborales: Estudios factoriales, fiabilidad y validez. (Presentacióndel Cuestionario S4/82). Rev. de Filosofía, Psicología y Ciencias de la Educación, [S.l.], v. 11, n. 3-4, pp.43-78, 1986.

[47] MOSCOVICI, Fela. Renascença organizacional. 5 ed. Rio de Janeiro: José Olympio, 1995. MOTTA, Paulo R. Gestão contemporânea: a ciência e a arte de ser dirigente. Editora Record: Rio de Janeiro. 1995.

[48] NUNES, F. M. G.; RODRIGUES, J. L. K. Clima organizacional: levantamento de variáveis que geram satisfação e insatisfação nos servidores de um instituto público de pesquisas. In: ENCONTRO LATINO AMERICANO DE INICIAÇÃO CIENTÍFICA, 16.; ENCONTRO LATINO AMERICANO DE PÓS GRADUAÇÃO, 11., 2011. Anais...São José dos Campos, SP.

[49] OLIVEIRA, J. M. BITENCOURT, J. A.; CHAVES, F. A. V.; CHAGAS, P. C. OLIVEIRA, R.A. Estudo da motivação organizacional entre servidores públicos e colaboradores terceirizados em um órgão da administração pública federal. In: SIMPÓSIO DE EXCELÊNCIA EM GESTÃO TECNOLÓGICA, 6, 2009, Rio de Janeiro. Anais... Rio de Janeiro: AEDB, 2009. PREARO, L. C.; GOUVÊA, M. A.; MONARI, C.; ROMEIRO, M. C. Avaliação do emprego da técnica de análise fatorial em teses e dissertações de algumas instituições de ensino superior. Revista Rege, v. 18, n. 4, p. 621-638, 2011.

[50] PINDER, C.C. Work Motivation in Organizational Behavior. Upper Saddle River, NJ: Prentice Hall, 1998.

[51] PUGH, D. S.; HICHSON, D. J. Os teóricos das organizações. Revisão de Suzana Rodrigues et al. Tradução de Afrânio Carvalho Aguiar et al. Rio de Janeiro: QualityMark, 2004. RODRIGUES, Aroldo. Psicologia Social. 2. ed. Petrópolis: Vozes, 1973.

[52] SILVA, R. et al. Fatores Motivacionais: Um Estudo Empírico em uma Indústria Têxtil no Centro Oeste do Brasil. Revista de Administração de Roraima, v. 6, n. 2, p. 299, 2016. WAGNER III, J. A.; HOLLENBECK, J. R. Comportamento organizacional: criando vantagem competitiva. Tradução de Cid Knipel Moreira. São Paulo: Saraiva, 2009.

[53] WRIGHT, P. M.; MCMAHAN, G. C.; MCWILLIAMS, A. Human resources and sustained competitive advantage: a resource-based perspective. International Journal of Human Resource Management, v. 5, n. 2, p. 301-326, 1994. 


\section{Capítulo 9}

\section{PLANO DE CARGO E SALÁRIOS: UM ESTUDO SOBRE A APLICAÇÃO EM UMA INDÚSTRIA DE MÁQUINAS ÓTICAS}

\section{Paulo César Schotten}

Solange Fachin

Rodrigo Santolini Soares

Norah Patricia Panozo Rivero

Resumo: 0 objetivo da presente pesquisa foi estudar a aplicação do plano de cargos e salários um uma indústria de máquinas óticas localizada no noroeste do Estado do Paraná - Brasil. Para que o objetivo fosse atingido, bibliograficamente foi apresentado os conceitos e suas variáveis dos temas: administração de recursos humanos, administração de cargos e salários bem como a análise (método de coleta de informação sobre cargos e metodologia para análise de dados) e descrição de cargos. Metodologicamente, essa pesquisa é caracterizada como descritiva, quanto aos procedimentos técnicos trata-se de um estudo de campo. No levantamento de dados foi observada a aplicação efetiva do modelo e foi constatado que não existe um Plano de Cargos e Salários formal, contudo existem alguns meios informais que a empresa adere para suprir essa carência. Como respostas ao trabalho foram apresentadas algumas considerações sobre o estado atual da organização quanto aos seus procedimentos e apresentadas sugestões que, se aplicadas poderão resultar em melhorias.

Palavras-chave: Administração de Cargos; Administração de Salário; Gestão de pessoas. 


\section{INTRODUÇÃO}

Esta pesquisa tem como finalidade estudar a aplicação do plano de cargos e salários em uma indústria de máquinas óticas localizada no noroeste do estado do Paraná, Brasil e para tanto foram abordados temas como Administração de Gestão de Pessoas e Administração de Cargos e Salários abordando assuntos como análise e descrição de cargos, pesquisa salarial, política salarial e formas de remuneração.

As descrições de cargo são valiosas para os funcionários e para a empresa de acordo com Bohlander, Snell e Sherman (2003), pois do ponto de vista dos funcionários, elas podem ajudá-los a conhecer seus deveres e lembrá-los dos resultados que deles são esperados. Do ponto de vista do autor, descrições de cargo documentadas podem servir como base para minimizar os desentendimentos entre gerentes e funcionários a respeito de quesitos do cargo. Elas definem também o direito da gerência tomar medidas corretivas quando os deveres contidos na descrição do cargo não são executados como exigido.

O plano de cargos e salários na visão de Silva (2002) é uma ferramenta utilizada para determinar ou sustentar as estruturas de cargos e salários de forma justa dentro da organização. Esse plano tem como objetivo alcançar os equilíbrios internos e externos, através da definição das atribuições, deveres e responsabilidades de cada cargo e os seus níveis salariais. 0 principal objetivo, portanto, é estudar a aplicação do plano de cargos e salários na indústria de máquinas óticas localizada no noroeste do Estado do Paraná - Brasil.

O presente estudo, uma vez concluído, contribuirá na ampliação da a compreensão das empresas de um modo geral, pois possibilita um enriquecimento de conhecimento na área de recursos humanos. Para tanto, o tema abordado terá a finalidade de descrever as etapas de análise de cargos e detalhar as etapas do processo para descrição de cargos através da análise da empresa e sugestão de possíveis correções alegadas e defendidas no estudo.

Essa pesquisa está estruturada da seguinte forma: Os marcos teóricos que fundamentam as variáveis são apresentados; A metodologia de pesquisa é delineada; Os resultados são discutidos; e As conclusões, limitações da pesquisa e sugestões para estudos futuros são proporcionadas.

\section{ADMINISTRAÇÃO DE RECURSOS HUMANOS}

A gestão de pessoas na visão de Barbieri (2012) é percebida cada vez mais como estratégia e não como um centro de custos; a gestão de RH ainda é uma função em consolidação; RH deve gerar valor à organização por meio da gestão de pessoas; os executivos do negócio devem compreender as demandas do RH e devem oferecer recursos para a concretização das estratégias.

Para trabalhar efetivamente com pessoas, Bohlander, Snell e Sherman (2003) afirmam que, temos de entender o comportamento humano, e precisamos conhecer os vários sistemas e práticas disponíveis para nos ajudar a construir uma força de trabalho qualificada e motivada. Ao mesmo tempo, para atingir as metas da empresa, temos que estar ciente das questões econômicas, tecnológicas, sociais e jurídicas que facilitam ou restringem nossas iniciativas.

Dito isso, o conceito de Administração de Recursos Humanos, apresentado por Milkovich e Boudreau (2009), refere-se a uma série de decisões integradas que formam as relações de trabalho; sua qualidade influencia diretamente a capacidade da organização e de seus empregados em atingir seus objetivos. E para isso é necessário contar com pessoas eficazes, pois sem elas seria simplesmente impossível para qualquer empresa atingir seus objetivos.

A gestão de pessoas de acordo com Milkovich e Boudreau (2009), é uma preocupação central de todo executivo em qualquer organização. Os executivos das áreas de finanças, marketing, distribuição, operações, P\&D, compras e planejamento são todos gestores de recursos humanos. Cabe a eles a responsabilidade definitiva pelo treinamento, desempenho, criatividade e satisfação dos empregados que lideram.

As empresas de sucesso, complementam Bohlander, Snell e Sherman (2003), são aquelas que combinam a experiência dos gerentes de linha com conhecimentos específicos de especialistas de $\mathrm{RH}$ para desenvolver e utilizar ao máximo os talentos de seus funcionários. Tratar de questões de RH raramente é responsabilidade exclusiva dos departamentos de RH que agem sozinhos. Em vez disso, os gerentes de RH têm trabalhado lado a lado com os gerentes de linha para tratar de questões relacionadas ao pessoal da empresa. Embora esse relacionamento nem sempre atinja um ponto ideal, a situação tem melhorado 
consideravelmente. Os gerentes de RH estão assumindo um papel maior no planejamento e nas tomadas de decisão da alta gerência, contribuições importantes ao sucesso da organização.

As atividades da administração de RH segundo Milkovich e Boudreau (2009), são programas desenhados em resposta à fixação dos objetivos e gerenciados para sua obtenção. A abordagem diagnóstica identifica quatro grandes categorias de atividades: Staffing, desenvolvimento, recompensa e relações trabalhistas. A natureza de cada uma delas varia com o passar do tempo e são diferentes para cada empresa, dependendo de suas condições organizacionais e externas, assim como de seus objetivos específicos.

Figura 01 - Organograma de Administração de Recursos Humanos.

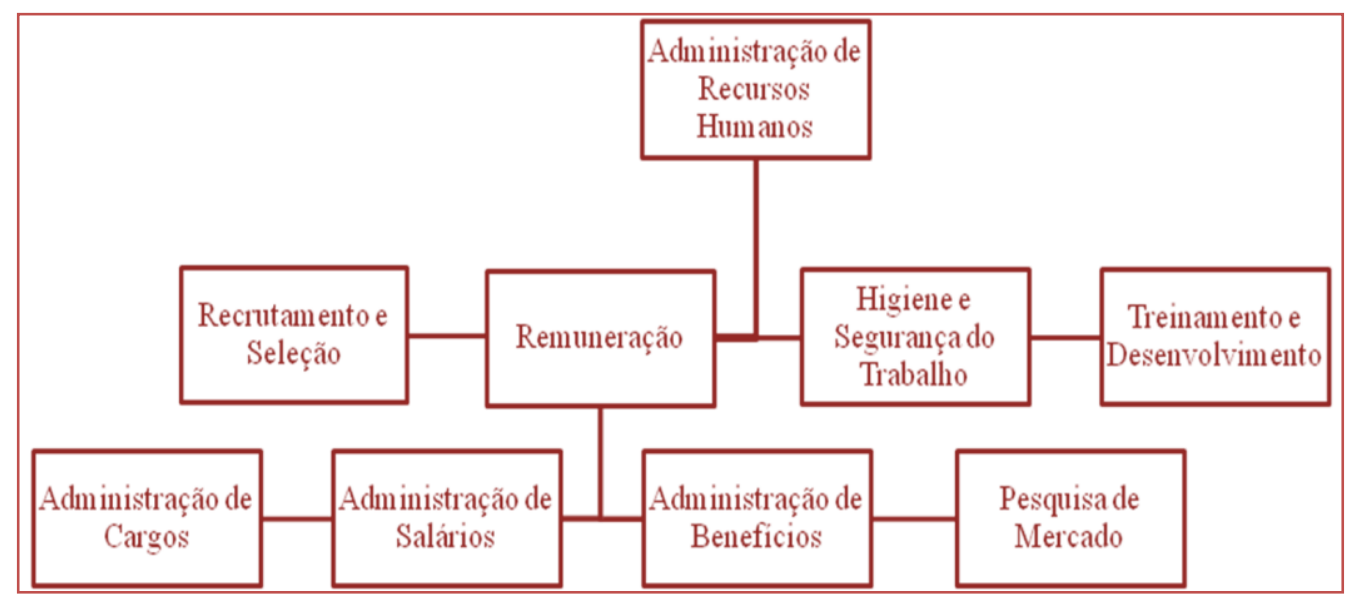

Fonte: Marras (2009, p. 91)

\subsection{ADMINISTRAÇ̃̃O DE CARGOS E SALÁRIOS}

A administração de cargos e salários, juntamente com a sistemática de avaliação de desempenho e do plano de carreira segundo Tachizawa, Ferreira e Fortuna (2006) forma o processo de planejamento, execução e controle das recompensas salariais (administração de salários, políticas de salários, composto salarial ou outra expressão equivalente). Na prática, os três instrumentos se complementam como se observa na Figura 02.

Figura 02 - Plano de Cargos e Salários.

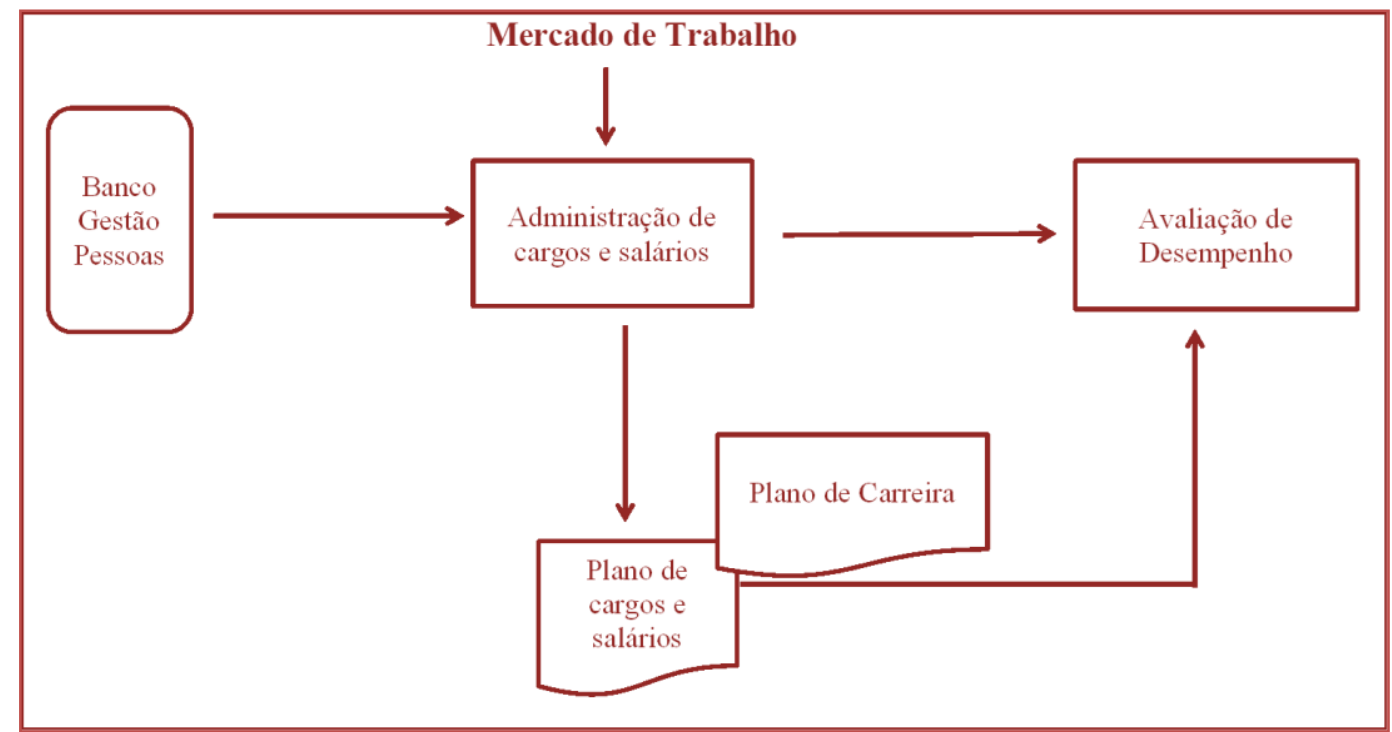

Fonte: Tachizawa, Ferreira e Fortuna (2006, p. 179) 
O conceito de plano de cargos e salários na visão de Silva (2002) é apresentado como uma ferramenta utilizada para determinar ou sustentar as estruturas de cargos e salários de forma justa dentro da organização. Segundo o autor Esse plano tem como objetivo alcançar os equilíbrios internos e externos, através da definição das atribuições, deveres e responsabilidades de cada cargo e os seus níveis salariais.

O Plano de cargos e Salários de acordo com Lacombe (2005) engloba algumas variáveis como:

- A relação dos cargos existentes e sua descrição em formulário padronizado;

- Os fatores utilizados na avaliação dos cargos e os níveis de cada fator, bem como a descrição daquilo que se entende para cada fator e cada nível;

- A pontuação de cada nível em cada fator e sua justificativa;

- A avaliação resultante de cada cargo em função dos fatores utilizados, dos níveis atribuídos a cada cargo em cada fator e da pontuação.

A estruturação de cargos envolve a descrição e a análise dos cargos segundo Boas e Andrade (2009). Se por um lado, a descrição de cargos envolve a determinação do conteúdo intrínseco de cada cargo, ou seja, os métodos de trabalho a serem adotados pelos seus integrantes e as relações com os demais cargos, por outro a análise de cargos delineia aspectos extrínsecos ao cargo e diz respeito às características pessoais que devem ser encontradas nos diversos profissionais, a fim de alcançar os objetivos organizacionais. De acordo com o autor trata-se da especificação do conteúdo do cargo, métodos de trabalho e relações com os demais cargos para atender às necessidades organizacionais, às condições ambientais e às necessidades pessoais.

A análise de cargos para Bohlander, Snell e Sherman (2003), é o processo de obtenção de informações sobre cargos, determinando deveres, tarefas ou atividades que eles envolvem. A análise de cargos implica a investigação sistemática do cargo, por meio de uma série de passos predeterminados, e devem resultar em um relatório escrito, com o resumo das informações obtidas do exame de 20 ou 30 tarefas, atividades individuais ou funções.

Pontes (2005) faz uma diferencia entre os principais termos usados na análise de cargos:

- Tarefa: atividade desenvolvida por uma pessoa na organização;

- Função: conjunto de tarefas designadas às pessoas na organização;

- Cargo: somatório das funções semelhantes quanto à natureza da tarefa executada e com as especificações requeridas aos ocupantes.

Ao montar a análise do cargo, de acordo com Boas e Andrade (2009), deve-se levar em consideração os requisitos físicos e mentais que ajudam a definir o perfil do futuro ocupante do cargo, o que serve de base também para recrutamento e seleção, definição de salários, avaliação de desempenho, entre outras atividades da área de gestão de pessoas. Além disso, complementa o autor, a análise ajuda a definir as responsabilidades envolvidas no cargo e as condições de trabalho que o ocupante vai encontrar na empresa. A gestão estratégica de pessoas tem sua base ou ponto de partida em dados e informações dessa natureza. Como é possível notar no Quadro 01. 
Quadro 01- Fatores de Especificação na análise de Cargos

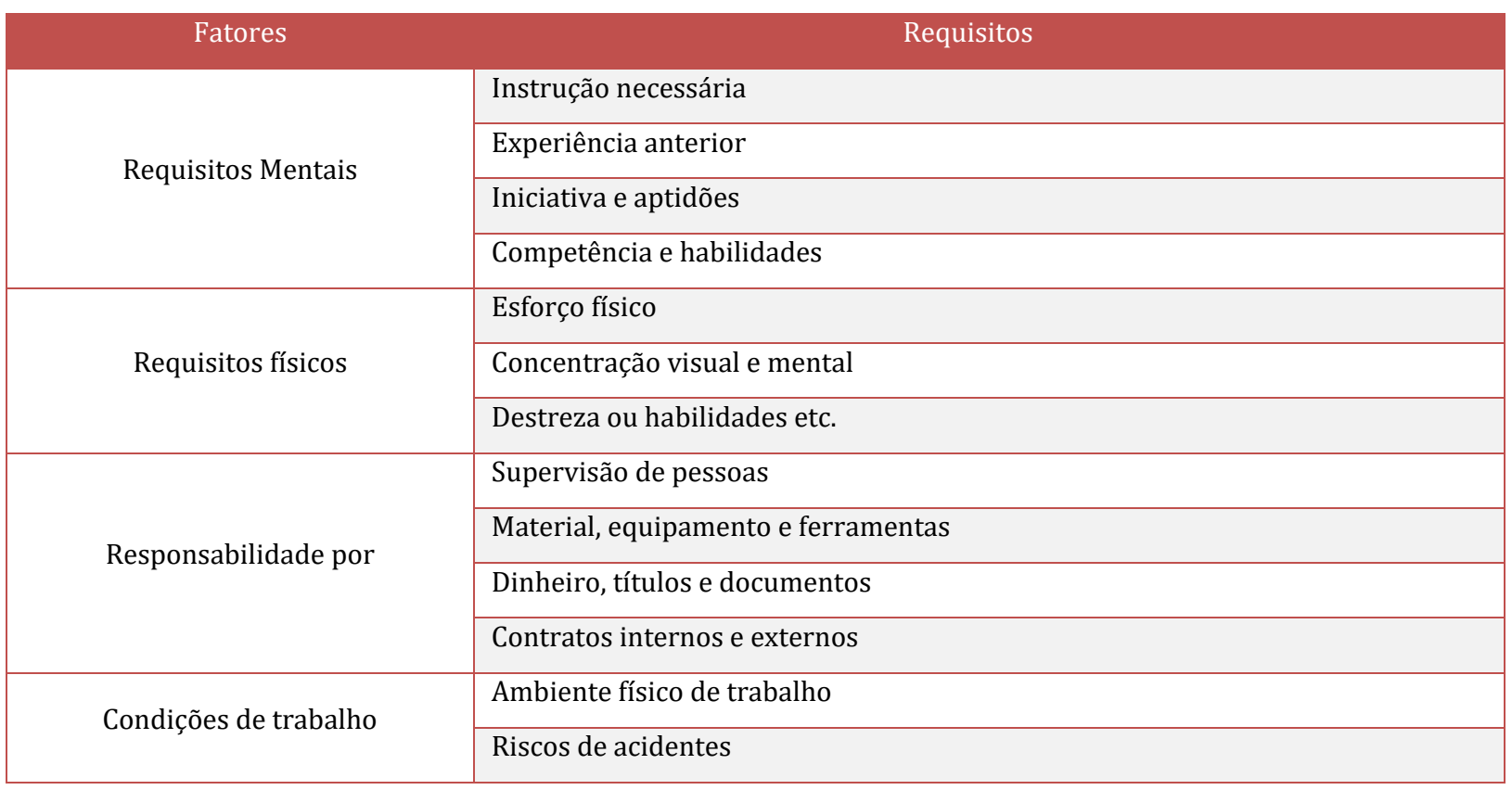

Fonte: Boas e Andrade (2009, p. 24)

O objetivo principal da análise de cargos para Bohlander, Snell e Sherman (2003), é aperfeiçoar o desempenho da empresa e sua produtividade. A figura 03 ilustra como a análise de cargos é realizada, incluindo as funções para as quais é usada.

Figura 03- Processo de Análise de Cargos.

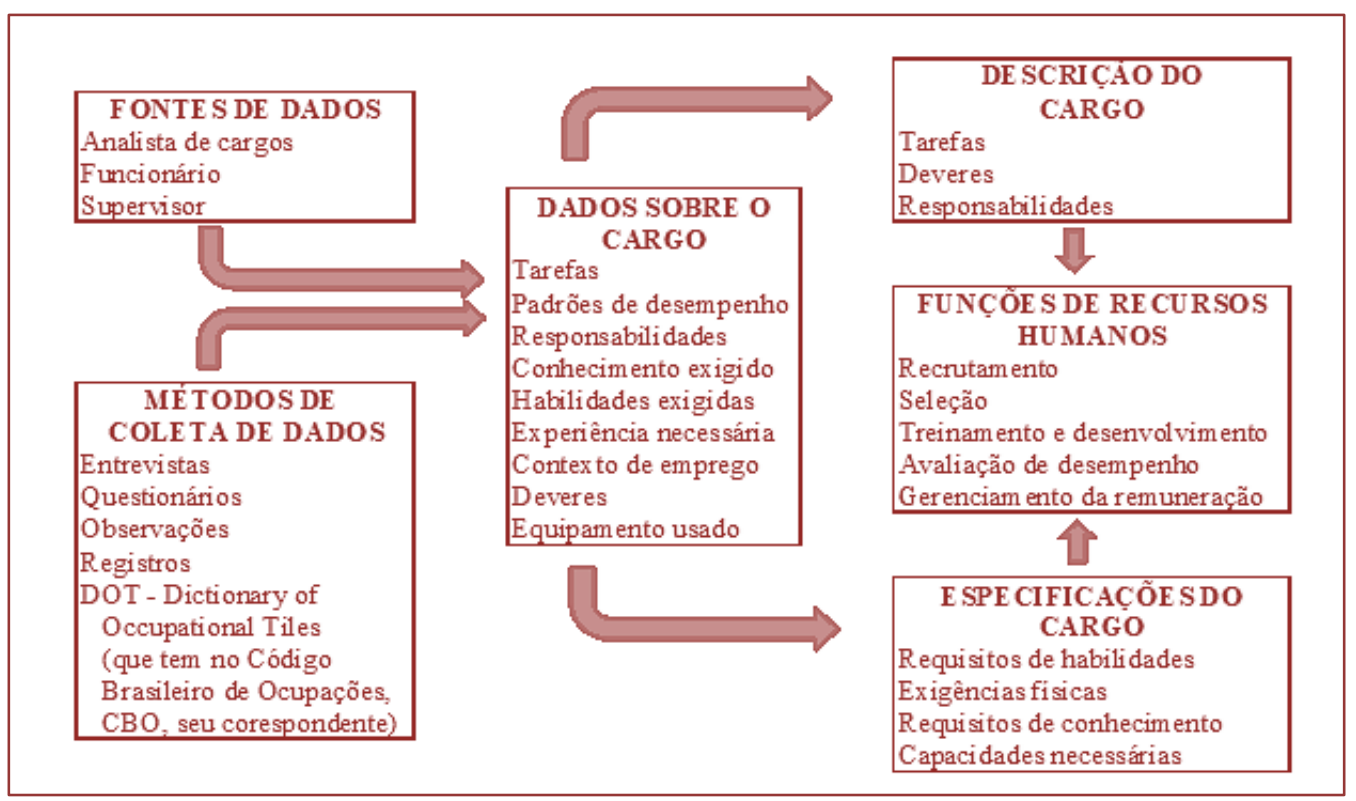

Fonte: Bohlander, Snell e Sherman (2003, p. 32)

De acordo com Bohlander, Snell e Sherman (2003), os dados sobre cargos podem ser obtidos de diversas maneiras. Os métodos mais comuns segundo o autor são apresentados no Quadro 02. 
Quadro 02- Métodos de obtenção de dados sobre Cargos.

\begin{tabular}{|c|l|}
\hline Método & \multicolumn{1}{c|}{ Conceito } \\
\hline Entrevistas & $\begin{array}{l}\text { Trata-se de perguntas feitas individualmente aos funcionários e aos gerentes sobre o cargo que } \\
\text { está sendo revisado. }\end{array}$ \\
\hline Questionários & $\begin{array}{l}\text { São formulários cuidadosamente preparados a serem preenchidos individualmente pelos } \\
\text { ocupantes do cargo analisado e pelos gerentes. Fornecem dados sobre deveres e tarefas de } \\
\text { trabalho desempenhados, objetivo do trabalho, ambiente físico, requisitos para o desempenho do } \\
\text { cargo (habilidade, nível de instrução, experiência, demandas físicas e mentais), equipamento e } \\
\text { materiais usados e preocupações especiais com saúde e segurança. }\end{array}$ \\
\hline Observação & $\begin{array}{l}\text { O analista obtém informações sobre cargos observando as atividades dos funcionários e } \\
\text { registrando notas em um formulário padronizado. Gravar em vídeo a atividade para estudo } \\
\text { posterior é uma abordagem usada por algumas empresas. }\end{array}$ \\
\hline Registros & $\begin{array}{l}\text { Os próprios funcionários no cargo fazem um registro diário de suas atividades durante um ciclo } \\
\text { de trabalho completo. Os registros normalmente são preenchidos nos intervalos específicos em } \\
\text { que há mudança de atividades e mantidos durante um período de duas a quatro semanas. }\end{array}$ \\
\hline
\end{tabular}
Fonte: Bohlander, Snell e Sherman (2003, p.33)

A Análise de Cargos para Bohlander, Snell e Sherman (2003), serve para justificar descrições de cargo e outros procedimentos de seleção. Diversas abordagens de análise de cargos são usadas para reunir dados, cada uma com vantagens e desvantagens específicas. Quatro dos métodos mais populares são:

- Análise Funcional de Cargos: Utiliza o levantamento dos vários tipos de funções ou atividades que constituem determinado cargo. A AFC supõe, assim, que cada emprego envolve o desempenho de certas funções. Especificamente, há três amplas funções do trabalhador na base do sistema: Dados, Pessoas e Coisas. Essas três categorias são subdivididas para formar uma hierarquia de escalas de função/ trabalhador. Ao estudar o cargo que está sendo revisado, o analista de cargos indicará o nível funcional de cada uma das três categorias. Isso é feito para cada uma das três áreas, e os três níveis funcionais devem ser iguais a $100 \%$. 0 resultado final é um cargo avaliado quantitativamente. A AFC pode ser usada facilmente para descrever o conteúdo de cargos e auxiliar na redação de suas descrições e especificações. Ela serve de base para o código DOT. (Comumente referido como DOT, o Dictionary of Occupational é compilado pelo Ministério do Trabalho dos Estados Unidos. Ele contém descrições padronizadas e abrangentes de cerca de 20 mil cargos. O principal objetivo do DOT é agrupar ocupações em uma estrutura ocupacional classificatória sistemática baseada em inter-relacionamentos de tarefas e requisitos de cargo. Esse agrupamento de classificações ocupacionais é feito por um sistema de codificação. Conforme os autores Bohlander, Snell e Sherman, o DOT tem contribuído para maior uniformidade nos títulos e descrições de cargos. No Brasil, o CBO foi desenvolvido com objetivo similar).

Figura 04- Níveis de Dificuldade das Funções do Trabalhador.

\begin{tabular}{|l|l|r|l|l|l|}
\multicolumn{2}{|l|}{ Dados (4․ Dígito) } & \multicolumn{2}{c|}{ Coisas (60 Dígito) } \\
\hline 0 & Sintetizar & 0 & Orientar & 0 & Montar \\
\hline 1 & Coordenar & 1 & Negociar & 1 & Trabalhar com precisão \\
\hline 2 & Analisar & 2 & Instruir & 2 & Operar/ Controlar* \\
\hline 3 & Compilar & 3 & Supervisionar & 3 & Dirigir/ Operar* \\
\hline 4 & Calcular & 4 & Desviar & 4 & Manipular \\
\hline 5 & Copiar & 5 & Persuadir & 5 & Cuidar \\
\hline 6 & Comparar & 6 & Falar/ Sinalizar & 6 & Alimentar/ Carregar* \\
\hline & & 7 & Servir & 7 & Conduzir \\
\hline & & 8 & Tomar instruções / Ajudar* & & \\
\hline
\end{tabular}

Fatores com * são individuais

Fonte: U.S. Department of Labor, Employment and Training Administration, Revised Handbook for Analyzing Jobs. Washington: U.S apud Bohlander, Snell e Sherman (2003) 
- Sistema de Questionários de Análise de Posição: Trata-se de um método de coleta de dados que abrange 194 tarefas diferentes orientadas para o trabalhador. Usando uma escala de cinco pontos, o QAP busca determinar em que grau, se houver, as diferentes tarefas, ou elementos do cargo, estão envolvidas no desempenho de um cargo especifico.

- Método do Incidente Crítico: 0 objetivo desse método é identificar tarefas fundamentais do cargo, isto é, os deveres importantes e as responsabilidades desempenhadas pelos funcionários que levam ao sucesso no cargo. Informações sobre as tarefas fundamentais de cargo podem ser coletadas por meio de entrevistas com funcionários ou gerentes ou por meio de relatórios escritos pelos funcionários que ocupam esses cargos. 0 analista de cargos escreverá de cinco a dez tarefas importantes para cada cargo a ser estudado. 0 produto final serão declarações escritas da tarefa claras, completas e facilmente entendidas por aqueles que não conhecem o cargo. 0 método do incidente crítico é importante na análise de cargos porque ensina o analista a focalizar comportamentos fundamentais do funcionário para o desempenho bem-sucedido.

- Análise Informatizada de Cargos: Os sistemas de informação de recursos humanos facilitam imensamente o processo de análise de cargos. Atualmente existem vários programas de software específicos para analisar cargos e redigir suas descrições e especificações com base nessa análise. Esses programas normalmente contêm declarações de tarefas generalizadas, que se aplicam a diferentes cargos. Os gerentes e os funcionários selecionam as declarações que descrevem melhor o cargo que está sendo revisado, indicando, quando apropriado, a importância da tarefa para o cargo. Aplicativos avançados de computador combinam a análise com a avaliação de cargos e a determinação do valor do pagamento referente aos cargos de empresas. Implantar sistemas informatizados de análise de cargos pode ser caro, mas, quando a empresa tem muitos cargos a analisar, o custo por cargo pode ser baixo.

O conceito de descrição de cargos defendido por Marras (2009) é descrito como um documento escrito que determina um cargo a partir dos deveres, condições de trabalho, responsabilidades e especificações. Sendo assim, a descrição dos cargos baseia-se em resumir e padronizar as características de um cargo através de observação, estudo e redação. Detalha as principais exigências do cargo ao seu ocupante, para que suas tarefas sejam realizadas com eficiência e eficácia.

As funções da descrição de cargo de acordo com Tachizawa, Ferreira e Fortuna (2006), são quase sempre correlatas e mantêm coerência com os níveis de escolaridade e responsabilidade do seu ocupante. Um conjunto de cargos, dispostos em seqüência crescente, define uma carreira. Uma empresa pode ter várias carreiras em seu plano.

Todos os cargos devem ser descritos com base nas funções e tarefas exercidas no ponto de vista de Barbieri (2012); deve-se definir a missão dos mesmos dentro da organização, a responsabilidade por produzir resultados, e também o nível de reporte e relacionamento da posição com outros cargos na estrutura organizacional.

De acordo com Boas e Andrade (2009), a descrição de cargos pode ser considerada como um "retrato" simplificado do conteúdo e das principais atribuições do ocupante, pode-se afirmar que ela deve definir o que o ocupante faz, quando, onde e por que, conforme ilustra o Quadro 03.

Quadro 03-Elementos da Descrição de Cargos

\begin{tabular}{|l|l|}
\hline O que faz? & Tarefas e atividades a executar \\
\hline Quando faz? & Periodicidade: diária, semanal, mensal, anual, esporádica \\
\hline Como faz? & Através de pessoas, máquina e equipamentos, materiais, dados e informação \\
\hline Quem faz? & Local e ambiente de trabalho \\
\hline Por que faz? & Objetivos do cargo. Metas e resultados a atingir \\
\hline
\end{tabular}

Fonte: Boas e Andrade (2009, p. 23)

A maioria das descrições de cargo segundo Bohlander, Snell e Sherman (2003) contém pelo menos três partes: título do cargo, sua identificação e a relação de deveres que ela implica. Em relação aos cargos o autor destaca: 
- Identificação de Cargo;

- Atribuições de Cargo ou Funções Essenciais;

- Requisitos e Especificações de cargo

Apresenta o quadro 04 um modelo de descrição de cargo normalmente aplicável a organizações extremamente estruturadas (TACHIZAWA, FERREIRA E FORTUNA, 2006).

Quadro 04- Modelo de Descrição de Cargos segundo Tachizawa, Ferreira e Fortuna

\begin{tabular}{|l|l|}
\multicolumn{2}{|c|}{ Título do cargo: } \\
\hline Descrição Sumária: & \\
\hline Descrição Geral: & \\
\hline Requisitos: & \\
\hline Condições de trabalho: & \\
\hline Pontuação na escala salarial: & \\
\hline
\end{tabular}

Fonte: Tachizawa, Ferreira e Fortuna (2006, p. 181).

A descrição de cargo de acordo com Lacombe (2005) é feita para fins de administração salarial. Ao descrever um cargo o autor acredita que deve-se ter em mente que a descrição é genérica e deve abranger as diversas funções nele incluídas. Na figura 05, pode-se observar como deve ser feita a Descrição de Cargos.

\subsection{ADMINISTRAÇÃO DE SALÁRIOS}

O conceito de pontuação na escala salarial de acordo com Tachizawa, Ferreira e Fortuna (2006), trata-se de uma pontuação decorrente da avaliação de cargos da organização e leva em conta, entre outros aspectos, nível de responsabilidade, importância para o negócio e grau de experiência. Na visão do autor, a administração de cargos e salários pode adotar diferentes sistemas de avaliação.

Após os cargos terem sido descritos e avaliados, surge a questão da política salarial que a empresa quer utilizar, conforme Barbieri (2012). 0 conceito sobre o salário proposto pelo autor é descrito como sendo composto por somas de salários secundários. Segundo o autor o salário mensal é o salário-base, o salário total é a soma do salário mensal mais o bônus ou salário variável, enquanto a remuneração global é a soma do salário-base, do salário total e dos benefícios. E é só após os cargos terem sido descritos e avaliados que surgem questões que englobam a política salarial que a empresa irá utilizar. Um modelo de descrição de cargos e salários é apresentado por Silva (2009), figura 5.

A política salarial apresentada por Boas e Andrade (2009), trata-se do conjunto de decisões organizacionais tomadas a respeito de assuntos relacionados com a remuneração e benefícios concedidos aos funcionários. 0 objetivo principal, conforme relatado pelo autor é criar um sistema de recompensa que seja equitativo, tanto para a organização como para os funcionários. Por esse motivo, uma política salarial deve atender simultaneamente a alguns critérios como:

- Ser equilibrada: a estrutura salarial deve-se basear nos padrões mínimos estabelecidos pelo governo ou pelos acordos sindicais;

- Ser equitativa: cada pessoa deve ser paga proporcionalmente, de acordo com seu esforço, habilidades e capacitação profissional; 
Figura 5 Descrição de cargos e Salários

\section{EMPRESA XXXXX}

Descrição de Cargo Mensalista

Cargo:Analista de Cargos e Salários Sênior

\section{SUMÁRIO DO CARGO ou DESCRIÇÃO SUCINTA}

Reportando-se ao Supervisor de Remuneração, auxiliando-o no planejamento estratégico da área, bem como responde pelas análises do organograma da empresa, análises e movimentações da massa salarial, cargos e salários da empresa. Representa a área em reuniões de trabalho de remuneração e benefícios.

\section{TAREFAS PERIÓDICAS}

PARTICIPA na confecção do planejamento do departamento fornecendo informações e analisando cenários internos e externos.

ANALISA: (i) todas as alterações propostas internamente no que se refere a cargos e salários., confrontando-as com os procedimentos e políticas em vigor, aprovando, ou não, e enviando-as à instância superior para dar seguimento aos processos; (ii) as estruturas salariais e respectivas alterações e ajustes.

RESPONDE pelo desenho de organograma da empresa e sugestões de modificações neste, ou por solicitação de outras gerências ou por sugestão própria, sempre visando ao melhor desempenho dos efetivos e da produtividade da empresa.

CONFECCIONA relatórios finais da área de remuneração para subsidiar decisões superiores em assuntos como: comportamento da massa salarial, participação no mercado, índices de gestão e outros.

\section{TAREFAS OCASIONAIS}

(Se houver)

\section{SUBORDINAÇÃO}

Reporta-se ao Supervisor de Remuneração

\section{REQUISITOS OU QUALIFICAÇÕES EXIGIDAS}

- Escolaridade: superior em Administração de Empresas

- Experiência Anterior: mínimo de três anos na função de Analista Pleno

- Conhecimentos: digitação, Office, redação, habilidade no relacionamento humano, cálculos de média complexidade, fluência verbal e escrita, visão abrangente do business, forte poder de argumentação e convencimento.

\section{APROVAÇÕES}

Superior Imediato Analista de C\&S

Gerente da Área

Data:

Fonte: Silva (2009)

- Ser balanceada: salários, benefícios e outras recompensas devem proporcionar um pacote salarial adequado à realidade da empresa;

- Ser eficaz quanto ao custo: os salários não podem ser excessivos, no entanto eles devem ser estabelecidos em função do que a organização pode pagar;

- Ser segura: os salários devem ser suficientes para ajudar os empregados a sentirem-se seguros, de maneira a satisfazer as suas necessidades;

- Ser incentivadora: os salários devem motivar eficazmente o trabalho produtivo;

- Ser aceitável para os empregados: as pessoas devem compreender o sistema de salários e sentir que ele representa um sistema razoável tanto para elas quanto para a organização. 
Basicamente, a remuneração de acordo com França (2008), divide-se em remuneração fixa (da qual fazem parte os benefícios) e remuneração variável. Segundo o autor a remuneração fixa, por não possuir muita flexibilidade para ser alterada, tem como referencial o desenvolvimento que se mostra aditivo ao longo do tempo, e a remuneração variável, por sua vez, baseia-se no esforço e no estado de ânimo do profissional, aliados a características momentâneas da organização e do ambiente.

De acordo com a CLT art. 457 e seguintes, a remuneração consiste em todo o valor pago ao empregado seja realizado pelo empregador ou por terceiros em virtude do seu trabalho. A remuneração é igual ao salário mais gorjetas, ou seja, o salário é composto por salário direto que é pago pelo empregador e o salário indireto que é pago por terceiros.

Existem diversas maneiras de definir o termo salário, dependendo de sua forma de aplicação ou como ele se apresenta para o empregado ou para o empregador. De acordo com Marras (2009) algumas das principais definições estão no Quadro 05.

Quadro 05- Definições de Salário

\begin{tabular}{|c|c|}
\hline Tipo de Salário & Definição \\
\hline 1. Salário Nominal & $\begin{array}{l}\text { É aquele que consta na ficha de registro, na carteira profissional e em todos os } \\
\text { documentos legais. Pode ser expresso em hora, dia, semana, mês etc. }\end{array}$ \\
\hline 2. Salário Efetivo & $\begin{array}{l}\text { É o valor efetivamente recebido pelo empregado, já descontadas as obrigações } \\
\text { legais (INSS, IR etc.) }\end{array}$ \\
\hline 3. Salário Complessivo & $\begin{array}{l}\text { É o que tem inserido no seu bojo toda e qualquer parcela adicional (hora extra } \\
\text { etc.) }\end{array}$ \\
\hline 4. Salário Profissional & $\begin{array}{l}\text { É aquele cujo valor está expresso na lei e se destina especificamente a algumas } \\
\text { profissões (por exemplo, médicos, engenheiros). }\end{array}$ \\
\hline 5. Salário Relativo & É a figura da comparação entre um salário e outro na mesma empresa. \\
\hline 6. Salário Absoluto & $\begin{array}{l}\text { É o montante que o empregado recebe, líquido de todos os descontos, e que } \\
\text { determina o seu orçamento. }\end{array}$ \\
\hline
\end{tabular}

Fonte: Marras (2009, p. 92)

Apesar das discussões entre os autores, o salário é um dos elementos importantes na motivação do empregado para o trabalho (Albuquerque, 1982). Segundo o autor o salário deve ser cuidadosamente administrado, incluindo a adoção de técnicas, métodos, regras e políticas para a elaboração de um adequado plano salarial, que garanta o estabelecimento de uma remuneração justa em retribuição ao trabalho desempenhado pelos empregados.

\section{METODOLOGIA}

O objetivo desta pesquisa é estudar a aplicação do Plano de Cargos e Salários em uma indústria de máquinas óticas localizada na região noroeste do Estado do Paraná - Brasil.. Para que o objetivo fosse atingido optou-se por utilizar uma pesquisa descritiva, uma vez que busca identificar com bases teóricas e pesquisa de campo, fatores relacionados à descrição e análise de cargos e salários desta organização. Na visão de Gil (2002), a pesquisa descritiva tem como objetivo primordial a descrição de características de determinada população ou fenômeno ou, então, o estabelecimento de relações entre variáveis. Segundo Danhke (1989 apud SAMPIERI, R.H; COLLADO, C.F; LUCIO, P.B, 2006), os estudos descritivos procuram especificar as propriedades, as características e os perfis importantes de pessoas, grupos, comunidades ou qualquer outro fenômeno que se submeta à análise.

Em relação aos procedimentos técnicos, essa pesquisa classifica-se como estudo de campo. Para Gil (2002), essa pesquisa é desenvolvida por meio da observação direta das atividades do grupo estudado e de entrevistas com informantes para captar suas explicações e interpretações do que ocorre no grupo [...], pois somente com essa imersão na realidade é que se podem entender as regras, os costumes e as convenções que regem o grupo estudado.

Em relação ao método de análise essa pesquisa é qualitativa, pois se caracteriza pelo não emprego de técnicas estatísticas no levantamento e análise de dados. A metodologia qualitativa de acordo com 
Marconi e Lakatos (2011) preocupa-se em analisar e interpretar aspectos mais profundos, descrevendo a complexidade do comportamento humano. Fornece análise mais detalhada sobre a investigação, hábitos, atitudes, tendências de comportamento e etc.

Na coleta de dados foram utilizados os métodos de entrevista e observação. As entrevistas foram feitas ao funcionário encarregado pelo setor de RH. Trata-se de um questionário semi-estruturado realizado com o responsável do RH com o intuito de delinear, como foi feito e como se desenvolve, o plano de cargos e salários efetivamente na empresa. A observação foi feita no decorrer das entrevistas que ocorreram nos meses de Julho e Agosto de 2017.

\section{APRESENTAÇÃO E ANÁLISE DOS DADOS}

A empresa analisada desenvolve equipamentos de precisão para laboratórios de ótica. De acordo com a empresa a idéia surgiu no final da década de 80 , devido à insatisfação existente no mercado ótico brasileiro. Essas atividades tiveram início no começo da década de 90 em uma área de $15 \mathrm{~m}^{2}$. Hoje a empresa conta com uma equipe de mais de 40 profissionais trabalhando na área de desenvolvimento tecnológico, na produção de moldes, organizadores, sistemas de medição, máquinas cilíndricas e geradores de curvas CNC e PLC, estruturada em sede própria com $1250 \mathrm{~m}^{2}$ de área construída em uma superfície total de $11000 \mathrm{~m}^{2}$, tendo também outra unidade fabril de $450 \mathrm{~m}^{2}$ em uma área de $12000 \mathrm{~m}^{2}$.

A organização da área de Recursos Humanos (RH) da empresa é dividida de acordo com as necessidades de cada setor. A empresa não possui um plano de cargos e salários estruturado, apenas um organograma dividido pelos cargos da empresa. Entretanto algumas operações vitais e imprescindíveis para a corporação são feitas por meios informais.

O desempenho dos funcionários é auferido através de um molde produzido pela empresa e esse sistema tem uma engenharia capaz de constatar e fornecer relatórios diariamente contendo a produção de cada funcionário/máquina. Porém esse método só pode ser aplicado na área de produção, já nos demais setores não existem maneiras concretas para se conseguir dimensionar o desenvolvimento real de cada funcionário no seu respectivo cargo, somente por intermédio da percepção dos outros funcionários e superiores. A empresa acredita que de uma maneira geral consegue identificar os funcionários que não produzem de forma satisfatória no período de experiência, o que lhes permite optar pela não contratação.

Os cargos que existem dentro da empresa não têm suas tarefas definidas de forma clara. Quando o funcionário é recrutado, as atividades que deve desempenhar são dadas pelo gerente de produção, quando se trata de um funcionário de nível produtivo, e quando for um funcionário do setor administrativo essas tarefas são repassadas pelo RH e no dia-a-dia pelos colegas de trabalho. Por essa razão não é possível exigir ações dos funcionários diferente das previamente exigidas no primeiro momento. A empresa procura recrutar pessoal internamente para os cargos mais qualificados, oferecendo oportunidade de desenvolvimento para os colaboradores com o intuito de motivar a atualização constante dos níveis de conhecimento com um estímulo salarial. Os critérios de promoção e ascensão são muitos, dentre os quais pode-se destacar o mérito, tempo de serviço, perfil e conhecimento na área.

De acordo com a empresa existe um grande problema na indefinição de atividades, ocasionando sobrecarga principalmente nos funcionários dos setores administrativos, o que gera um atraso nas atividades ou até mesmo o não cumprimento delas, prejudicando assim o bom andamento da organização. Contudo, a empresa alega que não há problemas de gestão de pessoas, como falta de comando ou desobediência por parte dos funcionários. Atualmente a empresa toma alguns cuidados referentes ao recrutamento, como: Análise de documentos, análise de currículos e suas procedências, bem como as referências profissionais. Outra ação adotada pela empresa para se proteger de riscos externos é exigir o exame admissional no momento da contratação.

Para a empresa o que define um salário justo é o tipo de atividade a ser desenvolvida e o grau de conhecimento necessário para manusear as ferramentas de trabalho. Os salários que são pagos aos funcionários são comparados com os pagos por outras empresas que tenham o mesmo tipo de atividade ou semelhantes aos seus. Esta comparação é feita por cargo e no nível do teto salarial da cidade por meio de consultas pela internet e algumas vezes por telefone. 0 reajuste do salário dos funcionários é feito pelo sindicato da categoria. Existe um salário base de contratação e conforme os funcionários se destacam em suas funções, a empresa os incentiva com um aumento salarial e verifica o desenvolvimento dos funcionários através de comparações feitas entre os colaboradores do mesmo setor, sendo atribuídos os benefícios ao funcionário que se destacou em relação aos demais. Na visão da empresa, podem ser detectadas algumas deficiências no seu modo de remuneração que muitas vezes gera injustiça entre os 
colaboradores, por exemplo, um funcionário de destaque ter seu salário nivelado ao dos funcionários padrão, perdendo assim o incentivo de aumentar a sua produção.

Para a empresa a remuneração dos colaboradores é competitiva em relação ao mercado e coerentes com os níveis de responsabilidades e conhecimento. Como apresentado anteriormente o salário base dos empregados em cargos idênticos são os mesmos. A empresa trabalha com a remuneração fixa e variável. Os benefícios que a empresa oferece são: Vale-alimentação, plano de saúde, convênios com dentistas, laboratórios e sindicatos. Todos os benefícios são oferecidos para todos os colaboradores.

A empresa acredita que sua maior dificuldade em implantar um sistema adequado de descrição de cargos e administração de salários, se deve ao fato de não ter vislumbrado a necessidade anteriormente e conforme a organização foi se desenvolvendo não teve a iniciativa de gerir melhor essa situação, no entanto a empresa tem consciência de que precisa de um plano de cargos e salários para que possa continuar gerando resultados positivos mediante um desenvolvimento saudável.

\subsection{ANÁLISE GERAL DA PESQUISA}

Como visto na pesquisa, a empresa não possui um sistema formal de descrição de cargos e salários. Essa ausência de descrição pode acarretar dificuldades comprometendo o objetivo da própria ação, descrito por Bohlander, Snell e Sherman (2003), como sendo essencial para aperfeiçoar o desempenho da empresa e sua produtividade.

Os cargos que existem dentro da empresa não têm suas tarefas definidas de forma clara. Isto pode resultar em um desnorteio, ou até mesmo a sobrecarga do funcionário em relação as suas atividades o qual sem dúvida precisará recorrer ao gerente de produção, para que lhe seja delegado as atividades que lhe cabem, podendo estas estar ou não condizentes com o seu cargo dentro da empresa. Diante desta situação podese citar Silva (2002), que explica que o plano de cargos e salários é uma ferramenta utilizada para determinar ou sustentar as estruturas de cargos e salários de forma justa dentro da organização. Bohlander, Snell e Sherman (2003, p. 38), completam que as descrições de cargo são valiosas para os funcionários e para a empresa, pois do ponto de vista dos funcionários, elas podem ajudá-los a conhecer seus deveres e lembrá-los dos resultados que deles são esperados na empresa

Mesmo com todas essas deficiências relatadas pela empresa o método de recrutar pessoas internamente para os cargos mais qualificados, contribui para que os funcionários que almejam uma posição de mais destaque e reconhecimento na organização tenham maior empenho em seu desenvolvimento, o que resulta em benefício para ambos.

Aparentemente os níveis salariais adotados pela empresa são competitivos em relação ao mercado e coerentes com os níveis de conhecimento e responsabilidade, porém podem ser detectadas algumas deficiências no seu modo de remuneração devido à ausência de um plano de cargos e salários. Segundo Albuquerque (1982), o salário deve ser cuidadosamente administrado, incluindo a adoção de técnicas, métodos, regras e políticas para a elaboração de um adequado plano salarial, que garanta o estabelecimento de uma remuneração justa em retribuição ao trabalho dos empregados.

Os métodos de análise usados pela empresa não são aptos para medir de uma maneira satisfatória e confiável o desenvolvimento dos seus funcionários. Por isso é preciso que a empresa adote métodos melhores para avaliar o desempenho dos funcionários bem como a sua política salarial e todas as variáveis que envolvam o trabalhador, para isso o primeiro passo e talvez o mais urgente seja a implantação efetiva do plano de cargos e salários para que a corporação possa atuar em um universo amplo e transparente, podendo assim se situar melhor em relação a todos os processos da empresa, a começar por uma política salarial mais justa baseada nas efetivas atividades desempenhadas pelo funcionário e a partir disso possibilitar a elaboração de técnicas capazes de medir o desempenho do funcionário, visto que com este, a empresa não estará sobrecarregando o trabalhador com atividades que não lhe cabem.

\section{CONSIDERAÇÕES FINAIS}

O objetivo inicial de pesquisa foi estudar a aplicação do plano de cargos e salários em uma indústria de máquinas óticas localizada no noroeste do Estado do Paraná. Como visto dentro da organização, com a falta de um Plano de Cargos e Salários efetivo, são utilizados meios informais e sem embasamento teórico como tentativa de suprir as reais necessidades que as empresas possuem. Mesmo com essa carência a empresa foi capaz de desenvolver suas atividades rotineiras até o momento. Contudo não se pode afirmar 
ao certo o nível de prejuízo da empresa em relação ao capital humano, pois de acordo com Masiero (2007), a partir da descrição de cargos é possível estabelecer os salários correspondentes [...]. Conforme o autor a remuneração apropriada poderá atrair e manter satisfeitos os empregados.

As principais deficiências apontadas em relação aos aspectos estudados foram: A falta de clareza das atividades que compõem cada cargo, a remuneração equivocada de funcionário de destaque ter seu salário nivelado ao dos funcionários padrão, perdendo assim o incentivo de aumentar a sua produção, e a falta de um sistema capaz de avaliar o desempenho dos funcionários.

A falta de um sistema formal capaz de delinear de forma concreta e com embasamento teórico as atividades que devem ser desenvolvidas pelo funcionário, não permite muitas vezes que a empresa consiga obter eficiência, eficácia, efetividade e relevância organizacional. Assim sendo, sugere-se que a empresa desenvolva um Plano de Cargos e Salários para que possa atuar em um universo amplo e transparente podendo, de esta maneira, se situar melhor em relação a todos os processos estabelecidos na empresa e começar por uma política salarial mais justa baseada nas efetivas atividades desempenhadas pelo funcionário e a partir disso elaborar técnicas capazes de medir o desempenho do mesmo, visto que o funcionário terá a clareza dos objetivos esperados pela empresa em relação ao seu trabalho, possibilitarse-á o estímulo para os colaboradores aumentarem seu rendimento criando uma indústria com maior capacidade de crescimento com qualidade.

\section{REFERÊNCIAS}

[1] ALBUQUERQUE, Lindolfo Galvão. Administração Salarial e Aspectos Comportamentais em Instituições de Pesquisa e Desenvolvimento. Tese de Doutorado. São Paulo: FEA/USP, 1982.

[2] BARBIERI, Ugo Franco. Gestão de Pessoas nas Organizações: Práticas atuais sobre o RH Estratégico. São Paulo: Atlas, 2012.

[3] BOAS, A. A. V; ANDRADE, R. O. B. Gestão Estratégica de Pessoas. Rio de Janeiro: Elsevier, 2009.

[4] BOHLANDER, G. S.; SNELL, S.; SHERMAN, A.Administração de Recursos Humanos. São Paulo: Cengage Learning, 2009.

[5] ChIAVENATO, Idalberto. Recursos Humanos. Edição Compacta, 3. ed. São Paulo: Atlas, 1994.

[6] FRANÇA, Ana Cristina Limongi. Práticasde Recursos Humanos- PRH: Conceitos, ferramentas e procedimentos. 1. ed. São Paulo: Atlas, 2012.

[7] GIL, ANTÔNIO CARLOS. Como Elaborar Projetos de Pesquisa. 4. ed. São Paulo: Atlas, 2002.

[8] LACOMBE, Francisco. Recursos Humanos: Princípios e Tendências. São Paulo: Saraiva, 2005.

[9] MARCONI, M.A; LAKATOS, E. M. Metodologia Científica. 6. ed. São Paulo: Atlas, 2011.

[10] MARRAS, Jean Pierre. Administração de Recursos Humanos:Do operacional ao estratégico. 13. ed. São Paulo: Saraiva, 2009.

[11] MASIERO, Gilmar. Administração de Empresas: Teorias e Funções com Exercícios e Casos. São Paulo: Saraiva, 2007.

[12] MILKOVICH, G. T.; BOUDREAU, J. W. Administração de Recursos Humanos. 1. ed.Editora: Atlas, 2009.

[13] PONTES, Benedito Rodrigues. Administração de cargos e salários.11. ed. São Paulo: LTR, 2005.

SAMPIERI, R.H; COLLADO, C. F; LUCIO, P. B. Metodologia de Pesquisa. 3. ed. São Paulo: McGraw-Hill, 2006.

[14] SILVA, Claudio. Apostila: A administração de Cargos e salarios - Tradicional. Disponivel em http://www.administraçãovirtual.com. Acesso em 04/05/2018, às 12:51.

[15] SILVA, Mateus de Oliveira. Manual de gestão de pessoas e equipes. São Paulo: Gente, 2002.

[16] TACHIZAWA, T.; FERREIRA, V. C. P.; FORTUNA, A. A. M. Gestão com Pessoas: Uma abordagem aplicada às estratégias de negócios. 5. ed. Rio de Janeiro: Editora FGV, 2006.

[17] TENÓRIO, Fernando G. Gestão de ONGs: Principais funções gerenciais. 11. ed. Rio de Janeiro: Editora FGV, 2009. 


\section{Capítulo 10}

PROJETO DE LEI 9.960/2018 UMA OPORTUNIDADE PARA O AUTISTA OU DESVIO DA MÃO DE OBRA?

\section{Rose Kelly I. S. da Conceição Melicio \\ Oduvaldo Vendrametto}

Resumo: No Brasil, há diversas leis que vem sendo conquistados para o autista e consequentemente seus familiares, dentre essas a mais conhecida é a lei 12.764, de 2012, que institui a Política Nacional de Proteção dos Direitos da Pessoa com Transtorno do Espectro Autista; que fez o reconhecido do Autista como Deficiente, e assim, garantiu os mesmos direitos que constam na Constituição Federal de 1988 a pessoa considerada deficiente. 0 artigo levanta as leis trabalhistas em favor do deficiente e discuti o Projeto de Lei 9960/2018 se assim aprovado altera a Lei no 12.764, de 27 de dezembro de 2012, para instituir incentivo fiscal para a contratação de pessoa com transtorno do espectro autista. Elenca-se o risco que pode ocorrer fazendo o mau uso da mão de obra autista. Tendo em vista o escopo foi realizado pesquisas em referenciais teóricos, processos trabalhistas do Ministério Público e artigos que permitiram elucidar e discutir se ocorrerá um aumento na demanda propiciando uma oportunidade para as pessoas com Transtorno Espectro Autista ou se é mais uma estratégia de se beneficiar com esse tipo de contratação, com objetivo especifico de alertar a Gestão Pública Trabalhista o perigo eminente , em busca de uma fiscalização efetiva. Conclui-se que existe uma lacuna na gestão pública no que tange a fiscalização e gestão de pessoas no que se refere obter um maior aproveitamento da capacidade e habilidade de uma pessoa com Transtorno Espectro Autista.

Palavras-chave: Transtorno Espectro Autista. Lei 9.960/2018. Gestão Pública. 


\section{INTRODUÇÃO}

O Transtorno do Espectro Autista (TEA), definição dada por pesquisadores, médicos, psicólogos e dentre outros, é um transtorno mental que afeta o neurodesenvolvimento caracterizado por prejuízos na comunicação, interação social e comportamental, distribuídos em diversos graus de manifestações (KLIN, 2006).

A Inclusão e Capacitação Profissional de Pessoas com Autismo é uma forte tendência, em alguns países lá fora ("home | PROFISSÕES", [s.d.]) . No Brasil, há diversas leis que vem sendo conquistados para o autista e consequentemente seus familiares, dentre essas a mais conhecida é a lei 12.764, de 2012, que institui a Política Nacional de Proteção dos Direitos da Pessoa com Transtorno do Espectro Autista; que fez o reconhecido do Autista como Deficiente, e assim, garantiu os mesmos direitos que constam na Constituição Federal de 1988 a pessoa considerada deficiente.

0 trabalho é o resultado de uma ação, em que se torna fundamental para subsistência de toda vida humana (ENGELS, 2018). A inserção no mercado de trabalho hoje está cada vez competitiva, não dando oportunidades justa para os portadores de deficiência (LOBATO, 2009). Por isso é necessário para as pessoas com deficiência física ou mental gozem de proteção legal, que embora seja instrumento importante para assegurar benefícios, acaba em situações especiais, cerceando e limitando o desenvolvimento de habilidades passiveis de aprendizado por parte do portador.

Envolvidas nos preceitos da inclusão profissional e políticas públicas como a lei de inclusão, cotas e incentivo fiscal para pessoas com espectro autista, vem crescendo nos últimos anos. Com esse objetivo o artigo propõem levantar as leis trabalhistas em favor do deficiente e discuti o Projeto de Lei 9960/2018 se assim aprovado, entra em vigor dia 01 de Janeiro de 2019 alterando a Lei no 12.764 , de 27 de dezembro de 2012, para instituir incentivo fiscal para a contratação de pessoa com transtorno do espectro autista. Por isso ressalta-se o risco do mau uso da mão de obra autista. Tendo em vista o escopo foi realizado pesquisas em referenciais teóricos, processos trabalhistas do Ministério Público e artigos que permitiram elucidar e discutir se ocorrerá um aumento na demanda propiciando uma oportunidade para as pessoas com Transtorno Espectro Autista ou se é mais uma estratégia de se beneficiar com esse tipo de contratação, com objetivo especifico de alertar a Gestão Pública Trabalhista o perigo eminente , em busca de uma fiscalização efetiva.

0 presente artigo apresenta as bases da pesquisa desenvolvida neste trabalho, por meio de um referencial teórico, sendo um breve histórico das teorias sobre o autismo iniciando a discussão com a ampliação do que seja e suas as características com os critérios de diagnóstico segundo a classificação do DSM-5. Ainda as principais leis trabalhistas voltadas aos deficientes e segue-se uma breve problematização sobre a questão da lei já citada, os resultados encontrados e as notas conclusivas.

\section{TRANSTORNO ESPECTRO AUTISTA}

O Transtorno do Espectro Autista (TEA), definição dada por pesquisadores, médicos, psicólogos e dentre outros, é um transtorno mental que afeta o neurodesenvolvimento caracterizado por prejuízos na comunicação, interação social e comportamental, distribuídos em diversos graus de manifestações (KLIN, 2006). Assim como o TEA é de origem desconhecida, também é sua cura. Apesar do desenvolvimento do conhecimento sobre o Autismo, até hoje os tratamentos são para amenizar seus efeitos, que podem se manifestar de maneira leve ou outras mais comprometedoras.

A proveniência da palavra autismo é grega, sendo que (autos), que significa Eu/ por si mesmo. 0 que leva a dizer que é um estado em que o indivíduo é centrado nele próprio, vive no seu mundo (ROCHA, 2012). Conforme o Ministério da Saúde, (BRASIL, 2014), é importante esclarecer que o quadro do autismo é uma "síndrome", que significa "um conjunto de sinais clínicos", (dentre eles manias, comportamentos estereotipado e / ou personalidade diferenciada) , sendo que o conjunto que define uma certa condição de vida diferente daquela até então experimentada pela família.

Desde 1809 onde os primeiros relatos de Haslam (BETELHEIM, 2001), citam-se entre as mais famosas pesquisas e teorias:

- 1906 de Suíço Plouller - Psiquiatra que introduziu o termo "autismo", para descrever pacientes que faziam referência a tudo no mundo e a sua volta, consigo mesmo, ou seja isolamento frequente, em alguns casos considerado processo psicótico" (SOUZA et al., 2004). 
- 1911 de Eugen Bleur - Designa a perda do contato com a realidade, o que acarretava uma grande dificuldade ou impossibilidade de comunicação (GADIA; TUCHMAN; ROTTA, 2004a).

- 1943 de Leo Kanner psiquiatra infantil austríaco, naturalizado americano - Denomina como uma síndrome única até então não descrita, seu primeiro paciente foi Donald T., alguns anos depois, o médico publicou o artigo Distúrbios Autísticos do Contato Afetivo, com a percepção de 11 casos de pacientes com transtorno (Ferreira, Teixeira, e Britto 2010) . Ainda Kanner teria dado origem ao conceito 'mãe geladeira', pois esse descreveu o comportamento das mães observadas como frio, mecanizado e obsessivo (MINISTÉRIO DA SAÚDE., 2013).

- 1944 de Hans Aspeger - Descreve como um tipo de criança peculiar e interessante que pode compensar suas deficiências por um alto nível de pensamento e experiência pessoal que podem levá-los a excepcionais êxitos na vida adulta (DIAS, 2015).

- 1998 de Andrew Wakefield - Publicou um artigo fazendo uma ligação do autismo com a vacina tríplice viral (I. PICCINATO, 2018). Porém teoria descartada posteriormente.

- Biólogos levantam hipóteses da manifestação do Autismo poderia ser por ingestão de medicamentos pelas gestantes (I. PICCINATO, 2018) .

- Psicólogos - defendem a teoria de alteração e várias mutações genéticas (I. PICCINATO, 2018) .

- 2014 Escola de Saúde Pública de Havard, nos Estados Unidos, apontou risco de crianças apresentarem autismo dobra em casos de gestantes que passaram muito tempo expostas à poluição (I. PICCINATO, 2018) .

\subsection{ESCALA DE CLASSIFICAÇÃO}

Resumidamente com o passar dos anos, o Autismo recebeu diversos nomes para ser representado (SAUDÁVEL, 2017). Entre eles estão:

- Transtorno do Espectro Autista;

- Condição do Espectro do Autismo;

- Autismo Clássico;

- Autismo Kanner;

- Transtorno Invasivo do Desenvolvimento;

- Autismo de Alto Funcionamento;

- Síndrome de Asperger;

- Demanda Patológica Avoidance.

Mas foi em 1980, que pela primeira vez a comunidade científica reconheceu e classificou como uma nova classe de alteração mental (I. PICCINATO, 2018). Atualmente, por conta das mudanças recentes e dos principais manuais de diagnóstico (utilizada na área médica para classificação de doenças mentais) o termo que abrange todos os outros (Transtorno Autista; o transtorno de Rett/causa genética conhecida; o transtorno desintegrativo da infância; Síndrome de Asperger e o transtorno global do desenvolvimento sem outra especificação) será o mais comumente na hora do diagnóstico pela nova edição do manual de Diagnósticos e Estatísticas dos Transtornos Mentais (DSM- 5) denominada Transtorno do Espectro Autista (TEA) (GADIA; TUCHMAN; ROTTA, 2004b).

Para melhor concepção, o autismo no mercado de trabalho, é indispensável compreender suas manifestações que segue os critérios de diagnóstico segundo a classificação do DSM-5 são ilustrados na Tabela 1. 
Tabela 1 - Critérios de diagnóstico para Perturbação do Espectro do Autismo DSM- 5.

A. Déficits persistentes na comunicação social e na interação social em diversos contextos, não explicados por atrasos do desenvolvimento global e manifestando-se atualmente ou na história por:

1. Défices na reciprocidade emocional/social.

2. Défices nos comportamentos de comunicação não-verbal usados na interação social.

3. Défice para desenvolver, manter e compreender relacionamentos

B. Padrões de comportamentos, interesses ou atividades restritos e repetitivos, manifestados, por pelo menos, dois dos seguintes:

1. Movimentos motores, uso de objetos ou discurso estereotipado ou repetitivo.

2. Resistência à mudança, adesão inflexível a rotinas ou padrões ritualizados de comportamento verbal ou nãoverbal.

3. Interesses absorventes, altamente restritos, com intensidade ou foco anormal.

4. Hiper ou hipo-reactividade a estímulos sensoriais ou interesse invulgar em aspetos sensoriais do ambiente.

C. Os sintomas devem estar presentes na infância precoce (mas podem não se manifestar plenamente até as exigências sociais excederem as limitações das capacidades, ou podem estar "mascarados" por estratégias aprendidas mais tarde.

D. Os sintomas causam um prejuízo clinicamente significativo a nível social, ocupacional ou noutras áreas importantes do funcionamento atual.

E. Estes distúrbios não são melhor explicados por perturbação do desenvolvimento intelectual ou atraso global do desenvolvimento. A perturbação do desenvolvimento intelectual e perturbação do espectro do autismo frequentemente coexistem; para fazer diagnóstico de comorbidade da Perturbação do espectro do autismo e Perturbação do Desenvolvimento Intelectual, a comunicação social deve ser inferior ao esperado para o nível de desenvolvimento geral.

Fonte: (RIBEIRO, 2015).

Após avaliação especializada o diagnóstico vem acompanhado pelo seu nível de gravidade, conforme o comprometimento do mesmo, ilustrado na tabela 2 .

Tabela 2 - Níveis de gravidade na Perturbação do Espectro do Autismo.

\begin{tabular}{|c|c|c|}
\hline Nível de gravidade & Comunicação Social & $\begin{array}{l}\text { Comportamentos restritivos e } \\
\text { repetitivos }\end{array}$ \\
\hline $\begin{array}{c}\text { Nível } 1 \text { / Leve } \\
\text { Requerem suporte }\end{array}$ & $\begin{array}{l}\text { Sem suporte no espaço ocorrem défices na } \\
\text { comunicação social causando prejuízo. } \\
\text { Dificuldade em iniciar interações sociais, e } \\
\text { respostas claramente atípicas ou sem } \\
\text { sucesso na abertura social com o outro. } \\
\text { Pode parecer existir um desinteresse pelas } \\
\text { interações sociais. }\end{array}$ & $\begin{array}{l}\text { O comportamento inflexível causa } \\
\text { uma interferência significante em } \\
\text { um ou mais contextos. Dificuldade } \\
\text { em mudar entre atividades. } \\
\text { Problemas de organização e } \\
\text { planejamento da independência }\end{array}$ \\
\hline $\begin{array}{l}\text { Nível } 2 \text { / Moderado } \\
\text { Requerem suporte } \\
\text { substancial }\end{array}$ & $\begin{array}{l}\text { Défices marcados nas competências } \\
\text { verbais e não-verbais da comunicação } \\
\text { social; dificuldade social apesar de suporte } \\
\text { no espaço; iniciação de interações sociais } \\
\text { limitadas; respostas desadequadas ou } \\
\text { reduzidas a interações sociais iniciadas } \\
\text { pelo outro }\end{array}$ & $\begin{array}{l}\text { Comportamento inflexível, } \\
\text { dificuldade ao nível do "coping" na } \\
\text { mudança, ou outros } \\
\text { comportamentos } \\
\text { restritivos/repetitivos que surgem } \\
\text { com uma frequência que se torna } \\
\text { óbvia ao observador e interfere com } \\
\text { o funcionamento numa variedade de } \\
\text { contextos. Stress e/ou dificuldade } \\
\text { em mudar o objeto da atenção ou } \\
\text { ação. }\end{array}$ \\
\hline $\begin{array}{l}\text { Nível } 3 \text { / Severo } \\
\text { Requerem suporte } \\
\text { bastante substancial }\end{array}$ & $\begin{array}{l}\text { Défices graves nas capacidades verbais e } \\
\text { não-verbais que causam prejuízo grave no } \\
\text { funcionamento, e resposta social mínima } \\
\text { com os outros. }\end{array}$ & $\begin{array}{l}\text { Comportamento inflexível, extrema } \\
\text { dificuldade ao nível do "coping" na } \\
\text { mudança, ou outros } \\
\text { comportamentos } \\
\text { restritivos/repetitivos que } \\
\text { interferem marcadamente com o } \\
\text { funcionamento em todas as esferas. }\end{array}$ \\
\hline
\end{tabular}


"Esse diagnóstico é interessante porque oferece inúmeras possibilidades: você não consegue encontrar dois autistas iguais. Eles podem até apresentar características semelhantes, mas nunca serão crianças idênticas" , ressalta André Soares Trindade, presidente da Associação Mundial de Educação Especial AMEE (I. PICCINATO, 2018).

\section{DO DIREITO}

No Brasil, há diversas leis que vem sendo conquistados para o autista e consequentemente seus familiares, dentre essas a mais conhecida é a lei 12.764, de 2012, que institui a Política Nacional de Proteção dos Direitos da Pessoa com Transtorno do Espectro Autista, que fez o reconhecido do Autista como Deficiente, e assim, garantiu os mesmos direitos que constam na Constituição Federal de 1988 a pessoa considerada deficiente, ou seja:

- Diretrizes de inclusão escolar;

- Transporte;

- Prioridade de Atendimento;

- Assistência Social;

- Serviço de Saúde Pública;

- Símbolo De Acesso;

- Desporto;

- Turismo;

- Lazer;

- Previdência Social;

- Trabalho;

- Edificação Pública;

- Habitação;

- Cultura;

- Amparo À Infância E À Maternidade;

- Jornada de Trabalho dos Pais com cargos federais, reduzida sem prejuízo de salário;

- Redução de Impostos ;

- E Outros Que Propiciem Bem-Estar Pessoal, Social E Econômico.

\subsection{LEIS TRABALHISTAS}

Para salientar o escopo do objetivo, citar-se as leis referentes ao trabalho; o Ministério do Trabalho e Emprego, em 2009, divulgou dados informando que os deficientes intelectuais, quadro em que é inserido o autismo, representam apenas 2,41\% dos 350 mil deficientes inseridos ("Artigo", 2015). E em 2011, empresas de todas as partes do Brasil apontaram que esse número era de 5,78\%, ou seja, aproximadamente 18.785 pessoas. Esse aumento vem devido alguns incentivos e leis adquiridos, conforme a Tabela 3: 
Tabela 3 - As Principais Leis Trabalhistas em favor do Deficiente / Autista.

\begin{abstract}
1925: Recomendação no 22 - dispõe sobre a indenização por acidentes de trabalho.
1955: Recomendação no 99 - dispõe sobre a adaptação e a reabilitação profissional dos incapacitados.

1983 - Convenção no 159 - dispõe sobre a reabilitação profissional e o emprego para pessoas incapacitadas.

1983 - Recomendação no 168 - Acompanha a Convenção no 159 e oferece conselhos para a sua aplicação. Prevê a participação comunitária no processo, a reabilitação profissional em áreas rurais, contribuições de empregadores, empregados e das próprias pessoas com deficiência na formulação de políticas específicas.
\end{abstract}

Lei 8.213/1991/ 14.076 / Lei 12.711 - A chamada "Lei de Cotas" - No Artigo 93 estão descritas as cotas de contratação de pessoas com deficiência e/ou reabilitados do INSS para empresas com 100 (cem) ou mais funcionários. 0 percentual a ser preenchido varia de 2 a 5\%, conforme esquema abaixo:

100 a 200 funcionários $-2 \%$

201 a 500 funcionários - 3\%

501 a 1000 funcionários - 4\%

...1001 funcionários - 5\%

§1ㅇ - A dispensa de trabalhador reabilitado ou de deficiente habilitado ao final de contrato por prazo determinado de mais de 90 (noventa) dias, e a imotivada, no contrato por prazo indeterminado, só poderá ocorrer após a contratação de substituto de condição semelhante.

$\S 2$ o - O Ministério do Trabalho e da Previdência Social deverá gerar estatísticas sobre o total de empregados e as vagas preenchidas por reabilitados e deficientes habilitados, fornecendo-as quando solicitado, aos sindicatos ou entidades representativas dos empregados.

Decreto Legislativo no 186 de 2008: Aprova o texto da Convenção da ONU sobre os direitos das pessoas com deficiência.

Artigo 3: Princípios Gerais: Respeito pela dignidade inerente, a autonomia individual, inclusive a liberdade de fazer as próprias escolhas e a independência das pessoas.

A não-discriminação

A plena e efetiva participação e inclusão na sociedade

0 respeito pela diferença e pela aceitação das pessoas com deficiência como parte da diversidade humana e da humanidade

A igualdade de oportunidades

A acessibilidade

Artigo 27: Trabalho e Emprego

Proibição de Discriminação

Condições de Igualdade

Condições Justas e Favoráveis de Trabalho (remuneração, condição segura e salubre, etc...)

Direitos Trabalhistas e Sindicais

Acesso efetivo a programas de orientação técnica, profissional, serviços de colocação no trabalho e de treinamento profissional e continuado

Promoção de oportunidades e ascensão profissional

Promoção de oportunidades de trabalho autônomo, empreendedorismo, cooperativas, etc...

Empregar pessoas com deficiência no setor público e privado

Prever adaptações no local de trabalho

Promoção de Reabilitação Profissional

Projeto de lei 9960/2018, entrar em vigor 1/1/2019 - para instituir incentivo fiscal para a contratação de pessoa com transtorno do espectro autista.

Fonte: Autora 2018. 
Segundo a Organização Mundial da saúde (OMS), pessoas com deficiência mental ou intelectual, são as que tem mais barreiras para serem inseridos no mercado de trabalho, que embora seja difícil, não é impossível (I. PICCINATO, 2018). Observa-se que amparados pela lei federal 8.213 de 24 de julho de 1991, que dispõe sobre a contratação de deficientes nas empresas, a abertura potencial de postos de trabalho para pessoas com deficiência, dentre eles o autista. Contudo o desconhecimento dos potenciais de trabalho das pessoas com transtorno espectro autista, bem como a sua desqualificação os deixa em desigualdade para concorrer a estas vagas.

\title{
4 PROJETO DE LEI 9960/2018 - INCENTIVO FISCAL PARA A CONTRATAÇÃO DE PESSOA COM TRANSTORNO DO ESPECTRO AUTISTA.
}

Diante da importância em se promover a adequada inserção de autistas no mercado de trabalho foi proposto no Brasil a exigência de contratação de pessoas com deficiência, entende-se que a inclusão desses indivíduos ainda está muito aquém do desejado. Devido a essa situação o Projeto de Lei 9960/2018 se assim aprovado altera a Lei no 12.764, de 27 de dezembro de 2012, para instituir incentivo fiscal para a contratação de pessoa com transtorno do espectro autista. Conforme:

\begin{abstract}
"Art. 7o-A. As pessoas jurídicas regularmente instituídas que empreguem ou tomem serviços prestados por pessoa com transtorno do espectro autista ficam isentas do pagamento das contribuições previstas nos incisos I, II e III do art. 22 da Lei no 8.212, de 24 de julho de 1991, ( referentes às remunerações pagas, devidas ou creditadas a qualquer título a aqueles indivíduos. Parágrafo único. As pessoas jurídicas que recolham a contribuição previdenciária sobre o valor da receita bruta poderão excluir do total da receita as remunerações pagas, devidas ou creditadas a qualquer título a empregado ou prestador de serviço com transtorno do espectro autista. Art. 7ํ-B. As pessoas jurídicas regularmente instituídas e tributadas com base no lucro real que empreguem ou tomem serviços prestados por pessoa com transtorno do espectro autista poderão deduzir da base de cálculo do imposto de renda e da contribuição social sobre o lucro líquido, em cada período de apuração, quantia correspondente ao total das remunerações pagas, devidas ou creditadas a qualquer título a empregado ou prestador de serviço com transtorno do espectro autista.
\end{abstract}

Parágrafo único. A dedução a que se refere o caput não poderá exceder, em cada período de apuração, a $2 \%$ (dois por cento) da base de cálculo, podendo as despesas não deduzidas no período correspondente ser utilizadas em período posterior. Art. 7ํ-C. Os benefícios de que tratam os arts. 7ํ-A e 7ํ-B desta Lei serão concedidos por até 4 (quatro) anos contados a partir da efetiva contratação e desde que não haja interrupção do contrato de trabalho ou do vínculo de prestação de serviço durante o período." Art. 2ํ Esta Lei entra em vigor no dia $1^{\circ}$ de janeiro do ano subsequente ao de sua publicação.

Apresenta-se na tabela 4, uma simulação da Projeção da Folha de Pagamento sobre uma Autista, comparado de um funcionário neurotípico. 
Tabela 4 - Projeção da Folha de Pagamento sobre um Autista.

\begin{tabular}{|c|c|c|c|c|}
\hline $\begin{array}{l}\text { Encargos Sociais e } \\
\text { Trabalhistas }\end{array}$ & $\begin{array}{l}\text { 1ª SITUAÇÃO - } \\
\text { Empresa Optante } \\
\text { Pelo Simples } \\
\text { (Comér/Ind.) - } \\
\text { Cálculo Sobre } \\
\text { Salário } \quad \text { De } \\
\text { Mensalista }\end{array}$ & $\begin{array}{l}2^{\text {a }} \text { SITUAÇÃO - } \\
\text { Empresa Optante } \\
\text { Pelo Simples } \\
\text { (Comér/Ind.) } \\
\text { Cálculo Sobre Salário } \\
\text { De Mensalista de } \\
\text { Autista }\end{array}$ & $\begin{array}{l}3 \text { a } \text { SITUAÇÃO - } \\
\text { Empresa Não } \\
\text { Optante Pelo } \\
\text { Simples - Cálculo } \\
\text { Sobre Salário De } \\
\text { Mensalista }\end{array}$ & 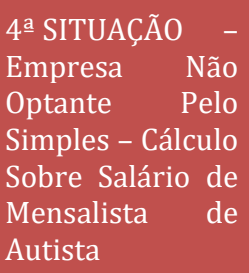 \\
\hline \multicolumn{5}{|l|}{ Encargos Trabalhistas } \\
\hline 13오alário & $8,33 \%$ & $8,33 \%$ & $8,33 \%$ & $8,33 \%$ \\
\hline Férias & $11,11 \%$ & $11,11 \%$ & $11,11 \%$ & $11,11 \%$ \\
\hline \multicolumn{5}{|l|}{ Encargos Sociais } \\
\hline INSS & $0,00 \%$ & - & $20,00 \%$ & - \\
\hline SAT/RAT & $0,00 \%$ & - & $3,00 \%$ & - \\
\hline Salário Educação & $0,00 \%$ & - & $2,50 \%$ & - \\
\hline $\begin{array}{l}\text { INCRA/SEST/SEBRAE } \\
\text { /SENAT }\end{array}$ & $0,00 \%$ & - & $3,30 \%$ & - \\
\hline FGTS & $8,00 \%$ & - & $8,00 \%$ & - \\
\hline $\begin{array}{l}\text { FGTS/Provisão de } \\
\text { Multa para Rescisão }\end{array}$ & $4,00 \%$ & - & $4,00 \%$ & - \\
\hline Total Previdenciário & $12,00 \%$ & Isento & $40,80 \%$ & Isento \\
\hline $\begin{array}{l}\text { Previdenciário s } / 13^{\circ} \text { e } \\
\text { Férias }\end{array}$ & $2,33 \%$ & Isento & $7,93 \%$ & Isento \\
\hline SOMA BÁSICO & $33,77 \%$ & $19,44 \%$ & $68,17 \%$ & $19,44 \%$ \\
\hline $\begin{array}{l}\text { Ex: Salário } \\
\mathrm{R} \$ 1000,00\end{array}$ & $\mathrm{R} \$ 337,70$ & $\mathrm{R} \$ 194,40$ & $\mathrm{R} \$ 681,70$ & $\mathrm{R} \$ 194,40$ \\
\hline Total & $\mathrm{R} \$ 1.337,70$ & $\mathrm{R} \$ 1.194,40$ & $\mathrm{R} \$ 1.681,70$ & $\mathrm{R} \$ 1.194,40$ \\
\hline
\end{tabular}

Fonte: Autora 2018

Como se observa-se na simulação da folha de pagamento, a empresa contratante terá vantagens financeiras ao contratar pessoas com Transporto Espectro Autista, podendo ocasionar uma margens de riscos para que se o propósito ao qual foi criada seja desviado ao longo do tempo caso, não haja uma fiscalização efetiva.

A pesquisa justifica-se baseado na Lei do estágio - № LEI № 11.788 DE 25/09/2008, que busca garantias ao estudante que adquira conhecimento prático por meio de estágio seja ele remunerado ou não, tendo como incentivo para as empresas a isenção de impostos trabalhistas (BRASIL, 2008). Porém o que se tem visto em muitas empresas é a deturpação na finalidade; onde encontramos por parte do estudante um meio de se auto subsidiar e custear-se por causa da presente pobreza do país, também a pouca oferta para o primeiro emprego ou inserção no mercado de trabalho que sem o respaldo da lei não teria a essa oportunidade; e por parte das empresas desviando as funções dos mesmos para atender a escassez de colaboradores, que ocorre devido como visto na tabela 4 o ônus ocasionado pelos impostos trabalhistas, ficando inviável a contratação de muitos funcionários (REIS, 2012).

Conforme se busca demonstrar o ordenamento jurídico a cada dia inúmeras denúncias e ações sobre exploração de mão de obra barata tem chegado ao Ministério Público do Trabalho - MPT (DUARTE, 2013).

O Ministério Público do Trabalho tem como uma das suas principais funções fiscalizar, como mostra o art. 83 da Lei Complementar 75/93 elenca de forma específica como deve ser a atuação do MPT na seara laboral:

Compete ao Ministério Público do Trabalho o exercício das seguintes atribuições junto aos órgãos da Justiça do Trabalho: 
I - promover as ações que lhe sejam atribuídas pela Constituição Federal e pelas leis trabalhistas;

II - manifestar-se em qualquer fase do processo trabalhista, acolhendo solicitação do juiz ou por sua iniciativa, quando entender existente interesse público que justifique a intervenção;

III - promover a ação civil pública no âmbito da Justiça do Trabalho, para defesa de interesses coletivos, quando desrespeitados os direitos sociais constitucionalmente garantidos;

IV - propor as ações cabíveis para declaração de nulidade de cláusula de contrato, acordo coletivo ou convenção coletiva que viole as liberdades individuais ou coletivas ou os direitos individuais indisponíveis dos trabalhadores;

V - propor as ações necessárias à defesa dos direitos e interesses dos menores, incapazes e índios, decorrentes das relações de trabalho;

VI - recorrer das decisões da Justiça do Trabalho, quando entender necessário, tanto nos processos em que for parte, como naqueles em que oficiar como fiscal da lei, bem como pedir revisão dos Enunciados da Súmula de Jurisprudência do Tribunal Superior do Trabalho;

VII - funcionar nas sessões dos Tribunais Trabalhistas, manifestando-se verbalmente sobre a matéria em debate, sempre que entender necessário, sendo-lhe assegurado o direito de vista dos processos em julgamento, podendo solicitar as requisições e diligências que julgar convenientes;

VIII - instaurar instância em caso de greve, quando a defesa da ordem jurídica ou o interesse público assim o exigir;

IX - promover ou participar da instrução e conciliação em dissídios decorrentes da paralisação de serviços de qualquer natureza, oficiando obrigatoriamente nos processos, manifestando sua concordância ou discordância, em eventuais acordos firmados antes da homologação, resguardado o direito de recorrer em caso de violação à lei e à Constituição Federal;

$\mathrm{X}$ - promover mandado de injunção, quando a competência for da Justiça do Trabalho;

XI - atuar como árbitro, se assim for solicitado pelas partes, nos dissídios de competência da Justiça do Trabalho;

XII - requerer as diligências que julgar convenientes para o correto andamento dos processos e para a melhor solução das lides trabalhistas;

XIII - intervir obrigatoriamente em todos os feitos nos segundo e terceiro graus de jurisdição da Justiça do Trabalho, quando a parte for pessoa jurídica de Direito Público, Estado estrangeiro ou organismo internacional (BRASIL, 1991).

Dentre as questões apresenta-se introspecções que sugerem as controvérsias da efetividade do cumprimento das leis no âmbito de isenção de impostos trabalhistas, motivado pela inconstância de fiscalização por parte do Ministério Público do Trabalho; permanecendo a pergunta em aberto se elas são legítimas oportunidades ou transvio da mão de obra.

\section{CONSIDERAÇÕES FINAIS}

Verifica-se por meio da lei 9960/2018 se aprovada entrará em vigor no próximo ano 2019; ficando-se evidenciado que há um incentivo para empresas, promoverem um crescimento real na demanda de contratação de pessoas com Transtorno Espectro Autista, fazendo jus a essa pesquisa, que visa em buscar a verificação da qualidade desses postos de trabalhos nas mais variáveis áreas em que os mesmo possam buscar a estarem aptos a atuarem e atenderem as exigências no mercado de trabalho referente as competências que são constituídas por referenciais construídos na mesma lógica utilizada no ensino técnico e profissional, a partir das mesmas categorias de saberes, "saber fazer" e "saber ser" cuja posse é medida em termos de "ser capaz de". Na prática é a articulação dos vários saberes oriundos de várias esferas (formais, informais, teóricos, práticos, tácitos), ou seja, a qualificação real se resume em saber o que fazer e como fazer quando os imprevistos e problemas surgirem (DELUIZ, 2017).

Ressalta-se a importância do cumprimento de suas funções por parte do Ministério Público do Trabalho em fiscalizar e acompanhar para que não haja desvio de intensão, função ou exploração de mão-de-obra barata. Deixando para os trabalhos futuros, a continuidade dessa investigação, para elucidar-se sobre o cumprimento da mesma. 


\section{REFERÊNCIAS}

[1] Artigo: Inclusão dos deficientes intelectuais no mercado de trabalho. Disponível em: <https://www.migalhas.com.br/dePeso/16,MI223677,21048-

Inclusao+dos+deficientes+intelectuais+no+mercado+de+trabalho>. Acesso em: 20 out. 2018.

[2] BETElHEIM, B. A Fortaleza Vazia. 1. ed. [s.l.] São Paulo: Martins Fontes LTDA,., 2001.

[3] BRASIL, C. C. L11788. Disponível em: <http://www.planalto.gov.br/ccivil_03/_Ato20072010/2008/Lei/L11788.htm>. Acesso em: 20 nov. 2018.

[4] BRASIL, M. DA S. S. DE A. À S. D. DE A. P. E. D. DE A. À R. DA P. COM T. DO E. DO A. (TEA) / M. DA S., Secretaria de Atenção à Saúde, Departamento de Ações Programáticas Estratégicas. -. Brasília :. Ministério da Saúde. Diretrizes de Atenção à Reabilitação da Pessoa com Transtornos do Espectro do Autismo (TEA). 1. ed. [s.l: s.n.].

[5] BRASIL, P.-G. DO T. Revista do Ministério Público do Trabalho / Procuradoria-Geral do Trabalho. n. 1, mar. 1991.

[6] DELUIZ, N. A globalização econômica e os desafios à formação profissional. Boletim Técnico do Senac, v. 30, n. 3, p. 73-79, 27 set. 2017.

[7] DIAS, S. Asperger e sua síndrome em 1944 e na atualidade. Revista Latinoamericana de Psicopatologia Fundamental, v. 18, n. 2, p. 307-313, jun. 2015.

[8] DUARTE, A. R. 0 estágio como fraude à legislação trabalhista - Página 3/4 - Jus.com.br | Jus Navigandi. Disponível em: <https://jus.com.br/artigos/25129/do-contrato-de-estagio-como-meio-de-fraude-a-legislacaotrabalhista/3>. Acesso em: 20 nov. 2018.

[9] ENGELS, F. O PAPEL DO TRABALHO NA TRANSFORMAÇÃO DO MACACO EM HOMEM (1876). Revista Trabalho Necessário, v. 4, n. 4, 8 jun. 2018.

[10] GADIA, C. A.; TUCHMAN, R.; ROTTA, N. T. Autismo e doenças invasivas de desenvolvimento. Jornal de Pediatria, v. 80, n. 2, p. 83-94, abr. 2004a.

[11] GADIA, C. A.; TUCHMAN, R.; ROTTA, N. T. Autism and pervasive developmental disorders. Jornal de Pediatria, v. 80 , n. 2, p. 83-94, abr. 2004b.

[12] home | PROFISSÕES. Disponível em: <https://www.autistologos.com/profissoes-para-autistas>. Acesso em: 20 out. 2018.

I. PICCINATO, R. Segredo da Mente: Autismo. 2. ed. Rio de Jeneiro: Ricardo Piccinato, 2018.

[13] KLIN, A. Autismo e síndrome de Asperger: uma visão geral Autism and Asperger syndrome: an overview. Rev Bras Psiquiatr., p. 9, 2006.

[14] LOBATO, B. C. Pessoas com deficiência no mercado de trabalho: implicações da Lei de cotas. 21 jan. 2009.

[15] MINISTÉRIO DA SAÚDE., S. DE A. À S. D. DE A. P. E E. C. N. DE S. M., Álcool e Outras Drogas. AUTISMO: CONSTRUÇÃO HISTÓRICA DO CONCEITO, $2013 . \quad$ Disponível <http://www.sedes.org.br/Departamentos/Psicanalise/arquivos_comunicacao/autismo_cp.pdf>. Acesso em: 15 out. 2018

[16] REIS, R. Vida de Estagiário - Fraude à Lei do Estágio e outras questões trabalhistas - Matérias Especiais - TST. Disponível em: <http://www.tst.jus.br/materias-especiais/-/asset_publisher/89Dk/content/vida-de-estagiariofraude-a-lei-do-estagio-e-outras-questoes-trabalhistas>. Acesso em: 20 nov. 2018.

[17] RIBEIRO, J. F. A. Perturbação do espectro do autismo : artigo de revisão das comorbidades associadas. Lisboa - Portugal: Universidade de Lisboa, 2015.

[18] ROCHA, C. L. Professor-Mediador da Criança Autista. p. 42, 2012.

[19] SAUDÁVEL, R. M. O que é Autismo, sintomas, tipos (infantil, leve) e mais | MSMinuto Saudável, 29 jun. 2017. Disponível em: <https://minutosaudavel.com.br/o-que-e-autismo-sintomas-tipos-infantil-leve-e-mais/>. Acesso em: 5 out. 2018

[20] SOUZA, J. C. et al. Atuação do psicólogo frente aos transtornos globais do desenvolvimento infantil. Psicologia: Ciência e Profissão, v. 24, n. 2, p. 24-31, jun. 2004. 


\section{Capítulo 11}

\section{O MERCADO DE TRABALHO PARA FORMAÇÃO SUPERIOR: ANÁLISE DO PERFIL ACADÊMICO E SUA ADEQUAÇÃO AOS REQUISITOS PROFISSIONAIS.}

\section{Dayan Rios Pereira}

Resumo: 0 presente artigo foca a análise do mercado de trabalho na Região Metropolitana de Belém (RMB) para os profissionais com formação superior em Administração de Empresas. Com base em pesquisa já desenvolvida em 2011 sobre o perfil dos formandos e sua perspectiva de inserção no mercado de trabalho, este projeto vem aprofundar este estudo analítico abordando as competências profissionais exigidas pelo empresariado atuante no Município de Belém e Região Metropolitana. A metodologia utilizada foi o estudo de caso com desenvolvimento de pesquisas tipo survey nas maiores empresas de seleção e recrutamento atuantes no Estado do Pará. Os resultados revelam a baixa especialização da mão-de-obra local com fatores críticos relacionados às competências de comunicação, liderança e autonomia empreenditiva.

Palavras Chave: Mercado de Trabalho, Formação Acadêmica, Qualificação Profissional. 


\section{INTRODUÇÃO}

Um dos quesitos inovadores que compõe a avaliação do Exame Nacional de Desempenho Estudantil (Enade) realizado pelo MEC junto às IESPr é o Indicador de Diferença entre os Desempenhos Observado e o Esperado (IDD). A ênfase do mesmo está em possibilitar uma análise do desempenho dos concluintes de cada instituição levando em consideração o perfil do estudante que ingressa no curso. Em outros termos, foca a agregação de valor - medida em termos de conhecimento - dos acadêmicos ingressantes e concluintes de dado curso superior. Seu propósito reside em última instância, no fato de que não é admissível, do ponto de vista educacional, que um acadêmico ingresse em uma formação superior e a conclua com o mesmo (ou pior) nível de conhecimento do ingresso.

O Indicador de Diferença Entre os Desempenhos Observado e Esperado (IDD) foi elaborado com a finalidade de avaliar o grau de acurácia do processo de formação superior e, por conseguinte, num indicador de eficácia educacional relativa entre as IES sob avaliação.

0 propósito deste estudo, portanto, alinha-se ao IDD na medida em que pretende avaliar a importância da formação acadêmica (efeito curso) na projeção profissional do egresso e sua perspectiva de investimento na formação acadêmica. Dentre os benefícios do trabalho, destaca-se a compreensão dos mecanismos explicativos que permitam, por um lado, dotar o corpo gerencial de informações que o auxiliem no planejamento e tomada de decisão e; por outro, planejar o desenvolvimento de projetos de pós-graduação que atendam às expectativas do mercado e dos graduados.

O aumento da população estudantil do Ensino Superior nas IES privadas no Brasil e sua heterogeneidade justificam estudos que descrevam as experiências acadêmicas e as percepções desta população sobre sua formação, o interesse em dar continuidade na formação acadêmica e a aplicabilidade dos conhecimentos adquiridos na formação no mercado de trabalho.

\section{REFERENCIAL TEÓRICO}

\subsection{EMPREGABILIDADE E MERCADO DE TRABALHO}

Neri $(2008$, p.24) ressalta que a valoração da educação, entendida como uma premiação, pode ser expressa em termos de preço que o mercado de trabalho, segundo as leis de oferta e demanda, determina para o atributo educação. Com efeito, Langoni apud Neri $(2008$, p.24) em seu trabalho "Distribuição da Renda e Desenvolvimento Econômico do Brasil" de 1973 e reeditado em 2005, observa que a tensão entre a oferta e demanda por mão-de-obra qualificada oriunda, respectivamente, da expansão da educação e do progresso tecnológico definem o preço como retorno à educação.

Utilizando-se do modelo de equações mincerianas de salário para análise dos prêmios oferecidos pela educação, Neri (2008, p.29) verifica, com base nos microdados da PNAD/IBGE de 2007, que o pico da renda de trabalho se dá aos 54 anos (Fig.1) e o auge da chance de dispor de ocupação aos 42 anos. 0 referido estudo também revelou que a política pública no Brasil favoreceu a ascensão econômica da juventude.

Figura 1 - Mercado de Trabalho e Ciclo de Vida - 2007

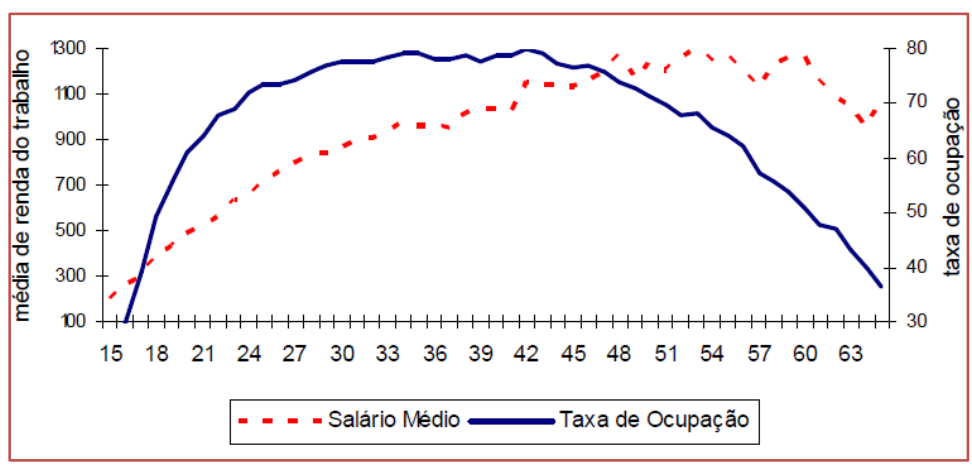

Fonte CPS/FGV a partir dos microdados da PNAD/IBGE 
A fig. 2 revela com clareza como a educação, medida em anos de estudo (0 a 18 anos), impacta na ocupação e nível salarial da mão-de-obra. Neri (2008, p.36) destaca que os salários dos universitários pósgraduados são 544\% superiores aos dos analfabetos e a chance de ocupação no mercado de trabalho de $422 \%$ superior.

Figura 2 - Retorno Educacional por Anos de Estudo - 2007

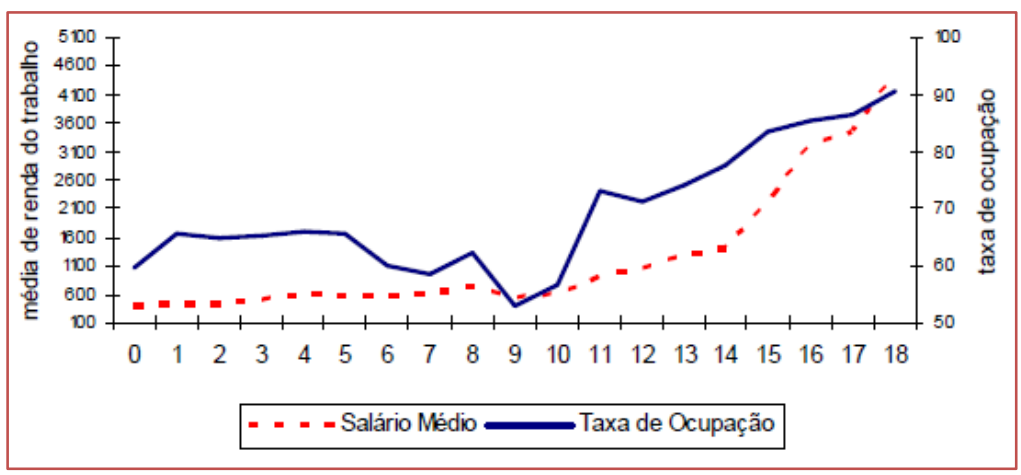

Fonte CPS/FGV a partir dos microdados da PNAD/IBGE

Segundo Neri (2008,p.38) destaca que analisando hoje a população em idade ativa, o crescimento do salário chega a 15,07\% por cada ano adicional de estudo e 3,38\% para taxa de ocupação.

\section{MATERIAL E MÉTODO}

O método a ser utilizado na pesquisa é o estudo de caso. Bell (1989) ressalta que o estudo de caso tem sido descrito como um termo guarda-chuva para uma família de métodos de pesquisa cuja principal preocupação é a interação entre fatores e eventos. Como vantagens para a implementação do método, BELL (1989) destaca a possibilidade do pesquisador concentrar-se em um aspecto ou situação específica e identificar, ou tentar identificar, os diversos processos que interagem no contexto estudado.

O escopo do trabalho envolveu 50,93\% do montante de acadêmicos do último período dos cursos de bacharelado e tecnológico conforme os seguintes quadros discriminativos.

\section{EXAME DOS DADOS DA PESQUISA}

\subsection{CARACTERIZAÇÃO DO OBJETO DE PESQUISA}

0 público-alvo da pesquisa (formandos de 2011) está predominantemente situado na faixa etária de 18 a 25 anos (Fig. 3).

Figura 3 - Perfil etário dos formandos pesquisados

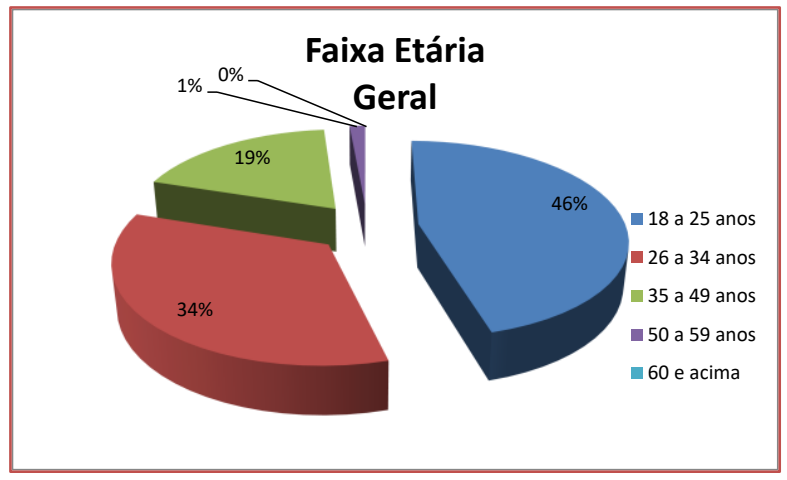


Esta proporção representa bem a realidade de todos os cursos estudados com exceção da segunda turma do Curso de Direito, que apresenta maior proporção na faixa de 26 a 34 anos (40\%).

Na perspectiva dos formandos quanto ao seu desempenho e aproveitamento dos conhecimentos e habilidades trabalhados ao longo de sua formação acadêmica (Fig.4), observa-se que, em geral, houve um nível de aproveitamento - entre bom e ótimo - de 75\% do curso na perspectiva dos próprios discentes.

Figura 4 - Desempenho acadêmico declarado

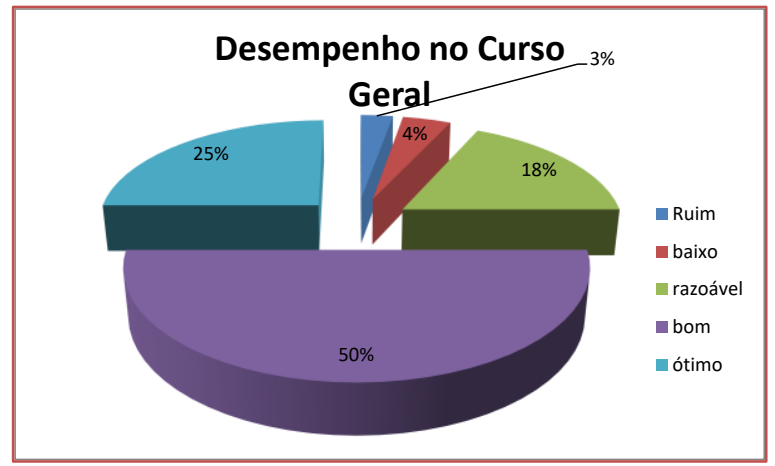

Na análise por Curso destacou-se, dentre os bacharelados, o Curso de Engenharia Civil como melhor percentual de aproveitamento acadêmico (43\%). Nos Tecnológicos, Processos Gerenciais apresentou o melhor desempenho (25\%). O curso de Engenharia Civil também apresenta o maior índice de amadurecimento profissional dentre os cursos analisados.

\section{TESTE DE HIPÓTESES}

0 teste de contraste trabalha com a hipótese nula de que a formação acadêmica agregou valor aos formandos o qual assume um nível de significância (erro alfa) de 0,05 com prova bilateral. Os sujeitos da pesquisa são formados pelos diferentes cursos de graduação da IES com diferente número de observações, constituindo assim, dados independentes. BISQUERRA (2004, p.77).

Para a realização das provas de significação estatística, foram adotados os supostos paramétricos de variável dependente quantitativa contínua medida em uma escala de intervalo e amostra procedente de uma população com distribuição normal.

A amostra contou com um total de 82 discentes formandos (50,93\% do total) para um nível de significância de 95\% e um erro amostral de 1,5 com um desvio-padrão populacional calculado em 6,97.

\subsection{TESTE DE HOMOSCEDASTICIDADE (ANOVA)}

Com o intuito de corroborar os supostos paramétricos sobre a homogeneidade de variâncias, realizou-se o teste de homoscedasticidade (Quadro 1).

Quadro 1 - Teste de Homocedasticidade

\begin{tabular}{||l|r|r|r|r|}
\hline \multicolumn{5}{|c|}{ Test of Homogeneity of Variances } \\
\hline & $\begin{array}{c}\text { Levene } \\
\text { Statistic }\end{array}$ & $\mathrm{df1}$ & $\mathrm{df2}$ & \multicolumn{1}{c|}{ Sig. } \\
\hline AmadProf & 3,229 & 5 & 69 &, 011 \\
AplConhe & 2,294 & 5 & 69 &, 055 \\
FormAcad & 2,995 & 5 & 69 &, 017 \\
QualiCur &, 657 & 5 & 70 &, 657 \\
ValDipl & 1,199 & 5 & 70 &, 319 \\
SatCur & 2,839 & 5 & 68 &, 022 \\
IngCur & 2,059 & 5 & 66 &, 082 \\
SatFaci & 4,170 & 5 & 70 &, 002 \\
\hline
\end{tabular}


Os graus de significação das variáveis amadurecimento profissional $(\mathrm{p}=0,011)$, formação acadêmica $(\mathrm{p}=0,017)$, satisfação com o curso $(\mathrm{p}=0,022)$ e satisfação com a IES $(\mathrm{p}=0,002)$ são significativas ao nível de $95 \%(\alpha=0,05)$. Isto posto, rejeita-se a hipótese nula de homogeneidade de variâncias entre os grupos analisados. Tal fato ocorre quando as diferenças observadas entre as variâncias de dois ou mais grupos (Anova) são estatisticamente significativas, isto é, apresentam o valor (em módulo) do grau de significação calculado "p" inferior ao valor do nível de significância " $\alpha$ ".

\subsection{ANÁLISE DE VARIÂNCIA (ANOVA)}

Com o intuito de comparar as médias dos cursos simultaneamente (Quadro 2) a fim de verificar se as amostras procedem da mesma população, efetuou-se o teste ANOVA.

Quadro 2 - Análise de Variância

\begin{tabular}{|c|c|c|c|c|c|c|}
\hline \multicolumn{7}{|c|}{ ANOVA } \\
\hline & & $\begin{array}{l}\text { Sum of } \\
\text { Squares }\end{array}$ & $d f$ & Mean Square & $\mathrm{F}$ & Sig. \\
\hline \multirow[t]{3}{*}{ AmadProf } & Between Groups & 9,880 & 5 & 1,976 & 1,191 & 323 \\
\hline & Within Groups & 114,467 & 69 & 1,659 & & \\
\hline & Total & 124,347 & 74 & & & \\
\hline \multirow[t]{3}{*}{ AplConhe } & Between Groups & 9,175 & 5 & 1,835 & 1,099 &, 369 \\
\hline & Within Groups & 115,172 & 69 & 1,669 & & \\
\hline & Total & 124,347 & 74 & & & \\
\hline \multirow[t]{3}{*}{ FormAcad } & Between Groups & 7,618 & 5 & 1,524 & ,824 &, 537 \\
\hline & Within Groups & 127,529 & 69 & 1,848 & & \\
\hline & Total & 135,147 & 74 & & & \\
\hline \multirow[t]{3}{*}{ Qualicur } & Between Groups & 5,805 & 5 & 1,161 & .656 & .658 \\
\hline & Within Groups & 123,827 & 70 & 1,769 & & \\
\hline & Total & 129,632 & 75 & & & \\
\hline \multirow[t]{3}{*}{ ValDipl } & Between Groups & 18,532 & 5 & 3,706 & 2,335 & ,051 \\
\hline & Within Groups & 111,099 & 70 & 1,587 & & \\
\hline & Total & 129,632 & 75 & & & \\
\hline \multirow[t]{3}{*}{ SatCur } & Between Groups & 15,614 & 5 & 3,123 & 1,794 & 126 \\
\hline & Within Groups & 118,386 & 68 & 1,741 & & \\
\hline & Total & 134,000 & 73 & & & \\
\hline \multirow[t]{3}{*}{ IngCur } & Between Groups & 19,959 & 5 & 3,992 & 1,229 &, 306 \\
\hline & Within Groups & 214,361 & 66 & 3,248 & & \\
\hline & Total & 234,319 & 71 & & & \\
\hline \multirow[t]{3}{*}{ SatFaci } & Between Groups & 13,016 & 5 & 2,603 & 1,342 & 257 \\
\hline & Within Groups & 135,773 & 70 & 1,940 & & \\
\hline & Total & 148,789 & 75 & & & \\
\hline
\end{tabular}

Os resultados mostraram que se pode aceitar a hipótese nula de que não existem diferenças significativas entre as médias observadas, ou seja, as diferentes amostras procedem da mesma população.

\subsection{TESTE DE HIPÓTESE UNIVARIADO}

Como teste de hipótese univariado, admite-se que a população de formandos responderia em média um conceito ótimo $(4,0)$ numa escala de 5 pontos (excelente) nas questões sobre análise da graduação como fator de agregação de valor profissional e pessoal. A hipótese nula é que a população dos formandos avalia (em média) como ótima (conceito 4) a contribuição da graduação acadêmica para sua valorização profissional.

A intenção do teste está em avaliar a opinião dos formandos pesquisados quanto à agregação de valor do curso no qual estão concluindo e avaliar sua significância estatística em relação a avaliação (estimada) da população (conceito 4). 0 nível de risco ( $\alpha$ ) assumido é de 5\% nas duas caldas da distribuição t de Student (erro tipo I). 
Quadro 4 - Teste estatístico de um Fator

\begin{tabular}{|c|c|c|c|c|c|c|c|}
\hline \multicolumn{8}{|c|}{ One-Sample Test } \\
\hline \multirow[b]{3}{*}{ Curso } & & \multicolumn{6}{|c|}{ Test Value $=4$} \\
\hline & & \multirow[b]{2}{*}{$t$} & \multirow[b]{2}{*}{ df } & \multirow[b]{2}{*}{ Sig. (2-tailed) } & \multirow[b]{2}{*}{$\begin{array}{c}\text { Mean } \\
\text { Difference }\end{array}$} & \multicolumn{2}{|c|}{$\begin{array}{l}95 \% \text { Confidence Interval of the } \\
\text { Difference }\end{array}$} \\
\hline & & & & & & Lower & Upper \\
\hline \multirow[t]{2}{*}{$\mathrm{ADM}$} & AmadProf &,- 538 & 28 &, 595 &,- 138 &,- 66 & ,39 \\
\hline & AplConhe & ,378 & 28 & ,708 & ,103 &,- 46 & ,66 \\
\hline \multirow[t]{2}{*}{ DIR01 } & AmadProf &, 429 & 9 & ,678 & , 100 &,- 43 & ,63 \\
\hline & AplConhe & , 000 & 9 & 1,000 &, 000 &,- 67 & 67 \\
\hline \multirow[t]{2}{*}{ DIR02 } & AmadProf &,- 632 & 8 &, 545 &,- 333 & $-1,55$ & ,88 \\
\hline & AplConhe &, 756 & 8 & .471 &, 333 &,- 68 & 1,35 \\
\hline \multirow[t]{2}{*}{ ENG. CIVL } & AmadProf & 2,121 & 6 & ,078 &, 429 &,- 07 & ,92 \\
\hline & AplConhe & 2,121 & 6 &, 078 & ,429 &,- 07 &, 92 \\
\hline \multirow[t]{2}{*}{ GEST.AMB } & AmadProf & $-1,388$ & 10 & , 195 &,- 727 & $-1,89$ &, 44 \\
\hline & AplConhe & $-1,295$ & 10 & ,224 &,- 636 & $-1,73$ &, 46 \\
\hline \multirow[t]{2}{*}{ TECNOL } & AmadProf & 1,835 & 8 & , 104 & ,444 &,- 11 & 1,00 \\
\hline & AplConhe & 2,294 & 8 & ,051 &, 556 &, 00 & 1,11 \\
\hline
\end{tabular}

Os resultados do teste de hipóteses univariado (Quadro 3), com um risco de erro $\alpha$ (tipo I) de 5\% (ou nível de significância de 0,05), demonstra que não há motivos para se rejeitar a hipótese nula (H0). Isto implica dizer que todos os formandos concordam quanto a importante contribuição da sua formação superior para o seu amadurecimento profissional e à aplicação dos conhecimentos adquiridos no seu cotidiano. Outra questão relevante sobre a continuidade na formação acadêmica dos formandos está posta como segue:

Os formandos pretendem cursar uma pós-graduação ligada à sua área de atuação profissional?

A expectativa é que a média populacional seja 4,0 em uma escala de cinco pontos. Assim, a hipótese nula a ser testada é a de que a média da população de formandos não será diferente de 4,0.

Quadro 5 - Teste estatístico de um Fator

\begin{tabular}{|c|c|c|c|c|c|c|c|}
\hline \multicolumn{8}{|c|}{ One-Sample Test } \\
\hline \multirow{3}{*}{\multicolumn{2}{|c|}{ Cod.Curs }} & \multicolumn{6}{|c|}{ Test Value $=4$} \\
\hline & & \multirow{3}{*}{$\frac{\mathrm{t}}{, 137}$} & \multirow{3}{*}{$\frac{\mathrm{df}}{26}$} & \multirow{3}{*}{$\begin{array}{r}\text { Sig. (2-tailed) } \\
, 892\end{array}$} & \multirow{3}{*}{$\begin{array}{r}\begin{array}{c}\text { Mean } \\
\text { Difference }\end{array} \\
, 037\end{array}$} & \multicolumn{2}{|c|}{$\begin{array}{l}\text { 95\% Confidence Interval of the } \\
\text { Difference }\end{array}$} \\
\hline & & & & & & Lower & Upper \\
\hline 1,00 & PosProfi & & & & &,- 52 &, 59 \\
\hline 2,00 & PosProfi &,- 408 & 9 & ,693 &,- 200 & $-1,31$ & 91 \\
\hline 3,00 & PosProfi &, 243 & 7 & ,815 & ,125 & $-1,09$ & 1,34 \\
\hline 4,00 & PosProfi & 1,922 & 6 & ,103 &, 571 &,- 16 & 1,30 \\
\hline 5,00 & PosProfi &,- 166 & 10 & 871 &,- 091 & $-1,31$ & 1,13 \\
\hline 6,00 & PosProfi &, 316 & 8 & ,760 & ,111 &,- 70 &, 92 \\
\hline
\end{tabular}

Os resultados mostram (Quadro 5) que H0 pode ser aceita, isto é, os formandos de todos os cursos pesquisados julgam importante a pós-graduação, principalmente, aquelas que estejam relacionadas à sua área de atuação profissional.

Ao avaliar o conceito dos formandos quanto à qualidade da pós-graduação oferecida na IES onde está graduando, formulou-se a seguinte questão:

Os formandos avaliam a pós-graduação da IES como sendo de alta qualidade?

A hipótese nula a ser testada é a de que a média da população de formandos não difira de 4,0. 
Quadro 6 - Teste estatístico de um Fator

\begin{tabular}{|c|c|c|c|c|c|c|c|}
\hline \multicolumn{8}{|c|}{ One-Sample Test } \\
\hline \multirow[b]{3}{*}{ Curso } & & \multicolumn{6}{|c|}{ Test Value $=4$} \\
\hline & & \multirow[b]{2}{*}{$t$} & \multirow[b]{2}{*}{ df } & \multirow[b]{2}{*}{ Sig. (2-tailed) } & \multirow[b]{2}{*}{$\begin{array}{c}\text { Mean } \\
\text { Difference }\end{array}$} & \multicolumn{2}{|c|}{$\begin{array}{l}\text { 95\% Confidence Interval of the } \\
\text { Difference }\end{array}$} \\
\hline & & & & & & Lower & Upper \\
\hline ADM & QualiPos & $-2,434$ & 27 & ,022 &,- 821 & $-1,51$ &,- 13 \\
\hline DIR01 & QualiPos & $-2,250$ & 9 & ,051 & $-1,200$ & $-2,41$ & ,01 \\
\hline DIR02 & QualiPos & $-3,308$ & 9 & ,009 & $-1,500$ & $-2,53$ &,- 47 \\
\hline ENG. CIVIL & QualiPos & $-1,549$ & 6 & , 172 &,- 571 & $-1,47$ & ,33 \\
\hline GEST.AMB & QualiPos & $-2,782$ & 10 & ,019 & $-1,091$ & $-1,96$ &,- 22 \\
\hline TECNOL & QualiPos & $-1,890$ & 8 & ,095 & $-1,111$ & $-2,47$ & 24 \\
\hline
\end{tabular}

Aceita-se H0, ou seja, julgam a pós-graduação da IES como sendo de elevada qualidade, somente os cursos de Engenharia Civil, Direito 1 e os Tecnológicos (Redes de Computadores, Processos Gerenciais). Já para Direito 2, Administração e Gestão Ambiental, rejeita-se H0. Os resultados (Quadro 6) mostram que a avaliação da pós-graduação pelos formandos não apresenta um elevado conceito.

Os formandos pretendem cursar uma pós-graduação ligada à sua área de formação acadêmica?

Assim, a hipótese nula a ser testada é a de que a média da população de formandos não será diferente de 4,0 .

Quadro 7 - Teste estatístico de um Fator

\begin{tabular}{|c|c|c|c|c|c|c|c|}
\hline \multicolumn{8}{|c|}{ One-Sample Test } \\
\hline \multirow[b]{3}{*}{ Curso } & & \multicolumn{6}{|c|}{ Test Value $=4$} \\
\hline & & \multirow[b]{2}{*}{$t$} & \multirow[b]{2}{*}{$\mathrm{df}$} & \multirow[b]{2}{*}{ Sig. (2-tailed) } & \multirow[b]{2}{*}{$\begin{array}{c}\text { Mean } \\
\text { Difference }\end{array}$} & \multicolumn{2}{|c|}{$\begin{array}{c}95 \% \text { Confidence Interval of the } \\
\text { Difference }\end{array}$} \\
\hline & & & & & & Lower & Upper \\
\hline $\mathrm{ADM}$ & PosGrad & ,610 & 25 &, 548 & , 154 &,- 37 &, 67 \\
\hline DIR01 & PosGrad & ,688 & 9 &, 509 &, 200 &,- 46 & ,86 \\
\hline DIR02 & PosGrad & 246 & 9 & ,811 & , 100 &,- 82 & 1,02 \\
\hline ENG. CIVIL & PosGrad & 1,441 & 6 & ,200 & 429 &,- 30 & 1,16 \\
\hline GEST.AMB & PosGrad &,- 504 & 10 & ,625 &,- 273 & $-1,48$ & ,93 \\
\hline TECNOL & PosGrad & 1,512 & 8 & .169 & 444 &,- 23 & 1,12 \\
\hline
\end{tabular}

O teste aceita $\mathrm{H} 0$ e mostra que o interesse dos formandos em cursar uma pós-graduação ligada a sua área de formação é elevado (Quadro 7). Revela ainda que tal critério é mais significativo ainda (ou prioritário) que o interesse em uma pós-graduação ligada à sua área de atuação profissional.

Uma última questão formulada diz respeito à pós-graduação pública.

Os formandos pretendem cursar uma pós-graduação somente em uma IES pública? 
Quadro 8 - Teste estatístico de um Fator

\begin{tabular}{|c|c|c|c|c|c|c|c|}
\hline \multicolumn{8}{|c|}{ One-Sample Test } \\
\hline \multirow[b]{3}{*}{ Curso } & & \multicolumn{6}{|c|}{ Test Value $=4$} \\
\hline & & \multirow{3}{*}{$\frac{t}{-5,858}$} & \multirow{3}{*}{$\frac{\mathrm{df}}{25}$} & \multirow{3}{*}{$\frac{\text { Sig. (2-tailed) }}{, 000}$} & \multirow[b]{2}{*}{$\begin{array}{c}\text { Mean } \\
\text { Difference }\end{array}$} & \multicolumn{2}{|c|}{$\begin{array}{l}95 \% \text { Confidence Interval of the } \\
\text { Difference }\end{array}$} \\
\hline & & & & & & Lower & Upper \\
\hline ADM & PosPublica & & & & $-1,462$ & $-1,98$ &,- 95 \\
\hline DIR01 & PosPublica & $-1,964$ & 9 & ,081 &,- 900 & $-1,94$ & 14 \\
\hline DIR02 & PosPublica & $-3,265$ & 7 & ,014 & $-1,625$ & $-2,80$ &,- 45 \\
\hline ENG. CIVIL & PosPublica & $-2,976$ & 6 & 025 & $-1,571$ & $-2,86$ &,- 28 \\
\hline GEST.AMB & PosPublica & $-1,677$ & 9 & ,128 & $-1,000$ & $-2,35$ & ,35 \\
\hline TECNOL & PosPublica & $-3,506$ & 8 & ,008 & $-1,444$ & $-2,39$ &,- 49 \\
\hline
\end{tabular}

Os resultados revelam que H0 é aceita para os cursos Direito 1 e Gestão Ambiental, ou seja, há uma preferência clara por uma pós-graduação em uma IES pública nestas turmas (Quadro 8). Contudo rejeitase H0 para os cursos Administração, Direito 2, Engenharia Civil e Tecnológicos que não apresentam tal preferência.

\subsection{TESTE DE HIPÓTESES BIVARIADO}

\subsubsection{TABULAÇÃO CRUZADA COM O USO DA ANÁLISE QUI-QUADRADO}

Com o objetivo de descrever relações entre os grupos e variáveis pesquisadas, procede-se a construção de uma tabela onde se tabula as respostas para cada grupo e as compara entre si. A análise qui-quadrado permite testar se há diferenças estatísticas entre grupos.

As questões levantadas e suas respectivas análises são:

- Há diferenças entre os formandos dos Cursos analisados quanto à percepção do grau de amadurecimento profissional proporcionado pela graduação?

Quadro 9 - Teste Qui-quadrado

\begin{tabular}{||l|r|r|r|}
\hline \multicolumn{4}{|c|}{ Chi-Square Tests } \\
\hline & \multicolumn{1}{|c|}{ Value } & \multicolumn{1}{|c|}{ df } & $\begin{array}{c}\text { Asymp. Sig. } \\
\text { (2-sided) }\end{array}$ \\
\hline Pearson Chi-Square & $23,825^{\text {a }}$ & 25 &, 530 \\
Likelihood Ratio & 25,458 & 25 &, 437 \\
N of Valid Cases & 75 & & \\
\hline & & \\
a. 34 cells (94,4\%) have expected count less than 5. The \\
minimum expected count is ,09.
\end{tabular}

O teste qui-quadrado (Quadro 9) demonstra que não há motivos para se rejeitar a hipótese nula de igualdade de percepções entre os formandos dos cursos quanto ao reconhecimento do amadurecimento profissional.

- A aplicação dos conhecimentos adquiridos ao longo da formação acadêmica diverge entre os formandos dos Cursos?

Quadro 10 - Teste Qui-quadrado

\begin{tabular}{|l|r|r|r|}
\hline & \multicolumn{1}{|c|}{ Chi-Square Tests } \\
\hline Vearson Chi-Square & $27,395^{\text {a }}$ & df & $\begin{array}{c}\text { Asymp. Sig. } \\
\text { (2-sided) }\end{array}$ \\
\hline Likelihood Ratio & 27,587 & 20 &, 125 \\
N of Valid Cases & 75 & &, 120 \\
\hline
\end{tabular}

a. 26 cells $(86,7 \%)$ have expected count less than 5 . The minimum expected count is, 09 . 
De acordo com o teste qui-quadrado (Quadro 10), aceita-se a hipótese nula de igualdade de proporções entre os formandos dos Cursos analisados no que diz respeito a aplicação dos conhecimentos adquiridos ao longo da formação em sua vida cotidiana.

- A avaliação da qualidade do curso e a validade do seu diploma no mercado de trabalho diferem entre os formandos dos cursos pesquisados?

Quadro 11 - Teste Qui-quadrado

\begin{tabular}{||l|r|r|r|}
\hline \multicolumn{4}{|c|}{ Chi-Square Tests } \\
\hline & \multicolumn{1}{|c|}{ Value } & \multicolumn{1}{|c|}{ df } & $\begin{array}{c}\text { Asymp. Sig. } \\
\text { (2-sided) }\end{array}$ \\
\hline Pearson Chi-Square & $17,633^{\text {a }}$ & 20 &, 612 \\
Likelihood Ratio & 20,916 & 20 &, 402 \\
N of Valid Cases & 76 & & \\
\hline \\
a. 27 cells (90,0\%) have expected count less than 5. The \\
minimum expected count is ,55. \\
\hline
\end{tabular}

Aceita-se H0 indicando que os formandos de todos os cursos analisados têm um conceito semelhante e positivo sobre a qualidade do curso (Quadro 11).

Quadro 12 - Teste Qui-quadrado

\begin{tabular}{||l|r|r|r|}
\hline \multicolumn{4}{|c|}{ Chi-Square Tests } \\
\hline & \multicolumn{1}{|c|}{ Value } & df & $\begin{array}{c}\text { Asymp. Sig. } \\
\text { (2-sided) }\end{array}$ \\
\hline Pearson Chi-Square & $35,698^{\text {a }}$ & 25 &, 076 \\
Likelihood Ratio & 37,311 & 25 &, 054 \\
N of Valid Cases & 76 & & \\
\hline
\end{tabular}

O mesmo pode ser dito sobre a credibilidade do diploma no mercado (Quadro 12). Aceita-se H0 de modo que todos os formandos de todos os cursos acreditam no valor do diploma desta IES no mercado de trabalho.

- Existe relação entre o curso e o interesse do formando em ingressar em outra graduação?

Quadro 13 - Teste Qui-quadrado

\begin{tabular}{||l|r|r|r|}
\hline \multicolumn{1}{|c|}{ Chi-Square Tests } \\
\hline & \multicolumn{1}{|c|}{ Value } & df & $\begin{array}{c}\text { Asymp. Sig. } \\
\text { (2-sided) }\end{array}$ \\
\hline Pearson Chi-Square & $31,067^{\text {a }}$ & 25 &, 187 \\
Likelihood Ratio & 32,629 & 25 &, 141 \\
N of Valid Cases & 72 & & \\
\hline \\
a. 34 cells (94,4\%) have expected count less than 5. The \\
minimum expected count is ,14. \\
\hline
\end{tabular}

A estatística qui-quadrado (Quadro 13) mostra que não há influência nas respostas de um curso sobre as respostas de outros cursos quanto à intenção dos seus formandos em ingressar noutra graduação, isto é, todos os cursos seguem o padrão de escolhas teoricamente esperados.

- Existe relação entre o curso e o interesse do formando em ingressar em uma pós-graduação lato ou strictu sensu? 
Quadro 14 - Teste Qui-quadrado Latu Sensu

\begin{tabular}{||l|r|r|r|}
\hline \multicolumn{4}{|c|}{ Chi-Square Tests } \\
\hline & \multicolumn{1}{|c|}{ Value } & \multicolumn{1}{c|}{ df } & $\begin{array}{c}\text { Asymp. Sig. } \\
\text { (2-sided) }\end{array}$ \\
\hline Pearson Chi-Square & $27,399^{\mathrm{a}}$ & 25 &, 336 \\
Likelihood Ratio & 30,183 & 25 &, 217 \\
N of Valid Cases & 75 & & \\
\hline \multicolumn{4}{|c|}{} \\
a. 34 cells (94,4\%) have expected count less than 5. The \\
\hline
\end{tabular}

(94,4\%) have expected count less than 5 . The

Quadro 15 - Teste Qui-quadrado Strictu Sensu

\begin{tabular}{|c|c|c|c|}
\hline \multicolumn{4}{|c|}{ Chi-Square Tests } \\
\hline & Value & $\mathrm{df}$ & $\begin{array}{l}\text { Asymp. Sig. } \\
\text { (2-sided) }\end{array}$ \\
\hline Pearson Chi-Square & $23,513^{a}$ & 25 &, 548 \\
\hline Likelihood Ratio & 28,646 & 25 & ,279 \\
\hline $\mathrm{N}$ of Valid Cases & 74 & & \\
\hline
\end{tabular}

0 teste qui-quadrado mostra que um curso não influencia nas opiniões dos outros cursos (variáveis independentes). Com relação às respostas de intenção dos seus formandos em ingressar em uma pósgraduação, isto é, todos os cursos seguem o padrão de escolhas teoricamente esperados. Aceita-se, portanto, H0 (Quadro 14) - Lato $(\mathrm{p}=0,336)$ e Strictu (Quadro 15) ( $\mathrm{p}=0,548)$ - de que a proporção de formandos dos cursos analisados que pretendem ingressar numa pós-graduação são semelhantes e favoráveis à formação acadêmica continuada.

\subsection{COMPARAÇÃO DE DUAS MÉDIAS OBSERVADAS COM DADOS RELACIONADOS}

O objetivo deste teste está identificar se a correlação entre as variáveis relacionadas são significativas e positivas. Tais relações estão assim enquadradas nas seguintes questões:

- Par 1 - o amadurecimento profissional (variável 1) contribui para a aplicação dos conhecimentos dos formandos (Variável 2)?

- Par 2 - a qualidade do curso (variável 1) contribui para o aumento da satisfação dos formandos (Variável 2)?

- Par 3 - a valorização do diploma no mercado de trabalho (variável 1) contribui para a satisfação dos formandos com a IES (Variável 2)?

- Par 4 - a formação acadêmica (variável 1) contribui para o ingresso dos formandos em outras graduações (Variável 2)?

A hipótese nula a ser testada é de que não há relação entre as variáveis 1 e 2 elencadas.

Quadro 16 - Correlação da amostras pareadas

\begin{tabular}{|l|r|r|r|}
\hline \multicolumn{4}{|c|}{ Paired Samples Correlations } \\
\hline & N & Correlation & \multicolumn{1}{|c|}{ Sig. } \\
\hline AmadProf \& AplConhe & 75 &, 649 &, 000 \\
QualiCur \& SatCur & 74 &, 673 &, 000 \\
ValDipl \& SatFaci & 76 &, 541 &, 000 \\
FormAcad \& IngCur & 71 &, 253 &, 033 \\
\hline
\end{tabular}

Através da análise de correlação de Pearson (Quadro 16), observa-se que somente o par 4 (formação acadêmica e Interesse em outra graduação) apresentam pequena mas definida força de associação ( $\mathrm{r}=$ 0,253 ) com significância estatística que implica na rejeição de H0. Contudo, seu coeficiente de determinação (R2) é de 0,064 o que equivale dizer que apenas 6,4\% da variação na formação acadêmica é 
explicada pelo ingresso em outro curso, fato este que resulta em muito pouca utilidade prática para efeito de análise. HAIR (2005, p.316)

Os demais pares analisados são significativos $(p=0,0001)$ rejeitando-se H0 e aceitando a hipótese alternativa de que há uma relação entre as mesmas. Seus respectivos coeficientes de determinação são 0,4212 (par 1), 0,453 (par 2) e 0,2926 (par 3) representando um razoável percentual de explicação das variações observadas (Quadro 17). 0 que equivale a uma moderada força de associação $(0,41$ a 0,70$)$ com proporção direta entre amadurecimento profissional e aplicação dos conhecimentos $(r=0,65)$, qualidade do curso e satisfação com o curso $(r=0,673)$ e peso do diploma no mercado e satisfação com a IES ( $\mathrm{r}=$ $0,541)$.

Quadro 17 - Teste de amostras pareadas

\begin{tabular}{|c|c|c|c|c|c|c|c|c|c|}
\hline \multicolumn{10}{|c|}{ Paired Samples Test } \\
\hline & & \multicolumn{5}{|c|}{ Paired Differences } & \multirow[b]{3}{*}{$\mathrm{t}$} & \multirow[b]{3}{*}{ df } & \multirow[b]{3}{*}{ Sig. (2-tailed) } \\
\hline & & & & & \multicolumn{2}{|c|}{$\begin{array}{l}95 \% \text { Confidence Interval of the } \\
\text { Difference }\end{array}$} & & & \\
\hline & & Mean & Std. Deviation & $\begin{array}{l}\text { Std. Error } \\
\text { Mean }\end{array}$ & Lower & Upper & & & \\
\hline Pair 1 & AmadProf-AplConhe &,- 187 & 1,087 & ,125 &,- 437 & , 063 & $-1,488$ & 74 & ,141 \\
\hline Pair 2 & QualiCur - SatCur &,- 297 & 1,082 & ,126 &,- 548 &,- 047 & $-2,364$ & 73 &, 021 \\
\hline Pair 3 & ValDipl - SatFaci & , 158 & 1,307 & , 150 &,- 141 & ,457 & 1,053 & 75 & ,296 \\
\hline Pair 4 & FormAcad - IngCur & ,761 & 1,975 & ,234 & ,293 & 1,228 & 3,246 & 70 &, 002 \\
\hline
\end{tabular}

O objetivo deste teste está em comparar o nível de empregabilidade e ganhos financeiros dos formandos no momento inicial e final do curso. Deste modo, a hipótese nula é a que não há relação entre tais níveis de empregabilidade e ganhos.

Quadro 18 - Teste de correlação de amostras pareadas

Paired Samples Correlations

\begin{tabular}{|c|c|c|c|c|}
\hline \multicolumn{2}{|c}{} & N & Correlation & Sig. \\
\hline Pair 1 & Sim \& Afirmativo & 83 &, 337 &, 002 \\
\hline Pair 2 & HumSM \& UmSm & 83 &,- 054 &, 630 \\
\hline Pair 3 & TresSM \& TreSm & 83 &, 220 &, 045 \\
\hline Pair 4 & CincoSM \& CincSm & 83 &, 159 &, 152 \\
\hline Pair 5 & DezSM \& DeSm & 83 &,- 025 &, 825 \\
\hline Pair 6 & DezAcima \& DeAc & 83 &, 703 &, 000 \\
\hline
\end{tabular}

Com base na análise de correlação de Pearson (Quadro 18) os resultados mostrados no quadro acima para o Par 1 - variável emprego no início e final do curso - mostram uma pequena, mas definida correlação entre as variáveis ( $r=0,337$ ) para um grau de significação de 0,002 (rejeita-se H0), o que implica dizer que trabalhar no início do curso contribui para a inserção do acadêmico no mercado de trabalho ao final do curso. Contudo, como o coeficiente de determinação (R2) é de apenas 11,35\%, a análise fica comprometida por apresentar pouca utilidade em termos práticos, haja vista sua reduzida capacidade de explicação das variações. HAIR (2005, p.316)

A primeira faixa de renda (até um salário mínimo) apresenta correlação inversa quase imperceptível (r=0,054) com grau de significação de 0,63, (aceita-se H0) atestando assim que os ganhos de renda dos acadêmicos empregados no início do curso nesta faixa não influenciam nos ganhos desta mesma faixa ao final do curso. Na segunda faixa (um a três salários mínimos), a correlação é pequena, mas definida ( $\mathrm{r}=$ 0,22), para um grau de significação de 0,45 (rejeita-se H0) e coeficiente de determinação de 4,84\% resultando em conclusões análogas à faixa de renda anterior. Na terceira faixa de renda (de três a cinco salários mínimos) a correlação é quase imperceptível $(r=0,159)$, entretanto, o grau de significação por não ser expressivo $(p=0,152)$ faz com que a hipótese nula seja aceita. Evidenciando, assim, que não há relação entre ganhos de renda nesta faixa nos períodos sob análise. A quarta faixa de renda (de cinco a dez 
salários mínimos) têm-se uma correlação inversa pequena mas definida ( $r=-0,025)$ com grau de significação de 0,845 (aceita-se H0). A conclusão segue o mesmo padrão da análise desenvolvida na faixa de renda anterior.

Por outro lado, somente na faixa de dez salários mínimos e acima ocorre uma alta correlação $(r=0,703)$ entre a realidade inicial e conclusiva do curso. 0 teste revelou que há uma relação significativa entre os ganhos dos formandos situados nesta faixa de renda (rejeita-se H0). Em outros termos, pode-se concluir que formandos que ingressaram no curso, já empregados e, auferindo uma elevada renda, tenderam a manter tal situação no decorrer do curso e expandir seus ganhos de renda ao final deste. Tal fato é corroborado ainda por um coeficiente de determinação de 49,42\%.

HAIR (2005, P.316) observa que nos casos onde a correlação for pequena, pode-se concluir que não existe uma relação coerente e sistemática entre as variáveis ou; que a associação existente não tem natureza linear, necessitando assim, considerar outros tipos de relação. Por outro lado, mesmo nos casos em que se verifica a significância estatística, isso não implica dizer que têm significância (ou aplicabilidade) na prática.

\subsection{O PERFIL DA INSERÇÃO DOS FORMANDOS NO MERCADO DE TRABALHO}

Os dados mostram que o nível de emprego dos formandos no início do curso é de $41 \%$ do total de ingressantes (Fig.5). As funções de Assistentes predominam nos acadêmicos de Administração, Engenharia Civil e Tecnológicos e representam 61\% do total de formandos empregados. Atividades microempreendedoras (4,9\%) e funções de Direção $(2,4 \%)$ e Presidência $(4,9 \%)$, só foram verificadas nos acadêmicos de Direito. Cargos de gerência (4,9\%) só manifestaram-se nos cursos de Administração e Tecnológicos.

Figura 5 - Mercado de Trabalho e Ciclo de Vida - 2007

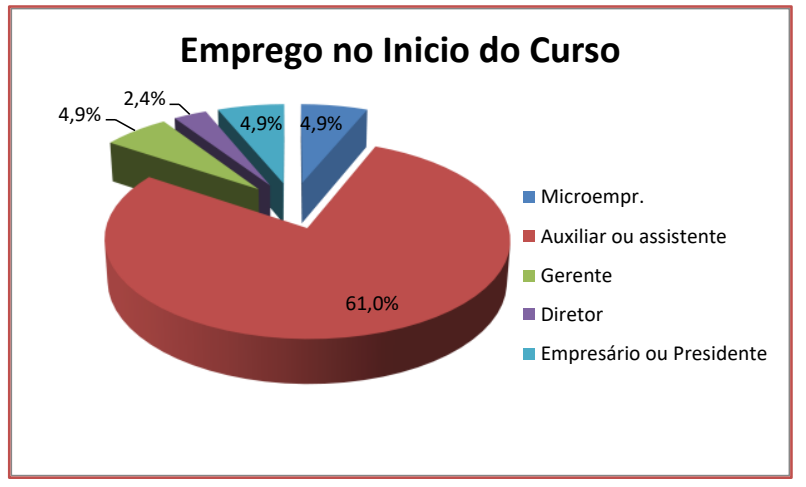

Tal fato pode ser corroborado mediante uma análise mais robusta com base nos dados levantados. Aplicou-se, portanto, o teste univariado t de Student onde a hipótese nula é de que a população de formandos já se encontra inserida no mercado de trabalho ao ingressar no curso superior. 0 nível de significância aceito é de $5 \%$ nas duas caldas.

Quadro 19 - Teste estatístico de uma Amostra

\begin{tabular}{|c|c|c|c|c|c|c|}
\hline \multicolumn{7}{|c|}{ One-Sample Test } \\
\hline & \multicolumn{6}{|c|}{ Test Value $=1$} \\
\hline & & & & & \multicolumn{2}{|c|}{$\begin{array}{c}\text { 95\% Confidence Interval of the } \\
\text { Difference }\end{array}$} \\
\hline & $t$ & df & Sig. (2-tailed) & $\begin{array}{c}\text { Mean } \\
\text { Difference } \\
\end{array}$ & Lower & Upper \\
\hline MicEmp & $-27,928$ & 40 &, 000 &,- 951 & $-1,02$ &,- 88 \\
\hline AuxAss & $-5,060$ & 40 &, 000 &,- 390 &,- 55 &,- 23 \\
\hline Gerente & $-27,928$ & 40 & ,000 & -951 & $-1,02$ &,- 88 \\
\hline Diretor & $-40,000$ & 40 & , 000 &,- 976 & $-1,02$ &,- 93 \\
\hline Presidente & $-27,928$ & 40 & , 000 &,- 951 & $-1,02$ &,- 88 \\
\hline
\end{tabular}


Os resultados (Quadro 19) revelaram ( $p=0,0001$ ) que os formandos no início do curso não se encontram significativamente - do ponto de vista estatístico - inseridos no mercado de trabalho (rejeita-se H0).

Com relação ao emprego no final do curso as análises mostraram que persiste ainda o cenário de baixa alocação no mercado de trabalho, conforme os dados a seguir.

A hipótese nula é a de que a população de formandos encontra-se inserida no mercado de trabalho na fase conclusiva do curso. Com significância de $5 \%$ realizou-se o teste t para os dados coletados.

Os resultados mostram (Quadro 20) que mesmo estando no período conclusivo de sua formação, a inserção dos formandos no mercado de trabalho ainda é pouco significativa (rejeita-se H0). Em termos percentuais, $61,4 \%$ dos pesquisados declararam que estavam trabalhando.

Quadro 20 - Teste estatístico de uma Amostra

\begin{tabular}{|c|c|c|c|c|c|c|}
\hline \multicolumn{7}{|c|}{ One-Sample Test } \\
\hline & \multicolumn{6}{|c|}{ Test Value $=1$} \\
\hline & & & & & \multicolumn{2}{|c|}{$\begin{array}{c}95 \% \text { Confidence Interval of the } \\
\text { Difference }\end{array}$} \\
\hline & $t$ & df & Sig. (2-tailed) & $\begin{array}{c}\text { Mean } \\
\text { Difference }\end{array}$ & Lower & Upper \\
\hline SInd & $-28,862$ & 51 &, 000 &,- 942 & $-1,01$ &,- 88 \\
\hline sCom & $-15,610$ & 51 &, 000 &,- 827 &,- 93 &,- 72 \\
\hline SServ & $-6,872$ & 51 & ,000 &,- 481 &,- 62 &,- 34 \\
\hline SInf & $-28,862$ & 51 & ,000 &,- 942 & $-1,01$ &,- 88 \\
\hline
\end{tabular}

\section{CONSIDERAÇõES FINAIS}

Com base nos dados e análises desenvolvidos ao longo deste trabalho, pode-se destacar alguns aspectos relevantes com respeito ao perfil dos formandos e suas perspectivas de formação profissional e acadêmica.

No que concerne à empregabilidade dos formandos, verificou-se que sua inserção no mercado não se dá imediatamente e/ou predominantemente ao longo do curso. Isto também inclui as transformações em suas faixas de renda. Por outro lado, observa-se que a captação de acadêmicos oriundos de empresas (turmas empresariais) principalmente nos setores secundário (indústria) e terciário (comércio) constituise num potencial nicho mercadológico a ser prospectado.

Quanto a sua formação, os formandos compreendem sua importância e acreditam que devem continuar investindo em sua formação como instrumento de valorização e qualificação profissional. Contudo, a pesquisa mostra que outras competências e habilidades que compõem a categoria empregabilidade necessitam ser trabalhadas em sua formação com vistas a elevar o índice de inserção no mercado de trabalho após o término da graduação com ganhos significativos de renda.

Neste aspecto a pesquisa revelou que a pós-graduação representa um campo da formação superior que deverá estar focado muito mais na área de formação acadêmica que nas atuais funções desempenhadas pelos graduados no mercado de trabalho de modo que a especialização como diferencial competitivo para o profissional torna-se mais relevante que as adequações de sua formação às atividades circunstancialmente desempenhadas no mercado de trabalho.

Outro ponto importante a ressaltar está na crença dos pesquisados que curso com qualidade reflete positivamente em sua valorização profissional, expressos na credibilidade do diploma e na satisfação com o curso e a Instituição de Ensino Superior (IES). Todavia, vale destacar que a satisfação com a IES está vinculada a questões também administrativas que, por sua vez, influencia no conceito de qualidade da pós-graduação por parte dos acadêmicos da graduação. Isto posto, a pesquisa revelou que fatores extra pedagógicos, mas que compõem a IES, tem papel decisivo para uma boa avaliação da instituição. 


\section{REFERÊNCIAS}

[1] BELL, Judith. Doing your research project: a guide for the fist-time researchers in education and social science. 2. reimp. Milton Keynes, England: Open University Press, 1989. 145p.

[2] BISQUERRA, R.,SARRIERA, J.C., MARTÍNEZ, F. Introdução à Estatística: enfoque informático com o pacote estatístico SPSS. Porto Alegre : Bookman, 2004.

[3] BRAGA, Márcio Bobik et al. Matemática para economistas. - São Paulo: Atlas, 2003.

[4] HAIR, J. F et al. Análise Multivariada de Dados. - Porto Alegre : Bookman, 2005.

[5] HAIR, J. F. et al. Fundamentos de Métodos de Pesquisa em Administração. - Porto Alegre : Bookman, 2005.

[6] NERI, Marcelo C. Você no mercado de Trabalho. - Rio de Janeiro: FGV/IBRE, CPS, 2008. 


\section{Capítulo 12}

\section{Análise de processo de recrutamento e seleção, com base nas competências requeridas para os cargos.}

\section{Paulo Cesar Schotten}

\section{Rodrigo Santolini Soares}

Solange Fachin

Resumo: A pesquisa tem a pretensão de avaliar se o processo de recrutamento e seleção de pessoas tem atingindo as expectativas organizacionais com relação as competências exigidas para o os cargos. Para responder a questão de pesquisa, o estudo estabeleceu os seguintes objetivos: descrever o processo de recrutamento e seleção adotado pela organização em questão, identificar as competências requeridas para novos funcionários, comparar as competências requeridas nos cargos com as obtidas nos novos funcionários. Para que o objetivo fosse atingido realizou-se um levantamento bibliográfico sobre o tema, detalhando o recrutamento interno, recrutamento externo e recrutamento misto, o processo de seleção, bem como as competências exigidas para os cargos e bases documentais e entrevistas para compreender a organização estudada. Metodologicamente trata-se de uma pesquisa descritiva, cumprindo os procedimentos técnicos de um estudo de caso. No transcorrer da pesquisa, constatou-se que a organização não está estruturada para uma gestão de competências, embora conste no organograma funcional um setor especifico para a gestão de Recursos Humanos, não se identificou um profissional especifico para atuação na área. Nota-se que embora que de maneira informal, a instituição tem algumas linhas e ações que condizem com a gestão por competências, porém evidenciou-se uma compreensão equivocada do conceito.

Palavras Chaves: Recrutamento e Seleção, Competências, Gestão por Competências. 


\section{INTRODUÇÃO}

As pessoas constituem o bem mais valioso de uma organização, são recursos humanos dotados de habilidades, capacidades, conhecimentos e atitudes, que no desenvolver de suas atividades laborais contribuem para o atingimento das metas organizacionais e para com o desenvolvimento econômico da sociedade.

Data a importância das pessoas nas organizações, o estudo está focado no processo de ingresso das mesmas na empresa, sendo assim, Marras (2008) definiu o termo Recrutamento em: atrair, buscar pessoas potencialmente qualificadas para ocupar um determinado cargo ou função dentro da empresa, gerar informação ao qual a organização divulga aos departamentos as ofertas de emprego, que podem ser de forma Interno, Externo ou Mista. 0 recrutamento fomenta a Seleção quem tem por finalidade identificar o indivíduo que tem o perfil mais compatível com as exigências e necessidades da organização.

O processo de recrutamento e seleção de pessoas, é responsável pela composição do quadro organizacional, avalia quais são as atividades, responsabilidade, atribuições e obrigações que serão inerentes a cada cargo (descrição dos cargos), e o perfil de cada vaga, considerando suas habilidades, conhecimentos e competências necessárias aos candidatos.

A importância deste trabalho é o papel estratégico do setor de recurso humano, pois cabe a ele cuidar da essência de toda organização, que são as pessoas. Tendo um trabalho de previsão da necessidade futura de pessoas que se estende até o ponto de identificação da pessoa mais capacitada para o exercício da função.

Esta pesquisa visa avaliar se o recrutamento e seleção de pessoas tem atingindo as expectativas em relação às competências atribuídas pela organização aos cargos. Neste cenário delineou-se como objetivos específicos descrever o processo de recrutamento e seleção adotado pela organização, conhecer e relacionar as competências requeridas para os cargos e identifica-las nos novos funcionários. De forma a comparar as competências requeridas com as obtidas nos candidatos selecionados. Para evidenciar essa problemática, o processo de recrutamento e posterior seleção de pessoas, identifica se as características e perfil de cada candidato se enquadram com as competências técnicas, habilidades e atitudes exigidas pela organização, e os avalia durante o período de experiência, integração na empresa e seu nível motivação para com o novo desafio laboral.

A gestão com base nas competências é uma combinação de conhecimentos, habilidades e atitudes que se expressam através do desempenho profissional em um determinado contexto organizacional, agregando valor às pessoas e à própria organização. Seguindo a premissa de alinhar as competências existentes na organização com as competências consideradas necessárias para o alcance dos objetivos organizacionais, descobrindo e valorizando talentos.

\section{REFERENCIAL TEÓRICO}

\subsection{RECRUTAMENTO}

Recrutamento é conceituado por Chiavenato (1998) como um conjunto de técnicas e procedimentos que visa atrair candidatos potencialmente qualificados e capazes de ocupar cargos dentro da organização. Nesse caso, na visão do autor, o recrutamento é basicamente um sistema de informação, através do qual a organização divulga e oferece ao mercado de RH oportunidades de emprego que pretende preencher.

Diz ainda, Chiavenato(1998) que "para ser eficaz o recrutamento deve atrair contingentes candidatos suficientes para abastecer adequadamente o processo de seleção". Aliás, a função do recrutamento é a de suprir a seleção de matéria-prima básica (candidatos) para seu funcionamento.

Segundo Werther e Davis (1983) apud Pontes (1996) é o processo de encontrar e atrair candidatos capazes para solicitação de emprego. Já conforme Toledo e Milione apud Pontes (1996), recrutamento "é a etapa inicial do processo de busca e atração de mão de obra para a organização, procura prover o número adequado de candidatos para as posições em aberto".

Quanto à importância do recrutamento, Milkovick e Boudrean (2010) afirmam que o recrutamento não é importante apenas para a organização, ele é um processo de comunicação bilateral onde os candidatos desejam informações precisas sobre como será trabalhar nessa empresa, por seu lado, a organização deseja saber que tipo de empregado será o candidato, caso seja contratado.

Os autores anteriormente mencionados, afirmam que ambos os lados enviam sinais sobre as relações no trabalho, ou seja, os candidatos sinalizam que são bons concorrentes e devem receber a oferta de 
emprego, também tentam obter da organização as informações para que decidam ou não entrar para ela, enquanto as organizações sinalizam que são bons lugares para se trabalhar; pretendem obter dos candidatos sinais que mostrem claramente o valor potencial deles como futuros empregados.

A partir do recrutamento, Carvalho e Nascimento (1998) comentam que o sistema de RH passa a centralizar suas ações e programas no ocupante de cargo, quer dizer no candidato que concorre ao exercício das funções que compõem esse mesmo cargo e o contexto da identificação do ocupante do cargo que a empresa recorre ao mercado de trabalho, ao qual pode ser local, isto é, presente na própria comunidade onde a organização atua, ou, de acordo com as exigências do cargo a ser preenchido, regional, nacional ou até internacional todo esse intercâmbio é de responsabilidades da atividade de recrutamento, a qual pode ser identificada como sendo o processo que objetiva pesquisar dentro e fora da empresa onde estão os potenciais talentos.

\section{Quadro 01 - Tipos de recrutamento}

\begin{tabular}{|c|c|}
\hline Interno & $\begin{array}{l}\text { É o processo que ocorre quando, havendo uma determinada vaga a empresa procura } \\
\text { preenchê-la através do remanejamento de seus empregados, que podem ser promovidos ou } \\
\text { transferidos ou ainda transferidos com promoção. }\end{array}$ \\
\hline Externo & $\begin{array}{l}\text { Funciona com candidatos vindos de fora da organização. Havendo uma vaga, a organização } \\
\text { procura preenchê-la com pessoas estranhas, ou seja, com candidatos externos atraídos pelas } \\
\text { técnicas de recrutamento onde o recrutamento externo incide sobre candidatos reais ou } \\
\text { potenciais, disponíveis ou aplicados em outras organizações. }\end{array}$ \\
\hline Misto & $\begin{array}{l}\text { Na prática as empresas nunca fazem apenas recrutamento interno ou apenas recrutamento } \\
\text { externo. Ambos se complementam e se completam. Devido às vantagens e desvantagens dos } \\
\text { recrutamentos interno e externo. Uma solução eclética tem sido preferida pela maioria das } \\
\text { empresas: o recrutamento misto, ou seja, aquele que aborde tanto fontes internas como fontes } \\
\text { externas de recursos humanos. }\end{array}$ \\
\hline
\end{tabular}

Fonte: Adaptado de Chiavenato, 2006.

Em relação à abrangência do recrutamento, Lacombe (2005) aponta que esse abrange o conjunto de práticas e processos usados para atrair candidatos para as vagas existentes ou potencias. Na visão do autor, o recrutamento deve ser efetuado em uma unidade centralizada, e é uma atividade permanente, sendo apenas intensificada nas ocasiões em que existem vagas. Finaliza afirmando que o recrutamento é apenas a primeira etapa de um processo que termina como contrato definitivo após o período de experiência. Chiavenato (2006) conclui que o recrutamento é dividido em três tipos de processos, conforme apresentado no quadro 01.

\subsection{COMPETÊNCIAS}

O mundo dos negócios está cada vez mais competitivo segundo Vilas Boas (2011), obrigando as organizações a estarem sempre buscando o diferencial que lhe permita a sua sobrevivência. Para isso, algumas empresas vêm investindo na oferta de seus produtos ou em seus serviços prestado, enquanto procura conhecer profundamente quem é seu público alvo. Parti desse ponto o surgimento da gestão por competência.

O termo competência, conforme conceituado por Fischer, Dutra e Amorim (2009) vem da palavra latina competens que significa "o que vai com", "o que é adaptado". A competência não é um estado ou conhecimento adquirido; a competência precisa de ação para existir. Segundo o autor, o conceito de competência mostre uma realidade dinâmica, mais um processo do que um estado, ou seja, usando a competência é o que nos torna competente.

Competências segundo Mascarenhas (2008) são usadas para a criação de uma abordagem alternativa às metodologias tradicionais de gestão do desempenho - a gestão das competências. 0 autor aponta com essa abordagem que a noção de competência individual surge em substituição ao mesmo conceito da qualificação para um posto de trabalho como base para o desenvolvimento de modelos integrados de gestão de pessoas que sejam mais abrangentes que possam caracterizar as organizações em aprendizagem. 
Competência é tratada por Vilas Boas e Andrade (2009) como uma prática estratégica tendo como objetivo principal melhorar o desempenho geral da empresa por meio de acrescentar o desenvolvimento individual dos funcionários. Pode-se dizer em termos gerais que alguma empresa ou alguém só é competente quando se tem a capacidade, habilidade, vontade e atitude para realizar algo. Uma visão mais ampla sobre a competência é, que ela pode ser definida ainda como o saber agir responsável e reconhecimento, que implica mobilizar, integrar e transferir seus conhecimentos. Além disso, ser competente significa mobilizar recursos e habilidades que possam agregar valores econômicos às organizações e valores sociais ao indivíduo.

Quanto às competências requeridas, Sant'Anna apud Schotten, (2011) afirma após três levantamentos de dados empíricos, descritos como o primeiro realizado junto a 654 pós-graduandos da área de Administração, um segundo compreendendo a investigação de 220 egressos pós-graduandos de programas de pós-graduação lato sensu não área de telecomunicações e um terceiro estudo abrangendo 129 graduandos em administração, que as novas competências individuais requeridas são: o domínio de novos conhecimentos técnicos associados ao exercício do cargo ou função ocupada; capacidade de aprender rapidamente novos conceitos e tecnologias; criatividade; capacidade de inovação; capacidade de comunicação; capacidade de relacionamento interpessoal, capacidade de trabalhar em equipes; autocontrole emocional; visão de mundo ampla e global; capacidade de lidar com situações novas e inusitadas; capacidade de lidar com incertezas e ambiguidades; iniciativa de ação e decisão; capacidade de comprometer-se com os objetivos da organização; capacidade de gerar resultados efetivos e capacidade empreendedora.

A competência é vista por Dutra (2011) como uma capacidade de entrega da pessoa, e também, como um conjunto de qualificação que o indivíduo possui para se dedicar totalmente a empresa, mostrando a suas capacidades de trabalho. Competência é na verdade colocar em prática tudo aquilo que se sabe.

\subsection{COMPETÊNCIAS INDIVIDUAIS}

O conceito competência para Vilas Boas e Andrade (2009) passou-se a se desenvolver no campo da administração ao longo dos anos de 1990, formando assim, uma nova estratégica: a gestão por competência, que envolve o estudo das competências individuais para melhorar o desempenho da organização como um todo. Competência individual também pode ser conhecida como competências humanas ou como competências profissionais, referindo-se as características que os funcionários devem ter para o auxílio na realização de objetivos nas empresas.

Dentro deste conceito os autores dizem que as competências individuais representam um conjunto de conhecimentos, habilidades, atitudes de indivíduo ou das equipes de trabalho a que irão gerar diferencial competitivo para a empresa. Trata-se não só de competências técnicas, mas também comportamentais.

Para sustentar esses conhecimentos evidentes, Pereira (2012) fala que é necessário estar sempre preparado para as mudanças que surgem ser flexível, ter iniciativas, ser ousado e ter coragem. É preciso também saber agir, ter escolhas, tomar decisões, ter mobilidade, ser comunicativo, aprender assumir responsabilidades e se comprometer com as atividades exercidas.

Continua ele afirmando que o sucesso da organização é o ajuntamento da competência individual com as essenciais e com seus objetivos estratégicos, e é bom estar sempre consciente de que o sucesso está nas mãos de todos, que direta ou indiretamente todos estão envolvidos com seu resultado final. É assim que se faz a diferença nas competências individuais.

Mascarenhas (2008)assimila novas dimensões de qualificação ao conceito de competência individual e que aponta capacidade de pensar diferencialmente, já que os trabalhos mediados pelos computadores tornam-se distante de suas referências físicas, o raciocínio indutivo, uma vez que a informações impõe aos indivíduos a necessidade de se pensar analiticamente, compreendendo assim as relações potenciais entre os dados e utilizando-os para reflexão, construção e teste de hipóteses e, por último a concepção teórica dos processos aos quais os dados se referem, ou uma espécie de roteiro sobre os processos.

Kanaane (2011) competência técnica é um valor agregado ao trabalho e ao trabalhador, de forma em que se dá um significado à sua participação enquanto um profissional, mas desde que, não basta só o indivíduo se apropriar somente da ciência e dá tecnologia, uma vez que, ao atuar social e profissionalmente, terá que fazer com que apareça ou que surgem alternativas de comportamentos e atitudes sociais, compatíveis e autênticas sua. 
Fischer, Dutra e Amorim (2009) apontam vários autores contemporâneos que mostram que o diferencial de uma empresa líder em diferentes pontos da atualidade do mercado é a qualidade de seu recurso humano e a forma como essas competências individuais são exploradas. Os autores afirmam ainda que esse tipo de acontecimento tenha levado as pessoas e as empresas a buscar um novo referencial ou até mesmo uma nova conduta e novas competências que permita uma melhoria na sua competitividade.

\section{3-METODOLOGIA}

O objetivo inicial desta pesquisa de avaliar se o recrutamento e seleção de pessoas tem atingindo as expectativas organizacionais, em relação às competências exigidas para os cargos, em especifico para a empresa em questão e identificar se as competências requeridas são compatíveis com as obtidas nos novos funcionários.

Este artigo foi desenvolvido através de uma pesquisa descritiva de base qualitativa, que Rodrigues (2007) define a pesquisa qualitativa de modo descritiva tendo em vista uma descrição de interpretações dos fenômenos e das atribuições dos significados serão de forma básica esclarecedora. Estudo descritivo na visão de Gil (2009) tem como objetivo principal a descrição das características de uma determinada população ou fenômenos, ou então, o estabelecimento de relação entre variáveis. 0 autor complementa que uma das suas características mais significativas está na utilização de técnicas padronizadas de coleta de dados, tais como questionários e observação sistemática.

A coleta de dados foi realizada através de visitas de observação e coleta documental, além de entrevistas no setor de RH da empresa localizada na região noroeste do Paraná, fato que ocorreu no primeiro semestre de 2013. Na ocasião das visitas, o objetivo foi além de conhecer o setor, sua localização dentro do organograma da empresa, identificar as competências que os funcionários contratados pela a empresa deve ter para fazer parte de sua estrutura organizacional, saber se essas competências estão sendo identificadas nos candidatos a vagas, e buscar saber qual o processo adotado pelo o RH da empresa para identificar se os novos funcionários apresentam as competências exigidas na descrição do cargo.

Foram realizadas entrevistas com roteiro semiestruturado, com o responsável pelo o setor de RH. Essas são, de acordo com Marconi e Lakatos (1996) apud Nascimento (2008) um encontro entre duas pessoas, afim de que uma delas obtenha informações a respeito de determinado assunto, mediante uma conversação de natureza profissional. É um procedimento utilizado na investigação social, para a coleta de dados ou para ajudar no diagnóstico ou no tratamento de um problema social. Após coletados os dados nas entrevistas foi analisado e descrito as respostas pelo entrevistador. Os questionários e entrevistas foram conduzidos diretamente pelo pesquisador.

\section{4 - LEVANTAMENTOS DE DADOS}

\section{1 - CARACTERIZAÇÕES DA ORGANIZAÇÃO.}

A empresa estudada atua no ramo industrial e está localizada no noroeste do Estado do Paraná tendo como produtos principais o arroz e derivados do leite, conta com um quadro funcional de 80 empregados. A Empresa se divide em três principais áreas de negócios: Indústria de Beneficiamento de Arroz, Laticínio e Casa Agropecuária.

A principal atividade organizacional está no comércio atacadista de matérias-primas agrícolas com atividade de fracionamento e acondicionamento associada; e como atividade secundária o transporte rodoviário de carga, exceto produtos perigosos e mudanças, intermunicipal, interestadual e internacional, comércio varejista de mercadorias em geral com predominância de produtos alimentícios supermercados. 0 organograma da empresa está ilustrado a seguir e visa identificar a funcionalidade do setor de RH e suas relações estratégicas. 
Figura 01 - Organograma da empresa.

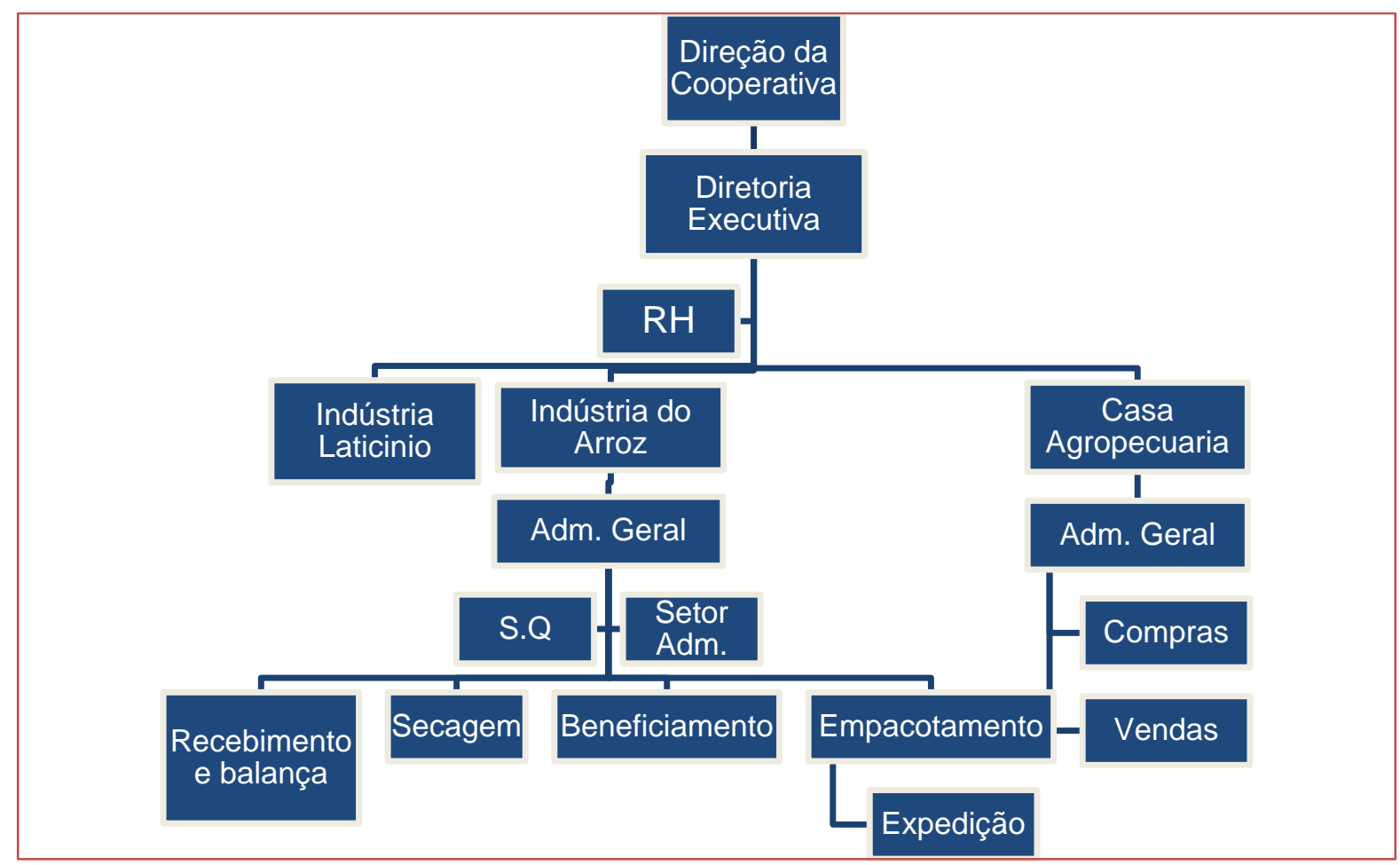

Fonte: Arquivos da empresa.

Em relação à formação do setor de RH, embora conste no organograma funcional um quadro específico para o setor, na realidade ele não é estruturado, ou seja, não há um profissional especifico da área, sendo suas atividades distribuídas entre os demais funcionários do setor administrativo. A chefia fica a cargo do Diretor Executivo, e as atividades de rotina distribuídas com funcionários que acumulam outras funções organizacionais. Vale ressaltar, conforme afirmam Milkovick e Boudrean (2010) que o recrutamento não é importante apenas para a organização, ele é um processo de comunicação bilateral onde os candidatos desejam informações precisas sobre como será trabalhar nessa empresa, por seu lado, a organização deseja saber que tipo de empregado será o candidato, caso seja contratado.

0 fato de a empresa manter em seu organograma um setor específico de Recursos Humanos demonstra que a mesma tem consciência da importância e necessidade do setor o que condiz com a afirmação de Lacombe (2005) que aponta que o recrutamento deve ser efetuado em uma unidade centralizada, e é uma atividade permanente, sendo apenas intensificada nas ocasiões em que existem vagas. Finaliza afirmando que o recrutamento é apenas a primeira etapa de um processo que termina como contrato definitivo após o período de experiência.

Em relação à função de recrutamento, constatamos que fica a critério do administrador da empresa. 0 processo funciona da seguinte forma: A admissão é feita pelo gerente geral e administrativo que delega o poder que faz parte da burocrática, sendo que a contratação de funcionários é feita conforme a necessidade da empresa, a divulgação é feita por seus próprios funcionários e sem a formalização de um manual de descrição de cargos e muito menos de um requerimento de contratação de pessoal.

\subsection{COMPETÊNCIAS REQUERIDAS PELA ORGANIZAÇÃO.}

A empresa busca os princípios básicos que ordenem em suas atividades pessoais para a consecução dos objetivos da empresa, os quais devem ser aplicáveis a todo o quadro pessoal. Embora descrito pelo gestor não está oficializado ou redigido documentalmente. Foram relacionadas como competências exigidas: ser sistemática, ser consistente, ter clareza e facilidade de compreensão. Visto que os dirigentes não tinham um padrão de conhecimento sobre competências requeridas para os cargos, foi elaborado um questionário avaliativo com sugestões de valorização de competências, com base nos estudos de Sant'Ana, apud Schotten (2011), obtendo-se os resultados apresentados no quadro a seguir: 
Quadro 02 - Competências requeridas

Capacidade de lidar com situações novas e inusitadas;

Capacidade de gerar resultados efetivos e capacidade empreendedora;

Iniciativa de ação e de decisão capacidade de comprometer-se com os objetivos da organização;

Capacidade de inovação e de comunicação;

Capacidade que o funcionário tem em aprender rapidamente novos conceitos sobre a tecnologia;

Capacidade de trabalhar em equipes;

Domínio de novos conhecimentos técnicos associados ao exercício do cargo ou função ocupada;

Criatividade

Fonte: Dados da pesquisa.

Sugerido discussão das competências acima, nota-se que em relação aos novos contratados a empresa visa identificar as competências a seguir relacionadas:

a) Capacidade de lidar com situações novas e inusitadas: Este item pode ser o diferencial dentre a equipe de trabalho que pode demonstrar a capacidade de coordenar a equipe, pois para isto é preciso o conjunto de diversos fatores (já citados) como criatividade, iniciativa e compromisso com a empresa.

b) Capacidade de gerar resultados efetivos e capacidade empreendedora: A eficiência na execução do trabalho é o fator primordial para qualquer tarefa que o funcionário venha desenvolver na empresa, e a capacidade empreendedora basicamente é o conjunto dos itens descritos anteriormente, é a capacidade de ver o "todo" e perceber os rumos possíveis a serem tomados para a empresa, portanto indispensável para cargos de gerenciamento e direção da empresa.

c) Iniciativa de ação e de decisão capacidade de comprometer-se com os objetivos da organização: é muito importante a capacidade de exercer o trabalho sem a necessidade constante de ordenar o que deve ser feito e a cumplicidade junto às metas da empresa, pois é claro que se o funcionário faz com que a empresa cresça naturalmente ele cresce junto, este item é indispensável para cargos de coordenação e gerenciamento.

d) Capacidade de inovação e de comunicação: A capacidade de inovação pode significar iniciativa, mas a comunicação tem maior peso para o trabalho coletivo e principalmente nos cargos de coordenação de equipes.

e) Para a capacidade que o funcionário tem em aprender rapidamente novos conceitos sobre a tecnologia: Como dito anteriormente, a tecnologia é dinâmica, por isso é indispensável que o funcionário sempre tenha o interesse e capacidade de seguir reciclando seus conhecimentos e se aperfeiçoando.

f) Capacidade de trabalhar em equipe: É indispensável para a empresa o trabalho em equipe, pois a produção em escala é desenvolvida em diversos setores e equipes de trabalho.

g) O domínio de novos conhecimentos técnicos associados ao exercício do cargo ou função ocupada: O conhecimento básico sobre a atividade a ser realizada é importante, no entanto a tecnologia é algo dinâmico e, portanto, sempre haverá a necessidade de buscar o aperfeiçoamento e a reciclagem do conhecimento, sendo assim é mais importante o interesse em sempre aprender.

h) Criatividade: Pode demonstrar iniciativa, no entanto em excesso e por si só pode se confundir com autossuficiência, gerando problemas com a execução do trabalho coletivo e/ou equívoco na tomada de decisões que podem afetar a cadeia de produção.

Pode ser visto que a empresa, embora não de forma sistemática, procura uma maneira de enquadrar as competências requeridas de seus potenciais candidatos à realidade organizacional ressaltando-se a afirmação de Dutra (2011) para quem a competência pode ser vista como uma capacidade de entrega da pessoa, e também, como um conjunto de qualificação que o indivíduo possui para se dedicar totalmente a 
empresa, mostrando a suas capacidades de trabalho. Competência é na verdade colocar em prática tudo aquilo que se sabe.

\subsection{PROCESSOS ADOTADOS PELO RH NO RECRUTAMENTO EM BUSCA DESSAS COMPETÊNCIAS.}

Não existe um processo especificamente adotado na empresa que registre ou identifique a busca de competências, como dito anteriormente, a empresa é dividida entre áreas de negócios, e cada uma tem suas particularidades na maneira de recrutar pessoas. Cada área tem um Executivo Geral que exerce essa função, as contratações são feitas através das necessidades setoriais, mas procuram seguir um mesmo padrão de contratação que é por meio de:

\section{Entrevista}

2. Contrato de Experiência por 45 dias com renovação por 45.

3. Treinamento Introdutório.

4. Avaliação do Desempenho pelo Coordenador do Setor.

5. Contração definitiva ou dispensa.

\subsection{CRUZAMENTOS DE INFORMAÇÃO ENTRE COMPETÊNCIAS REQUERIDAS X COMPETÊNCIAS OBTIDAS.}

Ao procurar resultados obtidos com as competências identificadas nos novos funcionários, o diretor administrativo, segundo o qual poderia descrever esse resultado através de atribuições de notas dadas a esses funcionários de 0 a 10. Na sua visão os funcionários após contratados em relação ao requisito competências poderiam levar a nota 07 de acordo com a organização, sendo na maioria dos casos após o funcionário passar por certo período de experiência essa nota atribuída a ele pode se elevar a nota 08, pois 90\% de seus funcionários novos não possuem experiência e/ou a formação necessária para desenvolver trabalhos designados.

Além disso, pode se observar que a organização vê a evolução profissional de cada funcionário de forma a identificar os futuros líderes das equipes e em qual setor o funcionário obterá maior produtividade. Portanto a empresa acaba investindo em treinamento durante o período de experiência, assim a capacidade e o interesse de aprender de cada funcionário são essências para a sua permanência na empresa.

A partir desta constatação, destaca-se que os autores dizem que as competências individuais representam um conjunto de conhecimentos, habilidades, atitudes de indivíduo ou das equipes de trabalho a que irão gerar diferencial competitivo para a empresa. Trata-se não só de competências técnicas, mas também comportamentais. Destaca-se ainda que para sustentar esses conhecimentos evidentes, Pereira (2012) fala que é necessário estar sempre preparado para as mudanças que surgem ser flexível, ter iniciativas, ser ousado e ter coragem. É preciso também saber agir, ter escolhas, tomar decisões, ter mobilidade, ser comunicativo, aprender assumir responsabilidades e se comprometer com as atividades exercidas.

\subsection{ANÁLISE GERAL DO PROCESSO}

Na visão do pesquisador, nota-se que a empresa não está estruturada para uma gestão de competência. Não há uma preocupação em talvez formalizar essas competências visando apenas à percepção de seus colaboradores no processo em uma rápida análise poderia se apontar que a organização apesar dela ter um organograma em que aponta que a um setor de RH ela demonstra certas dificuldades com o quadro de funcionalidade desse setor por não ter uma pessoa especifica nessa área que possa tomar frente a todas as contratações da empresa, tirando assim de seus diretores administrativos essa responsabilidade de contratações.

Ao verificar tal situação, demonstra-se que a empresa não é atenta a importância do processo de Recrutamento, dificultando o processo visto que Carvalho e Nascimento (1998) comentam que o sistema de RH organizado passa a centralizar suas ações e programas no ocupante de cargo, quer dizer no candidato que concorre ao exercício das funções que compõem esse mesmo cargo e o contexto da identificação do ocupante do cargo que a empresa recorre ao mercado de trabalho, ao qual pode ser local, isto é, presente na própria comunidade onde a organização atua, ou, de acordo com as exigências do cargo 
a ser preenchido, regional, nacional ou até internacional todo esse intercâmbio é de responsabilidades da atividade de recrutamento, a qual pode ser identificada como sendo o processo que objetiva a pesquisa, dentro e fora da empresa.

Com um setor de RH definido e bem estruturado a organização conseguirá ir a busca dessas competências exigidas por ela, e terá um conhecimento mais amplo de seus novos funcionários podendo perceber neles quais são suas habilidades que possa contribuir na produtividade da empresa.

Em relação à operacionalidade, nota-se que embora de maneira informal, a instituição tem algumas linhas que condizem à gestão por competências, ou seja, fazem muitas vezes sem ter noção de que estão fazendo. Isso fica evidente nas pesquisas com os gestores responsáveis pela contratação e pela avaliação das pessoas dentro de seu período de experiência. Essa informalidade pode comprometer o resultado organizacional visto que na visão de Vilas Boas (2011) o mundo de negócios está cada vez mais competitivo obrigando as organizações a estarem sempre buscando o diferencial que lhe permita a sobrevivência.

Vale ressaltar que os aspectos positivos em relação à gestão por competências localizados na organização são a busca por princípios básicos que ordenem suas atividades pessoais consecutivas para ir à busca de seus objetivos valorizando as habilidades de seus funcionários. A competência é tratada por Vilas Boas e Andrade (2009) como uma prática estratégica tendo como objetivo principal melhorar o desempenho geral da empresa por meio de acrescentar o desenvolvimento individual dos funcionários. Pode-se dizer em termos gerais que alguma empresa ou alguém só é competente quando se tem a capacidade, habilidade, vontade e atitude para realizar algo.

Em contrapartida, os aspectos negativos são os dirigentes não terem um conhecimento mais amplo sobre a gestão de competências e por não terem um setor de RH bem estruturado que pudesse valorizar mais esse processo adotado por essa gestão que é essencial para o desenvolvimento da empresa. Esse processo não estruturado compromete todo o processo de recrutamento, pois como afirmado por Toledo e Milione apud Pontes (1996), recrutamento "é a etapa inicial do processo de busca e atração de mão de obra para a organização, procura prover o número adequado de candidatos para as posições em aberto”.

\section{CONSIDERAÇÕES FINAIS}

Esta pesquisa teve como objetivo avaliar se o processo de recrutamento e seleção de pessoas tem atingindo as expectativas organizacionais em relação às competências exigidas para os cargos, descrever todo o processo de recrutamento adotado pela a organização, identificar as competências requeridas para novos funcionários, comparar as competências requeridas com as obtidas de novos funcionários.

Para atingir ao objetivo inicial, em seu referencial teórico a pesquisa aborda o processo de recrutamento que está dividido em três etapas como, por exemplo, Recrutamento Interno, Recrutamento Externo e Recrutamento Misto. Dando continuidade as avaliações de identificação das competências atribuídas a cada cargo.

Aponta-se como resultado do trabalho que embora a organização demonstre em seu organograma um setor de RH, na realidade da empresa ele não é estruturado da forma que deveria ser. Ou seja, não existe um profissional específico para esse setor, sendo assim, suas atividades são distribuídas aos seus diretores executivos acumulando suas funções organizacionais. A contratação de funcionários ocorre quando há uma necessidade da empresa. Na admissão de um funcionário é feito por um gerente geral e administrativo, sendo que as divulgações de uma oportunidade de trabalho são feitas pelo seu próprio funcionário.

Em relação à gestão por competências a empresa não segue nenhum processo específico em busca dessas competências e que nem seus dirigentes tinham um conhecimento sobre essas competências requeridas, foi elaborado então um questionário em que se pudessem avaliar as valorizações dessas competências. Como resultado do questionário, conclui-se que embora de maneira não sistematizada a organização tenha informalmente uma preocupação, não um processo, apenas preocupação com a competência da pessoa que é admitida para exercer atividades dentro da organização.

Como limitação dessa pesquisa, aponta-se que o objetivo era identificar se as pessoas contratadas pelo setor de Recursos Humanos ofereciam para a empresa as competências requeridas, ficando prejudicado pela própria falta de informação ou processo formal de trabalho visando isto. Mas com base nas pesquisas, identificou-se que no processo informal há sim uma oferta das competências requeridas pelos recémcontratados. Não era objetivo interferir na realidade organizacional, o que não foi feito. 
Finaliza-se por apontar que essa pesquisa pode contribuir com trabalhos futuros no desenvolvimento para uma nova ideia de como avaliar o processo de gestão por competência, deixando o leitor atualizado sobre o que a organização vem cobrando das pessoas para poder torna-se um membro dela, o leitor pode ter um conhecimento de como funciona o processo de recrutamento influenciando ele a se capacitar para estar preparado para um processo seletivo de recrutamento.

\section{REFERÊNCIAS}

[1] CARVALHO, Antônio Vieira, NASCIMENTO. Luiz Paulo. Administração de Recursos Humanos. São Paulo, 1aㅗ Edição, Editora Saraiva. 1998.

[2] CHIAVENATO, Idalberto. Recursos Humanos: Capital das Organizações. São Paulo, 8ª Edição, Editora Atlas. 2006.

[3] CHIAVENATO, Idalberto. Recursos Humanos. São Paulo, 5ạ Edição, Editora Atlas S.A. 1998.

[4] DUNTRA, Joel Souza. Gestão de Pessoas: Modelo, Processos, Tendências e Perspectivas. São Paulo, 1a Edição, Editora Atlas. 2011. (pag. 21).

[5] FISCHER, André Luiz; DUTRA, Joel Souza; AMORIM, Wilson Aparecido Costa. Gestão de Pessoas: Desafios estratégicos das Organizações Contemporâneas. São Paulo, 1aㅡ Edição, editora Atlas. 2009. (pag. 57 e 78).

[6] GIL, Antônio Carlos, Como Elaborar Projetos de Pesquisa. São Paulo, 4a Edição, Editora Atlas. 2002.

[7] KANAANE, Roberto. Comportamentos Humanos nas Organizações. São Paulo, 3a Edição, Editora Atlas. 2009.

[8] LACOMBE, Francisco. Recursos Humanos: Princípios e Tendências. São Paulo, 8ª Edição, Editora Saraiva. 2005.

[9] MASCARENHAS, André Ofenheim. Gestão Estratégica de Pessoas: evolução, teoria e crítica. São Paulo, Cengage Learning, 2008.

[10] MILKOVICH, George T.; BOUDREAN, John W. Administração de Recursos Humanos. São Paulo, 8ª Edição, Editora Atlas, 2010.

[11] PONTES, B. R. Planejamento, Recrutamento e Seleção de Pessoas. São Paulo, 2ª Edição, Editora LTr, 1996.

[12] RODRIGUES, William Costa. Metodologia cientifica. 2007. Disponível em: <http://professor.ucg.br/SiteDocente/admin/arquivosUpload/3922/material/Willian\%20Costa\%20Rodrigues_meto dologia_cientifica.pdf > . Acessado em 25 de junho de 2012 as $09 \mathrm{hs:} 12 \mathrm{~min}$.

[13] SCHOTTEN, Paulo César. Gestão por Competências: Evolução dos Conceitos e Comparativo entre Competências Individuais e Competências Organizacionais. $2011 . \quad$ Disponível em https://www.academia.edu/7854063/ARTIGO_GESTAO_DE_COMPETENCIA_PCS

[14] VILAS BOAS, Ana Alice. ANDRADE, Rui Otávio Bernardes de. Gestão Estratégica de Pessoas; 1o Edição, Editora Campus, 2009, São Paulo. 


\section{Capítulo 13}

TENDÊNCIA EMPREENDEDORA: UMA ANÁLISE COMPARATIVA ENTRE OS ACADEMMICOS DOS CURSOS DE ADMINISTRAÇÃO E CIÊNCIAS CONTÁBEIS DO CAMPUS PANTANAL DA UNIVERSIDADE FEDERAL DE MATO GROSSO DOSUL

\section{Rafaela Esmorges Assad \\ Roosiley dos Santos Souza \\ Valdir da Costa Pereira}

Resumo: 0 objetivo do estudo foi identificar e comparar a tendência empreendedora dos acadêmicos dos cursos de Administração e Ciências Contábeis no campus Pantanal, da Universidade Federal de Mato Grosso do Sul. Tratou-se de uma pesquisa de caráter exploratório, apoiada em uma abordagem quantitativa. Utilizou-se como instrumento de coleta de dados, um questionário sociodemográfico e o teste Tendência Empreendedora Geral (TEG). 0 teste permite afirmar se o indivíduo possui ou não tendência ao empreendedorismo, com base na análise das médias obtidas em cinco características comuns aos empreendedores de sucesso: Necessidade de sucesso, tendência criativa, necessidade de autonomia, propensão a riscos e impulso/determinação. 0 teste foi aplicado em uma amostra de 60 acadêmicos, selecionada de maneira não probabilística intencional, compreendendo as séries iniciais e finais dos cursos participantes. 0 resultado da aplicação do TEG apresentou um nível de empreendedorismo abaixo da média esperada entre os cursos, objeto desta pesquisa, evidenciando a importância do desenvolvimento de atividades e projetos voltados à conexão da teoria com a prática por parte dos cursos. Tais medidas podem contribuir para o desenvolvimento de comportamentos, habilidades e conhecimentos necessários na formação de profissionais com competências empreendedoras.

Palavras-chave: Perfil Empreendedor; Tendência Empreendedora Geral (TEG); Ensino do Empreendedorismo. 


\section{INTRODUÇÃO}

Segundo Souza, Silveira e Carmo (2016) a educação para o empreendedorismo é vista pelo governo como um desafio econômico e social fundamental, que através de políticas públicas procuram estimular o desenvolvimento do comportamento empreendedor. Dornelas (2014) afirma que o contexto atual é propício para o surgimento de novos empreendedores, sendo necessária a capacitação desses indivíduos. Devido a isso, há a preocupação por parte das escolas e universidades de oferecer matérias e cursos específicos voltados ao empreendedorismo.

As IES, como instituições voltadas para a transmissão e geração de conhecimento, exercem um papel de fundamental importância, pois oferecem as informações e conhecimentos pertinentes para que possam ser desenvolvidos profissionais dinâmicos e inovadores que façam a diferença no ambiente em que atuam. É necessária a adoção de novos modelos educacionais para acompanhar as mudanças do ambiente. 0 ensino superior, mais especificamente os cursos de graduação, contribui para manifestar o perfil empreendedor.

O empreendedorismo nos cursos de graduação, neste caso os cursos de Administração e Ciências Contábeis, deve permitir que os acadêmicos adquiram conhecimentos relevantes sobre o tema e desenvolvam mudanças comportamentais, incentivando o desenvolvimento do perfil empreendedor. Com o intuito de entender a abordagem do empreendedorismo nas IES e o interesse de investigar o perfil empreendedor de acadêmicos, o objetivo deste estudo foi identificar e comparar as características empreendedoras dos acadêmicos dos cursos nível bacharelado de Administração e Ciências Contábeis do Campus Pantanal da Universidade Federal do Mato Grosso do Sul, através da aplicação do teste de Tendência Empreendedora Geral, respondendo ao seguinte questionamento: Qual é a tendência empreendedora dos acadêmicos dos referidos cursos, levando em consideração as contribuições que o ambiente acadêmico proporciona para a construção deste perfil?

Este trabalho está dividido com a seguinte estrutura: revisão da literatura, para esclarecimentos acerca do tema abordado nesta pesquisa; metodologia utilizada; discussão e análise dos dados obtidos e as considerações finais.

\section{REVISÃO DA LITERATURA}

\subsection{EMPREENDEDORISMO NO BRASIL}

O empreendedorismo no Brasil tomou forma quando fatores políticos e econômicos afetaram o país e fez com que grandes empresas buscassem alternativas para manterem-se competitivas no mercado. Com a criação do Estatuto da Micro e Pequena Empresa, em 1984, e de entidades como o Serviço Brasileiro de Apoio às Micro e Pequenas Empresas (Sebrae) e a Sociedade Brasileira para Exportação de Software (Softex), na década de 1990, o empreendedorismo ganhou maior impulso. Antes disso, não se falava em empreendedorismo ou criação de pequenas empresas. 0 empreendedor não encontrava informações para ajudá-lo (Dornelas, 2014).

Dada a grande influência dos empreendedores no crescimento econômico do país, as universidades brasileiras criaram cursos e programas para o ensino do empreendedorismo. A primeira disciplina relacionada ao empreendedorismo no Brasil surgiu em 1981, na Escola Superior de Administração de Empresas da Fundação Getúlio Vargas, em São Paulo. Denominada "Novos Negócios", a disciplina foi ministrada entre os anos de 1981 e 1987. Desde então, muitas outras universidades incorporaram em suas grades curriculares disciplinas e projetos relacionados ao empreendedorismo (Dolabela, 1999 apud Espirito Santo, 2011).

Segundo Dornelas (2014) o Brasil encontra-se hoje com todo o potencial para desenvolver um dos maiores programas de ensino do empreendedorismo. Ações históricas e algumas mais recentes como: a criação do programa Brasil Empreendedor, que vigorou entre 1999 e 2002, que tinha como objetivo a capacitação de mais de seis milhões de empreendedores em todo o país; ações voltadas para a capacitação do empreendedor, como os programas Empretec e Jovem Empreendedor do Sebrae; crescimento de incubadoras no país, apontam para tal direção.

O empreendedorismo é visto como um gatilho para a geração de novos conhecimentos e tecnologias, potencializando o papel dos empreendedores como agentes de inovação e desenvolvimento (SOUZA, SILVEIRA E CARMO, 2016). Ainda de acordo com Souza, Silveira e Carmo (2016) o empreendedorismo vendo sendo evidenciado pelas novas demandas de mercado que exigem indivíduos, empresas e regiões mais preparados para atuarem com práticas empreendedoras, sustentáveis, competitivas e inovadoras. 
Sendo assim, é de fundamental importância compreender como o empreendedorismo pode ser ensinado e porque ele deve ser ensinado. Dada essa necessidade de compreensão a educação para empreendedorismo no Brasil tem sido objeto de estudos.

Neste cenário, destaca-se o projeto de pesquisa Global Entrepreneurship Monitor (GEM), que tem como objetivo compreender o papel do empreendedorismo no desenvolvimento econômico e social do país (GEM, 2015). Para o GEM (2015), o empreendedorismo consiste em qualquer tentativa de criação de um novo empreendimento. Em 2015, a Taxa Total de Empreendedorismo (TTE) para o Brasil foi de 39,3\%, estimando-se que 52 milhões de brasileiros com idade entre 18 e 64 anos estavam envolvidos na criação ou manutenção de algum negócio. Comparada à TTE de 2014 (34,4\%), observa-se aumento significativo, o que intensifica a trajetória de crescimento observada desde 2011, conforme ilustrado na figura 1.

Figura 1: Evolução da taxa total de empreendedores - Brasil 2002:2015

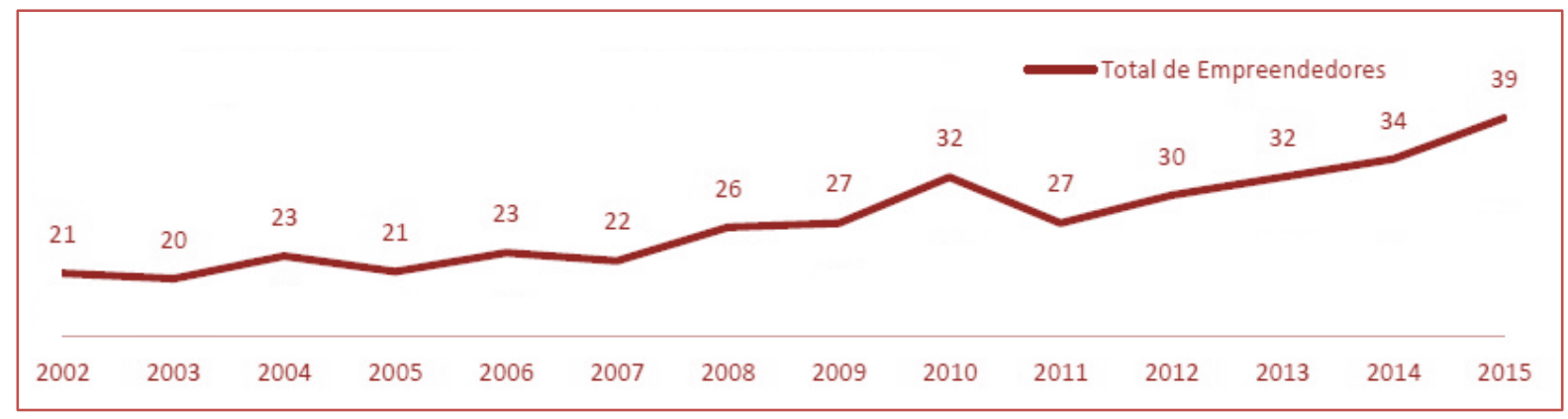

Fonte: adaptado de IBPQ/Pesquisa GEM 2015

Segundo a pesquisa GEM (2015), características como criatividade e resiliência são favoráveis ao empreendedorismo no Brasil, mesmo em um ambiente marcado pela incerteza. Os especialistas afirmam que o amplo acesso à informação sobre negócios e empreendedorismo contribui para a disseminação do conhecimento e favorece a minimização de custos do negócio. As políticas governamentais implementadas na última década como o Simples Nacional e o Micro Empreendedor Individual (MEI) também favorecem e fortalecem o ambiente empreendedor no Brasil. No entanto, faltam políticas públicas adequadas às necessidades dos empreendedores.

Ainda de acordo com o projeto GEM (2015) a educação e treinamento são algumas das condições que interferem na atividade empreendedora no Brasil. Neste contexto, torna-se necessário, no Brasil, que o empreendedorismo seja disciplina transversal e esteja presente em todos os níveis educacionais, especialmente no ensino superior, de modo a estimular o desenvolvimento de características empreendedoras em seus alunos.

\subsection{EDUCAÇÃO EMPREENDEDORA}

Segundo Kuratko (2005 apud Souza, Silveira e Carmo, 2016) a educação para o empreendedorismo surgiu da intenção do indivíduo de empreender como rota de desenvolvimento da cultura empresarial e para estimular o espírito empreendedor através da aprendizagem. Os mesmos autores, afirmam que a educação voltada para o empreendedorismo é tratada em todos os níveis de ensino - desde o básico ao superior, com o objetivo de criar profissionais que sejam agentes de inovação e desenvolvimento, com o intuito de estabelecer uma cultura empreendedora nos países.

As IES têm importante participação neste processo pois elas podem preparar profissionais com habilidades e competências necessárias para iniciar seu próprio negócio através da adoção de programas de educação empreendedora. Segundo Espírito Santo (2011) as IES devem adotar metodologias que aliem a teoria à prática inovadora e potencializadora de resultados para a sociedade. De acordo com Dornelas (2014) o ensino do empreendedorismo é importante, pois ajuda na formação de melhores empresários, melhores empresas e a maior geração de riquezas para o país.

De acordo com Masiero (2009), o ensino do empreendedorismo deve desenvolver e favorecer diversas habilidades e capacidades do indivíduo, proporcionando vivência de experiências e o desenvolvimento de atitudes empreendedoras, com o intuito de que o mesmo seja um agente de desenvolvimento da sociedade onde vive. Para Dornelas (2014), a metodologia de ensino do empreendedorismo difere de uma universidade para outra, mas de maneira geral os cursos voltados para este ensino devem focar na 
identificação e no entendimento das habilidades do empreendedor, na inovação e no processo empreendedor, importância do empreendedor para o desenvolvimento econômico, na identificação e análise de oportunidades, e como elaborar um plano de negócios e gerenciar e fazer a empresa crescer em um ambiente mutável e competitivo.

Conforme relatório da pesquisa "Empreendedorismo nas Universidades Brasileiras 2014", realizada pela Endeavor em parceria com o Sebrae, as disciplinas de empreendedorismo nas IES brasileiras são de caráter introdutório. A pesquisa ainda revela que as disciplinas de empreendedorismo não estão bem distribuídas entre os cursos de ensino superior. A pesquisa revela que as IES têm grande capacidade para fornecer mais apoio para empreendedores e potenciais empreendedores, de modo que estes consigam implantar ideias mais inovadoras para melhorar a sociedade que as cercam (Empreendedorismo nas Universidades Brasileiras 2014). Isso pode ocorrer com a implantação de uma educação empreendedora voltada para a geração e disseminação de conhecimentos que culminem na formação de agentes de inovação e desenvolvimento econômico.

\subsection{ESTUDOS ANTERIORES}

Observa-se especificamente na IES, objeto deste estudo, que o interesse em identificar o Perfil Empreendedor surgiu em 2011. Os estudos citados a seguir buscaram investigar a Tendência Empreendedora Geral especificamente na cidade de Corumbá/MS, em âmbito acadêmico e âmbito empresarial. A aplicação do questionário TEG teve o intuito de trazer contribuições para as IES e seus respectivos cursos, no sentido de identificar o perfil empreendedor dos acadêmicos e a partir de aí verificar quanto aos ensinamentos e o ambiente da IES pode contribuir positivamente para o desenvolvimento e aperfeiçoamento do perfil empreendedor dos seus acadêmicos.

Espírito Santo (2011) desenvolveu o trabalho denominado "Tendência Empreendedora: uma análise do perfil dos acadêmicos do curso de administração em instituição de ensino superior da cidade de CorumbáMS", com objetivo de identificar a tendência empreendedora entre os acadêmicos dos cursos de Administração da Universidade Federal de Mato Grosso do Sul, Campus do Pantanal e com dois polos universitários de Educação à Distância (EAD) presentes na cidade de Corumbá-MS: UNIDERP ANHANGUERA e UNOPAR, fazendo uma análise comparativa.

A pesquisa realizada com uma amostra de 149 acadêmicos constatou uma baixa tendência ao empreendedorismo em todas as IES participantes. Este resultado sugere que as IES desenvolvam atividades e disciplinas que possam estimular características empreendedoras entre seus acadêmicos. A pesquisa ainda apresentou que os acadêmicos de curso EAD têm uma tendência maior para 0 empreendedorismo, enquanto que na IES Federal o perfil é mais para concurso público.

Nessa mesma linha, Silva (2016) desenvolveu o trabalho denominado "Análise da tendência empreendedora entre os acadêmicos do curso de Administração do Campus Pantanal da Universidade Federal de Mato Grosso do Sul". Tal estudo apresentou como objetivo a identificação e análise da tendência empreendedora entre os acadêmicos do curso de Administração do Campus Pantanal da Universidade Federal de Mato Grosso do Sul. A pesquisa compreendeu uma amostra composta por 77 acadêmicos e constatou baixo grau de tendência ao empreendedorismo, evidenciando que a Universidade tem possibilidade de trabalhar os conceitos que regem o desenvolvimento de características que compõem o perfil empreendedor, com o intuito de formar administradores mais capacitados e com maior conhecimento sobre o empreendedorismo para o mercado de trabalho.

Numa outra vertente em que se aplicou o TEG, desenvolvido por Samaniego (2014), denominado "Tendência Empreendedora: Um estudo sobre o perfil dos motos taxistas do município de Corumbá-MS", teve como objetivo identificar a tendência empreendedora entre os motos taxistas da cidade de Corumbá/MS, fazendo uma análise comparativa entre os motos taxistas do SIMTAC-MS, da COOPERMOTO-TAXI e dos não associados. A pesquisa compreendeu uma amostra de 92 moto taxistas e constatou baixa tendência ao empreendedorismo. Tal resultado indicou a possibilidade de investimentos em estudos de capacitação com o propósito de desenvolver uma cultura empreendedora perante a classe moto taxista da cidade de Corumbá/MS.

Ainda o estudo de Souza, Silveira, Nascimento e Espírito Santo (2014) denominado "Vendedores Ambulantes e Modelo de Caird (1991): Tendência Empreendedora Geral (TEG)"; teve o objetivo de analisar a tendência empreendedora geral dos vendedores ambulantes da cidade de Corumbá/MS. A pesquisa compreendeu uma amostra de 28 vendedores. Os indivíduos participantes da pesquisa não atingiram a média esperada em nenhuma das cinco características analisadas, indicando que os mesmos 
iniciaram seus empreendimentos pela necessidade de garantir o sustento ou complementar a renda familiar.

Amorim (2015), o autor desenvolveu o trabalho denominado "Mulheres empreendedoras e os desafios da gestão". Tal estudo teve como objetivo apresentar o perfil empreendedor das empresárias da cidade de Corumbá/MS e os principais desafios na gestão de seus empreendimentos. A pesquisa compreendeu uma amostra de 14 empresárias e constatou baixo grau de tendência empreendedora, evidenciando a necessidade de conhecimento e viabilização de iniciativas empreendedoras por parte do governo local a fim de fomentar o desenvolvimento econômico local através da abertura de novos negócios.

Espírito Santo (2015) desenvolveu como trabalho de conclusão final em nível de mestrado denominado "Empreendedorismo na Administração Púbica: um estudo do perfil empreendedor da equipe administrativa de uma Instituição Federal de Ensino Superior, como ferramenta de melhoria no desempenho organizacional". Tal estudo teve como objetivo estudar o perfil empreendedor encontrado na equipe de técnico-administrativos do Campus de Três Lagoas (CPTL), através da aplicação do questionário TEG, procurando demonstrar como o perfil empreendedor dos agentes públicos pode contribuir com o fomento do intraempreendedorismo e com melhoria do desempenho organizacional. A pesquisa compreendeu uma amostra constituída por 53 servidores e constatou baixo grau de tendência ao empreendedorismo (neste caso, intraempreendedorismo), evidenciando que o excesso de burocracia e formalismo impedem o surgimento de práticas inovadoras, a proatividade a promoção de melhorias no desempenho organizacional.

O Quadro 1 apresenta os resultados obtidos no Teste TEG em estudos empíricos anteriores em âmbito acadêmico. Nele podemos observar que as dimensões com maior índice são: Impulso/determinação.

Quadro 1: Comparação dos resultados obtidos em estudos empíricos anteriores em âmbito acadêmico.

\begin{tabular}{|l|c|c|c|}
\hline \multicolumn{1}{|c}{ Dimensões } & Média Esperada & $\begin{array}{c}\text { Espirito Santo } \\
(2011)\end{array}$ & 8,57 \\
\hline Necessidade de Sucesso & 9 & 8,85 & 3,42 \\
\hline Necessidade de autonomia/independência & 4 & 3,45 & 7,12 \\
\hline Tendência Criativa & 8 & 6,91 & 7,12 \\
\hline Propensão a riscos & 8 & 7,38 & 9,42 \\
\hline Impulso/Determinação & 8 & 8,62 & \\
\hline
\end{tabular}

Fonte: Elaborado pela autora

Realizando análise comparativa entre os estudos de Espírito Santo (2011) e Silva (2016), o percentual de tendência criativa no curso de administração possui um aumento 0,21 e impulso/determinação 0,8. Os referidos acréscimos podem ter ocorrido por conta da inserção de disciplinas com ênfase em empreendedorismo na grade curricular do curso, conforme o projeto pedagógico em vigor desde 2014. Já em relação à dimensão propensão a riscos houve uma diminuição de 0,26 , comparando os índices obtidos em 2011 e 2016. Tal resultado pode estar relacionado à atual conjuntura econômica, política e social que o país atravessa.

O Quadro 2 apresenta os resultados obtidos no teste TEG nos estudo empíricos anteriores no âmbito empresarial. Observa-se que apenas a média relativa à dimensão impulso/determinação é a que se sobressai. 
Quadro 2: Comparação dos resultados obtidos em estudos empíricos anteriores em âmbito empresarial.

\begin{tabular}{|l|c|c|c|c|c|}
\multicolumn{1}{|c}{ Dimensões } & $\begin{array}{c}\text { Média } \\
\text { Esperada }\end{array}$ & Souza et al (2014) & $\begin{array}{c}\text { Samaniego } \\
(2014)\end{array}$ & $\begin{array}{c}\text { Amorim } \\
(2015)\end{array}$ & $\begin{array}{c}\text { Espirito } \\
\text { Santo (2015) }\end{array}$ \\
\hline Necessidade de Sucesso & 9 & 7,21 & 8,7 & 8,14 & 8,11 \\
\hline $\begin{array}{l}\text { Necessidade de } \\
\text { autonomia/independência }\end{array}$ & 4 & 3,32 & 3,68 & 3,43 & 2,83 \\
\hline Tendência Criativa & 8 & 6,39 & 4,90 & 6,64 & 6,66 \\
\hline Propensão a riscos & 8 & 6,32 & 5,74 & 7,36 & 6,19 \\
\hline Impulso/Determinação & 8 & 6,85 & 9,45 & 9,43 & 9,28 \\
\hline
\end{tabular}

Fonte: Elaborado pela autora

Relacionando com a teoria, existe capacidade de criar, porém, não é o suficiente para dizer que possui o perfil, as demais dimensões estão muito abaixo e pode estar relacionado a diversos fatores tais como o desejo pela estabilidade, o receio de assumir riscos e tomada de decisão, entre outros; proporcionando novas possibilidades de investigação.

\section{METODOLOGIA}

A pesquisa é exploratória, e tem o intuito de obter maior conhecimento sobre o assunto. A fundamentação teórica baseou-se nos estudos de Peloggia (2001), Ferreira e Aranha (2008), Espírito Santo (2011), e Souza et al (2014), e em pesquisa bibliográfica em livros, relatórios de estudos na área, sites específicos da área, dissertações, teses e artigos sobre o tema em estudo. Desse modo utilizou-se o levantamento de fontes secundárias através de pesquisa bibliográfica e, em segundo momento, houve a coleta de dados primários através da aplicação de um questionário sociodemográfico. 0 questionário foi constituído de questões fechadas que, segundo Gil (2008) conferem maior uniformidade às respostas e podem ser facilmente processadas.

O questionário foi aplicado simultaneamente com o teste de Tendência Empreendedora Geral - TEG. 0 teste TEG foi desenvolvido na Durham University Business School, em 1988. Consiste em um instrumento de coleta de dados composto por 54 afirmações, em que os respondentes manifestam sua concordância ou discordância. Este teste tem como objetivo analisar os traços de perfil empreendedor através de cinco dimensões: necessidade de sucesso; necessidade de autonomia/interdependência; tendência criativa; propensão a riscos e impulso/determinação.

a) Necessidade de sucesso: está ligada com a realização pessoal. Segundo Uriarte (2000), a necessidade de sucesso está relacionada com a realização pessoal. No entanto, deve haver um equilíbrio, pois o excesso da mesma, sem a preocupação com as relações humanas pode levar a uma busca desenfreada pelo poder.

b) Necessidade de autonomia/interdependência: o indivíduo prefere tomar suas próprias decisões. Segundo Dornelas (2014) essa característica define o indivíduo empreendedor como aquele que tem a necessidade de estar sempre à frente das mudanças e de ser dono do próprio destino.

c) Tendência criativa: é a capacidade de utilizar a imaginação e a criatividade para solucionar problemas. Segundo Espírito Santo (2011), essa característica estimula a capacidade de raciocínio alternativo, de usar a criatividade para sair de dificuldades ou até mesmo para aumentar os lucros.

d) Propensão a riscos: Segundo Dornelas (2014), é a pessoa que tem tendência a estabelecer metas desafiadoras, porém realistas, assumindo riscos calculados e avaliando as possibilidades de sucesso.

e) Impulso/determinação: para Dornelas (2014), é a capacidade de buscar, de modo veemente, identificar oportunidades e maneiras de se beneficiar da mudança. Segundo Uriarte (1999 apud SANTOS E FLORES, 2012) é a capacidade de criar situações favoráveis e alternativas para resolução de um problema, mesmo antes de ele ter acontecido. 
A aplicação do questionário e do teste TEG deu-se por meio impresso, pois tem sido a prática deste tipo de pesquisa. De acordo com Peloggia (2001), o método para tabulação dos dados se dá pelas seguintes etapas:

1. 0 cartão resposta é composto por áreas sombreadas e não sombreadas. Deve-se anotar 1 ponto para cada "não concordo" (N) assinalado nas casas sombreadas e 1 ponto para cada "concordo" (C) assinalado nas casas não sombreadas.

2. A pontuação deve ser somada por linha e anotada.

3. Em seguida, é feito o lançamento dessa pontuação por linha em uma tabela com duas colunas, sendo uma coluna com o número da linha e outra coluna com a pontuação obtida, de forma a facilitar a visualização.

4. Os pontos obtidos nas linhas serão somados e atribuídos às suas respectivas características da seguinte maneira:

Quadro 3: Metodologia de tabulação do TEG

\begin{tabular}{|c|l|}
\hline \multicolumn{1}{|c|}{ Linhas } & \multicolumn{1}{c|}{ Características } \\
\hline $1+6$ & Necessidade de sucesso \\
\hline 3 & Necessidade de autonomia/independência \\
\hline $5+8$ & Tendência criativa \\
\hline $2+9$ & Propensão a riscos \\
\hline $4+7$ & Impulso e determinação \\
\hline \multicolumn{2}{|l}{ Fonte: Adaptado de Peloggia (2001, p.45-46) } \\
\hline
\end{tabular}

Ferreira e Aranha (2008) apresentam as médias propostas por Caird (1991) ao desenvolver o Teste TEG, que serão utilizadas como parâmetros de análise das médias obtidas com a presente pesquisa, conforme ilustrada pelo quadro 4:

Quadro 4: Metodologia para análise da média das cinco características do perfil empreendedor.

\begin{tabular}{|l|c|c|}
\multicolumn{1}{|c|}{ Característica } & Pontuação Máxima & Média Esperada \\
\hline Necessidade de sucesso & 12 & 9 \\
\hline Necessidade de autonomia/independência & 6 & 4 \\
\hline Tendência criativa & 12 & 8 \\
\hline Propensão a riscos & 12 & 8 \\
\hline Impulso e determinação & 12 & 8 \\
\hline
\end{tabular}

Fonte: Adaptado de Ferreira e Aranha (2008, p. 5)

Quanto à abordagem do problema, a pesquisa foi definida como quantitativa. A pesquisa quantitativa usa a quantificação na coleta de dados e no tratamento das informações coletadas, utilizando medidas estatísticas como o percentual, a média, o desvio-padrão, entre outras.Segundo Lakatos (2006) o enfoque quantitativo vale-se do levantamento de dados para provar hipóteses baseadas na medida numérica e da análise estatística para estabelecer padrões de comportamento.

0 universo desta pesquisa constituiu-se pelos acadêmicos dos cursos de Administração e Ciências Contábeis, nível bacharelado do CPAN/UFMS, constituído por um total de 301 acadêmicos, sendo classificado como universo finito, pois o número de elementos que o constitui não excede 100.000 (GIL, 2008).

Nesta pesquisa, utilizou-se a amostragem não probabilística por acessibilidade, pois o pesquisador seleciona os elementos a que tem acesso, admitindo que estes, de alguma forma, representam o universo 
(GIL, 2008). Como critério da seleção da amostra, aplicou-se a pesquisa nas turmas iniciais e finais dos cursos objeto deste estudo com o intuito de observar e avaliar o grau de contribuição do ensino superior na formação do perfil empreendedor dos acadêmicos ingressantes e concluintes dos cursos objeto do estudo.

A amostra compreendeu os acadêmicos regularmente matriculados e frequentes nas séries iniciais e finais dos cursos de Administração e Ciências Contábeis da Instituição pesquisada, tendo como principal critério de inclusão a presença na aula durante a qual foi aplicado o questionário.No primeiro semestre de 2016, os cursos de Administração e Ciências Contábeis apresentavam a seguinte situação com relação à quantidade de acadêmicos matriculados e frequentes nos períodos iniciais e finais:Administração: 52 acadêmicos no primeiro semestre e 53 acadêmicos no sétimo semestre; Ciências Contábeis: 52 acadêmicos no primeiro semestre e 42 acadêmicos no sétimo semestre.

No segundo semestre de 2016, a realidade apresentada pelos cursos para aplicação do questionário foi diferente. Em ambos os cursos ocorreram desistências na transição do primeiro para o segundo semestre, no entanto, pode-se afirmar que os cursos apresentaram uma quantidade significativa de acadêmicos na composição da amostra.

O curso de Administração contou com a participação de 40 acadêmicos, sendo 25 do segundo semestre e 15 do oitavo semestre. 0 curso de Ciências Contábeis contou com a participação de 20 acadêmicos, sendo 10 do segundo semestre e 10 do oitavo semestre.

A pesquisa foi aplicada no referido curso entre os períodos de 24 e 30 de novembro de 2016, 23 a 27 de janeiro e 6 a 10 de fevereiro de 2017.A metodologia utilizada para análise dos dados quantitativos foi a estatística descritiva básica com auxílio do software Microsoft Excel.

\section{DISCUSSÃO E ANÁLISE DOS DADOS}

De acordo com os resultados obtidos na pesquisa, o gênero predominante no Curso de Administração é o gênero feminino com percentual $(64 \%) \mathrm{n}=40$, faixa etária predominante entre os iniciantes com percentual de $44 \%$ está entre 18 a 21 anos, e entre os concluintes 22 e 26 anos, que corresponde a $66,66 \%$. 0 estado civil predominante é o solteiro, o que corresponde a $80,01 \%$, tanto os ingressantes quanto os concluintes e em sua grande maioria são provenientes do município de Corumbá. Tal resultado difere dos resultados encontrados por Espírito Santo (2011, p. 63), que constatou que $50 \%$ dos acadêmicos ingressantes provinham de outras regiões do país. A renda familiar bruta entre os acadêmicos ingressantes e concluintes encontram-se na faixa de 02 a 05 salários mínimos, o que permite dizer que são pertencentes às classes B1, B2 e C1 conforme oCritério de Classificação Econômica Brasil (ABEP, 2016).

Os acadêmicos ingressantes apresentam maior tempo para estudo visto que a sua maioria não possui outra ocupação. Todavia, entre os concluintes há a predominância de funcionários de empresa privada e funcionários públicos.

Os acadêmicos ingressantes e concluintes, em sua maioria, provêm de escolas públicas. Tal resultado difere do estudo realizado por Espírito Santo $(2011$, p. 65) que constatou que os acadêmicos concluintes daquele ano foram provenientes de escolas privadas.

Ainda sobre os acadêmicos ingressantes e concluintes, eles escolheram curso Administração para trabalhar em cargo público. 0 resultado revela o pouco conhecimento que se tem das inúmeras possibilidades que o curso de administração permite em termos de atuação profissional e ainda revela que esses acadêmicos buscam estabilidade e padrão de vida.

Os entrevistados, em sua grande maioria, consideram que o curso de Administração/CPAN é composto por disciplinas que fornecem subsídios que os auxiliam a serem bons funcionários e conhecimento necessário para abertura do próprio negócio, tais como as disciplinas "Empreendedorismo" e "Jogos Empresariais". Apesar de disciplinas específicas que abordam o tema empreendedorismo só acontecerem no período final do curso em virtude da necessidade de conhecimento em áreas da Administração como a gestão de pessoas, a administração financeira e orçamentária e a administração de produção, entre outras.

Os acadêmicos ingressantes e concluintes não possuem, em sua maioria, nenhum familiar empreendedor até o momento da presente pesquisa, o que fica sob a responsabilidade do curso em despertar o comportamento empreendedor. Para os entrevistados, a definição de empreendedor é compreendida por todos acadêmicos. 
Já os acadêmicos do Curso de Ciências Contábeis que participaram da amostra, apresentaram que o curso é composto em sua maioria pelo gênero feminino $(70 \%) \mathrm{n}=20$ no início do curso, enquanto entre os formandos é composto em sua maioria pelo gênero masculino $(60 \%) \mathrm{n}=20$. A faixa etária de 22 a 26 anos entre os iniciantes e entre os concluintes a faixa etária de 27 a 35 anos. Entre os acadêmicos ingressantes há predominância do estado civil "solteiro", enquanto entre os acadêmicos concluintes há predominância do estado civil "casado".

Diferentemente dos resultados do curso de administração, no curso de Ciências Contábeis, os acadêmicos, ingressantes e concluintes, provêm de outras regiões do país. Os estados citados pelos respondentes foram Rio de Janeiro, São Paulo, Rio Grande do Sul e Rio Grande do Norte. Uma das hipóteses que pode explicar tal fato se deve à vinda de militares do Exército e da Marinha.

Em relação à renda familiar bruta ambos os acadêmicos ingressantes e concluintes estão concentrados na faixa de 02 a 05 salários mínimos, o que permite dizer que são pertencentes às classes B1, B2 e C1 conforme o Critério de Classificação Econômica Brasil (ABEP, 2016). Tal resultado se equipara aos acadêmicos do curso de administração. Os acadêmicos ingressantes e concluintes, em sua maioria, são servidores públicos, pertencem ao quadro das instituições militares na região.

Os acadêmicos ingressantes, em sua maioria, e os acadêmicos concluintes, em sua totalidade, afirmam ter escolhido o curso de Ciências Contábeis com objetivo de adquirir conhecimentos a fim de conseguir e emprego em cargo público ou melhorar a sua condição.

A grande maioria dos respondentes, tanto ingressantes como concluintes consideram que o curso de Ciências Contábeis oferece uma formação que possibilita ao acadêmico ser um bom funcionário, e a possibilidade de abrir seu próprio negócio, através de disciplinas que explanam sobre o domínio das funções contábeis. Apesar da grade curricular do curso não oferecer disciplinas específicas que desenvolvam o comportamento empreendedor, ressalta-se que 30\% dos acadêmicos ingressantes responderam sim, tendo a possibilidade de simular abertura de empresa e o funcionamento da mesma, como atividade prática.

Quanto à perspectiva profissional a grande maioria dos entrevistados, ingressantes e concluintes, optou pelo desejo de ocupar cargo em instituição pública. Tal fato se justifica pela maioria pertencer a alguma instituição pública como as forças armadas.

A maioria dos acadêmicos ingressantes não possuem familiares empreendedores. Entretanto, entre os acadêmicos concluintes, o percentual de familiares próximos foi de $60 \%$, o que difere dos resultados encontrados no curso de Administração.

A definição de empreendedor é melhor compreendida pelos acadêmicos ingressantes. Entre os concluintes, embora alguns deles terem desenvolvido atividades que remetam ao tema, ainda apresentam $10 \%$ que não possuem o conhecimento conceitual suficiente acerca do assunto.

Analisando comparativamente as médias obtidas no teste TEG entre os acadêmicos do curso de Administração constata-se uma diferença nas médias entre acadêmicos ingressantes e concluintes nas características: "Autonomia/Independência" e "tendência criativa".

Essa diferença positiva entre as médias dos acadêmicos ingressantes e concluintes pode ser explicada pelo fato de o curso de Administração oferecer disciplinas que incentivam os acadêmicos a expressar sua opinião frente aos problemas e utilizar sua imaginação e criatividade para resolvê-los (FERREIRA e ARANHA, 2008, p. 3 - 4). Em contrapartida as características "necessidade de sucesso", "propensão a riscos" e "impulso/determinação" apresentaram diferença negativa em suas médias. Tal fato sugere que o curso ofereça disciplinas que proporcionem subsídios para a formação de profissionais desafiadores, capazes de agir para aproveitar as novas oportunidades, de modo a atingir o sucesso pessoal. 
Gráfico 1:TEG ingressantes x TEG concluintes Administração CPAN

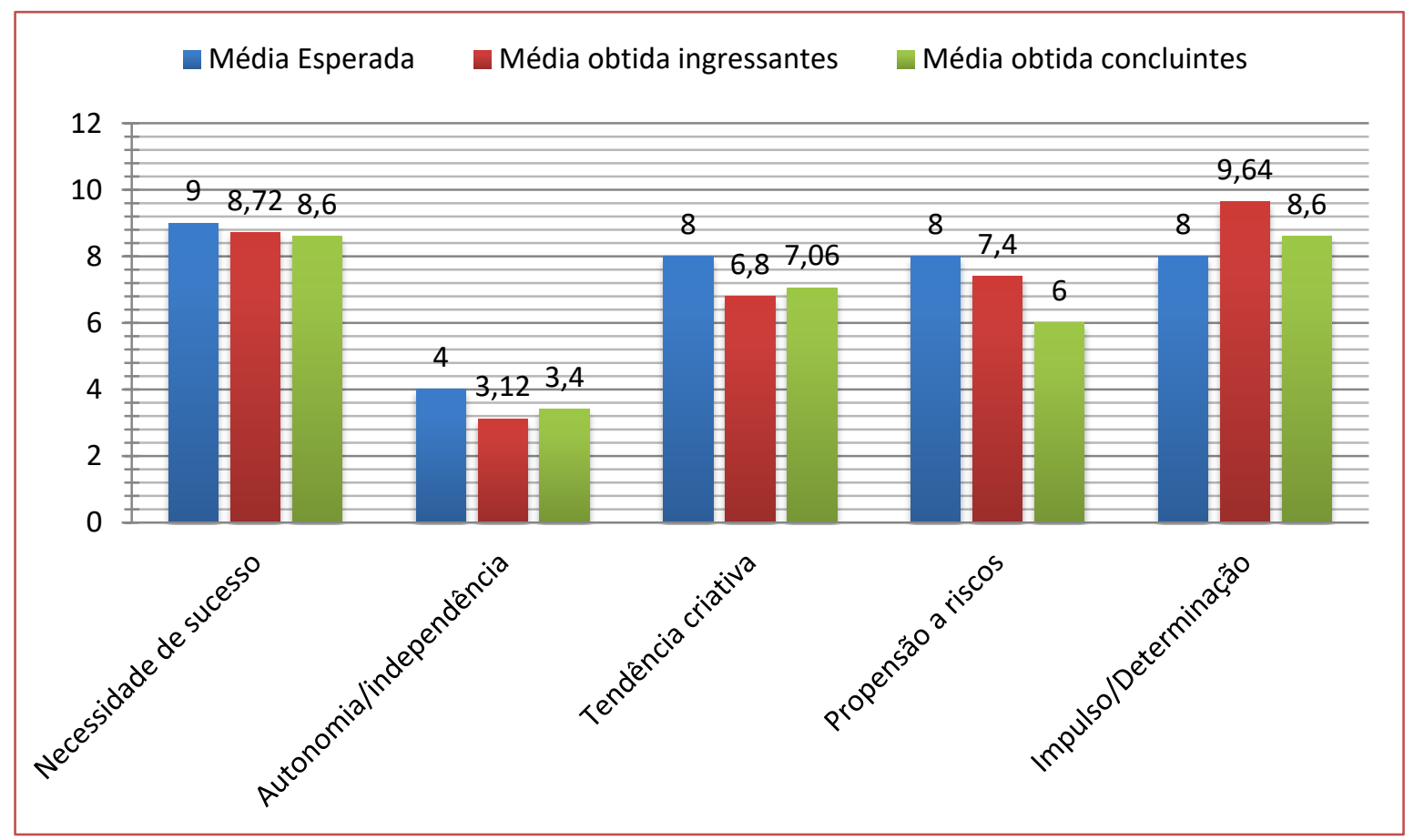

Fonte: Dados da pesquisa

Analisando comparativamente as médias obtidas no teste TEG entre os acadêmicos do curso de Ciências Contábeis constata-se uma diferença positiva nas médias entre acadêmicos ingressantes e concluintes nas características: "Necessidade de sucesso", "Autonomia/Independência”, "Propensão a riscos" e "Impulso/Determinação". Apesar de apresentar um pequeno aumento entre as médias dos acadêmicos ingressantes e concluintes, o gráfico 2 sugere que o curso de Ciências Contábeis/CPAN inclua em sua grade curricular disciplinas que contribuam para a formação de profissionais visionários, criativos e desafiadores, capazes de aproveitar as oportunidades que lhes são oferecidas mantendo sua opinião frente aos problemas, de forma a atingir o sucesso pessoal.

Gráfico 2:TEG ingressantes x TEG concluintes Ciências Contábeis/CPAN

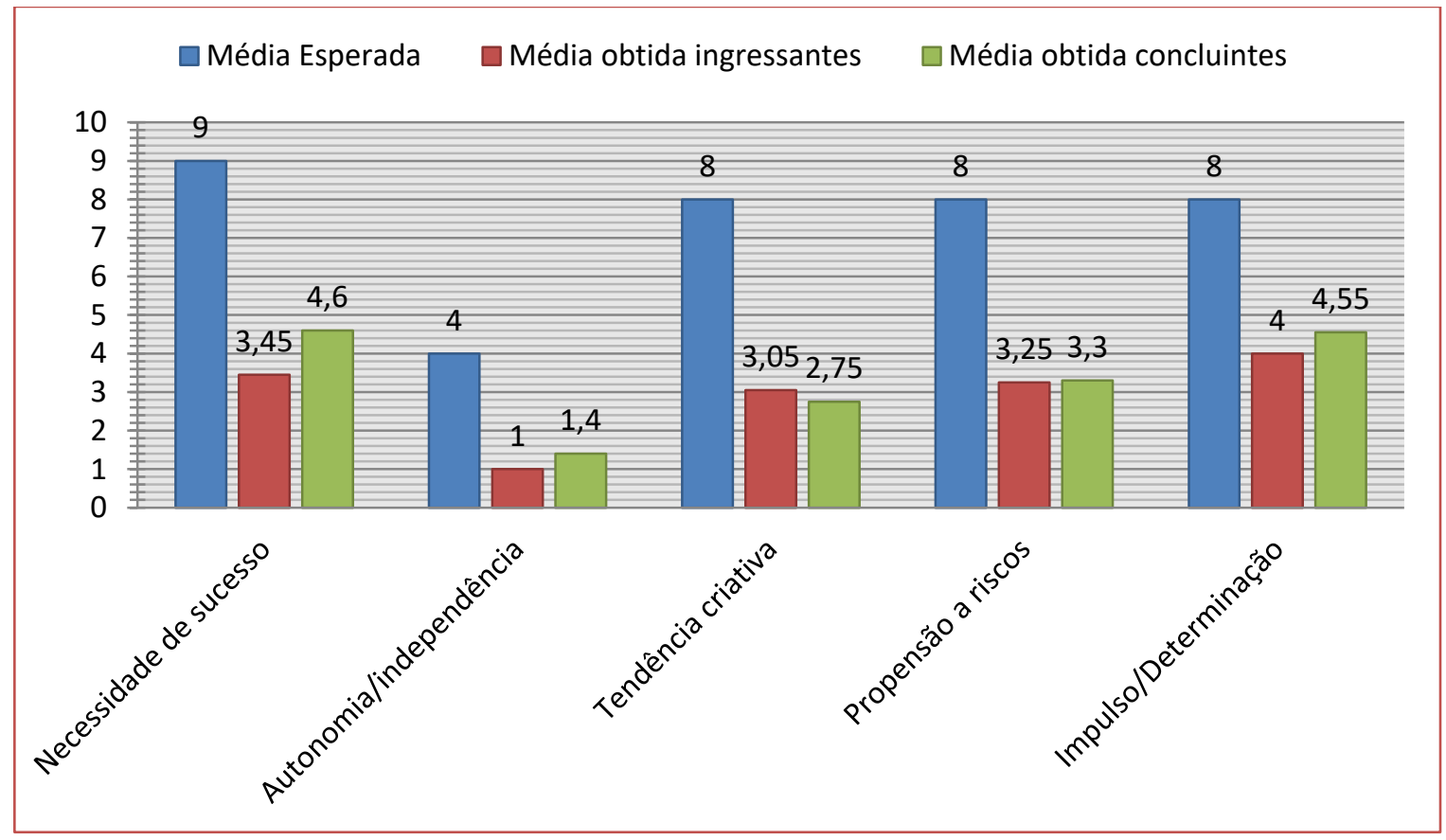


Fonte: Dados da pesquisa

Analisando comparativamente as médias obtidas no teste TEG pelos acadêmicos do curso de Administração $(n=40)$ e de Ciências Contábeis $(n=20)$ do campus Pantanal, constata-se que os cursos possuem baixa tendência ao empreendedorismo.

A média da característica "Impulso/determinação" foi atingida por ambos os cursos e possui uma variação de 0,7 entre si. A média da característica "Necessidade de sucesso" não foi atingida por ambos os cursos e possui variação de 0,625 entre si. A média da característica "Necessidade de Autonomia/Independência" não foi atingida por ambos os cursos e possui variação de 0,825 entre si. A média da seção "Tendência criativa" não foi atingida por ambos os cursos e possui uma variação de 1,1. É nesta categoria que ambos os cursos tiveram a média mais baixa, quando comparada à média esperada. A média da característica "Propensão a riscos" não foi atingida, também, por ambos os cursos e possui variação de 0,325, sendo essa a menor variação de média entre os cursos.

Gráfico 3: TEG entre os acadêmicos do curso de Administração X Ciências Contábeis

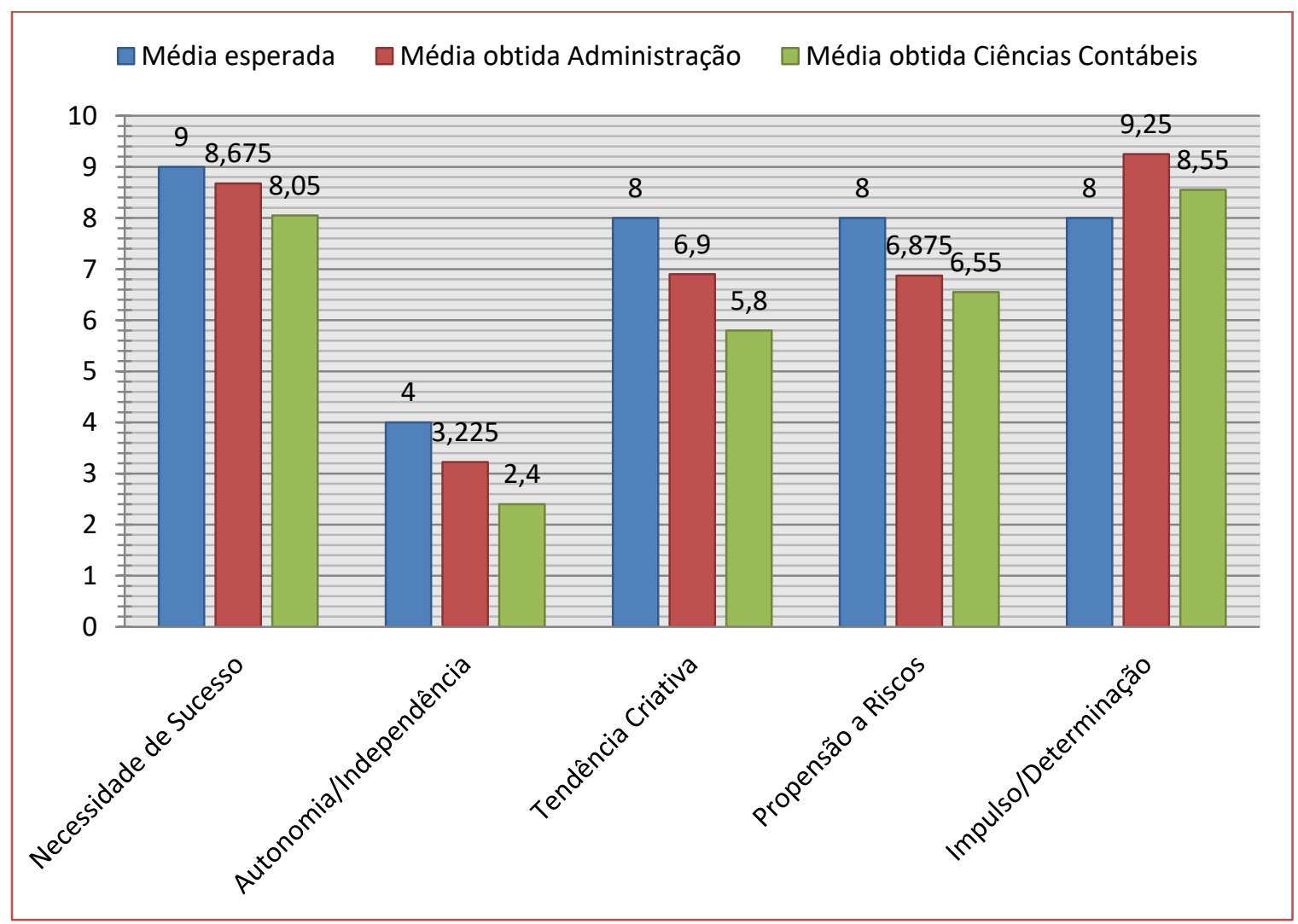

Fonte: Dados da pesquisa

Os resultados obtidos com essa pesquisa e comparados com pesquisas anteriores em âmbito acadêmico, são apresentados a seguir no quadro 5. Observa-se que a médias atingidas nas categorias "Necessidade de sucesso", "Necessidade de autonomia/independência", "Tendência criativa" e "Propensão a riscos" vêm diminuindo gradativamente conforme a realização de novos estudos. Tal fato pode ser atribuído à cultura local da cidade de Corumbá-MS, que desfavorece a manutenção de um ambiente empreendedor e, consequentemente, desestimula comportamentos e características empreendedoras.

Entretanto, a dimensão "Impulso/Determinação" é a que se sobressai, tendo aumento gradativo conforme realização de novos estudos. Isso pode ser atribuído ao fato de que a universidade proporciona um ambiente que estimula o aproveitamento das oportunidades e a formação de profissionais autoconfiantes e determinados, comprometidos a realizar com êxito as tarefas que lhes são propostas. 
Quadro 5: Comparação dos achados da pesquisa com os estudos empíricos anteriores em âmbito acadêmico.

\begin{tabular}{|c|c|c|c|c|c|}
\hline & $\begin{array}{c}\text { Média } \\
\text { Esperada }\end{array}$ & $\begin{array}{c}\text { Espirito Santo } \\
(2011)\end{array}$ & $\begin{array}{c}\text { Silva } \\
(2016)\end{array}$ & \multicolumn{2}{c|}{$\begin{array}{c}\text { Assad (2016) } \\
\text { ADM X CC }\end{array}$} \\
\hline Necessidade de Sucesso & 9 & 8,85 & 8,57 & 8,675 & 8,05 \\
\hline $\begin{array}{c}\text { Necessidade de } \\
\text { autonomia/independência }\end{array}$ & 4 & 3,45 & 3,42 & 3,225 & 2,4 \\
\hline Tendência Criativa & 8 & 6,91 & 7,12 & 6,9 & 5,8 \\
\hline Propensão a riscos & 8 & 7,38 & 7,12 & 6,875 & 6,55 \\
\hline Impulso/Determinação & 8 & 8,62 & 9,42 & 9,25 & 8,55 \\
\hline
\end{tabular}

Fonte: Dados coletados pela autora

\section{CONCLUSÕES}

A questão da pesquisa foi respondida. A tendência empreendedora dos acadêmicos dos referidos cursos é considerada baixa. Da mesma forma os objetivos propostos nesta pesquisa, que seriam identificar e comparar o perfil empreendedor dos acadêmicos dos cursos de Administração e Ciências Contábeis no campus Pantanal, da Universidade Federal de Mato Grosso do Sul; foram alcançados, conforme se conclui, em sequência.

De acordo com os resultados obtidos na pesquisa, é possível afirmar que o gênero predominante no Curso de Administração é o gênero feminino com percentual $64 \% \mathrm{n}=40$, faixa etária predominante entre os iniciantes com percentual de $44 \%$ está entre 18 a 21 anos, e entre os concluintes 22 e 26 anos, que corresponde a $66,66 \%$. 0 estado civil predominante é o solteiro, o que corresponde a $80,01 \%$, tanto os ingressantes quanto os concluintes e em sua grande maioria são provenientes do município de Corumbá. Tal resultado difere dos resultados encontrados por Espírito Santo (2011, p. 63), que constatou que 50\% dos acadêmicos ingressantes provinham de outras regiões do país. A renda familiar bruta entre os acadêmicos ingressantes e concluintes encontram-se na faixa de 02 a 05 salários mínimos, o que permite dizer que são pertencentes às classes B1, B2 e C1 conforme o Critério de Classificação Econômica Brasil (ABEP, 2016).

Os acadêmicos ingressantes apresentam maior tempo para estudo visto que a sua maioria não possui outra ocupação. Todavia, entre os concluintes há a predominância de funcionários de empresa privada e funcionários públicos.

Os acadêmicos ingressantes e concluintes, em sua maioria, provêm de escolas públicas. Tal resultado difere do estudo realizado por Espírito Santo (2011, p. 65) que constatou que os acadêmicos concluintes daquele ano foram provenientes de escolas privadas.

Ainda sobre os acadêmicos ingressantes e concluintes, eles escolheram curso Administração para trabalhar em cargo público. O resultado revela o pouco conhecimento que se tem das inúmeras possibilidades que o curso de administração permite em termos de atuação profissional e ainda revela que esses acadêmicos buscam estabilidade e um padrão de vida.

Os entrevistados, em sua grande maioria, consideram que o curso de Administração/CPAN é composto por disciplinas que fornecem subsídios que os auxiliam a serem bons funcionários e conhecimento necessário para abertura do próprio negócio, tais como as disciplinas "Empreendedorismo" e "Jogos Empresariais". Apesar de disciplinas específicas que abordam o tema empreendedorismo só acontecerem no período final do curso em virtude da necessidade de conhecimento em áreas da Administração como a gestão de pessoas, a administração financeira e orçamentária e a administração de produção, entre outras.

Entre os acadêmicos ingressantes e concluintes não possuem, em sua maioria, nenhum familiar empreendedor até o momento da presente pesquisa, o que fica sob a responsabilidade do curso em despertar o comportamento empreendedor.

Para os entrevistados, a definição de empreendedor é compreendida por todos acadêmicos.

Já os acadêmicos do Curso de Ciências Contábeis que participaram da amostra, apresentaram que o curso é composto em sua maioria pelo gênero feminino $(70 \%) n=20$ no início do curso, enquanto entre os 
formandos é composto em sua maioria pelo gênero masculino (60\%) n=20. A faixa etária de 22 a 26 anos entre os iniciantes e entre os concluintes a faixa etária de 27 a 35 anos. Entre os acadêmicos ingressantes há predominância do estado civil "solteiro", enquanto entre os acadêmicos concluintes há predominância do estado civil "casado".

Diferentemente dos resultados do curso de administração, no curso de Ciências Contábeis, os acadêmicos, ingressantes e concluintes, provêm de outras regiões do país. Os estados citados pelos respondentes foram Rio de Janeiro, São Paulo, Rio Grande do Sul e Rio Grande do Norte. Uma das hipóteses que pode explicar tal fato se deve à vinda de militares do Exército e da Marinha. Em relação à renda familiar bruta, ambos os acadêmicos ingressantes e concluintes estão concentrados na faixa de 02 a 05 salários mínimos, o que permite dizer que são pertencentes às classes B1, B2 e C1 conforme o Critério de Classificação Econômica Brasil (ABEP, 2016). 0 se equipara aos acadêmicos do curso de administração. Os acadêmicos ingressantes e concluintes, em sua maioria, são servidores públicos, como foi explanado pertencem ao quadro das instituições militares na região.

Os acadêmicos ingressantes, em sua maioria, e os acadêmicos concluintes, em sua totalidade, afirmam ter escolhido o curso de Ciências Contábeis com objetivo de adquirir conhecimentos a fim de conseguir e emprego em cargo público ou melhorar a sua condição.

A grande maioria dos respondentes, tanto ingressantes como concluintes consideram que o curso de Ciências Contábeis oferece uma formação que possibilita ao acadêmico ser um bom funcionário, e a possibilidade de abrir seu próprio negócio, através de disciplinas que explanam sobre o domínio das funções contábeis. Apesar da grade curricular do curso não oferecer disciplinas específicas que desenvolvam o comportamento empreendedor, ressalta-se que 30\% dos acadêmicos ingressantes responderam sim, tendo a possibilidade de simular abertura de empresa e o funcionamento da mesma, como atividade prática.

Quanto à perspectiva profissional a grande maioria dos entrevistados, ingressantes e concluintes, optou pelo desejo de ocupar cargo em instituição pública. Tal fato se justifica pela maioria pertencer a alguma instituição pública como as forças armadas.

A maioria dos acadêmicos ingressantes não possuem familiares empreendedores. Entretanto, entre os acadêmicos concluintes, o percentual de familiares próximos foi de 60\%, o que difere dos resultados encontrados no curso de Administração.

A definição de empreendedor é melhor compreendida pelos acadêmicos ingressantes. Entre os concluintes, embora alguns deles terem desenvolvido atividades que remetam ao tema, ainda apresentam $10 \%$ que não possuem o conhecimento conceitual suficiente acerca do assunto.

O TEG entre os acadêmicos do curso de Administração X Ciências Contábeis, representado pelo gráfico 3 acima supracitado revela que o curso de Administração tem maiores possibilidades de inserir no mercado profissionais com algumas características empreendedoras se comparado com o curso de Ciências Contábeis. A seção "Impulso/determinação" possui uma variação de 0,7 entre as médias atingidas pelos cursos. Essa variação pode ser atribuída à maneira como os cursos em questão buscam construir um ambiente acadêmico voltado ao aproveitamento de oportunidades. Das categorias que não atingiram a média esperada no teste TEG as seções "Necessidade de sucesso" e "Propensão a riscos" obtiveram as menores variações, sendo 0,625 e 0,325 respectivamente. As categorias "Necessidade de autonomia/independência" e "Tendência criativa" obtiveram as maiores variações, sendo 0,825 e 1,1 respectivamente.

A partir da base teórica construída e da apresentação e análise dos dados obtidos, constatou-se a importância dos cursos participantes desta pesquisa na formação de profissionais que tenham competências empreendedoras que contribuam com um perfil empreendedor. É de extrema importância que os cursos de Administração e Ciências Contábeis no campus Pantanal, da Universidade Federal de Mato Grosso do Sul, desenvolvam atividades e projetos voltados à conexão da teoria com a prática, buscando desenvolver e fomentar entre seus acadêmicos comportamentos, habilidades e conhecimentos necessários na formação de profissionais com perfil empreendedor.

Recomendam-se novos estudos e pesquisas orientados para a tendência empreendedora no meio acadêmico, buscando resultados voltados à análise da educação empreendedora no Campus Pantanal. 


\section{REFERÊNCIAS}

[1] AMORIM, Lorrayne Karen Alves. Mulheres Empreendedoras e os Desafios da Gestão. 71 fls. Estágio Obrigatório Profissional II (Curso de Administração) - Universidade Federal de Mato Grosso do Sul, Corumbá, 2015.

[2] ASSOCIAÇÃO BRASILEIRA DE EMPRESAS DE PESQUISA. Critério de Classificação Econômica Brasil. Dados com base no Levantamento Sócio Econômico 2009 - IBOPE. ABEP, 2016. Disponível em <www.abep.org>. Acesso em 17 jan. 2017.

[3] BRASIL, ENDEAVOR. Empreendedorismo nas Universidades Brasileiras 2014. Disponível em https://endeavor.org.br/pesquisas/. Acesso em: jun. 2016.

[4] DORNELAS, José Carlos Assis, Empreendedorismo: transformando ideias em negócios / José Carlos Assis Dornelas. - 5. ed. - Rio de Janeiro: Empreende / LTC, 2014.

[5] ESPÍRITO SANTO, Michelle Oliveira. Tendência Empreendedora: Uma Análise do Perfil dos Acadêmicos do Curso de Administração em Instituição de Ensino Superior da Cidade de Corumbá-MS. Corumbá: Curso de Administração, Campus do Pantanal, Universidade Federal de Mato Grosso do Sul, 2011, 133 p. Monografia de Graduação.

[6] __. Empreendedorismo na Administração Púbica: um Estudo do Perfil Empreendedor da Equipe Administrativa de uma Instituição Federal de Ensino Superior, como Ferramenta de Melhoria no Desempenho Organizacional. Campo Grande: Mestrado Profissional em Administração Pública em Rede Nacional - PROFIAP, Escola de Administração e Negócios, Universidade Federal de Mato Grosso do Sul, 2015, 80 p. Trabalho de Conclusão Final.

[7] FERREIRA, R. C.; ARANHA, E. A.Análise do perfil empreendedor de graduados em Engenharia de Produção Mecânica. Universidade Federal de Itajubá. MG: UNIFEII, 2008.

[8] GIL, Antonio Carlos. Métodos e Técnicas de Pesquisa Social. 6.ed. São Paulo: Ed Atlas, 2008.

[9] GLOBAL ENTREPRENEURSHIP MONITOR (GEM). Empreendedorismo no Brasil: 2015.Simara Maria de Souza Silveira Greco et. al.Curitiba: IBPQ, 2015.

[10] MASIERO, Gilmar. Administração de Empresas: Teoria e funções com exercícios e casos. 2 ed. São Paulo: Saraiva, 2009.

[11] SAMANIEGO, Flavio Cabral. Tendência Empreendedora: Um estudo sobre o perfil dos mototaxistas do município de Corumbá-MS. 2014. 94 fls. Trabalho de Conclusão do Curso de Administração - Universidade Federal de Mato Grosso do Sul - Campus Pantanal, Corumbá-MS, 2014.

[12] SANTOS, L. F.; FLORES, A. A. D. M. O perfil empreendedor em acadêmicos em administração em uma cidade do sul do país. RASM, Alvorada, ano 4, n.1, p. 71-88, jan./jun. 2014. Disponível em: <http://www.saomarcos.com.br/ojs> Acesso em 18 mai. 2016.

[13] SILVA, Rodrigo Nascimento. Análise da tendência empreendedora entre os acadêmicos do Curso de Administração do Campus do Pantanal da Universidade Federal de Mato Grosso do Sul. 72 fls. Estágio Obrigatório II (Curso de Administração) - Universidade Federal de Mato Grosso do Sul, Corumbá, 2016.

[14] SOUZA, Roosiley dos Santos; SILVEIRA, Amelia; CARMO, Hermani Magalhães Olivense do. Educação para o empreendedorismo: estudo em universidades federais de Mato Grosso do Sul. Disponível em <http://www.egepe.org.br/2016/artigos-egepe/324.pdf> Acesso em 08 Jun. 2016.

[15] SOUZA, Roosiley dos Santos; SILVEIRA, Amélia; NASCIMENTO, Sabrina do; ESPÍRITO SANTO, Michelle Oliveira do. Vendedores Ambulantes e o Modelo de CAIRD (1991): Tendência Empreendedora Geral (TEG), 2014. Disponível em <http://www.egepe.org.br/anais/tema12/326.pdf> Acesso em 08 Jun. 2016. 


\section{Capítulo 14}

\section{O MICROEMPREENDEDOR INDIVIDUAL NO ESTADO DE MATO GROSSO DO SUL}

\section{Raíssa de Melo Morinigo \\ Roosiley dos Santos Souza \\ Eva Carina Martins Aldrigue}

Resumo: A criação da Lei Complementar n.o 128, de 19 de dezembro de 2008, oportunizou a nova figura jurídica o - Microempreendedor Individual (MEI), permitindo que profissionais autônomos tivessem a oportunidade de deixarem a informalidade. 0 objetivo deste estudo foi descrever o perfil do microempreendedor individual, registrado no estado de Mato Grosso do Sul. A pesquisa foi qualitativa descritiva. Após consulta a base de dados SciELO, não foram encontrados estudos nessa vertente, referenciando o Estado de Mato Grosso do Sul, o que oportunizou o desenvolvimento desta proposta. 0 suporte teórico desenvolvido considerou os seguintes conceitos: empreendedorismo, condicionantes que afetam a atividade empreendedora, setor informal e microempreendedor individual. Os dados principais foram retirados do site oficial Portal do Empreendedor, e assim, foi possível, com base nas informações disponíveis no site, descrever o perfil do MEI sul-mato-grossense. 0 microempreendedor individual em Mato Grosso do Sul, é formado por 53,71\% do gênero masculino, com idade predominante entre 18 a 40 anos, que representa 53,78\% dos microempreendedores, cuja escolaridade é de nível médio, atuando principalmente em estabelecimento fixo.

Palavras-chave: Microempreendedor individual; Mato Grosso do Sul; Informalidade; Formalidade. 


\section{INTRODUÇÃO}

A Lei Complementar n.o 128, de 19 de dezembro de 2008, criou uma nova figura jurídica - a do Empreendedor Individual ou Microempreendedor Individual (MEI), oportunizando aos que querem empreender ou que já empreendem, a oportunidade de legalizar seu empreendimento.

A formalização permite ao MEI ter acesso a benefícios como auxilio maternidade, auxilio doença e aposentadoria por ser um contribuinte da Previdência Social; acesso a serviços bancários, destinados exclusivamente às empresas; isenção de taxas para registro da empresa e facilidade do citado registro, os quais podem ser diretamente efetuados através do Portal do Empreendedor www.portaldoempreendedor.com.br ou junto ao Serviço de Apoio às Micro e Pequenas Empresas SEBRAE ou ainda nas Salas do Empreendedor, mantidas pelas prefeituras municipais, bem como, tem a oportunidade de registro no Cadastro Nacional de Pessoas Jurídicas (CNPJ), possibilitando-lhe a emissão de notas fiscais, prestar serviço para empresas e participar de processos licitatórios; possui isenção de tributos federais, pagando apenas a previdência social, o imposto sobre circulação de mercadorias e prestação de serviços e/ou imposto sobre serviços de qualquer natureza. Os valores cobrados são atualizados anualmente, de acordo com o salário mínimo.

De acordo com o Portal do Empreendedor, até maio de 2017, foram registrados 6.978 .888 microempreendedores individuais no Brasil por código conforme a Classificação Nacional de Atividades Econômicas (CNAE). IBGE (2014), expõe que o estado de Mato Grosso do Sul aparecia na 17o posição entre os estados de empresas de alto crescimento em suas estatísticas de empreendedorismo, sendo as áreas de 'Comércio; reparação de veículos automotores e motocicletas' as de maior crescimento, com 30.608 unidades, empregando 157.639 pessoas, sendo delas 121.634 assalariadas, com média de 1,9 salários mínimos. Já o FECOMÉRCIO MS (2017), informou que o número de microempreendedores amentou 16,8\% esse ano em Mato Grosso do Sul, comparado ao ano passado.

Diante do exposto e ainda pela insuficiência de trabalhos acadêmicos nesta vertente no estado do Mato Grosso do Sul, tornou-se importante levantar, analisar informações sobre os microempreendedores que buscaram a legalização e desta forma contribuir para um entendimento maior de quem são os MEI'S hoje, no estado, bem como conhecer as principais áreas de atuação.

\section{REVISÃO DA LITERATURA}

\subsection{EMPREENDEDORISMO}

Hisrich, Peters e Sheperd (2014), defendem que o empreendedorismo exige uma ação empreendedora, que consiste na criação de novos produtos/processos e/ou a entrada em novos mercados sendo uma nova organização ou uma organização já existente. Os autores afirmam que essa ação empreendedora surge quando o empreendedor percebe uma oportunidade a ser aproveitada e se essa oportunidade pode ser aproveitada por ele. Para ele definir se é possível assumir a oportunidade, é necessário que ele desenvolva o pensamento empreendedor, que, segundo os autores, são os processos mentais de que o indivíduo supera a ignorância de decidir se a oportunidade pode ser assumida por ele; o conhecimento prévio sobre o assunto, avaliação de viabilidade, motivação, estratégia pessoal, avaliação de predisposição, tudo isso é avaliado na viabilidade da ação empreendedora.

Para Bessant e Tidd (2009) empreendedores têm motivos diferentes para iniciar seu próprio negócio, mas, o empreendedor inovador cria o empreendimento primeiramente para criar algo novo ou para mudar algo, ao invés de buscar a obtenção de riqueza e independência, apesar de ambos poderem ser uma consequência do negócio. Os autores apontam que uma gama de fatores influência a criação de novos empreendimentos inovadores, alguns deles são contextuais, como apoio institucional, disponibilidade de capital e cultura, já outros mais pessoais, como personalidade, histórico pessoal, habilidades e experiência. Ser inovador, é de suma importância para o empreendedor, para que seu empreendimento permaneça no mercado cada vez mais competitivo

O Brasil está entre os países com as maiores taxas de empreendedorismo, porém, estudos tem revelado altas taxas de mortalidade dos pequenos negócios nos primeiros anos de vida, cerca de $23 \%$ dos negócios fecham ainda no seu segundo ano de funcionamento (SEBRAE, 2016), a criação do microempreendedor individual tem ajudado a diminuir essas taxas. Ainda, de acordo com pesquisa do SEBRAE (2012) sobre o perfil do empreendedor brasileiro, $70 \%$ dos empreendedores optaram pelo empreendedorismo por oportunidade de negócio e $30 \%$ por necessidade. Na pesquisa também se apurou que $44 \%$ sonhavam em ter negócio próprio e $25 \%$ desejavam seguir uma carreira em uma empresa. Como nível de escolaridade 
aparece $39 \%$ com o primeiro grau completo, $47 \%$ com o segundo grau completo e apenas $14 \%$ com o ensino superior completo ou mais. Mais da metade dos empreendedores brasileiros pertenciam à Classe "C" com 55,2\%, 37,5\% pertenciam à Classe "A e B", e apenas 7,3\% da Classe "D e E". Quanto à faixa etária, $48,7 \%$ era de 31 a 49 anos, 28,8\% de até 30 anos, 22,4\% com 50 anos ou mais, sendo assim, o empreendedor brasileiro tinha uma média de 39 anos.

A pesquisa da Confederação Nacional de Jovens Empreendedores, de 2016 (CONAJE, 2016), realizada nos 26 estados brasileiros e no Distrito Federal, descreveu o jovem empreendedor brasileiro pessimista em relação ao cenário político e econômico do país (54\%), citando a elevada carga tributária (58\%), burocracia (23\%), e legislação (8\%) como principais desafios externos à atividade, mas, continuam com o desejo de investir em um novo seguimento de negócio. Para os jovens empreendedores brasileiros da pesquisa, o que determina o sucesso a uma empresa é oferecer um produto/serviço diferenciado (48\%), enquanto na segunda opção aparece ter uma equipe capacitada (24\%). A pesquisa mostrou que a empresa desses empreendedores estão se tornando mais estáveis e duradouras; $49 \%$ dos entrevistados possuem cinco anos ou mais de negócio.

A pesquisa Global Entrepreurship Monitor (GEM) é um estudo de âmbito mundial, iniciado em 1999 pela London Business School, da Inglaterra, e o Babson College, dos Estados Unidos. Ela é realizada anualmente em cada país participante com o intuito de avaliar o nível nacional de atividade empreendedora, e o papel do empreendedorismo no crescimento econômico nacional e as características associadas às atividades empreendedoras (IBQP).

Em 2015, participaram da pesquisa GEM 62 países dos cinco continentes responsáveis por 83\% do PIB mundial e $70 \%$ da população mundial. 0 país com a maior taxa de empreendedores impulsionados por fatores é o Senegal com 38,6\% e o menor é a Índia com 10,8\%; o impulsionado por eficiência com a maior taxa é o Equador com 33,6\% e o menor é a Malásia com 2,9\%, o Brasil fica em oitavo com 21\% atrás de países como: México, Peru, Chile, Líbano, Colômbia e Barbados. Já os impulsionados por inovação aparecem em primeiro lugar o Canadá com 14,7\% e em último a Alemanha com 4,7\%. 0 Brasil cresceu de 17,2\% em 2014 para 21\% em 2015.

No Brasil podemos perceber um pequeno crescimento na taxa de empreendedorismo do ano de 2014 que apresentava uma taxa de 34,4\% empreendedores, entre iniciais e estabelecidos da população de 18 a 64 anos, para 39,3\% no ano de 2015. Dos empreendedores de 2015, 39\% é de empreendedorismo total (TTE), 21\% de empreendedorismo inicial (TEA) e 19\% de empreendedorismo estabelecido (TEE). Apesar da taxa do PIB brasileiro ter tido uma queda significativa de 2014 para 2015, comparado aos demais anos, $-4 \%$ em 2015, a taxa de empreendedorismo apresentou resiliência.

Com relação a região Centro-Oeste, o último GEM do Centro-Oeste de 2014, relatou-se que a taxa total de empreendedorismo (TTE) da região foi inferior à taxa do Brasil, 33\% no Centro-Oeste e 34,5\% no Brasil, também foi inferior ao ano de 2013 (36,3\%), porém, a taxa foi maior que a do ano de 2012 (30,8\%).

A taxa de empreendedores iniciais (TEA) da Região Centro-Oeste também foi inferior à taxa do Brasil em 2014 com 15,6\%, inferior a todas as outras regiões brasileiras e no Brasil (17,2\%). Na composição da TEA, na região Centro-Oeste, a taxa de empreendedores novos (14,3\%) é idêntica à de 2013 e superior a de 2012 (12,9\%). Já na taxa de empreendedores nascentes (1,6\%) foi a mais baixa das regiões brasileiras e menor que a média nacional (3,7\%), ela vem diminuindo desde 2012.

A taxa de empreendedores estabelecidos (TEE) em 2014 foi de 17,5\%, superior a TEA (15,6\%), mas com uma expressiva queda em relação à taxa de 2013 (19,8\%). Porém, foi idêntica à taxa brasileira (17,5\%).

Esse estudo foi realizado com a população de 18 a 64 anos, que na região Centro-Oeste, em 2014, era estimada em cerca de 10 milhões de indivíduos, estimando que desse total, 3,3 milhões é o número de empreendedores, e desses, 156 empreendedores nascentes, 1,4 milhões de empreendedores novos e, 1,7 milhões de empreendedores estabelecidos.

Portanto, pode-se observar que o empreendedor brasileiro tem o interesse de continuar empreendendo e que a quantidade de empreendedores brasileiros poderia ser muito maior se houvesse políticas públicas que incentivassem o empreendedorismo e o primeiro negócio, além da capacitação para ter o seu próprio negócio, já que 86\% relataram que não se prepararam para empreender, e que 23\% não buscaram nenhum apoio para a abertura ou o crescimento do negócio (SEBRAE, 2016). 


\subsection{CONDICIONANTES QUE AFETAM A ATIVIDADE EMPREENDEDORA}

Safarti (2013, p.29-30) com base na literatura de (OECD, 2010; Henrekson e Stenkula, 2009; Hall e Sobel,2006; Murdock, 2009; Lundstrom e Stevenson, 2001; Storey, 2008), descreve que os principais condicionantes que afetam a atividade empreendedora são: Mudanças demográficas: movimentos migratórios, idade, etc; Mudanças sociais: consciência ambiental, nível de educação, etc.; Mudanças econômicas: estabilidade macroeconômica, relações comerciais com outros países, etc.; Mudanças regulatórias: oportunidades advindas em mudanças de regulação em setores específicos, incluindo regulações definidas em contextos multilaterais e Mudanças tecnológicas: emergência de novas tecnologias.

Esses condicionantes são mudanças ocorridas, principalmente, no ambiente externo, que envolvem também o desenvolvimento de políticas públicas de empreendedorismo e MPMEs. Ainda de acordo com Safarti (2013, p.30), essas políticas podem ser divididas em políticas regulatórias e políticas de estímulo.

Para o autor, as políticas regulatórias afetam a atividade empreendedora, as MPMEs e as políticas de estímulo, e que tendem a fomentar o empreendedorismo de alto impacto.

- As Políticas Regulatórias:Regras de entrada e saída de negócios, Regras trabalhistas e sociais. Regras de propriedade, Regras tributárias, Regras de propriedade intelectual, Regras de falência e Regras que afetam a liquidez e disponibilidade de capital (incluindo taxa de juros e acesso a financiamento).

- As Políticas de Estímulo: Promoção de cultura e educação empreendedora; Desenvolvimento de indústria de incubadoras e venture-capital; Programas de promoção a inovação (pesquisa e desenvolvimento); Programas de fomento à internacionalização;

Assim, a atividade empreendedora é afetada por diversos condicionantes. Ainda o mesmo autor relata também que todas essas políticas podem, ainda, ser analisadas em diversas dimensões verticais tais como: Política nacional ou regional; Focadas em setores específicos (como biotecnologia) e Grupos de indivíduos (negros, mulheres, jovens).

\subsection{SETOR INFORMAL}

Segundo Theodoro (2000), o termo setor informal, surgiu como forma de explicar o velho fenômeno da existência de atividades de econômicas de baixa produtividade desenvolvida à margem da legislação.

Nessa linha, Gennari (2009, p. 398) citando Oliveira, diz que, no capitalismo, o setor informal apenas anuncia o futuro do setor formal, onde "o conjunto dos trabalhadores é transformado em uma soma indeterminada de exército da ativa e da reserva, que se intercambiam não nos ciclos de negócios, mas diariamente".

Há aqueles que se referem ao setor informal, com o termo "economia informal". Para Ramos (2007), seja qual for o termo utilizado, a informalidade é predominante nas economias periféricas, e seria impossível não supor a existência da conexão entre subdesenvolvido e informalidade. 0 autor questiona se a informalidade seria fruto de uma excessiva e burocrática legislação que ocupa um espaço negligenciado no tipo de inserção do Estado, ou se seria cultural diante dos trabalhadores que escolheram estar trabalhando informalmente.

Leone (2010) expõe que desde a década de 1990, quando houve um enorme crescimento no setor terciário, todos os setores tiveram reduzido o seu grau de formalização do trabalho. Assim, o intenso processo de terceirização da economia brasileira resultou numa deterioração geral das relações de trabalho, com redução do assalariamento e o crescimento dos empregos sem carteira assinada, afetando todos os trabalhadores, principalmente as mulheres, que estão impossibilitadas de superar barreiras de equidade no mercado de trabalho em termos de igualdade de remuneração e superação da segmentação de gênero nas ocupações.

Ainda Leone (2010), define trabalho informal como:

Associam-se às atividades informais características como indefinição dos locais de trabalho, condições de trabalho que não garantem saúde nem segurança, baixos níveis de qualificação e de produtividade, rendimentos baixos e irregulares, longas jornadas de trabalho, falta de acesso à informação, aos mercados, ao financiamento, à formação e à tecnologia. 
Essa diversidade de situações adversas que atinge aos trabalhadores informais induz, muitas vezes, ao uso dos conceitos de precariedade, subemprego e informalidade como sinônimos. (LEONE, 2010, p.9)

Para Nassif, Ghobril e Amaral (2009), os empregos informais não são um trabalho ilegal, porque ele não significa ser ilícito, mas não se submete às normas da legalidade. Assim, entende-se como se não existisse, embora exista.

\subsection{MICROEMPREENDEDOR INDIVIDUAL}

Microempreendedor Individual (MEI) é o pequeno empresário que trabalha por conta própria e tenha auferido receita bruta de até $\mathrm{R} \$ 60.000,00$ (sessenta mil reais), não podendo ter participação em outra empresa como sócio ou titular, podendo ter até um empregado contratado que receba o salário mínimo ou o piso da categoria.

A criação desta categoria foi um esforço do Governo Brasileiro em trazer os diversos empreendedores individuais que trabalhavam na informalidade, oferecendo uma oportunidade, pois, após a abertura do CNPJ e a formalização, o empreendedor obterá um alvará provisório no período de 6 meses, onde os dados dele serão enviados à Junta Comercial do Estado correspondente e à Receita Federal. Passado o período indicado, o microempreendedor deverá procurar a prefeitura local e regularizar o alvará com o município, caso não realizada tal regularização, o microempreendedor corre o risco de suspenção do CNPJ. Após a abertura, toda e qualquer alteração de atividade ou baixa da empresa deve ser realizada na Junta Comercial e terá que subtrair taxas como qualquer empresa.

Assim como toda empresa, o MEI tem valores tributários a pagar, porém, são valores fixo e bem inferiores às demais categorias existentes. Desde o dia $1^{\text {o }}$ de janeiro de 2010, o valor fixo recolhido pelos MEI'S mensalmente, passou a ser de no máximo $\mathrm{R} \$ 62,10$ (sessenta e dois reais e dez centavos) para os empreendedores que não tiverem empregados, respeitando os limites para o seu enquadramento, e independente da receita auferida no mês.

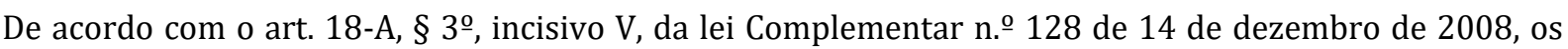
impostos devidos pelo MEI se dividem:

Art. 18-A. O Microempreendedor Individual - MEI poderá optar pelo recolhimento dos impostos e contribuições abrangidos pelo Simples Nacional em valores fixos mensais, independentemente da receita bruta por ele auferida no mês, na forma prevista neste artigo. [...]

V - o Microempreendedor Individual recolherá, na forma regulamentada pelo Comitê Gestor, valor fixo mensal correspondente à soma das seguintes parcelas: a) $\mathrm{R} \$ 45,65$ (quarenta e cinco reais e sessenta e cinco centavos), a título a contribuição prevista no inciso IV deste parágrafo; b) $R \$ 1,00$ (um real), a título do imposto referido no inciso VII do caput do art. 13 desta Lei Complementar, caso seja contribuinte do ICMS; e c) R\$ 5,00 (cinco reais), a título do imposto referido no inciso VIII do caput do art. 13 desta Lei Complementar, caso seja contribuinte do ISS. (BRASIL, Lei Complementar n. $\stackrel{\text { o }}{128}$ de 14/12/2008. Art. 18-A)

Nessa linha, o quadro 1 apresenta os tributos que são atribuídos aos empreendedores individuais.

Quadro 1: Tributos do Empreendedor Individual

\begin{tabular}{|c|c|c|}
\hline Atividade & Valor Mensal a Pagar & Tributos Abrangidos \\
\hline Comércio & $\mathrm{R} \$ 47,85$ & $\begin{array}{l}\text { Contribuição Previdenciária: } \mathrm{R} \$ 46,85 \\
\text { ICMS: R\$ } 1,00\end{array}$ \\
\hline Industria & $\mathrm{R} \$ 47,85$ & $\begin{array}{l}\text { Contribuição Previdenciária: R\$ 46,85 } \\
\text { ICMS: R\$ } 100\end{array}$ \\
\hline Prestação de Serviço & $\mathrm{R} \$ 51,85$ & $\begin{array}{l}\text { Contribuição Previdenciária: R\$ 46,85 } \\
\text { ISS: R\$ 5,00 }\end{array}$ \\
\hline Comércio e Prestação de Serviços & $\mathrm{R} \$ 52,85$ & $\begin{array}{l}\text { Contribuição Previdenciária: R\$ 46,85 } \\
\text { ICMS: R\$ } 1,00 \text { ISS: R\$ 5,00 }\end{array}$ \\
\hline
\end{tabular}


Tudo se originou por meio da Lei complementar n. 123 , de 14 de dezembro de 2006, em que foi criado o Simples Nacional que estabelece normas gerais em relação ao tratamento diferenciado e favorecido as microempresas e empresas de pequeno porte no âmbito dos Poderes da União, dos Estados, do Distrito Federal e dos Municípios. Posteriormente, em 19 de dezembro de 2008, ela foi alterada para a criação da Lei Complementar n. - 128 , que dá aos microempreendedores individuais, criados nessa mesma data, os mesmos direitos do Simples Nacional, dentre eles, isenção de tributos federais (Imposto de Renda, Pis, Confins, IPI e CSLL), pagando somente um valor fixo mensal de R \$ 47,85 (comércio ou indústria), R \$ 51,85 (prestação de serviço) ou R \$52,85 (comércio e serviços), que é destinado à Previdência Social e ao ICMS ou ao ISS. Essas quantias são atualizadas anualmente de acordo com o salário mínimo. Dentre os diversos benefícios que a formalização do microempreendedor traz ao empresário, o acesso ao Instituto Nacional do Seguro Social (INSS) é o mais destacado e considerado na ação empreendedora (Souza et al, 2015).

Abaixo retratamos o quadro 2, desenvolvido por Silva et al (2016), no qual é apresentado os tipos de tributos previstos pela Constituição Federal.

Quadro 2: Tributos da União, Estado e Município, previstos pela Constituição Federal.

\begin{tabular}{|c|c|c|}
\hline União & Estado & Município \\
\hline $\begin{array}{c}\text { Imposto de Importação } \\
\text { Imposto de Exportação (IE) } \\
\text { Imposto de Renda (IR) } \\
\text { Imposto sobre Produtos } \\
\text { Industrializados (IPI) } \\
\text { Imposto sobre Operações Financeiras } \\
\text { (IOF) } \\
\text { Imposto sobre Propriedade } \\
\text { Territorial Rural (ITR) } \\
\text { Imposto sobre Grandes Fortunas } \\
\text { (IGF) }\end{array}$ & $\begin{array}{l}\text { Imposto sobre Operações Relativas à } \\
\text { Circulação de Mercadorias e sobre } \\
\text { Prestações de Serviços de Transporte } \\
\text { Interestadual e Intermunicipal e de } \\
\text { Comunicação (ICMS) } \\
\text { Imposto sobre a Propriedade de } \\
\text { Veículos Automotores (IPVA) } \\
\text { Imposto de Transmissão Causa } \\
\text { Mortis e Doação (ITCMD) }\end{array}$ & $\begin{array}{l}\text { Imposto Sobre Serviços de Qualquer } \\
\text { Natureza (ISS) } \\
\text { Imposto sobre Propriedade Predial e } \\
\text { Territorial Urbana (IPTU) } \\
\text { Imposto sobre Transmissão de Bens e } \\
\text { Imóveis Inter vivos (ITBI) }\end{array}$ \\
\hline
\end{tabular}

Conforme observado no quadro 2, o destino dessa tributação é retido para as esferas: União, Estado e Município. 0 Estado de Mato Grosso do Sul adota o Regime Especial Unificado de Arrecadação de Tributos e Contribuições devidos pelas Microempresas e Empresas de Pequeno Porte (Simples Nacional), como fica claro no Art. 3o da Lei Complementar n. 197 de 24 de dezembro de 2014:

Art. 3ํ 0 Estado adotará o Regime Especial Unificado de Arrecadação de Tributos e Contribuições devidos pelas Microempresas e Empresas de Pequeno Porte (Simples Nacional), instituído pela Lei Complementar Federal n.o 123, de 2006, em relação ao Imposto sobre Operações Relativas à Circulação de Mercadorias e sobre Prestações de Serviços de Transporte Interestadual e Intermunicipal e de Comunicação (ICMS), devido pelas microempresas, pelas empresas de pequeno porte e pelos microempreendedores individuais estabelecidos em seu território, que optarem pelo referido regime. (BRASIL, Lei complementar n. $\stackrel{0}{197}$ de 24/12/2014. Art. 3ํ)

Os Municípios também adotam a tributação do Simples Nacional para a cobrança de tributos. Em Mato Grosso do Sul, sua capital, Campo Grande, passou a vigorar a tributação através da Lei Complementar n. ${ }^{\circ}$ 142 de 21 de setembro de 2009 como mostra o Art. 42:

Art. 42. O Microempreendedor Individual - MEI, poderá recolher os impostos e contribuições abrangidos pelo Simples Nacional em valores fixos mensais, independentemente da receita bruta por ele auferido no mês, obedecidas as normas específicas previstas na Lei Complementar Federal no 123 , de 14 de dezembro de 2006, alterações posteriores e na forma regulamentada pelo Comitê Gestor.

Parágrafo único. Em relação ao disposto no caput deste artigo, o valor relativo ao Imposto Sobre Serviço de Qualquer Natureza - ISSQN, caso o Microempreendedor Individual - MEI seja contribuinte desse imposto, será o fixado pela Lei Complementar Federal, independentemente da 
receita bruta por ele auferida no mês, não se aplicando a ele quaisquer isenções, desconto ou redução de base de cálculo relativa ao tributo municipal. (BRASIL, Lei Complementar n.o 142 de 21/09/2009. Art.42).

Silveira, Carmo e Souza (2017), verificou que os microempresários apontam a possibilidade de que a contratação de mais um ou dois funcionários seria um maior incentivo ao crescimento e a ampliação da microempresa no seu todo, considerando a estrutura e o portfólio de produtos. 0 MEI só poderá contratar um segundo funcionário quando o primeiro estiver afastado por algum motivo como: licença-maternidade ou auxílio-doença. Porém, assim que o colaborador titular retornar, o substituto deve ter seu contrato encerrado, acabando com a oportunidade de gerar emprego e renda. E se o empresário desejar abrir filiais, deverá mudar de categoria empresarial.

Carmo et al (2015, p. 3) cita Schwingel e Rizza (2013), o qual diz que a intenção do governo brasileiro, com essa legislação, foi a de tirar milhões de brasileiros da informalidade, ou seja, formalizar os trabalhadores que atuam por conta própria e, consequentemente, promover a inclusão empresarial.

Oliveira e Krakauer (2016) expõem que, apesar da oportunidade que a criação do MEI oferece aos brasileiros de se formalizarem, não garante a longevidade do empreendimento, dado os problemas que a gestão de um negócio pode gerar. Dentre eles, a ausência de conhecimento, de gestão e de planejamento de negócios está entre os principais motivos de falência. Além disto, a categoria tem um alto nível de inadimplência, com um total de 51\% inadimplentes. Pois, ao se formalizar MEI é obrigatório o pagamento do Documento de Arrecadação do Simples Microempreendedor Individual (DAS-SIMEI), independente da venda, ou prestação de serviço não ocorrerem, visto que a abertura da empresa já é um fato gerador de tributação.

\subsection{VANTAGENS DO MICROEMPREENDEDOR INDIVIDUAL}

Várias são as vantagens de se formalizar como microempreendedor individual, de acordo com Portal do Empreendedor (2015), como: Serviços Gratuitos: empresas contábeis, optantes pelo Simples Nacional oferece assessoria contábil gratuita para a realização da inscrição até a primeira declaração anual simplificada da microempresa individual (DASN - SIMEI); Apoio técnico do Sebrae: o Serviço Brasileiro de Apoio às Micro e Pequenas Empresas (Sebrae) conta com assessoria e orientação para os microempreendedores individuais que necessitarem de auxilio, além de contar com cursos e planejamento para melhor capacitar o empreendedor a administrar seu negócio; Legalização do Negócio: com a legalização do próprio negócio, o empreendedor ganha maior confiança do mercado, podendo adquirir crédito com maior facilidade, pode emitir Nota Fiscal etc; Menor Burocracia: para sair da informalidade, o empreendedor só precisa acessar o Portal do Empreendedor, www.portaldoempreendor.gov.br, e se cadastrar de forma rápida e gratuita; Segurança Jurídica: após legalizado, o empreendedor fica amparado pela lei para possíveis problemas; Direitos a benefícios previdenciário: com a formalização, o empreendedor passa a ser protegido pela Previdência Social, adquirindo benefícios como o direito a aposentadoria por idade ou por invalidez, auxílio-doença ou salário maternidade e também, a família tem o benefício de pensão por morte e auxilio reclusão. Tudo isto a partir do primeiro pagamento da taxa do MEI; Crédito acessível: o MEI tem direito a conta bancária empresarial e financiamento com redução de tarifas e taxas de juros como forma de incentivo a desenvolver o seu negócio; Menos Tributos: os tributos do MEI são mais baratos através de um valor fixo e feito de forma unificada mensalmente. Nele estão inclusas as taxas destinadas para o INSS, arrecadação estadual (ICMS) e arrecadação municipal para prestadores de serviços (ISS); Facilidade da escrituração contábil e fiscal: comprovar que o seu faturamento não ultrapassou $R \$ 60$ mil é uma das únicas obrigatoriedades do MEI, e para isso o empreendedor deve fazer a Declaração Anual do Simples Nacional para o Microempreendedor Individual (DASN - SIMEI), e a declaração é feita de forma rápida pelo Portal do Simples Nacional www8.receita.fazenda.gov.br; Possibilidade de contratação: o MEI pode ter até um funcionário que receba um salário mínimo ou piso salarial da categoria. Para tal, o empreendedor deve preencher a Guia do FGTS e Informação à Previdência Social (GFIP), além de depositar mensalmente o FGTS na base de 8\% sobre o valor do salário do colaborador, além de 3\% do salário para a Previdência Social; Compras e vendas em conjunto: o MEI tem a vantagem de poder comprar e vender juntamente com outras empresas; Possibilidade de vender para o Governo: o MEI pode vender para todas as esferas do governo. Inclusive participar de licitações.

No ano de 2016, para maior facilidade do microempreendedor individual, foi criada a Lei Complementar n. -154 , de 18 de abril de 2016, decretando que o MEI poderá utilizar a própria residência como sede do estabelecimento, quando não for indispensável a existência de local próprio para exercício da atividade. 
A formalização de um Microempreendedor Individual é gratuita e pode ser realizada no site do Portal do Empreendedor, ou com a ajuda de empresas de contabilidade optantes pelo Simples Nacional e que estão espalhadas pelo Brasil. Essas empresas vão realizar a formalização e a primeira declaração anual sem cobrar nada (PORTAL DO EMPREENDEDOR).

Essas vantagens e benefícios têm favorecido a decisão da formalização desses empresários. Pesquisa realizada pelo Sebrae (2015, p. 60-61), mostra que 63\% dos empreendedores citaram como motivo principal para a formalização fatores relacionados diretamente ao negócio formal, como "ter uma empresa formal", citado por 22\%, 10\% "possibilidade de emitir nota fiscal"; $9 \%$, "possibilidade de crescer mais como empresa"; 7\%, "evitar problemas com a fiscalização"; 6\%, "facilidade de abrir a empresa"; 4\%, "custo de formalizar é baixo"; e 10\% deram outras respostas, e não somente no cidadão, apesar de $32 \%$ citarem os benefícios do INSS como motivação.

\section{METODOLOGIA}

Inicialmente, utilizou-se a pesquisa exploratória para obtenção de maior conhecimento sobre o tema. 0 embasamento teórico foi feito por meio da pesquisa bibliográfica, tendo como fonte, livros, artigos, teses, dissertações e sites especializados no tema.

Segundo Andrade (1997), a pesquisa exploratória é o primeiro passo de um trabalho científico, pois, por meio dela, o pesquisador aprofunda seu conhecimento sobre o assunto abordado, podendo, assim, delimitar o tema do trabalho e enfocar no objetivo a ser alcançado.

A pesquisa bibliográfica foi realizada por meio de registro disponível em pesquisas publicadas em revista e eventos científicos que tratam sobre o referido assunto, em documentos impressos, como livros, artigos, dissertações e teses, jornais e sites. Os dados secundários tiveram como principal fonte de pesquisa o Portal do Empreendedor, o site http://www.portaldoempreendedor.gov.br, onde foi possível encontrar estatísticas a respeito dos registros desde o primeiro ano de vigência da lei, além de oferecer a possibilidade de coletar os dados do Estado de Mato Grosso do Sul e das outras regiões do Centro-Oeste. Da fonte citada, foi possível identificar dados como: Número de registro de Microempresários Individuais de 2009 a 2017, no Brasil, no Centro-Oeste e em Mato Grosso do Sul. Gênero, idade, código de Classificação Nacional de Atividades Econômicas (CNAE) e forma de atuação dos Microempresários Individuais registrados. Gênero, idade, código CNAE e forma de atuação das Empresas individuais, enquadradas no Simples Nacional que requisitaram sua alteração para Microempresário Individual.

Apesar de serem encontradas essas informações no Portal do Empreendedor, houve limitações em relação à data das informações disponíveis no site, pois, não é possível encontrar as informações em data de interesse do estudo, as informações são disponibilizadas apenas de acordo com a última atualização do site, sem opção de acessar a informação em datas anteriores, além de não constar o gênero na informação por código CNAE no âmbito nacional, não há informações como escolaridade, renda familiar, estado civil, etc.

Há informações que não são possíveis de se encontrar no site, contudo elas são importantes para o conhecimento de quem se interessa pela categoria e que poderiam funcionar como incentivo para que mais pessoas viessem se inscrever como microempreendedor porque são informações referente à quantidade de empresário individuais que transitam de MEI para microempresa, e a quantidade, caso haja, que cancela sua inscrição como microempreendedor individual.

Num segundo momento foi dado um enfoque descritivo. Gonsalves (2011) afirma que o objetivo da pesquisa descritiva é de caracterização do objetivo de estudo. Nesse tipo de pesquisa existem as que atualizam as características de um grupo social, nível de atendimento do sistema educacional, ou aquelas que pretendem descobrir a existência de relações entre variáveis. No entanto, a pesquisa não tem interesse no porquê dos fenômenos, ela apenas se preocupa em apresentar as características do fenômeno. Ainda de acordo com Cervo (2007), a pesquisa descritiva objetiva descobrir, com maior precisão possível, observando, registrando, analisando e correlacionando fatos ou fenômenos (variáveis) sem manipulá-los, apenas as descrevendo em seus detalhes.

Quanto à natureza das variáveis pesquisadas, foi realizada uma pesquisa qualitativa. Segundo Gil (1996), essa modalidade considera o ambiente natural como a fonte direta para coleta de dados e o pesquisador como instrumento chave. Os pesquisadores geralmente analisam seus dados indutivamente. 0 processo e seu significado são os focos principais de abordagem. De acordo com o mesmo autor, a pesquisa quantitativa considera que tudo pode ser quantificável, o que significa traduzir em números as opiniões e 
informações para classificá-las e analisá-las, gerando resultados eficazes. Ela requer o uso de recursos e de técnicas estatísticas tais como: percentagem, média, moda, mediana, desvio padrão, entre outras. A utilização simultânea desses dois tipos de pesquisa permitiu a mensuração, análise e apresentação eficaz das informações a partir dos dados coletados.

A pesquisa concentrou-se apenas em dados do Estado de Mato Grosso do Sul, que é uma das 27 unidades federativas do Brasil. 0 estado de Mato Grosso do Sul localiza-se no sul da região centro-oeste do Brasil. De acordo com dados do Instituto Brasileiro de Geografia e Estatística (IBGE)/censo demográfico de 2010, o estado possui uma área de $357.145,534 \mathrm{~km}^{2}$, sua população é composta por 2.449 .024 habitantes, segundo dados do IBGE/Censo demográfico 2010, com estimativa de 2.682.386 habitantes em 2016. Ainda de acordo com informações do IBGE censo 2010 sobre as unidades de federação, o estado possui 79 municípios e tem Campo Grande como sua capital e cidade mais populosa. Além da capital, outros municípios com a população superior a cem mil habitantes são: Dourados, Corumbá e Três Lagoas. Seus limites territoriais fazem fronteira com cinco estados brasileiros: Mato Grosso (norte), Goiás e Minas Gerais (nordeste), São Paulo (leste) e Paraná (sudoeste); além de dois países sul-americanos: Paraguai (sul e sudoeste) e Bolívia (oeste).

\section{DISCUSSÃO E ANÁLISE DOS DADOS}

Desde 2009, quando se iniciou a atividade do microempreendedor individual até maio de 2017, inscreveram-se 6.978.888 microempresários, sendo 100.834 no estado de Mato Grosso do Sul (PORTAL DO EMPREENDEDOR, 2017). No quadro a seguir, podemos compreender a evolução da categoria no âmbito nacional, região do Centro-Oeste e o Estado de Mato Grosso do Sul.

Tabela 1: Total de Empresas Optantes no SIMEI pela UF - MS - nos inscritos total.

\begin{tabular}{|c|c|c|c|}
\hline ANO & BRASIL & 2.693 & 0 \\
\hline 2009 & 44.118 & 74.625 & 14.592 \\
\hline 2010 & 771.715 & 154.309 & 27.876 \\
\hline 2011 & 1.656 .953 & 245.083 & 42.906 \\
\hline 2012 & 2.665 .605 & 335.178 & 56.252 \\
\hline 2013 & 3.659 .781 & 420.819 & 69.707 \\
\hline 2014 & 4.653 .080 & 503.909 & 82.517 \\
\hline 2015 & 5.680 .614 & 579.442 & 95.890 \\
\hline 2016 & 6.649 .896 & 619.194 & 100.834 \\
\hline $31 / 05 / 2017$ & 6.978 .888 & & MATO GROSSO DO SUL \\
\hline
\end{tabular}

Fonte: Adaptado pela autora a partir de dados disponíveis no Portal do Empreendedor, Portal do Empreendedor, 2017 - www.portaldoempreendedor.

A tabela 1 demonstra que no ano da implantação da Lei do MEI, que foi em 2009, o estado de Mato Grosso do Sul não apresentou inscritos. Aqui abre-se um parêntese que justifica a falta desta informação no portal, o registro [...] no site portal do empreendedor, foi disponibilizado inicialmente para os estados do Ceará, do Espírito Santo, Minas Gerais, Paraná, Rio Grande do Sul, Rio de Janeiro, São Paulo, Santa Catarina e Distrito Federal, enquanto que para outros estados o sistema era buscar o SEBRAE. (SEBRAE, p.13, 2015). Já na região Centro-Oeste, houve inscrição de 2.693 MEI'S, somente em 9 de fevereiro de 2010, que o endereço do Portal do Empreendedor, na internet, (www.portaldoempreendedor.gov.br) passou a oferecer o serviço de formalização do MEI para todo o País (SEBRAE, 2015). Já no território nacional, houve 44.118 inscrições de MEI'S no ano de 2009. Como se observa, apesar de ter uma grande evolução no número de microempresários formalizados no estado de Mato Grosso do Sul, ainda é uma evolução pequena e lenta se comparada com a evolução nacional e da região do centro-oeste, tendo-se em consideração que a quantidade de microempreendedores do estado é de apenas 1,44\% do total de empreendedores nacional.

Com relação as diversas formas de atuações, na tabela 2 a seguir, é possível identificar. 
Tabela 2: Total de Empresas Optantes no SIMEI, da Unidade Federativa MS, por Forma de Atuação.

\begin{tabular}{|l|c|c|c|}
\hline \multicolumn{1}{|c|}{ Forma de Atuação } & \% em relação ao Brasil & \% em relação à UF & No. MEI \\
\hline Total & $1,3571 \%$ & $100 \%$ & 135.453 \\
\hline $\begin{array}{l}\text { Portabelecimento fixo } \\
\text { ambulante }\end{array}$ & $0,6767 \%$ & $49,86 \%$ & 67.543 \\
\hline Em local fixo, fora da loja & $0,3978 \%$ & $29,31 \%$ & 39.706 \\
\hline Internet & $0,1068 \%$ & $7,87 \%$ & 10.661 \\
\hline Televendas & $0,0982 \%$ & $7,23 \%$ & 9.799 \\
\hline Correios & $0,0385 \%$ & $2,84 \%$ & 3.841 \\
\hline Máquinas automáticas & $0,0278 \%$ & $2,05 \%$ & 2.773 \\
\hline
\end{tabular}

Fonte: Portal do Empreendedor, 2017.

A tabela 2 faz-nos observar que quase metade dos microempresários individuais sul-mato-grossenses atuam em estabelecimento fixo, e que esse montante de empresários representa apenas $0,67 \%$ do montante nacional. É possível identificar também que a segunda forma de atuar é mais expressiva é a de porta a porta, postos móveis ou por ambulantes.

Quanto à Classificação Nacional da Atividade Econômica desenvolvida por esses empreendedores em Mato Grosso do Sul, pode-se analisar na tabela 3:

Tabela 3: Total de Empresas Optantes no SIMEI, da Unidade Federativa MS, por Código CNAE, descrição CNAE e Sexo.

\begin{tabular}{|c|c|c|c|}
\hline CNAE & TOTAL & MASCULINO & FEMININO \\
\hline $\begin{array}{l}\text { Comércio varejista de artigos do vestuário e } \\
\text { acessórios }\end{array}$ & 12.468 & 2.708 & 9.760 \\
\hline Cabeleireiros, manicure e pedicura & 7.503 & 1.563 & 5.940 \\
\hline Obras de alvenaria & 5.532 & 5.354 & 178 \\
\hline Lanchonetes, casas de chá, de sucos e similares & 3.785 & 1.690 & 2.095 \\
\hline Instalação e manutenção elétrica & 2.472 & 2.269 & 203 \\
\hline Comércio varejista de bebidas & 2.449 & 1.366 & 1.083 \\
\hline $\begin{array}{l}\text { Bares e outros estabelecimentos especializados } \\
\text { em servir bebidas }\end{array}$ & 2.409 & 1.237 & 1.172 \\
\hline $\begin{array}{l}\text { Comércio varejista de mercadorias em geral, com } \\
\text { predominância de produtos alimentícios - } \\
\text { minimercados, mercearias e armazéns }\end{array}$ & 2.340 & 1.069 & 1.271 \\
\hline Outras atividades de tratamento de beleza & 2.289 & 75 & 2.214 \\
\hline $\begin{array}{l}\text { Fornecimento de alimentos preparados } \\
\text { preponderantemente para consumo domiciliar }\end{array}$ & 2.024 & 577 & 1.447 \\
\hline Total & 100.206 & 53.825 & 46.381 \\
\hline
\end{tabular}

Fonte: Portal do Empreendedor, 2017.

A tabela 3 mostra as 10 categorias com maior número de registro, das 369 categorias registradas no estado de Mato Grosso do Sul. A atividade "Comércio varejista de artigos do vestuário e acessórios" é a que aparece com a maior quantidade de atuantes entre as demais, com a predominância do gênero feminino, sendo quase o dobro do segundo colocado, que é a atividade de "Cabeleireiro", que também é predominado pelo gênero feminino. Apesar dessas categorias serem as que têm mais atuantes e serem dominadas pelo gênero feminino, mais de metade dos microempreendedores individuais sul-matogrossense são do gênero masculino, com $53,71 \%$. 
A tabela 4 a seguir apresenta a faixa etária do microempreendedor individual, formalizado no estado de Mato Grosso do Sul e no Brasil.

Tabela 4: Total de Empresas Optantes no SIMEI, da Unidade Federativa MS e do Brasil, por Faixa Etária.

\begin{tabular}{|c|c|c|}
\hline Faixa Etária & Número de MEI no Brasil & $\begin{array}{c}\text { Número de MEI em Mato Grosso do } \\
\text { Sul }\end{array}$ \\
\hline $16-17$ & 812 & 14 \\
\hline $18-20$ & 73.505 & 1.016 \\
\hline $21-30$ & 1.537 .348 & 22.396 \\
\hline $31-40$ & 2.309 .616 & 31.814 \\
\hline $41-50$ & 1.721 .981 & 24.892 \\
\hline $51-60$ & 1.083 .704 & 16.614 \\
\hline $61-70$ & 331.921 & 5.162 \\
\hline Acima de 70 & 60.635 & 782 \\
\hline Total & 7.119 .432 & 102.690 \\
\hline
\end{tabular}

Fonte: Portal do Empreendedor, 2017.

Os dados da tabela 4 apontam que mais da metade dos MEI'S são jovens adultos. A faixa etária de 18 a 40 anos é de 53,78\% em Mato Grosso do Sul, e de 55,07\% no Brasil. Os adolescentes de 16 a 17 anos representam apenas $0.0001 \%$ dos microempresários sul-mato-grossenses e no Brasil. Já o público adulto maduro representa 46,21\% em Mato Grosso do Sul e de 44,92\% no Brasil. Dados que se assemelham a pesquisa GEM.

Na tabela 5, aparecem as oito nacionalidades dominantes nos microempreendedores individuais em Mato Grosso do Sul.

Tabela 5: Total de Empresas Optantes no SIMEI da Unidade Federativa MS, por Nacionalidade.

\begin{tabular}{|c|c|}
\hline Nacionalidade & №. MEI em MS \\
\hline Brasileira & 102.168 \\
\hline Paraguaia & 197 \\
\hline Boliviana & 141 \\
\hline Peruana & 25 \\
\hline Portuguesa & 22 \\
\hline Chinesa & 20 \\
\hline Libanesa & 17 \\
\hline Colombiana & 17 \\
\hline Total & 102.690 \\
\hline
\end{tabular}

Fonte: Portal do Empreendedor, 2017.

Na tabela 5, identifica-se que os microempreendedores individuais são predominantemente brasileiros, a segunda nacionalidade de maior expressão no Estado de Mato Grosso do Sul é a paraguaia seguida pelos bolivianos, que se explica pelas nossas fronteiras Brasil Paraguai e Brasil Bolívia.

\section{CONCLUSÕES}

O desenvolvimento do presente estudo possibilitou uma análise do perfil do microempreendedor individual do estado de Mato Grosso do Sul. 
Com os dados obtidos, revelou-se que no estado do Mato Grosso do Sul, o microempreendedor individual é predominantemente brasileiro, até a data de 31 de maio de 2017, inscritos no portal representam 102.690 MEI's, seguido por duas nacionalidades - Paraguai com 197 inscritos e, Boliviana com 141, que se justifica pelas fronteiras, porém, chama a atenção que outras nacionalidades de países próximos ou de outros continentes estão se instalando na região, como a peruana, portuguesa e chinesa.

A pesquisa revelou que mais da metade desses empresários são de jovens adultos na faixa estaria de 18 a 40 anos, com 53,78\% no estado de Mato Grosso do Sul. Identificou-se ainda, que, embora as atividades com maior quantidade de inscritos serem dominadas pelo gênero feminino, a categoria do microempreendedor individual é predominantemente do gênero masculino, com 53,71\% em Mato Grosso do Sul, e que essas atividades são desenvolvidas em sua maioria em 'estabelecimento fixo', ou 'porta a porta, postos móveis ou ambulante'.

Constatou-se que a categoria do microempreendedor individual vem crescendo em Mato Grosso do Sul, quanto no Brasil, o que torna um tema importante de ser estudado, pois, é um setor que atua diretamente na economia local, regional e nacional. A formalização do trabalho promove a inclusão social desses cidadãos que viviam à margem da sociedade formal, e assegura os direitos dos trabalhadores, e também seus deveres perante à lei.

Portanto, este estudo atingiu o seu objetivo de descrever o perfil do microempreendedor individual, registrado no estado de Mato Grosso do Sul.

Para estudos futuros, recomenda-se apurar a parcela de microempreendedores individuais que migram de categoria, e se o processo é simples como a inscrição do MEI e quais os incentivos para que isso aconteça. Identificar porque a população de MEI é maior do gênero masculino enquanto a estimativa da população brasileira é de maioria feminina, com 50,64\% (IBGE, 2017). E também, investigar o perfil do microempresário menor de 18 anos que foi possível identificar a existência dessa categoria na presente pesquisa, qual sua motivação, seu conhecimento sobre empreendedorismo e o que poderia atrair e fortalecer ainda mais as características empreendedoras desse público.

\section{REFERÊNCIAS}

[1] ANDRADE, Maria Margarida de. Introdução à metodologia do trabalho científico: elaboração de trabalhos na graduação / Maria Margarida de Andrade. - 2. ed. - São Paulo: Atlas, 1997.

[2] BESSANT, John, TIDD, Joe. (01/2009). Inovação e Empreendedorismos - Administração. [Minha Biblioteca]. Disponível em:< https://integrada.minhabibliotéca.com.br/\#/books/9788577805112> Acesso em: 28 de dezembro de 2016.

[3] BRASIL. Lei Complementar no 128, de 19 de Dezembro de 2008. Disponível em: <http://www.planalto.gov.br/ccivil_03/leis/LCP/Lcp128.htm> Acesso em: 15 de dezembro de 2016.

[4] CARMO, Hérmani Magalhaes Olivense do. Et al. MICROEMPRENDEDOR INDIVIDUAL (MEI): Benefícios e Desafios da Legislação Brasileira para a Aplicação na Prática da Ação. XVIII SEMEAD.Seminários em Administração / novembro de 2015.ISSN 2177-3866

[5] CONAJE. Perfil do Jovem Empreendedor Brasileiro. Disponível em: < http://conaje.com.br/projetos/pesquisa-conaje/> Acesso em: 18 de janeiro de 2017.

[6] FEDERAÇÃO DO COMÉCIO DE BENS, SERVIÇOS E TURISMO DO ESTADO DE MATO GROSSO DO SUL. Total de microempreendedores aumentou 16,8\% este ano em MS. Disponível em: < http://www.fecomercioms.com.br/noticias/total-de-microempreendedores-aumentou-168-este-ano-em-ms> Acesso em: 06 de setembro de 2017.

[7] GENNARI, Adilson Marques. OLIVEIRA, Robson de. História do pensamento econômico. - 1. ed. São Paulo: Saravia, 2009.

[8] GIL, Antonio Carlos. Métodos e técnicas de pesquisa social/ Antonio Carlos Gil. - 6. ed. - São Paulo: Atlas, 2008.

[9] GONSALVES, Elisa Pereira. Conversas sobre iniciação à pesquisa científica/ Elisa Pereira Gonsalves. - 5. ed. Campinas, SP: Editora Alínea, 2011.

[10] GLOBAL ENTREPRENEURSHIP MONITOR. Empreendedorismo no Brasil : 2015 \Coordenação de Simara Maria de Souza Silveira Greco ; autores : Mariano de Matos Macedo... [et al] -- Curitiba: IBQP, 2014. Disponível em: <http://www.bibliotecas.sebrae.com.br/chronus/ARQUIVOS_CHRONUS/bds/bds.nsf/4826171de33895ae2aa12cafe9 98c0a5/\$File/7347.pdf> Acesso em: 23 de janeiro de 2017. 
[11] HISRICH, D., R., PETERS, P., M., SHEPERD, A., D. (01/2014). Empreendedorismo, 9. ed. [Minha Bibliotéca]. Disponível em: < https://integrada.minhabiblioteca.com.br/\#/books/9788580553338/ > Acesso em: 02 de janeiro de 2017.

[12] INSTITUTO BRASILEIRO DE GEOGRAFIA E ESTATÍSTICA. Dados do Estado de Mato Grosso do Sul. Disponível em: < http://www.ibge.gov.br/estadosat/perfil.php?sigla=ms> Acesso em: 04 de março de 2017.

[13] INSTITUTO BRASILEIRO DE GEOGRAFIA E ESTATÍSTICA. Série estudos e pesquisas: estatística de empreendedorismo. Disponível em: < https://cidades.ibge.gov.br/v4/brasil/ms/pesquisa/10062/60100> Acesso em: 05 de setembro de 2017.

[14] INSTITUTO BRASILEIRO DA QUALIDADE E PRODUTIVIDADE. Rede Sim. Disponível em: < http://www.ibqp.org.br/projetos/gem/> Acesso em: 02 de janeiro de 17

[15] LEONE, Eugenia Troncoso. O perfil dos trabalhadores e trabalhadoras na economia informal / Eugenia Troncoso Leone; Escritório da OIT no Brasil. - Brasília: OIT, 2010.

[16] LEGISWEB. Rede Sim. Disponível em: <https://www.legisweb.com.br/legislacao/?id=279343> Acesso em: 02 de março de 17

[17] NASSIF, V. M. J.; GHOBRIL, A. N.; AMARAL, D. J. do. Empreendedorismo por necessidade: o desemprego como impulsionador da criação de novos negócios no Brasil. Revista do programa de estudos pós-graduados em Administração - FEA. São Paulo, 2009.

[18] OLIVEIRA, Reginaldo Aparecido de. KRAKAUER, Patricia Viveiros de Castro. Microempreendedor Individual: estudo sobre benefícios e principais dificuldades encontradas na gestão de negócios. 2016.

[19] PORTAL DO EMPREENDEDOR. Rede Sim. Disponível em: <http://www.portaldoempreendedor.gov.br/> Acesso em: 28 nov. 2016.

[20] RAMOS, Carlor Alberto. Setor Informal: do excedente estrutural à escolha individual. Marcos interpretativos e alternativas de políticas. Econômica, Rio de Janeiro, v. 9, n. 1, p. 115-137, junho 2007. Disponível em: <http://www.uff.br/revistaeconomica/N9V1/CARLOS.PDF> Acesso em: 20 de março de 2017.

[21] SAFARTI, G. Estágios de desenvolvimento econômico e políticas públicas de empreendedorismo e de micro, pequenas e médias empresas (MPMEs) em perspectiva comparada: os casos do Brasil, do Canadá, do Chile, da Irlanda e da Itália. Rev. Adm. Pública — Rio de Janeiro 47(1):25-48, jan./fev. 2013.

[22] SERVIÇO BRASILEIRO DE APOIO ÀS MICRO E PEQUENAS EMPRESAS, 5 anos: microempreendedor individual - MEI: um fenômeno de inclusão produtiva. SEBRAE - Brasília: Sebrae, 2015.

[23] SEBRAE. Empreendedorismo na Região Centro-Oeste do Brasil. 2014. Disponível em: <https://www.sebrae.com.br/Sebrae/Portal\%20Sebrae/Estudos\%20e\%20Pesquisas/gem\%202014_centrooeste.pdf> Acesso em: 13 de fevereiro de 2017.

[24] SILVA, Patrícia de Souza Santana et al. Microempreendedor Individual e Seus Aspectos de Transição. 2016.

[25] SILVEIRA, Amélia, CARMO, Hérmani Magalhães Olivense do, SOUZA, Roosiley dos Santos. Microempreendedor Individual (MEI): Benefícios e Desafios da Legislação Brasileira para a Aplicação na Prática da Ação. 2017. Revista Livre de Sustentabilidade e Empreendedorismo, v. 2, n. 1, p. 117-137, jan-mar, 2017 


\section{Capítulo 15}

SUCESSÃO

GERACIONAL

FAMILIAR

$E M$

PROPRIEDADES RURAIS DE AGRICULTORES

ASSOCIADOS EM COOPERATIVA DE CRÉDITO

\section{Geneci da Silva Ribeiro Rocha}

Maielen Lambrecht Kuchak

\section{Patricio Duarte Rocha}

Adriano Lago

Resumo: Esta pesquisa analisa o processo de sucessão geracional em propriedades rurais de agricultores associados à Crehnor, unidade de atendimento do município de Jaboticaba-RS. Para alcançar o objetivo geral, considerou-se como princípios básicos a agricultura familiar, a sucessão geracional e a influência das cooperativas de crédito no processo sucessório. A pesquisa, exploratória e descritiva, foi realizada por meio de questionário composto por 33 questões abertas e fechadas, aplicada a 38 agricultores associados. Os mesmos foram entrevistados em visitas às propriedades e também no posto de atendimento. Os dados foram coletados e analisados entre os meses de agosto e outubro de 2016. A partir das análises dos dados, identificou-se que a maioria das propriedades está bem estruturada, aparentemente com bom retorno financeiro e a maior parte dos entrevistados estão satisfeitos com as atividades desenvolvidas na propriedade. Os agricultores, sendo associados à cooperativa de crédito, manifestaram mais segurança pela disponibilidade de linhas de crédito com seguro agrícola, entre outros. Entretanto, estão encontrando dificuldades em dar continuidade às atividades agrícolas, devido a indefinição de um possível sucessor, associado, muitas vezes, a não realização de planejamento sucessório, à falta de comunicação nas famílias e ao êxodo rural dos jovens. A grande parte dos associados entrevistados são agricultores consolidados e que já passaram por um processo sucessório ao assumirem a propriedade de seus pais. Contudo, estão preocupados em quem vai lhe substituir.

Palavra-chave: Agricultura familiar. Sucessão Geracional. Cooperativismo. 


\section{INTRODUÇÃO}

A agricultura familiar desempenha um papel muito importante no desenvolvimento do país, pois, além de produzir quase toda a alimentação que vai para a mesa dos brasileiros, é uma fonte de geração de emprego e renda no meio rural. Segundo Silvestro et al. (2001), a agricultura familiar atualmente vem se tornando o ator principal entre as políticas públicas, com importância social e econômica, para garantir ao homem do campo a participação da agricultura familiar na modernização da sociedade em geral.

Os debates sobre sucessão geracional agrícola são recorrentes. Nem toda a atenção dada à agricultura familiar nos últimos tempos foi suficiente para manter o jovem agricultor no campo. Assim, muitos deles continuam migrando para as cidades, estabelecendo dificuldades na transferência da propriedade rural. De acordo com Feijó (2011), as pessoas ainda estão deixando o campo. 0 êxodo rural continua significativo, com grandes desafios e incertezas quanto ao futuro das propriedades familiares rurais.

Segundo Brumer e Spanevello (2008), o prosseguimento da agricultura familiar e de suas unidades produtivas depende de uma série de fatores, como condições socioeconômicas, tipo de trabalho, educação, lazer, entre outros, que, podem facilitar ou dificultar a permanência dos jovens no meio rural. Além disso, as autoras enfatizam as diferenças de gêneros, onde o processo de sucessão acontece de maneira diferenciada entre homens e mulheres, visto que muitos pais preferem filhos homens para dar continuidade à propriedade.

Diante disso, este estudo, que tem como pano de fundo a sucessão familiar nas propriedades rurais, com o desafio de explicar como ocorre o processo de sucessão nas propriedades dos associados do posto de atendimento da Crehnor de Jaboticaba, destacando as contribuições da cooperativa no processo de sucessão e na permanência dos jovens nas propriedades rurais. 0 tema proposto tem como embasamento a importância da agricultura familiar para a economia local, regional e do país. Nesse aspecto, este estudo tem como objetivo analisar o processo de sucessão geracional em propriedades rurais dos agricultores associados à CREHNOR localizada no município de Jaboticaba - RS. Além disso,se propõe a identificar as dificuldades enfrentadas pelos agricultores na permanência no meio rural, descrevendo o perfil das propriedades rurais e dos jovens sucessores, contemplando as ações e estratégias da cooperativa de Crédito que podem contribuir na permanência dos associados no meio rural e na sucessão geracional.

\section{AGRICULTURA FAMILIAR}

A agricultura familiar passou a merecer maior destaque em âmbito nacional a partir em 1990, através dos movimentos sociais, que pediam atenção aos pequenos agricultores, que estavam excluídos. Desde então, percebe-se uma maior atenção por parte do governo federal com mais políticas públicas destinadas à agricultura familiar, como pela criação do Programa Nacional de Fortalecimento da Agricultura familiar, o (PRONAF), em 1995 (FEIJÓ, 2011). Atualmente, a agricultura familiar exerce um papel social muito grande na sociedade e na economia, com a produção de diferentes produtos agrícolas e pecuários, abastecendo, assim, toda a população do país.

Segundo Magri e Correa (2012, p.94), "a agricultura familiar é responsável por 70\% dos alimentos que chegam à mesa dos brasileiros e 10\% do Produto Interno Bruto (PIB) do país". De acordo com Censo Agropecuário realizado em 2006 pelo Instituto Brasileiro de Geografia Estatística (IBGE); no Brasil $84,40 \%$ das propriedades rurais são familiares, o que demonstra que cerca de 4,37 milhões de propriedades são familiares, com $50 \%$ localizadas no Nordeste do país e ocupam uma área de $35 \%$ do total das terras dessa região.

Segundo Coradini (2011) e de acordo com dados do Instituto Brasileiro de Geografia Estatística (IBGE 2006), a agricultura familiar do Rio Grande do Sul, apresenta-se em vantagem no faturamento agropecuário em relação aos dados nacionais. De acordo com os dados do IBGE (2006), a renda média alcançada no ano de 2006 com a comercialização de produtos agropecuários foi de $\mathrm{R} \$ 13.600 .00$ entre os produtores brasileiros, ao passo que os produtores do Rio Grande do Sul obtiveram em média $\mathrm{R} \$ 22.038,00$ no mesmo ano (CORADINI, 2011).

Conforme Magri et al. (2008), a participação da agricultura familiar no Rio Grande do Sul representa 27\% do PIB do Estado e obteve um crescimento nos últimos três anos de 52\%. Contudo, ainda segue a preocupação sobre a viabilidade econômica que garanta a permanência das famílias, especialmente dos jovens no campo, assim como também o modelo de agricultura que até hoje é praticado.

A produção da agricultura familiar é formada pelo cultivo de plantas alimentares e o desenvolvimento da fruticultura (SOUZA; ANDRADE, 2013), onde são produzidos alimentos básicos como mandioca, feijão, 
milho, leite, ovos, suínos, entre outros. É direcionada fundamentalmente para o mercado interno, com uma produção bastante diversificada, garantindo assim diversas variedades de culturas em uma mesma propriedade (LASCHEFSKI; SOUZA, 2009).

De acordo com a Organização das Nações Unidas para Agricultura e Alimentação (FAO), citada por Rodrigues (2000, apud FREITAS, 2002, p.47), agricultura familiar é definida a partir de três características centrais: 1) "a gestão da unidade produtiva é realizada por pessoas que mantêm ligações entre si de parentesco e casamento; 2) uma grande parte do trabalho, se não a maior, é feita por membros da família; 3) os meios de produção (embora nem sempre a terra) pertencem à família".

Para Feijó (2011), na agricultura familiar a produção agrícola é organizada numa forma social específica, que enfatiza a mão de obra própria da família, constituindo-se na principal fonte geradora de empregos e renda no meio rural.

\subsection{SUCESSÃO GERACIONAL EM PROPRIEDADES RURAIS}

Nos últimos anos, as famílias das áreas rurais vêm diminuindo significativamente devido ao rápido crescimento das cidades, à falta de oportunidades no campo e o acesso à terra. Isso faz com que as propriedades rurais tenham falta de sucessores para dar continuidade a seus trabalhos no meio rural (SILVESTRO et al. 2001).

Para Magri (2008, p.77), "a ausência de perspectivas na qualidade de vida envolvendo a capacitação técnica e incentivo financeiro é um dos motivos que fazem com que os jovens saiam do meio rural". A margem de lucro que fica no setor primário é pequena. Isso faz com que não haja interesse dos jovens em permanecer no campo. Ainda segundo Magri (2008, p.77), "o próprio jovem demonstra falta de interesse em continuar na agricultura, até mesmo porque a família não o incentiva", sendo poucos os pais que apresentam uma organização na gestão da propriedade que leve em consideração o processo de sucessão. Segundo Spanevello (2008), a sucessão no campo considera dois aspectos centrais: 1) a sucessão geracional, que é um processo com várias etapas; 2 ) a sucessão é marcada pelo processo de participação e socialização dos filhos, porque desde crianças participam das atividades de produção agrícola na propriedade.

De acordo com Silvestro et al. (2001, p.28),

Os filhos e filhas integram-se aos processos de trabalho na agricultura familiar, acompanhando seus pais em algumas tarefas, auxiliando a conduzir os animais e ajudando na casa desde muito cedo. E assim aos poucos vão assumindo atribuições de maior importância e chegam à adolescência dominando as técnicas e os principais aspectos da gestão da propriedade, observados durante sua vivência no campo. No entanto, estes conhecimentos não significam que os jovens organizem seu futuro com os olhos essencialmente voltados para a propriedade paterna.

Segundo Spanevello (2008) a sucessão varia muito, pois há uma diferenciação na escolha dos filhos. Conforme a autora, quase sempre a escolha dos pais é pelos filhos homens para dar continuidade ao legado deixado pelo patriarca da família. No caso das mulheres, a sucessão ocorre geralmente quando as mesmas são filhas únicas ou quando há falta de sucessor homem para continuar na propriedade.

0 trabalho das mulheres, de modo especial na agricultura, não é reconhecido como produtivo ou com valor econômico, mas é visto como "ajuda". A agricultura é definida pela divisão do trabalho como uma ocupação masculina. Isso faz com que as mulheres sejam vistas como donas de casa, não importando qual sua contribuição à agricultura familiar (DEERE; LEON, 2002 apud SPANEVELLO, 2008).

Segundo Carneiro (2005), ainda que legalmente as mulheres tenham direito à terra como herança, este direito é impedido pela própria família por valores e interesses, pela integridade da produção e reprodução da unidade familiar. As mesmas, por terem uma relação subordinada, e por não terem outra opção, vão em busca de trabalho assalariado no meio urbano.

Para Coradini (2011), a permanência dos jovens na agricultura por meio da sucessão é um processo coordenado pelos próprios agricultores, já que a centralidade da família garante o domínio dos pais em torno da sucessão. Silvestro et al. (2001), afirmam que a permanência do jovem no meio rural dependerá das ações que serão tomadas com relação ao processo decorrente da sucessão. Portanto não basta que os prováveis sucessores estejam preparados para assumir a propriedade, mas é necessário que as 
propriedades estejam preparadas com terras, tecnologia, equipamentos e capital financeiro para que o trabalho na agricultura seja rentável, sustentável economicamente, e que as famílias deem autonomia e reconheçam o trabalho de seus sucessores, para que os mesmos consigam gerir suas propriedades e dar continuidade ao desenvolvimento rural de nosso país, do qual dependemos muito.

\subsection{COOPERATIVISMO}

Podemos definir cooperativa como sendo uma associação de no mínimo 20 pessoas, sem fins lucrativos, mas com fins econômicos. É a união de pessoas voltadas para um objetivo comum, visando alcançar os objetivos propostos na constituição estatutária. De acordo com a lei no .5 .750 de 16 de dezembro de 1971, a cooperativa é: "Uma sociedade de pessoas, com forma e natureza jurídica própria, de natureza civil e não sujeita a falência, constituída para prestar serviços aos associados" (BRASIL 1971).

As sociedades cooperativas são sistemas de cooperação econômica que podem envolver várias formas de produção de trabalho e que historicamente apareceu junto com o capitalismo. 0 ideal cooperativista se disseminou pelo mundo e atua em todos os setores da economia. Hoje é conhecido como um sistema adequado, participativo, justo, democrático que visa atender aos interesses dos trabalhadores (VEIGA; FONSECA, 2001). Já para Rios (1989, p.16) define "cooperativa como sendo uma associação voluntária com fins econômicos, podendo nela ingressar os que exercerem uma mesma atividade".

De acordo com Veiga e Fonseca (2001, p.18) “o cooperativismo busca defender a economia dos trabalhadores e se caracteriza por garantir a participação mais ampla possível da população nos frutos da atividade econômica". Deste modo é uma forma alternativa de pensar e realizar o trabalho e coordenar a economia.

Segundo Rios (1989, p.27) “A cooperativa é um empreendimento que compreende tantas variedades econômicas, quantas são as necessidades possíveis de serem atendidas”. Sendo que existem diversos tipos de cooperativas, como agropecuária, crédito, consumo, habitação, trabalho, saúde, entre outras. Que segundo a lei 5.764 de 1971, constitui que as cooperativas se classifiquem de acordo com os objetivos ou pelas atividades desenvolvidas.

\subsubsection{A HISTÓRIA DO COOPERATIVISMO}

As cooperativas tiveram suas origens nas reações defensivas de trabalhadores que lutavam contra altos preços dos bens de primeira necessidade como alimentos e roupas. A cooperativa mais antiga que se tem notícia teve seu início em 1760 por trabalhadores que trabalhavam nos moinhos de cereais de Woolwiche Chatham, na Inglaterra. Dessa perspectiva associativa é que surgiram mais tarde as cooperativas operárias de produção (VEIGA; FONSECA, 2001).

A primeira cooperativa moderna que surgiu foi a de consumo em 1844, na cidade de Rochdale, fundada por 28 tecelões que estavam com dificuldades financeiras, então resolveram associar-se para a compra de produtos em conjunto e assim conseguirem preços mais baixos (RIOS, 1989, p.22).

O pensamento do cooperativismo surgiu na Europa ocidental no início do século XIX, com a chegada da revolução industrial, as consequências econômicas e sociais deram origem ao movimento de ideias nos países europeus, que a partir de inúmeros pensadores dessa época, foi formada a filosofia que dá embasamento ao cooperativismo até os dias de hoje em todo o mundo (VEIGA; FONSECA, 2001).

Segundo Alves (2002, p.32) foi neste momento que se constituiu a base dos atuais princípios doutrinários do cooperativismo que se norteiam até os dias de hoje. Que são eles: adesão livre e voluntária; gestão democrática dos sócios; participação econômica; autonomia independência; educação, formação, informação; cooperação entre as cooperativas; interesse pela comunidade.

Segundo Gonçalves, (2012) o cooperativismo surgiu no Brasil com um grande número de imigrantes que chegavam para a substituição da mão de obra escrava, no final do século XIX. Alguns imigrantes mudaramse para o sul do país formando pequenas propriedades agrícolas, onde constituíram as primeiras cooperativas de crédito rural, assim como as cooperativas agropecuárias.

No século passado apareceram as primeiras cooperativas no Brasil especialmente em São Paulo e no Sul do país. Elas surgiram em virtude da necessidade de unir esforços a de que houvesse melhores condições de vidas dos trabalhadores (FEIJÓ, 2011).

No que afirma Veiga e Fonseca, (2001, p. 27) sobre o desenvolvimento do cooperativismo no Brasil, 
Por volta de 1887, foram constituídas as primeiras cooperativas no Brasil, como a Cooperativa de Consumo dos Empregados da Companhia Paulista, na Cidade de Campinas (SP). Em 1889 foi à vez da Cooperativa de Consumo de Ouro Preto (MG), a Sociedade Econômica Cooperativa dos Funcionários Públicos de Minas Gerais. Em 1891, em Limeira a Cooperativa da Companhia Telefonia, e, em 1884, no Rio de Janeiro (RJ), a Cooperativa dos Militares.

\subsubsection{COOPERATIVISMO DE CRÉDITO}

A primeira cooperativa de crédito foi fundada em 1902, por produtores de vinho, em Nova Petrópolis (RS). O Padre Jesuíta suíço, Theodoro Amstad teve a ideia de uma caixa de crédito rural nos moldes das caixas Raiffeisen, idealizadas por Friedrich Raiffeisen (VEIGA; FONSECA, 2001, p. 27). Após várias alterações no nome, passou então a ser chamada de "Cooperativa de Crédito de Livre Admissão de Associados à Pioneira da Serra Gaúcha- Sicredi Pioneira RS”.

0 italiano Luigi Luzzatti inspirado nos pioneiros alemães elabora em 1865, na cidade de Milão a constituição da primeira cooperativa do tipo Luzzatti. No Brasil, esse modelo de cooperativa tem como característica a inexistência de vínculo com o associado, com exceção de algum limite geográfico, (cidade, bairro etc.), cota capital e concessão de crédito em pequenos valores sem garantias reais (PINHEIRO, 2008).

De acordo com Alves (2002, p.69) "as cooperativas precisam observar limites de capital realizado e patrimônio líquido ajustado, na forma da lei que estiver em vigor." Outros instintos apresentam as mesmas como entidades designadas a promover a poupança e financiar necessidades ou empréstimos de seus associados.

Pinheiro (2008, p.7), conceitua as cooperativas de créditos como sendo:

Instituições financeiras constituídas sob a forma de sociedade cooperativa, tendo por objetivo a prestação de serviços financeiros aos associados, como concessão de crédito, captação de depósitos à vista e a prazo, cheques, prestação de serviços de cobrança, de custódia, de recebimentos e pagamentos por conta de terceiros sob convênio com instituições financeiras públicas e privadas e de correspondente no País, além de outras operações específicas atribuições na legislação em vigor.

De acordo com o Banco Central do Brasil, as cooperativas de crédito são instituições financeiras com formas de natureza jurídicas próprias, de natureza civil sem fins lucrativos. Segundo Magri et al. (2010, p.151) "os associados assumem ao mesmo tempo a condição de proprietários e responsáveis pela direção da cooperativa". Para Veiga e Fonseca (2001) os colaboradores controlam lucros com as várias operações realizadas com seus depósitos, estes são repartidos entre os cooperados ou reinvestidos conforme deliberados em assembleia, ou até mesmo podendo financiar outros empreendimentos cooperativos. Por isso dá importância das cooperativas de crédito como instrumento de desenvolvimento dos países.

Perius (2001, p. 205), afirma que:

A maior vantagem de ser sócio em cooperativa de crédito é ser o "banqueiro" o dono da cooperativa, para qual se destina todo o resultado operacional. Trabalhar com a mesma significa que a riqueza gerada fica com sócios que ganham e se apropriam do resultado do trabalho em conjunto. Assim a uma profunda diferença entre uma cooperativa em outro sistema que quem ganha é o dono do banco.

No que afirma Pinheiro (2008, p.14) “As cooperativas de crédito ainda que ocupem um pequeno espaço no SFN tanto quanto às operações de crédito quanto no patrimônio líquido". As mesmas vêm apresentando um extraordinário crescimento, não só em volume, mas também em percentual de participação na área bancaria do sistema financeiro. Mas esse segmento ainda é considerado muito pequeno se comparado a outros países mais desenvolvidos. Em dezembro de 2006 o Brasil respondia por 2,26\% das operações de crédito e possuía 2,62\% do patrimônio líquido total do Sistema Financeiro Nacional, atendendo mais de três milhões de pessoas.

De acordo com Pinheiro (2008, p. 15) no Brasil não há uma entidade de cúpula única para o cooperativismo de crédito, e sim organizada em quatro grandes sistemas principais; "Sicredi, Siscoob, 
Unicred, Ancosol, que são as cooperativas de $3^{\circ}$ grau. Diferentemente de outros países onde há uma única cúpula".

Segundo Perius (2001, p.204), com base no estudo do OBC (1999), “o Brasil possui 920 cooperativas, com 1.407.089 associados apontando-se em terceira colocação, com 16.908 funcionários. As cooperativas de crédito apresentam-se em três subdivisões: 10 Luzzatti, 353 Rural, e 537 de crédito mútuo".

As cooperativas de crédito Luzzatti permite a livre admissão de associados de qualquer ramo ou profissão, com as seguintes características:

Capital social dividido em quotas-partes de pequeno valor; responsabilidade limitada ao valor da quota capital; área de operações circunscrita, tanto quanto possível, ao território do município em que tiver a sua sede, só podendo estabelecer área maior, fora desse território, quando municípios próximos abrangessem zonas economicamente tributárias da aquela em que estiver, não se incluindo, entretanto, no limite da área, aquelas operações que constituíam em cobranças ou permutações de fundos; empréstimos concedidos exclusivamente aos associados domiciliados na circunscrição considerada como área de operações, dando a administração sempre preferência as operações de menor valor e ao crédito pessoal sobre o de garantia real; administração constituída por um conselho de administração, composto pelos menos de cinco membros, eleitos pela assembleia geral, sendo o presidente do conselho e o diretor-gerente da sociedade designados diretamente na ata da eleição, permanentemente, e mais um conselheiro a cada mês de turno, formando a diretoria executiva, cabendo ao corpo coletivo as atribuições mais gerais e de regulamentação e à diretoria as funções mais particularizada e executivas (PINHEIRO 2008, p.32).

As cooperativas de crédito rural devem ter seu quadro social formado por pessoas físicas que desenvolvam atividades agrícolas, pecuárias ou extrativistas e que se dediquem a operações de captura e transformação de pescado e especialmente por pessoas jurídicas e que exerçam exclusivamente as mesmas atividades, a concessão de empréstimos somente por meio de cédulas de créditos rurais e duplicatas rurais (PINHEIRO, 2008).

Segundo Pinheiro (2008), as cooperativas de crédito mútuo são originadas do sistema Desjardins, que exige vínculo entre os associados, onde só é admitido como associados pessoas de determinada profissão classe ou atividades comuns ou que estejam vinculadas a entidades por pessoas jurídicas e se conceitue como micro e pequena empresa, ou sem fins lucrativos, cujos sócios integrem, obrigatoriamente o quadro de cooperados.

De acordo com a portaria no 1.098 do ministério da agricultura estabeleceu que:

VI- São cooperativas de crédito mútuo as que têm como associados somente pessoas vinculadas a uma determinada entidade, corporação ou empresa com área de ação reduzida e que realizem operações ativas e passivas únicas e exclusivamente com os associados.

A primeira cooperativa de crédito mútuo no Brasil é a Cooperativa de Crédito dos funcionários da Matriz do Banrisul Ltda. Fundada em 2 de março de 1946, onde continua em atividade e sob a denominação de Cooperativa de Crédito Mútuo dos empregados do Banrisul Ltda (PINHEIRO, 2008).

\subsubsection{REGULAMENTAÇÃO JURÍDICA DAS COOPERATIVAS DE CRÉDITO}

De acordo com Perius (2001), a constituição jurídica das cooperativas está amparada pela Lei no 5.764 de 1971. No que afirma Pinheiro (2008, p.38), por meio da Lei no 4.595, 31 de dezembro de 1964, as cooperativas de créditos igualaram-se as demais instituições financeiras conforme o art. 55 dessa lei transfere ao Banco Central do Brasil (BCB) as atribuições de regulamentar e fiscalizar as instituições financeiras, entre elas as cooperativas de créditos.

Segundo Pinheiro (2008, p.36) " a Lei no 1.412, de 13 de agosto de 1951, alterou a Caixa de Crédito no Banco Nacional de Crédito Cooperativo (BNCC), com o intuito de promover a assistência e proteção das cooperativas". 0 qual era controlado pela união, que tinha uma participação inicial de $60 \%$ de seu capital, e as cooperativas tinham uma participação de $40 \%$ do capital restante.

De acordo com Pinheiro (2008) atual Lei no 5.764 de dezembro de 1971, revogou os decretos-leis no 59 e 60.597, instituindo o regime jurídico das sociedades cooperativas, definindo as mesmas como sociedades de pessoas de natureza civil, mas mantendo a fiscalização e controle ao Banco Central. 
Entretanto, com a liquidação do BNCC, o Sistema Nacional de Crédito Cooperativo ficou à deriva, sem nenhuma fonte catalisadora e coordenadora de recursos originários do cooperativismo. Além disso, tinha também os serviços como compensação de cheques e outros papéis que eram obrigatoriamente operados através de convênio com o Banco do Brasil, o qual acabava trazendo alguns importunos e custos para o sistema (SOARES; SOBRINHO, 2008).

Anos depois da vigência da Resolução no 1.914/1992, o CMN considerou oportuna a criação de bancos cooperativos a qual foi concretizada através da resolução no 2.193, de 1995, sendo de imediata aproveitada pelos principais sistemas de cooperativas, "o Sicredi, com o banco do cooperativo Sicredi (Bansicredi), e o Sicoob, que criou o Banco Cooperativo do Brasil (Bancoob)” (SOARES; SOBRINHO, 2008, p.73).

\subsection{A IMPORTÂNCIA DO COOPERATIVISMO NA SUCESSÃO GERACIONAL}

Segundo Spanevello e Lago (2007), as cooperativas são meios de desenvolvimento rural, pois buscam uma maior produtividade e rentabilidade para seus associados, gerando assim empregos e renda e um aumento na arrecadação nos municípios onde estão inseridas.

Para Koopmans (2006), o trabalho em conjunto traz vantagens, pois vêm de encontro para solucionar problemas que os agricultores enfrentam na garantia de preços justos para seus produtos e alternativas para aquisição de bens e serviços. E hoje isso vem causando uma forte influência diante dos jovens, por ter conhecimento, de que podem contar com um grupo na luta diária de empreendimento rural, garantindo assim a continuação das atividades rurais e sua permanência no campo.

De acordo com Spanevello e Lago (2007), as cooperativas não atuam somente na questão produtiva e comercial dos produtos de seus associados, mas também trazendo ao associado à oportunidade de qualificação dos mesmos, facilitando assim a inclusão no mercado competitivo. Deste modo, as cooperativas propiciam várias alternativas que fazem com que os jovens tenham um maior interesse pela agricultura, já que a cooperativa é um meio de ampliar o conhecimento, garantindo a sua permanecia no campo.

Neste sentido o cooperativismo vem desencadeando várias formas de desenvolvimento, acontecimento estes verificados na organização social e econômica do país, com mais acesso ao crédito de forma qualificada, atua de maneira eficaz nos processos de agregação de valor na industrialização e comercialização da produção de seus associados, contribuindo assim com inclusão social de milhares de pessoas do meio rural e urbano (MAGRI; CORREA, 2012).

Segundo Magri e Correa (2012), o cooperativismo assume compromisso de aprofundar-se nas noções de desenvolvimento integral baseando-se nas organizações sociais, na cidadania, nos direitos humanos do trabalho e renda, saúde, educação, moradia e segurança alimentar, promovendo maior acesso à terra, ao crédito, ao mercado e com novas formas de relação entre o campo e a cidade. De tal modo os jovens de hoje sentem-se influenciados a continuar no meio rural, em perceber que o trabalho em conjunto traz vantagens, visto que o cooperativismo vem de encontro a solucionar problemas enfrentados no campo diariamente.

De acordo com Drebes (2012, p. 02),

A sucessão geracional não diz respeito apenas à sobrevivência das propriedades rurais e da agricultura familiar, mas também a sobrevivências das próprias cooperativas, visto que a saída cada vez mais acentuada dos jovens fica a perspectiva de como se dará a renovação das gerações de agricultores no campo e do corpo de associados das cooperativas. Neste sentido, têm-se uma compreensão de que as cooperativas possuem certa responsabilidade social, atuando no meio rural como promotoras de desenvolvimento. As cooperativas apenas mantêm e renovam o seu quadro social através da sucessão dos filhos de agricultores (possíveis sucessores) no lugar de seus pais (antigos associados).

No que afirma Spanevello e Lago (2007) em seu estudo, grande parte dos jovens pesquisados procuram nas cooperativas um suporte para a saúde financeira das propriedades rurais além de se beneficiarem com cursos de capacitação e créditos facilitados. Segundo os mesmos autores a condição econômica das propriedades é um fator importante no processo sucessório, já que os filhos de agricultores teriam interesse em ficar nas propriedades que estão ativas e rentáveis. 
Segundo Spanevello e Lago (2007) a assistência técnica, inserção mercadológica, acesso aos insumos, retorno das sobras, informação, capacitação e acesso ao crédito são fatores apontados pelos sucessores como vantagens oferecidas pelas cooperativas. Sendo assim, as cooperativas caracterizam-se como extensão da propriedade. Neste sentido, as cooperativas têm um papel relevante como agente de desenvolvimento econômico e social.

Para que melhorias de qualidade de vida ocorram, as cooperativas deverão investir na educação, formação de seus associados para que possa acorrer crescimento e desenvolvimento tanto da cooperativa, como de seus cooperados. A cooperativa deve ter uma preocupação tanto com bem estar da sociedade, devendo trabalhar para a comunidade onde está inserida, com compromisso educativo, social e econômico, uma vez que a cooperação importa em uma combinação de ajuda mútua (LEITZKE; SANTOS, 2013, p.322)

\section{PROCEDIMENTOS METODOLÓGICOS}

A fim de alcançar o objetivo do estudo de analisar o processo de sucessão geracional em propriedades rurais dos agricultores associados à CREHNOR localizada no município de Jaboticaba - RS foi realizada uma pesquisa descritiva. Para Malhotra (2010), a pesquisa descritiva significa delinear alguma coisa, características ou funções, é pré planejada, estruturada e geralmente fundamenta-se em amostras grandes e representativas. Estudos descritivos procuram descrever com que frequência às coisas acontecem, por isso, os temas abordados precisam ser registrados para posteriormente sejam analisados.

Além disso, este estudo também utilizou uma abordagem qualitativa, é aquela que considera que há uma relação dinâmica entre o mundo real e o sujeito, não requer o uso de métodos e técnicas estatísticas e ambiente natural, a fonte direta para coleta de dados é o pesquisador que é o instrumento-chave. Para Deslandes (1994, p. 22) a pesquisa qualitativa "trabalha com universo de percepções, significados, aspirações, crenças, valores e atitudes, o que compreende num espaço mais profundo das relações, dos processos e dos fenômenos que não podem ser reduzidos a operacionalidade de variáveis".

0 universo presente neste estudo consiste na população de agricultores associados à cooperativa de crédito (CREHNOR) da unidade do município de Jaboticaba-RS.

Os dados foram coletados através de um formulário em forma de entrevistas estruturadas a fim de obter informações e percepções dos agricultores associados em relação ao processo de sucessão geracional familiar e como a Cooperativa do Sistema Crehnor contribuiu para esse processo. Marcone e Lakatos/ (2003) define formulário como o contato face a face entre pesquisador e o respondente, sendo o roteiro de perguntas preenchidas pelo pesquisador no momento da entrevista.

O formulário foi preparado de acordo com a necessidade de conseguir respostas aos objetivos sugeridos pela pesquisa e para a solução dos problemas abordados, constituído de 33 questões abertas e fechadas, aplicado a 38 agricultores associado à cooperativa de Crédito Chenor.

A pesquisa foi realizada no posto de atendimento da Crehnor situado em Jaboticaba- RS. A população presente neste estudo são agricultores associados nesta unidade de atendimento e que movimentam suas contas pelo menos uma vez por mês.

Quanto ao plano amostral foi definida por conveniência, e o pesquisador usa métodos subjetivos, bem como a experiência pessoal, convivência e conhecimento (HAIR, et al., 2005).

A pesquisa de campo foi realizada entre os meses de agosto e outubro de 2016. Em seguida, foi realizada análise dos dados de forma descritiva, também foram dados nomes fictícios aos agricultores entrevistados. Que se procurou apresentar as características de determinada população, fenômeno, ou estabelecer relação entre variáveis (DIEHL; TATIM, 2004).

\section{ANÁLISE DOS RESULTADOS}

Nesta etapa serão apresentadas questões referentes à pesquisa sobre sucessão geracional, realizada com agricultores familiares associados na Crehnor, unidade de atendimento de Jaboticaba, conforme estabelecido pela metodologia desta pesquisa. Primeiramente, será apresentada a caracterização dos agricultores entrevistados. Em seguida a caracterização dos estabelecimentos rurais dos entrevistados, a gestão dos estabelecimentos familiares, por último, a sucessão geracional. 


\subsection{CARACTERIZAÇÃO DOS AGRICULTORES ENTREVISTADOS}

Nesta etapa do estudo será analisado o perfil dos agricultores familiares, através da apuração dos dados coletados mediante a aplicação de um formulário a cada um dos agricultores entrevistados.

Percebe-se que grande parte, dos entrevistados se encontra na faixa etária entre 48 a 52 e 59 a 65 anos que equivale a $48 \%$ dos entrevistados, enquanto a minoria está entre 24 a 29 anos e 36 a 41 anos com $15 \%$, que demonstrou que estes já são sucessores recentes de suas famílias. Estes dados evidenciam a predominância de pessoas com mais idade no meio rural.

Em segundo momento procurou-se analisar o sexo dos associados entrevistados. Considerando que a maioria dos questionários foram aplicados no próprio ponto de atendimento da Crehnor, portanto, por conveniência, pode-se perceber que a predominância do sexo masculino. Ou seja, as transações financeiras são essencialmente masculinas, dentre os associados daquela localidade. As mulheres tiveram uma participação menor como respondentes com apenas 5\%. No entanto, esse percentual não quer dizer que todas comandam a gestão da propriedade, pois uma parte delas são aposentadas rurais e que foram até a agência para receber seu benefício.

Em relação ao estado civil dos entrevistados, $92 \%$ são casados e $5 \%$ são solteiros, sendo que $3 \%$ são viúvos. Dos que afirmaram ser solteiro, são jovens que estão com idade entre 24 e 29 anos e que estão assumindo a gestão da propriedade de seus pais.

Também se pode analisar através da pesquisa a questão do número de filhos por entrevistado, onde é percebido que um total de 34 respondentes que citaram ter filhos. Sendo que 4 respondentes afirmaram não ter filhos. Dos entrevistados que responderam ter filhos, a grande maioria tem entre 1 a 3 filhos. Entretanto, um número pequeno de agricultores entrevistados respondeu ter entre 4 e 6 filhos. Onde 6 entrevistados citam ter somente um filho e na maioria deles o filho está estudando fora e que dificilmente vai voltar e assumir a gestão da propriedade.

0 envelhecimento da população do meio rural, somado a redução do número de filhos, traz dificuldades em obter mão de obra para o trabalho na agricultura e no processo sucessório.

No caso em estudo identificou-se que, $74 \%$ possuem ensino fundamental incompleto, $8 \%$ ensino fundamental completo, $2 \%$ ensino médio incompleto e $16 \%$ possuem ensino médio completo. Podemos perceber que os agricultores têm um nível baixo de escolaridade, sendo que a grande maioria dos entrevistados possui somente o ensino fundamental incompleto, deste a maior parte cursou somente até quarta série. A baixa escolaridade dos agricultores entrevistados se dá, entre outros fatores, muitas vezes porque os pais deram pouca importância aos estudos em anos passados, com predominância da dedicação ao trabalho (SPANEVELLO, 2008).

Em relação à renda mensal, a venda dos produtos da agricultura familiar representa o maior percentual do sustento familiar. Em termos salariais $54 \%$ dos respondentes, afirmaram ter uma renda de 2 a 4 salários. 0 percentual dos entrevistados com renda entre 6 a 8, de 8 a 10 e mais de 10 salários é baixo, sendo que $22,00 \%$ dos agricultores responderam ter uma renda de 0 a 2 salários. Ou seja, 76,00\% dos respondentes possuem renda mensal familiar menor que 4 salários.

Os mesmos atribuem está renda ao tamanho da propriedade ser pequena, não terem maquinários próprios e o lucro é pouco considerando o alto custo dos insumos e produção. Outros ainda são aposentados e plantam somente para sua subsistência. Dos poucos que tem uma renda maior são na grande maioria produtores de leite, que tem maquinários, tecnologia na propriedade e garantem, assim, maior produtividade e uma maior lucratividade. Observa-se que as propriedades podem ter mais de uma renda, seja com a venda dos produtos agrícolas ou até mesmo com a aposentadoria rural. 
Quadro 1 - Caracterização dos agricultores

\begin{tabular}{|c|l|}
\hline $\begin{array}{c}\text { Descrição } \\
\text { Sexo }\end{array}$ & Participação foi essencialmente masculina, com 95\%. \\
\hline Faixa etária & $\begin{array}{l}\text { A maioria dos entrevistados está entre 48 a 65 anos equivalendo a 48\%, e a minoria entre 24 a } 41 \\
\text { anos com 15\%. 0 que evidência a predominância de pessoas com mais idade no meio rural. }\end{array}$ \\
\hline Estado Civil & $92 \%$ são casados, 5\% são solteiros e 3\% são viúvos. \\
\hline $\begin{array}{c}\text { Número de } \\
\text { Filhos }\end{array}$ & $\begin{array}{l}\text { 34 agricultores tem filhos e 4 afirmaram não ter. Os que possuem filhos, a maioria tem entre 1 a } 3 \\
\text { filhos e a minoria, entre 4 e 6 filhos. E somente 6 agricultores, citaram ter somente um filho. }\end{array}$ \\
\hline $\begin{array}{c}\text { Grau de } \\
\text { Instrução }\end{array}$ & $\begin{array}{l}74 \% \text { possuem ensino fundamental incompleto, 8\% ensino fundamental completo, 2\% ensino médio } \\
\text { incompleto e 16\% possuem ensino médio completo. }\end{array}$ \\
\hline $\begin{array}{c}\text { Renda } \\
\text { Mensal }\end{array}$ & $\begin{array}{l}76 \% \text { dos respondentes possuem renda mensal familiar menor que 4 salários, sendo 54\% com renda } \\
\text { de 2 a 4 salários e 22\% de 0 a 2 salários. }\end{array}$ \\
\hline
\end{tabular}

Fonte: Elaborado pelos autores.

\subsection{CARACTERIZAÇÃO DOS ESTABELECIMENTOS RURAIS DOS ENTREVISTADOS}

Uma vez feita à caracterização do perfil dos agricultores familiares, é exposto nesta etapa à caracterização dos estabelecimentos, visando o maior detalhe de informações sobre o assunto.

Identificou-se que a maior concentração de terras dos entrevistados está na faixa de 11 a 21 hectares, citados por 14 dos respondentes, que representa em um percentual de $36,80 \%$, sendo que 11 dos entrevistados responderam ter até 10 hectares obtendo um percentual de $29,70 \%$. Enquanto que as propriedades de 22 a 32 hectares correspondem a 15,80\% dos casos. A faixa 33 a 43 hectares respondem por $10,50 \%$ dos casos, de 44 a 54 hectares apresentam $5,30 \%$. Quanto às propriedades com mais de 55 hectares correspondem a $2,60 \%$.

Pode-se identificar que grande parte dos entrevistados possuem terras próprias, com um percentual de 84\%, com área média de 21 hectares (variando de 3,5 até 120 hectares). Dos que arrendam terras de terceiros para utilizarem em sua produção teve um percentual de 13\%, com área média de 14 hectares arrendadas de terceiros, e 3\% trabalham em forma de parceria. Identificou-se também, que os agricultores que arrendam são na grande maioria os mesmos que possuem terras próprias, pois são os agricultores consolidados, que tem maquinários e que então necessitam de mais terras para atender suas demandas produtivas.

Quando questionados sobre as formas em que os agricultores adquiriram suas terras, os dados indicam que os principais meios de acesso à terra são pela herança e compra de terceiros. Onde pode-se fazer um comparativo de quantos hectares foram herdados e quantos comprados pelos agricultores entrevistados. Sendo que dos 38 entrevistados, 20 citaram ter herdado e comprado algumas terras, 8 deles citam que somente herdaram e 10 entrevistados citaram que somente compraram suas terras de terceiros.

Identificou-se que grande parte dos agricultores entrevistados produzem grãos e leite $(40 \%$ e $37 \%$ respectivamente). Em média são plantados 15,50 ha de soja, 18,30 ha de milho, 13,20 ha de trigo e 3,50 ha de feijão, com uma produção em torno de 50 sacas por hectare de soja, 100 de milho, 40 de trigo e 25 sacas de feijão. A produção de leite aparece como a segunda atividade desenvolvida nas propriedades com uma produção em média de 5.600 litros ao mês. Outra produção que aparece em terceiro lugar com $9 \%$ dos casos pesquisados foi a produção de carne e seus derivados com uma produção em média de $1.360 \mathrm{~kg}$ ao ano. Já as hortaliças com apenas 4\%, com uma produção de $370 \mathrm{~kg}$ ao ano, fruticultura $3 \%$ e produção de $430 \mathrm{~kg}$ ao ano e derivados de leite $3 \%$ e produção de $390 \mathrm{~kg}$ ao ano, demonstraram ser pouco produzido entre os agricultores entrevistados. Dentre outros produtos citados pelos entrevistados aparecem com $4 \%$ a cana-de-açúcar, fumo e o mel de abelhas-africanas.

Percebeu-se neste estudo, que as culturas tradicionais continuam sendo produzidas em grande escala na agricultura familiar, em comparação com outras culturas como a produção de hortaliças, fruticultura, derivados de leite, produção de carne e seus derivados, entre outras atividades da agricultura familiar. Pois cabe ressaltar que tem maior incentivo à produção de grão como soja, milho e trigo devido ao 
processo de modernização, e onde existe pouco incentivo à produção de alimentos. Ao passo que esta é de suma importância para a sobrevivência da população e da agricultura familiar.

Quando questionados se possuem implementos agrícolas na propriedade, 52,60\% dos entrevistados responderam que sim, possuem implementos, sendo que em média cada entrevistado citou ter de 1 a 5 implementos, sendo o trator o mais citado, seguido por ensiladeira, semeadeira, pulverizador, colheitadeira, entre outros que auxiliam na condução dos processos de produção das propriedades. Os agricultores entrevistados que não possuem nem um tipo de implemento chega a 47\%, os mesmos afirmaram ter pouca terra, então não compensa ter maquinário é mais compensador pagar para realizar os serviços como (plantar, colher etc.).

\section{Quadro 2 - Caracterização dos estabelecimentos rurais}

\begin{tabular}{|c|c|}
\hline Descrição & Caracterização \\
\hline $\begin{array}{l}\text { Tamanho das } \\
\text { propriedades }\end{array}$ & $\begin{array}{l}\text { Dos entrevistados, apenas } 2,60 \% \text { dos agricultores possuem acima de } 55 \text { ha. Sendo então } \\
\text { caracterizados os entrevistados como pequenos proprietários de terra devido a } 65,5 \% \\
\text { desses } 38 \text {, possuírem somente entre } 10 \text { a } 21 \text { ha. }\end{array}$ \\
\hline Condição das terras & $\begin{array}{l}\text { 84\% dos entrevistados possui terras próprias (média } 21 \text { ha), } 13 \% \text { arrendadas de terceiros } \\
\text { (média } 14 \text { ha) e } 3 \% \text { trabalham em parceria. }\end{array}$ \\
\hline $\begin{array}{l}\text { Meios de acesso à } \\
\text { terra }\end{array}$ & Os principais destacados foram por meio da herança e compra de terceiros. \\
\hline $\begin{array}{l}\text { Produção nas áreas } \\
\text { cultivadas }\end{array}$ & $\begin{array}{l}\text { Destaca-se a produção de grãos } 40 \% \text { (soja, milho, trigo e feijão), leite } 37 \% \text {, carne e seus } \\
\text { derivados } 9 \% \text {, hortaliças } 4 \% \text {, fruticultura 3\%, derivados de leite } 3 \% \text { e } 4 \% \text { cana-de-açúcar, } \\
\text { fumo e mel. }\end{array}$ \\
\hline $\begin{array}{l}\text { Implementos } \\
\text { agrícolas }\end{array}$ & $\begin{array}{l}\text { 52,60\% dos entrevistados possuem maquinários (média de } 1 \text { a 5), entre os mais citados } \\
\text { estando o trator, ensiladeira, semeadeira, pulverizador e colheitadeira. Já, } 47 \% \text { dos } \\
\text { agricultores não possuem, devido a possuírem pouca terra. }\end{array}$ \\
\hline
\end{tabular}

Fonte: Elaborado pelos autores.

\subsection{GESTÃO DOS ESTABELECIMENTOS FAMILIARES}

Nesta etapa da pesquisa são apresentadas questões referentes às formas de gestão da propriedade rural. Visto que uma boa gestão de um estabelecimento é importante para um bom andamento de qualquer negócio, sendo que nas propriedades rurais não é diferente.

A pesquisa constatou que a grande maioria dos entrevistados trabalha com assistência técnica em sua propriedade, com percentual de $84 \%$, sendo que $16 \%$ dos respondentes afirmaram que não trabalham. Percebe-se que boa parte dos agricultores que trabalha com assistência técnica na propriedade tem uma produção melhor na atividade que desenvolve nela. No que afirma um entrevistado (22), quando ele não trabalhava com assistência técnica, ele colhia em torno de 80 sacas de milho, hoje com assistência técnica ele colhe em torno de 150 sacas. Na produção de leite, cada vaca produzia em torno de 20 litros de leite por dia, hoje produz 35 litros.

Quando questionados se costumam fazer a contabilidade referente aos gastos de entrada e saída de dinheiro da propriedade. Percebeu-se que uma grande parte dos entrevistados tem um controle da entrada e saída de dinheiro em suas propriedades, tendo um percentual de $65,50 \%$ dos respondentes. Sendo que $42,10 \%$ realizam todos os meses e $18,40 \%$ uma vez por ano. Em contrapartida, aqueles que não realizam nenhum tipo de controle de dinheiro em suas propriedades são de 39,50\% dos entrevistados.

Considerando a importância desse controle, o percentual dos que não realizam é considerado alto, pois é através desse controle que o agricultor vai saber se a atividade que está realizando em sua propriedade está sendo rentável ou não. No que afirma Spanevello $(2008$, p.136) em seu estudo sobre a dinâmica sucessória na agricultura familiar "que a contabilidade não é uma prática recorrente entre agricultores familiares, se registra preocupação com a parte administrativa da produção com que realmente sobra".

Levando em consideração a importância de uma boa gestão nos estabelecimentos, os agricultores entrevistados foram questionados sobre as formas de gerenciamento em suas propriedades, $68 \%$ responderam que acontece com o envolvimento de todos da família. Com isso percebe-se a união dos 
membros, mostrando assim uma maior maturidade, onde todos da família sintam-se valorizados, respeitados, motivados e ainda comprometidos com a propriedade. Já $24 \%$ afirmaram que há somente um responsável pela gestão da propriedade, ou seja, a figura paterna. Em apenas 3\% os filhos gerenciam a propriedade, $5 \%$ dos entrevistados responderam que há outras formas de gestão, como exemplo citado; o casal gerencia, o pai e um dos filhos, a mãe e um dos filhos.

Analisando a satisfação dos entrevistados a respeito da atividade agrícola exercida na propriedade $79,00 \%$ dos agricultores encontram-se satisfeitos e muito satisfeitos com 3,00\%. No entanto, a insatisfação aparece com um percentual de 2,00\%, pouco satisfeito com 16,00\%.

Percebe-se que o grau de insatisfação dos entrevistados está associado a rendas baixas, pouca terra, preços dos produtos baixos, comparados aos custos de produção, e as intempéries climáticas que prejudicam o rendimento da produção. Isso demonstra que muitos desses agricultores entrevistados não têm tecnologia e nem uma boa gestão na propriedade, com isso não conseguem ter uma lucratividade esperada. Observa-se que a satisfação vem atrelada a motivos como retorno financeiro esperado, gostam do meio rural. Também foi possível constatar que os entrevistados satisfeitos ou muito satisfeito são aqueles que passaram por um processo sucessório, estão diversificando a produção na propriedade com uso da tecnologia e uma boa gestão.

\subsection{SUCESSÃO GERACIONAL}

Esta etapa da pesquisa tem por objetivo destacar estudos que aborda diretamente a temática sucessão geracional com agricultores associados à Crehnor - Unidade de atendimento de Jaboticaba. Em seguida apontam-se opiniões dos agricultores sobre a saída dos jovens do meio rural, fatores que levam o jovem a sair do campo, problemas que afetam a agricultura familiar e o processo sucessório. São colocadas questões como a influência e incentivo da Cooperativa de Crédito Crehnor para manter o jovem no campo e no processo de sucessão geracional.

Quando questionados sobre incentivar os jovens a permanecer na agricultura e seguir a profissão de agricultor, a grande maioria dos agricultores entrevistados, 92,10\% afirmaram incentivar seus filhos a permanecerem na agricultura, enquanto 7,90\% aponta que não incentivam.

Percebeu-se através da análise das afirmações dos entrevistados que os pais que incentivam seus filhos a permanecer no meio rural, devido ao gosto de lidar na agricultura e com animais, a tranquilidade do campo e a vontade de dar continuidade a atividade que está desenvolvendo na propriedade, geralmente são agricultores estruturados e capitalizados. Em contrapartida, aqueles que não incentivam estão atrelados a pouca terra, não tem infraestrutura em suas propriedades e estão descapitalizados financeiramente.

Segundo Silvestro et al. (2001), em seu estudo realizado no Oeste de Santa Catarina ressalta que 16\% dos pais descapitalizados não incentivam seus filhos a permanecerem na agricultura, 7\% dos que estão em transição e $10 \%$ dos capitalizados influenciam seus filhos a saírem do campo.

No que se percebe através das respostas dos entrevistados que há mais possibilidade de sucessão nas famílias de agricultores capitalizados e com infraestrutura em suas propriedades, que as dificuldades maiores de sucessão estão nas propriedades com pouca terra e retorno financeiro. No entanto, não existem garantias da permanência dos filhos no campo, pois a sucessão é um processo complexo e delicado até mesmo em uma propriedade com estabilidade econômica. Já que são muitos os fatores que influenciam no processo de sucessão, que podem ser internos ou externos na propriedade familiar, onde na maioria das vezes envolve valores sociais e culturais das famílias.

Em um segundo momento, os entrevistados foram questionados sobre a saída dos jovens do meio rural, e os problemas que a agricultura familiar enfrenta ou vai enfrentar no futuro com essa saída. As opiniões mais frequentes dos agricultores entrevistados sobre a saída dos jovens do meio rural podem ser visualizadas no (Quadro1) 
Quadro 3 - Opiniões dos entrevistados sobre a saída dos jovens do meio rural

- A saída dos jovens do meio rural é muito ruim para agricultura, pois temos menos gente produzindo alimentos na agricultura familiar, mas para os jovens é bom, levando em conta que na cidade vão ter uma renda maior que no campo (AGRICULTOR JÚLIO, 59 ANOS).

- Muito ruim para agricultura familiar, muitas famílias não tendo quem lhe substituam acabam vendendo suas propriedades para grandes produtores rurais, que pegam o maquinário e empurram tudo para dentro de um açude, terminando com toda caracterização da pequena propriedade (AGRICULTORA JOÇARA, 61ANOS).

- A saída dos jovens do meio rural é melhor para eles, pois na agricultura não é fácil sobreviver (AGRICULTOR EVANDRO, 52 ANOS).

- Ruim para todo o país, já que no futuro podemos não ter mais produtos que só agricultura familiar produz (AGRICULTOR ALCINDO, 42 ANOS).

- Para agricultura é muito ruim, porque o meio rural está ficando vazio e as cidades superlotadas, os jovens não conseguem ter uma renda que teria na agricultura, com isso muitas vezes não conseguem sobrevive nos grandes centros urbanos (AGRICULTOR PAULO, 61 ANOS).

- Muito ruim para agricultura familiar, a agricultura é rentável, se os agricultores investir os recursos corretamente ela torna-se lucrativa, mas o problema é que os jovens não querem ficar mais no campo (AGRICULTOR DORVALINO, 72 ANOS).

Fonte: Elaborado pelos autores.

Percebe-se que grande parte dos agricultores entrevistados expressa preocupação com saída dos jovens do meio rural e nos problemas que vão enfrentar por falta de sucessores para lhe substituírem. Além disso, estão preocupados com a produção de alimentos que somente é produzido na pequena propriedade. No que afirma Spanevello (2008), a saída do jovem do campo pode advertir na redução das características agrícolas dos municípios, em especial da agricultura familiar.

Quando questionados sobre os fatores que levam os jovens sair do meio rural. Os entrevistados citam como principais fatores; fator econômico, renda baixa, propriedade pequena, retorno financeiro demorado, falta de incentivo por parte dos pais e do poder púbico, muitos pais não dão autonomia para os jovens e isso causa conflitos eles acabam saindo do meio rural. 0 próprio estudo faz com que os jovens saiam do meio rural, incentivos dos grupos de amizades, a própria cultura das famílias, incentivo por parte dos grupos de amizades, a própria cultura das famílias, falta de planejamento familiar e instrução dos pais, altos custos de produção associadas à prática de preços baixos pagos pela produção, onde muitas vezes acabam dificultando a possibilidade de investimentos em novas tecnologias e novos maquinários, com isso acaba desestimulando os jovens a permanecerem no meio rural.

Quanto ao questionamento sobre sucessão familiar, se a mesma irá ser um problema para a agricultura familiar no futuro, a grande maioria dos agricultores entrevistados $95 \%$, afirmam que sim, a sucessão familiar vai ser um problema para agricultura no futuro, sendo assim percebe-se a preocupação com o futuro da agricultura familiar. Porém, pode-se perceber também que 5\% dos entrevistados, não veem a sucessão como um problema para a agricultura familiar no futuro.

De acordo com as justificativas dos entrevistados percebe-se grande preocupação com a sucessão em propriedades da agricultura familiar, afirmando que muitos dos jovens não querem mais ficar no campo. Conforme Spanevello (2008), em seu estudo, há crescente preocupação familiar pode ser verificada através dos dados estatísticos do meio rural brasileiro, o qual confirma o êxodo no meio rural principalmente da população mais jovem. Embora o êxodo rural no Brasil fosse mais intenso até a década de 80 o mesmo era mais homogêneo quanto à idade e gênero, onde todos da família deixavam o meio rural, diferentemente dos dias de hoje onde os jovens são os que mais migram para os centros urbanos. No que afirma Weischeimer (2004) a migração dos jovens está cada vez mais tornando-se rotina na agricultura familiar. Essa migração não acontece muitas vezes pela ampla oferta de trabalho nos centros urbanos, mas sim pelas baixas perspectivas de crescimento do meio rural.

Questionados sobre as práticas de preparação que as famílias agricultoras estão adotando para o processo sucessório na propriedade, $52,60 \%$ responderam que não estão realizando nem um tipo de atividade, considerando que mais da metade das famílias estão despreparadas, ou sem nenhuma tática de continuidade da unidade familiar e das atividades agrícolas que desenvolvem em sua propriedade. No entanto $47,40 \%$ afirma que estão tendo algumas práticas de preparação para que no futuro haja sucessão em suas propriedades. 
Percebeu-se pelas respostas dos agricultores entrevistados que a grande maioria afirma que é por meio do envolvimento dos filhos com o trabalho na propriedade, pois argumentam que é desde cedo que os filhos têm que ir pegando gosto pelo trabalho do campo. De acordo com Spanevello (2008) a perspectiva de manter garantida a sucessão das propriedades familiares estão associadas às características familiares internas ao processo de ensino aprendizagem no trabalho familiar. Portanto, para que a agricultura familiar prossiga ao longo dos anos é imprescindível à passagem da gestão para outra geração.

Quando questionados sobre a possibilidade de no futuro haver um sucessor para assumir a propriedade, a grande maioria dos agricultores entrevistados $86,80 \%$ afirmaram que sim vão ter alguém para assumir a gestão da propriedade. Porém 13,20\% afirmam que não vão ter sucessor.

Apesar de a grande maioria responder que vão ter um sucessor para assumir sua propriedade, observouse que a incerteza quanto ao futuro da agricultura familiar pela não definição certa de um sucessor e a não realização de práticas voltadas a esse fim, traz dificuldades a continuidade das atividades agrícolas no meio rural. No estudo de Silvestro et al (2001) realizado em Santa Catarina apontou que as questões sucessórias são pouco debatidas entre a família. Com isso em alguns casos, usando as atribuições de chefe de família, os pais já escolheram o seu sucessor, mas na maioria das vezes esta decisão não foi mencionada para toda a família.

Questionados sobre as principais dificuldades em dar continuidade a atividade agrícola por meio da sucessão, 76,30\% dos entrevistados afirmaram ter dificuldade e 23,70\% responderam não ter nem uma dificuldade em dar continuidade a atividade agrícola. No que afirma o agricultor (Mateus, 47 anos), se os filhos estão envolvidos no processo de gerenciamento da propriedade não há dificuldade, pois, os jovens querem é ter autonomia dos pais para comandar a propriedade e controlar a parte financeira.

Quando perguntado sobre o que poderia ser feito para favorecer a permanecia dos jovens no meio rural, os entrevistados referiram-se principalmente sobre incentivos do poder público municipal, pois a grande maioria dos entrevistados trabalha com produção de leite sente-se necessidade da patrulha agrícola para desenvolvimento do trabalho na propriedade, no entanto os agricultores reclamam não receber atenção suficiente dos municípios. Portanto, é de suma importância que os poderes públicos definam programas de incentivo ao agricultor familiar e que os mesmos adaptem as particularidades dos territórios e que sejam capazes de despertar o interesse dos jovens pelo meio rural (MENDONÇA et al. 2008). Na segunda justificativa mais frequente e que os pais devem dar mais autonomia aos filhos na gestão da propriedade. Percebe-se de acordo com as respostas dos respondentes que os pais estão preocupados em como manter seus filhos na propriedade e principalmente reconhecendo que devem dar mais autonomia aos mesmos para que venha ocorrer à sucessão na agricultura familiar.

Quando questionados sobre o destino que pretende dar para sua propriedade, a grande maioria dos entrevistados pensa em continuar no campo, aumentar a produção e principalmente melhorar sua propriedade com mais estrutura e tecnologia. No que percebeu-se nas entrevistas, dos que querem continuar com a propriedade são a maioria agricultores consolidados e que gostam da atividade que estão desenvolvendo em sua propriedade. Por outro lado, os que pretendem vender são minoria e grande parte são agricultores descapitalizados e endividados ou tem pouca terra.

Questionados sobre a percepção dos mesmos com relação ao modelo de vida no meio rural, a grande parte dos agricultores $63,20 \%$ citaram ser bom, 21,10\% afirmaram ser muito bom, 10,5\% mais ou menos bom e $5,30 \%$ citaram ser ruim a vida no campo.

$\mathrm{Na}$ avaliação dos entrevistados que afirmaram ser bom ou muito bom viver no meio rural, estão relacionados com a não ter hora para trabalhar; produzir alimentos saudáveis para o consumo próprio; a vida é mais calma e tranquila, livre e em contato com a natureza (comparativamente com a vida do meio urbano); custo de vida menor e maior diversificação de atividades, que vai desde a produção para consumo próprio até a de excedentes para a venda. Percebe-se pelas respostas que são agricultores bem estruturados e capitalizados que estão tendo retorno financeiro esperado com as atividades desenvolvidas em suas propriedades.

Entretanto dos que afirmaram ser mais ou menos ou ruim, citaram estar longe da cidade, trabalho pesado, pouca infraestrutura na propriedade que causa dificuldade no desenvolvimento das atividades, dificuldade de acesso à internet e outras tecnologias.

Nas justificativas dos agricultores, os depoimentos resumem a percepção deles sobre o modelo de vida no meio rural: 
A vida no campo é sofrida, mas é divertida, é muito bom de viver no meio rural, a gente vive com mais liberdade, não cumpre horário, mas tem que desenvolver as atividades quando necessita. Além de produzir toda a nossa alimentação, também produz a alimentação do povo brasileiro inteiro, hoje temos estrada boa, se uma pessoa da família fica doente tem um carro da saúde para ir buscar e levar no médico (AGRICULTOR MATEUS, 47 ANOS, 3 FILHOS, COM SUCESSÃO).

Antes eu não vivia bem no meio rural, eu não tinha assistência técnica, hoje posso dizer que vivo muito melhor, tenho uma propriedade com assistência técnica, as mais novas tecnologias, posso afirmar que tenho uma propriedade com autogestão, tenho quase tudo que tem na cidade, tenho internet, telefone, computador, tenho tudo que preciso para mim e minha família viver bem (AGRICULTOR ANTÔNIO, 61 ANOS, 2 FILHOS, COM SUCESSÃO).

É mais ou menos, a gente fica retirado do comércio, se precisar comprar alguma coisa tem que ir de carro ou de moto se não tem fica complicado, além disso, o trabalho é pesado, mas os problemas maiores são agrotóxicos que temos que usar, ainda a gente usa certo, mas tem vizinho que usa de forma abusiva que às vezes até mata a plantação da gente (AGRICULTOR ROGÉRIO, 48 ANOS, 1 FILHO, SEM SUCESSÃO).

Quando questionados sobre as vantagens de ser sócio da cooperativa Crehnor, citam ter muitas vantagens. As citadas com mais frequências pelos agricultores entrevistado foi de ser dono de parte do negócio, poder participar das decisões da cooperativa, atendimento diferenciado, fácil acesso ao crédito e tarifas de contacorrente mais baixa.

Ao serem questionados sobre a importância das cooperativas de créditos para permanência do jovem no campo, $100 \%$ dos agricultores entrevistados responderam que sim as cooperativas são importantes para manter os jovens no campo. As justificativas mais frequentes dos respondentes podem ser visualizadas no (Quadro 2).

Quadro 4 - As cooperativas são importantes para a permanência dos jovens no meio rural

- $\quad$ Elas orientam os jovens na condução dos meioseconômicos (AGRICULTOR ANDRÉ 65 ANOS).

- Tem mais recursos e mais fácil acesso ao crédito ao jovem pequeno agricultor (AGRICULTOR CLAUDIO, 54 ANOS).

- As cooperativas priorizam o pequeno agricultor (AGRICULTOR LUIZ, 55 ANOS).

- As cooperativas são o lugar mais fácil de conseguir recursos (AGRICULTORA JOÇARA, 61 ANOS).

- As cooperativas agregam mais união e aproxima o agricultor dela (AGRICULTOR CARLOS, 51 ANOS).

- Nas cooperativas é mais fácil de negociar, já que como sócio tenho participação nos lucros (AGRICULTOR VALDIR, 51 ANOS).

- Pelas várias linhas de créditos que a mesma proporciona ao associado com mais facilidade e menos burocracia com juros mais baixos, com valor da manutenção de contas menor que os bancos (AGRICULTOR, 40 ANOS).

Fonte: elaborado pelos autores.

As respostas dos entrevistados vêm ao encontro à afirmação de Magri e Correa (2012) que diz que o cooperativismo promove várias ações voltadas para o desenvolvimento local e regional. Sendo a cooperativa um instrumento que fortalece a gestão local e envolvem as pessoas em processos inclusivos de formação, autonomia e decisão. Ela melhora o acesso dos micros e pequenos agricultores aos empréstimos, reduzem os custos de transação entre emprestadores e tomadores de crédito, visto que se processa um grande empréstimo com o proprietário externo dos fundos e depois é repassado aos membros da cooperativa (FEIJÓ, 2011).

Quando questionados sobre as formas de contribuição da cooperativa Crehnor para a permanência dos jovens no meio rural, os associados entrevistados citam as diversas linhas de créditos com juros mais baixos que nos bancos; Pronaf custeio, habitacional, citam que as cooperativas contribuem com cursos e palestras direcionados a agricultura familiar de como melhor investir os recursos na propriedade.

$\mathrm{Na}$ análise sobre a influência ou não influência da cooperativa de Crédito Crehnor no processo geracional tem-se o seguinte cenário: 97,40\% responderam ter influência e 2,60\% responderam que a cooperativa não influencia. As formas de influências mais frequentes citadas pelos agricultores entrevistados podem ser visualizadas no (Quadro3). 
Quadro 5 - Formas de influência da cooperativa Crehnor no processo sucessão geracional

\begin{tabular}{|c|c|}
\hline \multirow{6}{*}{$\begin{array}{l}\text { Sim } \\
\text { Os entrevistados que afirmaram que } \\
\text { sim, a Cooperativa Crédito Crehnor } \\
\text { influência no processo de sucessão } \\
\text { geracional. Caracterizam-se como } \\
\text { agricultores associados com idade } \\
\text { entre } 28 \text { a } 72 \text { anos, têm em média de } 1 \\
\text { a } 3 \text { filhos, casados e a maioria é do } \\
\text { sexo masculino. }\end{array}$} & De que forma \\
\hline & $\begin{array}{l}\text { Com diversas linhas de créditos: como Pronaf custeio, investimento, } \\
\text { habitação e crédito pessoal com juros mais baixos. }\end{array}$ \\
\hline & Financiamento com seguro agrícola para custear a produção. \\
\hline & $\begin{array}{l}\text { Com cursos e palestras de capacitação para melhor aplicação dos } \\
\text { recursos na propriedade. }\end{array}$ \\
\hline & $\begin{array}{l}\text { Acesso facilitado dos pequenos agricultores ao crédito e programas } \\
\text { direcionados a agricultura familiar. }\end{array}$ \\
\hline & $\begin{array}{l}\text { Incluindo os jovens ao crédito, pois jovens que fazem parte de uma } \\
\text { cooperativa de crédito, consegue financiamento mais facilitado com isso } \\
\text { os mesmos ficam motivados a continuar na propriedade rural. }\end{array}$ \\
\hline & $\begin{array}{l}\text { Os filhos vendo os pais negociar, vai se sentir motivado a continuar com o } \\
\text { negócio. }\end{array}$ \\
\hline Não & \\
\hline $\begin{array}{l}\text { Agricultor associado sucessor, com } \\
\text { idade de } 24 \text { anos, solteiro e sem filhos, } \\
\text { sexo masculino. }\end{array}$ & $\begin{array}{l}\text { A sucessão geracional não depende das cooperativas, e sim do } \\
\text { entendimento familiar. }\end{array}$ \\
\hline
\end{tabular}

Fonte: Elaborado pelos autores.

Quando questionados sobre as formas de incentivo que a Cooperativa de Credito Crehnor proporciona aos associados, citam a cota capital; manutenção de conta e taxa de juros menores que nos bancos; bom atendimento; programas direcionados a agricultura familiar com cursos e palestras de como investir melhor os recursos na propriedade, inclusão a várias linhas de crédito por meio do Pronaf. De acordo com Magri e Correa (2012) o Pronaf em suas diversas modalidades tem proporcionado aos agricultores condições de produção e agregação de valores nos seus produtos. Diante disso o PRONAF tem sido considerado um importante instrumento de Estado ao possibilitar a captação de recursos financeiro e humanos que viabiliza a obtenção da sustentabilidade dos agricultores familiares (DAMACENO; KHN; LIMA, 211).

Questionados sobre os motivos que levaram os agricultores entrevistados a se associarem à Cooperativa de Crédito Crehnor, percebeu-se através das análises que as variáveis mais citadas, pelos entrevistados, como diferencial ao associar-se na Crehnor foram "pelos incentivos que proporciona a agricultura familiar e para fazer melhorias em suas propriedades". Outros motivos que levaram os agricultores a se associar foi, "para ter acesso ao crédito e último lugar ser o dono de parte do negócio". Onde foi possível perceber que quando o agricultor ressalta que se associou para trazer melhorias para sua propriedade, muitos deles financiaram reformas de suas casas ou construíram casas novas através do financiamento habitacional da Crehnor. No que afirma Magri e Correa (2012, p.58), "as cooperativas do Sistema Crehnor constituíram grande experiência na construção e reforma de habitação, tem sido a pioneira nesta área e contribuindo decisivamente para democratização do acesso dessa política pública"

\section{CONSIDERAÇõES FINAIS}

Diante das análises dos dados coletados e das informações obtidas pode-se concluir que os objetivos propostos nesta pesquisa foram alcançados. A metodologia utilizada propiciou a identificação dos desafios e dificuldades encontradas com mais frequência nas propriedades rurais dos agricultores associados quanto a atividades agrícola desenvolvidas e o processo de sucessão geracional

Por meio do estudo identificou-se que a maioria das propriedades estão bem estruturadas e aparentemente com bom retorno financeiro, a maior parte dos entrevistados estão satisfeitos com as atividades que estão desenvolvendo. Mas estão encontrando dificuldades em dar continuidade as atividades agrícolas por meio da sucessão devido a indefinição de um possível sucessor, associado muitas 
vezes a não realização de planejamento sucessório, atrelado ainda a falta de comunicação nas famílias e ao êxodo rural dos jovens.

Os resultados obtidos na pesquisa ajudam a entender a importância do uso de estratégias pela agricultura familiar, a fim de que os jovens queiram continuar no campo. Grande parte dos associados entrevistados são agricultores consolidados e que já passaram por um processo sucessório assumindo a propriedades de seus pais, entretanto estão preocupados em quem vai lhes substituir.

Constatou-se também que há fatores externos que influenciam no processo sucessório; como a falta de políticas públicas, principalmente a municipal que se mostram inadequadas no atendimento ao agricultor e falta de valorização do setor agrícola, associado aos altos custos de insumos e maquinários, além das variações climáticas.

Quanto à importância das cooperativas de crédito para permanência dos jovens no campo, 100\% dos associados entrevistados citam as cooperativas como muito importantes para manter os jovens no campo. Onde citam que a mesma incentiva e influência no processo sucessório com várias linhas de crédito mais facilitado, com menos burocracia e com cursos e palestras de formação direcionada a agricultura familiar. Mas o que se percebeu é que a Cooperativa de Crédito Crehnor não apresenta ações específicas voltada para ao processo sucessório e para a permanência dos jovens no meio rural. Contudo se faz necessário que se olhem as propriedades como um todo e que se perceba este segmento como um empreendimento rural.

Ficou constatado na pesquisa as dificuldades em relação à sucessão geracional na agricultura, já que muitas vezes elas derivam de não ter um sucessor ou do não interesse dos jovens em assumir a propriedade de seus pais. Entretanto deve haver planos de ação referente ao processo de sucessão nas famílias agricultoras, com gestão e comunicação eficiente entre os membros da família. E que o poder público contribua para o processo sucessório com políticas públicas adequadas para incentivar a passagem da gestão das propriedades rurais de uma geração para outra.

Contudo, vale ressaltar a importância do devido estudo, salientando a relevância de semelhantes pesquisas no assunto, em cooperativas de outros setores que tenham agricultores como associados, em todas as unidades de atendimento da Crehnor ou em todas as cooperativas de crédito solidário, enfatizando a sucessão geracional nas famílias do meio rural.

Por fim, o que se deseja com os resultados deste estudo é que se tenha utilidade para posteriores pesquisas e que auxilie na construção do sucesso da passagem da gestão das propriedades de uma geração para outra, na agricultura familiar.

\section{REFERÊNCIAS}

[1] ALVES, M. A. P. Cooperativismo - "Arte \&Ciência”. São Paulo: Universitária de Direito. 2002.

[2] BRUMER, A.; SPANEVELLO, R. M. Jovens agricultores familiares da região sul do Brasil. Relatório de Pesquisa. Universidade Federal do Rio Grande do Sul, Porto Alegre, 2008.

[3] CARNEIRO, M. J. Juventude Rural; Projetos e Valores. Retratos da juventude brasileira: Análise de uma perspectiva nacional. São Paulo; Fundação Perseu Abramo: Instituto Cidadania, 2005.

[4] CORADINI. C. Projetos profissionais: juventude e a perspectiva de reprodução social na agricultura familiar. Porto Alegre 2011. Dissertação (Mestrado em Sociologia) Programa de Pós-Graduação em Sociologia. Universidade Federal do Rio Grande do Sul. Porto Alegre, 2011.

[5] DAMASCENO, N.P.; KHAN, A, S.; LIMA, P.V.P. S. O impacto do Pronaf sobre a sustentabilidade da agricultura familiar, geração de emprego e renda no Estado do Ceara. Rev. Economia e Social Rural. 2011.

[6] DESLANDES. S. F. A construção do projeto de pesquisa. 23. ed. Rio de Janeiro: Vozes, 1994.

[7] DREBES, L.M. O papel das cooperativas agropecuárias na permanência das novas gerações de agricultores familiares no campo. 2012.51f. Trabalho de Conclusão de Curso (Graduação em Agronomia) - Universidade Federal de Santa Maria - Campus de Frederico Westphalen, Frederico Westphalen. 2012.

[8] DIEHL, A. A.; TATIM, D. C. Pesquisa em ciências sociais aplicadas: Métodos e técnicas. São Paulo: Pearson Prentice Haill, 2004.

[9] FREITAS, G. S. A Conciliação de práticas cooperativas com desafio da conquista e manutenção da sustentabilidade: o caso da cooperativa regional de agricultores familiares ecologistas (ECOVALE) Dissertação (Mestrado em Agronegócio) - Universidade Federal do Rio Grande do Sul. Porto Alegre/RS. 2002.

[10] FEIJÓ, R. L. C.; Economia agrícola e desenvolvimento rural. Rio de Janeiro: LTC, 2011. 
[11] HAIR, J. F.; BABIN, B.; MONEY, A.H.; SAMUEL, P. Fundamentos métodos de pesquisa em administração. Porto Alegre: Bookman, 2005.

[12] LEITZKE, V.W.; SANTOS, V. Z. Juventude Rural e Inclusão do jovem na Gestão de Cooperativas da Economia Solidaria Nordeste do RS. In: COTRIM, D, S(Org.). Gestão de cooperativas: Produção acadêmica da Ascar. Porto Alegre: EMATER-ASCAR, 2013. Disponivel em: < http://www.emater.tche.br/site/arquivos_pdf/teses/Vilmar\%20 Leitzke.pdf>. Acesso em: 18 dez. 2016.

[13] MARCONI, M. A.; LAKATOS, E. M. Fundamentos de metodologia científica. 5 ed. São Paulo: Atlas, 2003.

[14] __. MAGRI, C. A.; CONTI, L. I. Alternativas em construção. Passo Fundo. Instituto Superior de Filosofia Berthier, $\overline{2008}$.

[15] _. MAGRI, C. A. et al. Cooperativismo de crédito solidário: reflexões e boas práticas. Passo Fundo: IFIBE, 2010.

[16] _ MAGRI, C. A.; CORREA, E. C. Cooperativismo de crédito familiar e solidário.

[17] Passo Fundo: IFIBE, 2012.

[18] MALhOTRA, N. K. Pesquisa de marketing: uma orientação aplicada. 6. ed. Porto Alegre: Bookman, 2010.

[19] MENDONÇA, K. R; RIBEIRO, M. E. A; GALIZONI. Sucessão na agricultura familiar: estudo de caso sobre o destino dos jovens do alto Jequitinhonha, MG.2008. Disponível em: <http://www.abep.nepo.unicamp.br/encontro2008/docsPDF/ABEP2008_1292.pdf>. Acesso em: 31 out. 2016.

[20] PERIUS, F. V. Cooperativismo e lei. São Leopoldo: UNISINOS, 2001.

[21] RIOS, G. S. L. O que é cooperativismo. 2 ed. São Paulo: Editora brasilense,1989.

[22] SOUZA, N. O.; LASCHEFSKI, K.; Agricultura Familiar: Caracterização dos agricultores que comercializam seus produtos na feira de sábado a Avenida Santa Rita, Viçosa - MG. In:

[23] SIMPOSIO INTERNACIONAL DE GEOGRAFIA AGRARIA, IV. 2009, Niterói, Anais eletrônicos... Niterói: UFF, $2009 . \quad$ Disponível em: <http://www.uff.br/vsinga/trabalhos/Trabalhos\%20Completos/Nayara\%20de\%200liveira\%20Souza.pdf>. Acesso em 15 maio. 2016.

[24] SOUZA, P. A. R.; ANDRADE, F. A. V.; A agricultura familiar e a geração de renda na Amazônia: uma abordagem empreendedora no município de Parintins AM. Revista Interdisciplinar Científica Aplicada, Blumenau, n.3, p.01-17, 2013. Disponível em: <http://www.revistas.ufg.br/index.php/espaco/article/view/19382/11270\#.VKsuwNLF_1h>. Acesso em: 15 maio. 2016.

[25] SILVESTTRO, M. L. et al. Os impasses sociais da sucessão hereditária na agricultura familiar. Brasília, Ministério do desenvolvimento Agrário. Brasília. 2001.

[26] SPANEVELLO, R. M.; LAGO. A. As Cooperativas Agropecuárias e a sucessão profissional na agricultura Familiar. In: XLV Congresso da Sociedade Brasileira de Economia, Sociologia e Administração Rural, 2007, Londrina, Anais eletrônicos... Londrina, SOBER 2007.

[27] SPNEVELLO, R. M. A dinâmica sucessória na agricultura familiar. Programa de Pós-Graduação em Desenvolvimento Rural da Faculdade de Ciências Econômicas, Universidade Federal do Rio grande do Sul, Porto Alegre, 2008.

[28] SCHIFFMAN, L. G.; KANUK, L. L. Comportamento do consumidor. 9. ed. Rio de Janeiro: Copyht, 2009.

[29] KOOPMANS, R. Iniciar uma cooperativa, 2006. Disponível em: <http://books.google.com.br// >. Acesso em: 04 mai. 2016.

[30] WEISHEIMER, N. Juventude rural mapas de estudo recentes. 2004. Disponível em: <http://books.google.com.br//> Acesso em: out.2015.

[31] VEIGA, S. M.; FONSECA, I. Cooperação: uma evolução pacífica em ação. Rio de Janeiro: DP \& A: Fase, 2001. 


\title{
Capítulo 16
}

PERCEPÇÃO DE IMPORTANNCIA DA CONTABILIDADE DE CUSTOS NA PRODUÇÃO DE LEITE: UM ESTUDO COM PRODUTORES RURAIS DE ALFREDO CHAVES-E.S.

\author{
Miguel Carlos Ramos Dumer \\ Mark Miranda de Mendonça \\ Wando Belffi da Costa \\ Alcinete Aparecida Basso Favero da Silva \\ Ana Carolina Júlio
}

Ariana Marchezi de Souza

Resumo: 0 presente artigo objetivou demonstrar a percepção de importância da contabilidade de custos na tomada de decisão, relatados pelos produtores rurais da atividade de pecuária leiteira do município de Alfredo Chaves, no estado do Espírito Santo. Para isso foi desenvolvido e aplicado junto a 74 produtores de leite deste município um questionário estruturado contendo questões objetivando conhecer o perfil dos produtores rurais, características de sua propriedade, a relevância da produção de leite para o desempenho econômico da propriedade e, em especial, 10 questões que avaliavam a descrição de importância atribuída à utilização de ferramentas e atributos da contabilidade de custos para a gestão da pecuária leiteira de cada empreendimento rural. De modo geral, conclui-se através da análise da literatura sobre o tema, que a contabilidade rural, mais especificamente a contabilidade de custos, é um instrumento de controle de extrema relevância para o bom desempenho das empresas do agronegócio. Os dados coletados junto aos produtores de leite demonstram que a maioria atribui uma alta percepção de importância aos atributos e ferramentas da contabilidade de custos abordadas, porém em todas as questões também existem produtores relatando considerar como irrelevantes estes atributos e ferramentas.

Palavras-chave: Agronegócio; Contabilidade Rural; Contabilidade de Custos. 


\section{INTRODUÇÃO}

Para Marion e Segatti (2005) o cenário atual de evolução constante da tecnologia e de competitividade cada vez mais acirrada nos diversos setores da economia não é diferente na atividade agrícola. Produtores rurais devem se preocupar em buscar o desenvolvimento de novas técnicas que permitam melhorar o desempenho da produção e contribuam no objetivo de uma gestão eficiente e eficaz. "O fazendeiro está se transformando em empresário rural, um administrador profissional, que, além de se preocupar com a produção, busca a produtividade e a lucratividade" (MARION; SEGATTI, 2005, p. 4). Nesse contexto a contabilidade rural é considerada pelos autores como um importante grupo de ferramentas ainda pouco utilizadas por produtores rurais.

A contabilidade de custos, dentre as diversas áreas atendidas pela Ciência Contábil, é um importante campo de estudo com diversas ferramentas para boa gestão de organizações dos diversos setores econômicos (MARTINS, 1998; VIEIRA, 2008).

A acelerada inovação tecnológica faz com que os consumidores estejam sempre em busca de produtos de alta qualidade, dessa maneira os produtores rurais acabam tendo que investir no melhoramento das atividades produtivas e no aprimoramento dos processos de gestão. Porém, nem sempre contratam profissionais qualificados para atuar no controle dos gastos de produção e acabam colocando seu produto no mercado com um preço alto, ou muitas vezes tendo prejuízos, alguns nem sabem da importância de terem esses valores dos diversos gastos da organização com precisão. Dessa forma, acaba muitas vezes colocando todo o seu empreendimento em risco (NOAL et al, 2005).

Diante do exposto, a presente pesquisa teve o objetivo central de averiguar, junto a produtores de leite do município de Alfredo Chaves-E.S. qual o grau de conhecimento e efetiva utilização das ferramentas de custos na atividade de pecuária leiteira em suas propriedades.

A investigação pretendeu responder a seguinte questão: Qual o nível de relevância atribuída pelos produtores de leite do município de Alfredo Chaves-E.S a ferramentas e atributos da contabilidade de custos para boa gestão da atividade leiteira?

Para tanto foi adotado o método de pesquisa survey, com a aplicação de um questionário, entre os meses de janeiro e outubro de 2014, para coleta de dados junto a setenta e quatro (74) produtores de leite, todos com atividades situadas em propriedades rurais no município de Alfredo Chaves, localizado no estado do Espírito Santo. A amostra foi estabelecida por conveniência, ou seja, quando o pesquisador possui liberdade para selecionar os elementos (COOPER; SCHINDLER, 2003; BRYMAN, 2012).

Desta maneira, serão trabalhadas neste estudo características como: abordagem de questões do mundo real, com potencial para a obtenção de resultados inovadores ou inesperados que preencham lacunas do conhecimento, levando em consideração aspectos de pesquisas anteriores, que, para Chow e Harrison (2002), são consideradas qualidades relevantes de pesquisas em contabilidade gerencial.

Os principais resultados evidenciam que a maioria declara uma alta percepção de importância dos atributos e ferramentas da contabilidade de custos abordadas nas dez (10) questões. Porém também demonstram que em todas as questões existem produtores relatando considerar como irrelevantes estes atributos e ferramentas.

\section{REVISÃO DE LITERATURA}

\subsection{AGRONEGÓCIO E A CONTABILIDADE RURAL}

O agronegócio deve ser entendido como cadeias organizadas relacionadas a atividades agropecuárias e como arranjos, cadeias e sistemas agroindustriais (PEREIRA, 2007). 0 termo agronegócio é a tradução do termo agrobusiness apresentado referindo-se ao conglomerado de atividades vinculadas à agropecuária. Somente a partir da década de 80 começou a ser difundida, ainda em inglês, onde atravessou praticamente toda a década sem tradução para o português e foi adotado de forma generalizada, inclusive por alguns jornais, que, mais tarde, trocaram o nome de cadernos agropecuários para agribusiness. Somente a partir da segunda década de 90, o termo agronegócio começa a ser aceito e adotado nos livros e nos jornais, culminando com a criação dos cursos superiores de agronegócios, em nível de graduação universitária (NEVES, 1995). Fontelles (2007, p. 64) afirma que o agronegócio no Brasil, "além de ser o setor que mais gera emprego no país, [...] é fundamental para a busca do equilíbrio das contas externas, possibilitando a geração de superávits na balança comercial". 
A contabilidade, como ciência social aplicada, possui como função o papel de auxiliar os diversos tipos de empresas em diversas necessidades de informação de controle, a fim de contribuir para sua a boa gestão. Entre elas as empresas rurais que compõem as atividades do agronegócio. A área da contabilidade que atende estas demandas é chamada de Contabilidade Rural.

Calderelli (2003, p. 105) descreve a Contabilidade Rural como "aquela que tem as suas normas fundamentadas na orientação, que controla e registra os atos e fatos acontecidos e praticados por uma empresa cujo objetivo do comércio ou da indústria seja agricultura ou pecuária". Para Crepaldi (2005, p. 84) a contabilidade rural deve ser enxergada como uma importante ferramenta disponível para a administração e tem como finalidades: "apurar o resultado, controlar o patrimônio e prestar informações sobre o patrimônio e o resultado das entidades rurais". A contabilidade rural é a parte da contabilidade que estuda todo o patrimônio rural, colaborando com diversas informações geradas para a boa gestão das empresas rurais integrantes do atual cenário de competitividade desse setor que, para Marion e Segatti (2005, p. 4) tem como consequência uma mudança na postura dos gestores, para os autores "o fazendeiro está se transformando em empresário rural, um administrador profissional, que, além de se preocupar com a produção, busca a produtividade e a lucratividade".

Porém, a contabilidade rural é uma ferramenta raramente usada pelos produtores rurais, já que é vista como uma técnica difícil, com pouco retorno na prática, e conhecida somente para a Declaração do Imposto de Renda, assim, os produtores não apresentam interesse na sua aplicação e utilização. Dentre outros fatores, o que também tem contribuído para isso, é a carência dos sistemas contábeis, responsáveis em retratar as características da atividade agropecuária, bem como, a falta de profissionais capacitados na concessão de tecnologias administrativas aos produtores rurais, daí, a não inclusão da Contabilidade Rural como instrumento de políticas governamentais agrícolas ou fiscais (CREPALDI, 2005).

\subsection{CONTABILIDADE DE CUSTOS E O AGRONEGÓCIO}

A contabilidade de custos, dentre as diversas áreas atendidas pela Ciência Contábil, é um importante campo de estudo com diversas ferramentas para boa gestão de organizações. A contabilidade de custos originou-se da contabilidade financeira, quando começou a exigência de se controlar e avaliar estoques nas indústrias, desde a época da Revolução Industrial, trabalhos, até então, de fácil avaliação, uma vez que as empresas eram pequenas e familiares, basicamente de artesanatos (MARTINS, 1998; VIEIRA, 2008).

Silva et al (2008) conceitua a contabilidade de custos como um ramo da ciência contábil utilizada para identificar, mensurar, armazenar e apresentar os custos dos produtos, mercadorias ou serviços vendidos, aplicando os princípios contábeis da mesma forma que a contabilidade geral, com o objetivo de que sejam apurados os resultados e valorizados os estoques, alertando os administradores para quaisquer resultados que precisem ser corrigidos.

De acordo com Martins (1998), a contabilidade de custos apresenta duas funções. 0 auxílio ao controle, onde sua principal obrigação é apresentar dados, orçamentos e outras formas de previsão e em seguida acompanhar o que de fato tenha acontecido para a comparação com valores antes determinados. Já com relação ao apoio às tomadas de decisões, o papel da contabilidade de custos consiste no fornecimento de informações sobre valores ressaltantes que dizem respeito às consequências de curto e longo prazo sobre medidas de corte de produtos, opção de compra e fixação de preços de venda.

A Contabilidade de Custos é uma ferramenta de extrema importância para a tomada de decisão, e, além disso, fornece informações valiosas aos empresários rurais, como conhecimento de como produzir com custos reduzidos e também de como administrar adequadamente na gestão de sua propriedade rural (BORILLI et al, 2005). Para Valle (1987, p. 102), "nas atividades rurais, o custo da produção compreende o conjunto de todas as despesas que devem ser suportadas para a obtenção dos produtos".

Identificar custos em empresas rurais é de extrema importância para auxiliar as tomadas de decisões gerenciais (EYERKAUFER et al, 2007), através dela é possível analisar e escolher a melhor cultura, as criações e as práticas que adotará em sua administração. "O controle dos custos e comparação de resultados [...] são indispensáveis para planejar a diversificação de culturas e a modernização do setor" (BORILLI et al, 2005 , p. 77).

Porém, Hofer et al (2004), identificam que a utilização de ferramentas contábeis para o gerenciamento de empresas não é comum no Brasil, sendo ainda mais reduzida a utilização das informações da contabilidade de custos. Para eles, o motivo de tal desalinhamento advém do fato de que diversas das 
organizações rurais não possuírem pessoa jurídica, ou seja, a falta de uma estrutura formal, e por isto não executarem escrituração e registro de informações contábeis.

\subsection{IMPORTÂNCIA DA CONTABILIDADE DE CUSTOS NA PECUÁRIA LEITEIRA}

A acelerada inovação tecnológica faz com que os consumidores estejam sempre em busca de produtos de alta qualidade, sendo assim os produtores são impelidos a investir mais no controle das atividades produtivas e na gestão destas atividades. Porém nem sempre efetuam os registros dos custos e outros gastos de produção, muitas vezes utilizam apenas de sua memória e de seus conhecimentos adquiridos das gerações anteriores. Não contratam profissionais qualificados e acabam colocando seu produto no mercado com um preço alto, ou muitas vezes tendo prejuízos. Outros, nem sabem da importância de terem esses valores conhecidos com precisão. Dessa forma, acabam muitas vezes não separando as despesas familiares das despesas de sua propriedade, tomam decisão sem fundamentação de dados reais, realiza investimentos sem conhecer a real situação financeira da organização, o que pode comprometer todo o seu empreendimento (NOAL e tal, 2005).

A variação intensa nos preços de mercado deste setor, dentre outros acontecimentos, tem cooperado para que os produtores de leite reflitam sobre a necessidade de gerenciar bem a atividade, tornando-se mais eficientes e, logo, mais competitivos (CARVALHO et al, 2007). Os custos de produção são considerados informações necessárias para boa administração da atividade leiteira (GOMES; FERREIRA FILHO, 2007; SILVA et al, 2008). Contudo, seu cálculo envolve algumas questões simples, outras nem tanto, razão pela qual seu uso é pouco praticado na atividade de pecuária leiteira (GOMES; FERREIRA FILHO, 2007).

Diante do cenário de competitividade desse setor, possuir um controle apropriado e, principalmente, possuir um sistema de custos de produção de leite que forneça informações que auxiliem na tomada de decisões rápidas e objetivas é fundamental para o sucesso das empresas rurais com atividade leiteira (LOPES et al, 2004). Este panorama tem incentivado a realização de pesquisas e estudos de custos de produção com o objetivo de apresentar a verdadeira situação econômica das atividades leiteiras, para que produtores, pesquisadores e grupos de interesse deste setor possam compreender e orientar as melhores práticas que orientem a tomada de decisões (PRADO et al, 2007).

Mediante os acontecimentos caracterizados pela limitação do poder de negociação no mercado, pelo fato do produtor não conseguir controlar o preço dos produtos que vendem, intensifica nos gestores de agronegócios da pecuária leiteira a percepção de relevância em administrar as variáveis que estão sob o seu controle (LOPES et al, 2007). Uma das poucas alternativas que têm os produtores de leite para continuar se mantendo de forma competitiva na atividade leiteira se dá pela compreensão dos gastos, com vistas ao controle e redução dos custos de produção, cujo conhecimento e entendimento são essenciais para o efetivo controle da atividade rural e indispensável para o processo de tomada de decisão nestas organizações. (FASSIO et al, 2006).

\section{METODOLOGIA, DESCRIÇÃO DA AMOSTRA E ANALISE DOS RESULTADOS}

O presente estudo pode ser caracterizado como descritivo que, para Cervo e Bervian (2002, p. 66), é um tipo de pesquisa que "[...] desenvolve-se, principalmente, nas ciências humanas e sociais, abordando aqueles dados e problemas que merecerem ser estudados e cujo registro não consta de documentos". Quanto ao método de pesquisa adotado, pode ser classificada como survey, recomendado por Freitas et al (2000, p. 105-106) quando "o interesse é produzir descrições quantitativas de uma população" e quando "o ambiente natural é a melhor situação para estudar o fenômeno de interesse".

Para tanto, o trabalho foi dividido em duas etapas, a primeira realizada em livros, artigos de revistas acadêmicas e consulta a sítios eletrônicos a fim de conceituar a relevância da informação contábil para as atividades rurais, principalmente da contabilidade de custos, assim como proporcionar uma breve caracterização da região onde o estudo foi desenvolvido.

Na segunda etapa, foram coletados dados junto a 74 produtores de leite do município de Alfredo Chaves durante os meses de setembro e outubro do ano de 2014. Essa amostra foi estabelecida por conveniência, ou seja, quando o pesquisador possui liberdade para selecionar os elementos que farão parte da amostra (COOPER; SCHINDLER, 2003; BRYMAN, 2012)

Optou-se pela utilização de questionário estruturado, ou seja, composto por dez (10) questões fechadas que intencionavam captar a percepção desses produtores rurais quanto à relevância da utilização de 
ferramentas e atributos de custos, na atividade de produção de leite. Adicionalmente foram inseridas no questionário questão objetivando conhecer o perfil dos produtores rurais, características de sua propriedade e a relevância da produção de leite para o desempenho econômico do empreendimento rural como um todo.

\subsection{DESCRIÇÃO DO PERFIL DOS ENTREVISTADOS E CARACTERÍSTICAS DE SUAS EMPRESAS RURAIS}

Também foram coletados dados sobre as características dos produtores rurais entrevistados e os resultados demonstram que do total de 74 entrevistados 19 eram mulheres e 55 homens. A média de idade foi de aproximadamente quarenta e um (41) anos. A maioria possui ensino fundamental completo. A Tabela 1 descreve a escolaridade dos entrevistados.

Tabela 1 - Escolaridade dos produtores de leite entrevistados.

\begin{tabular}{|c|c|c|}
\hline Escolaridade & Frequência & Percentual \\
\hline Até o Ensino Fundamental Incompleto & 25 & $33,8 \%$ \\
\hline Até o Ensino Fundamental Completo & 26 & $35,1 \%$ \\
\hline Até o Ensino Médio Completo & 21 & $28,3 \%$ \\
\hline Até a Graduação Completa & 01 & $1,4 \%$ \\
\hline Até a Pós-Graduação Completa & 01 & $1,4 \%$ \\
\hline TOTAL & 74 & $100 \%$ \\
\hline
\end{tabular}

Fonte: elaborado pelos autores.

A maioria possui ensino fundamental completo, seguido pelo fundamental incompleto, demonstrando a predominância de uma baixa escolaridade entre os componentes da amostra. Nenhum dos entrevistados com graduação e pós-graduação completa possuía formação na área de negócios ou na área rural, tanto o graduado quanto o pós-graduado possuem formação na área de Direito. Cabe ressaltar que treze (13) entrevistados declararam possuir formação também em cursos técnicos, destes o total de seis (06) são formados como técnico agrícola.

As empresas rurais possuem uma média de quarenta e cinco (45) cabeças de gado, com tamanho médio das propriedades de 44,5 hectares, mas destes o tamanho médio dedicado a pecuária leiteira é de 29,7 hectares, ou seja, em média é utilizado dois terços da área disponível na produção de leite. Todos descreveram como as principais atividades geradoras de renda a produção de leite, sendo o café a segunda mais importante.

Contudo, apenas um dos produtores entrevistados contratava um profissional contador para, entre outras atribuições, realizar o cálculo e análise dos dados de custos da produção agrícola.

\subsection{DESCRIÇÃO E ANÁLISE DA PERCEPÇÃO DE IMPORTÂNCIA DA CONTABILIDADE DE CUSTOS}

Nesta parte, é evidenciado o que os produtores rurais consideram importante, no que diz respeito à contabilidade de custos como ferramenta para a tomada de decisão. Foram elaboradas 07 questões relacionadas à relevância de artefatos da contabilidade de custos e da informação contábil na gestão da atividade rural, em especial a atividade de produção de café. Cada um dos quarenta produtores rurais teve a opção de determinar se tal componente é irrelevante, útil, importante ou crucial para sua atividade rural de produção leiteira, a definição desses parâmetros seguiu a utilizada por Kowalski et al (2010). Com base nas respostas pode-se evidenciar o nível de importância atribuído pelos produtores.

Adicionalmente foi questionado aos produtores o nível de relevância da cafeicultura para o desempenho econômico da propriedade, seguindo os mesmos parâmetros de respostas, descrito na Tabela 2. 
Tabela 2 - Nível de importância atribuída à produção de leite para o desempenho econômico da propriedade.

\begin{tabular}{|l|c|c|c|c|}
\multicolumn{1}{|c}{ QUESTÃo } & $\begin{array}{c}\text { IRRELEVANTE } \\
\text { (percentual) }\end{array}$ & $\begin{array}{c}\text { ÚTIL } \\
\text { (percentual) }\end{array}$ & $\begin{array}{c}\text { RELEVANTE } \\
\text { (percentual) }\end{array}$ & $\begin{array}{c}\text { CRUAL } \\
\text { (percentual) }\end{array}$ \\
\hline $\begin{array}{l}\text { Qual a importância da } \\
\text { produção de leite para } \\
\text { o desempenho } \\
\text { econômico da sua } \\
\text { propriedade? }\end{array}$ & 0 & 0 & 01 & $(1,4 \%)$ \\
\hline
\end{tabular}

Fonte: elaborada pelos autores.

Quase a totalidade dos respondentes atribui como "crucial" a produção de leite para o desempenho econômico da propriedade, apenas um respondeu a opção "relevante", nenhum considera apenas "útil" ou "irrelevante". Esse resultado ressalta a importância de discutir e conhecer a relevância da qualidade da gestão na produção de leite na região estudada e com agricultores cooperados, reforçando a relevância da presente pesquisa.

A Tabela 03 apresenta as dez (10) questões efetuadas no questionário bem como o nível de importância atribuído pelos produtores rurais entrevistados a cada tema abordado nas questões, seguindo os parâmetros utilizados por Kowalski et al (2010).

Dentre as respostas possíveis uma é considerada fortemente atípica para os padrões recomendados desejados - de um gestor rural pela maior parte da literatura, o parâmetro "irrelevante". Cabe ressaltar que a presente pesquisa não objetiva explicar as razões que levem qualquer respondente a optar por esta resposta, o que sugere novas possibilidades de pesquisa.

Tabela 3 - Nível de importância atribuída a ferramentas e atributos da contabilidade de custos.

\begin{tabular}{|l|c|c|c|c|c|}
\multicolumn{1}{|c}{$\begin{array}{c}\text { QUESTÕES } \\
\text { (percentual) }\end{array}$} & $\begin{array}{c}\text { ÚTIL } \\
\text { (percentual) }\end{array}$ & $\begin{array}{c}\text { RELEVANTE } \\
\text { (percentual) }\end{array}$ & $\begin{array}{c}\text { CRUCIAL } \\
\text { (percentual) }\end{array}$ \\
(percentual)
\end{tabular}


Tabela 3 - Nível de importância atribuída a ferramentas e atributos da contabilidade de custos.

(continuação...)

\begin{tabular}{|c|c|c|c|c|c|}
\hline $\begin{array}{l}7 \text { - Qual a importância de saber o ponto de equilíbrio mensal da } \\
\text { produção de leite em sua propriedade? }\end{array}$ & $\begin{array}{c}02 \\
(2,7 \%)\end{array}$ & $\begin{array}{c}06 \\
(8,1 \%)\end{array}$ & $\begin{array}{c}21 \\
(28,4 \%)\end{array}$ & $\begin{array}{c}45 \\
(60,8 \%)\end{array}$ & $\begin{array}{c}74 \\
(100 \%)\end{array}$ \\
\hline $\begin{array}{l}8 \text { - Qual a importância de saber o custo unitário por cabeça de } \\
\text { gado na atividade da produção de leite em sua propriedade? }\end{array}$ & $\begin{array}{c}06 \\
(8,1 \%)\end{array}$ & $\begin{array}{c}03 \\
(4,1 \%)\end{array}$ & $\begin{array}{c}37 \\
(50,0 \%)\end{array}$ & $\begin{array}{c}28 \\
(37,8 \%)\end{array}$ & $\begin{array}{c}74 \\
(100 \%)\end{array}$ \\
\hline $\begin{array}{l}9 \text { - Qual a importância de realizar anotações para registro e } \\
\text { controle dos gastos da produção de leite em sua propriedade? }\end{array}$ & $\begin{array}{c}04 \\
(5,4 \%)\end{array}$ & $\begin{array}{c}05 \\
(6,7 \%)\end{array}$ & $\begin{array}{c}30 \\
(40,6 \%)\end{array}$ & $\begin{array}{c}35 \\
(47,3 \%)\end{array}$ & $\begin{array}{c}74 \\
(100 \%)\end{array}$ \\
\hline $\begin{array}{l}10 \text { - Qual a importância de contratar um profissional qualificado } \\
\text { para contabilizar os custos da produção de leite em sua } \\
\text { propriedade? }\end{array}$ & $\begin{array}{c}07 \\
(9,5 \%)\end{array}$ & $\begin{array}{c}05 \\
(6,7 \%)\end{array}$ & $\begin{array}{c}41 \\
(55,4 \%)\end{array}$ & $\begin{array}{c}21 \\
(28,4 \%)\end{array}$ & $\begin{array}{c}74 \\
(100 \%)\end{array}$ \\
\hline $\begin{array}{c}\text { TOTAL } \\
\text { (percentual) }\end{array}$ & $\begin{array}{c}47 \\
(6,3 \%)\end{array}$ & $\begin{array}{c}36 \\
(4,9 \%)\end{array}$ & $\begin{array}{c}407 \\
(55,0 \%)\end{array}$ & $\begin{array}{c}250 \\
(33,8 \%)\end{array}$ & $\begin{array}{c}740 \\
(100 \%)\end{array}$ \\
\hline
\end{tabular}

Fonte: elaborada pelos autores.

De forma geral os resultados são alinhados com as recomendações encontradas na literatura, ou seja, a maioria considera relevante $(55,0 \%)$ ou crucial $(33,8 \%)$ a utilização de atributos e ferramentas da contabilidade de custos na gestão da produção de leite em suas propriedades agrícolas. Por outro lado, é possível identificar que em todas as questões existe mais de um produtor de leite que considera o tema abordado como irrelevante, com destaques para questão 3 e questão 10 onde o total de sete (7) produtores declaram considerar como irrelevante os atributos e ferramentas avaliados. Além disso, a quantidade total de produtores que marcaram a opção "irrelevante" supera o total que marcaram a opção "útil". Estes resultados parecem indicar uma quantidade razoável de produtores não alinhados com as recomendações da literatura sobre a relevância da contabilidade de custos para gestão de empreendimentos rurais, em especial para produção de leite.

É possível perceber que os produtores de leite entrevistados atribuem significativa importância para o conhecimento da ferramenta ponto de equilíbrio para boa gestão da produção de leite (questão 7) onde a maioria $(60,8 \%)$ declara essa ferramenta como "crucial", obtendo o maior resultado para esta resposta entre todas dez (10) questões avaliadas e o menor número de produtores $(2,7 \%)$ que considerem "irrelevante". Não é difícil entender tamanha atribuição de importância para este recurso, o conhecimento exato do ponto de equilíbrio proporciona ao gestor uma segurança quanto ao resultado alcançado, ou o empenho de esforços extras para alcança-lo antes do fechamento de um período pré-determinado.

A questão 3 obteve o pior desempenho de percepção de relevância, e ao mesmo tempo ela possui a menor quantidade de respondentes que considerem "crucial" (16,2\%) saber a diferença entre custos fixos e variáveis, e a maior quantidade de produtores que declaram considerar irrelevante o conhecimento destes atributos da contabilidade de custos para o bom desempenho da atividade de pecuária de leite.

Outra interessante constatação é a alta percepção de importância atribuída a realização de anotações para registro e controle dos gastos da produção de leite na questão 9, sendo a segunda mais marcada no quesito "crucial". Por outro lado a questão 10 que avaliava a importância contratar um profissional qualificado para contabilizar os custos da produção de leite recebeu baixa atribuição de "crucial" $(28,4 \%)$ e foi considerada como a mais "irrelevante" (empatado com a questão 3). Tais resultados apresentam uma percepção possivelmente contraditória, ou seja, ao mesmo tempo em que os produtores de leite entrevistados consideram o registro e controle das informações de gastos de produção elementos fundamentais para boa gestão da propriedade, também demonstram baixa disposição de investir em mão de obra qualificada para análise destas informações. Um dado anteriormente elencado na parte de descrição das organizações rurais dos entrevistados corrobora com esta possível percepção dicotômica, quando relatado que apenas um dos produtores entrevistados contratava um profissional contador para 
realizar o cálculo e análise dos dados relacionados a custos da produção agrícola, evidencia também alinhada com a consideração de Crepaldi (2005) sobre o baixo índice de utilização da contabilidade rural pelos gestores de agronegócios em geral no Brasil. Outro ponto que parece merecer análise futura minuciosa.

A questão 1 possui uma formulação que questiona a relevância atribuída a contabilidade de custo de forma abrangente, não especificando uma ferramenta ou atributo específico dessa área de conhecimento, talvez por isso seja a terceira questão com a maior concentração de respostas nos quesitos intermediários, o total de $70,2 \%$ consideram ser importante ou útil, enquanto $25,7 \%$ consideram crucial.

As outras questões $(02 ; 04 ; 05 ; 06$; e 08$)$ demonstram resultados semelhantes entre si e aproximados do comportamento da média geral.

Cabe especial destaque para uma contradição entre o nível de importância atribuída a produção de leite para o desempenho econômico das propriedades rurais (Tabela 2) e o nível de importância atribuída a ferramentas e atributos da contabilidade de custos na gestão da atividade de produção de leite (Tabela 3). Na Tabela 2 é possível identificar que na opção de resposta "crucial" existe uma concentrada percepção de relevância da atividade de pecuária leiteira no resultado econômico das empresas rurais, sendo que nenhum respondente marcou as opções "irrelevante" e "útil". Por outro lado, a Tabela 3 demonstra que em todas as dez (10) questões existem produtores declarando considerar apenas "útil", ou até mesmo "irrelevante", conhecimentos e práticas relacionadas a atributos e ferramentas da contabilidade de custos e considerados pela literatura sobre os temas relevantes para boa gestão de atividades rurais, em especial para atividade de produção de leite.

\section{CONSIDERAÇÕES FINAIS}

Este estudo objetivou avaliar, junto a um grupo de 74 produtores de leite, qual percepção de importância atribuída a contabilidade de custos na gestão de seus empreendimentos rurais, mais especificamente na atividade de pecuária leiteira.

Através da revisão da literatura sobre o tema foi possível perceber que a contabilidade de custos é indicada como um instrumento de controle considerado indispensável para gestão de atividades rurais, incluindo assim as propriedades com produção de leite.

Quando analisadas os dados coletados junto a produtores rurais com atividades de pecuária de leite do localizados no município de Alfredo Cahves-E.S., é possível identificar que, de forma geral os resultados são alinhados com as recomendações encontradas na literatura, ou seja, a maioria considera relevante e crucial a utilização de atributos e ferramentas da contabilidade de custos na gestão da produção de café em suas propriedades agrícolas.

Dos elementos abordados, foram consideradas mais relevantes o conhecimento do ponto de equilíbrio da produção (questão 7), e a contribuição de realizar anotações para registro e controle dos gastos da produção de leite (questão 9) obteve a segunda melhor percepção de importância atribuída pelos respondentes. Por outro lado, foi possível identificar que a percepção de importância sobre o conhecimento da diferença entre custos fixos e variáveis da produção de leite (questão 3), e sobre a contratação de um profissional qualificado para contabilizar os custos da produção de leite em sua propriedade (questão 10), tiveram cada uma total de sete (7) produtores que declaram considerar estes conhecimentos e ferramentas como "irrelevante", resultado que pode ser considerado contraditório para os padrões recomendados - desejados - de um gestor rural pela maior parte dos autores sobre o tema, porém alinhados com a sugestão de Crepaldi (2005) que considera baixo índice de utilização da contabilidade rural pelos gestores de agronegócios no Brasil.

Os resultados também mostram uma possível discrepância nas percepções dos respondentes, ao mesmo tempo em que os produtores de leite entrevistados consideram o registro e controle das informações de gastos de produção elementos fundamentais para boa gestão da propriedade (questão 9), também demonstram baixa disposição de investir em mão de obra qualificada para análise destas informações (questão 10). Além disso, na Tabela 2 é possível identificar que na opção de resposta "crucial" existe uma concentrada percepção de relevância da atividade de pecuária leiteira no resultado das empresas rurais, sendo que nenhum respondente marcou as opções "irrelevante" e "útil", por outro lado, a Tabela 3 evidencia que em todas questões existem produtores declarando considerar apenas "útil", ou até mesmo "irrelevante", conhecimentos e práticas relacionadas a atributos e ferramentas da contabilidade de custos 
e considerados pela literatura sobre os temas relevantes para boa gestão de atividades rurais, e consequentemente para seu desempenho.

Recomenda-se que outros para pesquisas tentem desenvolver uma análise pormenorizada das motivações que contribuem para que uma quantidade não inexpressiva de produtores considerarem irrelevantes as ferramentas e atributos da contabilidade de custos abordados nesta pesquisa, assim como pesquisas que tentem evidenciar se a percepção de importância influencia o nível efetivo de utilização destas ferramentas e atributos da contabilidade de custos por gestores de empresas rurais.

\section{REFERÊNCIAS}

[1] BORILLI, S. P.; PHILIPPSEN, R. B.; RIBEIRO, R. G.; HOFER, E. O uso da contabilidade rural como uma ferramenta gerencial: um estudo de caso dos produtores rurais no município de Toledo - PR. Revista de Ciências Empresariais da UNIPAR, Toledo, v. 6, n. 1, p. 77-95, jan./jun. 2005.

[2] BRYMAN, A. Social research methods. 4. ed. New York: Oxford, 2012.

[3] CALDERELLI, A. Enciclopédia contábil e comercial brasileira. 28 ed. São Paulo: CETEC, 2003.

[4] CARVALHO, G. R.; CARNEIRO, A. V. STOCK; L. A.; YAMAGUCHI, L. C. T.; MARTINS, P. C. Avaliação de impacto do preço de alimentos concentrados nos sistemas de produção de leite no estado do Paraná. In: CONGRESSO DA SOCIEDADE DE ECONOMIA, ADMINISTRAÇÃO E SOCIOLOGIA RURAL, XLV, 2007. Anais eletrônicos... Londrina: SOBER, 2007.

[5] CERVO, A. L.; BERVIAN, P. A. Metodologia científica. 5. ed. São Paulo: Prentice Hall, 2002.

[6] CHOW, C. W.; HARRISON, P. D. Identifying meaningful and significant topics for research and publication: a sharing of experiences and insights by "influential" accounting authors. Journal of Accounting Education, v. 20, n. 3, p. 183-203, 2002.

[7] CREPALDI, S. A. Contabilidade rural: uma abordagem decisorial. 3. ed. São Paulo: Atlas, 2005.

[8] COOPER, D. R.; SCHINDLER, P. S. Métodos de pesquisa em administração. 7. ed. Porto Alegre: Bookman, 2003.

[9] DAVIS, J. H.; GOLDBERG, R. A. A concept of agribusiness. Boston: Havard University Press, 1957.

[10] EYERKAUFER, M. L.; COSTA, A.; FARIA, A. C. Métodos de custeio por absorção e variável na ovinocultura de corte: estudo de caso em uma cabanha. Organizações Rurais \& Agroindustriais, Lavras, v. 9, n. 2, p. 202-215, 2007.

[11] FASSIO, L. H., REIS, R. P., E GERALDO, L. G. Desempenho técnico e econômico da atividade leiteira em Minas Gerais. Ciência e Agrotecnologia, Lavras, v. 30, n. 6, p. 1154-1161, 2006.

[12] FONTELLES, A. B. Perfil de investimento do produtor rural. 2007. 85 f. Dissertação (Mestrado em Economia) - Programa de Pós-Graduação em Economia, Faculdades Ibmec, Rio de Janeiro, 2007.

[13] FREITAS, H.; OLIVEIRA, M.; SACCOL A. Z.; MASCAROLA, J. O método de pesquisa survey. Revista de Administração, São Pauo, v. 35, n. 3, p. 105-112, jul./set. 2000.

[14] GOMES, A. L; FERREIRA FILHO, J. B. S. Economias de escala na produção de leite: uma análise dos Estados de Rondônia, Tocantins e Rio de Janeiro. Revista de Economia e Sociologia Rural, Rio de Janeiro, v. 45, n. 3, p. 591-619, 2007.

[15] HOFER, E.; ENGEL, W.; CARMO, W. A.; SCHULTZ, C. A.; BELTRAME, S. L. Custo de produção para a atividade da pecuária leiteira: um estudo de caso. In: CONGRESSO BRASILEIRO DE CUSTOS. XI, 2004. Anais eletrônicos... Porto Seguro: ABC, 2004.

[16] KOWALSKI, F. D.; FERNANDES, F. C.; FARIA, A. C. Análises dos controles internos relacionados às atividades ambientais das cooperativas catarinenses de energia elétrica por meio da matriz de importância-desempenho de Slack. Revista Contabilidade Vista \& Revista, Belo Horizonte, v. 21, n. 2, p. 153-177, abr./jun. 2010.

[17] LOPES, M. A. LIMA, A. L. R,; CARVALHO, F. M.; REIS, R. P.; SANTOS, I. C.; SARAIVA F. H. Controle gerencial e estudo da rentabilidade de sistemas de produção de leite na região de Lavras, MG. Ciências e Agrotecnologia, Lavras, v. 28, n. 4, p. 883-892, jul./ago. 2004.

[18] LOPES, P. F.; REIS, R. P.; YAMAGUCHI, L. C. T.; Custos e escala de produção na pecuária leiteira: estudo nos principais estados produtores do Brasil. Revista de Economia e Sociologia Rural, Rio de Janeiro, v. 45, n. 3, p. 567-590, jul./set. 2007.

[19] MARTINS, E. Contabilidade de custos. 6. ed. São Paulo: Atlas. 1998.

[20] NEVES, M. F. Sistema agroindustrial citrícola: um exemplo de quase-integração no agribusiness brasileiro. 1995. 87 f. Dissertação (Mestrado em Administração) - Faculdade de Administração da Universidade de São Paulo, São Paulo, 1995. 
[21] NOAL, E. B.; ANCELES, P. E. S.; RIBEIRO, O. D. J. Apuração de custos na pecuária leiteira, um estudo de casos. Dusc. Scientia, Santa Maria, v. 1, n. 1, p. 167-180, 2005.

[22] PEREIRA, J. P. C. N. A concentração geográfica de empresas no agronegócio de flores: uma análise das localidades de Holambra e Mogi das Cruzes. 2007. 273 f. Tese (Doutorado em Engenharia da Produção) - Escola Politécnica da Universidade de São Paulo, São Paulo, 2007.

[23] PRADO, E.; GERALDO, L. G.; CARDOSO, B. M. Rentabilidade da exploração leiteira em uma propriedade durante cinco anos. Arquivo Brasileiro de Medicina Veterinária e Zootécnica, Belo Horizonte, v. 59, n. 2, p. 501-507, abr.2007.

[24] SIlVA, H. A.; KOEHLER, H. S.; MORAES, A.; GUIMARÃES, V. D. A.; HACK, E.; CARVALHO, P. C. F. Análise de viabilidade econômico da produção de leite a pasto e com suplementos na região dos Campos Gerais - Paraná. Ciência Rural, Santa Maria, v.38, n.2, p.445-450, mar. 2008.

[25] VALLE, F. Manual de contabilidade agrária. São Paulo: Atlas, 1987.

[26] VIEIRA, E. P. Noções básicas de contabilidade de custos. Ijuí: Unijuí, 2008. 


\title{
Capítulo 17
}

\section{DEMANDA POR CONSULTORIA AGRICOLA DOS CAFEICULTORES DO CÓRREGO CACHOEIRÃO, NO MUNICÍPIO DE SIMONÉSIA - MG}

\author{
Maxwell Pacelli de Souza Marcial \\ José Carlos de Souza \\ Rock Kleyber Silva Brandão \\ Rosane Aparecida Moreira \\ Marluci Moraes Pereira
}

Resumo: A cafeicultura é de grande importância econômica para o município de Simonésia - MG, sendo responsável direta por mais de 35\% do seu PIB (Produto Interno Bruto). Entendendo a importância do setor para o município e a complexidade da administração rural, dada a grande cadeia do agronegócio e as características peculiares do mesmo, este trabalho se propõe a identificar a demanda por consultoria agrícola no córrego Cachoeirão em Simonésia. Para obter os resultados, foi feita uma pesquisa descritiva com questionários aplicados a 29 cafeicultores da comunidade, seguindo uma amostragem não probabilística, por conveniência. Com a análise dos dados foi possível observar que a maioria dos entrevistados têm toda ou a maior parte da renda familiar proveniente da cafeicultura; que o nível de escolaridade deles é baixo, visto que a maioria não concluiu o Ensino Fundamental; que apenas 6,9\% recebem um serviço regular de consultoria, que a maioria deles recebe consultorias ocasionais, por meio de fornecedores de insumos, ou não recebem nenhum tipo de consultoria. Por fim observou-se que os cafeicultores que não recebem nenhuma consultoria têm produtividade média de 23 sacas de café por hectare, enquanto os que contratam o serviço regularmente atingem média de 42,5 sacas por hectare, ou seja $84,8 \%$ a mais de produção na mesma área, evidenciando-se que tanto os cafeicultores em particular, como a economia local têm necessidade de acesso aos serviços de consultoria e às tecnologias disponibilizadas por estes profissionais.

Palavras-Chave: Consultoria agrícola, Cafeicultura, Administração rural, Tecnologias. 


\section{INTRODUÇÃO}

O município de Simonésia, segundo o IBGE - Instituto Brasileiro de Geografia e Estatística (2010), tem extensão territorial de $486.543 \mathrm{~km}^{2}$ e no ano de 2010 tinha $61,2 \%$ da sua população residindo na zona rural, sendo a população total de 18.298 habitantes e a população rural de 11.202 habitantes. A cafeicultura é a principal atividade econômica do município, responsável direta por 37,84\% do PIB no ano de 2012, quando o PIB total de Simonésia foi da ordem de $\mathrm{R} \$ 149.564 .000,00$ e o PIB proveniente da cafeicultura foi de $\mathrm{R} \$ 56.628 .000,00$. (IBGE 2012).

Entendendo que o agronegócio envolve uma grande cadeia antes da propriedade, que fornece tecnologias e insumos, e depois, visando beneficiamento, escoamento e transformação dos produtos agrícolas para consumo, e observando o que acontece em Lajinha- MG, município vizinho a Simonésia, onde segundo Barbosa et al (2013), 93,4\% dos comerciantes observaram que a cafeicultura impacta diretamente no comércio do município e $82 \%$ dos comerciantes observaram que a interferência se dá pelo aumento do faturamento, principalmente na época da safra de café, pode-se inferir que o PIB proveniente da cafeicultura em Simonésia é um dos principais, senão o principal propulsor econômico do município.

Assim, devido à complexidade da administração de uma propriedade, aqui vista como uma empresa rural e a importância das mesmas para o município verifica-se que a consultoria agrícola constitui-se numa importante ferramenta para auxiliar os cafeicultores na gestão do negócio, e contribuir com a economia local, pois os seus resultados impactam significativamente a economia do município.

A pesquisa se justifica por permitir ao poder público verificar a eficácia de suas políticas voltadas ao fomento da atividade e ainda às empresas, profissionais autônomos e instituições, que prestam algum tipo de consultoria agrícola, verificar o nível de resultado obtido e até conhecer melhor o mercado para este serviço. Aos cafeicultores, principais interessados, permite-se avaliar a eficiência e eficácia dos sistemas produtivos, criando condições para melhoria de sua gestão, sugerindo-se estudos similares em outros ambientes semelhantes e em outros sistemas produtivos relacionados ao agronegócio, que é bastante amplo em nossa região, incluindo a produção de olericulturas, açúcar mascavo, aguardentes, entre outros.

Portanto este trabalho propõe-se a identificar a demanda por consultoria agrícola no Córrego Cachoeirão, Município de Simonésia - MG, visando conhecer o perfil dos cafeicultores do Cachoeirão; levantar a variação de produtividade entre os cafeicultores entrevistados; e analisar a influência da consultoria agrícola em suas produtividades, partindo da seguinte questão: Como o cafeicultor do Córrego do Cachoeirão, Município de Simonésia - MG percebe a importância da consultoria agrícola no desenvolvimento de sua atividade.

\section{FUNDAMENTAÇÃO TEÓRICA}

\subsection{EMPRESAS RURAIS}

Segundo Marion (2002, p.24) "empresas rurais são aquelas que exploram a capacidade produtiva do solo por meio do cultivo da terra, da criação de animais e da transformação de determinados produtos agrícolas".

Entretanto, para Aloe e Valle (1978) apud Faria et al (2010) além das atividades de exploração da terra e criação de animais como atividades de fonte de renda, a empresa rural tem funções complementares, próprias de qualquer empresa:

- Função técnica, de produção agrícola, zootécnica e agroindustrial;

- Função comercial, de compra de adubos, sementes, inseticidas, implementos agrícolas, animais e agroindustriais;

- Função financeira, de recebimentos e pagamentos, obtenção de financiamentos, depósitos bancários, retiradas de depósitos, etc;

- Função econômica, de obtenção de lucros e consequente aumento do patrimônio;

- Função social, de criação de bens econômicos, para satisfazer as necessidades humanas.

Ainda segundo Aloe e Valle (1978) apud Faria et al (2010b) as empresas rurais são classificadas da seguinte maneira: Pequenas, médias e grandes. As pequenas empresas exploram propriedades de pequenas dimensões, constituídas de sítios, chácaras e pequenas lavouras; onde não se encontram registros contábeis, devido a falta de instrução e poucos recursos do agricultor. Em algumas propriedades 
o que existe é uma caderneta, onde são anotados os serviços dos empreiteiros e os salários a serem pagos, assim como as contas a receber. As empresas médias exploram fazendas onde os proprietários possuem maiores recursos e investem muitas vezes em uma única cultura, com pequenas criações. Nesta categoria se encontram a relação de contas pendentes de liquidação, o livro Diário, cadernetas com a relação de cada funcionário e o extrato de contas correntes, onde toda escrituração demonstra no final do ano agrícola somente a renda liquida em dinheiro. As grandes empresas exploram fazendas de grande extensão territorial, verdadeiros latifúndios que predominam com a policultura, com indústrias agrícolas e grandes criações. Possuem uma contabilidade completa com registros minuciosos que possibilitam o controle de toda propriedade.

\subsection{ADMINISTRAÇÃO RURAL}

Para Maximiano (2004) a administração é um processo dinâmico de tomar decisões sobre a utilização de recursos, para possibilitar a realização de objetivos. E esse processo envolve basicamente quatro etapas, planejamento, organização, execução e controle. E Chiavenato (2001), ressalta que o sucesso de qualquer empreendimento depende diretamente da capacidade de quem exerce as funções administrativas.

Arruda (2013) diz que a administração rural surgiu no começo do século XX junto às universidades de ciências agrária, na Inglaterra e Estados Unidos nos chamados "land grant", com a preocupação de sobretudo, analisar, a credibilidade econômica e as técnicas agrícolas. E consiste em disciplinar os elementos de produção e submeter a produtividade a um controle de qualidade, para obter um resultado eficaz e o necessário retorno financeiro.

Diferentemente dos demais setores da economia, o administrador rural precisa conviver com algumas características que distinguem o setor agrícola, conforme destaca Crepaldi (2006), apud Faria et al (2010):

- Dependência do Clima: É a característica mais citada pelos estudiosos e da qual muitas outras dependem. 0 clima condiciona a maioria das explorações agropecuárias. Determina épocas de plantio, tratos culturais, colheitas, escolha de variedades e espécies, vegetais e animais;

- Correlação Tempo de Produção versus Tempo de Trabalho: 0 processo produtivo desenvolve-se em algumas fases, independentemente da existência do trabalho físico imediato. 0 que não ocorre em outros setores da economia, como, por exemplo, na indústria onde somente o trabalho modifica a produção. Fator este que deverá ser sempre levado em conta;

- Dependência de Condições Biológicas: As condições determinam a irreversibilidade do ciclo produtivo, ou seja, não se pode alterar a sequência da produção (interromper o desenvolvimento de uma lavoura de milho para produzir soja). Por outro lado, limita-se a adoção de medidas que normalmente são utilizadas em outros setores da economia, como recursos para acelerar a produção, como o estabelecimento de um terceiro turno de trabalho. A pesquisa agropecuária pode conseguir espécies animais e variedades vegetais mais precoces e produtivas, mas ainda assim sujeitas a condições biológicas;

- Terra como Participante da Produção: Na agropecuária, a terra não é apenas um suporte para o estabelecimento de atividades produtivas, ao contrário, na maioria das explorações agropecuárias, participa diretamente do ciclo produtivo. Assim, é importante conhecê-la e analisála em suas condições químicas, físicas, biológicas e topográficas;

- Estacionalidade ou Sazonalidade da Produção: No setor agrícola, normalmente, não existe fluxo continuo de produção, como na indústria e uma tarefa pode também não depender de outra. As atividades estão dispersas por toda a empresa, podendo ocorrer em locais distantes um do outro. Não há relação, por exemplo, entre o trabalho executado por uma equipe que reforma as cercas da propriedade com outra que faz "a limpeza" das pastagens;

- Incidência de Riscos: Na agropecuária a existência de riscos é de grande proporção, pois explorações podem ser afetadas por problemas causados pelo clima (seca, geada, granizo), pelo ataque de pragas e moléstias, e também pelas flutuações de preços de seus produtos;

- Produtos não Uniformes: Na agropecuária, ao contrário da indústria, há dificuldades em se obter produtos uniformes quanto à forma, ao tamanho e à qualidade. Esse fato é decorrente das condições biológicas e acarreta, para o empresário rural, custos adicionais com classificação e padronização, além de receitas mais baixas, em virtude do menor valor dos produtos que apresentarem padrão de qualidade inferior; 
- Alto Custo de Saída e/ou Entrada: No negócio agrícola, algumas explorações exigem altos investimentos em benfeitorias e máquinas e, consequentemente, condições adversas de preço e mercado devem ser suportadas em curto prazo, pois o prejuízo, ao abandonar a exploração, poderá ser maior. A cultura de café e a pecuária leiteira podem ser consideradas como explorações de alto custo de entrada, enquanto culturas anuais - milho e soja, por exemplo - são explorações de menor custo de entrada.

Lourenzani et al (2012), destaca que, de maneira geral, a produção agropecuária é o elo menos profissionalizado de toda cadeia produtiva agroindustrial. E que o principal problema não se encontra nas técnicas agropecuárias em si, mas reside, sobretudo, na compreensão do funcionamento dos mercados, que impõe articulação com os segmentos pré e pós-porteira, à montante ou à jusante, novas formas de negociação e práticas de gestão do processo produtivo.

Tal deficiência provoca impactos negativos no desenvolvimento desse segmento e, consequentemente, na sua cadeia agroindustrial.

Ainda segundo Lourenzani et al (2012), cabe ao administrador rural decidir, a partir das informações disponíveis, como os recursos (insumos, capital, tecnologia) serão utilizados, com a necessária interação com a equipe de trabalho, para serem transformados em produtos finais. Decisões como o quê produzir, quanto produzir, como produzir, quando produzir e para quem produzir devem ser tomadas, considerando fatores restritivos como o tamanho da propriedade, a tecnologia disponível e a saúde financeira do empreendimento.

A relação entre as decisões produtivas e os recursos disponíveis é que vai definir o custo de produção dos produtos. As relações familiares (organização, delegação de responsabilidades, comando), bem como a maneira como as atividades (operações) são realizadas, também influenciam todo o processo produtivo do empreendimento. Por fim, os resultados (financeiros, informações e satisfação) obtidos ao final de um ciclo produtivo é que vão subsidiar, aperfeiçoar ou, até mesmo, inibir novas atividades. Lidar com essa complexidade de funções, tendo que observar também os fatores externos que afetam o setor agrícola, capacitações gerenciais, ausentes na maioria dos administradores rurais e, consequentemente, nas suas organizações. Uma das principais razões desta dificuldade é a falta de uma visão sistêmica do empreendimento rural (LOURENZANI et al, 2012).

Analisando essas características singulares da empresa rural, Andrade (2000), apud Faria et al (2010), observa que as mesmas isoladas ou em conjunto, para a administração rural, surtem efeito mais prejudicial do que benéfico, indicando que o empresário rural deve assumir ações administrativas eficazes, que atenuem e modifiquem os efeitos prejudiciais de cada uma delas.

\subsection{CAFEICULTURA}

De acordo com a Secretaria de Estado de Agricultura Pecuária e Abastecimento de Minas Gerais (2017), o Brasil é hoje líder mundial na produção de café, responsável por 35,9\% da produção mundial; e Minas Gerais é o maior produtor nacional do grão, uma vez que o estado representa 56,4\% da produção nacional. Herszkowicz (2008) considera ainda que além de maior produtor, o Brasil também é o maior exportador e segundo maior consumidor de café do mundo. De 1996 a 2007 a produção brasileira foi ampliada em 33\%, passando de 27 milhões de sacas no período 1996/2000 a 36 milhões de sacas no período 2003/2007. Sendo que a produtividade média brasileira também cresceu de 12 para 17 sacas/hectare neste período.

Figueiró (2011) apud Barbosa et al (2013) destaca ainda que nas duas últimas décadas o café passou por três grandes revoluções, a primeira foi o surgimento do Vietnã como grande produtor, a segunda foi a ampliação do mercado de cafés especiais e a terceira o incremento de consumo dos países produtores.

Entretanto, analisando o processo de produção de café em si, dentro da porteira, vemos que "o fornecimento de nutrientes, através da adubação e calagem, é muito importante para o sucesso da cafeicultura, pois as lavouras atuais de café, em sua quase totalidade, encontram-se implantadas em solos naturalmente pobres[...]." (MATIELLO et all, 2008, p. 4).

Já Alixandre (2008) destaca que ao implantar uma lavoura, deve-se atentar para escolha do

sistema de produção, observando o espaçamento da lavoura, a forma de condução das plantas, a variedade a ser implantada, a escolha ideal das mudas, preparo da área, adubação das covas e época de plantio. E depois de implantada devem ser feitas adubações de cobertura, as quais seguem definições de acordo com 
a fertilidade do solo e devem ser dividas em calagem, gessagem e em três etapas de adubação. Também deve-se observar o manejo do mato, desbrotas e manejo integrado de pragas e doenças.

Zambolim et al (2008) descreve ainda, que para proteger o cafeeiro da ferrugem, que é uma das principais doenças da cultura, adotam a pulverização preventiva com fungicidas cúpricos e também pode-se optar pelo uso de fungicidas sistêmicos, que podem ser formulados com inseticidas ou separadamente, e são aplicados via solo. Ainda Zambolim et al (2008) considera que o manejo de doenças do cafeeiro deve ser integrado, observando a escolha de variedades resistentes, o espaçamento adotado na implantação da lavoura, de forma a não favorecer as doenças, as formas de "escape" para se evitar as doenças e por fim os tratamentos de proteção e controle das doenças.

Guimarães et al (1999) considera também que na cultura de café arábica é normal ter em um ano uma produtividade elevada e no ano seguinte uma produtividade baixa, o que caracteriza a bienalidade do cafeeiro.

\subsection{CONSULTORIA AGRÍCOLA}

A "consultoria empresarial é um processo interativo de um agente de mudanças externo à empresa, o qual assume a responsabilidade de auxiliar os executivos e profissionais da referida empresa nas tomadas de decisões [...]" (OLIVEIRA, 2011, p.4).

Já Belfort (2004), diz que o consultor é um agente externo que leva sua "visão de fora" e suas vivências para empresa. Suas principais atividades são o processo interativo, que é o conjunto estruturado de atividades sequenciais que desenvolvem ações recíprocas, lógicas e evolutivas, visando atender, preferencialmente, suplantar as expectativas e necessidades dos clientes.

0 agente de mudanças externo é o profissional capaz de desenvolver comportamentos, atitudes e processos que possibilitem à empresa transacionar, proativa e interativamente, com os mais diversos fatores do ambiente empresarial, tendo a responsabilidade de auxiliar as pessoas, direcionando-as no desenvolvimento de metodologias, técnicas e processos que determinem a sustentação para os que os gestores das empresas tomem suas decisões com qualidade, de acordo com a proposta de processo decisório, que tem as seguintes partes: o dado, o tratamento, a informação, a alternativa, o recurso e o resultado. (BELFORT 2004).

Peixoto (2014) explica que o Brasil conta com programas oficiais de Assistência Técnica e Extensão Rural (ATER) desde os anos 1960, buscando levar informações agrícolas aos produtores rurais. Porém, desde sua criação o programa passou por diversos desafios, mudanças de governo e possivelmente até desinteresse dos mesmos em levar os serviços aos agricultores. Tudo isso faz com que os serviços sejam insuficientes ou inexistentes para a grande maioria dos agricultores familiares, que não dependem apenas de acesso a crédito para aquisição de insumos, para investimento em benfeitorias e equipamentos e para comercialização, mas também de acesso a conhecimento sobre como implementar as inovações tecnológicas e como gerir suas atividades.

Alves e Souza (2014) por sua vez entendem que a difusão de tecnologia por parte das agências de extensão rural, como é o caso da ATER, tem papel fundamental tanto no crescimento da produção brasileira como na sua dispersão. Informa ainda o autor que esta agência beneficiou 500 mil estabelecimentos e deixou à margem 3,9 milhões de outros no país. Isso caracteriza um problema muito sério de difusão de tecnologia e também para a sociedade brasileira, ou seja, a tecnologia alcançou uma minoria de estabelecimentos e contribuiu para que eles fossem responsáveis por grande parte da produção nacional, porém marginalizou a grande maioria com prejuízos e consequências decorrentes.

A solução agrícola do problema de pobreza implica necessariamente no aumento do valor da produção de cada estabelecimento, aumento esse muito dependente da tecnologia, portanto, de sua difusão para os que ficaram à margem desta modernização. (ALVES E SOUZA 2014).

Peixoto (2014) considera que os agentes de extensão do setor público muitas vezes são generalistas, enquanto as atividades de extensão privadas frequentemente fornecem informação especializada, mais demandada por produtores rurais que buscam modernização e integração às cadeias produtivas. Assim, a extensão e assistência comercial estão se tornando mais comum uma vez que ela dá suporte aos interesses comerciais de fornecedores de insumos e compradores de produção que requerem ou se beneficiam do provimento de serviços de extensão sólidos para atender à administração e produção agrícola. 
Nesse contexto, a informação agrícola transforma-se numa fonte maior de vantagens competitivas estratégicas para o setor privado, crescentemente integrado por organizações não governamentais (ONGs), indústrias de insumos, máquinas e equipamentos agrícolas, revendas agropecuárias, profissionais liberais ou suas empresas de assistência técnica, agroindústrias e atacadistas que distribuem sua produção. As organizações públicas de pesquisa e extensão foram lentas em perceber que estavam sendo crescentemente deslocadas pelo setor privado e que necessitavam identificar uma nova missão que poderia justificar a continuação de investimentos de fundos públicos. (PEIXOTO, 2014).

Oliveira (2011), diz ainda que o consultor externo, apesar de ficar menos tempo na empresa- cliente, não ter poder formal na mesma e menos conhecimento dos seus aspectos informais, tem maior condição de fazer uma consultoria eficaz, devido a experiência em outras atuações, a maior aceitação dos níveis superiores da administração e por sua imparcialidade nos grupos informais da empresa.

Ban (2000) apud Peixoto (2014) ponderou ainda que as fontes dos recursos para financiamento de organizações da extensão podem ser:

1) Governo mediante imposto pago por contribuintes.

2) Governo mediante cobrança de taxas sobre determinados produtos agrícolas.

3) Companhia comercial que vende insumos aos produtores rurais e/ou que compra seus produtos e que, em seu relacionamento com seus clientes, igualmente usa a extensão.

4) Associação de produtores rurais que paga os serviços de extensão com fundos arrecadados pela cobrança de suas taxas de mensalidade.

5) Associação de produtores rurais que é subvencionada pelo governo.

6) ONG financiada por doações de dentro ou fora do País e/ou por companhias comerciais para finalidades de responsabilidade social.

7) ONG financiada por subsídios ou por contratos com o governo (nacional ou um patrocinador governamental).

8) Empresa de consultoria que cobra uma taxa dos produtores rurais, que são seus clientes.

9) Empresa de publicação que vende jornais agrícolas ou outras publicações aos produtores rurais.

10) Combinações diferentes das acima.

Entretanto, apesar da importância do consultor agrícola, Peixoto (2014, p.894) diz que,

“O processo de transferência de informação entre produtores rurais caracteriza- se tradicionalmente por uma troca de informação cooperativa, livre e interpessoal. Os produtores obtêm a maior parte das informações de fontes variadas: família, amigos, produtores vizinhos, grupos informais de produtores [...]".

\section{MÉTODO DE PESQUISA}

O estudo foi realizado no Córrego Cachoeirão, Zona Rural do Município de Simonésia - MG. De acordo com IBGE (2010) o córrego Cachoeirão faz fronteira com os Córregos Água Limpa, São Vicente, Champrão, Escadinha e com o município de Santana do Manhuaçu - MG.

A pesquisa é do tipo descritiva, "as pesquisas deste tipo têm como objetivo primordial a descrição das características de determinada população ou fenômeno ou o estabelecimento de relações entre variáveis." (GIL, 2008, p.28). E foi realizada de acordo com um levantamento de campo, que segundo Gil (2008) o levantamento de campo se caracteriza pela interrogação direta das pessoas cujo comportamento se deseja conhecer.

A amostragem foi realizada por acessibilidade, sendo que de acordo com a figura 1, o córrego foi dividido em 5 regiões, região 1(R1), região 2 (R2), região 3 (R3), região 4 (R4) e região 5 (R5); foram contadas as casas de cada região e aplicados questionários aleatoriamente, seguindo arredondamento, a 30\% das casas, sendo aplicado 1 questionário por casa ao titular da propriedade. 0 Cachoeirão tem, de acordo com a contagem da pesquisa, 95 casas habitadas, foram aplicados 29 questionários, de acordo com a seguinte distribuição:

- R1: 21 casas habitadas, 6 questionários; 
- R2: 19 casas habitadas, 6 questionários;

- R3: 20 casas habitadas, 6 questionários;

- R4: 24 casas habitadas, 7 questionários;

- R5: 12 casas habitadas, 4 questionários;

Adotou-se o questionário aplicado, validado no mesmo córrego, ou seja, aplicado uma vez a pessoas diferentes para verificar se ele responderia aos objetivos e depois aos entrevistados entre os dias 24 de outubro e 04 de novembro de 2017. De acordo com Gil (2008), o questionário aplicado é caracterizado quando as questões são formuladas oralmente pelo pesquisador, seguindo uma entrevista ou formulários. Ainda de acordo com Gil (2008), os questionários por escrito podem excluir as pessoas que não sabem ler e impede o auxílio ao informante quando este não entende as perguntas; o que neste caso dificultaria a pesquisa.

FIGURA 1: Croqui, divisão do Córrego Cachoeirão em regiões.

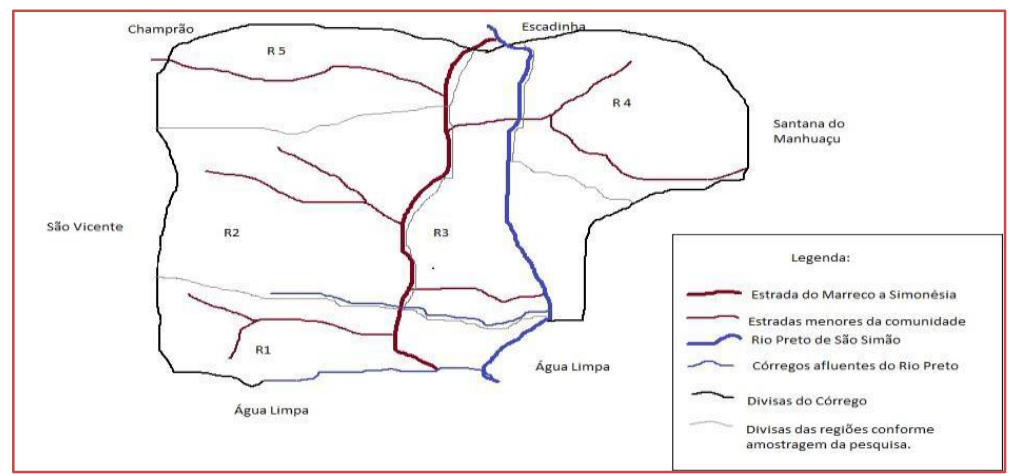

Fonte: Adaptado Mapa Municipal Estatístico, IBGE 2010.

\section{ANÁLISE DOS RESULTADOS}

De acordo com o estudo, 34,5\% dos responsáveis pelas propriedades do Córrego do Cachoeirão têm entre 25 e 40 anos de idade; 20,7\% têm entre 40 e 55 anos; e 44,8\% têm mais de 55 anos. Sendo que $93 \%$ são homens e 7\% mulheres. E 89,7\% dos responsáveis são casados ou amasiados e 10,3\% são viúvos (as).

Quanto a escolaridade, o gráfico 1 mostra que 76\% não concluíram o Ensino Fundamental, 21\% concluíram o Ensino Fundamental e apenas 3\% concluíram o Ensino médio.

Em relação a propriedade das empresas rurais, 86,2\% dos responsáveis são donos, proprietários da terra; 10,4\% são herdeiros/comodatários, responsáveis pelas decisões, mas ainda não têm a posse da empresa; e apenas 3,4\% tem alguma sociedade na posse e/ou produção da empresa. (DADOS DA PESQUISA).

GRÁFICO 1 - Nível de escolaridade dos cafeicultores do Cachoeirão.

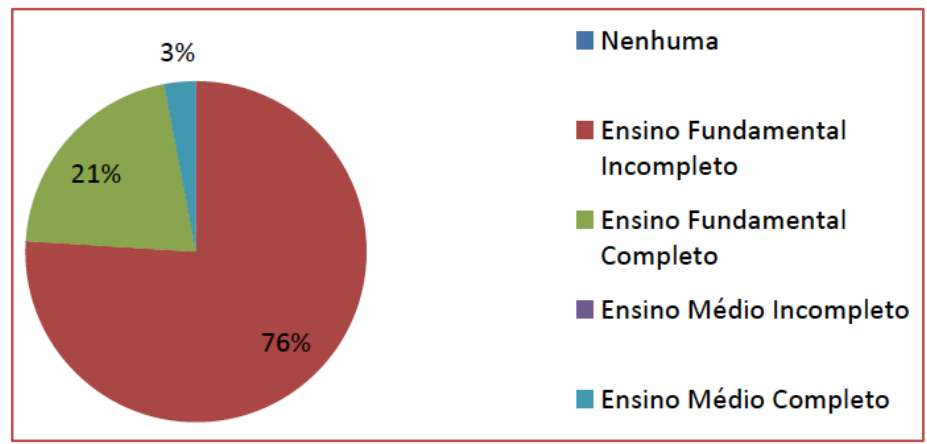

Fonte: Dados da pesquisa. 
Quanto às fontes de renda das famílias, 41,4\% dos entrevistados tem a cafeicultura como única fonte de renda da família; 34,5\% recebem aposentadoria ou pensão; 20,7\% têm membros da família empregados fora da propriedade; e apenas 3,4\% tem empreendimentos caracterizando negócios além da cafeicultura. Entretanto, todas as famílias que tem outras fontes de renda, veem a renda principal como sendo a da cafeicultura. (DADOS DA PESQUISA).

No que diz respeito à mão de obra demandada na propriedade, $80 \%$ dos membros das famílias entrevistadas trabalham constantemente nas lavouras, sendo que para completa execução das atividades, 10,3\% dos entrevistados contam apenas com a ajuda da família; 31\% trabalham com a família e precisam ocasionalmente de mão de obra externa, geralmente, apenas para colheita do café; $31 \%$ tem a maior parte dos serviços realizados por parceiros agrícolas, os chamados meeiros; 20,7\% tem a ajuda da família e contam com meeiros ou colaboradores fixos; e, apenas, $7 \%$ tem a maior parte das atividades realizadas por funcionários. (DADOS DA PESQUISA). Em relação a máquinas, veículos, equipamentos e benfeitorias para trabalho, beneficiamento, armazenagem do café e etc., conforme mostra o gráfico 2, $100 \%$ dos entrevistados têm terreiro para secar café; 37,9\% têm secador de café; 6,9\% têm máquina para pilar café; 48,3\% têm tulha para armazenar café; $17,2 \%$ têm galpão para instalação de máquinas, armazenagem de insumos e de café; 58,6\% têm caminhonetes para transporte; 13,8\% têm trator; e 10,3\% têm caminhão. (DADOS DA PESQUISA).

Em relação ao tamanho, dividimos as propriedades em propriedades com até 5 hectares (ha) de café, entre 6 e 15ha de café, entre 16 e 30ha de café e mais de 30ha de café, e constatou-se que 20,7\% dos entrevistados tem até 5 ha de café; $72,4 \%$ tem entre 5 e 16ha; e 6,9\% tem entre 16 e 30ha. (DADOS DA PESQUISA).

GRÁFICO 2 - Máquinas, veículos e benfeitorias.

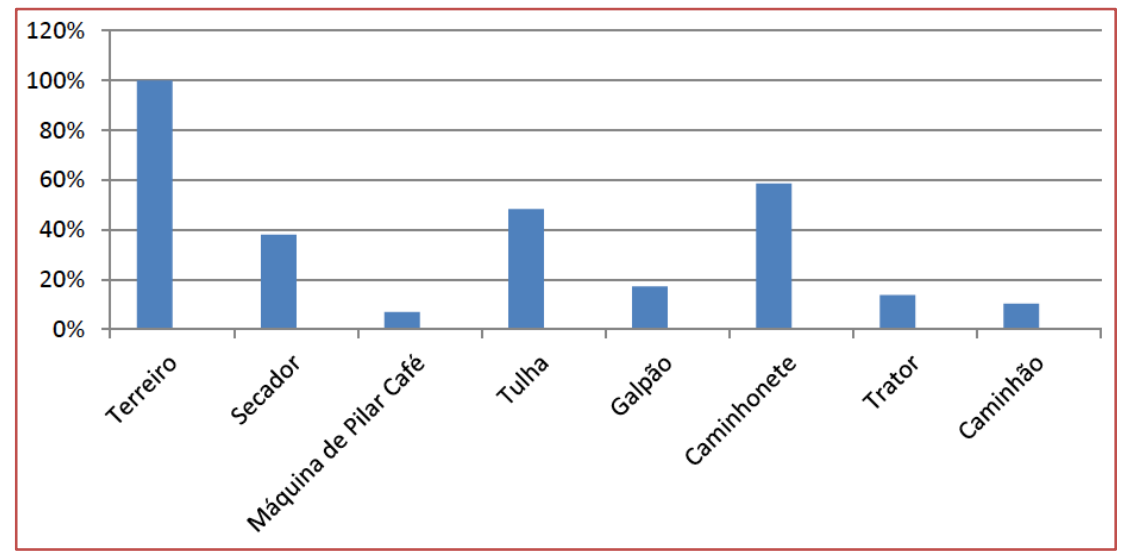

Fonte: Dados da pesquisa.

Quanto a adensamento das lavouras, tratamento padrão e frequência de podas para renovação do cafezal, constatou-se, que 41,4\% dos entrevistados têm menos de 3000 plantas/ha; 48,3\% têm entre 3001 e 4000 plantas/ha; e 10,3\% têm entre 4001 e 5000 plantas/ha. 41,4\% adotam como tratamento padrão calagem, adubação e aplicação de defensivo via solo; e 58,6\% fazem calagem, adubação, aplicam defensivo via solo e pulverizam as lavouras. Constatou-se também que 31\% dos entrevistados só fazem podas quando as lavouras ficam improdutivas; 58,6\% procuram sempre renovar uma área e plantar mais um pouco; e 10,3\% renovam sempre, mas não plantam mais café em áreas novas. (DADOS DA PESQUISA).

Constatou-se ainda que a produtividade média das lavouras, analisando a média das duas últimas safras para ponderar a bi anuidade, varia de 20 a 55 sacas de café por hectare (sc/ha), sendo que 20,6\% dos entrevistados produz média de $20 \mathrm{sc} / \mathrm{ha} ; 31 \%$ produz média de $25 \mathrm{sc} / \mathrm{ha} ; 10,3 \%$ produz média de 30 $\mathrm{sc} /$ ha; 24,1\% produz média de $40 \mathrm{sc} / \mathrm{ha} ; 3,4 \%$ produz média de $45 \mathrm{sc} / \mathrm{ha}$; e 10,3\% produz média de 55 sc/há. (DADOS DA PESQUISA).

Analisando a frequência de participação em eventos, palestra e feiras de agronegócio, para capacitação e conhecimento de novas tecnologias, viu-se que, 44,8\% dos entrevistados nunca participaram de nenhum evento; 41,4\% participam menos de uma vez por ano; e 13,8\% participam de 1 a 4 vezes por ano de algum evento para capacitação. (DADOS DA PESQUISA). 
Em relação a formas de organização e controle da propriedade, 82,8\% dos entrevistados não faz nenhum tipo de anotação ou registro; e 17,2\% fazem registros constantes. Quanto aos registros, 100\% dos que fazem anotações, discriminam os dados e despesas com a colheita do café; $100 \%$ registram as despesas com insumos; $80 \%$ registram as movimentações financeiras da empresa rural; $40 \%$ discriminam todas as despesas com mão de obra; e 40\% registram todas as receitas da propriedade. (DADOS DA PESQUISA).

Já em relação ao domínio do custo de produção e margem de lucro deixada pelo negócio, 51,7\% dos entrevistados não domina nem o custo de produção e nem a margem de lucro obtida; e 48,3\% dizem saber seu custo de produção e margem de lucro. Entre os que dizem dominar a margem de lucro, 14,3\% dos entrevistados diz ter lucro variável de 15 a 20\% da receita, dependendo do ano; 21,4\% atribui ter margem de $20 \%$ de lucro sobre a receita obtida; 42,9\% afirma ter margem de lucro de 30\%; e 10,3\% dos entrevistados diz ter margem de $40 \%$ de lucro. Entretanto, dos entrevistados que dizem dominar o custo de produção e saber qual é a margem de lucro obtida com o negócio, 64,3\% não faz nenhum tipo de anotação ou registro para controle de custos e receitas da atividade. A tabela 1 cruza as informações entre a margem de lucro declarada e os registros feitos para controle de custos e receitas. (DADOS DA PESQUISA).

TABELA 1 - Registro de informações x margem de lucro declarada

\begin{tabular}{|l|c|c|c|c|c|}
\hline \multirow{2}{*}{$\begin{array}{c}\text { Informações } \\
\text { registradas }\end{array}$} & \multicolumn{5}{|c|}{ Margem de lucro declarada } \\
\cline { 2 - 6 } & Não domina & 15 a $20 \%$ & $20 \%$ & $30 \%$ & $40 \%$ \\
\hline Receitas & - & $100 \%$ & - & - & - \\
\hline Mão de obra & - & $100 \%$ & - & - & - \\
\hline Dados da colheita & - & $100 \%$ & - & $50 \%$ & - \\
\hline Despesas com insumos & - & $100 \%$ & - & $50 \%$ & - \\
\hline Financeiro & - & $100 \%$ & - & $50 \%$ & - \\
\hline
\end{tabular}

Fonte: Dados da pesquisa.

Analisando a tabela 1, percebe-se que os entrevistados que declararam não conhecer sua margem de lucro não fazem nenhum tipo de registro ou anotação. Os que declararam ter margem de 15 a $20 \%$ de lucro registram as receitas, despesas com mão de obra, dados relativos a colheita do café, despesas com insumos, e movimentações financeiras. Os que declararam ter margem de $20 \%$ de lucro não fazem nenhum tipo de registro. Entre os que declararam ter lucro de $30 \%$ das receitas, 50\% registram dados relativos a colheita, 50\% registram as despesas com insumos, 50\% registram os movimentos financeiros e ninguém faz registros relativos a receitas e mão de obra. E os que declararam ter margem de $40 \%$ de lucro também não fazem nenhum tipo de registro ou anotação. (DADOS DA PESQUISA).

Em relação a empréstimos e financiamentos bancários, 75,8\% dos entrevistados tem algum tipo de empréstimo ou financiamento. Sendo que terreiro de cimento é o que mais foi financiado através de bancos, 34,5\% dos entrevistados o financiaram; depois vem o secador de café com 31\%; empréstimo para renovação de lavoura, com 10,3\%; galpão com 7\%; trator com 6,8\%; e máquina de pilar café com 3,4\%. 0 gráfico 3 compara o percentual de máquinas, veículos e benfeitorias declaradas com o financiado. (DADOS DA PESQUISA).

GRÁFICO 3 - Máquinas, veículos e benfeitorias (capital próprio x financiadas)

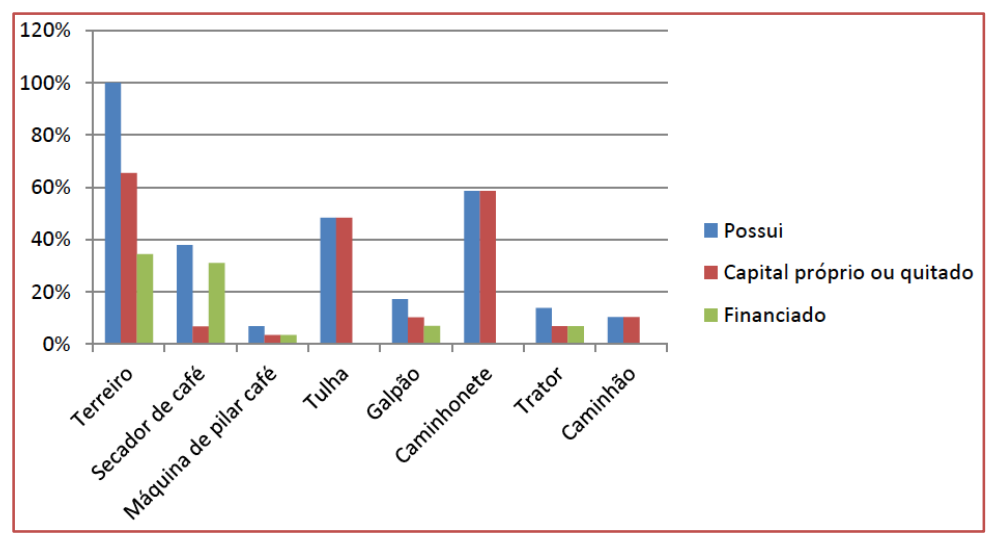

Fonte: Dados da pesquisa. 
Em relação a tomadas de decisão sobre tratamento da lavoura e investimentos, todos os entrevistados disseram tomar decisões compartilhadas com a família e/ou os demais envolvidos diretamente na empresa rural. Entretanto, 51,7\% declarou que procura aconselhamentos e influências junto a produtores maiores e/ou mais tecnificados que eles; $34,5 \%$ declarou ser influenciados pela família ou por amigos do ramo nas tomadas de decisão; $24,1 \%$ são influenciados pelos fornecedores de insumos; e 6,9\% declararam ser influenciados pelos consultores agrícolas. (DADOS DA PESQUISA).

Quanto a consultoria agrícola, 6,9\% dos entrevistados recebe consultoria regularmente, de origem particular; $48,3 \%$ dos entrevistados considera que recebe consultoria ocasional, quando tem algum caso de doença na lavoura ou na hora de decidir o tratamento do ano agrícola, essa consultoria ocasional é recebida através dos fornecedores de insumos; 3,4\% dos entrevistados declarou que já recebeu consultoria agrícola de origem privada e não recebe mais. E 41,4\% dos entrevistados alega que não recebe nenhum tipo de consultoria. Entre os entrevistados, ninguém recebe consultoria de origem pública, nem através de associações, cooperativa ou mesmo de sindicatos. (DADOS DA PESQUISA).

Tabela 01 - Nível de recebimento de Consultoria

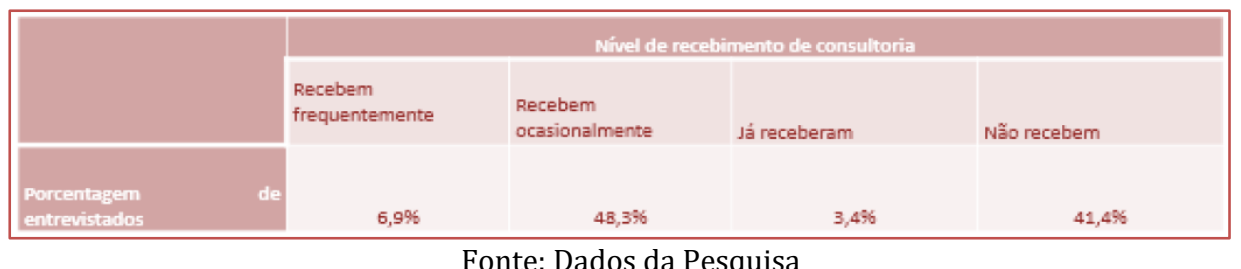

Fonte: Dados da Pesquisa

Separando os entrevistados em grupos, vemos que:

- Entre os que não recebem nenhum tipo de consultoria, 75\% alegam que o custo de se contratar uma consultoria privada é alto e $25 \%$ acham que não tem necessidade de receber consultoria, pois entendem suficientemente do negócio;

- Os que já receberam consultoria e não recebem mais, declararam que perceberam benefícios no serviço privado, principalmente em relação a orientações técnicas, mas que os resultados não justificavam o custo;

- Entre os que recebem consultoria ocasional através de fornecedores de insumos, 21,4\% declararam que julgam desnecessário contratar uma consultoria privada, parte por receber as orientações necessárias junto aos fornecedores de insumos e parte acredita que domina suficientemente o negócio; 35,7\% julga que o custo de uma consultoria privada é alto; e 42,9\% consideram importante o serviço, mas que têm outras prioridades. Entretanto, questionados quanto ao nível de confiança e aceitação das orientações dos consultores que os atendem, todos declararam confiar no consultor, sendo que 64,3\% não seguem todas as recomendações feitas por ele; e $35,7 \%$ disseram que os insumos da empresa representada por este são caros.

- Já os entrevistados que contratam consultoria privada disseram que optaram por contratar o serviço de consultoria devido ao consultor privado ser imparcial em relação a marcas de insumos, ser comprometido com o resultado do cliente e fazer visitas e atendimentos com adequada frequência, possibilitar maior confiança nas recomendações e ser um serviço relativamente barato em vista dos resultados entregados. Questionados quanto aos benefícios percebidos com o trabalho, os entrevistados declararam ter tido aumento na produção, economia no custo total de produção e principalmente que aprenderam mais sobre o negócio devido a interação com o consultor.

A tabela 2 compara o tamanho das propriedades, adensamento adotados, tratamento padrão adotados, padrão de registro de informações, participação em eventos para capacitação e os resultados obtidos entre os grupos de entrevistados que recebe consultoria regularmente, que recebem consultoria ocasional, que já receberam consultoria agrícola e os que não recebem consultoria. 
Tabela 02 - Comparação dos resultados entre os níveis de consultoria recebidos pelo produtores

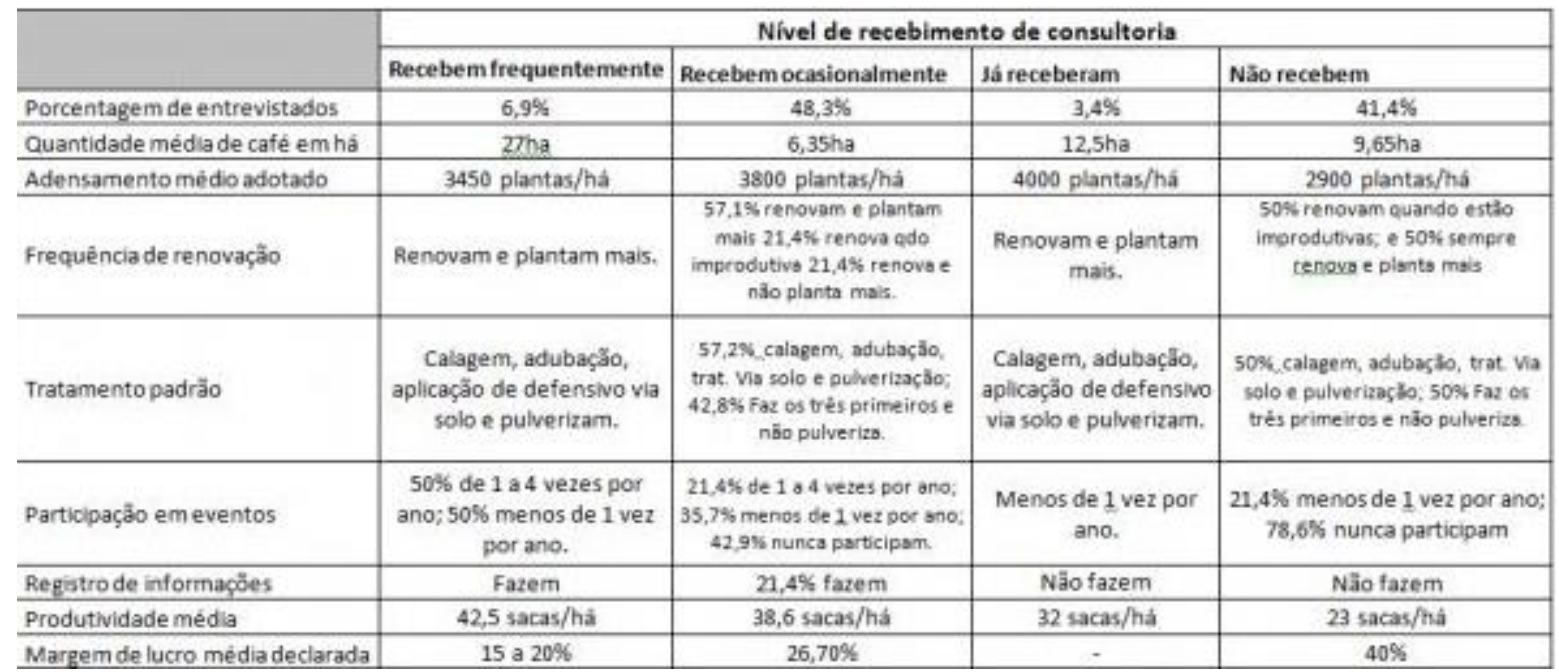

Fonte: Dados da Pesquisa

\section{CONCLUSÕES}

O objetivo deste estudo foi levantar a demanda por consultoria agrícola no Córrego Cachoeirão, em Simonésia - MG. Através da análise dos resultados é possível concluir que existe pouca demanda, porém os cafeicultores do ambiente têm necessidade do serviço. Apesar de uma parte significativa dos entrevistados (10\%) ter declarado que não precisa de nenhum tipo de consultoria, a diferença dos resultados obtidos pelo grupo que não recebe nenhum tipo de consultoria, dos que já receberam, e ainda dos que recebem ocasional ou regularmente, mostra que a presença do consultor na empresa rural eleva a produtividade e o nível de organização das atividades desenvolvidas pelos cafeicultores.

Analisando os extremos, observamos que o grupo que não recebe consultoria $(41,4 \%$ dos entrevistados) atinge produtividade média de $23 \mathrm{sc} / \mathrm{ha}$, enquanto os que recebem consultoria regular $(6,9 \%$ dos entrevistados) produzem a uma média de $42,5 \mathrm{sc} /$ ha, ou seja, quem não recebe o serviço, atinge apenas $54 \%$ da produtividade de quem o recebe regularmente. Isso confirma a visão de Alves e Souza (2014) de que a tecnologia beneficiou apenas uma pequena parte dos estabelecimentos agrícolas no país o que pode constituir-se num fator de desequilíbrio da produtividade em particular e até de desequilíbrio social, uma vez que reduz os ganhos dos cafeicultores do ambiente pesquisado.

0 resultado obtido pelo grupo que recebe consultoria ocasional, apesar de também ser menor que o do grupo que contrata o serviço, atingindo $90,8 \%$ da produtividade dele, mostra que mesmo o serviço irregular, oferecido geralmente como ferramenta para venda de insumos aos produtores, trás resultado. A produção deste grupo atingiu uma média de 38,6 sc/há, resultado significativamente maior que a do primeiro grupo, que não recebeu nenhuma consultoria, que é de $23 \mathrm{sc} / \mathrm{ha}$.

Outra visão confirmada no trabalho é a de Peixoto (2014), de que a extensão e assistência comercial estão se tornando mais comum e os serviços públicos equivalentes menos demandados, pois todos os produtores que recebem consultoria é por meio comercial, 6,9\% dos entrevistados contrata o serviço e 48,3\% o recebem por meio de fornecedores de insumos. 0 que também é um sinal preocupante, pois revela ineficácia das políticas públicas de extensão rural que não atingiram aos grupos pesquisados. Também é preocupante o fato de não haver nenhuma organização dos produtores por meio de cooperativas, associações e nem mesmo sindicato.

Outro fator crítico observado no estudo é o nível de organização e controle gerencial dos entrevistados, pois $82,7 \%$ deles não faz nenhum tipo de escrituração ou registro de informações, sendo que $51,7 \%$ declararam que não dominam o custo de produção e nem a margem de lucro obtida com o negócio; 31\% diz saber o custo de produção e declararam suas margens de lucro sem nenhum gerenciamento de receitas e custos. E as maiores margens de lucro declaradas estão entre os produtores que não fazem gerenciamento e tem a menor produtividade. Entende- se que parte deste equívoco quanto ao lucro obtido, se dá pela não contabilização da mão de obra da família, sendo considerado como despesa, por esse grupo, apenas o que é gasto com compra de insumos e mão de obra externa. 
Essa deficiência gerencial percebida e também a dificuldade significativa em aceitar o serviço de consultoria agrícola, porque entre os que não recebem o serviço, 75\% alegam que não contratam por causa do custo e os que pagam o serviço dizem que o custo é baixo em vista dos resultados, e estes têm a produção significativamente maior. Enfim, essas duas carências, provavelmente estão ligadas ao baixo nível de formação dos responsáveis pelas empresas rurais (76\% não concluiu o ensino fundamental) e talvez exista também uma resistência natural em aceitar informações e influências vindas de fora, devido a tradição exposta por (Peixoto, 2014, p.894) de transmitir informações entre produtores e familiares, uma vez que todos os entrevistados declararam partilhar as tomadas de decisão e que buscam influências junto a amigos, familiares e cafeicultores mais qualificados, podendo haver até certo preconceito, com as influências externas, pois apesar das limitações, esses produtores vêm se mantendo no ramo e contribuindo com a economia de uma forma geral.

Em relação a limitações da pesquisa, a mesma foi realizada em uma comunidade pequena, sem informações oficiais sobre o número real de empreendimentos rurais existentes, o que dificulta a determinação ideal de uma amostra a ser estudada. Por isso 30\% das casas habitadas foi um valor escolhido de forma não probabilística e por conveniência ou acessibilidade, dividindo-se o Córrego do Cachoeirão em microrregiões o que de alguma forma representa o universo analisado, pois o desenvolvimento da atividade guarda certa semelhança nas diversas propriedades rurais da região. Entretanto, pessoas que tem propriedade no referido córrego e moram em outras regiões não tiveram a oportunidade de participar da pesquisa devido às dificuldades próprias de acessibilidade.

Sugere-se que novos estudos sejam feitos na área, ampliando a região estudada, a fim de comprovar melhor a demanda e necessidade de consultoria na cafeicultura, uma vez que o trabalho revelou um desafio às empresas e profissionais autônomos que visam vender os serviços de consultoria agrícola, pois os cafeicultores que pagam pelo serviço são ligeiramente maiores do que os demais, demonstrando que quem quiser entrar nesse mercado terá que ajustar sua forma de trabalho para conseguir ser acessível aos produtores menores e vencer a resistência natural que eles tem em aceitar o serviço.

E por fim sugiro novos estudos em uma região maior para verificar melhor a ineficácia dos serviços públicos de ATER (Assistência Técnica e Extensão Rural); entender o motivo de existir diversas linhas de financiamentos subsidiadas pelos governos e não existir serviços de

assistência técnica e administrativa aos cafeicultores na mesma proporção; e verificar também a dificuldade de organização dos cafeicultores em associações e cooperativas. Uma vez que a organização entre produtores pode ser a melhor forma de proporcionar o acesso a um serviço de consultoria privado, voltado a atender as necessidades daqueles que não tem como contratar sozinhos os serviços de consultoria agrícola, que contribuem com cada empreendimento e também com a economia e sociedade em geral.

\section{REFERÊNCIAS}

[1] ALIXANDRE, F. T. Renovação das lavouras cafeeiras do Espírito Santo visando a sustentabilidade da atividade. In: Tomaz, M. A. et al. Seminário para a Sustentabilidade da Cafeicultura. Alegre: CCA-UFES, 2008. p. 57-66.

[2] ALVES, E.; SOUZA, G. da S. Desafios da Agencia de Extensão Rural. In: Buainain, A. M.; Alves, E.; Silveira, J. M. da; Navarro, Z. 0 mundo rural no Brasil do século 21 : a formação de um novo padrão agrário e agrícola. Brasília: Embrapa, 2014. p. 891-924. Disponível em:

[3] <http://www.embrapa.br/busca-de-publicacoes/-/ publicacao/994073/o-mundo-rural-no- brasil-doseculo-21-a-formacao-de-um-novo- padrao-agrario-e-agricola>. Acesso em: 22 Abr. 2015.

[4] ARRUDA, L. Apostila de administração rural e economia rural. 2013. Disponível em:

[5] <http://www.ifcursos.com.br/Sistemas/ admin/ arquivos/ 14-29-36-apostiladeeconomiarural.pdf>. Acesso em: 22 Abr. 2016

[6] BARBOSA, L. M. de O.; BRANDÃO, R. K. da S.; SOUZA, F. R. Os impactos econômicos da cafeicultura no desenvolvimento do comércio no município de lajinha/MG. X Simpósio de Excelência em Gestão e Tecnologia. Gestão e tecnologia para a competitividade. 23. 24.

[7] 25 de Outubro de 2013. Disponível em: <http:// www.aedb.br/segt/arquivos/artigos13/29918237.pdf>. Acesso em: 17 de Nov. 2015.

[8] BELFORT, J. Consultoria empresarial: A função do consultor nas empresas. Presença revista de educação, cultura e meio ambiente. Maio. № 28, vol. VIII, 2004. Disponível em: <http://tupi.fisica.ufmg.br/ michel/ docs/ Artigos_e_textos/Gestao/ consultoria_empresarial.pdf>. Acesso em: 6 out. 2016. 
[9] BRASIL. IBGE. Censo demográfico de Simonésia, 2010. Disponível em: http://www.cidades.ibge.gov.br Acesso em 20 de Agos. 2017.

[10] BRASIL. IBGE. Produção Agrícola Municipal - Lavoura Permanente, 2012. Disponível em: http://www.cidades.ibge.gov.br Acesso em 20 Agos. 2017.

[11] CHIAVENATO, Idalberto. Teoria Geral da Administração. - 6. Edição. Rio de Janeiro: Campus, 2001.

[12] ESTADO DE MINAS GERAIS, BRASIL. Secretaria de Estado de Agricultura, Pecuária e Abastecimento. Subsecretaria do Agronegócio. Café, 2017. Disponível em: http://www.agricultura.mg.gov.br/images/ Arq_Relatorios/ Agricultura/ 2017/Jan/perfil_cafe_jan_2017.pdf Acesso em 25 out. 2017.

[13] FARIA, D. C.; MONTOVANI, E.; MARQUES, S. M. A contabilidade rural no desenvolvimento do agronegócio. Iniciação Científica. Varginha - FACECA, v.1, n.8, p. 9- 24, jan. / dez. 2010. Disponível em: <http:www.faceca.br/ revista/ índex.php/ revista-01/ article/ download/ 113/pdf-13>. Acesso em: 17 nov. 2015.

[14] GIL, A. C. Métodos e técnicas de pesquisa social. São Paulo: Atlas, 2008. HERSZKOWICZ, N. Ameaças e Oportunidades para os cafés do Brasil. In: Tomaz, M. A. et al. Seminário para a Sustentabilidade da Cafeicultura. Alegre: CCA-UFES, 2008. p. 267- 288.

[15] LOURENZANI, W. L.; FILHO, H. M. de S.; Bànkuti, F. I. Gestão Da Empresa Rural - Uma Abordagem Sistêmica., 2012. Disponível em: http://www.gepai.dep.ufscar.br. Acesso em 01 de Out. 2017.

[16] MARION, J. C. Contabilidade rural: Contabilidade agrícola, contabilidade da pecuária, imposto de renda pessoa jurídica. 7.ed. São Paulo: Atlas, 2002.

[17] MATIELLO, J.B.; Garcia, A. W. R; Almeida, S. R. Adubação racional na lavoura cafeeira. Varginha: Gráfica Editora Bom Pastor, 2008.

[18] MAXIMIANO, Antônio César A. Teoria Geral da Administração. - 4. Edição. São Paulo: Atlas S.A., 2004.

[19] PEIXOTO, M. Mudanças e desafios da extensão rural no Brasil e no mundo. In: Buainain, A. M.; Alves, E.; Silveira, J. M. da; Navarro, Z. 0 mundo rural no Brasil do século 21 : a formação de um novo padrão agrário e agrícola. Brasília: Embrapa, 2014. p. 891-924. Disponível em: <http://www.embrapa.br/busca-de-publicacoes/-/ publicacao/994073/o- mundo-rural-no-brasil-do-seculo-21-a-formacao-de-um-novo- padrao-agrario-e-agricola>. Acesso em: 22 Abr. 2017.

[20] ZAMBOLIM, L.; ZAMBOLIM, E. M.; JUNIOR, W. C. de J. Manejo integrado das doenças do cafeeiro. In: Tomaz, M. A. et al. Seminário para a Sustentabilidade da Cafeicultura. Alegre: CCA-UFES, 2008. p. 167-190. 


\section{Capítulo 18}

As ferramentas de gestão da qualidade nas agroindústrias de arroz, na região da campanha do RS: Um estudo multicaso

Thaís Arrué Melo Gonçalves

Tatielle Belem Langbecker

Fernando Zocche

Janaina Wohlenberg

Resumo: 0 objetivo principal deste estudo é identificar e analisar o estado atual e as perspectivas da utilização de ferramentas de gestão da qualidade nas agroindústrias de arroz da região da campanha do RS. Por tratar-se de estudo exploratório, foi adotado o método de pesquisa qualitativa de multicasos, envolvendo um total de quatro empresas. O cultivo de arroz está presente no Rio Grande do Sul de forma bastante expressiva, representando $64,4 \%$ da produção do Brasil. As agroindústrias do setor orizícola são responsáveis pelo armazenamento, beneficiamento e distribuição do produto final. As empresas têm adotado ferramentas de gestão da qualidade para aprimorar a forma de beneficiamento e assim obter um maior controle dos pontos com maior incidência de risco em relação à qualidade, no arroz os maior riscos são físicos, porém sem a exclusão dos químicos e biológicos. 0 presente trabalho aborda ferramentas de gestão da qualidade, como Boas Práticas de Fabricação - BPF, Procedimento Operacional Padrão POP, Análise dos Perigos e Pontos Críticos de Controle, ISO 9001, entre outras.

Palavras-chave: Agroindústrias de arroz. Cadeia de suprimentos. Ferramentas de gestão de qualidade. 


\section{INTRODUÇÃO}

A cadeia produtiva do arroz tem grande representação no agronegócio nacional. 0 cultivo de arroz está bastante presente no Rio Grande do Sul, sendo o Estado que é o maior produtor do Brasil com $64,4 \%$ da produção total, com projeção de aumento de $1 \%$ ao ano, representando uma parcela da renda de um percentual de produtores rurais, principalmente por ser um produto consumido diariamente por grande parte da população.

Miguel (2005, p.90) conceitua a gestão da qualidade como um "conjunto de atividades coordenadas para dirigir e controlar uma organização com relação à qualidade englobando o planejamento, o controle, a garantia e a melhoria da qualidade". 0 conceito de qualidade de alimentos, na visão do consumidor, nada mais é do que a satisfação de características como sabor, aroma, aparência, embalagem, preço e disponibilidade (WURLITZER, 2007 apud BERTHIER, 2007).

"Um arroz de qualidade destaca-se por seu comportamento diferenciado no mercado, mostrando maior elasticidade de consumo do que a maioria do produto disponível no mercado" (CASTRO et al., 1999, p.28). Para obter a qualidade de arroz, há uma dependência de todos os elos da cadeia produtiva da cultura.

Para tratar de qualidade do arroz alguns fatores se destacam pela importância, como características da variedade plantada, condições do desenvolvimento da cultura, condições edafoclimáticas, método e sistema de secagem, armazenagem e conservação e o processo e operações de beneficiamento industrial dos grãos (MACAGNAN et al., 2008).

As ferramentas de gestão da qualidade vêm sendo criadas e implantadas para garantir alimentos seguros, proporcionando diminuição de custos, redução de perdas e otimização da produção (BERTHIER, 2007). Podem-se produzir alimentos seguros e com garantia de qualidade através de procedimentos padronizados, desta forma diminui o risco de transmitir doenças através do alimento (MACHADO, 2006).

O objetivo deste estudo é identificar e analisar o estado atual e as perspectivas da utilização de ferramentas de gestão da qualidade nas agroindústrias de arroz da região da campanha do RS, com o propósito de se são estratégias competitivas ou exigências de mercado. Para tanto, foram entrevistadas 4 empresas.

\section{CADEIA DE SUPRIMENTO}

Uma cadeia de suprimentos ("supply chain") constitui-se em um conjunto de relações verticais de compra e venda de ativos, cujos elos, devidamente conectados, produzem pares distintos, mas complementares, de um produto ou serviço, que visa a suprir as necessidades de um consumidor final (FURLANETTO, 2002: p.35).

A SCM (gestão da cadeia de suprimentos) trata do processo total do negócio e representa, excelente (e nova) maneira de controlar o negócio e os relacionamentos com outros membros da cadeia de suprimentos (Lisboa et al., 2009: p. 6).

Segundo Padovani (2007) a gestão da cadeia de suprimentos é importante para o sucesso de uma organização, sendo que qualquer agente da cadeia pode fazer sua gestão, analisando o ambiente externo (governaça) e o interno (estratégias da organização), bem como entendendo a complexidade da cadeia, analisando cada elo e seus princípios, e o grau de cooperação entre os agentes envolvidos.

De acordo com Ketchen e Hult (2007), a rivalidade está sendo crescentemente discutida no nível de análise de cadeia de suprimentos. Atualmente as organizações, além da competição "empresa versus empresa", estão competindo "cadeia de suprimentos versus cadeia de suprimentos". Neste contexto, a forma de criação de vantagem competitiva e desempenho superior emergem na cadeia de suprimentos de valor ideal. Segundo Padovani (2007) as estratégias competitivas são muito importantes dentro da gestão da cadeia de suprimentos, por poderem definir o retorno do investimento, as vendas e lucratividade dos elos que compõem a cadeia.

\section{QUALIDADE}

Para Mendonça et al. (2004) a qualidade foca na satisfação que um produto ou serviço proporciona aos seus clientes, acionistas, fornecedores e a sociedade como um todo, e quando ocorre defeito ou erros pode ser feito "recall", buscando contentar o cliente. Por outro lado, descreve que na produção de alimentos, o problema transcende ao "recall", pois será consumido pela população. Se a fábrica distribui um alimento 
com erros, este erro será a contaminação por agentes químicos, físicos ou biológicos, que pode causar intoxicação ou até mesmo a morte, antes que se faça o recolhimento do produto no mercado.

A qualidade também pode ser interpretada como a falta de condições que levem satisfação e segurança ao consumidor. Com relação à segurança, especificamente segurança de alimentos, pode-se afirmar que o alimento não é seguro quando há perigos (físicos, químicos ou biológicos) ao consumidor.

Mesmo não havendo um programa que formalize a análise dos perigos e riscos na cadeia produtiva de arroz, sabe-se que o arroz e subprodutos, podem acarretar danos à saúde do consumidor, através de agentes químicos, físicos e biológicos, conforme descrito a seguir por Machado (2006) e Araújo (2010):

- Os perigos biológicos são os responsáveis por grande número de casos e epidemias de doenças transmitidas por alimentos, sendo bactérias os maiores agentes causadores de doenças transmitidas por alimentos.

- Como perigos químicos temos os resíduos de agrotóxicos, nitratos e micotoxinas, eles podem chegar aos alimentos por descuido na produção e distribuição, seus efeitos podem ser em longo prazo.

- Perigos físicos podem contaminar o alimento através de material estranho ou/e impurezas podem ter diversas origens, como matéria-prima, etapas de manipulação ou processo de equipamentos. Os perigos físicos não causam doenças, mas injúria, como quebra de um dente, corte na boca, etc.

Com relação ao "risco", pode-se definir como probabilidade da ocorrência de um perigo (alta probabilidade da ocorrência de um perigo físico, químico ou biológico).

\subsection{GESTÃO DE QUALIDADE E FERRAMENTAS DE GESTÃO DA QUALIDADE}

Segundo Paladini (2009), a gestão da qualidade tem assumido atualmente um foco mais estratégico. Existindo uma ligação entre a gestão estratégica da qualidade com a busca de um aumento do desempenho empresarial, satisfazendo às necessidades dos consumidores.

As ferramentas de gestão da qualidade vêm sendo criadas e implantadas para garantir alimentos seguros, proporcionando diminuição de custos, redução de perdas e otimização da produção (BERTHIER, 2007). Podem-se produzir alimentos seguros e com garantia de qualidade através de procedimentos padronizados, desta forma diminui o risco de transmitir doenças através do alimento (MACHADO, 2006).

Programas como Boas Práticas de Fabricação (BPF) e Análise de Perigos e Pontos Críticos de Controle (APPCC) são ferramentas recomendadas pela Agência Nacional de Vigilância Sanitária - ANVISA e pelo Ministério da Agricultura, Pecuária e Abastecimento (MAPA), que são órgãos de fiscalização e podem ser implantadas em todas as cadeias alimentares, porém sua implantação não é feita de forma massiva nas agroindústrias, mesmo sendo previsto na legislação vigente.

Nas Portarias 326/97 do Ministério da Saúde (BRASIL, 1997a) e a Portaria 368/97 do Ministério da Agricultura (BRASIL,1997b) está determinada a obrigatoriedade da utilização das BPF nos estabelecimentos produtores e industrializadores de alimentos. Porém, as empresas que adotam os programas BPF e APPCC, não os implantam em sua totalidade, por falta de pessoal tecnicamente preparado, falta de adaptações na produção, custo de implantação e limitações da cadeia produtiva (MACHADO, 2006; BERTHIER, 2007).

Outra ferramenta é a Rastreabilidade que, conforme Machado (2000, p. 101) apud Pasche; Ferreira (2009) é resultado da recuperação de registros que respeitam processos de produção sistemáticos e, portanto, só se efetiva quando estiver embutida nas estruturas e nos mecanismos permanentes de controle de transações sequencialmente comprometidas com preceitos de segurança e qualidade dos alimentos.

As empresas têm como objetivo produzir com qualidade, por ser uma exigência para sua pré existência, além de ser uma estratégia de mercado (GOBIS; CAMPANATTI, 2012).

Independente da ferramenta adotada pela empresa, ela deve propiciar um efetivo controle de qualidade em todos os elos da cadeia, desde a produção até o consumo do alimento, assim como os processos de beneficiamento que se fizerem necessários. Seu objetivo é aumentar a segurança e qualidade do alimento, bem como aumentar a exportação, preparando-se para atender as exigências dos países importadores, agregando valor ao produto e aumentando a competitividade nas empresas (ARAÚJO, 2010). 


\subsubsection{BOAS PRÁTICAS DE FABRICAÇÃO}

No Brasil, as Boas Práticas de Fabricação - BPF são legalmente regidas pelas Portarias 1428/93(BRASIL, 1993) e 326/97 (BRASIL, 1997a). São pré- requisitos indispensáveis para implantação de programas de qualidade em qualquer empresa, por ser um conjunto de regras e princípios para manipulação correta de alimento, desde a matéria prima até produto final (PASCHE E FERREIRA, 2009; MACAGNAN et al. , 2008).

\subsubsection{PROCEDIMENTOS OPERACIONAIS PADRONIZADOS (POP'S)}

A RDC (Resolução da Diretoria Colegiada) no 275, de 21 de outubro de 2002 (BRASIL, 2002) dispõe sobre o Regulamento Técnico de Procedimentos Operacionais Padronizados aplicados aos Estabelecimentos Produtores/Industrializadores de Alimentos e a Lista de Verificação das Boas Práticas de Fabricação em Estabelecimentos Produtores/Industrializadores de Alimentos, emitido pela ANVISA - Agência Nacional de Vigilância Sanitária.

Objetivo da resolução é estabelecer Procedimentos Operacionais Padronizados (POP) que contribuam para a garantia das condições higiênicas sanitárias necessárias ao processamento/industrialização de alimentos, complementando as Boas Práticas de Fabricação, como aplicação nas atividades de produção/industrialização, fracionamento, armazenamento e transporte de alimentos industrializados.

\subsubsection{SISTEMA DE ANÁLISE DE PERIGOS E PONTOS CRÍTICOS DE CONTROLE - APPCC}

O Sistema de Análise de Perigos e Pontos Críticos de Controle teve origem na Indústria Química, na GrãBretanha, na década de 50 , sendo utilizado em projetos de plantas de energia nuclear. E no início da década 60, a National Aeronautics and Space Administration (NASA), com início dos voos tripulados, considerou que os alimentos seriam o principal veículo de entrada de doenças para os astronautas, por deixar incerteza, considerando que não eram suficientes para garantir a segurança dos alimentos, apenas as Boas Práticas e as análises. Para garantir esta segurança, a NASA junto com a Pillsbury Co., desenvolveram o sistema "Hazard Analysis and Critical Control Point" (HACCP), traduzido, no Brasil, como APPCC - Sistema de Análise de Perigos e Pontos Críticos de Controle (PASCHE; FERREIRA, 2009).

"O APPCC é um sistema que identifica, avalia e controla perigos que são significativos para a segurança de alimentos" (CODEX, 1997, apud Lopes, 2007, p. 6). Segundo Macagnan et al. (2008) o APPCC é um sistema de prevenção, buscando produzir alimentos inócuos, é produzir e manejar os alimentos desde o campo até o consumo baseado em princípios científicos e técnicos. Seus princípios podem ser aplicados a todas as fases da produção de alimentos, desde agricultura ou pecuária, industrialização e manipulação dos alimentos, distribuição e manejo, e a utilização do alimento pelo consumidor.

\subsubsection{RASTREABILIDADE}

A União Europeia, na normativa CEE 178/2002 art. 18, define que a rastreabilidade deve ser garantida em todos os passos da produção, transformação e distribuição de produtos alimentícios. Assim como para exportar produtos agroalimentares para os Estados Unidos, de acordo com a Lei de Bioterrorismo (2004) é exigido o sistema de rastreabilidade (MACHADO, 2006, p. 21).

Segundo Araújo (2010) atualmente a rastreabilidade tem sido pré-requisito para sistemas de segurança de alimentos, porém não funciona para prevenir a contaminação ou foco de doenças, para isso, deve usar outras ferramentas de controle de qualidade como BPF e APPCC.

\subsubsection{NBR ISO $9001 \mathrm{E}$ ISO 22000}

A norma ISO 9001 visa a garantia da qualidade e padronização dos serviços, através do estabelecimento de requisitos mínimos que devem ser atendidos pelas empresas. A implantação da norma NBR ISO 9001:2008 por muitas empresas tem sido uma iniciativa adotada atualmente, tendo o objetivo de melhorar a empresa através de um processo de desenvolvimento. A utilização da norma imprime às empresas um nível de progresso e confiabilidade (MARIN, 2012; SIMIOLI, 2010).

A ISO 22000 especifica requisitos para um "Sistema de Gestão de Segurança Alimentar", onde as empresas dos elos da cadeia alimentar obedecem a fim de garantir a qualidade dos alimentos e sua integridade. De 
acordo com a ABNT, quatro elementos - chave contemplada nos requisitos da norma envolve: a comunicação interativa, a gestão do sistema, os programas de pré-requisitos e os princípios APPCC (ARAÚJO, 2010; GOBIS; CAMPANATTI, 2012).

\subsubsection{QUALIDADE TOTAL}

O conceito de gestão pela Qualidade Total também é de difícil consenso assim como o de qualidade, embora tenha mais fácil absorção, por incluir em sua abrangência a definição e métodos de planejamento estratégico, organização e métodos, marketing, liderança, engenharia de produção, desenvolvimento do ser humano, dentre outros. Um produto ou serviço de qualidade é associado à satisfação do consumidor, podendo ser acompanhado interna e externamente, com ações preventivas, e antecipando e superando as expectativas dos consumidores (MENDONÇA et al., 2004).

Para a implantação da Qualidade Total um requisito fundamental é o estabelecimento de uma política de qualidade, com a adequação da empresa aos meios de colocá-la em prática. Seu conteúdo deve ser divulgado a todos os funcionários, e deve envolver a todos os colaboradores da empresa com comprometimento (MENDONÇA et al., 2004; GOBIS; CAMPANATTI, 2012).

\section{METODOLOGIA}

Optou-se pelo enfoque qualitativo para realização de uma pesquisa exploratória, pois serão investigadas agroindústrias de arroz da região da Campanha localizadas no estado do Rio Grande do Sul. 0 método utilizado foi o estudo de multicasos e a técnica empregada foi à entrevista semiestruturada com gestores de agroindústrias de beneficiamento do Rio Grande do Sul. A escolha das agroindústrias dependeu do aceite das mesmas.

A coleta de dados sobre as ferramentas de gestão da qualidade foi realizada por meio de revisão bibliográfica a partir de materiais tais como livros, artigos científicos, publicações periódicas, documentos eletrônicos e legislação brasileira. A segunda etapa constituiu a obtenção de dados primários, sendo que o instrumento utilizado constituiu-se em um roteiro de entrevista contendo questões abertas e fechadas, com objetivo de identificar as ferramentas de gestão da qualidade utilizadas pela empresa, bem como suas vantagens. A obtenção dos dados foi feita diretamente em quatro agroindústrias do setor arrozeiro na região Campanha do RS, com o responsável pelo processo de beneficiamento, entre os meses de março e maio de 2014.

\section{RESULTADOS}

Este estudo reúne os resultados de pesquisa referentes à 4 (quatro) Agroindústrias de Beneficiamento de Arroz da região Campanha do RS. As agroindústrias de beneficiamento de arroz, onde a pesquisa foi realizada, são denominadas no trabalho por empresa I, II, III e IV, caracterizadas no quadro 1.

Quadro 1: Caracterização das Empresas

\begin{tabular}{|c|c|c|c|} 
& \multirow{2}{*}{ № de Unidades } & \multicolumn{2}{c|}{ Beneficiamento Anual } \\
& & Sacos $50 \mathrm{~kg}$ & Toneladas \\
\hline Empresa I & 2 & 1.886 .494 & 94.325 \\
\hline Empresa II & 1 & 1.335 .997 & 66.800 \\
\hline Empresa III & 2 & 1.586 .740 & 79.337 \\
\hline Empresa IV & 1 & 662.418 & 33.121 \\
\hline
\end{tabular}

Fonte: Elaborado pelo autor

0 primeiro questionamento realizado consistia em identificar os produtos comercializados pelas empresas em estudo. No Quadro 2 é possível observar os resultados obtidos. 
Quadro 2: Tipo de produto elaborado pelas empresas orizícolas da região de Dom Pedrito, 2014.

\begin{tabular}{|c|c|c|c|c|}
\hline PRODUTO & $\begin{array}{c}\text { EMPRESA } \\
\text { I }\end{array}$ & $\begin{array}{c}\text { EMPRESA } \\
\text { II }\end{array}$ & $\begin{array}{c}\text { EMPRESA } \\
\text { IIII }\end{array}$ & $\begin{array}{c}\text { EMPRESA } \\
\text { IV }\end{array}$ \\
\hline ARROZ TIPO I & $\mathrm{X}$ & $\mathrm{X}$ & $\mathrm{X}$ & $\mathrm{X}$ \\
\hline ARROZ TIPO II & $\mathrm{X}$ & $\mathrm{X}$ & $\mathrm{X}$ & $\mathrm{X}$ \\
\hline ARROZ TIPO III & & $\mathrm{X}$ & $\mathrm{X}$ & $\mathrm{X}$ \\
\hline ARRO TIPO IV & & & & $\mathrm{X}$ \\
\hline ARROZ PARBOILIZADO & & & $\mathrm{X}$ & \\
\hline QUIRELA DE ARROZ & & & $\mathrm{X}$ & $\mathrm{X}$ \\
\hline FARELO DE ARROZ & & & $\mathrm{X}$ & $\mathrm{X}$ \\
\hline ARROZ ARBÓREO & & & $\mathrm{X}$ & \\
\hline ARROZ TIPO ABAIXO DO PADRÃO & & & $\mathrm{X}$ & \\
\hline ARROZ TIPO EXPORTADOR & & & & $X$ \\
\hline
\end{tabular}

Fonte: Elaborado pelo autor.

A determinação do produto a ser elaborado e comercializado por cada uma das empresas está ligado à estrutura física de beneficiamento existente, que pode ser específica para um determinado tipo de arroz, e também para a localidade que o produto será comercializado. A empresa I declara que o produto comercializado em São Paulo tem menor teor de grãos quebrados (arroz tipo 1)1, devido à exigência dos consumidores. Este comportamento revela uma adequação da empresa à demanda dos consumidores, o que determina a elaboração de diferentes produtos em função da aceitação (ou não) da apresentação e constituição do produto.

As empresas III e IV foram as que apresentaram a maior variedade de produtos elaborados. Esta industrialização se dá em função de demanda do consumidor, visto que, a empresa III, exporta arroz parboilizado em embalagem de $50 \mathrm{~kg}$, o qual é novamente embalado, em frações menores, no país de destino. A empresa IV elabora um produto denominado "para exportação" que tem um maior teor de grãos quebrado sem relação à quirela2, o que significa, em princípio, uma demanda de produto pelo país importador, e consequentemente de qualidade, diferente da exigida no Brasil, sendo, contudo, uma escolha de mercado consumidor.

\subsection{CONCEITO DE QUALIDADE, ALIMENTO SEGURO E SEGURANCA ALIMENTAR}

Numa intervenção introdutória buscou-se questionar as empresas quanto à percepção que possuem em relação aos conceitos de qualidade, segurança de alimentos e alimento seguro. Para obter essa visão da empresa foi realizado um questionamento aberto para que houvesse a descrição, e o critério de compilação dos dados foi por incidência das palavras e respectivos conceitos nas respostas das pessoas entrevistadas. Na visão das quatro empresas estudadas o conceito de qualidade é "fazer bem feito" e/ou" de acordo com a norma" e/ou"mantendo um padrão e visando atender as exigências do consumidor". A empresa III conceitua qualidade como "Garantir o fornecimento do produto com segurança ao consumidor".

Já em relação a alimento seguro e segurança alimentar, percebeu-se que embora não houvesse uma distinção clara entre alimento seguro e segurança alimentar, 100\% das empresas relacionam o alimento seguro à qualidade, em função da obrigatoriedade de produzir livre de perigos ao consumidor. Semelhante ao encontrado pelo conceito exposto por Machado (2007) que descreve que outras empresas do ramo orizícola no Rio Grande do Sul relacionaram qualidade à isenção de perigos e riscos, e expressaram que segurança alimentar é sinônimo de alimento seguro.

\footnotetext{
${ }^{1}$ Arroz Tipo 1, segundo legislação brasileira (BRASIL, 1988), é aquele que admite 10\% de grãos quebrados quirela.

${ }^{2}$ Define-se quirela de arroz como sendo o fragmento de grão de arroz que vazar em peneiro de furos circulares de milímetros de diâmetro (BRASIL, 1998).
} 


\subsection{PROGRAMAS DE QUALIDADE APLICADOS PELAS EMPRESAS}

Com base no estudo referente aos programas de gestão de qualidade utilizados pelas empresas, os mesmos podem ser verificados no Quadro 3.

Quadro 3: Programas de gestão de qualidade aplicados pelas Agroindústrias de Beneficiamento de arroz na região de Dom Pedrito, 2014.

\begin{tabular}{|l|c|c|c|c|}
\hline \multicolumn{2}{|c|}{ Empresa I } & Empresa II & Empresa III & Empresa IX \\
\hline Boas Práticas de Fabricação & $\mathrm{X}$ & $\mathrm{X}$ & $\mathrm{X}$ \\
\hline Qualidade Total & & & $\mathrm{X}$ & $\mathrm{X}$ \\
\hline APPCC & & & $\mathrm{X}$ & $\mathrm{X}$ \\
\hline Produção Integrada & & & & \\
\hline Programa 5S & $\mathrm{X}$ & $\mathrm{X}$ & $\mathrm{X}$ & \\
\hline NBR ISO 9000 & $\mathrm{X}$ & $\mathrm{X}$ & $\mathrm{X}$ \\
\hline NBR ISO 22000 & & $\mathrm{X}$ & $\mathrm{X}$ \\
\hline POP & $\mathrm{X}$ & $\mathrm{X}$ & $\mathrm{X}$ & $\mathrm{X}$ \\
\hline Rastreabilidade & $\mathrm{X}$ & $\mathrm{X}$ & \\
\hline
\end{tabular}

Fonte: Elaborado pelo autor.

Em relação aos programas aplicados pelas quatro empresas estudadas, os programas BPF- Boas Práticas de Fabricação, POP - Procedimentos Operacional Padrão (considerada pré-requisito para implantação de APPCC) e Rastreabilidade são utilizados por todas as empresas. Segundo Machado (2007) empresas do ramo orizícola entendem e aceitam que as agroindústrias consideram que o programa BPF deve ser o primeiro programa a ser implantado, e está implantado parcialmente (80\%) nas empresas entrevistadas por este autor.

A produção integrada3 é aplicada pelas empresas III e IV, no sentido de terem um controle de seus produtores e qual a variação de cultura foi plantada e insumos utilizados.

O programa 5S só não é aplicado pela empresa III, embora a empresa tenha todos os princípios por ter a certificação do APPCC. Resultado semelhante a este foi descrito por Machado (2006), que diz que empresas do ramo orizícola no RS possuem o programa implantado, e apenas $20 \%$ das empresas estudadas não utilizam.

O programa APPCC é aplicado pelas empresas III, que tem a certificação através de auditoria externa. 0 programa tem sido recomendado por órgãos de fiscalização e sendo utilizado por ser preventivo, ter especificação de controle de riscos que o alimento possa oferecer, com foco na qualidade sanitária (FURTINI E ABREU, 2005).

A NBR ISO 9000 é utilizada pelas empresas I e II, sendo que a empresa I está em fase de implantação da norma, com previsão de auditoria externa nos próximos seis meses. De modo geral foi possível observar que todas as empresas analisadas utilizam os programas de Boas Práticas de Fabricação, POP e Rastreabilidade, devido serem uma exigência institucional.

Também foi observado que os programas da NBR ISO 9001 (2008), APPCC e Qualidade Total são os que apresentam menor utilização pelas empresas em estudo devido às empresas escolherem um dos programas.

\subsection{PRINCIPAIS MOTIVOS DA ADOÇÃO DOS PROGRAMAS ESCOLHIDOS}

\footnotetext{
${ }^{3}$ Produção integrada é, por definição por um sistema agrícola de produção de alimentos de alta qualidade e de outros produtos utilizando os recursos naturais e os mecanismos de regulação natural em substituição de factores de produção prejudiciais a ambiente e de modo a assegurar, a longo prazo, uma agricultura viável (AMARO, 2003, p. 9).
} 
A preocupação com o consumidor e exigência de mercado foram os principais motivos para adoção de programas de qualidade, citado por todas as empresas estudadas. No estudo realizado por Machado (2007), o consumidor também foi citado como principal motivo para as agroindústrias adotarem programas de qualidade.

Os fatores proteção judicial e oportunidade/facilidade não foram citados pelas empresas, e menor custo e o mais conhecido foram citados apenas por uma empresa. Além disso, uma das empresas citou a higiene como um motivo para implantação.

Semelhante ao mencionado por Peretti e Abreu (2005), assim como nas outras cadeias produtivas de alimento no Brasil, a implantação de sistemas de gestão da qualidade e a certificação em agroindústrias de arroz tem como motivação as exigências do mercado externo e das grandes empresas multinacionais que passaram a exigi-las de seus fornecedores.

A competitividade, otimização de recursos e exigências legais foram citadas como motivos para duas das empresas estudadas (II e III). Tais empresas estão alinhadas com o citado por Paraginski (2012), que diz que num ambiente onde existe uma ampla competitividade, as organizações precisam inovar estrategicamente, pois os novos concorrentes vão entrando no mercado.

Fonseca (2011) em sua pesquisa realizada em um terminal de granéis agro-alimentares descreveu como motivação de implementação dos programas ISO 9001(2008) e ISO 22000(2006), estar inserido em um mercado que exige uma diferenciação perante as outras empresas do ramo, sendo que uma organização de seus recursos traz um crescimento na qualidade. Este raciocínio poderia ser pensado pelas agroindústrias de arroz na região deste estudo, uma vez que existem diversas empresas no ramo orizícola e, além disso, é crescente o ritmo de implantação de novas unidades beneficiadoras de grãos, especialmente de arroz e soja incrementado a competitividade do setor.

\subsection{DIFICULDADES PARA IMPLANTAR PROGRAMAS DE QUALIDADE}

O nível educacional dos colaboradores foi mencionado pelas empresas II e III como um fator de dificuldade para implantação de programas de gestão de qualidade. A mudança de costumes dos funcionários, e inserção de novos costumes como, por exemplo, ter que lavar as mãos a cada vez que entrar no ambiente de produção é extremamente difícil.

A empresa III mencionou que é alto o custo de implantação das ferramentas de gestão e existe uma baixa taxa de retorno, pois entende que o consumidor ainda não valoriza a preocupação com a aplicação de programas de qualidade, pois o mercado ainda é muito marginalizado, devido à falta de fiscalização em alguns lugares do país. Tal instrução aos colaboradores é ainda mais complexa dada a alta rotatividade de funcionários, que buscam melhores colocações no mercado de trabalho, fazendo com que cursos de reciclagem/atualização sobre boas práticas sejam uma constante nas empresas, demandando ainda mais atenção da equipe gestora dos programas de qualidade existentes.

A empresa II cita como outro fator a dificuldade de implantar o BPF, devido à dificuldade de capacitar os colaboradores com relação às práticas de higiene. Segundo a empresa, os colaboradores "tem dificuldade de modificar hábitos já intrínsecos na sua mente". Tais dificuldades são inerentes à área de produção de alimentos, que, em muitas vezes, são negligenciadas com relação às boas práticas que devem ser aplicadas pelos funcionários. Toledo et al. (2000) também relata como dificuldade de implantação da gestão da qualidade em outras agroindústrias alimentares são relacionadas ao nível de capacitação da mão-de-obra, à capacidade de investimento e ao controle do processo.

A empresa IV relatou como dificuldade, tendo em vista à diferença entre as normativas estaduais e federais. Da mesma forma a empresa I, que também relatou sobre a pouca disponibilidade de cursos para ensinar e treinar os colaboradores. 


\subsection{NÍVEL DE CONHECIMENTO DOS PROGRAMAS DE QUALIDADE}

Quando questionadas sobre o nível de conhecimento dos programas de qualidade, os programas BPF, Rastreabilidade, Normas do Ministério da Saúde, MAPA e INMETRO, são conhecidos e aplicados pelas quatro empresas estudadas.

O APPCC, apesar de ser um programa recomendado e muitas vezes exigido na comercialização com o mercado externo, é conhecido e aplicado somente pelas empresas I e III. A empresa II conhece e não aplica e a empresa IV declara que não conhece na íntegra o programa. Segundo (FURTINI; ABREU, 2005, p. 01),“A implantação do APPCC satisfaz à legislação nacional e internacional, dando segurança ao alimento e abrindo as portas para a exportação.No Brasil ainda existem algumas dificuldades para que este programa seja totalmente difundido e fiscalizado", dificuldades como a capacitação técnica e os investimentos em infra-estrutura, também evidenciadas nas agroindústrias do setor orizícola abordadas neste estudo.

A produção integrada é conhecida e aplicada pelas empresas I e III, sendo que a empresa III aplica parcialmente e a empresa II não está aplicando atualmente, mas em anos anteriores era aplicado pela mesma.

\subsection{CERTIFICAÇÃO E SELO DE QUALIDADE}

A empresa I não utiliza o selo na embalagem, pois alega que os custos para colocação são muito elevados. Já a empresa II utiliza o selo de certificação de utilização da ISO 9001 (2008).

A utilização de selo de qualidade na embalagem é utilizada apenas pela empresa III, como empresa com certificação em segurança alimentar. Porém o selo é de difícil identificação, não chamando a atenção na embalagem, e quando questionada a esse respeito, o entrevistado declarou a embalagem ser responsabilidade do departamento comercial, mas achou interessante a interpelação sobre o tamanho do selo e a falta de marketing em relação a possuir o mesmo.

A empresa IV está em implantação inicial da ISO 9001 (2008), como já mencionado acima, e pretende utilizar o selo na embalagem para agregar valor e demonstrar o quão criterioso está sendo o processamento do arroz que o consumidor está comprando.

Peretti e Araújo (2010) afirmam que foram criadas certificações específicas para produtos como café, arroz parboilizado, massas secas devido a fatores econômicos e sem considerar especificamente o impacto que os mesmos podem causar na saúde pública. E com o crescimento de selos de qualidade veiculados nos rótulos e propagandas de alimentos, é necessário analisar o tipo de garantia que está sendo oferecida ao consumidor. Tal análise é pertinente ao setor orizícola do Rio Grande do Sul que, comercializando arroz e/ou derivados, representa um percentual elevado na fatia comercial do produto no Brasil.

\subsection{VANTAGENS E BENEFÍCIOS DOS PROGRAMAS DE GESTÃO DE QUALIDADE}

Em relação às vantagens na utilização dos programas de gestão de qualidade as empresas são unânimes em mencionar a melhoria de todo o processo de produção, pois traz à empresa um melhor controle do mesmo.

A empresa I descreve como vantagem a padronização do processo e a garantia que o produto chegará ao consumidor final de acordo com as especificações e atendendo as expectativas do cliente. Para empresa II a certificação da ISO 9001 promove melhoria no controle do processo, onde a identificação e correção de um problema se tornam mais fácil, pois a empresa possui auditores internos que realizam avaliações periódicas em todos os setores, para se possível, identificar uma anomalia antes da auditoria externa.

A empresa IV identifica como vantagens poderem averiguar constantemente cada parte da produção, podendo averiguar constantemente a produção de cada máquina, o que facilita a identificação do ponto exato do problema, com maior controle e precisão, além de diminuição de custos. Semelhante a Furtini e Abreu (2005) que relacionam este fator a redução de perdas e a otimização do produto.

De acordo com a Norma da Codex para o Arroz (Codex Standard 198-1995) é recomendado que o produto esteja regulado pelos dispositivos da norma de preparo e manipulação de conformidade com a seção apropriada do Código Internacional de Prácticas Recomendado - Principios Generales de Higiene de los Alimentos (CAC/RCP 1-1969), e outros códigos de práticas recomendados pela Comissão da Codex Alimentar que sejam pertinentes ao produto. 
Os benefícios da utilização de programas de gestão de qualidade são observados no quadro 4:

Quadro 4: Benefícios dos Programas de Gestão de Qualidade identificadas em agroindústrias arrozeiras na região de Dom Pedrito, 2014.

\begin{tabular}{|c|c|c|c|c|}
\hline \multicolumn{2}{|c|}{ Empresa I } & Empresa II & Empresa III & Empresa IX \\
\hline Mercado Interno & $\mathrm{X}$ & $\mathrm{X}$ & $\mathrm{X}$ & $\mathrm{X}$ \\
\hline Mercado Externo & $\mathrm{X}$ & $\mathrm{X}$ & $\mathrm{X}$ \\
\hline $\begin{array}{c}\text { Agregação de valor a marca por parte } \\
\text { do cliente }\end{array}$ & $\mathrm{X}$ & $\mathrm{X}$ & \\
\hline Outro: & $\begin{array}{c}\text { Referencia ao } \\
\text { cliente }\end{array}$ & $\begin{array}{c}\text { Melhoria no } \\
\text { todo }\end{array}$ & \\
\hline
\end{tabular}

Fonte: Elaborado pelo autor.

Segundo Fonseca (2011), o terminal de graneis agro-alimentares, empresa especializado na descarga e armazenamento de cereais, em silos metálicos verticais e posterior distribuição de cereais por via rodo e ferroviária, encontrou como benefícios da utilização de certificação a melhoria da reputação da organização, custos reduzidos devido à elevada eficiência, melhor acesso e posicionamento no mercado, entre outros. Tais benefícios, apesar de não serem citados pelas empresas estudadas, também repercutem nestas, mesmo que de forma indireta e não claramente visíveis pelos gestores.

Observa-se que as empresas estudadas trabalham com um nicho de mercado específico que é a exportação, onde o que no Brasil seria um subproduto, há mercado em outros países, como a África, onde o produto chega com um maior valor agregado. Dentro deste contexto, Miritz (2007) afirma que na exportação de arroz a maior dificuldade é a diferença de cultura em relação ao consumo do alimento, pois o arroz longo fino produzido e consumido no Brasil é consumido em poucos países. Desta forma o Brasil tem como países alvos na exportação a África do Sul, Angola, Aruba, entre outros, com maior destaque na África do Sul, por exportar arroz quebrado, teoricamente com valor comercial inferior ao comercializado localmente.

\section{CONCLUSÃO}

Os principais programas utilizados pelas empresas estudadas são o BPF, POP (exigência institucional e considerados requisitos para implantação do programa APPCC) e Rastreabilidade. O programa APPCC é implantado na empresa III, que já está certificada. A empresa IV tem a certificação da ISO 9001, ambas têm o selo na embalagem do produto.

As principais motivações das empresas para aplicação de programa de gestão de qualidade é a satisfação do consumidor final e exigências de mercado. Em para alguns setores indústrias um padrão de qualidade trás uma vantagem competitiva importante, porém nas agroindústrias alimentares, pode ser considerado uma questão de sobrevivência, um consumidor que sofreu alguém dano ao consumir o alimento, evitará comprar o alimento daquela marca, assim um produto impróprio compromete definitivamente a imagem da marca

A busca pela qualidade que satisfaça o mercado a cada dia se tornará mais importante para as agroindústrias alimentícias, e o setor arrozeiro já está sentindo a necessidade de aprimorar-se para conquistar mercado, pois grandes empresas varejistas exigem a aplicação de um programa de gestão de qualidade, como APPCC, ISO 9001, entre outros. Além disso, o consumidor está mais exigente no momento da escolha do produto, mesmo que sua analise de qualidade esteja diretamente ligado ao percentual de grãos quebrados no produto escolhido, para atender está exigência a implantação de um programa de gestão de qualidade auxiliará no processo, além de garantir uma produção livre de perigos químicos, físicos e biológicos.

A qualidade e segurança são inseparáveis ao longo da cadeia alimentar, necessitando mais que regulamentações e inspeção governamental, precisam estarem interiorizadas em todos os agentes envolvidos na produção, vindo prevenir e melhorar continuamente o processo. Para Toledo et al (2000), “a gestão da qualidade é, além de uma vantagem competitiva, uma exigência dentro desse setor econômico". 
Percebe-se que as empresas valorizam utilização das ferramentas como forma de padronização do processo, porém não exploram como uma vantagem competitiva, de maneira estratégia, como diferencial de qualidade para satisfazer o consumidor final, pois poderiam utilizar o selo de qualidade como marketing, e poucas empresas tem o selo em suas embalagens, pois as empresas utilizam ferramentas mais relacionadas ao controle de processo e segurança alimentar como BPF (exigência institucional) e APPCC.

Desta forma as empresas podem avançar de uma gestão da qualidade voltada para inspeção e controle do processo, e evoluir para uma gestão mais sofisticada, onde possa se tornar um fator competitivo para as empresas, assim diferenciar seus produtos na dimensão de qualidade.

\section{REFERÊNCIAS}

[1] ARAÙJO, Ana Paula de. Ferramentas de Controle de Qualidade na Indústria Frigorífica de Frango. Porto Alegre: Universidade Federal do Rio Grande do Sul, 2010. 40 p.

[2] Associação Brasileira de Normas Técnicas (ABNT). NBR/ISO 22000 2006: sistemas e gestão da segurança de alimentos - requisitos para qualquer organização na cadeia produtiva de alimentos. Rio de Janeiro, 2006.

[3] BRASIL. Portaria no 1428, de 26 de novembro de 1993. Diário Oficial da União, Poder Executivo, de 02 de dezembro de 1993.

[4] BRASIL. PORTARIA № 269, DE 17 DE NOVEMBRO DE 1988. Diário Oficial da União, Poder Executivo, de 22 de novembro de 1988.

[5] BRASIL. Portaria no 326, de 30 de julho de 1997. Diário Oficial da União, Poder Executivo, de 01 de agost’ $^{\prime}$ 1997a.

[6] BRASIL. Portaria no 368, de 04 de setembro de 1997. Diário Oficial da União, Poder Executivo, de 04 de setembro de 1997b.

[7] BRASIL. Resolução RDC no275, de 21 de outubro de 2002. D.O.U. - Diário Oficial da União, Poder Executivo, de 23 de outubro de 2003. Seção 1, pág. 126.

[8] BERTHIER, Florence Marie. Ferramentas de Gestão da Segurança de Alimentos: APPCC e ISSO 22000. Brasília: Universidade de Brasília, 2007, 37p.

[9] CASTRO, Emílio da Maia de et al. Qualidade de Grãos em Arroz. Santo Antônio de Goiás: Embrapa Arroz e Feijão, 1999, p. 30.

[10] FONSECA, Teresa Maria Rocha. Implementação dos Sistemas de Segurança Alimentar ISO 22000 e HACCP. Universidade de Aveiro, 2011.113 p.

[11] FURLANETTO, E.L. Formação das Estruturas de Coordenação nas Cadeias de Suprimentos: Estudos de Caso em Cinco Empresas Gaúchas. Tese de Doutorado, Programa de Pós-Graduação em Administração, PPGA/UFRGS, 291p., 2002.

[12] GOBIS, Marcelo Aparecido; CAMPANATTI, Reynaldo. Os Benefícios da Aplicação de Ferramentas de Gestão de Qualidade Dentro das Indústrias do Setor Alimentício. Revista Hórus, volume 6, número 1 (Jan-Mar), 2012.

[13] KETCHEN, D. J.; HULT, G. T. M. Bridging organization theory and supply chain management: the case of best value supply chains. Journal of Operations Management, v. 25, p. 573-580, 2007.

[14] LISBOA, Rodrigo da Silva; BREITENBACH, Raqhel; ARBAGE, Alessandro Porporatti. Como Sobreviver E Crescer Num Mercado Competitivo: Análise das Estratégias de uma Empresa Processadora de Arroz. Porto Alegre: 47ํㅜ Congresso Sociedade Brasileira de Economia Administração e Sociologia Rural, 26 a 30 de Julho de 2009.

[15] MACAGNAN, Diego Teixeira; SCHEFER, Solange de Fatima; ROSA, Leandro Cantorskida. Identificação De Riscos Ocupacionais No Beneficiamento De Grãos: Modelo Fundamentado Na Metodologia APPCC. XXVIII Encontro Nacional de Engenharia de Produção, Rio de Janeiro, 13 a 16 de Outubro de 2008.

[16] MACHADO, Janice Garcia. Implementação de Sistemas de Produção de Alimentos Seguros em Agroindústrias Processadoras de Arroz do Rio Grande do Sul: Estudo de Caso. Pelotas: Universidade Federal de Pelotas, 2006, 127 p.

[17] MACHADO, Rosa Teresa Moreira. Sinais De Qualidade E Rastreabilidade De Alimentos:Uma Visão Sistêmica. Organizações rurais agroind., Lavras, v. 7, n. 2, p. 227-237, 2005.

[18] MIGUEL, Paulo Augusto Cauchick. Gestão da Qualidade Total e Modelos de Excelência em Desempenho Organizacional. In: CARVALHO, Marly Monteiro de; PALADINI, Edson Pacheco (Org.). Gestão da Qualidade: Teoria e Casos. Ed. Elsevier, 2 ${ }^{\mathrm{a}}$ Ed, p. $89-126$. 
[19] MIRITZ, Luciane Dittgen. Diferenciação e Diversificação na Agroindústria Arrozeira do Rio Grande do Sul. Porto Alegre, 2007. 84 p.

[20] MENDONÇA, Mauro Marcio Ferreira de; JOSÉ, Eliana Brilhante de São; COSTA, Stella Regina Reis da. Estudo de Gestão da Qualidade Aplicada na Produção de Alimentos. Florianópolis: XXIV Encontro Nacional de Engenharia de Produção, 03 a 05 de Novembro de 2004.

[21] NORMA DEL CODEX PARA EL ARRO. CODEX STAN 198-1995. Disponível em: http://pt.scribd.com/doc/91024898/Codex-Alimentarius-Para-Arroz. Acesso em: 18 jun. 2014, 14:58.

[22] PADOVANI, Cristina Blanco. O Papel da Governança na Cadeia de Suprimento Automotiva nos Fornecedores de Primeiro e Segundo Nível. 2007, 85p. Dissertação de Mestrado. Programa de Pós Graduação em Engenharia da Escola Politécnica da Universidade de São Paulo.

[23] PALADINI, E. P. Gestão estratégica da qualidade - princípios, métodos e processos. 2. ed. São Paulo: Atlas, 2009.

[24] PARAGINSKI, Ana Laura. A NATUREZA DAS INOVAÇÕES EM AGROINDÚSTRIAS DE ARROZ DO RIO GRANDE DO SUL. $\quad$ Santa $\quad$ Maria, $2012 . \quad$ Disponível http://www.ppgexr.com.br/arquivos/Dissertacao_Ana_Laura_Paraginski.pdf. Acesso em: 10 jun. 2014, 16:25.

[25] PERETTI, Ana Paula de Rezende; ARAÙJO,Wilma Maria Coelho. Abrangência do requisito segurança em certificados de qualidade da cadeia produtiva de alimentos no Brasil. Gest. Prod., São Carlos, v. 17, n. 1, p. 35-49, 2010. Disponível em: http://repositorio.unb.br/bitstream/10482/8106/1/ARTIGO_AbrangenciaRequisitoSeguranca.pdf. Acesso em: 10 jun. 2014, 16:19.

[26] TOLEDO, José Carlos de; BATALHA, Mário Otávio; AMARAL, Daniel Capaldo. Qualidade na indústria agroalimentar: situação atual e perspectivas. RAE - Revista de Administração de Empresas / EAESP / FGV, São Paulo, Brasil, 2000 


\section{Capítulo 19}

Manutenção preventiva no setor sucroalcooleiro Estudo de caso em uma usina no vale do rio Ivinhema.

\section{Willer Rodrigues da Costa}

Antonio Sérgio Eduardo

Thaís Nogueira da Silva

Resumo: A manutenção preventiva é uma ferramenta de suma importância para todas as empresas que realizam suas atividades utilizando maquinários, sejam eles de qualquer natureza, ainda nos dias atuais existem empresas que tratam a manutenção apenas como uma despesa necessária. Tal pesquisa busca aprimorar a visão da manutenção diante dos gerentes e empresários. A melhor maneira de alterar o ponto de vista dos mesmos com relação ao gasto e investimento é evidenciando o quanto ele deixou de ganhar por não investir em manutenção preditiva e preventiva. 0 trabalho se caracterizou como uma pesquisa bibliográfica e um estudo de caso contendo análise comparativa de dois equipamentos semelhantes, no qual apenas um deles passou pelos procedimentos de manutenção preventiva, evidenciando que o mesmo apresentou resultados de disponibilidade e produção muito maior em relação ao outro equipamento.

Palavras-chave: Manutenção, Estratégia, Disponibilidade. 


\section{INTRODUÇÃO}

Com o crescimento do setor sucroalcooleiro, ao decorrer dos anos contamos com o surgimento de novas tecnologias em automação do processo de produção sucroalcooleira. A constante evolução em mecanização traz cada dia, ao mercado uma novidade em processos e máquinas que aumenta em proporção significante a produção.

Em contrapartida essas evoluções exigem que os empresários invistam em treinamentos e capacitação profissional para seus colaboradores. Mesmo com os números positivos, ainda existem alguns empresários que veem estas mudanças como despesas e não como investimento.

Essas evoluções induzem o empresário a trabalhar de forma diferente, através de manutenção preventiva, para que se tenha um equipamento sempre a disposição.

Martins e Campos Alt (2010, p. 313) descreve a atividade básica de manutenção como:

"A atividade básica de um setor de manutenção é zelar para que seu cliente, interno ou externo, tenha sempre o recurso a sua disposição a hora em que precisar, com todas as condições normais de uso. Pouco importa ter recursos $99 \%$ disponível do tempo se, no instante em que for solicitado não funcionar, seria como um sistema de incêndio ligado a uma caixa d'agua, "está vazia justo na hora em que o fogo começou".

Dificilmente é possível se adequar a essas mudanças sem ter um bom planejamento. Segundo Maximiano (2011, p. 130), estratégia é "a seleção dos meios para realizar objetivos". Grande parte das empresas possui objetivos, mas há um grande número de falha quanto a alcançá-los, pelo fato dos funcionários não terem o conhecimento dos mesmos, por vezes chegam até constituir um planejamento, porém pela falta de conhecimento, cria-se algo ilusório e fora de contexto, onde o trabalhador não compreende o caminho para chegar aos propósitos da organização.

No setor sucroalcooleiro as questões como disponibilidades de frotas e equipamentos, vêm encontrando dificuldade, pela não utilização da manutenção de forma estratégica. Por não identificar o momento ideal e quais tipos de manutenção que podem auxiliar para uma solução da situação, qual tipo apresentará os melhores resultados na manutenção de seus equipamentos e maquinários.

Classifica-se a manutenção em preditiva, preventiva e corretiva, quando o setor realiza com certa frequência a análise dos equipamentos e máquinas, identificando componentes que estejam deteriorados e efetua a substituição dos mesmos, está realizando a manutenção preditiva, porém, quando busca identificar as possíveis falhas que venham a ocorrer, corrigindo os defeitos com antecedência é a manutenção preventiva e manutenção corretiva é aquela que quando o equipamento ou maquinário deixa de funcionar pela quebra de alguma peça e então se realiza o conserto.

Espera-se, portanto, com esse trabalho obter entendimento com relação aos seguintes questionamentos: Qual tipo de manutenção no setor sucroalcooleiro apresenta melhores resultados? Há algum de tipo de manutenção que provoca melhores resultados para a manutenção automotiva?

Portanto, este artigo tem como objetivo geral evidenciar o processo de manutenção, e suas vantagens como estratégia para disponibilidade de frota e equipamento ao processo produtivo.

Como objetivo específico, busca:

- Conceituar e apresentar as formas de manutenção;

- Comparar os ganhos realizados com manutenção;

- Analisar a viabilidade dos processos de manutenção.

A relevância desta pesquisa justifica-se na importância para os gestores que diante das constantes mudanças, o setor de manutenção de equipamento e frotas possa enxergar a manutenção como estratégia, e por fim identificar quais tipos de manutenção proporciona melhores resultados, consequentemente contribuindo com os objetivos organizacionais.

A estrutura deste trabalho contempla o referencial teórico onde os conceitos estarão divididos da seguinte maneira: estratégia, manutenção e suas formas de classificação como: preditiva, preventiva e corretiva; as causas de indisponibilidades de equipamentos na indústria sucroalcooleira; posteriormente é apresentada a metodologia que será utilizada no desenvolvimento do trabalho; logo após a apresentação e análise dos dados obtidos e por fim as considerações finais. 


\section{REFERENCIAL TEÓRICO}

Nesta etapa do trabalho serão apresentados: conceitos e técnicas relacionados à estratégia, manutenção de modo geral, e as divisões da manutenção, como: manutenção preditiva, manutenção preventiva e manutenção corretiva.

\subsection{ESTRATÉGIA}

No o contexto empresarial, diante da grande concorrência, novos conceitos de empresas, a busca por uma efetividade maior, faz com que o setor sucroalcooleiro necessite que seus objetivos integrem com um planejamento estratégico na qual direcionará as ações de uma organização.

Oliveira, $(2013$, p.5) classifica o propósito do planejamento como:

Desenvolvimento de processos, técnicas e atitudes administrativas, as quais proporcionam uma situação viável de avaliar as implicações futuras de decisões presentes em função dos objetivos, que facilitarão a tomada de decisão no futuro de modo mais rápido, eficaz e eficiente.

Segundo Cornelis \& Pearce II, (2007, p. 2):

Estratégia diz respeito a posicionar uma organização para a obtenção de vantagem competitiva. Envolve escolhas a respeito de que setores participarão quais produtos e serviços oferecer e como alocar recursos corporativos. Seu objetivo principal é criar valor para acionistas e outros stakeholders ao proporcionar valor para o cliente.

Para Bethlem (2008, p. 19), "O que se executa, voluntariamente, e antes aprendido e cooptado para executar algo, o ser humano precisa ter conhecimentos, habilidades e atitudes necessárias e suficientes", ou seja, utilizar de conceitos técnicas e processos, que estão ligados à ação que se pretende realizar.

É de grande importância para as empresas, que se tenha também um planejamento relacionado ao treinamento e capacitação de seus funcionários, e que se mantenha o acompanhamento ao aprendizado do colaborador, para obter sucesso no investimento em treinamento é preciso que se tenha interesse no crescimento de ambas as partes, empregador e empregado.

Novos conceitos, tecnologias e ideias de negócios nascem todos os dias. "Por exemplo, a internet, a inovação, a qualidade total, a flexibilidade e a velocidade foram reconhecidas como essenciais para a força e a agilidade competitiva de uma empresa". (Cornelis A \& Pearce II, 2007,p.4)

Ainda de acordo com Cornelis A \& Pearce II, (2007, p. 13 e 14). 0 processo de criação de uma estratégia pode ser organizado com base em três perguntas-chave: Onde estamos? Para onde vamos? E como chegaremos lá?

Onde estamos? Preocupa-se com a avaliação do estado atual do negócio ou da empresa como um todo. Ou seja, uma avaliação detalhada do desempenho atual da empresa; das tendências pertinentes nos ambientes sociopolítico, econômico, legal e tecnológicos mais amplos em que a empresa opera; de oportunidades e ameaças no ambiente setorial e de pontos fortes e fracos internos.

Para onde vamos? É projetada para gerar e explorar alternativas estratégicas baseadas nas respostas obtidas à primeira pergunta. 0 resultado é uma declaração de intenção estratégica, que identifica o conceito orientador de negócios ou a força motriz que impelirá a empresa para a frente.

Como chegamos lá? Está focada em como atingir os objetivos desejados. 0 produto final é um conjunto detalhado de inciativas para programar a estratégia escolhida e exercer disciplina e controle estratégicos.

Todos os departamentos de uma empresa devem estar conectados e atualizados com as novas tecnologias existentes no mercado, com o setor de manutenção, não é diferente quanto mais informação se tem, melhor será o desempenho e a qualidade do serviço desenvolvido pela equipe. 
Independente de qual seja o ramo ou o tamanho da empresa, sempre deve-se ter uma boa visão estratégica em todos os setores como forma de maximizar os resultados, no caso deste artigo vamos tratar sobre a visão estratégica na aplicação de uma manutenção preventiva.

\subsection{MANUTENÇÃO}

De acordo com o dicionário Aurélio, (2003, p. 445). o termo manutenção define-se como "ato ou efeito de manter as medidas ou os cuidados necessários para o funcionamento de alguma coisa". A NBR-Norma brasileira, aprovada pela a ABNT-Associação Brasileira de Normas Técnicas, define manutenção como: "Combinação de medidas técnicas e administrativas supervisionadas, destinadas a recolocarem e manter um item em condição de exercer sua função requerida". (NBR,1994.)

O objetivo principal da manutenção é fazer tudo para manter o equipamento em condições de operação, as avarias encontradas nos equipamentos, vão desde desgastes visuais causados pelo uso e pelo fator tempo, à perda de produção, produção de má qualidade, desperdício de insumos e poluição ambiental.

Na visão de Xenus, (2014, p. 21)

"As atividades de manutenção devem ter um propósito muito mais amplo do que apenas consertar e manter as condições originais do equipamento. "muitas vezes somente manter as condições é insuficiente. Por isso, a introdução de melhorias que visam aumentar a produtividade também deve fazer parte do departamento de manutenção."

Algumas falhas repetitivas em equipamentos exigem que a manutenção estude uma modificação e melhoramento no equipamento, para que além de realizar o conserto, desenvolva modificações que elimine de vez o problema, de modo que aumente a disponibilidade do equipamento e consequentemente aumente a produção.

Para Xenus. (2014, p. 20)

"Nos dias de hoje ainda existe ideias inocorrentes na forma de pensar sobre a atividade de manutenção e sobre gerenciamento. Isso pode ocasionar conflitos entre departamento de manutenção e de produção".

Existem três tipos de manutenção que atuam na vida dos equipamentos, de diferentes formas, mas todas estão ligadas entre si, são elas: manutenção preditiva, manutenção preventiva e manutenção corretiva, na qual abordaremos a seguir.

\subsection{MANUTENÇÃO PREDITIVA}

A técnica de manutenção preditiva vem crescendo bastante dentro das empresas, existe certa resistência quanto ao investimento em manutenção preditiva por se tratar de uma das formas de manutenção com maior custo. Esta é a etapa que está mais ligada à tecnologia.

De acordo com Xenus,(2014,p,25)

“A manutenção preditiva permite aperfeiçoar a troca das peças ou reforma dos componentes e estender o intervalo de manutenção, pois permite prever quando a peça ou componente estarão próximos do seu limite de vida".

A manutenção preditiva realiza a análise dos componentes de cada equipamento e cada componente é analisado de uma forma diferente, algumas empresas designam uma equipe somente para tratar da ação preditiva. Outras empresas preferem contratar companhias terceirizadas que já contam com engenheiros e equipamento especial para coletar dados e amostras de materiais e assim fornecer um diagnóstico mais concreto à empresa contratante.

Como exemplos têm-se: medidor ultrassônico avalia desgaste de pinos e buchas; medidor de vibração identifica o desgaste de rolamentos, laboratórios realizam análise dos óleos lubrificantes e identifica o desgaste interno do componente, pelo teor de diversos materiais encontrados no óleo. 
Portanto, precisamos entender claramente que a manutenção preditiva será um dos elementos da manutenção preventiva. Ao colocar em prática a manutenção preditiva, suas tarefas devem fazer parte do planejamento da manutenção preventiva. (XENUS, 2014, p, 26)

\subsection{MANUTENÇÃO PREVENTIVA}

A manutenção preventiva pode ser considerada como a parte mais importante da manutenção, é nesta etapa que se trabalha com maior aplicação de planejamento e estratégia, a ação preventiva busca identificar potenciais falhas que irá acontecer, e corrige o defeito antes mesmo dele acontecer.

A manutenção preventiva tende a ter um custo mais alto quando se comparada com a corretiva, mas esse custo maior é compensado com a disponibilidade do equipamento. Conforme Xenus, (2014, p. 25) "em compensação as falhas diminui, também a disponibilidade do equipamento aumenta e também diminuem as interrupções inesperadas na produção".

Se analisarmos os fatores ligados ao equipamento, podemos concluir que a manutenção preventiva é mais barata do que a corretiva, já que quando se trabalha preventivamente, a produção tende a ser maior.

Em concordância a este entendimento Xenus afirma; (2014, p. 25)

Se considerarmos o custo total, em várias situações a manutenção preventiva acaba sendo mais barata que a manutenção corretiva porque se tem domínio das paradas dos equipamentos, em vez de ficar sujeito à parada inesperada por falhas nos equipamentos.

A manutenção preventiva trabalha sempre buscando manter e aumentar a disponibilidade dos equipamentos, com este objetivo as organizações buscam a implantação de manutenção preventiva em suas atividades. Porém, grande parte das empresas não faz o planejamento de manutenção, e nem distinção das atividades de manutenção.

Algumas instituições acham que estão aplicando a manutenção preventiva, quando na verdade estão apenas corrigindo as falhas do dia a dia, de uma forma diferente, devemos lembrar que a manutenção preventiva utiliza de diversos métodos de diagnósticos, operando em parceria com manutenção preditiva realizando um diagnóstico e reparo cada vez mais eficiente.

É importante ressalvar que a disponibilidade não depende apenas da manutenção. Segundo Xenus, (2014, p. 25)

Também pode acontecer que, mesmo com o cumprimento sistemático da manutenção preventiva, as falhas não diminuam. A causa desse fenômeno pode estar tanto na falta de padrões e procedimentos de manutenção quanto no conhecimento e nas habilidades insuficientes dos técnicos de manutenção e operadores da produção.

Portanto, quando há falta de padronização dos procedimentos, do conhecimento por parte dos técnicos, ocorre a indisponibilidade de equipamentos.

\subsection{MANUTENÇÃO CORRETIVA}

A manutenção corretiva é efetuada depois que a falha ocorreu, quando olhamos para esse método com uma visão limitada apenas no momento da ação, tem-se a impressão de ser mais barata do que os outros métodos de manutenção.

Porém, ao levarmos em consideração o quanto esse equipamento deixou de produzir, e o tempo em que ele ficou parado aguardando manutenção, peça ou até mesmo uma mão de obra especializada, seu custo acaba sendo maior se comparado ao que ele deixou de produzir. Já que tal falha não foi prevista e provavelmente a equipe de apoio terá certa dificuldade em consertar o equipamento.

Xenus destaca que: $(2014 \mathrm{p}, 24)$

Em muitos casos, como não se pode prever o momento das falhas, existe a possibilidade de haver interrupções da produção de forma inesperada. Se a interrupção for excessivamente longa, poderá haver prejuízos significativos para a empresa. 
Embora a empresa adote apenas efetuar manutenção corretiva, involuntariamente ela acaba utilizando de procedimentos da manutenção preventiva, à medida que a empresa efetua ações corretivas, logo ela se depara com algumas falhas que são rotineiras, e neste caso ela já se previne antes do fato ocorrer, mantendo em estoque determinadas peças, e ferramentas especificas.

Mesmo optando pela manutenção corretiva para algumas partes menos críticas do equipamento, é preciso ter os recursos necessários, peças, mão de obra e ferramental, para agir rapidamente e reduzir possíveis impactos da falha na produção.

\subsection{CAUSAS DE INDISPONIBILIDADE DE MÁQUINAS NA INDÚSTRIA SUCROALCOOLEIRA}

A maior causa da indisponibilidade de frotas nas usinas é dada em virtude de pequenas falhas que não foram previstas, isto as levam a ser um grande contratempo para a equipe de apoio, uma vez que o setor de operação e colheita na maior parte das ocorrências está distante da base, local onde ficam situadas as peças de reparação.

A maior parcela da indisponibilidade é gerada por defeitos considerados pequenos, que acabam se tornando grandes problemas por não terem sidos identificados no devido tempo.

NBR 5462-1994 apud Xenus, 2014, p69. Traz a seguinte afirmação a seguinte definição para falha:

Falha é o termino da capacidade de um item de desempenhar a função requerida. E a diminuição total ou parcial da capacidade de uma peça, componente ou máquina de desempenhar sua função durante um período de tempo, quando o item deverá ser reparado ou substituído. A falha leva o item a um estado de indisponibilidade.

A menor parcela da indisponibilidade está relacionada a falhas operacionais, pequenos acidentes e más condições de operação, como terreno mau preparado, e fragmentos de outras operações deixadas no local de colheita.

A melhor forma de corrigir essas falhas antes delas ocorrerem é trabalhar preventivamente, tanto na operação do equipamento quanto na manutenção do mesmo.

Segundo Xenus, (2014, p 139).

Também fazem parte da manutenção preventiva às tarefas rotineiras como limpeza, lubrificação e inspeções mais simples, normalmente executadas no dia a dia pelos operadores da produção para reduzir ou evitar a degradação dos equipamentos.

Quando a operação também está preocupada com a disponibilidade do equipamento, viabiliza melhores condições para equipe de manutenção, para estar corrigindo falhas antes de elas ocorrerem, em virtude do operador passar mais tempo com o equipamento, ele possui maiores conhecimentos da condição do mesmo. Isso pode ser comparado com uma consulta médica de uma criança que ainda não fala, a mãe relata as ações e comportamento da criança e o médico passa o diagnóstico, e alguns exames dependendo dos fatos relatados.

Portanto, quando o operador descreve a situação atual do equipamento para o mecânico, o mecânico fará o diagnóstico, providenciando peças e ferramentas especiais para melhor aferição do equipamento. Assim evitará a falha, ou estar preparado quando ocorrer os problemas.

\section{METODOLOGIA}

Nesta fase do trabalho, buscamos apresentar os métodos e procedimentos utilizados na produção do mesmo.

0 referido trabalho foi realizado através de uma pesquisa bibliográfica e um estudo de caso baseado por informações fornecidas por uma empresa do setor sucroalcooleira situada no Vale do Rio Ivinhema localizado no Estado de Mato Grosso do Sul. Com uma abordagem qualitativa e quantitativa dos meios de manutenção como estratégia na redução de custos e disponibilidade.

Na elaboração deste trabalho foi escolhido o método de estudo de caso por possibilitar uma análise mais eficiente do tema, pois no estudo de caso o pesquisador trabalha com objetivos bem delineados e foca 
apenas nos dados relevantes, podendo adentrar no problema extraindo um maior número de informação de forma a se obter uma pesquisa mais conclusiva.

Quanto à forma de pesquisa Creswell (apud gil, 2009, p.06) expressa a seguinte definição:

O pesquisador explora uma simples entidade ou fenômeno limitado pelo tempo e atividade (um programa, evento, processo, instituição ou grupo social) e coleta detalhada de informação utilizando uma variedade de procedimentos de coleta de dados durante um período de tempo definido.

O estudo de caso favorece um melhor entendimento da pesquisa realizada, segundo Gil, (2009, p. 17 e 18).

Diferentemente dos levantamentos e dos experimentos de modo geral, investigam um fenômeno circunscrito a um determinado período de tempo, os estudos de caso favorecem o entendimento do dinamismo próprio dos grupos e das organizações. São, pois, estudos adequados para a compreensão do processo de mudança.

A pesquisa quantitativa busca quantificar ou determinar o número de respostas mediante uma pergunta, ou um item a ser pesquisado. (VERGARA 2005, apud OTANI E MACHADO 2008). A presente pesquisa é de natureza quantitativa, porque busca quantificar e determinar o número de respostas mediante uma pergunta e seus itens pesquisados e qualitativos por se tratar de estudo de gestão da manutenção automotiva, por meio de questionamentos ligados para uma melhor disponibilidade.

Embora difira quanto à forma de ênfase, os métodos qualitativos trazem como contribuição ao trabalho de pesquisa uma mistura de procedimentos de cunho racional e intuitivo capazes de contribuir para melhor compreensão dos fenômenos. (NEVES, 1996)

0 presente artigo teve como objeto de pesquisa dois equipamentos, buscando, coletando e comparando dados, sendo que um dos equipamentos foi realizado a manutenção preventiva e preditiva, e o outro não. Mas especificamente será feito a comparação entre duas colhedoras-de-cana de açúcar.

Justifica em virtude que manutenção está ligada a palavra disponibilidade, e o quanto a manutenção preventiva influencia no aumento da disponibilidade de frotas.

Todos os gráficos que serão apresentados neste trabalho foram elaborados pelo autor, mediante as informações disponibilizadas pela empresa no período de 12/06/2016 a 12/07/2016.

\section{COLETA DE DADOS}

A empresa analisada atua neste ramo a mais de 5 (cinco) anos, tem cerca de 680 (seiscentos e oitenta) funcionários. Sua produção diária em moagem de cana é de 5.000 (cinco) a 6.000 (seis) mil toneladas, realizada em três turnos de trabalho, totalizando as 24 (vinte e quatro horas).

A mesma se destaca dentre as outras usinas por ser proprietária de quase 90\% (noventa por cento) de toda a área plantada, e já foi citada em revistas do setor sucroalcooleiro, com destaque a qualidade de sua cana-de-açúcar.

Tal empresa também tem preocupação com o meio ambiente, quanto a descarte de resíduos poluentes e óleos lubrificantes, o setor de manutenção automotiva trabalha com grande intensidade para eliminar vazamentos em colhedoras de cana-de-açúcar, sendo este equipamento o que mais consome óleo hidráulico.

A referida empresa possui metas para reduzir o consumo de óleo lubrificante. Inicia a safra com uma referência adquirida em uma revista destinada ao seguimento sucroalcooleiro. Na qual apresenta estudo em várias usinas referente ao consumo de óleo hidráulico por tonelada de cana, a revista (Indicadores de Desempenho da Agroindústria Canavieira), relatou os seguintes valores, apresentados no quadro 1.

Na coleta de dados a empresa pesquisada possuía um consumo de óleo hidráulico por tonelada igual a $26,7 \mathrm{ml} / \mathrm{t}$. Tomando como referência o quadro 1 pode se dizer que seu consumo é mais do que ótimo, porém busca para reduzir ainda mais. 
Quadro 1- Consumo de óleo hidráulico das colhedoras por tonelada de cana colhida mecanicamente.

\begin{tabular}{|c|c|}
\hline Classificação & $\begin{array}{c}\text { Centro sul } \\
\mathrm{ml} / \mathrm{t}\end{array}$ \\
\hline Ótimo & $<37.0$ \\
\hline Bom & 37,0 a 48,5 \\
\hline Regular & 48,6 a 60,1 \\
\hline Ruim & $>60,1$ \\
\hline
\end{tabular}

Fonte: DIB, (2014, p136)

As informações apresentadas foram coletadas de acordo com o histórico de duas colhedoras de cana de açúcar no período de trinta dias. Sendo elas colhedora 01 e colhedora 02 . Observando que a colhedora 01 recebeu os procedimentos de manutenção preventiva e preditiva, ainda é importante salientar o tempo em que esses equipamentos estão em operação. A colhedora 01 possui cerca de 12.000 (HO) doze mil horas em operação e a colhedora 02 está próxima de 9.000 (HO) nove mil horas em operação.

Concluindo a coleta de dados e filtrando as informações relevantes foram elaborados os seguintes quadros.

Quadro 2- dados as serem representados no gráfico 1.

\begin{tabular}{|c|c|c|c|c|c|c|}
\hline EQUIP & $\mathrm{HO}$ & $\mathrm{HM}$ & $\mathrm{HE}$ & Produtivas & Improdutivas & Manutenção \\
\hline 1 & 720 & 436,45 & 237,28 & 24 & 92,59 & 190,96 \\
\hline 2 & 720 & 207,98 & 110,36 & 24 & 69,42 & 442,6 \\
\hline
\end{tabular}

Fonte: Elaborado pelo autor.

As siglas apresentadas possuem o seguinte significado:

- (HO) refere-se às horas no período de trinta dias.

- (HM) horas de motor, refere-se ao tempo em que o motor ficou em funcionamento neste período.

- (HE) horas de elevador, é dado pelo tempo em que a colhedora esteve colhendo cana.

- (Produtiva) representa as vinte e quatro horas de um dia.

- (Improdutiva) horas improdutiva, é o tempo em que acolhedora estava com o motor ligado, mas estava aguardando transbordo ou caminhão.

- (Manutenção) é o tempo em que a colhedora esteve em manutenção neste período.

A partir do gráfico 1 verifica-se o quanto a manutenção preventiva reflete na disponibilidade de frota, comparando as (HE) pode-se ver que o equipamento 01 esteve por muito mais tempo em operação do que o equipamento 02 , e consequentemente seus resultados foram todos superiores com exceção das horas improdutivas, em virtude de ter recebido todos os procedimentos de manutenção preventiva, e o equipamento 02 recebeu apenas métodos corretivos. 
Gráfico 01 - Relação entre horas em operação e horas em manutenção.

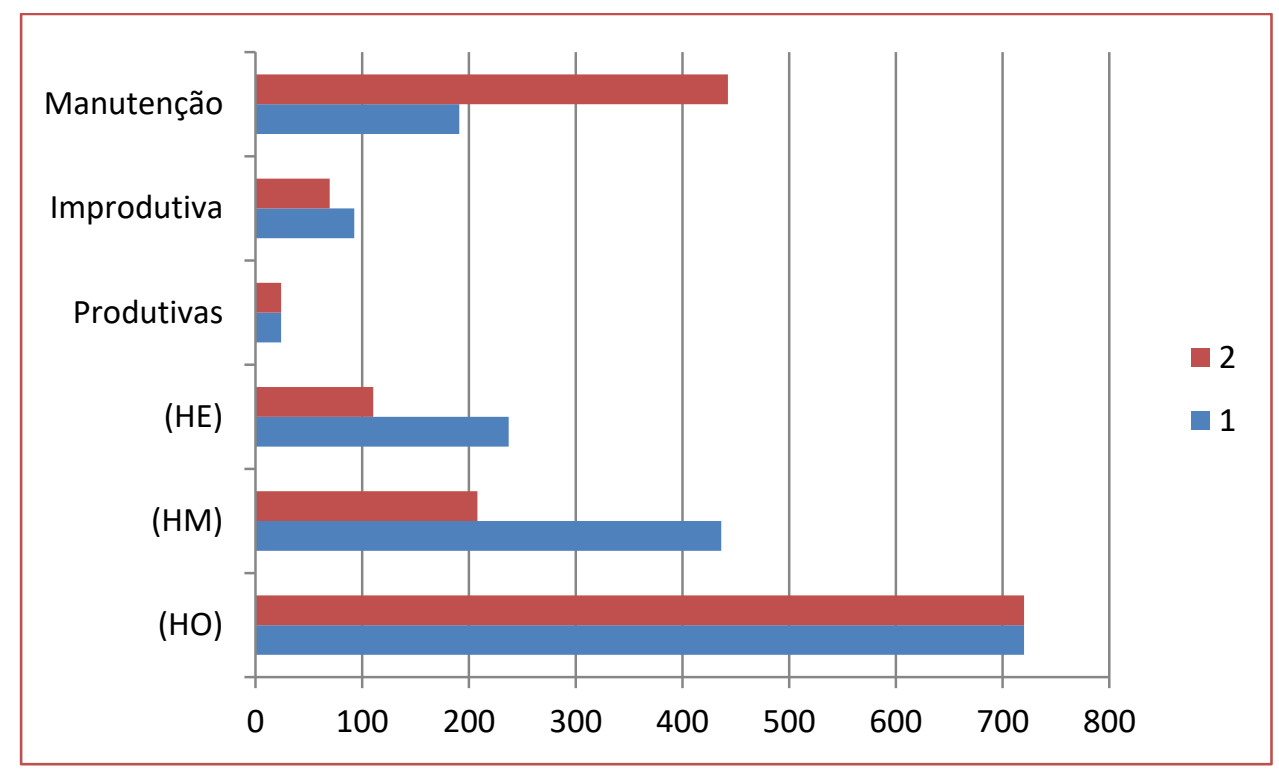

Fonte: Elaborado pelo autor.

Quadro 3- Dados a serem representados no gráfico 2.

\begin{tabular}{|c|c|c|c|c|c|}
\hline Equip. & $\%$ he $/ \mathrm{hm}$ & \%he/ho & Manut. & Aproveitamento & Disponibilidade \\
\hline 1 & $54 \%$ & $32 \%$ & $68 \%$ & $61 \%$ & $74 \%$ \\
\hline 2 & $53 \%$ & $15 \%$ & $87 \%$ & $29 \%$ & $38 \%$ \\
\hline
\end{tabular}

Fonte: Elaborado pelo autor.

Gráfico 2 - Proporção da manutenção na operação.

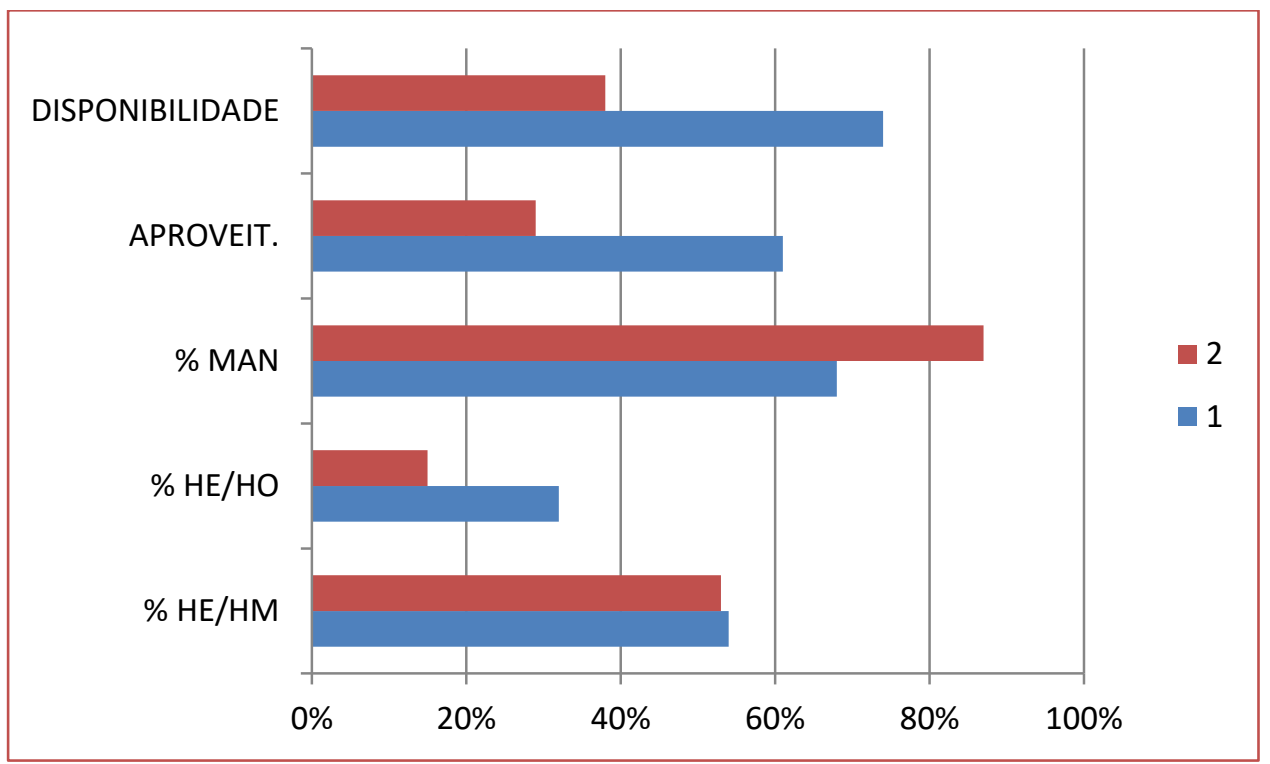

Fonte: Elaborado pelo autor. 
No gráfico 2 pode-se observar que o equipamento 01 teve o menor percentual referente às horas em manutenção, o que reflete nos demais indicadores de produção. Obteve mais horas em operação, com maior aproveitamento e consequentemente a disponibilidade do mesmo também é maior.

Quadro 4- dados a serem representados no gráfico 3.

\begin{tabular}{|c|c|c|c|c|c|c|}
\hline EQUIP. & PROD. (TON) & TON/HE & Diesel & l/ton & \multicolumn{2}{c|}{ Óleo } \\
hidráulico & l/ton \\
\hline 1 & $13.227,33$ & 55,70 & $17.984,00$ & 1,36 & 462,4 & 0,03 \\
\hline 2 & $6.622,35$ & 59,69 & $8.497,00$ & 1,28 & 543,8 & 0,08 \\
\hline
\end{tabular}

Fonte: Elaborado pelo autor.

Gráfico 3 - Relação entre produção e consumo.

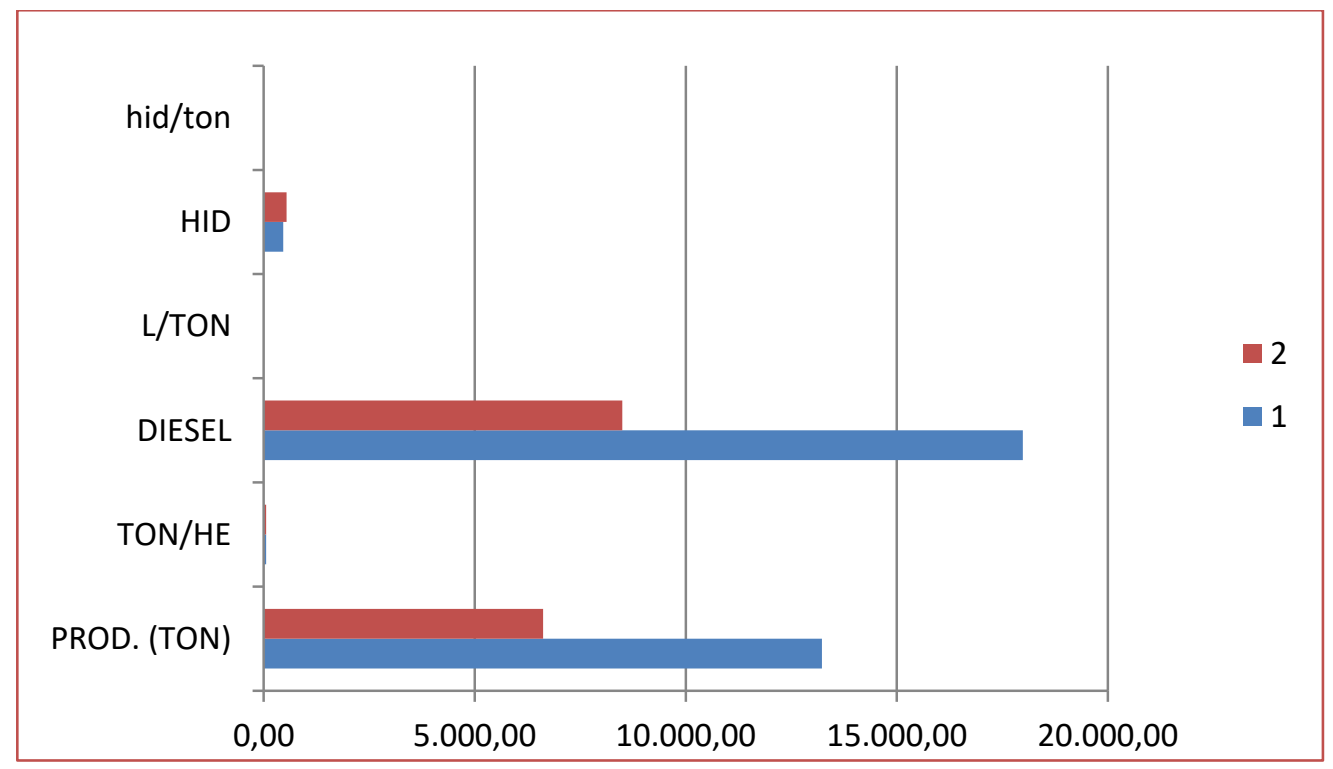

Fonte: Elaborado pelo autor.

0 gráfico 3 mostra de forma bem explícita o quanto cada equipamento produziu no período e também pode-se ver de forma clara o quanto a colhedora 01 produziu a mais que a colhedora 02 . Além da produção, o mesmo evidencia o quanto cada máquina consumiu em óleo hidráulico e diesel no período de trinta dias, e o quanto cada litro de óleo representa na produçao total.

Ao observamos o consumo de diesel das duas separadamente, vemos que a 01 consumiu 17.984,00 e a 02 teve o consumo de 8.497,00 litros de óleo diesel. Justifica tal consumo da 01 ser tão alto em razão da mesma ter mais horas em trabalho de colheita que a 02 , e consequentemente maior produção no período.

0 fato de o consumo de óleo hidráulico nos dois equipamentos serem altos neste periodo é dado em virtude das duas colhedoras terem passado pelo processo de diálise (processo onde todo óleo da máquina e drenado pra fazer filtragem de impurezas, e depois é resposto na mesma máquina ou em outro equipamento).

Após análise dos gráficos podemos entender que a manutenção preventiva em relação aos demais tipos de manutenções, apresenta grandes vantagens para empresa, aumentando a disponibilidade dos equipamentos, proporcionando uma vida útil do equipamento/máquinas.

Nos gráficos anteriores podemos observar o quanto à manutenção preventiva contribui de forma positiva para a disponibilidade dos equipamentos, e o quanto a empresa ganha em produção por trabalhar preventivamente, mediante a um comparativo como foi mencionado no início da análise dos dados. 
Agora veremos como a manutenção preventiva contribui economicamente com a empresa, e observar que quando aplicada de forma estratégica, a manutenção deixa de ser um gasto e passa a ser um investimento.

Sobre a cana de açúcar sabe-se que uma tonelada da planta produz entre 85 e 90 litros de álcool em média. Site,(NOVA CANA, 2016)

Pesquisa realizada no site do CPEA, o preço de venda médio do etanol nas usinas em: 19/08/2016 é de $\mathrm{R} \$ 1,55$ por litro. A partir destas informações, foi possível montar o quadro 5. CEPEA, (Centro de Estudos Avançados em Economia Aplicada).

Quadro 5- Produção e renda de cada equipamento.

\begin{tabular}{|c|c|c|c|c|c|}
\hline EQP. & $\begin{array}{c}\text { Cana } \\
\text { Colhida } \\
\text { tonelada }\end{array}$ & $\begin{array}{c}\text { Litros } \\
\text { produzido } \\
\text { por tonelada. }\end{array}$ & $\begin{array}{c}\text { Produzido } \\
\text { L }\end{array}$ & $\begin{array}{c}\text { Preço do } \\
\text { etanol }\end{array}$ & $\begin{array}{c}\text { Renda bruta } \\
\text { R\$ }\end{array}$ \\
\hline 01 & $13.227,33$ & 85 & $1.124 .323,05$ & 1,55 & $1.742 .699,41$ \\
\hline 02 & $6.622,35$ & 85 & $562.899,75$ & 1,55 & $872.494,61$ \\
\hline
\end{tabular}

Fonte: Elaborado pelo autor

A diferença da renda bruta dos equipamentos é de $\mathrm{R} \$ 870.204,55$ (oitocentos e setenta mil duzentos e quatro reais e cinquenta e cinco centavos), onde se conclui que por falta de manutenção preventiva o equipamento 02 apresentou um resultado muito menor do que o equipamento 01.

\section{CONSIDERAÇÕES FINAIS}

Este artigo teve como objetivo mostrar o processo de manutenção, e suas vantagens como estratégia na disponibilidade de frota e equipamentos ao setor produtivo de uma empresa do setor sucroalcooleiro.

Identificou-se com o comparativo de duas frotas semelhantes, que quando não se aplica a manutenção preditiva e preventiva, o equipamento pode estar trabalhando apenas com a metade de sua capacidade levando em consideração a produção da frota 01 e 02.

Observou-se que ao se aplicar o mesmo método nos equipamentos, além de melhorar a produção e rentabilidade dos equipamentos, aumenta-se a vida útil da frota.

Nota-se também, que quando o equipamento passa por manutenção preventiva, o mesmo estará sempre em boas condiçoes de uso, consequentemente com sua produção bem maior quando comparada a outro fdequipamento que não tenha a manutenção preventiva.

Tal pesquisa ainda poderia ter abordado temas como: a participação de terceiros, o custo com a contratação dos mesmos, a correlação deste custo com o valor de treinamentos e investimentos em equipamentos e ferramentas especiais para o quadro de funcionários, e quanto tempo de parada de um equipamento influencia nos demais dependentes, para o setor sucroalcooleiro colhedora de cana-deaçúcar (trator transbordo e caminhão canavieiro).

\section{REFERÊNCIAS}

[1] ABNT. Nbr5462. Disponível em: http://www.ebah.com.br/content/ABAAAAk3wAC/nbr5462. Acesso em: 09/09/2016

[2] BETHLEM, Agrícola de Souza. Estratégia Empresarial. 5o edição, São Paulo: Atlas, 2008.

[3] CEPEA, Etanol Hidratado. Disponível em:<http://cepea.esalq.usp.br/etanol/> Acesso em: 21/08/2016.

[4] CORNELIS A. de Kluyver; PEARCE II, John A. Estratégia Uma Visão Executiva. 2o edição. São Paulo: Pearson Prentice Hall, 2007.

[5] DIB, Nunes Jr. Eng. Agrônomo, IDEA, Instituto de desenvolvimento agroindustrial ltda. Ribeirão preto, SP, 2014.

[6] GIL, Antonio Carlos. Estudo de caso. São Paulo: Atlas, 2009. 
[7] MARTINS, Petrônio G; CAMPOS ALT, Paulo Renato, Administração de materiais e recursos patrimoniais. 3ํㅗ edição São Paulo: Saraiva 2009.

[8] MAXIMIANO, Antonio Cezar Amaru (2011) Introdução a administração. 8o edição, São Paulo, Atlas, 2011

[9] NEVES, José Luis. Pesquisa qualitativa, aracterísticas- Uso e possibilidades. Caderno de Pesquisa em Administração, São Paulo, V1, №3, 2ºSEM 1996.

[10] NOVA CANA. Etanol e Cana: Disponível em <www.novacana.com/n/etanol/mercado/precos/etanolhidratado-cai-anidro-usinas-cepea-esalq-150816/> Acesso em: 21/08/2016

[11] OTANI Mario; MACHADO, Waltair Vieira. A proposta de desenvolvimento da gestão de manutenção industrial na busca da excelência ou classe mundial. Revista Gestão Industrial, V4, №2: P 1-16,2008.

[12] PORTAL DA EDUCAÇÃO, Planejamento Estratégico Disponível em: <http://www.portaleducacao.com.br/educacao/artigos/3951/o-que-e-planejamento-estrategico\#ixzz4BabYvjkS> Acesso em: 27/07/2016.

[13] XENUS, Harilaus Georgius D’ Philippos. Gerenciando a manutenção produtiva 2o edição, Nova Lima: Falconi editora, 2014. 


\section{Capítulo 20}

\section{A EVOLUÇÃO DO COMPLEXO AGROINDUSTRIAL CITRÍCOLA PAULISTA NA DINÂMICA DOS CONTRATOS}

Murilo Secchieri de Carvalho

Luiz Fernando de Oriani e Paulillo

Paulo Henrique Palota

Elson Avallone

Paulo Cesar Mioralli

Resumo: Este capítulo apresenta um recorte temporal do complexo agroindustrial citrícola paulista subdividindo-o em cinco fases distintas, que vai desde o seu nascimento (décadas de 20 e 30), passando por um período de estruturação (décadas de 40 e 60) e prosperidade (décadas de 70 e 80), alcançando a sua maturidade (década de 90) e finalmente por um período de fortes desequilíbrios e disputas (pós anos 2000 até 2018). O principal objetivo é de analisar a evolução do complexo citrícola e verificar as relações contratuais estabelecidas entre citricultores e empresas processadoras a partir da década de 70, para repensar o atual momento e olhar para o futuro do complexo citrícola paulista. A revisão bibliográfica foi a metodologia utilizada para escrever este capítulo de livro, sendo que a importância dele está na capacidade de compreender os ciclos do complexo citrícola paulista, especialmente o de prosperidade, maturidade e o desequilíbrio sobre a ótica dos modelos contratuais vigentes em cada período descrito. 0 resultado deste recorte analítico levanta questões e demonstra a importância dos contratos na evolução do complexo citrícola paulista, seja no momento de maior crescimento ou no momento de maior instabilidade e desequilíbrios.

Palavras-chave: Complexo, Citrícola, Modelos, Contratos. 


\section{INTRODUÇÃO}

A história e a trajetória da citricultura brasileira se confundem com os períodos por que passou e vem passando o complexo citrícola paulista, uma vez que o crescimento da produção e sua industrialização acontecem quase que inteiramente dentro deste território produtivo, seja da laranja "in natura", do suco ou de seus subprodutos.

No complexo citrícola paulista é possível identificar e caracterizar cinco fases distintas durante as últimas nove (9) décadas: o seu nascimento (décadas de 20 e 30), a sua estruturação (décadas de 40 à 60), a sua prosperidade (décadas de 70 e 80), a sua maturidade (década de 90) e os seus desequilíbrios (pós anos 2000).

As fases apresentadas não têm o intuito de analisar a variação dos ciclos de preços agrícolas da caixa de laranja, mas apresentar brevemente as características dessas diferentes fases relacionadas à construção do complexo citrícola paulista ao longo das últimas nove (9) décadas e correlacionar as três últimas fases aos modelos contratuais vigentes na época.

Os ciclos ou as diferentes fases do complexo citrícola paulista foram parametrizados neste capítulo para melhor compreensão dos leitores e para traçar um paralelo destas fases intermediárias de prosperidade, maturidade e desequilíbrios com a assinatura dos contratos formais para compra/venda da caixa de laranja pela indústria, especialmente após a década de 70: contratos a preço fixo (1978 a 1985), contrato padrão (1986 a 1995) e contratos específicos (1996 a 2018) (ARAÚJO, 2006).

Neste sentido, o objetivo deste capítulo é fazer uma análise deste passado do complexo citrícola, olhando para a produção da laranja no seu início (MAIA, 1996), além das relações estabelecidas entre citricultores e empresas processadoras a partir da década de 70 (ELIAS, 2003), para repensar o atual momento e olhar para o futuro do complexo citrícola paulista e brasileiro (PAULILLO, 2005). Para tanto, foi feita uma revisão bibliográfica do assunto (LAKATOS, MARCONI, 1996), como método de estudo, para atingir este objetivo.

Por outro lado, as diferentes fases descritas acabam generalizando os eventos e fatos que se sucederam a partir da década de 20 no complexo citrícola, e classificá-los como sendo parte de um processo amplo não é algo trivial, pois as atividades de suporte agrícola, produção de laranja e até industrial; enfrentaram diferentes desafios, próprios da atividade e talvez não relacionados a estes ciclos específicos propostos.

Nas fases apresentadas, algumas são longas, outras mais curtas, e as mesmas não tem relação direta, mas indireta, com as crises econômicas conjunturais, brasileira ou internacional, como a crise do petróleo em 1973 e 1979, ou mesmo o período de alta inflacionária da década de 80.

A própria fase de estagnação da citricultura e profunda crise pós 2000, contrasta com um momento áureo da economia agrícola brasileira, dada as altas dos preços da maioria das commodities agrícolas, agroindustriais, energéticas e metálicas.

Neste sentido, a proposta de analisar brevemente e categorizar os distintos ciclos e fases do complexo citrícola paulista é determinar os elementos históricos que influenciaram a estabilidade das relações entre os dois principais atores da cadeia produtiva do Suco de Laranja Concentrado e Congelado (SLCC) e do suco não concentrado (SLNC) citricultores e empresas de processamento; para compreender a origem dos conflitos internos bilaterais que afetaram diretamente os custos transacionais, a discrepância da eficiência e competência individual dos atores.

A própria atividade citrícola, nos diferentes momentos de sua trajetória junto ao complexo citrícola paulista e à cadeia produtiva do SLCC, SLNC e dos subprodutos; enfrentou desafios ligados especificamente às pragas e doenças, que afetaram os pomares em distintos momentos, por exemplo, a tristeza da planta na fase de nascimento durante a década de 30 (1937) e mais recentemente o greening.

Nas próximas seções do capítulo, serão retratadas estas distintas fases, correlacionando-as não à conjuntura setorial ou econômica, mas aos problemas específicos encontrados dentro da indústria ou da produção citrícola apenas (fatores climáticos, pragas e doenças); além dos elementos condicionantes que levaram ao apogeu e a uma perigosa e preocupante fase de desequilíbrios do complexo citrícola paulista nos últimos anos. 


\section{O NASCIMENTO: FUTURO PROMISSOR}

As primeiras experiências, que representam o nascimento do complexo citrícola paulista, ocorreram na década de 20 e início de 30 , onde as mudas de laranjeiras são trazidas de outras regiões por estrada de ferro, especialmente do Rio de Janeiro através da Diretoria de Agricultura, sendo plantadas no interior de São Paulo e mais precisamente na região de Limeira, estado de São Paulo.

As primeiras exportações de laranja in natura datam de 1911 e foram para a Argentina (MAIA, 1996), sendo que a cultura se disseminou no interior de São Paulo, nas décadas de 20 e 30, como uma alternativa à cultura do café.

Com o número de pomares de laranja se expandindo, em 1927, houve a criação do serviço de citricultura, vinculados ao IAC e à ESALQ (NEVES; JANK et al., 2006), sendo este o passo organizacional inicial para estruturação do setor citrícola e a própria difusão da cultura da laranja no interior de São Paulo muito importante para a consolidação da citricultura.

Nestas décadas iniciais, de 20 e 30, o Rio de Janeiro ainda era o maior produtor e exportador da laranja in natura do Brasil, com cerca de 1,5 milhões de caixa em 1932. São Paulo, no mesmo ano, produzia cerca de 700 mil caixas e escoava sua produção através do porto de Santos, sendo que a região de Limeira se tornou cada vez mais atrativa para a atividade citrícola porque a laranja produzida na região possuía uma maior resistência ao transporte marítimo (NEVES; JANK et al., 2006).

A tristeza da laranja, uma doença que dizimou aproximadamente 10 milhões de pés-de-laranja no estado de São Paulo, foi uma das principais adversidades enfrentadas pelo setor produtivo da laranja neste período inicial, em especial a partir do final da década de 30, sendo que apenas as plantas enxertadas em laranja-azeda eram afetadas pela doença, as mudas com porta enxertos de limão-cravo foram resistentes.

A fase inicial, de implantação da atividade produtiva citrícola, seria fundamental para criar o elemento dinamizador e necessário para a experiência da fase seguinte de estruturação do complexo e as primeiras experiências de processamento da laranja: a geração de um excedente de produção que não ficaria no mercado interno e nem seria exportada.

A II grande guerra mundial, que paralisou momentaneamente a exportações de laranja do Brasil a partir de 1939, impedindo o aumento do já crescente volume de laranja in natura exportado, porém isso durou até o início da década seguinte.

Alguns estudos apontam para a queda de produtividade média por hectare neste período (CASER; AMARO, 2004), demonstrando numericamente o impacto desses novos desafios enfrentados pela citricultura paulista e pelo próprio complexo citrícola nascente com a incidência de pragas e doenças na produção agrícola.

A fase de estruturação e consolidação dos dois principais elos da cadeia produtiva agroindustrial do SLCC: o citrícola e a indústria de processamento, é descrita a seguir a partir dos fatos que se sucederam nas décadas de 40 até a de 60, descrito no ponto seguinte.

\subsection{A ESTRUTURAÇÃO CITRÍCOLA E AGROINDUSTRIAL}

0 início da década de 40 e a própria década de 50 representam a consolidação da produção de laranjas no interior de São Paulo, o território produtivo e cinturão citrícola brasileiro. Foi neste período que houve a formação da base de estruturação do complexo citrícola paulista, criando condições para as primeiras experiências no processamento das laranjas excedentes.

A década de 40 , foi muito penosa para a citricultura paulista pela incidência da doença da tristeza dos citros que dizimou milhões de árvores e retardou momentaneamente a expansão da produção de laranja.

Foram nas décadas de 40 e 50, que surge um comerciante de laranjas, chamado Giuseppe Cutrale, italiano que já comercializava laranjas na Sicília (Itália) e vindo para o Brasil começou a trazer laranjas do Rio de Janeiro para o mercado municipal de São Paulo e depois a exportá-las para o Canadá, Alemanha e Holanda (MANÉCOLO, 2012).

José Cutrale Junior4, seu filho, depois das geadas ocorridas na Flórida no início da década de 60, compra uma empresa de packing house de laranjas na cidade de Bebedouro5, onde inicia toda a trajetória do

\footnotetext{
${ }^{4}$ Faleceu em 29 de Dezembro de 2004 (MANÉCOLO, 2012).
} 
exportador de laranjas que se tornou o maior processador e exportador de SLCC do mundo e personagem importante nas diversas fases de estruturação do complexo citrícola nacional, desde o nascimento e estruturação até a fase de desequilíbrios da citricultura paulista.

Ainda na década de 50, no interior de São Paulo, ocorre a fabricação do primeiro lote de suco de laranja não concentrado, processado de maneira industrial e para evitar o desperdício da fruta, direcionando esta primeira produção para o mercado interno. Este modelo inicial de processamento não prosperou dada a própria limitação do mercado interno e as dificuldades de distribuição enfrentadas naquele período.

Na década seguinte, em 60, acontece efetivamente a estruturação da cadeia produtiva do SLCC no Brasil, com a instalação da primeira unidade de processamento de SLCC, a Cia. Mineira de Conservas em 1959 na cidade de Bebedouro, passando a operar em 1961. Depois vem a Citrosuco Paulista, de tecnologia norteamericana, na cidade de Matão-SP, ainda distrito de Araraquara-SP (ELIAS, 2003).

A Citrosuco Paulista foi constituída em 1963 (Matão-SP) a partir da união entre Carl Fischer (citricultor e dono de packing houses em Limeira e Bebedouro), Ludwuig Eckes (Eckes é um importador de suco de laranja da Alemanha) e a Pasco Packing Company (grande produtora de sucos na Flórida), que conseguiram realizar a exportação das primeiras 1.000 toneladas de SLCC (ELIAS, 2003).

Nestas décadas iniciais, o Brasil já era um grande produtor de laranjas vendidas in natura, e logo depois de uma severa geada ocorrida na Flórida em 1962, estado tradicional produtor e processador de laranjas, se tornou também uma alternativa de importação de suco de laranja concentrado e congelado (SLCC) para os EUA.

Algumas empresas processadoras foram fundadas entre as décadas de 60 e 70 no complexo citrícola paulista, dentre elas a: Companhia Mineira de Conservas em Bebedouro (1961), Suconasa em Araraquara (1963), Citrosuco Paulista em Matão (1963), Citrobrasil em Bebedouro (1964 ou 65), Universal Citrus em Bebedouro (1965), a Frular/Sucolanja em Limeira (1968), a Citral em Limeira (1971), Sucorrico em Araras (1973), Tropisuco em Santo Antônio da Posse (1974) e a Frutropic em Matão (1978) (BORGES; COSTA, 2007) (NEVES; JANK et.al., 2006) (ELIAS, 2003).

As processadoras eram de distintos tamanhos e possuíam diferentes origens de capital, algumas eram de capital misto (brasileiro e estrangeiro) e outras apenas de capital estrangeiro, e contribuíram para tornar o Brasil um importante exportador e fornecedor de SLCC, inicialmente para os EUA e depois para Europa e Ásia.

Depois do período de nascimento e estruturação do complexo citrícola paulista nas décadas de 40 a 60 , especialmente com a implantação do parque industrial para o processamento do excedente de laranja, é que foi aberto o espaço para um novo momento da citricultura brasileira e do próprio complexo, com o seu definitivo crescimento e fortalecimento no interior de São Paulo, especialmente a partir das décadas de 70 e 80.

A fase caracterizada como de prosperidade e crescimento compartilhados entre dois principais atores do elo produtivo agroindustrial citrícola é descrito no ponto seguinte, pois há uma evidente estruturação tanto da parte dos citricultores, quanto das empresas processadoras, através da capitalização e crescimento compartilhados.

\subsection{A PROSPERIDADE E O CRESCIMENTO COMPARTILHADOS.}

No final dos anos 60 e início de 70, ocorreram alguns processos de aquisição e outros de fusão de empresas de processamento de laranja, estes foram fundamentais para o crescimento e consolidação das empresas processadoras no interior de São Paulo.

Os anos de 70 até o início de 80, o setor citrícola e agroindustrial de exportação também foi seriamente afetado pelas sucessivas crises do petróleo de 1973 e 1979, porém, logo depois, já na década de 80, ocorreu o período de maior prosperidade do complexo citrícola paulista ligados: às desvalorizações cambiais ocorridas na época e às geadas na Flórida no início de 1981.

No início da década de 70, a indústria processadora de SLCC demandava algo em torno de 20 a 25 milhões de caixas de laranja para serem processadas por safra, limitadas especialmente pela sua capacidade

\footnotetext{
${ }^{5}$ MANÉCOLO, F. Cutrale: o maior empresário de Araraquara. Jornal online K3, de 01/06/2012. Notícia Disponível em $<\mathrm{http} / / /$ www.portalk3.com.br/Artigo/personagens/cutrale-o-maior-empresario-de-araraquara>, visitado em 10/04/2014.
} 
instalada, dez anos depois, na década de 80, essa demanda por matéria-prima passa a ser de 138 milhões de caixas de laranja (MAIA, 1996).

Este crescimento considerável na capacidade instalada de processamento representou uma nova fase para o complexo citrícola paulista e uma relação onde os interesses mútuos e de reciprocidade eram maiores entre os elos da cadeia produtiva agroindustrial do SLCC, pois ambos cresciam em tamanho e capacidade produtiva.

Algumas mudanças na estrutura industrial de processamento ocorrem, como a Suconasa, por exemplo, construída em 1967, foi passada a José Cutrale, que assumiu a massa falida da empresa, passando a se chamar: Sucocítrico Cutrale. Depois, em 1967, a Companhia Mineira de Conservas vendeu 50\% das ações para o grupo italiano Sanderson, vendida totalmente em 1970 e passando a chamar-se apenas: Sanderson do Brasil S/A.

Outra mudança foi a Companhia Mineira de Conservas, que comprou a Frular/Sucolanja também em 1970. Depois, em 1976, a Citrobrasil foi vendida ao grupo Cargill. Posteriormente, a Citral, Sucorrico e a Tropsuco foram adquiridas pelo grupo Cutrale, tudo ao final da década de 70 .

As décadas de 70 e 80 mais especificamente, foi o período onde a citricultura e o próprio complexo citrícola viveu seu momento de maior prosperidade, consolidando as estruturas produtivas e a própria cadeia do SLCC.

Neste momento houve grande lucratividade no campo, especialmente com preços atrativos pagos pela caixa de laranja (PAULILLO; MELLO, 2005), incentivando a entrada de novos citricultores e a expansão das áreas existentes dedicadas à atividade.

Houve também, durante este período, o surgimento de organizações de interesse coletivo: Associtrus (1974) e a Aciesp (1987)6, que foram fundamentais na intermediação das relações com as empresas processadoras.

No campo dos negócios, as décadas de 70 e 80 representaram relações mais estáveis e coesas dos citricultores com a indústria (TROCCOLI, ALTAF, 2009), apesar de já existirem algumas diferenças pontuais nos acordos comerciais, que serão tratados na próxima seção.

Havia na relação bilateral entre citricultores e indústria um interesse por ganhos compartilhados entre os dois atores, isso pode ser verificado por documentos endereçados ao governo brasileiro da época, que demonstram preocupação quanto à segurança e os ganhos reais para as partes.

A indústria cresce e se consolida nas décadas de 70, e especialmente a partir de 1980.

"Tais fatores, aliados à elevação das cotações do suco concentrado de laranja no mercado internacional nas décadas de 70 e 80 , propiciaram níveis crescentes de remuneração aos citricultores e ainda mais às indústrias, induzindo à expansão da produção citrícola paralelamente à do setor industrial." (ELIAS, 2003, pg. 158)

Mesmo durante a primeira crise do petróleo ocorrida em 1973, que reduz drasticamente os preços e as exportações de SLCC em 1974, impactando negativamente a indústria de processamento, a crise faz com que a própria indústria crie sinergias organizacionais e de aglutinação de interesses na discussão com o Estado, através do CACEX.

Em Julho de 1974 é elaborado um documento das principais empresas processadoras, entre elas: Sucocítrico Cutrale, Avante, Citrobrasil, Sucorrico, Citral e Tropisuco; menos a Sanderson e a Citrosuco Paulista, a respeito da safra de citros daquele ano (1974), endereçada aos ministros da: Fazenda, Agricultura, Indústria/Comércio e Planejamento sobre a safra citrícola daquele ano.

No documento formal, as exportadoras requeriam um planejamento e estabelecimento de uma cota máxima de suprimentos de laranja para cada empresa processadora, já estabelecidas pela CACEX, mas que deveria seguir uma nova política de preços da caixa de laranja, para reduzir as divergências existentes entre o fechamento do contrato no ano anterior e possíveis flutuações do preço do SLCC no mercado internacional no ano seguinte.

\footnotetext{
${ }^{6}$ A representação da Aciesp vai até a década de 90, sendo que apenas a Associtrus está em pleno funcionamento e atuante junto aos interesses dos citricultores nas rodadas de negociação com a indústria processadora.
} 
O documento requeria preços do SLCC e da caixa de laranja capazes de remunerar tanto a indústria quanto os próprios citricultores, demonstrando o interesse recíproco e bilateral ligados à manutenção integridade da relação bilateral.

A indústria havia comprado laranjas em um período de alta, em novembro de 1973, a um preço fixo de Cr\$12 (doze cruzeiros) a caixa de laranja e isso impactou diretamente quando a indústria viu os preços caírem de US\$700 FOB a tonelada do SLCC em Janeiro de 1974, para apenas US\$430 FOB meses depois no início da safra.

Essa conjuntura fez com que a Citrosuco Paulista adotasse uma estratégia de dumping, vendendo os estoques de SLCC com preços inferiores a $30 \%$ dos praticados no mercado, isso colaborou para a falência da Sanderson em 1974.

Esse fato demonstra que na década de 70 o ambiente organizacional do complexo citrícola não estava estabelecido e consolidado, pois as organizações de aglutinação de interesse coletivo de citricultores (Associtrus - 1978; e Aciesp - 1987) e da indústria de processamento (Abrasucos - 1980, Anic e Abecitrus -1986) ainda iriam surgir.

Também em 70, surgem novas empresas como a do grupo familiar Branco Peres S/A em Itápolis-SP (1979), a Central Citrus em Matão, a Citrovale em Olímpia, a Citromojiana em Conchal e a Bacitrus em Mirassol (1982). Além da falência da Sanderson (1974), outros processos acontecem como o da Frutropic em Abril de 19857, criada em 1978 em Matão-SP, foi vendida posteriormente ao grupo Louis Dreyfus.

A Branco Peres em Itápolis implantou em 1985 o transporte a granel do SLCC, sendo uma das primeiras empresas no Brasil, junto com a Cargill no início da década de 80 em Bebedouro, a exportar o suco a granel desde a unidade industrial até as empresas compradoras reconstituidoras sem a utilização de tambores (MARINO; AZEVEDO, 2001) (NEVES; JANK et.al., 2006).

O contrato estabelecido no final da década de 70 até 1985 (1978 a 1985) foi o modelo de contratos a preço fixo, onde os preços da caixa de laranja eram fixados em moeda nacional a partir dos estoques do volume do SLCC e com intermediação do governo através da CACEX (Carteira de Comércio Exterior do Banco do Brasil). A CACEX representava uma terceira parte na transação e que, nesta fase, representava aquele que mantinha os interesses compartilhados entre as partes na negociação.

Uma das experiências marcantes e importantes da década de 80 foi quando a cooperativa de citricultores (Coopercitrus) assume a Frutesp em 1980. A Frutesp foi vendida em 1993 para um grupo multinacional francês, a Louis Dreyfus Commodity (LDC), passando a se chamar Coimbra-Frutesp.

A Frutesp representou um modelo de contraponto na formação de preços para a caixa de laranja, pois ao final do ano/safra se pagava uma média dos preços pagos pela caixa de laranja pelas outras empresas, e acrescia-se a isso a distribuição de $50 \%$ dos lucros da indústria processadora8.

A própria atuação da Frutesp, como empresa ligada aos interesses tanto das empresas exportadoras quanto dos citricultores, especialmente a partir de 1979 (quando passa a ser gerida pela Coopercitrus Industrial9), permitiu um equilíbrio de forças e estabilidade das relações contratuais formais entre as partes na década de 80 e início de 90 , pois a divisão de $50 \%$ dos lucros pela venda do suco com os citricultores, definida pela Frutesp, permitia uma relação mais justa e duradoura, isso até sua venda em 1992 para o grupo francês Louis Dreyfus Commodities (LDC).

Esse método de transmissão de preços para caixa de laranja feito pela Frutesp-Coopercitrus, mesmo não sendo bem visto pelas outras empresas de processamento, começou a ser referência no mercado para estabelecer o preço da caixa de laranja para a indústria. Naquele momento, a Frutesp-Coopercitrus era uma empresa que representava os reais interesses entre as partes produtora rural (citricultores) e indústria (processador).

\footnotetext{
${ }^{7}$ Disponível em <http://www.jusbrasil.com.br/diarios/7210478/pg-82-poder-judiciario-caderno-1-diario-oficialdo-estado-de-sao-paulo-dosp-de-16-04-1985>, visitado em 13/02/2014.

${ }^{8}$ FRANCO, L. Entrevista: “Queremos indenização. Nosso prejuízo soma US\$7 bilhões.” Revista Globo Rural online. Edição 296, Jun/2010. Disponível em $<$ http://revistagloborural.globo.com/Revista/Common/0,,ERT149206-18286,00.html >, visitado em $10 / 05 / 2014$

${ }^{9}$ Ver história da Frutesp: <http://www.coopercitrus.com.br/?pag=revista\&p=materia\&codigo=6625>, visitado em 20 de Março de 2015.
} 
Tanto assim, que houve no mesmo período o surgimento do contrato padrão (1986 a 1995), que representou uma nova forma de compra pelas empresas processadoras da caixa de laranja e estabelecia ganhos aos produtores de laranja a partir do cálculo do preço utilizando as cotações de preços do suco de laranja concentrado e congelado em Nova Iorque.

No início da década de 90 ocorreu um processo de captura de fornecedores da Frutesp, através de preços muito mais atrativos por parte das outras empresas, oferecendo até US\$10,0010 (dez dólares) a caixa de laranja, enquanto na época o preço médio era US\$4,00 (quatro dólares) - safra 1993/94. Quando a Frutesp foi vendida em 1994, o preço pago na safra caiu drasticamente para US\$1,50 (um dólar e cinquenta centavos) (FRANCO, 2010).

0 pagamento de preços altos era possível dada à alta taxa de lucratividade das empresas processadoras, segundo a revista Veja de 14 de Maio de 2003, edição de nํ⒈802, a taxa de retorno da Sucocítrico Cutrale já havia ultrapassado na década de 80 a casa dos 70\% (SECCO; PATURY, 2003), segundo indica reportagem da revista.

Observando o número de extratoras para o processamento da laranja, houve um aumento realmente significativo nas décadas de 70 e 80, saindo de 56 para 511 extratoras respectivamente, demonstrando um crescimento da indústria de processamento em sua capacidade instalada.

GRÁFICO 1: Evolução do número de extratoras nas diferentes décadas.

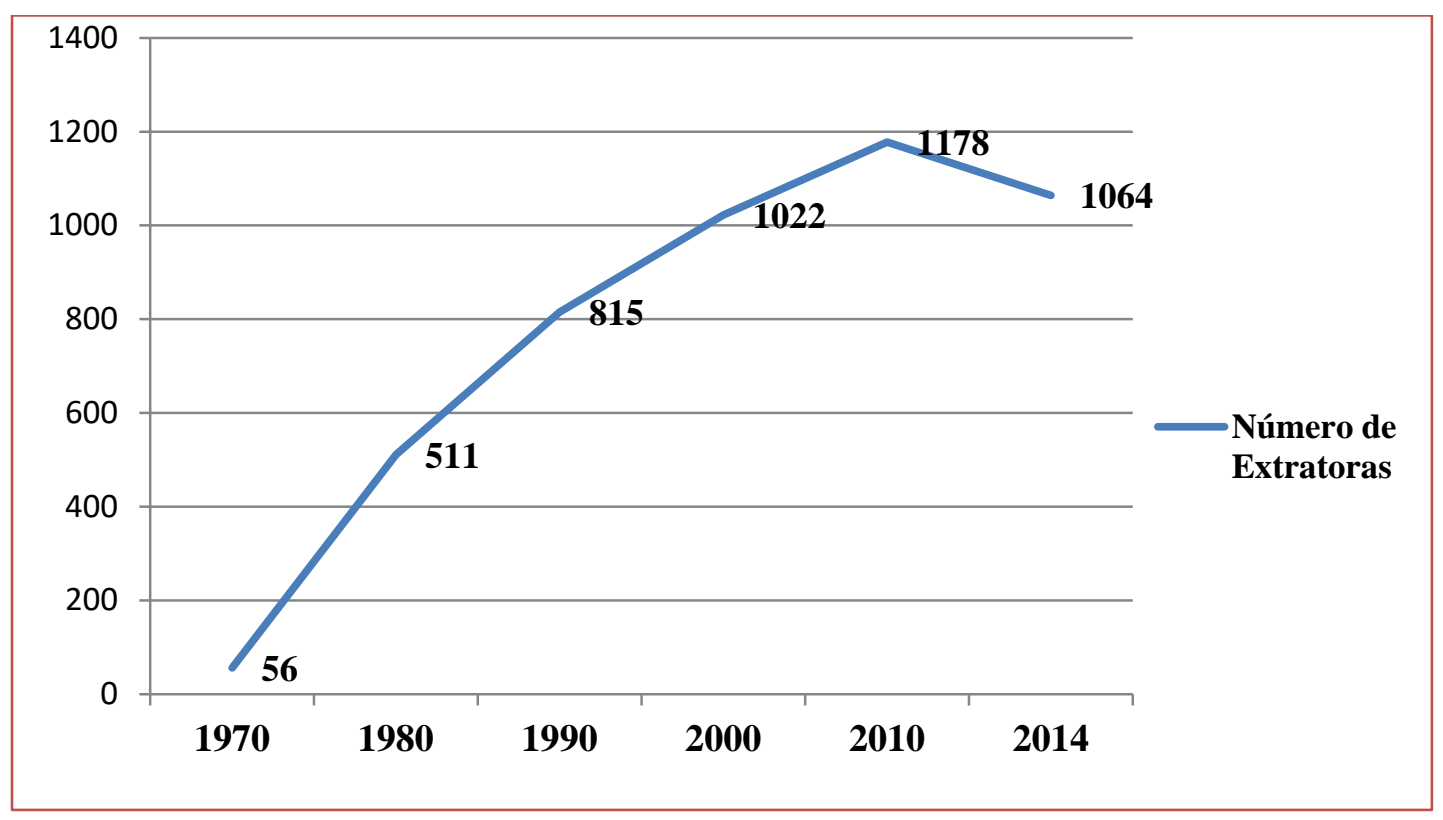

Fonte: NEVES coord., 2009 e dados compilados da CitrusBR no ano de 2014.

Na década de 90, fase de maturidade do complexo citrícola paulista, ocorre uma maturação dos vários investimentos realizados na década anterior de 80, especialmente das novas áreas de plantio e um número ainda mais expressivo de extratoras 815, demonstrando o crescimento da capacidade instalada da indústria.

O plantio de novas áreas de laranja da década passada provocou um aumento considerável da disponibilidade de matéria-prima para a indústria, que associado aos volumes produzidos na Flórida, fez com que os preços da caixa de laranja caíssem consideravelmente durante a década de 90 . É o início de

${ }^{10}$ Esses contratos eram "de gaveta", ou seja, não estavam registrados como contratos reais e em vigência. Os "contratos de gaveta" são comuns em transações ou mesmo relações contratuais diversas que são criados para selar acordos que não poderiam ser registrados ou formalizados juridicamente, por motivos vários e até oportunistas, mas que vinculariam compromissos assumidos e de interesse das duas partes. Alguns desses contratos de compra e venda de laranja com preços muito acima dos praticados no mercado, eram guardados em locais onde apenas duas pessoas: um representante da indústria e o citricultor (ou representante) poderiam ter acesso; conforme relato de um citricultor durante aplicação do questionário. 
uma nova fase que representou uma maturidade necessária para a consolidação do complexo citrícola paulista.

\subsection{A MATURIDADE: CONSOLIDAÇÃO E DIFERENÇAS.}

A crise da citricultura do início da década de 90, diferente das anteriores, representou uma maior maturidade dos atores ligados à cadeia produtiva do SLCC, uma vez que foi um momento de transformações setoriais e novas experiências, inclusive de governanças: integração para frente de citricultores (Cambuhy em Matão - 1991; Citrovita em Catanduva; Frutax em Monte Azul Paulista - 1994 a 1997, a Frucamp em Catanduva - 1995 e nem iniciou operação), formação de pools e o toll processing da Montecitrus - uma quase-integração (NEVES, 1995).

Em 1991, entra em funcionamento a Citrovita Agroindustrial, em Catanduva-SP, empresa do grupo Votorantim que, assim como a Cambuhy do grupo Moreira Salles, já possuía uma grande propriedade rural voltada para citricultura, Moreira Salles em Matão-SP e Votorantim em Itapetininga-SP. Essa produção de laranjas incentivou o grupo Votorantim a realizar o investimento no processamento.

No início de 1990, com os preços da caixa de laranja direcionados para indústria caindo, ocorreram divergências e acusações entre os dois elos da cadeia produtiva do SLCC no Brasil: citricultores e empresas de processamento.

Neste período de indecisão e início de crise na citricultura, ocorreu o surgimento de novas formas organizacionais, algumas híbridas, como os pools, uma associação coletiva informal para a venda de laranja para a indústria. Houve também o fortalecimento de organizações de interesse coletivo que surgiram no período anterior, a Associtrus (1974) e a Aciesp (1987), além de algumas experiências de integração para frente de alguns grandes produtores de laranja.

O conflito do início de 90 e venda da Frutesp em 1993 culminou com a apresentação pela Associtrus e Aciesp em 1994, junto à SDE (Secretaria de Direito Econômico), de uma denúncia de cartelização entre doze (12) empresas e imposição de preços na negociação da caixa de laranja, além de verticalização da indústria.

A SDE aceitou o argumento das entidades de representação coletiva (Aciesp e Associtrus) e abriu um processo junto ao CADE (Conselho Administrativo de Defesa Econômica). Porém, a autoridade de defesa econômica e da concorrência fez um acordo com a indústria para encerrar o processo: compromisso de cessação em 1995.

O compromisso de cessação (MARINO; AZEVEDO, 2001) estabelecido, impôs algumas sanções às empresas de processamento, a primeira foi acabar com a formalização do contrato padrão (1986 a 1995) nas negociações com os citricultores e a segunda foi acabar com o processo de integração para trás das empresas de processamento, chamado também de compra de pomares próprios das empresas.

A existência de diferenças de interesses entre os elos da cadeia produtiva, citricultores e processadores, se deve ao fato da indústria buscar reduzir ao máximo os custos da matéria-prima (caixa de laranja) e, de outro, os citricultores, reféns do poder de barganha (AZEVEDO, 1996) da indústria, quererem preços garantidores de seus ganhos para manutenção da atividade citrícola.

A saída da Frutesp, pela própria orquestração de ações promovidas pela indústria (captura através de preços mais elevados de alguns fornecedores de laranja), desencadeou o início de alguns questionamentos sobre o próprio desenho do contrato padrão e a necessidade de uma terceira parte, como era o CACEX na década de 80, para a manutenção da estabilidade das relações naquele momento.

Até o final da década de 90, o acordo de cessação das empresas processadoras com o CADE foi parcialmente cumprido, pois houve mesmo o fim do contrato padrão em 1995, porém com a continuidade das práticas anticoncorrenciais de compra de novas fazendas para plantio de laranja (pomares próprios) pelas empresas processadoras.

A indústria ainda manteve uma estrutura de mercado concentrada, oligoposônica, sendo que esta estrutura acentuou os conflitos de interesses e o próprio desenho contratual idiossincrático resultante, nunca o contrato formal esperado pelos produtores de laranja. As diferenças de poder (ITO, 2014) e interesses entre os dois elos podem ser associadas a uma intensificação da crise da citricultura na década seguinte. 
O acordo de cessação da indústria com o CADE só fez com que os citricultores sofressem algumas retaliações nas negociações do preço da caixa de laranja por parte da indústria, contribuindo para a diminuição do seu poder de barganha e aumento das assimetrias (AZEVEDO, 1996) nas negociações do contrato, além de intensificar a coalisão tática das empresas (MARINO; AZEVEDO, 2001).

Devido ao momento crítico por que passava o complexo citrícola com a venda da Frutesp, denúncia de cartelização e fim do contrato padrão, esta fase é considerada de maturidade setorial mas com início das diferenças, especialmente sobre as formas de negociação e desenho do contrato.

Esta fase de maturidade, primeira grande crise do complexo citrícola, fez com que houvesse a utilização de diferentes estratégias tanto por parte da indústria, com integração para frente e para trás da cadeia, como também dos citricultores, com a formação de pools e a integração para frente na cadeia produtiva agroindustrial do SLCC. Neste período, os citricultores foram os que saíram mais fragilizados numericamente e economicamente.

Nesta fase surgem diversas experiências de empresas processadoras, nascidas da produção citrícola. Estas formas organizacionais alternativas se contrapõem a estrutura de mercado dominante, e em 1994, além da Frutax e a Frucamp já citadas, surge a Citrol Bartol em Bebedouro-SP, com capacidade de processamento de quatro (4) milhões de caixas, e a Lins Citrus em Lins-SP, com capacidade de dez (10) milhões de caixas (PAULILLO, 2000).

A capitalização de alguns citricultores nas décadas passadas e a ideia empreendedora de investimento em produtos de maior valor agregado, como o suco e seus subprodutos, atraem esses atores e investidores.

Em 1993, a Cambuhy constituiu uma joint-venture com o pool de citricultores do grupo Montecitrus que processava sua produção na Cargill em Uchoa (estabelecida em 1984), através do arrendamento de parte da capacidade instalada da empresa (toll processing). Este caso é importante, pois representou estratégia distinta de um grupo de citricultores que resultou em outra relação de toll processing com a venda da Cambuhy para a Citrovita em 1998.

A Frutax, da família Blanco que saíram do pool de citricultores da Montecitrus, possuía onze (11) extratoras de suco em 1994, deixando de operar logo em seguida em 1997, pois encontrou fortes barreiras à entrada no mercado do SLCC, que era totalmente dominado pelas empresas líderes e que impunham certas restrições para as empresas entrantes.

Em 1996 surge a Sucorrico S.A. em Araras-SP, com capacidade de processamento de seis (6) milhões de caixas de laranjas por safra, vindas dos cento e vinte e três (123) citricultores proprietários da planta de processamento. Em 1997 a Sucorrico firma contrato de venda do SLCC com o Cutrale por cinco anos, isso faz a planta dobrar sua capacidade de processamento. A empresa foi vendida em 2005 para a Citrovita, grupo Votorantim, parte da estratégia que dominou o complexo citrícola a partir de 2000: a concentração industrial (NEVES; JANK, et.al, 2006).

A Citrus Kiki, fundada em 1999 na cidade de Engenheiro Coelho-SP, também teve o mesmo destino da Sucorrico de Araras, pois a empresa operou parcialmente alguns anos e depois foi arrendada para o grupo Louis Dreyfus Citrus em 2005.

O domínio e a capacidade de captura das empresas líderes, com forte influência sobre os compradores internacionais do SLCC (parcerias Coca Cola, Pepsico, Nestle, Gerber Foods, Eckes-Granini, entre outras), tornou praticamente inviável os investimentos em processamento realizado por alguns citricultores.

As empresas entrantes, que não se alinhavam aos interesses das empresas líderes, eram compradas ou não conseguiam competir, na maioria das vezes porque não tinham como oferecer preços competitivos como as empresas líderes faziam aos compradores do SLCC no mercado internacional ou mesmo porque não conseguiam comprar matéria-prima suficiente para o processamento e utilização da capacidade instalada das suas unidades, elevando os custos fixos unitários.

Neste sentido, já havia forte articulação de interesses das empresas já estabelecidas e com recursos de poder diversos sobre as estratégias de compra da matéria-prima (laranja) e de distribuição e comercialização do SLCC, de maneira mais eficaz e com menores custos do que as empresas entrantes.

Essa vantagem competitiva não vinha apenas das competências adquiridas por serem as primeiras a entrar (Cutrale, Citrosuco, Cargill, Coinbra-Frutesp/LDC), mas também devido aos investimentos realizados no transporte a granel: estoque com tanques refrigerados, caminhões com tanques refrigerados e leasing de navios com transporte a granel. 
As empresas que se alinharam aos interesses das empresas líderes, como a Sucorrico em Araras, a Branco Peres em Itápolis, a Cambuhy em Matão, a Citrovita em Catanduva e o próprio grupo Montecitrus; conseguiram um período de sobrevida maior. A Sucorrico foi vendida a Citrovita em 2005, assim como a Cambuhy em 1998 para a Citrovita, sendo depois esta mesma incorporada a Citrosuco através de um processo de fusão. A Branco Peres foi incorporada a Cutrale em 1998 e desativada em 2012.

A Montecitrus11 é pool de citricultores que de 1985 a 2012 fez experiências diversas com a indústria, como: toll processing com a Cargill (1985-1993), joint-venture com a Cambuhy MC (1994-1998) e depois novamente um toll processing com a Citrovita (1999 a 2012).

A maioria dos processos de fusão e aquisições ocorreram após 2000. A passagem de um período de maturidade para um processo de desagregação e estagnação dos produtores de laranja, a ser descrito na seção seguinte, correspondem especialmente ao fim do contrato padrão (1986 a 1995) e o início dos contratos específicos ou idiossincráticos (1996 a 2018), estabelecidos caso a caso entre citricultores e empresas processadoras.

Durante a década de 90, as vantagens competitivas das empresas líderes não permitiram a expansão das estruturas produtivas nascente. Isso, associado aos sucessivos recordes de safras durante esta fase, foi importante na imposição de regras nos contratos específicos, caso a caso, feitos pela indústria com os diferentes citricultores e apresentando diferentes métodos de precificação.

Essa imposição de cláusulas contratuais específicas, caso a caso, associado aos baixos preços pagos pela caixa de laranja provocou uma crescente descapitalização dos citricultores e sua crescente saída da atividade após 2000 .

A saída de citricultores, associada à diminuição da competitividade entre as empresas processadoras causada pela elevada concentração industrial (vertical e horizontal), demonstrou a total dependência dos citricultores, e das empresas entrantes, daquelas empresas líderes no período de maturidade do complexo citrícola.

Além disso, está havendo uma reflexão dos órgãos de defesa da concorrência, como o CADE, sobre as decisões realizadas no passado e a necessidade de consolidação de um novo ambiente institucional para a condução do complexo citrícola paulista.

O período de declínio e desequilíbrios no complexo citrícola paulista, especialmente de fragilidade e descapitalização dos citricultores, será tratado na seção seguinte do capítulo, identificando alguns pontos que diminuíram a coesão e o equilíbrio de forças entre citricultura e empresas de processamento ligados ao modelo de contratos específicos.

O período de desequilíbrio (pós anos 2000) até 2018, contrasta com o momento de prosperidade e crescimento compartilhados da década de 70 e 80 e de maturidade dos investimentos na década de 90 , onde houve o crescimento e o fortalecimento setorial integral.

\subsection{DESEQUILÍBRIO: CARTEL, CONCENTRAÇÃO E CONFLITOS.}

No início de 2000, especificamente a partir do fim do contrato padrão em 1996, a situação setorial no complexo citrícola paulista se agrava e o conflito, antes velado, agora se tornam iminentes, inclusive com denunciação de contratos por parte das empresas processadoras com início de processos na justiça pelos citricultores (CARVALHO, 2015).

Há disputas bilaterais entre os dois elos da cadeia produtiva agroindustrial, onde os citricultores abrem diversos processos que chegam até as cortes de justiça, nas suas diversas esferas e fóruns da justiça estadual e federal.

A principal argumentação da disputa se resume às condições contratuais impostas e não discutidas (negociadas) pelas empresas processadoras, como a obrigatoriedade do transporte pelos citricultores da

\footnotetext{
${ }^{11}$ Em 1986 a Montecitrus estabeleceu um acordo estratégico e pioneiro com a Cargill (empresa norte-americana com reputação e credibilidade em vários complexos agroindustriais de commodities), foi o contrato chamado toll processing, que acordava o processamento de sua produção de laranjas utilizando a capacidade instalada ociosa da unidade processadora da Cargill em Uchoa-SP. Além da Montecitrus, dois outros pools: a Concitrus (de Bebedouro) e a Citrosantos (de Cajobi); também estavam alugando capacidade ociosa da indústria para processar sua laranja (NEVES, 1995; CARVALHO, 2005).
} 
fruta e a combinação prévia entre elas dos preços a serem pagos pela caixa de laranja: o cartel. Além disso, alguns litígios surgem do não cumprimento de cláusulas nos acordos e compromissos assumidos, que prejudicaram e levaram os produtores ao prejuízo.

A própria denúncia feita através das organizações de interesse coletivo (Associtrus e na época a Aciesp) junto ao SDE em 1994, e encaminhada ao CADE, sobre a orquestração de preços por parte da indústria e a cartelização, provocou uma retaliação da indústria processadora a partir do fim do contrato padrão (1996), pois procurou impor, através de seu poder de barganha, as condições contratuais unilateralmente favoráveis a ela.

Em 2000, cerca de 200 citricultores acionaram conjuntamente a Cutrale na justiça contra o descumprimento contratual de recebimento de cinco (5) milhões de caixas de laranja, segundo alegaram os produtores, nos dias programados para a entrega, os portões para o recebimento da fruta estavam fechados (SECCO; PATURY, 2003).

A partir de 2000, inicia-se uma fase de declínio e desequilíbrios no complexo citrícola paulista, que afetou diretamente a cadeia produtiva agroindustrial do SLCC, porém, não a indústria de processamento da laranja que continuou se consolidando tanto verticalmente (expansão de pomares próprios) quanto horizontalmente (concentração industrial e investimentos pesados em logística distribuição).

Os recordes de produção citrícola ocorridos em períodos anteriores, especificamente nas safras 1997/98 e 1999/00, o que iria acontecer apenas doze anos-safra depois na safra 2011/12, também auxiliaram a indústria a manter seus estoques reguladores de fornecimento equilibrados, garantindo a cadeia de suprimentos e o mercado internacional do SLCC, assim como o do SLNC.

Os recordes na produção de laranja e a alta eficiência apresentada pela indústria contrasta com a decadência do elo representado pelos produtores de laranja.

Os citricultores (pequenos, médios ou grandes) foram taxados de ineficientes, uma classificação e percepção falsa devido ao baixo poder de barganha que afetava a negociação dos preços com a indústria (lucratividade baixa ou nula) associada à queda de produtividade por pé-de-laranja (GIORGI, 2014), devido principalmente ao aumento dos custos de produção dado o crescente ataque de novas pragas e doenças no pomar.

Havia uma incidência maior de pragas e doenças em algumas regiões produtoras específicas do interior de São Paulo, o que interferiu na produtividade por pé. Mesmo alguns estudos apontando para o aumento da produtividade por hectare pelas novas técnicas de adensamento e irrigação (CASER; AMARO, 2004), nem todos citricultores se capitalizaram o suficiente para reinvestir nestas técnicas e infraestrutura produtiva.

Há uma falsa impressão, ou uma percepção incorreta, de ineficiência da produção citrícola em relação à moderna capacidade de produção, processamento e logística da indústria.

Talvez, o que "é cruel" e começa a ocorrer a partir de 2000 foi uma deterioração das relações bilaterais na cadeia produtiva do SLCC e seus subprodutos e de uma má distribuição dos ganhos no complexo citrícola, não uma ineficiência da citricultura.

As reais causas da estagnação e crise no complexo, especialmente na citricultura, ocorrem pelo impacto de alguns fatores associados, como a: perda das competências centrais de cada ator na cadeia produtiva do SLCC, das governanças híbridas (contrato formal) com possível aumento dos custos transacionais (assimetrias) e aumento das responsabilidades contratuais específicas dos citricultores.

No que diz respeito ao primeiro fator de impacto no complexo, esse se deve a uma visível perda de competências e forças dos atores, uma vez que a indústria torna-se também produtora de laranjas, isso torna fraca a coesão relacional entre citricultores e empresas de processamento dada a diminuição considerável da dependência bilateral, afetando a estabilidade e comprometendo o futuro do complexo citrícola paulista no longo prazo.

O segundo fator, que colabora para a estagnação do setor, é o aumento do poder de negociação da indústria ocorrido com o fim do contrato padrão em 1995, com ampliação da capacidade de fornecimento próprio de laranja (AZEVEDO, 1996). Isso incorre também numa escalada dos custos transacionais advindos de algumas assimetrias informacionais e de poder (ITO, 2014) criadas entre os dois elos, especialmente na negociação e desenho contratual estabelecidos: contrato resultante.

0 modelo contratual específico, após 1996 e vigente até 2018, apresenta elementos escritos, normativos, que regulam a transação bilateral e dá garantias de forma apenas unilateral. 
Neste tipo de contrato, contratos específicos, estabelecidos pelas empresas processadoras na compra de laranja, após 1996 até 2018, a estrutura produtiva de suporte a atividade citrícola, como: contratação de trabalhadores temporários para a colheita e a contratação de logística para transporte da safra até a unidade de processamento; passam a ser responsabilidade contratual do citricultor, sem a contrapartida em melhores preços pela caixa de laranja.

Em suma, a perda das competências centrais, específicas e tácitas de cada ator na cadeia produtiva agroindustrial do SLCC, com reflexos na diminuição do grau de dependência mútua, conduziram a um aumento do poder de mercado da indústria e elevação dos custos transacionais, um período pós-contrato padrão, especificamente após o ano de 2000, de estagnação do complexo citrícola paulista.

Além disso, na forma de governança híbrida adotada, o contrato de compra e venda de laranja durante a vigência dos contratos específicos (1996 até 2018), não ocorre a divisão equânime das responsabilidades contratuais, isso levou a um aumento das assimetrias (de poder e de informações) e consequente elevação dos custos transacionais, a saber, na negociação e no desenho contratual resultante, devido aos problemas de má-adaptação.

A cultura perene da laranja, associada ao alto grau de concentração industrial, limitaram muito a capacidade de manobra dos citricultores durante a fase de declínio e desequilíbrio do complexo, tornando os produtores de laranja capturados pela indústria e estabelecendo um grau de dependência elevada por parte do citricultor.

A estagnação do complexo citrícola é evidenciada pela alta dependência do citricultor da indústria processadora na comercialização da laranja, pois não há outros canais de comercialização consolidados capazes de absorver a laranja excedente, não havendo estratégias consolidadas no mercado interno para tal.

As disputas que deveriam ter sido finalizadas com o "Termo de Compromisso de Cessação" (TCC) assinado em 1994 pelas empresas processadoras, que administram as práticas anticoncorrenciais e que culminou no fim do contrato padrão (1995), não pôs fim às práticas na negociação do preço da caixa de laranja. Por não acabar com tal prática anticoncorrencial de combinação de preços, um novo processo foi aberto em 1999, julgado apenas recentemente, em 28 de fevereiro de 2018, condenando as empresas processadoras pela prática de cartel.

Para isso, foram necessários os acordos de leniência das empresas processadoras que se declararam culpadas de tal prática, além de juntada as provas da "Operação Fanta" desencadeada em 24 de janeiro de 2006, documentos ainda arquivados no CADE.

Por outro lado, a baixa dependência da indústria da produção de laranjas dos citricultores independentes, dada a alta capacidade de abastecimento das plantas de processamento com laranjas próprias, criaram distorções endógenas à cadeia produtiva agroindustrial do SLCC que não poderiam ser facilmente resolvidas sem a intervenção de órgãos reguladores de defesa da concorrência como o SDE e o CADE. Sendo assim, o citricultor entra numa fase de crise (GIORGIO, 2014), devido tanto a fatores agronômicos, como também econômicos.

Alguns estudos na área agronômica apontam, por exemplo, para a queda de produtividade por pé-delaranja12 nas últimas décadas, causado por dois fatores associados: primeiro pelo esgotamento do modelo de aumento de produtividade proporcionado pela revolução verde, com utilização intensiva de adubos e defensivos químicos que aumentaram o ataque e a agressividade de pragas e doenças na citricultura, como exemplo o greening; e segundo, pelo empobrecimento do solo decorrentes do primeiro (GIORGI, 2014).

Outros estudos apontam para uma outra direção (CASER; AMARO, 2004), ou seja, o aumento da produtividade, não por planta, mas sim na média de caixas por hectare. Sendo que, as adoções de técnicas de adensamento e de tratos culturais elevaram a produtividade por hectare segundo banco de dados do IEA (BANCOIEA, 1983-2004) e apontado no estudo realizado por Denise Viani Caser e Antonio Ambrosio Amaro (2004).

\footnotetext{
${ }^{12}$ Segundo relata um recente livro que trata sobre a crise na citricultura, lançado em 2014 por Fábio Di Giorgi, nos últimos 30 anos houve uma queda considerável da produtividade por pé-de-laranja, sendo que a planta em 1983 produzia em média 2,0 caixas de 40,8 kg por pé, em 2004 a média caiu para 1,8 caixas por planta. A média de produtividade por planta, que esteve em torno de 1,85 caixas entre 1970 a 1990 , cai para 1,75 caixas por planta para o período entre 1990 e 2004, segundo próprio relato de Fábio Di Giorgi na página 15 de introdução do seu livro.
} 
A elevada centralidade e dominância de poucas empresas de processamento no direcionamento do complexo citrícola, apesar de aparentar um elevado grau de eficiência e capacidade de coordenação destas, colaborou na verdade para atestar a incapacidade das empresas processadoras em articular ganhos compartilhados com os citricultores que restaram, criando acordos bilaterais de ganhos apenas unilaterais.

Esses ganhos financeiros podem ser evidenciados pela elevada capitalização do setor agroindustrial, sendo que as principais empresas processadoras (Cutrale, Citrosuco e Louis Dreyfus Citrus) investiram na compra de unidades de processamento no Brasil (concentração industrial) e exterior (EUA e Europa) e investimentos altos também no transporte a granel do SLCC, em tanques refrigerados nas unidades processadoras, portos do Brasil e do exterior (estoques reguladores), assim como em navios para transporte marítimo.

A expansão horizontal e vertical, primeiro com a compra de unidades de processamento no Brasil e no exterior e segundo com os investimentos em pomares próprios e no transporte a granel do SLCC e do SLNC; permitiram um salto competitivo considerável e benéfico para a indústria, porém com pouco impacto e contrapartida para os citricultores.

Durante uma fase de crescimento e expansão das empresas processadoras, os citricultores viam seus custos de produção por caixa aumentarem ano a ano, devido aos: tratos culturais com adubação e pesticidas mais caros, produtividade por planta cair (incidência de pragas e doenças) e colheita/transporte da fruta até as unidades de processamento repassados; assim como ocorreu nos custos de transação, que será observado nos contratos de compra e venda de laranja no capítulo seguinte.

Por isso, nos últimos anos e a partir de 2012, houve a tentativa de uma mudança de postura da indústria e dos órgãos de defesa da concorrência (CADE) em criar um ambiente institucional propício e justo para a negociação da caixa de laranja, de maneira que tanto pequenos, quanto médios e grandes citricultores possam usufruir da estrutura, margens e dinâmica alcançadas pelos outros elos da cadeia produtiva do SLCC, SLNC e os subprodutos.

Relações unilaterais ocorridas a partir de 2000, onde apenas uma das partes ganhava, representou a fase de declínio e instabilidade na citricultura paulista, pois houve intensa concentração industrial, contínua integração para trás e para frente da indústria e deterioração das relações com os citricultores - elevação dos custos de produção e transacionais.

Esses elementos combinados: concentração industrial, integração para trás e contratos formais com ganhos unilaterais; representam uma fase de crise que perdura mais de uma década na citricultura e consequentemente no contexto de desequilíbrios dentro do complexo citrícola paulista13.

Nesta fase que se inicia em 200014, houve perda de eficiência do complexo citrícola e da citricultura, afetados pela crise institucional e das disputas organizacionais, que ampliaram os custos transacionais entre citricultores e processadores e afetou de maneira mais direta o produtor de laranjas, elo mais frágil, pois a indústria continuou crescendo horizontal e verticalmente.

A Coinbra-Frutesp, atual LDC (Louis Dreyfus Citrus) de capital francês, comprou uma planta agroindustrial em 2012, a Cocamar em Paranavaí-PR, capaz de processar sete (7) milhões de caixas por safra, um adicional às plantas em São Paulo e descentralizando um pouco o fornecimento de matéria-prima. Neste negócio específico a LDC venceu uma disputa com a Cutrale, e agora em 2014 tem capacidade de processar cerca de 80 milhões de caixa de laranja por safra. A LDC ganhou a disputa que travara com a Cutrale

${ }^{13}$ Isso é uma situação totalmente discrepante do ocorrido na maioria dos setores do agronegócio e produtores agrícolas no Brasil a partir de meados 2005, pois foi um período de ganhos e margens crescentes para os agricultores vendedores de commodities devido ao aumento de preços ocorrido na maioria dos mercados internacionais, uma conjuntura favorável que contrasta com a citricultura em crise neste período.

${ }^{14}$ A crise é o resultado também de decisões tomadas anteriormente, especialmente ligadas à mudança nas regras do jogo econômico, por exemplo, as estabelecidas pelo CADE em 1995 quando acabou com o contrato padrão. Esta decisão afetou diretamente o ambiente institucional vigente e as estruturas de governança no complexo citrícola, conduzindo-o a uma crise devido à intensificação da concentração industrial (oligopólio e oligopsônio) e a ampliação dos pomares próprios da indústria; que associado ao aumento dos custos produtivos advindo das novas pragas e doenças, foi fatal para a maioria dos citricultores. 
porque ofereceu uma garantia de negociação contratual por dez (10) anos com os cooperados a Cocamar15.

\section{CONSIDERAÇÕES FINAIS.}

A estagnação e a crise por que passa o complexo citrícola são elementos preocupantes para todos os agentes e participantes direta ou indiretamente complexo agroindustrial da laranja, e também para todos os demais atores indiretamente envolvidos e, por isso, existe uma preocupação das organizações de interesse coletivo (Associtrus e CitrusBR) em encontrar uma nova trajetória: conciliadora e renovadora.

Busca-se uma nova fase para recuperação dos pequenos e médios citricultores, aumento da coesão contratual e maior estabilidade nas relações bilaterais, transformando o atual cenário e fase do complexo citrícola paulista de desequilíbrio e conflitos iniciado em 2000 e imperando com os contratos específicos das empresas processadoras, que nada amenizam o problema dos preços da caixa de laranja enfrentado pelos citricultores.

A necessidade de mudanças no ambiente institucional, das regras do jogo, tem gerado uma grande rodada de discussões entre os principais representantes do complexo: Associtrus e a CitrusBR; na tentativa de criar um novo marco legal para a construção do Consecitrus e de um novo modelo contratual.

As empresas processadoras têm um papel central e de agente coordenador da cadeia produtiva agroindustrial, as empresas processadoras, e deveriam assumir o papel conciliador e coadjuvante no processo de restabelecer os ganhos compartilhados do complexo citrícola paulista. A tentativa em instalar uma Câmara Setorial da Cadeia Produtiva da Citricultura16 em 2004, não surtiu o efeito desejado, pois não houve adesão direta das entidades representativas das empresas de processamento, sendo as maiores interessadas e com real capacidade de coordenação do complexo citrícola.

0 ambiente institucional, representado pelas regras formais e informais criadas a partir de 2000, está se modificando paulatinamente em direção a um caminho distinto do encontrado em 1995, com o fim do contrato padrão e a desregulamentação de preços.

Neste sentido, existe a busca dos atores envolvidos, citricultores e indústria, para a criação de um acordo comercial conciliador e padrão entre os dois elos, através do Consecitrus, com a mediação do governo através do CADE, sendo que a câmara setorial da citricultura não foi eficaz nestas negociações.

Estes novos termos contratuais serão possivelmente lastreados definitivamente por uma entidade externa, uma terceira parte, representada pelo Consecitrus, com representação do ambiente organizacional tanto dos citricultores (Associtrus) quanto da indústria (CitrusBR), e criará as regras comuns a serem adotadas em todos os contratos formais no futuro.

O novo modelo contratual que envolve o trabalho de criação e consolidação do Consecitrus representa esta tentativa de transformação e renovação dos princípios que consolidaram a citricultura e a indústria, baseado na busca pala mutualidade e dos ganhos compartilhados presentes no período de crescimento da década de 70 e 80, mas deixados no período de maturidade e desequilíbrios a partir de 90 até 2018.

O ambiente organizacional representado pela Associtrus (citricultores), FAESP (poder público estadual), a Sociedade Rural Brasileira (SRB - proprietários rurais) a CitrusBR (indústria) têm se mostrado confiante neste novo modelo representado pelo Consecitrus, e vem discutindo os elementos que irão compor a governança transacional, que devem levar em consideração o histórico relacional anterior e os princípios dos ganhos compartilhados necessários para o sucesso bilateral no futuro.

Neste sentido, a fase de declínio, estagnação e desequilíbrios no complexo citrícola após 2000 é cheia de assimetrias e indefinições no setor, e uma discrepante relação bilateral com grande desigualdade na divisão dos ganhos relativos à venda do SLCC, do SLNC e dos subprodutos no exterior com os citricultores (FIGUEIREDO; SOUZA FILHO; PAULLILO, 2013).

15 A notícia veiculada pela "Agencia Estado" de 23 de Março de 2012, disponível em <http:/g1.globo.com/ economia/agronegocios/noticia/2012/03/ldc-vence-cutrale-em-disputa-por-fabrica-de-suco-da-cocamar.html> , visitado em 20/02/2014.

16 A câmara da citricultura foi instituída formalmente em 16 de Julho de 2004 no auditório da Estação Experimental de Citricultura de Bebedouro, em São Paulo, e institucionalmente através da portaria $n^{\circ} 516$, publicada em 22 de Dezembro de 2005 no Diário Oficial da União. 
Ainda em negociação, e quase desacreditado, o Consecitrus poderá ser a saída dos citricultores que permanecem na atividade, criando um ambiente institucional com melhor capacidade de planejamento, pois pode diminuir sensivelmente os riscos relativo aos preços da caixa de laranja, para isso as empresas de processamento, e a CitrusBR como seu representante, deveria proporcionar uma nova trajetória para o complexo citrícola paulista.

\section{REFERÊNCIAS}

[1] ARAÚJO, G.S. Mudanças nas relações contratuais na citricultura: um estudo de caso. Dissertação de Mestrado. Universidade Federal de São Carlos, 2006.

[2] AZEVEDo, P. F. Integração Vertical Parcial: instrumento de barganha ou de eficiência - o caso do sistema agroindustrial citrícola. Anais do 24ํ․ Encontro Nacional de Economia (ANPEC), Águas de Lindóia. Vol II, pp.420-439, 1996.

[3] BARROS A.M., PEROSA, R., PERINA R.A. Conteúdo do Modelo Consecitrus: respostas às dúvidas quanto aos princípios metodológicos do modelo de parametrização e de divisão de riscos e retorno na cadeia citrícola brasileira, Novembro de 2013. Disponível em <www.citrusbr.com.br>, e visitado em 19/01/2014.

[4] BATALHA, M. O. et.al, Gestão agroindustrial. Volume 1. São Paulo: Editora Atlas, 2 ed. 2001.

[5] BORGES, A.C.G.; COSTA, V.M.H.M. Fusões e aquisições no processo de evolução da indústria processadora de citros do Estado de São Paulo. Em: XLV Congresso da Sociedade Brasileira de Economia, Administração e Sociologia Rural e AIEA2 Internacional Association of Food and Agro-industrial Economy, p. 1-20, 2007.

[6] BOTEON, M.; BRAGA, D. Pós-furacões: Brasil confirma sua liderança mundial mas é preciso redefinir o mecanismo de remuneração na citricultura paulista. Revista Hortifruti Brasil, 2007. Disponível em < http://www.cepea.esalq.usp.br/pdf/mat_capa.pdf.>, visitado em 15/05/2014.

[7] BRANDT, R. Estoque alto de laranja dá prejuízo de R \$1,2 bilhão. Jornal O Estado de São Paulo, 16 de Julho de 2012. Disponível em <http://www.associtrus.com.br/imprime-noticia.php?id=3079>, visitado em 20/05/2014.

[8] CAMPANELLI, R. CALAZANS, O. MAIA, W. Considerações sobre o contrato de fornecimento de frutas da safra 87/88. Revista Laranja. Vol. 2, no8. P.335-344, 1987.

[9] CARVALHO, M.S. Estruturas de governança alternativa no complexo agroindustrial citrícola brasileiro: formas de integração para frente da citricultura orgânica paulista. São Carlos: UFSCar, 2005. 155 p.

[10] CARVALHO, M.S. Contratos formais entre empresas processadoras de laranja e citricultores: um estudo de múltiplos casos entre os anos-safras de 1978/79 a 2011/2012. São Carlos: UFSCar, 2015. 258 p. Disponível em <https://repositorio.ufscar.br / bitstream/handle/ufscar/7617/TeseMSC.pdf?sequence=1\&isAllowed=y >, visitado em $10 / 02 / 2018$.

[11] CASER, D.V. AMARO, A.A. Evolução da produtividade da citricultura paulista. São Paulo: Informações Econômicas, V.34, n.10, p.7-12, 2004. Disponível em < www.iea.sp.gov.br/out/253xpectative/pdf/tec1-1004.pdf> , visitado em 10/07/2014.

[12] ELIAS, D. Globalização e agricultura: a região de Ribeirão Preto - SP. Coleção Campi; 21. São Paulo: Editora da Universidade de São Paulo, 2003. 400p.

[13] FRANCO, L. Entrevista: “Queremos indenização. Nosso prejuízo soma US\$7 bilhões.” Revista Globo Rural online. Edição 296, Jun/2010. Disponível em < http://revistagloborural.globo.com/Revista/Common/0,ERT14920618286,00.html>, visitado em 10/05/2014.

[14] FERNANDES, F., ROLLI, C. Ex-fabricante de suco de laranja revela ação de cartel. Jornal Folha de São Paulo, Mercado, dia 15 de Março de 2010. Disponível em < http://www1.folha.uol.com.br/fsp/dinheiro/fi1503201002.htm>, visitado em 10/12/2013.

[15] FERNANDES, JR. W.B. Organizações associativas do sistema agroindustrial cítrico: o caso paulista. Tese de mestrado. Universidade de São Paulo, 1998.

[16] FIGUEIREDO, A.M.; SOUZA FILHO, H.M.; PAULLILO, L.F.O. Análise das margens e transmissão de preços no sistema agroindustrial do suco de laranja no Brasil. Na. Econ. Sociol. Rural [online]. 2013, vol.51, n.2, pp. 331-350.

[17] FIOREZI, A.A. Pedras no Caminho. Revista de Economia Agrícola: Agroanalysis, FGV, Vol. 19, no 5, $15 / 05 / 1999$.

[18] GIORGI, F.D. A emblemática crise na citricultura. Holambra: Setembro, 2014. 132p.

[19] ITO, N.C. Poder na formação do arranjo institucional do sistema agroindustrial citrícola paulista. Tese de doutorado em administração da Universidade de São Paulo. São Paulo: USP, 2014. 
[20] LAKATOS, E. \& MARCONI, M.A. Metodologia Científica. São Paulo: Atlas, 1996.

[21] LOPES, F.F.; CASTRO, L.T.; CÔNSOLI, M.A.; CARVALHO, D.T. Análise das transações entre produtor citrícola e as indústrias processadoras de frutas cítricas. IV International Conference on Agri-Food Chain/Networks Economics and Management. FEA Ribeirão Preto - USP, Outubro de 2003.

[22] MAIA, M.L. Citricultura paulista: evolução, estrutura e acordo de preços. São Paulo: IEA, Coleção de estudos agrícola, 1996. 157p.

[23] MANÉCOLO, F. Cutrale: o maior empresário de Araraquara. Jornal online K3, de 01/06/2012. Notícia Disponível em <http://www.portalk3.com.br/Artigo/personagens/cutrale-o-maior-empresario-de-araraquara>, visitado em 10/04/2014.

[24] MARINO, M.K.; AZEVEDO, P.F. Avaliação da intervenção do sistema brasileiro de defesa da concorrência no sistema agroindustrial da laranja. 2001. Tese de Doutorado. Universidade Federal de São Carlos.

[25] MARINO, M.K. Análise da evolução da relação contratual entre produtor e agroindústria citrícola, após a extinção do contrato padrão. In: Workshop Brasileiro de Gestão de Sistemas Agroalimentares. PENSA/FEA/USP. Ribeirão Preto. 1999.

[26] MELLO, F.O. T.; PAULILLO, L.F. Formas plurais de governança no complexo agroindustrial citrícola: estudo de caso na microrregião de Bebedouro. In: XLVI Congresso da Sociedade Brasileira de Economia e Sociologia Rural, Rio Branco, 2008. Disponível em <http://www.sober.org.br/palestra/9/319.pdf> , visitado em 02/12/2009.

[27] MENARD, C. The economics of hybrid organizations. Journal of Institutional and Theorical Economics (JITE), 345-376, 2004.

[28] MENARD, C. The Economics of Hybrid Organizations. 6th Conference of the International Society of New Institutional Economics, MIT-Cambridge-MA, 2002.

[29] MENDES, M. Para onde vai a citricultura, após as mudanças no setor? Jornal Folha de São Paulo: Commodities, B7, 12 de Julho, 2011.

[30] MOREIRA, R. São Paulo perde 5,7 milhões de pés-de-laranja. Jornal 0 Estado de São Paulo, Economia/Negócios. 14 de Agosto, 2014. Disponível em < http://economia.estadao.com.br/noticias/expectat,spperde-5-7-milhoes-de-pes-de-laranja, 1543862>, visitado em 20/08/2014.

[31] NEVES, M.F. et.al. O retrato da citricultura brasileira. Markestrat, 2009. Disponível em < www.markestrat.org/pt-br/livro.php?id_item=57>, visitado em 10/07/2014.

[32] NEVES, M.F.; JANK, M.S. et.al. Perspectivas da cadeia produtiva da laranja no Brasil: a agenda 2015.

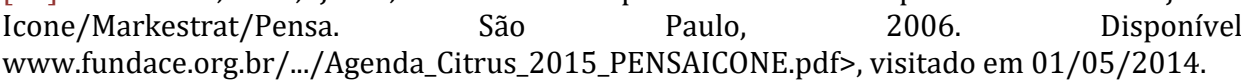

[33] PAULILLO, L.F.O. MELLO, F.T. Redes de poder e instituições: limites, incentivos e exclusão no agronegócio paulista. IN: FUSCO, J.P.A. (Coord.) Redes produtivas e cadeias de fornecimento. São Paulo: Arte\&Ciência, p. 305-390. 2005.

[34] PAULILLO, L.F.O. Análise organizacional em redes de recursos de poder: contribuições para os estudos da concorrência e das políticas públicas. In: FUSCO, J.P.(org.) Tópicos emergentes em gestão da produção. São Paulo: Arte\&Ciência, 2002, v.1, p.45-94.

[35] PAULILLO, L.F. Redes de Poder \& Territórios Produtivos. São Carlos: Rima/ Ed. UFSCAr, 2000. 214p.

[36] RAÍCES, Carlos. Plantador aluga ociosidade para fazer suco. In: Relatório da Gazeta Mercantil: A Indústria da Laranja. Pg. 1. 8/06/1989.

[37] SECCO, A.; PATURY, F. O campeão mundial do suco de laranja. Revista Veja. Ed. 1.802, 14 de Maio de 2003. Disponível em < http://veja.abril.com.br/140503/p_038.html>, visitado em 15/05/2014.

[38] SILVA, V.L.S.; AZEVEDO, P.F. Formas plurais no franchising de alimentos: evidências de estudos de caso na França e no Brasil. Revista de Administração Contemporânea-RAC, 1aㅡ Edição Especial, vol.11, Curitiba, 2007. Disponível em <http://www.scielo.br/pdf/rac/v11nspe1/a07v1ns1.pdf >, visitado em 04/12/2009.

[39] SOUZA, C. E. Cutrale compra maquinário da Bacitrus. Jornal Diário da Região. Economia. 4 de Fevereiro de 2012. Disponível em <www.diarioweb.com.br/novoportal/noticias/economia/ 86959,,Cutrale+compra+o+maquinario+da+Bascitrus.aspx>, visitado em 19/04/2014.

[40] SOUZA, A.C. Frutas cítricas: singularidades do mercado. In: Preços Agrícolas - IEA, Maio/Julho de 2001. Disponível em <www.iea.sp.gov.br>, acesso em 18/10/2003.

[41] UNICAMP-IE-NEIT, Cadeias: Citrus. Estudo da Competitividade de Cadeias Integradas no Brasil: impactos das zonas de livre comércio. Campinas, Julho, 2002. Disponível em <http://www.abecitrus.com.br/pesq_br.html>, acesso em $12 / 09 / 2003$. 
[42] United States Department of Agriculture - USDA. Citrus: World Markets and Trade. Foreign Agricultural Service, Office of Global Analysis, 2014. Disponível em < apps.fas.usda.gov/psdonline/circulars/citrus.pdf>, visitado em 11/04/2014.

[43] VIEGAS, F.C.P. 0 endividamento dos citricultores. Informativo Associtrus: Editorial. Fevereiro/Março, ano 10, número 51, 2014.

[44] VIEIRA, A. C.; ALVES, F. J. A evolução dos contratos de compra e venda no setor citrícola e consequências de sua extinção. ENCONTRO NACIONAL DE ESTUDANTES DE ENGENHARIA DE PRODUÇÃO-ENEGEP, 1997a.

[45] VIEIRA, A.C. ALVES, F.J.C. A quebra do contrato-padrão e o acirramento dos conflitos no Setor Citrícola. Informações Econômicas, S. Paulo. 27 (8):7-22, 1997b.

[46] VIEIRA, A. C. Desafios para os Pequenos Produtores de Laranja do Estado de São Paulo Diante de Novos Fatores na Relação Agricultura / Indústria nos Anos 90. São Carlos: UFSCar, 1998. Dissertação de Mestrado da Engenharia de Produção UFSCar.

[47] VIEIRA, J. G. V.; YOSHIZAKI, H. T. Y.; LUSTOSA, L. J. Um estudo exploratório sobre colaboração logística em um grande varejo supermercadista. Produção, Mar, vol.20, no.1, p.135-147. 2010.

[48] ZYLBERSZTAJN, D.; SZTAJN, R. et.al. Direito e economia. Rio de Janeiro: Elsevier, 2005a.

[49] ZYLBERSZTAJN, D. Papel dos contratos na coordenação agro-industrial: um olhar além dos mercados. Revista de Economia e Sociologia Rural. Brasília, v. 43, n. 03, p. 385-420, 2005 b. 


\section{Capítulo 21}

MENSURAÇÃO DA DESIGUALDADE DE RENDA E POBREZA NO ESTADO DO PARÁ E SUAS MESORREGIÕES ENTRE OS ANOS DE 2000 E 2009

\section{Jorge Eduardo Macedo Simões \\ Clayton Douglas Chagas de Oliveira \\ David Costa Correia Silva \\ Hayatahandeson Borges de Caldas}

Resumo: 0 presente estudo mensura a relação entre crescimento econômico, desigualdade de renda e pobreza no estado do Pará e suas mesorregiões. A metodologia utilizada é o modelo de crescimento Pró-Pobre e de Fronteira de Desigualdade Regional (FDR). Os resultados apontam que, embora o crescimento econômico do estado tenha reduzido à pobreza, essa redução foi acompanhada por um aumento da desigualdade de renda. A priori não se evidenciou a explicação do U invertido de Kuznets para o estado e suas mesorregiões de forma direta em virtude do período (1999-2009) ser bastante curto, mais ao longo da série para o estado e algumas mesorregiões mostra-se um indicativo de uma tendência na formação da curva U invertido de Kuznets, o que poderia ser observado numa serie mais longa.

Palavras-chave: Desigualdade de Renda, Crescimento "Pro-Pobre", Índice de Williamson, Fronteira de Desigualdade Regional. 


\section{INTRODUÇÃO}

Uma das mais importantes mudanças pelas quais a sociedade e a economia brasileira vêm passando nos últimos anos é o processo de queda contínua e significativa da concentração de renda, conseguindo desta forma a redução da pobreza e inclusão de mais de 50 milhões de brasileiros à cidadania. Tais transformações sociais e econômicas, deram-se de fato, através da redução da desigualdade de renda familiar per capita, que confirmam a trajetória de queda iniciada em meados da década de 1990 e assume intensidade mais acentuada a partir de 2001, assim permanecendo durante os anos subsequentes até 2005. Um dos resultados desse processo é que, nesse ano, a desigualdade de renda17 alcançou seu menor nível nas últimas três décadas. Todavia, podemos notar que, apesar das transformações ocorridas quanto ao seu crescimento econômico, a concentração de renda brasileira ainda é extremamente alta, encontrando-se o Brasil entre os países com mais elevados níveis de desigualdade.

No período de 2003 a 2010 milhares de pessoas deixaram a pobreza e outras milhares passaram a integrar a classe média, mostrando sua importância no período da crise de 2008 em que a inserção desta ajudou de certa forma a aumentar o consumo interno mantendo o nível de atividade econômica no país. Nesse sentido, os programas de transferências de renda condicionados, são apontados por diversos estudos como sendo um fator importante na redução da pobreza e na melhoria da condição de vida de diversas famílias em todo país (Barros et al. 2006).

E tendo em vista avaliar os desdobramentos dessas tendências mais recentes dos impactos dos níveis de crescimento econômico na redução da desigualdade de renda e do nível de pobreza, este trabalho tem a pretensão de apresentar uma análise para o estado do Pará e suas mesorregiões, tendo como via instrumental para esta análise a utilização dos modelos de crescimento "Pró-Pobre" e Fronteira de Desigualdade Regional (FDR). Além da utilização dos clássicos indicadores de Gini e Theil para a mensuração desta desigualdade em termos de renda.

Kakwani e Pernia (2000) definem como "Pró-Pobre" um modelo de crescimento onde os pobres que se beneficiem do crescimento mais proporcionalmente do que os "Não-Pobres". Nesse cenário, a desigualdade de renda é simultaneamente declinante durante o processo de crescimento. Já o modelo de Fronteira de Desigualdade Regional de Milanovic (1965), Lindert e Williamson (2007), pressupõem que sociedades muito pobres não devem exibir elevados índices de Gini, porque o excedente econômico é pequeno demais para ser apropriado pelos estratos superiores. 0 modelo por sua vez, mede o nível máximo de desigualdade que pode ser atingido a cada nível de renda e este estudo estende tais conceitos para tratar da dimensão regional.

Divide-se este trabalho em cinco seções: após esta introdução, na segunda seção faz-se uma revisão da literatura tendo como principal foco a relação entre pobreza, crescimento econômico e desigualdade de renda. Na terceira seção, apresenta-se a metodologia utilizada para a mensuração da desigualdade e pobreza no Brasil, Região Norte e Pará. Na quarta seção, realiza-se a análise dos resultados empíricos para o modelo de crescimento "Pró-Pobre" e da Fronteira de Desigualdade Regional (FDR). Por fim, apresentase as considerações finais.

\section{REFERENCIAL TEÓRICO}

Para analisar as relações entre os aspectos do crescimento econômico e suas implicações na redução e superação das condições de desigualdade e pobreza, deve-se fazer um debate acerca das principais vertentes do pensamento econômico relacionado a esta temática. Busca-se neste debate superar a dicotomia crescimento econômico versus desigualdade de renda, apoiado na ideia de que uma atuação política mais eficaz, voltada para o combate da desigualdade teria efeitos positivos e sinérgicos na redução da pobreza.

Outro aspecto relevante do debate sobre a relação entre desigualdade e pobreza, do ponto de vista teórico, refere-se às análises contemporâneas que têm tratado do tema da pobreza e da desigualdade em suas múltiplas dimensões. Para tal avaliaremos em nível geral a abordagem das capacitações de Sem (2000) como elemento de contraposição ao debate da desigualdade visto pelo ponto de vista exclusivo da renda (unidimensional), como será avaliado nesse trabalho.

Mundialmente o debate da relação entre crescimento econômico e desigualdade de renda teve início com o artigo de Kuznets (1955), na qual esta relação dar-se através da forma de U invertido, estabelecendo que

\footnotetext{
${ }^{17}$ Variável considerada (rendimentos do trabalho, salários, renda familiar per capita ou renda familiar) neste caso.
} 
na primeira fase de grandes taxas de crescimento de um país, ocorre um aumento na desigualdade de renda enquanto que na segunda fase grandes taxas de crescimento fazem com que haja uma redução na desigualdade de renda. 0 estudo teve por objetivo verificar se a desigualdade na distribuição de renda aumentava ou diminuía com o crescimento econômico do país, assim como os fatores que determinariam tanto o nível de renda quanto a desigualdade.

0 efeito da distribuição de renda sobre o crescimento econômico em determinado momento é analisada, neste sentido, sobre a óptica do interesse político, sendo que uma distribuição de renda desigual imprime pressões na direção de se adotar políticas de alocação da redistribuição de recursos, na qual levaria a uma inibição da acumulação de capital, visto que em longo prazo se reduziria as taxas de crescimento econômico.

Kuznets (1955) coloca a variável renda como principal parâmetro ao analisar a desigualdade de renda em função do crescimento econômico de um país, sem levar em consideração que há diversos outros fatores como os oriundos das diferenciações educacionais, saúde, tecnológicas, alimentares, ausência do estado em provir maior equidade e outras variáveis que estariam correlacionados com a disparidade da existência desta desigualdade faz com que haja um aumento da pobreza em seus mais diferentes aspectos.

Embora, o conceito de desigualdade esteja relacionado ao conceito de pobreza, como se viu anteriormente, estes não se confundem, pois a desigualdade caracteriza-se principalmente pela má distribuição dos recursos de um país entre as classes sociais; a pobreza, por seu turno, relaciona as necessidades básicas não atendidas de maneira adequada em função de diversos fatores, entre os quais a escassez do produto e a desigualdade na sua distribuição. Neste contexto, inclui-se o crescimento econômico como possibilidade de redução da pobreza aliado à redução das desigualdades.

Para Sen (2000), a pobreza pode ser definida como privação das capacidades básicas individuais e não apenas como uma renda inferior a um patamar pré-estabelecido. Por "capacidades" se entende as combinações alternativas de "funcionamentos" de possível realização. Portanto, a capacidade é um tipo de liberdade: a liberdade substantiva de realizar combinações alternativas de funcionamentos ou a liberdade para ter estilos de vida diversos.

Para Comim e Bangolin (2002) é importante ter em mente que a redução da pobreza através da renda não pode ser o único objetivo de políticas de combate à pobreza. Seguindo as mesmas premissas de Sem (2000) em que que a pobreza não se explica somente pelo fator renda, mais por diversos outros fatores: tais como, educação, saúde, alimentação e outros.

Tais privações de capacidades, como as citadas anteriormente, que permeiam a pobreza de forma mais abrangente, não desprezam o fato desta ser caracterizada como o de ter-se uma renda inferior estabelecida, e que a falta desta renda pode ser a primeira razão da privação de capacidade de uma pessoa. Sabe-se que não somente a renda impacta nas condições de pobreza da população e que outros fatores fazem-se presentes, pois se tem a noção das multidimensionalidades ocasionados por esta condição.

Para Diniz (2005), a evidência empírica internacional que afeta os países em desenvolvimento tem apontado uma correlação bastante forte entre a falta de um crescimento econômico sustentado, em alguns casos, crescimento negativo, e o aumento do número de pobres de suas populações, seja está expressa em termos de uma renda monetária limitada (pobreza absoluta), seja esta encarada sob um enfoque multidimensional relacionada, por exemplo, os indicadores de desenvolvimento humano como o acesso à saúde básica, educação, serviços de água e saneamento, entre outros. Ainda, que existam certas diferenças entre os canais de transmissão, há certa clareza sob os seguintes pontos gerais:

i) Nos países onde existe uma pobreza generalizada o crescimento econômico tem um forte efeito positivo em reduzi-la;

ii) A pobreza age como uma das principais restrições ao processo de crescimento econômico continuado (UNCTAD, 2002). Assim, ao mesmo tempo, que a pobreza pode ser entendida como uma consequência da falta de crescimento, ela é um fator limitador para sua sustentação. Nessas condições, em que os países estão "presos" a certas dificuldades estruturais para sair dessa situação convencionou-se chamar na literatura de "armadilha da pobreza" (PNUD, 2003).

Mais recentemente, tem-se verificado que as experiências ao redor do mundo têm mostrado que os países e mesmo as regiões dentro deles crescem de maneira desigual. Do mesmo modo, a distribuição de renda dentro deles e entre eles não é homogênea, podendo beneficiar determinadas parcelas da população, impactando de modo diferenciado a sua população de pobres e não pobres. Para tanto, o tema do crescimento chamado "Pró-Pobre" ganhou um importante destaque nas questões mundiais, que 
sinteticamente se traduz como aquele em que a população de mais baixa renda efetivamente se beneficia do crescimento (SILVEIRA NETO, 2005).

\section{METODOLOGIA}

\section{1 ÁREA DE ABRANGÊNCIA DO ESTUDO}

A presente seção tem como finalidade apresentar à área de abrangência, indicadores de desigualdade, as duas metodologias de análise empregadas no estudo, bem como a base de dados e a fonte dos mesmos além do período analisado, a metodologia Pró-Pobre que é baseada no trabalho de Son (2004), e o modelo de Fronteira de Desigualdade Regional baseado nos estudos de Monastério (2010) que, por sua vez, teve como fonte primária os estudos de Williamson (1965), Milanovic, Lindert e Williamson (2007).

\subsubsection{O ESTADO DO PARÁ}

0 estado do Pará está localizada na Região Norte do território brasileiro, é uma das 27 unidades federativas do Brasil ocupando uma extensão territorial de 1.570.745,680 $\mathrm{km}^{2}$, segundo o Censo de 2010 do IBGE. Possui uma população estimada em 7.581.051 habitantes e está dividido em 144 municípios (com a criação de Mojuí dos Campos). Segundo o Instituto Brasileiro de Geografia e Estatística (IBGE) possui a maior população de toda a região Norte com 48,35\% dos 15.679 .418 milhões de habitantes desta região.

Quanto aos seus aspectos geográficos tem como limites ao norte o Suriname e o Amapá, ao nordeste o oceano Atlântico, a leste o Maranhão, a sudeste Tocantins, ao sul Mato Grosso, a oeste o Amazonas e a noroeste Roraima e Guiana Holandesa. 0 relevo é baixo e plano; 58\% do território se encontram abaixo dos 200 metros. As altitudes superiores a 500 metros estão nas serras de Carajás, Caximbo e Acari. Os principais rios são Amazonas, Tapajós, Tocantins, Xingu, Jari e Pará.

A abrangência da pesquisa correspondente ao estado como um todo, ou seja, seus 143 Municípios e suas seis Mesorregiões (Baixo Amazonas, Marajó, Região Metropolitana de Belém, Nordeste Paraense, Sudeste Paraense e Sudoeste Paraense) nos periodos de 1999 a 2009. Contudo não está incluso o municipio de Mojui dos campos emancipado após o período em estudo. Tem como capital Belém reúne em sua região metropolitana cerca de aproximadamente dois milhões habitantes, sendo a maior população metropolitana da região Norte. Suas cidades importantes são: Abaetetuba, Altamira, Ananindeua, Barcarena, Castanhal, Itaituba, Marabá, Parauapebas, Redenção, Santarém e Tucuruí.

\subsection{MENSURAÇÕES DA DESIGUALDADE DE RENDA E PROPORÇÕES DE POBRES}

Para Solon (2008) a quantificação da pobreza e da extrema pobreza a partir da noção de insuficiência de renda, geralmente é utilizada as linhas de pobreza e de indigência, a partir da qual são estabelecidos valores monetários mínimos observados, referenciados em certas cestas de bens capazes de atender as necessidades dos indivíduos, seja apenas para alimentação, ou que inclua outros conjuntos de bens. Todos aqueles que se auferissem renda abaixo daquele valor seriam considerados pobres ou indigentes. As linhas de indigência são calculadas com base em uma quantidade de calorias suficiente a reprodução do indivíduo e da sua família, baseado nas preferências de uma determinada região e, então, convertidas em unidades monetárias. Por sua vez, as linhas de pobreza são calculadas a partir das linhas de indigência, aplicando-se o "multiplicador de Engel", àquelas como formas de incluir despesas com habitação, transporte, vestuário etc, ou seja, as necessidades não alimentares. Dessa forma, indivíduos que auferissem renda abaixo da linha de indigência não teriam recursos suficientes para atender suas necessidades nutricionais mínimas e os que estivessem abaixo da linha de pobreza não atenderiam a um conjunto mais amplo de suas necessidades.

O Instituto de Pesquisas Econômicas e Aplicadas (IPEA) utiliza em seus trabalhos quanto as Linhas de Pobreza e Indigência respectivamente $1 / 2$ e $1 / 4$ do salário mínimo. Já o Instituto de Estudos do Trabalho e Sociedades (IETS) adota valores regionalizados. Já o Banco Mundial adota em seus estudos e programas, comparações entre os países, baseadas na Paridade do Poder de Compra18 e classifica como indigente

18Teoria proposta no início do século XX por Cassel (1954) para calcular o poder de compra entre os países e medir o quanto uma determinada moeda pode comprar em termos internacionais, tendo em vista as diferenças de preçso dos bens e serviços de um país para outro. 
quem vive com até US\$ 1 per capita dia e pobre quem tem rendimentos acerca de US\$ 1 e US\$ 2 per capita dia.

O governo brasileiro não possui uma linha oficial de pobreza e, frequentemente, seus programas sociais utilizam a metodologia do Programa das Nações Unidas para o Desenvolvimento (PNUD), do Banco Mundial de US\$ 1 e/ou US\$ 2 per capita ajustada pela paridade do poder de compra. Contudo o Ministério do Desenvolvimento Social e Combate à Fome (MDS), adota para o Programa Bolsa Família como critério de seleção das famílias valores per capita, de $\mathrm{R} \$ 70,00$ e R\$140,00, para classificação dos beneficiários como extremamente pobres e pobres, respectivamente.

Para se mensurar o grau de desigualdade de renda existente nos países, e dentro das sociedades e entre indivíduos que delas fazem parte existem diversas metodologias, as mais utilizadas são o índice de Gini, índice T de Theil e a Proporção de Pobres, que a seguir se procede com uma breve exposição.

o Índice de Gini mede o grau de desigualdade existente na distribuição de indivíduos segundo a renda domiciliar per capita e seu valor varia de zero (em que não há desigualdade) e um (quando a desigualdade é máxima). É formado a partir da Curva de Lorenz, como uma razão das áreas formadas pelo diagrama da referida curva. Se a área entre a linha de perfeita igualdade e a curva de Lorenz é $\mathrm{A}$, e a área abaixo da curva de Lorenz é B, então o coeficiente de Gini é igual a A/ $(A+B)$. 0 coeficiente de Gini pode ser calculado da seguinte forma:

$$
\mathrm{G}=\frac{1}{\mu \cdot \mathrm{N}(\mathrm{N}-1)} \sum_{\mathrm{i}>j} \sum_{\mathrm{j}} \mathrm{x}_{\mathrm{i}}-\mathrm{x}_{\mathrm{j}}
$$

em que:

$\mu$ : É a renda familiar per capita média de uma dada população;

$\mathrm{N}$ e $x_{i}$ : Renda familiar per capita do indivíduo $\mathrm{i}$.

0 índice T de Theil mensura o grau de desigualdade da distribuição de indivíduos segundo a renda domiciliar per capita, varia de zero a um e quanto menor o seu valor menos desigual será a distribuição de renda. Seu cálculo dar-se da seguinte forma:

$$
\mathrm{T}=\left(\frac{1}{\mathrm{n}}\right) \sum_{\mathrm{i}=1}^{\mathrm{n}}\left(\frac{\mathrm{Y}_{\mathrm{i}}}{\mu}\right) \log \frac{\mathrm{Y}_{\mathrm{i}}}{\mu}
$$

em que:

$$
\begin{aligned}
& n \text { : É o tamanho da população; } \\
& Y_{i} \text { : É a renda do individuo } i ; \\
& \mu: \text { É a renda média da população; }
\end{aligned}
$$

Para obter-se a proporção de pobres utiliza-se a metodologia proposta em Hoffmann (2006), seja Y a renda domiciliar per capita nos domicílios de uma região, ordenados do menor para o maior, i:1,...n domicílios, a renda média desta população pode ser representada por $y$ e a distribuição de renda por $\left(F_{y_{0}}\right)$. Desta forma, define-se o indicador Proporção de Pobres abaixo: 


$$
P_{0}=F_{y_{0}}=p / n
$$

Em que:

$y_{0}$ : Linha de pobreza, ou seja, a renda mínima, tal que domicílios com renda per capita inferior a sejam considerados pobres;

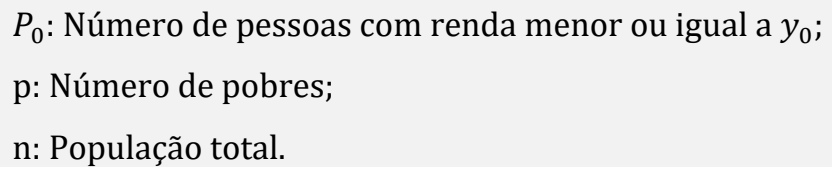

A proporção de pobres é um indicador utilizado dado a sua fácil compreensão, no entanto este parâmetro é insensível à severidade da pobreza ou aspectos ligados à desigualdade de renda, já que o número destes não se altera diante de mudanças na renda ou na distribuição de renda entre eles.

\subsection{MODELO PRÓ-POBRE}

De acordo com o estudo de Son (2004), suponha que a Curva de Lorenz $L(p)$, que descreve a participação na renda dos indivíduos situados entre os $p \%$ que pode ser definida como19:

$$
\begin{aligned}
& L_{(p)}=\frac{1}{\mu} \int_{0}^{x} y f_{(y)} d_{y} \\
& p=\int_{0}^{x} f_{(y)} \mathrm{d}_{\mathrm{y}}
\end{aligned}
$$

Em que:

$$
y \text { : É a renda domiciliar per capita com função densidade de probabilidade; }
$$

f(y) e $\mu$ : É a renda média da distribuição20.

Segundo Kakwani e Pernia (2000), o crescimento econômico pode ser chamado de Pró-Pobre se os pobres se beneficiam do crescimento proporcionalmente mais do que os Não-Pobres. Nesse cenário, a desigualdade de renda é simultaneamente declinante durante o processo de crescimento. Uma mudança na curva de Lorenz indica se a desigualdade é crescente ou decrescente com o crescimento econômico. Assim, o crescimento é claramente pró-pobre se toda curva de Lorenz se desloca para cima, $\Delta L_{(p)} \geq 0 \forall p$.

Baseando-se no teorema de Atkinson (1987), que permite associar deslocamentos para cima da Curva de Lorenz (elevações de $L_{(p)} \forall p$ ) a diminuições de pobreza, Son (2004) propõe a elaboração de uma "curva de crescimento-pobreza" que permite determinar a "qualidade" do crescimento (Pró-Pobre, Não PróPobre ou "Empobrecedor") a partir da avaliação do crescimento da renda de cada $p$ percentual mais pobre da população.

onde:

$p=0, \ldots, 100$.

Segundo Sen (2004) quando toda a curva de Lorenz se desloca para cima (baixo), pode-se afirmar, sem ambiguidade, que a pobreza diminui (aumentou). Esse resultado é valido para toda a classe de medidas de pobreza e todas as linhas de pobreza. Essa conclusão servirá de base para a "curva crescimento-pobreza".

Da definição da Curva de Lorenz, pode-se escrever: 


$$
L(p)=\frac{\mu_{p} p}{\mu}
$$

Que expressa à participação na renda dos $\mathrm{p} \%$ mais pobres, onde $\mu_{p}$ é a média da renda dos indivíduos $p \%$ mais pobres da população. Operando-se com os logaritmos de ambos os lados, a equação (6) torna-se:

$$
\operatorname{Ln}(\mu p)=\operatorname{Ln}(\mu L(p))-\operatorname{Ln}(p)
$$

A partir da diferença, na equação (7), entre dois pontos no tempo, obtêm-se:

$$
g(p)=\Delta \operatorname{Ln}(\mu L(p))
$$

Em que:

$g(p)=\Delta \operatorname{Ln}\left(\mu_{p}\right):$ É a taxa de crescimento da renda media dos $p \%$ mais pobres da população quando os indivíduos são ordenados em ordem crescente de renda per capita.

$g(p)$ : Varia com $p=0, \ldots, 100$ e pode ser chamado de curva de crescimento-pobreza. É importante notar que $g(p)$ não mede o crescimento da renda média do decil $p$, mas o crescimento da renda média até o decil $p$ 21. Com base no teorema de Atkinson (1985) e da equação (8), pode-se afirmar que se $g(p)>$ $0[g(p)<0] \forall p$, então a pobreza diminuiu (aumentou), sem ambigüidade, entre dois períodos. A equação (8) pode também ser escrita como:

$$
\begin{aligned}
& g(p)=g+\Delta \operatorname{Ln}(\mathrm{L}(\mathrm{p})) \\
& g=\Delta \operatorname{Ln}(\mu)
\end{aligned}
$$

em que:

$g$ : É a taxa de crescimento da renda média per capita de toda a sociedade. Observe que quando $p=100, g(p)=g$ visto que $\Delta L=0$ em $p=100$.

A equação (9) permite, portanto, a levar a compreensão das seguintes situações:

Se $g(p)>g$ para todo $p<100$, então o crescimento é Pró-Pobre visto que toda a curva de Lorenz desloca-se para cima $(L(p)>0 \forall p)$;

Se $0<g(p)<p \forall p<100$, então o crescimento reduz a pobreza, mas é acompanhado por um aumento da desigualdade $[L(p)<0 \forall p]$. Em outras palavras, o crescimento reduz a pobreza, mas os pobres recebem proporcionalmente menos benefícios do que os Não-Pobres, situação essa em que o crescimento seria não Pró-Pobre;

Se $g(p)<0 \forall p<100$ e $g>0$, então, tem-se um crescimento "empobrecedor", em que um crescimento econômico positivo aumenta a pobreza e, por fim,

Demais casos: Inconclusivo.

\subsection{FRONTEIRA DE DESIGUALDADE REGIONAL}

O modelo de Fronteira Williamson (1965) identificou a existência de uma curva em U invertido que relacionaria a desigualdade regional e renda per capita. Juntamente com Branko Milanovic e Lindert (2007), criaram os conceitos de fronteira de possibilidades de desigualdade (inequality possibillity frontier-IPF), com algumas adaptações este conceitos podem ser aplicados á análise de desigualdade de renda, chegando-se ao conceito de Fronteira de Desigualdade Regional (FDR). Tal modelo tem como ponto de partida, a teoria de U-invertido de Kuznets (1955) a qual afirmava que à medida que o país se desenvolve, há um aumento da disparidade regional devido à atração de mão-de-obra pelos polos desenvolvidos, o que implica um êxodo do campo para a cidade. Contudo, os centros urbanos, demandantes de mão-de-obra qualificada, são incapazes de abrigar contingentes populacionais advindos

21Por exemplo, a renda média até o segundo decil (quintil) é a média das rendas do primeiro e segundo decis. Seguindo o raciocínio, a renda média até o décimo decil é a renda média da população. 
do campo, uma vez que há uma desqualificação desses trabalhadores. Portanto, uma distribuição desigual da renda, tanto nas cidades quanto entre o campo e a cidade, e um desenvolvimento regional não balanceado podem ser observados. Conforme o aumento do nível de escolaridade e o de treinamento da população migrada (acomodação demográfica) vis-à-vis o desenvolvimento da economia, cada vez mais indivíduos vão sendo incorporados ao mercado de trabalho, acarretando a diminuição da desigualdade, já que outros indivíduos passam a se beneficiar do aumento da renda.

Pode-se entender a teoria de Kuznets (1955) a nível regional, em que ao invés de referirem-se as diferenças entre cidade e campo, faz-se uma análise entre as diferentes regiões de um mesmo estado nacional; onde a população de uma região menos desenvolvida ira em busca de melhores salários em regiões mais desenvolvidas dentro do estado, contudo estas regiões são incapazes de absorver tal mão-deobra, que é vis-à-vis à população da região atrativa.

Essa é a justificativa encontrada para explicar a razão da dessemelhança da renda e ainda, implicitamente, concluir que a diminuição da pobreza e das desigualdades em países em desenvolvimento só pode ser atingida depois de um período de tempo significativo e com uma tendência natural; ou seja, Kuznets (1955) monta toda a sua teoria tendo como pano de fundo o embasamento neoclássico. Ele mostra que para eliminar as disparidades regionais não é necessárias interferências, pois as mesmas serão em longo prazo eliminado. Há um avanço na forma de se entender a distribuição regional com a lei de Kuznets (1955), contudo sua teoria para muitos desta forma orientada de crescimento resulta numa concentração econômica ao invés de trazer melhorias da posição relativa dos grupos de baixa renda (TAQUES, 2009).

Houve desenvolvimento de modelos por parte dos estudiosos similares ao de Kuznets (1955), onde se debruçavam em buscar analisar e verificar suas ideias como é o caso de Willamson (1965). Para este as causas da disparidade regional seriam: a existência de recursos naturais diversos em cada região, migração do trabalho, movimento de capitais e políticas governamentais. Ele postulou um "coeficiente ponderado de avaliação que mede a dispersão dos níveis da renda regional per capita, relativamente à média nacional, enquanto cada desvio regional é ponderado por sua participação na população nacional".

\subsubsection{MODELO FRONTEIRA DE DESIGUALDADE REGIONAL}

A partir dos conceitos de Fronteira de Possibilidades de Desigualdade (inequality possibility frontier-IPF) criados por Milanovic, Lindert e Williamson (2007) para a análise da evolução da distribuição pessoal de renda, tais conceitos incorporam a noção de que existem limites máximos a cada nível de renda para a desigualdade. Monasterio (2010) mostra que os mesmos estudos obtidos por Milanovic, Lindert e Williamson (2007), com adaptações, pode ser aplicado à análise da desigualdade regional no longo prazo, chegando-se assim, aos conceitos de fronteira de desigualdade regional (FDR).

A Fronteira de Desigualdade Regional mostra o índice de Gini possível para cada nível de renda per capita em uma sociedade segundo MLW. A sua estimativa é bastante simples, partindo do cálculo da renda máxima possível (yh) de um grupo pequeno de indivíduos da classe de renda alta. Seja:

$$
y_{h}=\frac{\mu N-s N(1-\varepsilon)}{\varepsilon N}=\frac{1}{\varepsilon}[\mu-s(1-\varepsilon)]
$$

em que:

alta;

$y_{h}$ : Calculo da renda máxima possível de um grupo pequeno de indivíduos da classe de renda

$s$ : Renda de subsistência;

$N$ : Número de pessoas na sociedade;

$\mu$ : Renda per capita da sociedade como um todo;

$\varepsilon$ : Numero de pessoas na elite/numero de pessoas na sociedade(N).

0 índice de Gini para indivíduos que estão ordenados em classes ascendentes de renda é simplificado quando se supõe que haja plena igualdade dentro das classes e que não haja sobreposição entre as classes. Ou seja, ninguém da classe inferior aufere renda maior a qualquer um da classe superior. Desta forma: 


$$
G=\frac{1}{\mu}\left(y_{j}-y_{i}\right) p_{j} p_{i}
$$

Em que $p_{j}$ e $p_{i}$ representam a parcela da população nas classes i e j $\left(y_{j}>y_{i}\right)$. Fazendo-se:

$y_{h}=y_{j}, y_{i}$ e $s, \varepsilon=p_{j}$ e $(1-\varepsilon)=p_{i}$ pode-se chegar ao cálculo do índice máximo de Gini $\left(G^{*}\right)$ :

$$
G^{*}=\frac{1-\varepsilon}{\mu}(\mu-s)
$$

Para que se tenha a renda per capita como múltiplo da renda de subsistência, faz-se $\mu=\alpha s$.

$$
G^{*}=\frac{\alpha-1}{\alpha}(1-\varepsilon)
$$

Segundo Monastério (2010), a mesma questão apontada por Milanovic, Lindert e Williamson (2007) no tocante à distribuição pessoal da renda surge na análise da desigualdade regional. As rendas per capita das regiões não podem ser muito dispersas em níveis baixos de renda, porque há o limite inferior e o excedente não é grande o suficiente para permitir que as regiões mais ricas se distanciem.

\subsubsection{A TRANSPOSIÇÃO DO MODELO FRONTEIRA DE DESIGUALDADE REGIONAL PARA O ÂMBITO ESTADUAL}

A transposição do modelo para o âmbito estadual é feita de forma bastante direta, ao invés de se analisarem famílias ou classes sociais, o foco volta-se para as unidades espaciais (municípios). Conforme já foi dito, para construir a FDR, Milanovic, Lindert e Williamson (2007)) criam um contrafactual que atribui aos indivíduos da classe superior todo o excedente produzido, enquanto os demais permanecem na subsistência. Esta classe repartiria igualmente a renda extraída.

No caso regional, o contrafactual é construído de forma semelhante, ou seja, para cada nível de renda, atribui-se a uma unidade (neste caso, os estados) toda a renda excedente produzida na economia. Enquanto Milanovic, Lindert e Williamson (2007) tiveram que escolher certo valor percentual que representasse o papel da elite na sociedade, a diferença aqui é arbitrar a unidade mais rica quando se simula uma concentração espacial máxima da renda. 0 candidato natural é aquele local (no caso, o estado) que já é de fato o mais rico. Calcula-se assim, sua renda per capita supondo se que os demais estão no nível de subsistência, e transfere-se todo o excedente para a tal unidade mais rica. Desta maneira, a parcela não mais corresponde à parcela da classe, e sim a participação da população que vive na unidade mais rica do País.

0 índice de Williamson $\mathrm{Vw}$ nada mais é que um coeficiente de variação populacional ponderado pela parcela da população em cada região. Em sua versão original, ele é calculado da seguinte forma por Williamson.

$$
V_{w}=\frac{\sqrt{\sum\left(y_{i}-\mu\right)^{2}\left(p_{i} / N\right)}}{\mu}
$$

em que:

$y_{i}$ : É a renda per capita da i-ésima região (i-ésimo Município);

$N$ : População total do Estado;

$p_{i}$ : É população da i-ésima região (Município);

$\mu$ : Renda per capita do Estado; 
Desenvolve o coeficiente $V_{w}$ através da raiz quadrática do somatório das diferenças entre a renda per capita de cada região e a renda per capita total nacional, ponderada pela população regional sobre a população total, sendo este dividido pela renda per capita total.

Para o cálculo do valor Máximo do índice de Williamson $\left(\mathrm{Vw}^{*}\right)$, cria-se um artifício na qual a população de todas as unidades tem-se renda de subsistência, exceto a da unidade líder e está reparte todo o excedente, assim a equação se reduz a:

$$
V_{w}^{*}=\frac{\sqrt{(s-\mu)^{2}(1-\varepsilon)}+\sqrt{\left(y_{h}-\mu\right)^{2} \varepsilon}}{\mu}
$$

Em que:
$s:$ Renda de subsistência;
$\varepsilon$ : (População do município mais rico) / (N).

\subsubsection{RAZÃO DE DESIGUALDADE REGIONAL (RDR)}

É dada pela divisão do indicador de desigualdade observado pelo máximo para cada nível de renda. Assim, nos casos de Gini e Vw, tem-se:

$$
\begin{aligned}
& \mathrm{RDR}_{\mathrm{V}_{\mathrm{W}}}=\frac{V_{w}}{V_{w}{ }^{*}} \\
& \mathrm{RDR}_{\mathrm{G}}=\frac{\mathrm{G}}{\mathrm{G}^{*}}
\end{aligned}
$$

Um indicador de RDR próximo da unidade indica que a desigualdade observada é próxima da maior possível. Vale notar a trajetória da RDR ao longo do processo de desenvolvimento não é trivial, basta que a disparidade regional observada cresça em ritmo maior que o limite do limite máximo dos indicadores de desigualdade para que o RDR aumente.

\subsection{BASES DE DADOS}

Para essa análise foram utilizados dados anuais entre 1999 e 2009, utilizou-se como principais fontes de dados secundários o IBGE (Instituto Brasileiro de Geografia e Estatística), IPEA (Instituto de Pesquisas Econômicas e Aplacadas), IETS (Instituto de Estudos do Trabalho e Sociedades) e outras bases de dados tais como a RAIS (Relações Anuais de Informações Sociais), A PNAD (Pesquisa Nacional por Amostra de Domicílios), o Atlas do Desenvolvimento Humano do Brasil.

Utilizou-se o PIB22 per capita como proxy de renda per capita, tanto para a análise agregada do estado do Pará. Já para o valor de subsistência (s), utilizara-se o valor monetário23 da cesta básica referente ao estado Pará no ano corrente. Já para representação de $\varepsilon$ (população do município mais rico/ população do Estado).

Já para representação de $\varepsilon$ (população do município mais rico/ população do Estado), é importante salientar que, no caso agregado do Estado do Pará, em alguns anos da série observada, houve mudança no ranking dos municípios em termos de renda per capita. Mais especificamente, os municípios de Barcarena e Parauapebas alternaram-se na liderança do referido ranking. Entretanto, como o município de Barcarena liderou a maior parte do período, optou-se por preservar o referido município em cada ano, até o fim do período.

\footnotetext{
22 Valores constantes - R\$ de 2000 (mil) (mais informações ver http://www.ibge.gov.br).

${ }^{23} \mathrm{~A}$ série foi deflacionada pelo Índice Geral de Preços - Disponibilidade Interna (IGP-DI), tendo como ano base o ano 2000. Ressalta que fonte do referido índice foi o IPEADATA (mais informações ver http://www.ipea.gov.br/ipeadata).
} 


\section{RESULTADOS EMPÍRICOS}

Sabendo que um indicador social visa quantificar de forma especial a pobreza que apresenta em si um aspecto multidimensional, logo se pode dizer que as maiores razões de serem adotados tais indicadores dizem respeito ao do intenso desenvolvimento das bases de informações socioeconômicas, propiciadas pelas rápidas transformações realizadas pela tecnologia da informação nestas últimas décadas. Apesar do amplo reconhecimento das implicações do acesso aos bens e serviços públicos para a determinação da condição de pobreza, sua melhor caracterização encontrava restrições na disponibilidade reduzida de dados.

De acordo com a Tabela 1, em nível de Brasil, está havendo uma acentuada queda na proporção de pobres, visto que a variação deve levar em consideração que neste período tem-se a unificação a nível Federal dos programas de transferências de renda.

Quanto à porcentagem de indigentes, a região Norte apresentou números mais expressivos que a nível de Brasil. Verifica-se que a queda acentuada na proporção de pobres pertence à Região, sugerindo que um dos fatores a contribuir para está queda tenha sido o programa Bolsa Família, instituída em 2003 pelo Governo Federal. A variação de Indigentes no estado do Pará encontra-se em valores entre os da Região Norte e do Brasil.

Tabela 1 - Comparativo da Variação de Pobreza e indigência (1999/2009).

\begin{tabular}{|c|c|c|c|c|c|c|c|c|c|}
\hline & \multicolumn{3}{|c|}{ Brasil } & \multicolumn{3}{|c|}{ Região Norte } & \multicolumn{3}{|c|}{ Pará } \\
\hline & 1999 & 2009 & $\Delta$ & 1999 & 2009 & $\Delta$ & 1999 & 2009 & $\Delta$ \\
\hline $\begin{array}{c}\text { Proporção de } \\
\text { Pobres }\end{array}$ & 38,97 & 23,91 & $-10,80$ & 52,70 & 34,20 & $-12,10$ & 54,06 & 38,25 & $-10,26$ \\
\hline $\begin{array}{l}\text { Proporção de } \\
\text { Indigentes }\end{array}$ & 17,42 & 8,38 & $-7,70$ & 23,80 & 11,48 & $-9,95$ & 23,51 & 13,12 & $-8,41$ \\
\hline & 2004 & 2009 & $\Delta$ & 2004 & 2009 & $\Delta$ & 2004 & 2009 & $\Delta$ \\
\hline $\begin{array}{l}\text { Proporção de } \\
\text { Pobres }\end{array}$ & 37,46 & 24,31 & $-9,56$ & 51,70 & 36,99 & $-9,70$ & 53,65 & 41,14 & $-8,14$ \\
\hline $\begin{array}{l}\text { Proporção de } \\
\text { Indigentes }\end{array}$ & 15,36 & 8,50 & $-5,94$ & 21,12 & 12,34 & $-7,25$ & 21,29 & 13,75 & $-6,22$ \\
\hline
\end{tabular}

Fonte: Elaborado pelo IETS com base na Pesquisa Nacional por Amostra de Domicílios (PNAD).

Obs.: A pesquisa não foi a campo em 2000.

Valores expressos em Reais de 2009, deflacionados pelo INPC.

Elaboração dos autores.

Ao se analisar a taxa de crescimento do PIB paraense em relação à distribuição da renda no Gráfico 1, de fato, nota-se que somente o crescimento econômico não explica a redução das desigualdades, face que no período de 2003 a 2005 verifica-se uma alternância de situações com a concentração de renda. Coincidentemente, as políticas de universalização dos programas de transferência de renda e variações reais de ganhos sobre os salários no período em estudo, causam reflexos imediatos na redução das desigualdades para os anos subsequentes, logo, esta análise tem por objetivo mostrar referências para políticas públicas que visem a diminuir está lacuna existente entre crescimento econômico e desigualdade de renda, dado que a desigualdade está diretamente ligada à pobreza. Nesse sentido, surge à necessidade de se buscar soluções para a reversão deste quadro. 
Gráfico 1 - Evolução do Crescimento Real do PIB do Pará x Coeficiente de Gini (2003-2009).

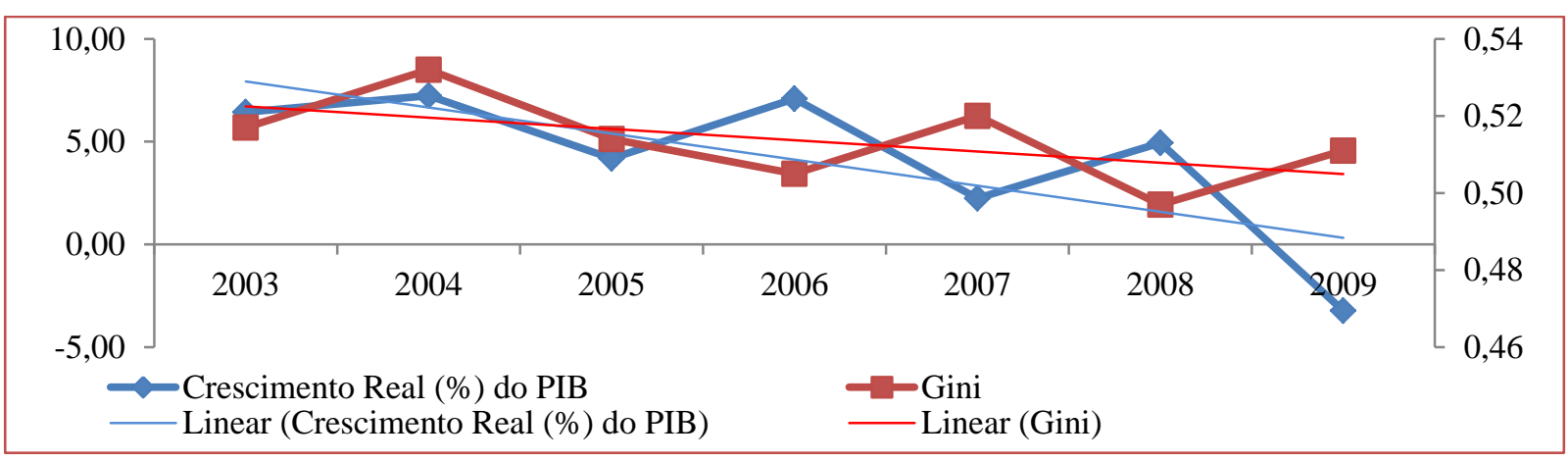

Fonte: IBGE/ IPEADATA /IDESP. Elaboração dos autores.

De acordo com Atlas do Desenvolvimento Humano no período de 1991 e 2000, o Pará registrou uma taxa média de crescimento populacional de 2,62\%, passando de 4.950 .060 em 1991 para 6.192 .306 em 2000. Neste mesmo período apresentou um aumento na taxa de urbanização de $52,45 \%$ para $66,55 \%$. Pode-se notar que há uma concentração mais acentuada nas regiões do Nordeste Paraense, em conjunto com grande parte da região do Sudoeste e Baixo amazonas.

Neste mesmo período (1991-2000) a esperança de vida teve um aumento de 5,08 anos passando de 63,42 anos em 1991 para 68,49 anos em 2000. Além disso, houve um decréscimo acentuado quanto à taxa de mortalidade, em torno de 37,11\%, passando de 52,55(por mil nascidos vivos) em 1991 para 33,05 (por mil nascidos vivos) em 2000.

O nível educacional da população adulta com 25 anos ou mais, passou em média de quatro anos de estudo em 1991 para cinco anos em 2000, de acordo com o Atlas do Desenvolvimento Humano no Brasil. Segundo o Atlas do Desenvolvimento Humano no Brasil, no período 1991-2000, o Índice de Desenvolvimento Humano Municipal (IDH-M) do Pará cresceu 11,23\%, passando de 0,650 em 1991 para 0,723 em 2000. A dimensão que mais contribuiu para este crescimento foi a Educação, com 47,7\%, seguida pela Longevidade, com $38,6 \%$ e pela Renda, com $13,6 \%$.

Neste período, o hiato de desenvolvimento humano (a distância entre o IDH do Estado e o limite máximo do IDH, ou seja, 1 - IDH) foi reduzido em 20,9\%. 0 estado do Pará emerge como um estado que carece de instrumentos que permitam ao gestor obter uma radiografia da situação socioeconômica de seus municípios, visualizando sua trajetória recente e seus principais desafios, bem como comparar com os outros municípios de sua região/território.

O Pará em 2000, apresentava mais da metade de sua população em estado de pobreza com aproximadamente $52 \%$,ou seja ,acima da média Nacional que era de aproximados $33 \%$. Ao se analizar o estado a partir de suas mesorregiões encontram-se três destas abaixo da média do estado (Metropolitana de Belém, Sudeste e Sudoeste Praense), mais bem acima da média nacional. 0 estado e suas mesorregiões, no geral, encontram-se próximos da média da população pobre da região Norte (50\%) no ano de 2000.

Tabela 2 - Indigência, Pobreza e Taxa de renda per capita (1991-2000).

\begin{tabular}{|c|c|c|c|c|c|}
\hline & $\begin{array}{c}\text { Percentual de } \\
\text { Indigentes em } \\
1991\end{array}$ & $\begin{array}{c}\text { Percentual de } \\
\text { Indigentes em } \\
2000\end{array}$ & $\begin{array}{c}\text { Percentual de } \\
\text { Pobres em } \\
1991\end{array}$ & $\begin{array}{l}\text { Percentual de } \\
\text { Pobres em } \\
2000\end{array}$ & $\begin{array}{l}\text { Taxa de } \\
\text { Crescimento da } \\
\text { renda per capita }\end{array}$ \\
\hline Brasil & 20,24 & 16,32 & 40,08 & 32,75 & 29,06 \\
\hline Norte & 27,25 & 26,60 & 52,76 & 49,60 & 17,89 \\
\hline Pará & 28,22 & 27,09 & 55,87 & 51,89 & 19,13 \\
\hline
\end{tabular}

Fonte: Instituto de Pesquisa Econômica Aplicada (IPEA) - Pobreza - pessoas indigentes (P0) e pessoas pobres (P0) - (\%).

Elaboração dos autores.

Obs1: Percentual de pessoas com renda domiciliar per capita inferior a $\mathrm{R} \$ 75,50$, equivalentes a $1 / 2$ do salário mínimo vigente em agosto de 2000.

Obs2: Renda per capita - R\$ de 2000 - Instituto de Pesquisa Econômica Aplicada (IPEA). 
Na Tabela 3, são apresentados os resultados para o Pará e suas seis mesorregiões, ressalta-se que a análise da "qualidade" do crescimento econômico é feita tanto em relação ao Brasil como em relação ao estado do Pará. É possível observar que nenhuma mesorregião apresentou crescimento Pró-Pobre pela definição de Son (2004), tanto em relação ao Brasil como em relação ao estado, bem como o estado do Pará em relação ao Brasil.

Tabela 3 - Crescimento Anual da Renda per capita dos p\% mais Pobres e Classificação das Mesorregiões do Pará de acordo com a "Qualidade" do Crescimento Econômico (1991-2000).

\begin{tabular}{|c|c|c|c|c|c|c|c|}
\hline \multirow{2}{*}{$\begin{array}{l}\text { Brasil, Pará e } \\
\text { Mesorregiões }\end{array}$} & \multicolumn{5}{|c|}{$\begin{array}{l}\text { Taxa de Crescimento da Renda Domiciliar per } \\
\text { capita dos p } \% \text { mais pobres (ao ano) }\end{array}$} & \multirow{2}{*}{$\begin{array}{c}\text { Qualidade do } \\
\text { Crescimento em } \\
\text { Relação ao Brasil }\end{array}$} & \multirow{2}{*}{$\begin{array}{l}\text { Qualidade do } \\
\text { Crescimento em } \\
\text { Relação ao Pará }\end{array}$} \\
\hline & $20 \%$ & $40 \%$ & $60 \%$ & $80 \%$ & $100 \%$ & & \\
\hline Brasil & 0,22 & 0,27 & 0,25 & 0,23 & 0,27 & - & - \\
\hline Pará & 0,18 & 0,18 & 0,14 & 0,14 & 0,21 & Não Pró-Pobre & - \\
\hline Baixo Amazonas & $-0,70$ & $-0,06$ & 0,10 & 0,18 & 0,21 & Inconclusivo & Inconclusivo \\
\hline Marajó & $-0,65$ & $-0,11$ & $-0,01$ & 0,02 & 0,10 & Inconclusivo & Inconclusivo \\
\hline $\begin{array}{l}\text { Metropolitana de } \\
\text { Belém }\end{array}$ & 0,11 & 0,13 & 0,12 & 0,14 & 0,20 & Não Pró-Pobre & Não Pró-Pobre \\
\hline Nordeste Paraense & $-0,55$ & $-0,04$ & 0,09 & 0,14 & 0,29 & Inconclusivo & Inconclusivo \\
\hline Sudeste Paraense & 0,20 & 0,15 & 0,23 & 0,22 & 0,26 & Não Pró-Pobre & Inconclusivo \\
\hline Sudoeste Paraense & 0,17 & 0,14 & 0,13 & 0,11 & 0,20 & Não Pró-Pobre & Não Pró-Pobre \\
\hline
\end{tabular}

Fonte: Elaboração dos autores com base em dados dos Censos Demográficos de 1991 e 2000.

Na verdade observa-se que para o estado do Pará os resultados apontaram para um crescimento "Não PróPobre", o que indica que embora o crescimento econômico estadual tenha reduzido à pobreza, essa redução foi acompanhada por um aumento da desigualdade. Em outras palavras, o crescimento reduziu a pobreza, mas os pobres receberam proporcionalmente menos benefícios do que os "Não-Pobres" no período analisado.

Resultados semelhantes foram observados para as seguintes mesorregiões: Metropolitana de Belém e Sudoeste Paraense - tanto em relação ao Brasil, como em relação à totalidade do estado do Pará e, para a mesorregião do Sudeste Paraense apenas na análise em relação ao Brasil. As demais mesorregiões apresentaram resultados Inconclusivos. Os resultados encontrados permitem inferir que, no período analisado, ocorreu uma má qualidade do crescimento econômico no estado do Pará e mesorregiões, uma vez que nenhuma região apresentou taxa de crescimento da renda per capita média de todos os p\% mais pobres, com $\mathrm{p}<100$, maior que aquela verificada para a renda per capita média de toda a população.

Em termos gerais os resultados encontrados para o estado do Pará e suas respectivas Mesorregiões foram satisfatórios para o período analisado. Ao analisar o Estado como um todo se pode inferir que no período estudado, há um elevado grau de desigualdade para o Pará e suas mesorregiões.

Tabela 4 - Comparação dos Índices Vw e G para o Estado e Mesorregiões (1999/2009).

\begin{tabular}{|c|c|c|c|c|c|c|}
\hline \multirow{2}{*}{ Estado e Mesorregiões } & \multicolumn{3}{|c|}{ Vw } & \multicolumn{3}{|c|}{ G } \\
\hline & 1999 & 2009 & $\Delta$ & 1999 & 2009 & $\Delta$ \\
\hline Pará & 0,93 & 0,85 & $-0,07$ & 0,62 & 0,61 & $-0,01$ \\
\hline Baixo Amazonas & 0,83 & 0,51 & $-0,32$ & 0,53 & 0,58 & 0,05 \\
\hline Marajó & 0,24 & 0,12 & $-0,12$ & 0,12 & 0,22 & 0,10 \\
\hline Metropolitana de Belém & 0,75 & 0,77 & 0,02 & 0,72 & 0,76 & 0,04 \\
\hline Nordeste Paraense & 0,43 & 0,24 & $-0,19$ & 0,24 & 0,36 & 0,12 \\
\hline Sudeste Paraense & 0,87 & 0,85 & $-0,02$ & 0,64 & 0,81 & 0,17 \\
\hline Sudoeste Paraense & 0,33 & 0,30 & $-0,03$ & 0,32 & 0,42 & 0,10 \\
\hline
\end{tabular}

Fonte: IPEADATA/IBGE/IDESP_PA.

Obs: PIB Municipal - R\$ de 2000 (mil) - Instituto Brasileiro de Geografia e Estatística - PIB.

Elaboração dos autores.

Na Tabela 4 nota-se que o Baixo Amazonas em conjunto com a Região Metropolitana apresentou um Vw muito maior se comparado às demais mesorregiões analisadas, chegando a alguns casos a serem o dobro e triplo em relação ao Marajó, Nordeste e Sudoeste Paraense. As variações no índice Vw mesmo sendo negativos e pequenos em algumas mesorregiões e para o estado, não são indícios de insignificância, 
contudo não se pode dizer que o índice seja bastante sensível a ponto de se dizer que em suas modificações numéricas encontre-se transformações estruturais profundas. Quanto ao índice de Gini, nota-se que, o Pará como todo apresentou uma variação negativa quase que imperceptível, sendo que em certas mesorregiões está variação foi positiva e considerável como é o caso do Sudeste Paraense, demonstrando o quanto nesta região a desigualdade de renda se faz presente.

Em termos gerais os resultados encontrados para o estado do Pará foram satisfatórios para o período analisado. De forma mais especifica, no Gráfico 2 verifica-se a evolução dos índices Vw e Gini para a série de 1999 a 2009. Logo a observância deste Gráfico mostra-se um indicativo de uma tendência na formação da curva U invertido de Kuznets o que poderia ser observado numa serie mais longa. 0 Gráfico 3 representa os movimentos relativos aos índices $\mathrm{Vw}, \mathrm{Vw}^{*}$ e RDR para o Estado do Pará. O RDR ficou estável ao longo da série mais em níveis bastantes altos, mostrando que, em termos gerais o estado apresenta um alto grau de desigualdade de renda.

Gráfico 2 - Índices Vw e G para o PIB per capita dos municípios do Estado Pará (1999-2009).

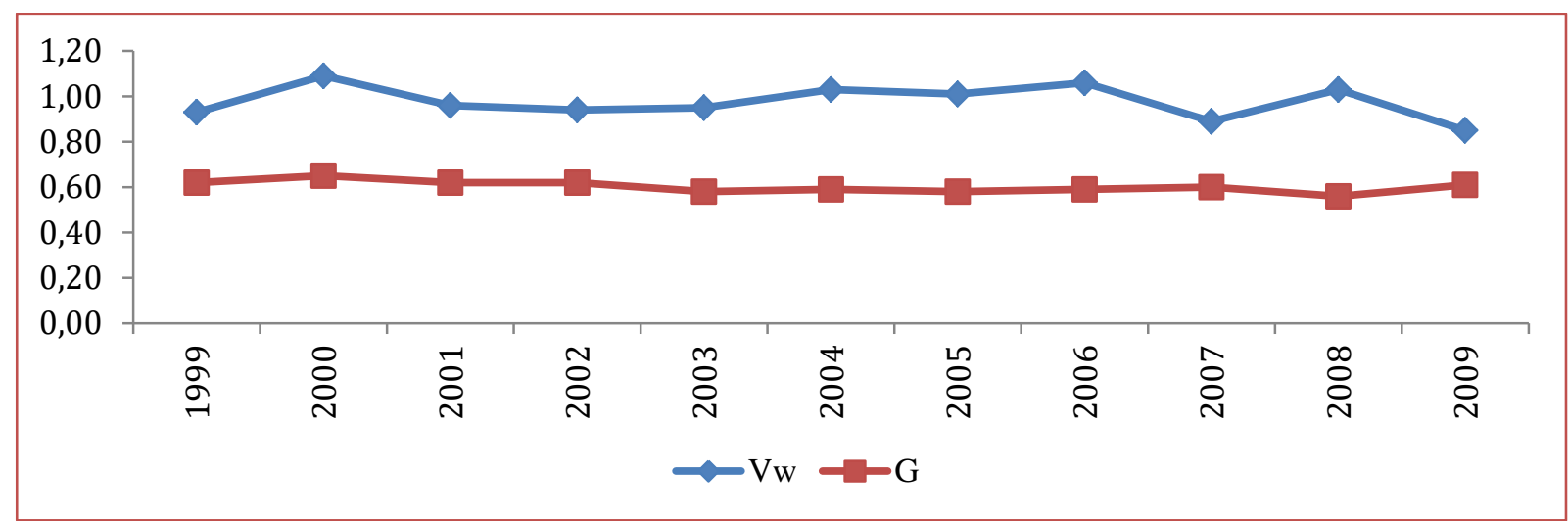

Gráfico 3 - Índices Vw, Vw*e RDR para os municípios Paraenses (1999-2009).

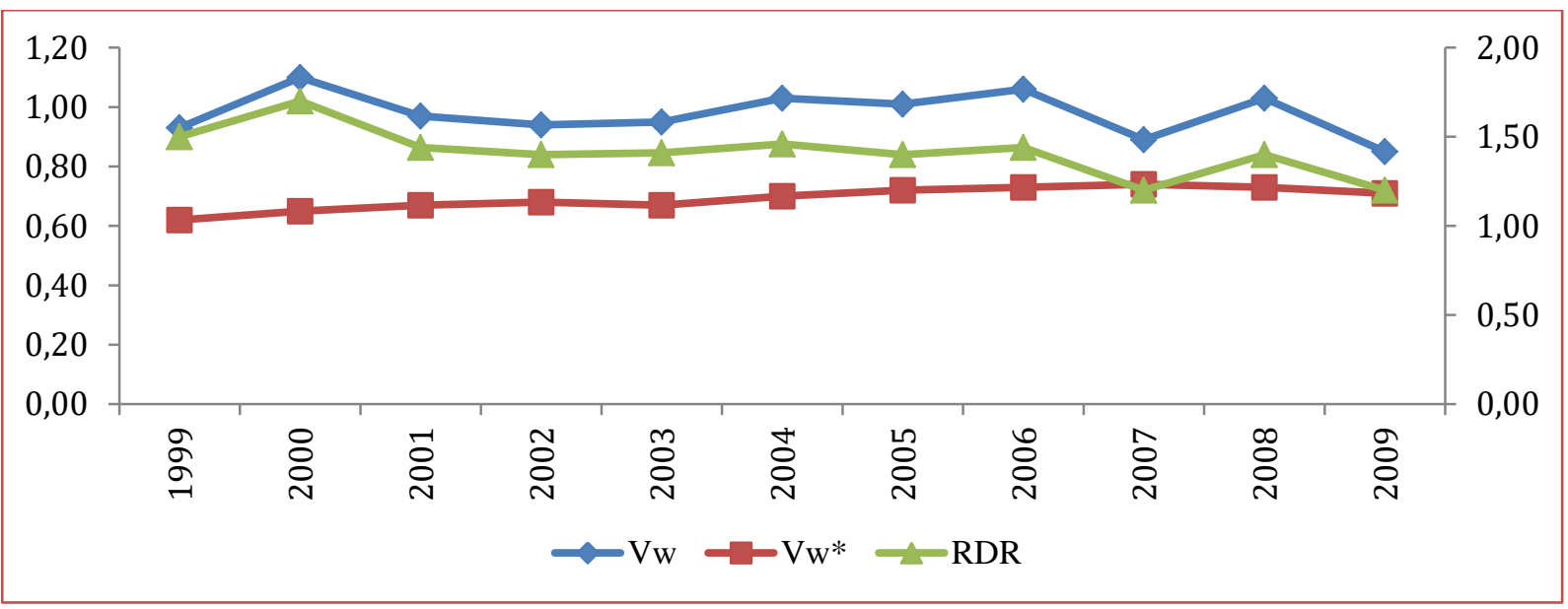

Fonte: IPEADATA/IBGE/IDESP_PA.

Obs: PIB Municipal - R\$ de 2000 (mil) - Instituto Brasileiro de Geografia e Estatística - PIB.

Elaboração dos autores. 


\section{CONSIDERAÇÕES FINAIS}

O trabalho em destaque teve como objetivos analisar o processo de crescimento econômico no estado do Pará e suas mesorregiões. Para tanto, foram utilizadas duas análises, a saber: a primeira refere-se à análise da qualidade do referido processo com o uso da técnica "Pró-Pobre" e, a segunda análise refere-se à qualidade da distribuição da renda com o uso do modelo de Fronteira de Desigualdade Regional no período de 1999 a 2009. Observa-se que para o estado do Pará os resultados apontaram para um crescimento "Não Pró-Pobre", o que indica que embora o crescimento econômico do estado tenha reduzido à pobreza, essa redução foi acompanhada por um aumento da desigualdade. Em outras palavras, o crescimento reduziu a pobreza, mas os pobres receberam proporcionalmente menos benefícios do que os "Não-Pobres" no período analisado.

A priori não se evidenciou a explicação do U invertido de Kuznets para o estado e suas mesorregiões de forma direta em virtude do período (1999-2009) ser bastante curto, mais ao longo da série para o estado e algumas mesorregiões mostra-se um indicativo de uma tendência na formação da curva U invertido de Kuznets o que poderia ser observado numa serie mais longa. Tem-se o fato que no decorrer da série inicialmente existem altos níveis de desigualdade para as análises feitas e que para pequenas variações deste índice (Vw), vistas ano a ano, não representam indícios de (in) significância. Em comparação aos resultados obtidos por Monastério (2010) em que este utilizou de um período mais longo (1872-2000) para a utilização do modelo a níveis de estado e países, o mesmo observou de forma acentuada que a teoria de Kuznets aplica-se ao Brasil, em que elevados períodos de crescimento demonstram grande desigualdade de renda no país.

Mostrou-se, também, que o popular índice Vw de Williamson está sujeito às mesmas distorções que caracterizam o índice de Gini para níveis de renda próximos aos de subsistência. Há necessidade de se analisar o Estado de forma geral, excluindo municípios cuja renda per capita esteja muito acima das de subsistência (outlier), ou seja, que influenciam como um todo o estudo. Por apresentar níveis de renda muito baixo na mesorregião do Marajó próximo ao da subsistência, recomenda-se neste caso que se utilize o cálculo da Fronteira de Desigualdade Regional (FDR) e a razão da desigualdade regional (RDR) de forma diferenciada para está mesorregião.

\section{REFERÊNCIAS}

[1] ATKINSON, A. B. On the measurement of poverty. Econométrica, v. 55, p. 749-764, 1987.

[2] BARROS, R.P.; HENRIQUES, R.; MENDONÇA, R. Desigualdade e pobreza no Brasil: retrato de uma estabilidade inaceitável. In Revista brasileira de ciências sociais, v.15, n.42, p. 123-142. Fev.2000. Disponível em < http://www.scielo.br/pdf/rbcsoc/v15n42/1741.pdf >. Acesso em Fevereiro de 2016.

[3] BARROS, R.P.; HENRIQUES, R.; MENDONÇA, R. A estabilidade inaceitável: desigualdade e pobreza no Brasil. Rio de Janeiro: IPEA, 2001. 29p. (Texto para discussão, 800).

[4] BARROS, R.P de; CARVALHO; M.; FRANCO, S.; MENDONÇA, R. Uma análise das principais causas da queda recente na desigualdade de renda brasileira. In Econômica, Rio de Janeiro, v.8, n.1, p.117-147, Jun. 2006.

[5] BOURGUIGNON, F. Pareto superiority of unegalitarian equilibria in stiglitz' model of wealth distribution with convex savings function. Econometrica, v.49, n.6, p. 1467-1475, Nov.1981.

[6] COMIM, F. BAGOLIN, I. Aspectos qualitativos da pobreza no Rio Grande do Sul. In Revista Ensaios, Porto Alegre, v.23, p. 467-490, 2002. Disponível em: <www.ppge.ufrgs.br/sabino/ecod03/asp-qualit-pob-reg-sul.pdf >. Acesso Junho de 2016.

[7] DINIZ, M. B. Contribuições ao estudo da desigualdade de renda entre os estados brasileiros. 2005. 209f. Tese (Doutorado em Economia) - Programa de Pós-Graduação em Economia - CAEN, Universidade Federal do Ceará, Fortaleza, 2005.

[8] HOFFMAN, R. Estatística para economistas. São Paulo: Pioneira, 1980, 432p.

[9] HOFFMANN, R. Elasticidade da pobreza em relação à renda média e à desigualdade no Brasil e nas unidades da federação. Revista Economia, v. 6, n.2, p. 255-289, 2005. Disponível em: < http://www.anpec.org.br/encontro2004/artigos/A04A054.pdf >. Acesso em Fevereiro de 2016.

[10] IBGE. INSTITUTO BRASILEIRO DE GEOGRAFIA E ESTATISTICA: Banco de dados do censo 2010. Disponível em: <http:// www.ibge.gov.br >. Acesso em março de 2016.

[11] IPEA. INSTITUTO DE PESQUISA ECONOMICA APLICADA. Disponível em <http:// www.ipeadata.gov.br>. Acesso em 10 de Março de 2016. 
[12] KAKWANI, N.; PERNIA, E. What is pro-poor growth. Asian Development Review, v. 16, n. 1, p. 1-22, 2000.

[13] KUZNETS, S. Economic Growth and Income Inequality. American Economic Review, n. 45, p. 1-28, 1955.

[14] LANGONI, C. G. Distribuição de renda e desenvolvimento econômico e no Brasil. 3ª ed. Rio de Janeiro: FGV, $2005,280 \mathrm{p}$.

[15] MILANOVIC, B.; LINDERT, H. P.; WILLIAMSON, G . J. Measuring Ancient Inequality. National Bureau of Economic Research, Cambridge, MA October 2007. Disponível no site < http://www.nber.org/paper/w13550> Acesso em 16 de Setembro de 2016.

[16] MONASTERIO, L. M. Fronteira de desigualdade regional: Brasil (1872-2000). Brasília: IPEA, 2010. 19p. (Texto para discussão, 1504) Disponível em: < http://www.ipea.gov.br/portal/images/stories/PDFs/TDs/td_1504.pdf >. Acesso em Fevereiro de 2016.

[17] ROCHA, S. Desigualdade regional e pobreza no Brasil: a evolução-1981/95. Rio de Janeiro: IPEA, 1998, 37p. (Texto para discussão, 567).

[18] _. Pobreza e desigualdade no Brasil: o esgotamento dos efeitos distributivos do plano real. Rio de Janeiro: IPEA, 2000, 26p.

[19] _. Pobreza no Brasil: afinal, de que se trata?. Rio de Janeiro: FGV, 2003, 244p.

[20] SEN, A. Desenvolvimento como liberdade. Trad. Laura Teixeira Mota. São Paulo: Companhia das Letras, 2000, $422 \mathrm{p}$.

[21] SILVEIRA NETO, R. Quão pobre tem sido o crescimento econômico no Nordeste? Evidências para o período 1991-2000. X Encontro Regional de Economia do Nordeste, Anais. CD-ROM. Fortaleza, 2005.

[22] SOLON,M.X.S. Uma Análise da Efetividade do Programa Bolsa Família Como Mecanismo de Combate à Pobreza e a Exclusão Social (2004 e 2006): Um Exercício Para o Brasil e Região Norte. Dissertação (Mestrado em Economia)- Programa de Pós-Graduação em Economia-PPGE, Universidade Federal do Pará, Belém, 2008.

[23] SON, H. H. A note on pro-poor growth. Economic Letters, v. 82, p. 307-314, 2004.

[24] TAQUES, F. H.; MAZZUTTI, C. C. de T. P. da C. Curva de Kuznets: mensuração do impacto do crescimento econômico sobre a desigualdade de renda para os estados brasileiros (1995-2005). In: Encontro Regional de Economia do Nordeste, 14, 2009, Fortaleza, 21p, 2009. Disponível em: < http://www.bnb.gov.br/ content/ aplicacao/eventos /forumbnb2009/docs/curva.pdf >. Acesso em Agosto de 2016. 


\section{Capítulo 22}

\section{AS EXPORTACCOEES DOS PRODUTOS AGRÍCOLAS DA}

FRUTICULTURA NO VALE DO SÃO FRANCISCO (PETROLINA): UMA ANÁLISE DAS VANTAGENS COMPARATIVAS REVELADAS

Sourou Gautier Goussi

Lilian Aldina Pereira Mendonça e Mendonça

Resumo: A fruticultura brasileira tem ganhado um destaque significativo na economia do país, mas especialmente na economia da região de Vale de São Francisco, o maior produtor exportador de manga e uva. Nesse sentido o objetivo desse trabalho consiste em analisar as exportações de manga e uva de Vale São Francisco através do indicador de mensuração de vantagem comparativa de Balassa tendo um alvo específico verificar a concentração dos principais produtos exportados utilizando índice de Gini-Hirchman. 0 uso da vantagem comparativa nesse trabalho destina-se à averiguação na vantagem de diferentes produtos exportados pela região além de manga e uva. A aplicação desse índice apresentou as uvas e as mangas com uma vantagem comparativa mais elevada. A uva apresentou o valor do índice vantagem comparativa mais alto devido ao seu crescimento crescente na exportação. No que diz respeito ao índice de concentração por produto (ICP), verificou-se uma pauta de produtos diversificada, ou seja, o município exporta vários produtos.

Palavras-chave: Fruticultura; Exportações; Vale de São Francisco. 


\section{INTRODUÇÃO}

O Brasil vem se destacando nos últimos anos no mercado mundial pelas suas produções de frutas. De acordo com (FAO, 2017), em 2014 o Brasil foi o terceiro maior produtor no nível mundial de frutas com 37,9 milhões de toneladas, perdendo apenas pela China, e a Índia. 0 impulso do país por sua vocação de produção agrícola levou o agronegócio a passar ter uma relevância importante na economia desde a abertura comercial. Essa abertura entre a década de 90 expandiu a exportação de frutas apresentando um crescimento de $62 \%$ na receita mundial com frutas e abrir uns novos mercados consumidores, maior rapidez nos meios de distribuição e preços atrativos impulsionaram as transações internacionais, de acordo com (CEPEA, 2007).

A integração do Brasil no comercio internacional vem mostrando que uma das regiões mais dinâmica da produção de fruta se encontra no nordeste, envolvendo o município do sertão dos estados da Bahia e de Pernambuco, ou seja, o vale de São Francisco. O Vale de São Francisco é a região de produção de frutas mais relevante para a economia dos dois estados que se envolvem. Segundo Araújo e Silva (2013), cerca de 90\% das produções do Vale São Francisco é exportado para o mercado internacional.

O Vale do São Francisco passou diferenciar seus produtos pelo padrão de qualidade esperada nas pautas de mercado internacional dentre os quais a uva e a manga são as culturas com um maior valor agregado e aprovado nos país mercado internacionais consumidores. Apesar da região apresenta umas restrições hídricas e de solo de semiárido, o Vale do São Francisco cultiva uva e manga durante todas as sessões do ano. A explicação para isto segundo (ZUZA, 2008), a produção não para devido a um processo histórico de politica publica que se foca no desenvolvimento da região implementando diversos perímetros irrigados e promoveu outros estímulos como o acesso ao credito e financiamento para o setor agropecuário. A região respondeu em 2015 por 3,14\% do valor de produção nacional de frutas de acordo com (BNB, 2017)

A fruticultura é um setor mais importante do agronegócio brasileiro pela crescente participação no comércio exterior e pelo abastecimento do mercado interno. Embora que o setor apresenta uma elevada rentabilidade e uma demanda de mão de obra expressiva, assumindo uma alternativa fundamental para a evolução dos produtos agrícolas na pauta de exportação do dito país. Fioravanço e Paiva (2002), afirma que o setor fruticultura se trata de uma amostra estratégica em termos de desenvolvimento econômico e social do país devida o aumento da participação no mercado exterior e pelo abastecimento do mercado interno.

A produção ganhou mais inovação, a introdução da tecnologia pelas organizações públicas como o Embrapa e os campos experimentais da Sudene garantindo melhoria as técnica de irrigação, manejo e cultivo de novas variedades possibilitando uma produção de uma qualidade melhor. Sendo assim a produção de uva e outra como a manga se destaca, ganhando espaço no mercado internacional produzindo safras que satisfazem as exigências do mercado consumidor externo.

Esse grande sucesso da produção de fruta decorre das condições ambientais relativa ao solo e ao clima, que são favoráveis ao cultivo de frutas tropicais, além da tecnologia utilizada para implementar uma nova técnica de produção e comercialização no manejo que garante um nível elevado de produção. Isto agregar valor o setor fruticultura, cirando uma visibilidade de grande importância no desenvolvimento regional.

As exportações das frutas no mercado internacional teve um impacto positivo na produção brasileira gerando renda, emprego e divisa para o país. 0 Vale de São Francisco sendo o maior polo de exportação de fruta tais que: manga e uva se responsabilizam por mais $84 \%$ das exportações de manga e $99 \%$ de uva segundo (MDIC,2014).

Esse estudo apresenta relevância para o entendimento das exportações de manga e uva de Vale São Francisco no mercado internacional, assim como ter uma concepção da importância da produção de fruticultura no desenvolvimento da região. 0 maior polo produtor de manga e uva se destaca pelo favorecimento às condições climáticas, disponibilidade extensa de uma área fértil e sua localização geográfica favorecida pela proximidade de portos que interliga os maiores importadores da produção de frutas.

Desta forma pretende se responder o seguinte questionamento: quais são os produtos que apresentam uma vantagem comparativa na exportação do setor fruticultura do Vale São Francisco?

0 tema é de suma importância, pois trata-se das exportações de fruticultura do Vale de São Francisco para o mercado exterior, mostra a cultura da produção, crescimento das exportações e o quão estes contribuem para o desenvolvimento econômico da região. Sendo que, as exportações agrícolas que sustentam a 
economia da região, geram toda uma atividade econômica, demanda de mão de obra, geração de emprego e renda.

A fruticultura além de ser uma produção de relevo na pauta de exportação brasileira, requer uma nova forma de produção devido à exigência de mercados consumidores. A evolução de produção e o aumento de áreas de cultivo incentivam Embrapa a investir no uso de tecnologia para elevar os índices de produtividade. Se for usar de forma eficiente a tecnologia na produção, o setor fruticultura deve apresentar uma vantagem competitiva. Sabendo dos principais produtos produzidos pelo setor da fruticultura e a inserção do livre comércio, exige a especialização nos produtos que apresentam um ganho no comércio mundial á base de vantagem comparativa.

O objetivo desse trabalho é analisar as exportações de manga e uva do Vale São Francisco através do indicador de mensuração de vantagem comparativa de Balassa e também as concentrações das exportações pelo índice de concentração de Hirchman. O estudo sobre a vantagem comparativa do maior polo produtor de frutas possibilita a conhecer de uma forma mais detalhada os produtos exportados pelo Vale de São Francisco que apresentam vantagem comparativa, sabendo que o país se coloca na melhor posição no setor de fruticultura. E ao medir os outros produtos exportados que não sejam manga e uva apresenta uma condição favorável no mercado para aumentar sua participação.

Este trabalho está divido em e quatro partes, além da introdução. A primeira parte apresenta uma abordagem teórica, em seguida traz a metodologia usada para alcançar os resultados. A terceira seção apesenta os resultados encontrados e suas análises. E, por fim as considerações finais.

\section{REFERENCIAL TEÓRICA}

No inicio do século XV o comércio internacional difundiu se pelo pensamento de mercantilista, que defende que uma nação se torna rica pela acumulação de metais preciosa. Os mercantilistas mediam a riqueza pelo volume de estoque de metais preciosos que gera um superávit na balança comercial. Nessa pratica, os defensores de mercantilismo estimula as exportações das nações e desestimula as importações pela imposições das barreiras comercial para aumentar sua riqueza afirma Carvalho (2004).

A ideia de mercantilismo se justifica por fortalecer a economia interna diante da competitividade dos bens estrangeiros, ou seja, competitividade zero. Segundo Smith (2008), a pratica ao protecionismo contra as importações se fazia por meio das taxas altas aplicadas a importações e cotas os bens vindos dos estrangeiros. 0 mercantilismo não sendo uma teoria solida para sustentar a teoria do comércio internacional, surge o pensamento dos economistas clássicas para defender o livre comércio entre as nações.

Adam Smith buscou a explicar a abertura do comércio entre as nações. Para o pensador, o livre comércio rende beneficio para os países envolvidos e para o mercado mundial, e gera um bem estar global para os consumidores. Para sustentar a teoria, Adam Smith desenvolveu a teoria de vantagem absoluta, nessa teoria o país se especializa no determinado produtos que ele produz a uma maior vantagem absoluta, exportando este produto e importando os produtos que ele é menos produtivo. A especialização de um país no produto que ele tem vantagem absoluta permite o aumento da produção de melhor qualidade a um custo baixo para os consumidores.

Dessa forma, cada país deve se concentrar na produção dos bens que lhe oferecem vantagem absoluta. Aquilo que exceder o consumo interno do bem produzido deveria ser exportado, e a receita equivalente ser utilizada para importar os bens produzidos em outro país. Como a capacidade de consumo dos países envolvidos no comércio internacional será maior após a efetivação das trocas, Smith (1985, pg 380) concluiu que o comércio exterior eleva o bem-estar da sociedade.

Segundo Menezes e Ramos (2006), nenhumas nações conseguem ser atuo-suficiente por mais riqueza que possuem, e para as indústrias e firmas prestadoras de serviços devolvem- se necessita a circulação dos bens entre as nações. Dessa forma afirma (SILVA, 2014), A motivação dos países em participarem de comércio internacional tem como resultado vantajoso para as nações que se integram nesse tal comércio livre. Os benefícios vão desde o aumento da diversidade de produto até mesmo a elevação do nível de produção, emprego e serviço, que tem por finalidade o aumento do nível de renda da população.

Posteriormente surgiu o modelo de David Ricardo que tem como a base a teoria de Adam Smith, estender a possibilidade de ganho de comércio para as nações que não possuem a vantagem absoluta. A vantagem comparativa de David Ricardo se baseia na produtividade do trabalho definido como o determinado comércio entre as nações. 
O principio de vantagem comparativa desenvolvida por David Ricardo (1982), sugere que cada país deve se especializar na produção do bem em que é relativamente mais eficiente ou que tem custo relativamente menor, por conseguinte este será o bem a ser exportado; por outro lado, importar o produto cuja sua produção implica um custo relativamente maior. Desta forma o autor explica a especialização das nações nos diferentes bens produzidos.

A vantagem comparativa reflete o custo de oportunidade relativa, ou seja, a produção dos bens que uma nação pode abrir mão para produção de outro. Segundo Coutinho (2005), a reflexão de vantagem comparativa como custo de oportunidade é a relação entre as quantidades de um determinado bem que os países necessitam deixar de produzir para se dedicar sua produção para outro bem. A teoria Ricardiana denomina a vantagem comparativa como a vantagem relativa, que origem das diferenças de produtividade do fator trabalho para os diferentes bens produzidos. As atribuições dessa diferença se relacionam ao clima e no ambiente de cada nação afirma Coutinho (2005). Pode- se observar que a região estudada, o Vale de São Francisco possui um ambiente favorável para a produção de frutas em que ele pode deter uma vantagem relativa.

A especialização dos países nos bens que eles têm vantagem comparativa aumenta a produção interna. Deste modo, o país atende a demanda interna e o excedente deveria ser exportado no mercado exterior. Os bens que o país é relativamente menor produtiva deveriam ser adquiridos no mercado internacional a um custo menor do que produzi-los internamente. Assim, o comércio seria vantajoso para todos os países. De acordo com Salvatores (1998), as nações saem ganhando com a especialização de cada um na produção e exportação do bem da sua vantagem comparativa. A vantagem comparativa afirma que cada nação se especializa na produção de um bem e que seu preço relativo excede seu custo de oportunidade. De tal forma, o comércio terá sentido quando cada um se especializar no que produz com mais eficiência, gerando o ganho e melhorar no bem-estar da economia.

A Inglaterra exportava tecidos em troca de vinho porque, dessa forma, sua indústria se tornava mais produtiva; teria mais tecidos e vinhos do que se os produzisse para si mesma; Portugal importava tecido e exportava vinho porque a indústria portuguesa poderia ser mais beneficamente utilizada para ambos os países na produção de vinho. (RICARD0,1982:107).

Apesar da sua importante contribuição que ele trouxe para o modelo clássico, o modelo Ricardiano apresenta uma limitação pelo fato de considerar um único fator de produção "a mão de obra" para definir a vantagem comparativa. A teoria de Heckscher-Ohlin (H.O) para completar o modelo clássico usando dois fatores de produção: trabalho e capital. O modelo H.O prega que as regiões se diferem apenas no fator de produção na produção e que o fator tecnologia seja a mesma (GONÇALVES, 1998). Conforme (KRUGMAN \& OBSTFELD, 2009), as vantagens comparativas que definem comércio dependem da diferença de dotação dos fatores de produção entre os países. Segundo tal modelo que surge das diferenças internacionais de recursos seria aquele em que cada país exporta os produtos cujo seu processo produtivo é intensivo no fator que possui em relativa abundancia.

A atribuição de vantagem comparativa no modelo clássico resulta a diferente produtividade do trabalho entres as nações. Já o modelo de H.O, conforme (KRUGMAN \& OBSTFELD, 2001), as vantagens comparativas são oriundas dos diferentes níveis de estoque relativos dos distintos fatores de produção que influenciam o custo de produção desses bens. As nações possuem uma tecnologia equivalente, mas diferem na disponibilidade dos fatores de produções como: terra, recursos naturais, mão-de-obra e capital.

A produção de frutas necessita a terra, a mão de obra e o capital. Ao olhar O Vale de São Francisco observa-se a possessão de uma mão de obra abundante na região para a produção de frutas que precisa de fator trabalho intensiva. Isto proporciona uma vantagem relativa à região que deve exportar as frutas para o mercado exterior. Hidalgo (1985) em seu trabalho confirma que as exportações brasileiras são relativamente mais intensas em trabalho que as importações, o que confirma a teorema de Hecksher-Ohlin para o Brasil. 0 país no qual o fator de trabalho for relativamente abundante e barato poderá produzir um bem intensivo em seu fator abundante a um custo relativamente baixo, exportando-o.

Ao concluir, a hipótese do modelo H.O é a especialização de cada país na produção de bem em que possui um fator de produção em abundância relativa. Apesar de ser um modelo de sucesso para explicar a vantagem de comércio internacional, o modelo não aceito a realidade de comércio atual por causa da diferença no uso da tecnologia. 
As limitações do modelo H.O foram superadas no ano 1970 com o "A Nova Teoria do Comércio Internacional" que pressupõe a hipótese de mercado de competição imperfeita e de retornos crescente de escala (CAVALCANTI, 1997).

Nessa nova hipótese destacam-se alguns autores como: Krugman (1779), Helpman (1981), afirma que a existência do comércio é definida na vantagem em economia de escala e não nas diferenças nas dotações de fatores. Portanto, o país especializa-se na produção daquele bem que consegue obter a um custo menor de escala, proporcionando a capacidade de competir no mercado internacional.

Além destes, outro teve dado uma contribuição significativa para analisar os dados de comércio exterior. Uma teoria desenvolvida por Balassa (1965), para criar os conceitos de Vantagem Comparativa Revelada (VRC). 0 autor propõe o VRC como o método alternativo que poder ser utilizado para identificar os setores nos quais a região possui a vantagem comparativa na produção e nas exportações.

\section{PROCEDIMENTOS METODOLÓGICOS}

Para atingir o objetivo do trabalho, analisou-se os índices da vantagem comparativa que mede o grau da especialização de um país perante um produto e de concentração das exportações de fruticultura de Vale São Francisco no comércio exterior.

\subsection{VANTAGEM COMPARATIVA REVELADA}

O conceito de vantagem comparativa adotado neste trabalho mostra os produtos que têm vantagem comparativa nas exportações da região em relação ao resto mundo para aumentar sua especialização no mercado internacional. 0 índice foi baseado na lei das vantagens de David Ricardo. Balassa (1965) afirma, os indicadores de vantagem comparativa servem para mensurar a especialização de uma economia no mercado mundial.

A análise da evolução das vantagens comparativas reveladas permite caracterizar a especialização adotada pela economia regional. Os produtos que apresentam vantagem comparativa revelada e taxa de cobertura superior à unidade simultaneamente constituem ser chamado "os pontos fortes" de uma economia (GUTMAN G. E. \& MIOTTI, L. E. ,1996).

A aplicação do índice de vantagem de comparativa (IVC) permite identificar os produtos que apresentam uma vantagem no mercado e pode ser exportado diante do mercado internacional.

0 índice IVC é definido da seguinte forma:

é o valor das exportações do produto i da região ou país j;

$\sum$ é o valor das exportações totais da região ou país

j; é o valor das exportações do produto i da zona de referência z;

e $\sum$ é o valor total das exportações da zona de referência $z$.

Se a VCRij > 1 então o produto i apresenta vantagem comparativa revelada e se a VCRij < 1 então o produto i apresenta desvantagem comparativa revela

\subsection{VANTAGEM COMPARATIVA REVELADA ASSIMÉTRICA}

A vantagem comparativa revelada de Balassa detém a limitação de que a desvantagem e a vantagem comparativa possuem dimensão assimétrica. A primeira varia entre 0 e 1 , e a segunda, entre 1 e infinito (HIDALGO, 2005). A fim de superar essa limitação, Laursen (1998) desenvolveu um índice normalizando a expressão da seguinte forma:

Onde VCRSij representa o índice de vantagem comparativa revelada simétrica. Feita essa normalização, o índice VCRSij varia no intervalo - 1 e 1 . Assim, se tal índice se encontra no intervalo entre 0 e 1 , a economia terá vantagem comparativa revelada naquele produto. Por outro lado, se o índice se encontra no intervalo -1 e 0 , o produto apresentará desvantagem comarativa revelada. 


\section{3 ÍNDICE DE CONCENTRAÇÃO POR PRODUTOS (ICP)}

O indicador utilizado para mensuração da concentração das exportações, tanto em relação ao produto quanto em relação ao mercado de destino, será o coeficiente de Gini-Hirchman o qual é amplamente empregado na literatura econômica. 0 valor do ICP assume valores entre zero e um $(0 \leq \mathrm{ICP} \leq 1)$. Um valor próximo à unidade indica que as exportações estão concentradas em poucos produtos. Por outro lado, quanto menor o ICP maior a diversificação da pauta de exportação do setor. ICP baixo reflete uma maior diversidade de produtos na pauta de exportações.

Desta forma, quando o índice se aproxima de 1 temos uma estrutura de exportação restrita a poucos produtos, por outro lado, quando este se aproxima de 0, o país apresenta um equilíbrio maior de produtos. Um grande número de produtos destinados a exportação, permite uma maior estabilidade das receitas cambiais e favorece a estabilidade dos termos de troca, devido baixo índice ICP. E um ICP próximo de 1 pode gerar maiores variações nas receitas.

\subsection{FONTE DE DADOS UTILIZADOS}

Para calcular ICP e VCR foram utilizados dados referentes aos valores em dólares FOB (Free of board) das exportações de uvas frescas; mangas frescas ou secas; sucos de outras frutas, prods. horticolas, não fermentados; óleo de soja, refinado, em recipientes com capa cidade>5L; couros/peles, bovinos, prepars.dividid.C/A flor; peles depilad.de ovinos,curt.cromo"WET BLUE" e das exportações totais dos produtos de Petrolina, disponíveis no Ministério da Industria Comércio Exterior e Serviço (MDIC) e TRADEMAP.

\section{ANALISE DE RESULTADOS}

Nesta seção apresentam-se os valores calculados dos índices da literatura de economia internacional segundo o disposto nas Tabelas como seguem:

Tabela 1- Índice de Vantagem Comparativa Revelada por Grupos de Produtos, Petrolina para Resto do Mundo- 2007/2017.

\begin{tabular}{|c|c|c|c|c|c|c|c|c|c|c|c|}
\hline Produtos & 2007 & 2008 & 2009 & 2010 & 2011 & 2012 & 2013 & 2014 & 2015 & 2016 & 2017 \\
\hline 1-UVAS FRESCAS & 1660,93 & 1545,4 & 1150,64 & 1237,08 & 1097,71 & 1077,3 & 1017,08 & 642,868 & 564,052 & 458,262 & 622,695 \\
\hline LAS & 47,9397 & 98,1631 & 154,849 & 164,594 & 0 & 151,453 & 106,043 & 97,6621 & 92,1663 & 103,576 & 95,5775 \\
\hline $\begin{array}{l}\text { 4- OLEODESOJA,REFINADO,EMRECIPIENTES COM } \\
\text { CAPACIDADE }>5 \text { L }\end{array}$ & 0 & 35,6723 & 0 & 0 & 8,4878 & 43,4573 & 0 & 131,099 & 51,9265 & 113,157 & 268,766 \\
\hline 5-COUROS/PELES,BOVINOS,PREPARS.DIVID.C/AFLOR & 7,36714 & 32,4096 & 21,696 & 39,286 & 20,9927 & 17,7124 & 12,3731 & 35,0682 & 8,16865 & 22,1758 & 28,7938 \\
\hline
\end{tabular}

Fonte: Elaborada pelos autores. Dados disponibilizados pelo COMEXSTAT/MDIC. 2018

Tabela 2- Índice de Vantagem Comparativa Revelada Simétrica por Grupos de Produtos, Petrolina para Resto do Mundo- 2007/2017.

\begin{tabular}{|l|c|c|c|c|c|c|c|c|c|c|c|c|c|}
\hline \multicolumn{1}{|c}{ Produtos } & 2007 & 2008 & 2009 & 2010 & 2011 & 2012 & 2013 & 2014 & 2015 & 2016 & 2017 \\
\hline 1-UVAS FRESCAS & 0,9988 & 0,99871 & 0,99826 & 0,99839 & 0,99818 & 0,99815 & 0,99804 & 0,99689 & 0,99646 & 0,99565 & 0,99679 \\
\hline 2- MANGAS FRESCAS OU SECAS & 0,99537 & 0,99505 & 0,99408 & 0,99497 & 0,99485 & 0,99538 & 0,99492 & 0,99505 & 0,99397 & 0,99514 & 0,99432 \\
\hline $\begin{array}{l}\text { 3- SUCOS DEOUTRAS } \\
\text { FRUTAS,PRODS.HORTICOLAS,NAO FERMENTADOS }\end{array}$ & 0,95913 & 0,97983 & 0,98717 & 0,98792 & -1 & 0,98688 & 0,98132 & 0,97973 & 0,97853 & 0,98088 & 0,97929 \\
\hline $\begin{array}{l}\text { 4 OLEODESOJA,REFINADO,EMRECIPIENTES COM } \\
\text { CAPACIDADE } 5 \text { 5L }\end{array}$ & -1 & 0,94546 & -1 & -1 & 0,7892 & 0,95501 & -1 & 0,98486 & 0,96221 & 0,98248 & 0,99259 \\
\hline 5 COUROS/PELES,BOVINOS,PREPARS.DIVID.C/AFLOR & 0,76097 & 0,94014 & 0,91188 & 0,95036 & 0,90906 & 0,89312 & 0,85045 & 0,94455 & 0,78187 & 0,9137 & 0,93287 \\
\hline $\begin{array}{l}\text { 6 PELES } \\
\text { DEPILAD.DEOVINOS,CURT.CROMO"WETBLUE" }\end{array}$ & 0,9834 & 0,99044 & 0,99362 & 0,993 & 0,90867 & 0,96993 & 0,96356 & 0,99402 & 0,99454 & 0,99346 & 0,99191 \\
\hline
\end{tabular}

Fonte: Elaborada pelos autores. Dados disponibilizados pelo COMEXSTAT/MDIC. 2018

Na Tabela 1 e 2 retratam-se a evolução do índice de vantagem comparativa revelada e vantagem comparativa revelada simétrica, durante o período 2007/2017 medidos através da formula (1) e (2), de Petrolina e resto do mundo. 
Quanto ao (óleo de soja, refinado, em recipientes com capa cidade>5L) o município não apresentou nos quatros anos (2007, 2009, 2010 e 2013) produtividade nesse setor, nos últimos restantes dos anos apresentou VCR. Aconselha-se que o município se aperfeiçoe na produção deste, caso queira competir com este produto no mercado internacional ou até regional. Já quanto à aos cinco produtos apresentou-se VCR em todos os anos com valores altos. Só (sucos de outras frutas, prods. horticolas, não fermentados) que em 2011 não teve sua exportação. Os resultados positivos apresentados pelos produtos especificamente pelos valores altos de vantagem comparativa de manga e uva nos anos analisados demonstram o bom desempenho desses produtos na pauta de exportação da região devido os investimentos que se fizeram na região. Segundo Silva (2001). A criação do Grupo de Irrigação do São Francisco (Gisf) que teve como o objetivo estudar os recursos naturais da região, assim que seu levantamento de solo das áreas para a irrigação para saber as melhores culturas que são adaptadas na região para sua maior produção e exportação. Ainda para Silva (2014), o projeto de irrigação e a criação do sistema Produção Integrada de Frutas (PIF) contribuem para obtenção de vantagem para essas frutas.

Esta análise da evolução das vantagens comparativas reveladas nos permite caracterizar a especialização seguida pela economia petrolinense que é a produção da uva e manga, tendo elas como "ponto forte" desta economia.

Tabela 3-Índice de Concentração das Exportações por Produtos 2007-2017

\begin{tabular}{|l|c|c|c|c|c|c|c|c|c|c|c|c|c|}
\hline \multicolumn{1}{|c}{ Produtos } & 2007 & 2008 & 2009 & 2010 & 2011 & 2012 & 2013 & 2014 & 2015 & 2016 & 2017 \\
\hline 1 UVAS FRESCAS & 0,05715 & 0,05862 & 0,06564 & 0,06243 & 0,06026 & 0,06068 & 0,06166 & 0,06228 & 0,06541 & 0,06705 & 0,06503 \\
\hline 2 MANGAS FRESCAS OU SECAS & 0,04996 & 0,04804 & 0,05457 & 0,05155 & 0,05133 & 0,05218 & 0,05539 & 0,05883 & 0,06325 & 0,07052 & 0,07317 \\
\hline $\begin{array}{l}\text { 3 SUCOS DEOUTRAS } \\
\text { FRUTAS,PRODS.HORTICOLAS,NAO FERMENTADOS }\end{array}$ & 0,08716 & 0,08422 & 0,08715 & 0,08123 & 0,0835 & 0,08208 & 0,08147 & 0,07902 & 0,08211 & 0,08286 & 0,08073 \\
\hline $\begin{array}{l}\text { 4 OLEODESOJA,REFINADO,EMRECIPIENTES COM } \\
\text { CAPACIDADE }>\text { 5L }\end{array}$ & 0,06903 & 0,07634 & 0,06854 & 0,06957 & 0,07192 & 0,06851 & 0,06387 & 0,05954 & 0,06448 & 0,06523 & 0,06164 \\
\hline 5 COUROS/PELES,BOVINOS,PREPARS.DIVID.C/AFLOR & 0,06205 & 0,05309 & 0,04986 & 0,05194 & 0,05044 & 0,04794 & 0,05121 & 0,05472 & 0,05191 & 0,04785 & 0,0461 \\
\hline $\begin{array}{l}\text { 6 PELES } \\
\text { DEPILAD.DEOVINOS,CURT.CROMO"WETBLUE" }\end{array}$ & 0,01785 & 0,01698 & 0,01657 & 0,01618 & 0,01761 & 0,01556 & 0,01429 & 0,01289 & 0,01277 & 0,01163 & 0,01058 \\
\hline \multicolumn{1}{|c|}{ Média } & 0,0572 & 0,05621 & 0,05706 & 0,05548 & 0,05584 & 0,05449 & 0,05465 & 0,05455 & 0,05665 & 0,05752 & 0,05621 \\
\hline \multicolumn{1}{|c|}{ Média das medias } & 0,05599 & & & & & & & & & & \\
\hline
\end{tabular}

Fonte: Elaborada pelos autores. Dados disponibilizados pelo COMEXSTAT/MDIC. 2018

Tabela 4- Exportações totais de Manga e Uva do Vale São Francisco e seu crescimento em relação o Resto do Mundo

\begin{tabular}{|c|c|c|c|c|c|c|c|c|}
\hline \multirow{2}{*}{ Anos } & \multicolumn{2}{|c|}{ Manga } & \multicolumn{2}{|c|}{ Uva } & \multicolumn{2}{|c|}{ Manga } & \multicolumn{2}{|c|}{ Uva } \\
\hline & O.B. & $\%$ & F.O.B. & $\%$ & USs F.U.D. & $\%$ & F.O.B. & $\%$ \\
\hline 2007 & 17.593 .781 & 100 & 88.669 .067 & 100 & 4.672 .911 & 100 & 6.113 .346 & 100 \\
\hline 2010 & 17.807 .219 & 139,33 & 81.472 .565 & 129,07 & 5.426 .977 & 109,04 & 7.960 .846 & 110,56 \\
\hline 2011 & 24.988 .832 & 140,32 & 97.604 .924 & 119,8 & 6.445 .267 & 118,76 & 8.884 .541 & 111,6 \\
\hline 2012 & 25.700 .659 & 102,84 & 86.713 .889 & 88,84 & 6.773 .279 & 105,08 & 9.160 .346 & 103,1 \\
\hline 2013 & 23.220 .920 & 90,35 & 74.447 .574 & 85,85 & 7.879 .867 & 116,33 & 9.762 .224 & 106,57 \\
\hline 2017 & 47.702 .036 & 117,23 & 66.787 .847 & 162,69 & 12.736 .923 & 118,18 & 10.062 .958 & 103,31 \\
\hline
\end{tabular}

Fonte: Elaborada pelos autores. Dados disponibilizados pelo COMEXSTAT/MDIC e TRADEMAP.2018

Na Tabela 3 consta o índice de concentração das exportações por produtos, período de 2007 a 2017, medido através da formula (3). Os dados mostram ICP com média de 0,055988, que significa uma concentração muito elevada em vários produtos, ou seja, uma pauta de produtos diversificada. No processo de redução dessa concentração, não existe uma tendência definida. A tabela 4 mostra que as 
evoluções das exportações da região. Há uma maior exportação da manga e uva em relação ao resto do mundo. Percebe-se uma variação de crescimento das exportações de uva que apresenta uma porcentagem maior de crescimento em relação à manga e as exportações do resto do mundo. Isto nos mostra o quão é importante a produção dessas culturas na região.

\section{CONSIDERAÇõES FINAIS}

Ao analisar as exportações de mangas frescas ou secas; sucos de outras frutas, prods. horticolas, não fermentados; óleo de soja, refinado, em recipientes com capa cidade $>5 \mathrm{~L}$; couros/peles, bovinos, prepars.dividid.C/A flor; peles depilad.de ovinos,curt.cromo"WET BLUE" de Vale São Francisco concretamente município de Petrolina através do indicador de mensuração de vantagem comparativa revelada de Balassa, vantagem comparativa revelada simétrica e índice de concentração por produtos de Gini-Hirchman. As relações comerciais entre a Petrolina e o resto do mundo para formação da base exportadora petrolinense também foram analisadas.

Os resultados evidenciaram que as exportações petrolinense são concentradas em diversos produtos. 0 crescimento das exportações do município tem acompanhado o crescimento das exportações mundiais. Foi encontrado muito dinamismo nas exportações e uma alta concentração em muitos produtos tanto primários assim como de valores agregados. Através dos IVCR e IVCRS calculados pode-se concluir que a produção de uvas frescas e mangas frescas ou secas, ou seja, esses setores são chamados de "forte" no comércio exterior seguido por setores de sucos de outras frutas, prods. horticolas, não fermentados; óleo de soja, refinado, em recipientes com capa cidade>5L; couros/peles, bovinos, prepars.dividid.C/A flor; peles depilad.de ovinos,curt.cromo"WET BLUE". De acordo com o critério desenvolvido por Gutman e Miotti (1996), o setor é definido como "forte", quando vantagem comparativa revelada apresenta um valor maior que a unidade.

Este estudo teve como limitações importantes quanto à dados referentes aos destinos das exportações petrolinense, com isso poderíamos calcular índice de concentração por destino (ICD) que também é de Gini-Hirchman que mostra a mensuração da concentração por destino, também gostaríamos de calcular o índice de orientação regional (IOR) que tem como objetivo avaliar a importância de parceria comercial das exportações deste município que destaca muito no agronegócio brasileiro.

Ao longo do desenvolvimento deste estudo identificaram-se questões correlatas que permitiriam o desenvolvimento de outros estudos para ampliar o entendimento do fenômeno estudado, ou para buscar confirmação empírica dos resultados obtidos.

\section{REFERÊNCIAS}

[1] BALASSA, Bela. Trade liberalisation and revealed comparative advantage. Washington, D.C.: Banco Mundial, 1965

[2] BANCO DO NORDESTE -BNB. Disponível em < https://www.bnb.gov.br/> . Acesso em : 20 jul 2018

[3] CARVAlHO, M. A.; SILVA, C. R. LB Internacional. São Paulo: Saraiva. 3.ed, 2004. CAVALCANTI, M. F. H. Integração econômica e localização sob concorrência imperfeita. Porto Alegre: BNDES, 1997.

[4] CENTRO DE ESTUdOS AVANÇADOS EM ECONOMIA APLICADA - CEPEA.

[5] Disponível em: < https://www.cepea.esalq.usp.br/br>. Acesso em 20 jul.2018 CHUDNOVSKY, D. La competitividad internacional : principales questiones conceptuales y metoodologicas, CEIPOS. 1990.

[6] COUTINHO, Eduardo Senra; Et al. Economia de Empresas. In: Revista de Gestão USP. São Paulo, v.12, n.4,p. 101-113, dezembro 2005.

[7] FOOD AND AGRICULTURE ORGANIZATION - FAO. FAOSTAT. Disponível em:<http://faostat.fao.org>. Acesso em: 20 jul. 2018.

[8] FIORAVANÇO, J. C.; PAIVA, M. C. Competitividade e fruticultura brasileira. Informações Econômica, São Paulo, v. 32, n. 7, p. 24-40, jul.2002.

[9] GONÇALVES, Reinaldo; Et al. A nova economia internacional: uma perspectiva brasileira. Rio de Janeiro: Editora Campus. 1998. 11프 ed.

[10] GUTMAN, G.E. , MIOTTI, L.E. Exportaciones agroindustriales de América Latina y el Caribe. especialización, competitividad y oportunidades comerciales em los mercados de la OCDE. Nações Unidas: CEPAL, 1996. 
[11] HAGUENAUER,L. (1989); Competitividade: Conceitos e Medidas; TD IEI/UFRJ; n. 211; RJ.

[12] HILDAGO, Álvaro Barrentes. Intensidades Fatoriais na Economia Brasileira: novo teste empírico do teorema de Hecksher-Ohlin. Revista Brasileira de Economia VOL. 39, n1. Janeiro- Março. Rio de Janeiro, 1985.

[13] JUÁREZ, M. ; PADILLA, R. Efectos de la capacitación em la competitividad de la indústria manufacturera. Revista de La CEPAL, Local, n. 92, ago. 2007.

[14] KUPFER, D. Competitividade da indústria brasileira: Visão de conjunto e tendências de alguns setores. Revista Paranaense de Desenvolvimento. IPARDES; maio-ago. 1994. KRUGMAN, Paul; OBSTFELD Maurice. Economia Internacional. São Paulo: Makron Book. 2001 25a ed.

[15] .Economia internacional: teoria e política. São Paulo: Makron Books, 2009

[16] PORTER, M. E. A vantagem competitiva das nações. Rio de Janeiro: Campus, 1993.

[17] Estratégica competitiva: técnicas para análise de indústria e da concorrência. 7a ed. Rio de Janeiro: Campus, 1993

[18] MINISTÉRIO DE DESENVOVILMENTO, INDUSTRIA E COMÉRCIO - MDIC. Disponível em < http://www.mdic.gov.br/>. Acesso em 20 jul 2018

[19] SILVA,F.A. Comércio internacional e crescimentoeconômico: uma análise considerando os setores e aassimetria de crescimento dos estados brasileiros. Dissertação (Mestrado em Economia Aplicada) Programa de PósGraduação em Economia Aplicada, Universidade Federal de Viçosa, UFV, 2014.

[20] RICARDO, D. Princípios de Economia Política e Tributação. São Paulo: Abril Cultural, 1982.

[21] SALVATORE, Dominick. Economia Internacional. Rio de Janeiro: LTC. 1998.6 a ed. SMITH, Adam. Uma investigação sobre a natureza e causas da riqueza das nações. São Paulo: Hemus, 2008.

[22] SILVA, P.C.G.da. Articulação dos interesses públicos e privados no pólo Petrolina - PE/Juazeiro - BA: em busca de espaço no mercado globalizado de frutas frescas. Tese de Doutorado, Instituto de Economia, Universidade Estadual de Campinas - UNICAMP, 2001 SILVA, TIAGO; E al. A competitividade das exportações de manga e uva do vale submédio do são francisco: uma aplicação do método constant market-share e do indicador de vantagem comparativa revelada de Vollrath. In: ENPECOM Economia Regional e Agrícola, nov 2014

[23] ZUZA, J. V. C. F. A política econômica regional do Vale do São Francisco: uma busca do desenvolvimento do interior brasileiro. Revista Estudos Sociais, Mato Grosso, ano 10, n. 20,v.2.2008 


\title{
Capítulo 23
}

BIODIGESTORES NA SUINOCULTURA CATARINENSE: RELATO DE EXPERIÊNCIAS DE IMPLANTAÇÃO

\author{
Francisco Gelinski Neto \\ Eduardo Gelinski Junior \\ Nédio Rogério Rogoski
}

Resumo: A suinocultura tem importante participação na economia brasileira, constituindo-se o Brasil o quarto exportador mundial de carne suína. Em Santa Catarina a suinocultura é a segunda atividade em Valor Bruto de Produção. Todavia, esta atividade é uma forte geradora de externalidades negativas ao meio ambiente. Face a questão, os compromissos brasileiros na COP-15 tem levado o governo a procurar alternativas tecnológicas para redução de emissões causadoras do efeito estufa (GEE). Nesta linha também estão os esforços para a Suinocultura de Baixo Carbono. 0 ponto central deste trabalho foi verificar a situação das emissões de gás metano gerada pelos efluentes desta atividade. Buscou-se analisar a utilização da tecnologia de coleta, queima de biogás e/ou geração de energia. Assim, foram avaliados sistemas existentes em três microrregiões catarinenses Joaçaba, Concórdia e Xanxerê. Estas são os principais produtores de suínos no Estado e onde se localizam empresas tradicionais de processamento de proteína animal - BRF (ex-Sadia e Perdigão), Aurora, e JBS. Dessa forma, foi avaliada a evolução de tecnologias na geração de biogás, as dificuldades e o índice de utilização de biodigestores do modelo Canadense de fluxo contínuo tecnologia recomendada e mais empregada no segmento. Realizou-se pesquisa de campo, entrevistas com técnicos de empresas privadas, públicas e cooperativas, os quais permitiram verificar as dificuldades de manutenção dos sistemas de biodigestores como fonte de geração de gás. Constatou-se gradativo abandono de experiências e de projetos implantados em diversas unidades, além de não apontar para ampliação de uso em horizonte de curto prazo. A ineficácia da solução tecnológica preconizada e a inviabilidade econômica e financeira na geração de gás, bem como de acesso a fontes de financiamento de programas estatais vêm inibindo a busca de novas soluções tecnológicas pelos produtores de suínos no Estado na redução de GEE. Palavras-chave: Suinocultura. Biogás. Biodigestores. Gás de Efeito Estufa. 


\section{INTRODUÇÃO}

O Brasil é o quarto produtor e exportador de carne suína do mundo em 2016. A suinocultura brasileira contribui neste ano com 1,74\% do total das receitas de exportações do agronegócio em atingindo US\$ 84,9 bilhões (COMEX DO BRASIL, 2017). Foram exportados US\$1,483 bilhão de dólares, porém, a produção brasileira que no ranking mundial2 é de apenas 3,3\% (USDA, 2017), fato que poderia ser bem maior se comparada aos demais países com área geográfica semelhante. Por exemplo, China que produzem 51,8 milhões de toneladas, a União Européia 23,3, os EUA 11,3 e o Brasil apenas 3,7 milhões de toneladas (GIEHL, 2016).

O Estado de Santa Catarina é um dos líderes neste segmento produtivo. É o 1o colocado no País na produção de carne de suínos com 934 mil toneladas em 2016 e tem a segunda posição em termos de valor bruto da produção (VBP), com 3,96 milhões de reais (TORESAN, 2016). De acordo com a ACCS (2017) mais de 8 mil produtores de suínos dedicam-se a atividade no Estado. Santos Filho et all. (2015, p.7) destaca a presença significativa de pequenos agricultores familiares que se relacionam com as agroindústrias processadoras de carne no "sistema integrado de produção", bem como grandes produtores integrados de produção.

Este cenário econômico e social em Santa Catarina é decorrente de uma forte concentração da suinocultura nos últimos anos, dos grandes conglomerados agroindustriais de proteína animal que resultou em competitividade na disputar o mercado nacional e internacional da proteína animal.

Porém, quando a preocupação é o meio ambiente a atividade é visada pelo grande volume de efluentes (sólidos, líquidos e gasosos) oriundos da produção. A produção de resíduos/estercos atingem tal volume que a legislação ambiental restringiu a atividade dos produtores à disponibilidade de área para distribuir os mesmos visando minorar o risco de poluição conforme a Instrução Normativa no 11 (INE 11/FATMA).

Pelo menos desde o início dos anos 90, em Santa Catarina havia a preocupação com os dejetos oriundos das criações de suínos. Naquele momento o problema estava relacionado, sobretudo à poluição causada por coliformes fecais. Iniciava-se então uma grande movimentação para a busca de financiamentos e apoios para a construção de esterqueiras e lagoas de decantação e outros tratamentos para reduzir o impacto da atividade que era crescente no Estado. Por exemplo, no II Seminário de Administração Rural ocorrido na Cidade de Concórdia em dezembro de 1992 foi discutido entre outros o problema ambiental provocado pela atividade suinocultura. Isto foi emblemático por que Concórdia é um dos principais polos de criação de suínos em Santa Catarina, berço da EMBRAPA Suínos e Aves e da SADIA, atual BRF.

TESTA at al., (1996) visando a sustentabilidade econômica e ambiental, preconizavam para aquela época uma criação de ciclo completo com no máximo 25 matrizes por propriedade. Dessa forma estaria assegurada a eficiente distribuição e ou tratamento de esterco sem gerar poluição. Obviamente, dadas as atuais escalas4, essa situação não existe mais. A pressão de custos e preços tornou a pequena escala impossível, além de levar os produtores a se especializarem em uma etapa do ciclo5.

Embora o rebanho catarinense estivesse em torno de 4,4 milhões de cabeças em 1995 (MACHADO, 1999) já era preocupante o problema dos dejetos. Com o atual tamanho de rebanho os problemas com efluentes são maximizados, pois, foram produzidas 6,8 milhões de cabeças em 2015 (IBGE 2016). Estes animais gerariam aproximadamente $47.500 \mathrm{~m}^{3}$ de dejetos (efluentes) diariamente.

Dos efluentes, se forem corretamente tratados, pode-se obter biofertilizante e o biogás.

A fermentação e/ou decomposição anaeróbica dos dejetos/efluentes produzirá entre outros o metano. Para se evitar a liberação do metano na atmosfera se podem utilizar biodigestores que permitem a coleta e queima do biogás. 0 metano e o dióxido de carbono presentes no biogás são responsáveis pelo efeito estufa no globo terrestre (ABREU, AVELINO 2012 apud TORRES, SILVA 2015). 0 uso de biodigestores e os sistemas integrados de tratamento são mais eficientes na remoção da carga poluente comparativamente a utilização de simples esterqueiras, mas apresentam maiores custos o que torna restritivo para utilização de muitos produtores (MAIA at al.,, 2015).

Paralelamente à problemática ambiental há que se considerarem os ciclos econômicos da atividade de criação de suínos. É uma atividade que sempre tem sofrido pressão de custos a ponto de culminar com gigantescas escalas de operação e exclusão de produtores em razão de problemas ligados normalmente à elevação de custos de matérias primas e/ou de mercado com preços deprimidos (GRIEBELER, 2002; TESTA at al.,, 1996). Por exemplo, Rodrigues at al., (2013) verificaram que houve desvantagem econômica dos produtores de suínos de Santa Catariana na maioria dos meses do período compreendido entre janeiro de 2000 e setembro de 2012 quando a relação de trocas foi desfavorável aos produtores. Nesses 
casos, a inversão em sistema de biodigestão pode tornar-se dificultosa, pois, a geração de caixa será insuficiente para arcar com esse tipo de investimento colocando em risco a sustentabilidade econômica do produtor.

Porém, em um momento em que há uma preocupação crescente quanto à preservação do meio ambiente e a sustentabilidade, é natural que cresçam as exigências legais sobre a atividade. 0 mundo está preocupado entre outros aspectos com questões relacionadas ao bem estar animal e à problemática dos gases do efeito estufa (GEE) e outros aspectos relativos à poluição ambiental. Inclusive o Programa brasileiro agricultura baixo carbono (ABC) é um esforço no sentido de estimular os produtores a adotarem mecanismos redutores dos GEE e de conservação de recursos naturais conforme compromisso Brasileiro na 15a. Conferência das Partes (COP-15).

Nesse contexto, este trabalho pretende elucidar algumas questões: Como está atualmente a utilização de biodigestores nas principais regiões produtoras de suínos em Santa Catarina, a saber, as microrregiões de Concórdia, Joaçaba, Xanxerê e Videira e as perspectivas para esta prática e quais são as dificuldades no cumprimento de exigências ambientais para a suinocultura?

O objetivo geral é o levantamento da utilização do tratamento de dejetos de suínos por meio do uso de biodigestores em quatro (4) Microrregiões de Santa Catarina e verificar as dificuldades dos produtores em cumprirem todas as exigências ambientais. Especificamente busca-se a) descrever/levantar a importância da eliminação do metano; b) verificar a existência de estímulos ou incentivos para instalação de sistema de biodigestão; c) verificar exemplos de programas de biodigestores em Santa Catarina; d) dificuldade de implantação e manutenção de um sistema de biogás.

\section{METODOLOGIA}

Trata-se de uma pesquisa descritiva que utiliza de dados primários e secundários. É um estudo com escopo na economia da produção agrícola e da economia ambiental. A área geográfica de estudo abrange as Microrregiões de Concórdia, Joaçaba, Xanxerê e Videira, sendo que estão classificados respectivamente como $1^{\circ}, 2^{\circ}, 5^{\circ}$ e $7^{\circ}$ produtores em termos de volume no Estado segundo Giehl (2016). Os dados primários foram obtidos com entrevistas junto a produtores, técnicos de cooperativas e empresas públicas que trabalham na região9, empresas privadas (Granja São Roque e Granja Comelli). Os dados secundários são de relatórios técnicos das agroindústrias, Epagri, Cidasc, dissertações e outras fontes bibliográficas de periódicos indexados.

\section{A SUINOCULTURA E A POLUIÇÃo}

As principais formas de poluição são a poluição hídrica, b) poluição atmosférica10, c) poluição do solo, d) poluição sonora, e) poluição visual e f) poluição radioativa (SANTOS at al., , 2002 apud GUESSER, 2016). Já segundo o artigo 3a da Lei de n⿳0 6.938/81 que trata da Política Nacional do Meio Ambiente, poluição é a degradação da qualidade ambiental resultante de atividade que direta ou indiretamente: prejudiquem a saúde, a segurança e o bem-estar da população; criem condições adversas às atividades sociais e econômicas; afetem desfavoravelmente a biota; afetem as condições estéticas ou sanitárias do meio ambiente; lancem matérias ou energia em desacordo com os padrões ambientais estabelecidos (GUESSER, 2016).

A poluição ambiental causada por dejetos oriundos da suinocultura abrange elevado número de contaminantes que causam forte degradação do ar, do solo e principalmente dos recursos hídricos (águas superficiais e subterrâneas). 0 lançamento direto de estercos em cursos de água é a principal causa de poluição (NOLASCO et al., 2005).

O problema ambiental da suinocultura está no aumento do número de animais por metro quadrado por buscar obter, principalmente, economia de escala. Ao se aumentar o número de animais a consequência natural é o aumento do volume de dejetos. Caso não sejam tratados comprometerão o ambiente (WEYDMANN, 2014).

Nesse sentido, Valente et al., (2013) apud Guesser (2016) concluíram que na região Sul do Brasil a criação de suínos é altamente tecnificada em sistemas de confinamento, o que propicia grande concentração de animais por $\mathrm{m} 2$ gerando um grande volume de resíduos orgânicos principalmente na forma líquida. Isso exigiria cuidados especiais com relação ao seu manejo, armazenagem e distribuição. 
Maiores exigências da legislação ambiental bem como pressões do mercado consumidor têm levado as cadeias agroindustriais a ações pró-sustentabilidade ambiental e maior transparência em sua atuação relativamente aos recursos ambientais. 0 setor suinícola tem sido incentivado a reciclar os seus resíduos no sentido de obter maiores rendimentos e gerar menos resíduos a serem tratados (VALENTE et al., 2013). Ao comparar a legislação brasileira a de outros países produtores importantes, com escassez de área para utilizar os dejetos como fertilizante, a exemplo do Japão, Alemanha e Holanda, Weydmann (2014) verificou que estes têm evitado a expansão do setor diretamente por proibições e indiretamente através de legislação ambiental mais severa.

\subsection{A LEI E A NORMA PARA O LICENCIAMENTO AMBIENTAL DA ATIVIDADE}

Esta seção trata das leis e instrução normativa que regem o meio ambiente e a suinocultura em Santa Catarina e os tipos de licenças necessárias pelos produtores. Outorgada em 13 de abril de 2009, a Lei estadual de no 14.675/09, foi a responsável por instituir o Código Estadual do meio ambiente. Para a execução da atividade os suinocultores devem seguir uma série de normas, estas definidas pela Fundação do Meio Ambiente (FATMA) com base no código estadual. A instrução normativa (IN) no 11 é a que define o licenciamento e estabelece critérios para apresentação dos planos, programas e projetos ambientais para implantação de atividades relacionadas à suinocultura de pequeno, médio e grande porte. Nesta IN inclui-se o tratamento de resíduos líquidos, tratamento e disposição de resíduos sólidos, emissões atmosféricas, ruídos e outros passivos ambientais (FATMA, 2014, p.1).

Segundo Palhares (2008) as licenças ambientais requeridas pela legislação brasileira para produção animal são a) Licença Prévia (LP) requerida na fase de avaliação da viabilidade do empreendimento; b) Licença de Instalação (LI); c) Licença de Operação (LO) - esta tem prazo máximo de dez anos.

A licença de operação possui entre suas características as medidas de controle ambiental (padrões ambientais) que servirão de limite para o funcionamento do empreendimento ou atividade, especifica as condicionantes determinadas para a operação do empreendimento, cujo cumprimento é obrigatório sob pena de suspensão ou cancelamento da operação (FATMA, 2016). Estas licenças visam minorar o problema da poluição causada pela atividade em questão, pois o foco deste trabalho é o problema da poluição atmosférica que pode ser resolvida pela coleta e destinação adequada do biogás.

\subsection{O MANEJO DOS DEJETOS NA SUINOCULTURA E O BIOGÁS}

Considerando que os dejetos são compostos por sólidos, líquidos e gás, as formas de tratar o problema diferem conforme os investimentos necessários e os resultados visados. Pode-se priorizar, no tratamento de dejetos, apenas o adubo ou ainda adubo e biogás ou, além destes pode-se obter por meio de sistema integrado o adubo, biogás e peixes11 (SAVIOTTI, et al., 2016).

Os biodigestores são capazes de gerar energia por meio da coleta e queima dos gases oriundos do processo de fermentação aneróbica e viabilizam o aproveitamento do biofertilizante reduzindo os resíduos poluentes dos dejetos animais. Outra vantagem é a redução do mau cheiro ao remover os gases, além de reduzir a carga orgânica e concentrar os nutrientes por unidade de volume valorizando o uso do biofertilizante em áreas de lavouras e pastagens (HENN, 2005; OLIVEIRA, 2004 apud Maia et al., 2015).

Os sistemas integrados permitiriam remover praticamente toda a carga poluente ao se complementar o tratamento do biodigestor com a utilização do tanque de sedimentação, lagoa de aguapés e tanque de piscicultura conforme figura 1 (MAIA at al., 2015, p.226). 
Figura 1. Esquema de um sistema integrado com biodigestor

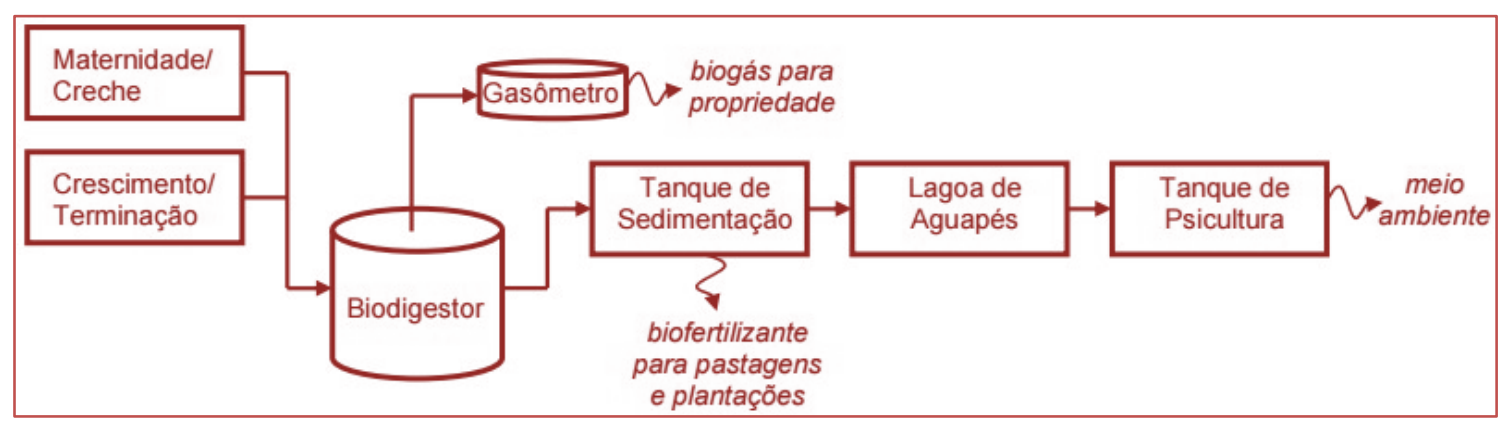

Fonte: MAIA at al., 2015, p.226.

Uma das principais preocupações ambientais e que está fortemente ligada à produção de suínos é a emissão de gases causadores do efeito estufa (GEE), em destaque o metano que absorve muito a radiação solar na superfície da terra aumentando o efeito estufa. A concentração global deste gás vem aumentando em média a uma taxa de $1 \%$ ao ano, sendo que $80 \%$ deste gás é oriundo da decomposição de matéria orgânica. "O grande desafio das regiões com alta concentração de animais é a exigência da sustentabilidade ambiental, energética e a redução da emissão dos GEE (OLIVEIRA et al 2006).

O sistema de biodigestores e/ou sistema integrado pode minorar o impacto ambiental gerando benefícios ambientais e econômicos aos produtores se resolvido o problema de manutenção. Nosso levantamento junto aos produtores e técnicos verificou o baixíssimo índice de utilização e mesmo o abandono do sistema. Por exemplo, Kruger (2016) verificou que apenas 5\% dos produtores de uma amostra de 163 gestores rurais do Oeste de SC possuem biodigestores para o tratamento dos resíduos gerados pela produção suinícola. "No Brasil, há aproximadamente 2500 biodigestores instalados. É um baixo número comparado ás 700 mil propriedades que produzem suínos no país. Destes já instalados, apenas 5\% são destinados a produção de energia" (BIONDO, 2015, p.1).

Nas décadas 1970 e 1980 a manutenção do interesse pelo uso de biodigestores e o biogás esbarraram no custo dos equipamentos e baixo conhecimento tecnológico e inexistência de materiais e complementos acessíveis. Atualmente a disponibilidades de novos materiais com preços acessíveis e novas tecnologias possibilitariam maior alcance e disseminação no uso dos biodigestores com finalidade energética e biofertilização. Também pesam nas decisões de produtores, agentes reguladores, governos e consumidores a problemática do aquecimento global decorrente de gases de efeito estufa (OLIVEIRA, HIGARASHI, 2006).

\section{SUINOCULTURA DE BAIXO CARBONO E RENDIMENTOS DO BIOGÁS}

Há urgência em ações para reverter o quadro antagônico em parte da população com relação à produção animal em razão da produção de metano nas atividades pecuárias. Neste sentido Gerber at al., (2013, apud EMBRAPA, 2016) destacam justamente a atuação de movimentos populares para redução e exclusão do consumo de carne por considerarem a produção animal como uma das principais emissoras de GEE. "A pecuária é responsável por grande parte dessa emissão de GEE, sendo que $9 \%$ é atribuído à produção de suínos. Desse montante de $9 \%, 16 \%$ é responsabilizado pela produção de metano devido ao manejo inadequado de dejetos" Gerber et al (2013) apud SAVIOTTI at al.,(2016, p.41).

A suinocultura, como outras atividades da agricultura brasileira, está enquadrada na necessidade de contribuí para o esforço do país em cumprir o compromisso voluntário de redução de emissão de gases de efeito estufa (GEEs) que foi firmado durante a 15 ${ }^{\text {a }}$ Conferência das Partes (COP-15).

Na COP-15 o Brasil comprometeu-se reduzir entre 36,1\% e 38,9\% das emissões de GEE projetadas para 2020. Para isto o governo elaborou o Plano Setorial de Mitigação e de Adaptação às Mudanças Climáticas para a Consolidação de uma Economia de Baixa Emissão de Carbono na Agricultura, também denominado Plano ABC (Agricultura de Baixa Emissão de Carbono) (BRASIL, s/d).

O Plano ABC12 tem por finalidade a organização e o planejamento das ações a serem realizadas para a adoção das tecnologias de produção sustentáveis13. O setor agropecuário respondeu por $37 \%$ das emissões totais em 2012, figurando, junto com o setor de energia, como o maior emissor setorial (Brasil, 2014, apud GURGEL at al., 2016). 
A agricultura, embora seja emissora de carbono em razão da produção de alimentos na forma intensiva para suprir a oferta necessária às populações crescentes e a excessiva dependência da queima de combustíveis fósseis ao longo das cadeias agroindustriais, deverá receber os impactos do aquecimento global em razão das intempéries que se abaterão sobre os campos de produção. São inundações, vendavais, temperaturas extremas ou outro. Portanto, a agricultura se distingue relativamente dos demais setores da economia no que se refere ao tratamento do tema.

A produção de alimentos e a decorrente segurança alimentar é importante tanto do ponto de vista fisiológico e nutricional quanto do estratégico e político (BRASIL, s/a). Segundo o MAPA (2011), a ocorrência da mudança do clima pode afetar a produção agropecuária e trazer consequências negativas e imprevisíveis para esse setor, por que deverá ocorrer: i) Aumento na concentração de CO2; ii) Aumento da temperatura do ar e do solo; iii) Aumento de secas e chuvas torrenciais que trarão diversos impactos sobre a produtividade e sobrevivência de animais e plantas (GUESSER, 2016).

Visando a produção sustentável de suínos e a redução de emissão de carbono para a atmosfera, em 2016 o Ministério da Agricultura, Pecuária e Abastecimento (MAPA) desenvolveu acordo de cooperação com o Instituto Interamericano de Cooperação para a Agricultura (IICA). Neste acordo busca-se operacionalizar o projeto Suinocultura de Baixa Emissão de Carbono no escopo do Plano ABC. Foram contratados consultores para divulgar modelos e maneiras de economizar carbono na suinocultura. Entre outras ações, os consultores realizaram Fóruns de Suinocultura de Baixa Emissão de Carbono em várias regiões do país14 (MAPA..., 2016).

Embora todo esforço para estimular os produtores a adotaram os biodigestores para eliminação dos gases há que se observar estímulos e factibilidade da tecnologia em função do porte/escala dos produtores. Parece que o modelo atual, o biodigestor modelo canadense não está dando conta em questões operacionais a ponto de ter ocorrido abandono em muitas propriedades como se verá adiante neste trabalho. Outro aspecto é o estímulo financeiro. Por exemplo, Wander at al., (2016) apontaram para menor tomada de recursos para tratamento de dejetos nas safras 2011/12 e 2012/13. De 9,9 milhões de reais e 22 contratos o valor utilizado do Plano ABC/Plano Safra se reduziu para 7,3 milhões de reais no período considerado indicando retrocesso na área de tratamento de dejetos na agricultura.

A combustão do biogás gerado no biodigestor evita a liberação de metano ao ambiente15. Além disso, “[...] o efluente ao passar pelo biodigestor tem melhorada as condições do material residual para finalidade agrícola, pois, aumenta a solubilidade de alguns nutrientes no biofertilizante" (AMARAL et al., 2006, p.41).

Em termos de geração de energia o biogás propicia os seguintes rendimentos, por exemplo: em uma propriedade com 200 suínos em terminação é possível produzir $16 \mathrm{~m}^{3}$ de biogás, $6 \mathrm{~kg}$ de GLP ou gerar 16 $\mathrm{kWh}$ de energia elétrica por dia (BGS, s.d.). Considerando para o Brasil como um todo 1.600 .000 matrizes tecnificadas, Pazinato Dias at al., (2016) estimaram que seria possível produzir $115.200 \mathrm{~m}^{3} /$ dia de biogás no país.

Foi estimado para o rebanho suinícola catarinense para o ano de 2008 uma produção de 556 milhões de $\mathrm{m}^{3}$ biogás /ano e 309 milhões de $\mathrm{m}^{3}$ CH4/ano (DAL MAGO, 2009). Angonese at al., (2006), analisando a eficiência energética de um sistema de produção de suínos com biodigestor, verificaram que o biofertilizante representa $30,2 \%$ e o biogás $13 \%$ dos valores totais da energia do sistema. 0 suíno representa $56,8 \%$. A energia "recuperada" do biogás e do biofertilizante quase chegam a $50 \%$ do sistema total. Estes dados estão alinhados com os valores encontrados por Goldemberg (1998) e Beber (1989). A efetiva utilização destes dois "sub-produtos" seria a renovação de energia, reduzindo o impacto ambiental e minimizando a importação de energia segundo os autores.

Embora seja possível a comercialização da energia gerada pelo sistema de biogás, de acordo com a Resolução Normativa 482 da Agência Nacional de Energia Elétrica - ANEEL, de abril de 2012, o que se deve observar é a economicidade. De acordo com Martins e Oliveira (2011) apud Pazinato Dias at al., (2016, p.2) temos pois "ser mais vantajoso economicamente o uso desta energia na propriedade rural, substituindo ou reduzindo a aquisição da energia elétrica distribuída pela concessionária". Em Santa Catarina as Centrais Elétrica de Santa Catarina (Celesc) passou a adquirir energia produzida com biogás a partir de 2010 e foi na granja São Roque município de Videira (meio oeste do Estado).

\section{AS EXPERIÊNCIAS CATARINENSES COM BIODIGESTORES}

Esta seção descreverá as diversas experiências públicas e privadas recentes na utilização de biodigestores na atividade da suinocultura em Santa Catarina16. 
A Sadia, atual BRF, iniciou em 2003 ações que culminaram com a criação do Programa 3S (Sistema de Suinocultura Sustentável)17. Os primeiros estudos e projetos foram relacionados à mitigação de gases do efeito estufa. Em 2004 foram instalados os primeiros biodigestores e criado o Programa. O Programa que apoiou produtores integrados para a construção de biodigestores. 0 sistema permite a queima dos gases gerados no processo do tratamento dos dejetos. Ainda em 2004, a Sadia criou o Instituto Sadia para promover o desenvolvimento sustentável em parceria com a comunidade (MARCOVITCH, 2008).

A adesão ao 3S era voluntária e pretendia que ao gerenciar os resíduos e reduzir a emissão de GEE ocorressem melhores condições de vida dos produtores de suínos, com um ambiente de trabalho mais saudável (MARCOVITCH18, 2008). A modificação de qualidade ambiental é importante por que a atividade é relativamente insustentável conforme declarou Marcovitch (2008, p.27) “[...] a suinocultura no Brasil não é sustentável devido aos níveis de poluição ambiental severa que causa precárias condições de trabalho e de vida de seus produtores". O tratamento de efluentes e resíduos faz parte de um conjunto amplo de ações para a sustentabilidade desenvolvida pela sadia/BRF.

"Em 2006, a empresa teve o Programa 3S reconhecido pelo Prêmio Brasil Ambiental, na categoria Mecanismo de Desenvolvimento Limpo (MDL), [...] como projeto importante dentro de critérios de desenvolvimento sustentável" (MARCOVITCH, 2008, p.12). Dos 3.500

O Programa 3 S da Sadia rendeu a sua inclusão no Relatório de 2008 da ONU sobre desenvolvimento20. 0 Relatório considerou o Programa $3 \mathrm{~S}$ importante pois a empresa incluiu a sustentabilidade no seu Plano de renda dos produtores uma vez que o processo de coleta e tratamento dos efluentes, em especial, os gases de efeito estufa poderiam ser comercializados dentro do Mecanismo de Desenvolvimento Limpo (créditos de carbono) facilitando os investimentos nos biodigestores (AGROSOFT, 2008, s.p). Realmente, até 2008 a Sadia já havia negociado créditos junto ao European Carbon Found que somaram mais de 2,4 milhões de toneladas de CO2. Tais créditos teriam contrapagamentos durante dez anos, quando comprovada a captura do gás nos biodigestores (MARCOVITCH, 2008). Aparentemente estes pagamentos não chegaram a se concretizar.

Vale destacar que o último relatório de atividades da BRF - Relatório 2015 só menciona a preocupação da empresa com o gerenciamento dos efluentes, mas não detalha ações específicas com o uso de biodigestores nas propriedades rurais.

A Cooperativa Central Oeste Catarinense - Aurora teria instalado, desde 2007, em duas granjas em Chapecó equipamento de biodigestão (figura 2) para tratar os efluentes e gerar energia com o biogás. 0 gás gerado pelos resíduos de 5.000 suínos é canalizado e encaminhado para consumo no frigorífico. São produzidos 20 mil quilos de gás por mês, o que representa 70\% do consumo da unidade (DEBONA, 2013).

A Cooperativa Agroindustrial Alfa - CoperAlfa teria instalado em sua Unidade de Produção de Leitões (UPL) de Palma Sola três biodigestores que produziriam energia para atender 100\% das necessidade da granja, sendo portanto autossustentável segundo Clenoir Antônio Soares engenheiro agrônomo da CoperAlfa (PROJETO, s.d.).

Figura 2: Biodigestores: grandes lonas infladas com o biogás (Aurora)

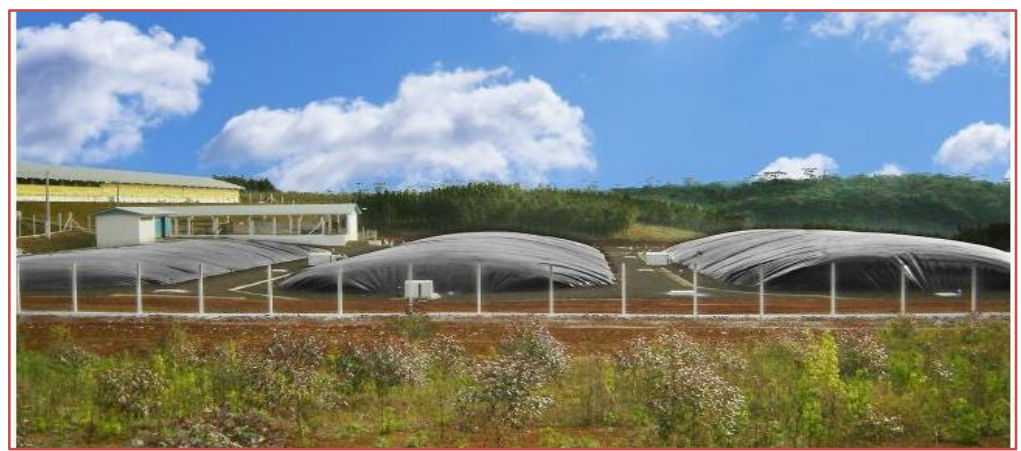

Foto: Gter Energias Renováveis. 
Outra experiência foi o fomento da Eletrosul no chamado Projeto Alto Uruguai, cuja primeira fase implantou 35 biodigestores em localidades de Santa Catarina e Rio Grande do Sul (29 cidades). A segunda etapa ocorreu em Itapiranga e visava a queima de metano para geração de energia, com investimento de R\$ 10 milhões em 10 biodigestores em várias propriedades do Município (DUDEK, 2013). A Eletrosul embora tivesse respondido ao pedido de informações não disponibilizou a tempo as informações que permitissem avaliação do andamento dos projetos citados.

Outros exemplos, em Santa Catarina, no município de Iomerê, a Master Iomerê e Granja Comelli buscaram implantar sistemas de geração de biogás a partir de dejetos21. Porem, os técnicos afirmam que por questões de ordem tecnológica, climática, de baixa eficiência técnica e econômica, a geração de biogás sofreu descontinuidade e se encontram desativadas ou em fase de redimensionamento. Estes problemas também ocorreram em Videira na Granja São Roque II (figura 3).

Figura 3 - Biodigestor da São Roque II desativação/fatores climáticos e Sedimentação de lodo

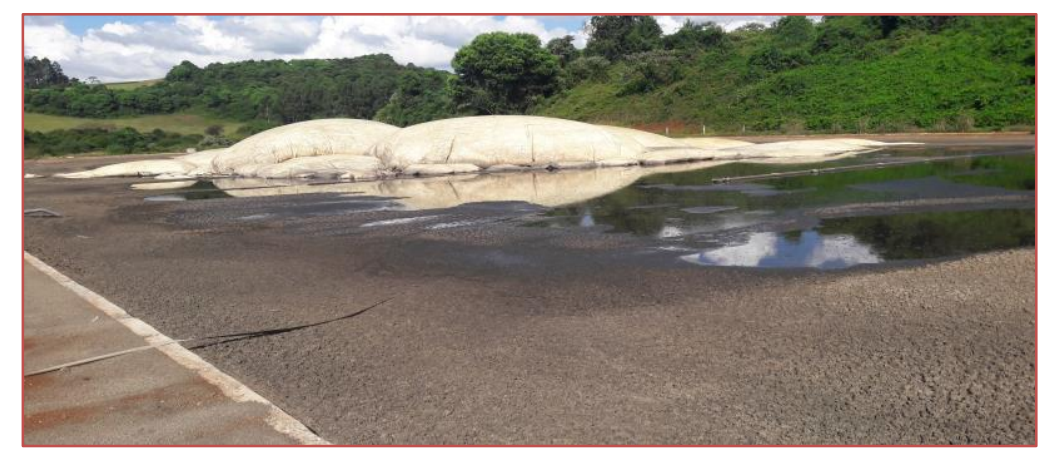

Fonte: autores em 10 mar. 2017.

A Master Iomerê foi à pioneira em termos de aplicação da tecnologia de biogás na região do meio oeste catarinense. Para tal, participou de uma rede de atores22 no Projeto de Validação de Tecnologias para o Manejo, Tratamento e Valorização dos Dejetos de Suínos em Santa Catarina que ocorreu de 2003/2007 via Fundo Verde Amarelo23. Recebeu aporte de recursos a fundo perdido para custear parte da infraestrutura das instalações do sistema de tratamento24.

Todavia, a tecnologia aplicada não demonstrou viabilidade. Diferentes testes realizados pela rede de atores que compunham o referido projeto não validaram a tecnologia utilizada referente à geração de biogás25. Dificuldades associadas à concepção do formato do biodigestor implantado na unidade piloto da Master que não atendia ao porte e fluxo de efluentes, a variabilidade de fatores climáticos como a temperatura. Além disso, fatores qualitativos dos efluentes variáveis em função do manejo da produção e utilização de produtos diversos impactavam no processo de geração de gás. Também a carga de efluentes interferia com a estabilidade do sistema de produção do gás. Tudo acabou impactando nos rendimentos e manejo da unidade. Ainda, dificuldades dos atores do Projeto em continuarem atuando em rede (termino dos recursos) e manutenção da equipe técnica (disponibilidade de recursos suplementares) das empresas privadas em dispor de técnicos para operar e continuarem os testes de eficiência, a geração de gás foi desativada. A empresa voltou a utilizar as formas convencionais de tratamento de dejetos.

A segunda empresa a adotar sistemas de geração de biogás no município de Iomerê foi a Granja Comelli que instalou com recursos próprios em 2004 coberturas de lonas em tanques que já eram utilizados para dejetos de suínos. Segundo o entrevistado Lauermann (2017) a produção de biogás era apenas para queima, e o sistema não chegou a funcionar de maneira constante e após a finalização do processo a experiência foi abandonada. A dificuldade de dimensionamento de gás e a tecnologia empregada nas lonas de cobertura determinou a inviabilização do processo. As lonas acabaram estourando e a empresa responsável pela instalação não mais atua na atividade e, portanto não há assistência e as lonas estão inservíveis.

Outro exemplo, no município de Videira foi o projeto de geração de biogás de 2003, o Projeto Granja São Roque de Redução de Emissão de GEE com biodigestores anaeróbios para captar o gás metano, gerar energia elétrica e auxiliar na sustentabilidade da unidade. Somente em 2008 passou a operar com geração de biogás e energia. 0 entrevistado Rogoski (2017) afirma que o Projeto buscava a melhoria da qualidade 
de vida da população, diminuindo a incidência de vetores patogênicos, o odor e melhorando a qualidade do efluente tratado.

Em 2011 o Grupo Master Videira adquiriu a Granja São Roque e estabeleceu parceira com as Centrais Elétricas de Santa Catarina (Celesc) para comercialização de energia elétrica excedente. Segundo Gregolin (2012) o sistema da Granja São Roque proporcionou redução de até 20\% dos custos de energia utilizados na propriedade em 2012. Em 2016 as lagoas anaeróbicas instaladas no projeto foram desativadas em razão de tempestade que rompeu as coberturas e ao assoreamento das mesmas com lodo.

De acordo com o entrevistado Gregolin (2017) o formato de operação dos biodigestores se apresentou como uma dificuldade, pois fatores como temperatura da região interferem no aquecimento dos biodigestores e na produção de biogás. Afirma que a agitação e o escoamento do lodo e sedimentado das lagoas anaeróbicas é um problema a ser resolvido. Pondera que estas e outras dificuldades provocaram colapso do sistema e assim foi desativado. Destaca ainda que o processo de purificação do biogás produzido é fator restritivo no sistema do Projeto, pois a presença de compostos químicos (enxofre) reduz a vida útil dos equipamentos. Conclui que o sistema de geração no formato atual está comprometido pela baixa eficiência em termos técnicos e econômicos (GREGOLIN 2017).

Porém, o Projeto Granja São Roque está sendo redimensionado dentro de um formato de parcerias de diferentes atores (iniciativa privada, governo, agências de fomento, universidades e instituições de pesquisa), no Projeto SISTRAT que já conta com investimento de 2 milhões de reais (GREGOLIN, 2017).

As linhas de financiamento via Programa $\mathrm{ABC}$ cujas taxas de juros variam entre $8 \%$ a $8,5 \%$ ao ano e com prazo de 10 anos e mesmo o Inova Agro da FINEP seriam impraticáveis aos suinocultores dadas as expectativas de receitas menores e variáveis em razão dos ciclos de receitas e custos decorrentes de imprevisibilidade climática e de mercado que acabam afetando a receita dos negócios conforme analisam Lauermann (2017), Rogóski (2017) e Gregolin (2017).

\subsection{A SITUAÇ̃̃O DO BIOGÁS NOS MUNICÍPIOS ESCOLHIDOS}

\subsubsection{CONCÓRDIA}

Técnicos de extensão pública e privada da região de Concórdia explanaram sobre a dificuldade da manutenção de biodigestores e que isto não tem estimulado os produtores a investirem nesse método de tratamento de efluentes. Há problema de assoreamento do fundo do depósito do biodigestor exigindo retirada manual, a própria lona que recobre o biodigestor precisa de manutenção, os equipamentos de queimar o biogás também exigem manutenção e que tudo isso exige volume razoável de recursos par uma atividade cíclica e de baixa margem que é a suinocultura. Além de tudo, não existe política de estímulo via crédito e mesmo assistência técnica para facilitar a disseminação da prática do uso de biodigestores. A maioria dos produtores ainda está preferindo tratamento por lagoa de contenção e fermentação que podem atingir até 120 dias.

Os extensionistas de cooperativas e da EPAGRI orientam os produtores nos casos de eventuais reduções de criações e substituição por outra atividade quando ocorre, por exemplo, a saturação de uma bacia hidrográfica por excesso de produção o que provoca muita presença de resíduos. Praticamente todos os associados da cooperativa local (600 produtores) não utilizam biodigestores, apenas 1 ou dois o fazem. Entre cooperados até 10 produtores utilizam a prática da composteira que é o tratamento com leiras de serragem misturada aos estercos e que passam por compostagem e necessitam de revolvimento mecânico. 0 não recebimento de pagamentos ou créditos por parte de quem fez utilização de biodigestores tem levado até mesmo os produtores do programa de biodigestores de agroindústria local a retraírem a utilização da prática, com equipamentos abandonados na região.

Isso foi confirmado por outros técnicos que atuam em Concórdia ao salientar que aparentemente o projeto de biodigestores na região estaria em câmara lenta e o mais comum são dois tipos de tratamento de dejetos a bioesterqueira que fermenta o material durante 3 meses para posterior distribuição em área de lavoura e a composteira que o material vai acumulando com maravalha por até um ano quando estará completamente neutralizado e pronto para uso como fertilizante. 


\subsubsection{XANXERÊ}

Verificou-se Xanxerê pela tendência verificada de redução de produtores/produção dedicados à suinocultura naquela região buscando averiguar se havia ou não continuidade da mesma. Entrevistas com os técnicos da região apontam a continuidade e relacionaram os

elementos que pressionam para a redução da atividade. i) o problema de dificuldade de mão de obra para fazer o manejo da criação (somente restaram nas propriedades pequenas o casal e que ao avançarem em idade acabam cansando da atividade), este caso ocorre, sobretudo a produtores que possuem até 300 animais; ii) a remuneração da atividade é cíclica com períodos de melhora e de piora principalmente relacionada ao problema de preço pago pelas agroindústrias que acabam remunerando em razão das flutuações do mercado, em termos de conversão de carcaça e mesmo época do ano e, o problema do custo de produção que tem variado em razão de oferta de matéria prima, predominantemente o milho; iii) outro problema que tem pressionado os produtores a abandonarem a atividade é a crescente pressão da legislação ambiental que não concede o licenciamento se os produtores não cumprirem com exigências cada vez mais crescentes.

De acordo ainda com as entrevistas, os produtores mais impactados seriam aqueles com produções entre 300 a 1500 animais. Por exemplo, atualmente a exigência é a existência de cisterna nas propriedades de criadores de suínos para coletar a água da chuva evitando desta forma a coleta de córregos e ou de outros locais dado os problemas recorrentes de estiagens. O técnico explicou que há apoio para a construção/instalação de cisterna se o produtor for enquadrável no Pronaf mais alimentos no qual ele pagará juros de $2,5 \%$ ao ano, caso contrário estará sujeito a taxas maiores do que $8 \%$. Informou ainda que a maioria dos produtores não utiliza biodigestores, fazendo, portanto o tratamento dos dejetos de forma convencional. Apenas 2 ou 3 produtores de porte médio, que criam/engordam ao redor de

1.500 suínos, possuem biodigestores, mas que não fazem a queima do biogás. Na região atua a empresa de energia elétrica Iguaçu Energia e que a princípio não teria nenhum esquema de permuta com a energia gerada por queima de biogás, diferentemente da Celesc28. Apenas um produtor na região faz tratamento por compostagem, este teria rebanho de 4.000 suínos. Este produtor estaria voltando a utilizar o processo de esterqueira, por dificuldade de continuar a operar o sistema de revolvimento do material compostado, talvez em razão de falta de supervisão de quem vendeu o equipamento ao produtor. É um equipamento caro e que poderá ser abandonado pelo produtor pelas dificuldades apontadas. Voltando à questão do impacto da legislação ambiental cada vez mais restritiva foi apontado o caso da Bacia do Rio Vitinho que seria rio classe I. Nesta bacia muitos produtores assinaram há alguns anos Termos de Ajuste de Conduta que os obrigava a fazerem muitas modificações em suas criações e isto não foi possível de forma que entre 10 a 12 produtores tiveram que abandonar a atividade, não restou ninguém produzindo suínos lá.

\subsubsection{JOAÇABA, IOMERÊ E VIDEIRA}

Os entrevistados técnicos da Epagri de Joaçaba e de empresas que implantaram biogás informaram que houve retrocesso nas experiências de biodigestores na região de Joaçaba, pois, com a entrada de energia elétrica nas propriedades reduziu a necessidade de fontes alternativas para aquecimento dos leitões ou outra finalidade. Além disso, se há alguns anos havia suinocultura na maioria das propriedades, atualmente $80 \%$ delas se dedicam a pecuária leiteira. Sendo assim, reduziu a pressão disseminada de tratamento de dejetos para a maioria das propriedades. 0 mínimo que existe de biodigestores é apenas para queima do biogás e não para o aproveitamento energético. Existem inclusive campânulas de biodigestores sem uso, abandonadas, na região. As experiências de Iomerê (Master Iomerê e Granja Comelli) e Videira (Granja São Roque) não parecem apontar bons resultados conforme se viu no tópico anterior.

\section{CONSIDERAÇÕES FINAIS}

Observou-se a baixíssima utilização de biodigestores nas microrregiões analisadas. 0 acervo técnico sobre tratamento de dejetos é grande e em especial aqueles compilados e pesquisados pela EMBRAPA, Universidades e empresas privadas. As diversas experiências, a campo, com biodigestores do Modelo Contínuo Canadense parecem apontar para algumas dificuldades conforme argumentaram os entrevistados das regiões de Joaçaba, Concórdia, Xanxerê e Videira. Esta situação tem levado ao abandono do tratamento com biodigestores. A tendência é a exclusão dos produtores que não conseguirem cumprir 
as exigências legais, conforme se verificou em Xanxerê, além da óbvia pressão oriunda de preços e custos. Aparentemente os estímulos que esparsamente existem não estão conseguindo "convencer" os produtores a migrarem das lagoas/esterqueiras para tratamentos com biodigestores, até por que em várias regiões não há previsão de "negociar" a energia com as companhias de eletricidade locais. Além disso, pesam ao produtor as dificuldades operacionais para lidarem com a necessidade de manutenção de equipamentos e de retirada de lodo do fundo dos

depósitos. Haveria mesmo um retrocesso nas experiências da Sadia/BRF, conforme apontaram alguns entrevistados.

Por último, se a sociedade deseja maior adoção da prática da produção e queima do biogás deverá estimular via apoio financeiro e de tecnologia que facilite o manejo e manutenção do sistema, caso contrário somente coercitivamente o produtor adotará uma prática mais trabalhosa (biodigestores) que as bioesterqueiras atualmente empregadas.

\section{REFERÊNCIAS}

[1] ABREU, F. V.; AVELINO, M. Análise energética da eficiência do motor de combustão interna utilizando como combustível o biogás. Anais... VII CONEM - Congresso Nacional de Engenharia Mecânica, São Luís - MA, Brasil, 8p, 2012

[2] ACCS. Relatório Anual 2011. Associação Catarinense de Criadores de Suínos. Disponível em: http://www.accs.org.br/arquivos_internos/index.php?abrir=relatorios_anuais Acesso 20/2/2017.

[3] BGS. Blog BGS Equipamentos. Cálculo para produção de biogás. Disponível em: http://bgsequipamentos.com.br/blog/calculo-de-producao-de-biogas-2/ Acesso em 09/02/2017.

[4] AGROSOFT. Sadia é incluída em relatório da ONU sobre desenvolvimento. Blog Agrosoft Brasil: agronegócio sustentável, 2008. Disponível em: http://www.agrosoft.org.br/br/sadia-e-incluida-em-relatorio-da- onu-sobredesenvolvimento/economia Acesso em 24/02/2017.

[5] AMARAL, Armando Lopes do; et alli. Boas Práticas de Produção de Suínos... Concórdia, suínos e aves, dez. /2006. Disponível em: https://www.embrapa.br/suinos-e-aves/busca-de-publicacoes/-

[6] /publicacao/443977/boas-praticas-de-producao-de-suinos Acesso em 20/2/2017. (Circular técnica, 50)

[7] ANGONESE, André R. at al.,. Eficiência energética de sistema de produção de suínos com tratamento dos resíduos em biodigestor. Revista Brasileira de Engenharia Agrícola e Ambiental, Campina Grande, PB, DEAg/UFCG, v.10, n.3, p.745-750, 2006.

[8] BARIVIERA, Joao Luiz. Estudantes realizam visita técnica à granja São Roque. Videira, Unoesc. 20 abr. 2010. Disponível em: http://www.unoesc.edu.br/noticias/single/estudantes-realizam-visita-tecnica-a-granja-saeo- roque Acesso em: 13 mar. 2017.

[9] BEBER, J. A. C. Eficiência energética e processos de produção em pequenas propriedades rurais. Santa Maria; UFSM, 1989, 295p. Dissertação Mestrado

[10] BIODIGESTOR Anaeróbio (11/01/2016). Disponível em: http://www.portaldobiogas.com/biodigestoranaerobio/ Acesso 10/02/2017.

[11] BIONDO, Mauro Mauricio. Biodigestor: Uma energia renovável pouco utilizada em SC. Chapecó. UNOCHAPECÓ/Jornalismo/Jornalismo ambiental, 3a. fase. 1 Jul. 2015.

[12] BORGES, W.; SOUZA, J.P de; CARIO, S.A.F.; SIMIONI, F.J. Barreiras de mobilidade presentes no sistema agroindustrial de carne suína no Brasil: um estudo de caso. Revista de Economia e Agronegócio. Universidade Federal de Viçosa. v. 13, n. 1,2,e 3, jan./dez., 2015.

[13] BRASIL. LEI № 6.938, de 31 de agosto de 1981 . Disponível em: http://www.planalto.gov.br/ccivil_03/LEIS/L6938.htm. Acesso em 15 de setembro de 2016.

[14] BRASIL. Ministério da Ciência, Tecnologia e Inovação. Estimativas anuais de emissão de gases de efeito estufa no Brasil. Brasília: MCTI, 2014. 164 p.

[15] BRASIL. SENADO FEDERAL DO BRASIL. Conferência Rio-92 sobre o meio ambiente do planeta: desenvolvimento sustentável dos países. http://www.senado.gov.br/noticias/Jornal/emdiscussao/rio20/a-rio20/conferencia-rio-92-sobre-o-meio-ambientedo-planeta-desenvolvimento-sustentavel-dos-paises.aspx Acesso em: 30 de março de 2016.

[16] BRF. Relatório Anual 2015. Disponível em: https://www.brf-global.com/brasil/responsabilidadecorporativa/relatorio-anual. Acesso em 22/2/2017 
[17] COMEX DO BRASIL/ABPA. Exportações de carne suína crescem 32\% em 2016 e geram receita de US\$1,483 bilhão. 17/01/2017. Disponível em: http://www.comexdobrasil.com/exportacoes-de-carne-suina-crescem- 32-em2016-e-geram-receita-de-us-1483-bilhao/ Acesso 21/2/2017

[18] DAL MAGO, Anigeli. Avaliação de biodigestores com o uso de dejetos de suínos, em braço do norte e em concórdia. Universidade Federal de Santa Catarina - Programa de Pós-Graduação em Engenharia Ambiental. Dissertação de Mestrado Florianópolis/ SC. 2009.

[19] DEBONA, Darci. Aurora, de Chapecó, transforma os dejetos dos suínos em biogás. Diário Catarinense. Florianópolis, 13/08/2013.

[20] DIESEL, Roberto; MIRANDA, C.R.; PERDOMO, C.C. Coletânea de tecnologias sobre dejetos de suínos. Boletim informativo BIPERS Pesquisa \&Extensão. v.10, n.14, $2002 . \quad$ Disponível em: https://docsagencia.cnptia.embrapa.br/suino/bipers/bipers14.pdf. Acesso em 13/02/2017.

[21] DUDEK, Patricia Mazzioni Apesar de ser uma alternativa para a produção de energia limpa, o alto custo de implantação do sistema inviabiliza a produção de biogás. UNOCHAPECó, Chapecó, 2013. Disponível em: https://www.unochapeco.edu.br/static/files/premio-jornalismo-ambiental/biodigestores.pdf. . Acesso em $2 / 03 / 2017$

[22] FATMA. Instrução Normativa № 11 - Suinocultura. Florianópolis, 2014 . Disponível em: http://www.fatma.sc.gov.br/ckfinder/userfiles/arquivos/ins/11/IN\%2011\%20Suinocultura.doc Acesso em $01 / 09 / 2016$.

[23] GERBER, P. J. et al. Tackling climate change through livestock: a global assessment of emissions and mitigation opportunities. Rome: FAO, 2013.

[24] GIEHL, Alexandre Luís. Carne Suína. Síntese Anual da Agricultura de Santa Catarina 2015/2016. EPAGRI/CEPA. Florianópolis, 2016.

[25] GOLDEMBERG, J. Energia, meio ambiente \& desenvolvimento. São Paulo: Editora da USP, 1998.

[26] GREGOLIN, Cleonei. Entrevista sobre Dificuldades/facilidades do sistema de biogás da Granja São Roque Master S. Roque. Videira, 10 mar. 2017.

[27] GRIEBELER, Jaques. A exclusão agropecuária no Oeste Catarinense: o caso da suinocultura no período de 1994/2001. UFSC/Departamento de Economia. Monografia Economia. Florianópolis, 2002.

[28] GUESSER, Filipe. Avaliação das exigências ambientais na suinocultura de Ibicaré/SC. UFSC/Departamento de Economia. Monografia. Florianópolis, 2016.

[29] HENN, A. A avaliação de dois sistemas de manejo de dejetos em uma pequena propriedade produtora de suínos: condição de partida. 2005. 157 f. Dissertação (Mestrado em Engenharia Ambiental) - Universidade Federal de Santa Catarina, Florianópolis.

[30] IBGE. Pesquisa Pecuária Municipal 2016

[31] IBGE. Censo agropecuário 2006: Brasil, grandes regiões e unidades da federação : segunda apuração. Rio de Janeiro, $2012 . \quad$ Disponível em: http://servicodados.ibge.gov.br/Download/Download.ashx?http=1\&u=biblioteca.ibge.gov.br/visualizacao/livros/ liv61914.pdf. Acesso em: 27 de setembro de 2016.

[32] IBGE. Censo Demográfico 2010. Disponível em: http://www.sidra.ibge.gov.br. Acesso em 12 de outubro de 2016.

[33] IBGE. Produção da Pecuária Municipal 2015. Disponível em: http://www.sidra.ibge.gov.br. Acesso em 15/11/2016. de novembro de 2016.

[34] KRUGER, Silvana; at al.,. Práticas organizacionais da atividade suinícola na região Oeste de Santa CatarinaBrasil . Book of abstracts: XI Iberian Conference on Rural Studies. Vila Real/Portugal 13 a 15 de out. 2016. Disponível em: http://xicier2016.utad.pt/sites/all/themes/professional_responsive_theme/images/files/Book_Abstracts.pdf. Acesso 18/02/2017

[35] LAUERMANN, Rudinei.Entrevista sobre Sistema de Biogás na Empresa Comelli de Iomerê. Iomerê, 12 mar. 2017.

[36] MACHADO, Jurandir Soares. Suínos. Síntese anual da agricultura de Santa Catarina 98/99. Instituto CEPA/SC. Florianópolis, 1999.

[37] MAIA, Alexandre Gori; ROMEIRO, A. R.; JUSTO, M. C. D. de M. Custo-efetividade de tratamentos de dejetos de suínos no Oeste Catarinense. In: TÔSTO, S.G. at al.,.Valoração de serviços ecossistêmicos: metodologia e estudos de caso. EMBRAPA/ Brasília: Embrapa Monitoramento por Satélite, 2015. 
[38] MINISTÉRIO DA AGRICULTURA, PECUÁRIA E ABASTECIMENTO. O Aquecimento Global e a Agricultura de Baixa Emissão de Carbono. Brasília MAPA / EMBRAPA / FEBRAPDP, 2011.

[39] MAPA prioriza suinocultura no Plano ABC. Ministério da Agricultura, Pecuária e Abastecimento/Suinocultura ABC. Brasília 21 dez. 2016. Disponível em: http://www.agricultura.gov.br/assuntos/sustentabilidade/planoabc/suinocultura-abc/arquivos-boletim-informativo/1-mapa-prioriza-suinocultura-no-plano-abc.pdf/view. Acesso em $21 / 2 / 2017$.

[40] MARCOVITCH, Jacques. Projetos sustentáveis de oito empresas brasileiras: um survey com inovadores primeira avaliação - $2008 \quad$ - Disponível em: http://www.usp.br/mudarfuturo/cms/wpcontent/uploads/290808MClimaEstrEmpr.pdf Acesso em 24/2/2017

[41] MASTER. Unidades Produtivas. Videira, 2017. Disponível em: http://master.agr.br/estrutura-solida/. Acesso em 13 mar. 2017.

[42] MORAES, Kellen. Resíduos Agropecuários: passada onda da biodigestão no Brasil, tecnologia resiste na suinocultura. RURALBR. 2012, atualizada em nov. 2014. Disponível em: http://www.canalrural.com.br/noticias/pecuaria/residuos-agropecuarios-passada-onda-biodigestao-brasiltecnologia-resiste-suinocultura-38558. Acesso em 13 mar. 2017.

[43] OLIVEIRA, P.A. Produção e aproveitamento do biogás. Concórdia, EMBRAPA, 2004.

[44] OLIVEIRA, P.A.V.; HIGARASHI, M.M. Geração e utilização de biogás em unidades de produção de suínos. Concórdia, EMBRAPA Suínos e $\quad$ Aves. jun./2006. Disponível em: http://www.cnpsa.embrapa.br/sgc/sgc_publicacoes/publicacao_14177t4r.PDF Acesso em 05/03/2017.

[45] PASCOAL, Nelso. Implantação do Projeto Granja São Roque: desafios e perspectivas. Videira, 2017. PROENÇA, Luís. Projeto Granja São Roque de Redução de Emissão de GEE. Formulário do documento de

[46] concepção de projeto (CDM-SSC-PDD) - Versão 03. São Paulo: BIOGERAR Cogeração de Energia LTDA, 2009. Disponível em http://www.cnpsa.embrapa.br/genomafrango/genomafrango.html Acesso em 12 mar. 2017.

[47] PAZINATO DIAS, Cleandro at al.,. A suinocultura brasileira e seu potencial de geração de energia elétrica através do tratamento dos dejetos suínos. Congresso da Sociedade Brasileira de Economia, Administração e Sociologia Rural (SOBER). 54ํ․ Anais... Maceió, ago./2016

[48] PROJETO Suinocultura de Baixa Emissão de Carbono conhece a Cooperalfa, a Granja Palma Sola e o Sistema Aurora. Boletim informativo, n. 07, s.l., s.d. Disponível em: http://www.agricultura.gov.br/assuntos/sustentabilidade/plano-abc/suinocultura-abc/arquivos-boletiminformativo/7-projeto-conhece-a-cooperalfa-a-granja-palma-sola-e-o-sistema-aurora.pdf. Acesso em 26/02/2017.

[49] RODRIGUES, A.T.; GELINSKI NETO, F; CARVALHO JÚNIOR, L. C. ; . ; O comportamento da relação de troca na suinocultura catarinense no período de 2000 a 2012 In: 51 Congresso SOBER. Anais... Belém - PA. UFPA, jul./ 2013.

[50] ROGOSKI, Nédio Ricardo. Entrevista sobre Sistemas de tratamento de efluentes na suinocultura. Tangará, $07 / 03 / 2017$.

[51] SANTOS FILHO, Jonas Irineu dos; at al.,. Cenários e oportunidades para a produção familiar de suínos: o que há de novo e o que já é possível. . Concórdia/SC, EMBRAPA suínos e aves, Documentos 174, Outubro, 2015. Disponível em: $\quad$ https://www.embrapa.br/suinos-e-aves/busca-de-publicacoes/-/publicacao/1030927/cenarios-eoportunidades-para-a-producao-familiar-de-suinos-o-que-ha-de-novo-e-o-que- ja-e-possivel. Acesso em 20/02/2017.

[52] SAVIOTTI, Bruno at al.,. Suinocultura de baixa emissão de carbono: tecnologias de produção mais limpa e aproveitamento econômico dos resíduos da produção de suínos. Ministério da Agricultura Pecuária e Abastecimento/IICA/EMBRAPA. Brasília. 2016. Disponível em: http://www.iicabr.iica.org.br/wp-

[53] content/uploads/2016/01/Suinocultura-de-baixa-emiss\%C3\%A3o-de-carbono-cartilha-MAPA-IICABrasil.pdf. Acesso em 07/03/2017.

[54] TESTA, Vilson Marcos, at al.,. O Desenvolvimento Sustentável do Oeste Catarinense (proposta para discussão). EPAGRI/CPPP. Florianópolis, 1996.

[55] TORESAN, Luiz. Desempenho da agropecuária catarinense - 2016. In: Síntese Anual da Agricultura de Santa Catarina 2015/2016. EPAGRI/CEPA. Florianópolis, 2016.

[56] TORRES, Tainara Regina Cerutti; SILVA, Robson Leal da. Potencial do biogás proveniente da suinocultura para a geração de energia elétrica no estado de mato grosso do sul. In: AGRENER GD 2015 - 10 Congresso sobre Geração Distribuída e Energia no Meio Rural. Anais... São Paulo, USP, 11 a 13 de novembro de 2015.

[57] WANDER, Alcido Eleonor at al.,. Uma avaliação formativa do Plano ABC. Revista de Política Agrícola/MAPA/CONAB. Brasília, n.3, jul./ago./set. 2016, p.62-72.

[58] WEYDMANN, Celso Leonardo. Suinocultura e Meio ambiente: Evidências dos EUA. Sociedade Brasileira de Economia, Administração e Sociologia Rural. Disponível em: http://www.sober.org.br/palestra/12/080406.pdf. Acesso em 24 de abril de 2016. 


\section{Capítulo 24}

COMO A PERCEPÇÃO DO SABOR E O CONHECIMENTO INFLUENCIAM O CONSUMIDOR NA DECISÃO DE COMPRA DE AZEITE DE OLIVA

\section{Larissa Bueno Ambrosini}

Roni Blume

Suzimary Specht

Paulo Lipp João

Resumo: Este trabalho tem como objetivo avaliar a percepção de sabor e o conhecimento dos consumidores de azeite de oliva sobre o produto, pois se tem como premissa que tal entendimento pode proporcionar para os profissionais ligados à gastronomia indicativos a serem explorados para aprimorar os saberes, as práticas culinárias, bem como indicadores de qualidade para a cadeia produtiva. Para a pesquisa realizou-se um levantamento do tipo survey de caráter exploratório do qual participaram 343 respondentes. Em termos de resultados verificou-se que em relação ao conhecimento geral, os entrevistados reconhecem que o azeite de melhor qualidade é o extravirgem, sendo que quanto "mais novo" melhor tende a ser a sua qualidade sensorial. A maioria reconhece a "cor" como atributo de qualidade, apesar de não ser. Quanto aos rótulos, $41 \%$ dos respondentes os consideram como deficientes em informações. Entre as motivações para a compra, as questões ligadas à saúde e boa alimentação são destacadas como importantes para $88 \%$ dos entrevistados, e $70 \%$ o adquirem para proporcionar um sabor diferenciado aos pratos. Em termos sensoriais os entrevistados preferem um azeite com sabor marcante, contrastando com pesquisas que indicam que o mercado prefere azeites de oliva com gosto neutro. Por fim, se verifica que promover experiências gastronômicas como hobby ou profissão podem fornecer indicativos para o entendimento da qualidade esperada nos alimentos, sendo importante investir em ações educativas e promocionais como forma de alavancar o desenvolvimento da olivicultura no Brasil.

Palavras-chave: Gastronomia, Conhecimento e Percepção do Consumidor, Azeite de oliva. 


\section{INTRODUÇÃO}

0 termo gastronomia vem ganhando cada vez mais impacto na mídia pela busca de sabores ligados à qualidade intrínseca dos alimentos. Associado a gastronomia encontramos diversas literaturas: alimentação com significado; saúde e alimentação; alimentos como tradução de diversidade e singularidade cultural; entre tantos outros. $\mathrm{Na}$ academia a questão se desdobra em diferentes frentes que buscam entender a alimentação pelas suas relações convergentes e divergentes para com as questões ambientais, políticas, sociais, filosóficas, ideológicas, indentitárias, nutricionais, mercadológicas, entre outras. Neste trabalho buscamos avaliar o conhecimento dos consumidores de azeite de oliva sobre o produto, pois tem-se como premissa que tal entendimento pode proporcionar para os profissionais ligados à gastronomia indicativos a serem explorados para aprimorar os saberes e práticas culinárias, bem como pode auxiliar no desenvolvimento de indicadores de qualidade para a cadeia produtiva. Tal expectativa foi gerada, pois o Brasil, ao final da safra de 2014/2015 tornou-se o segundo maior importador de óleo no mundo, segundo os dados do International Olive Oil Council. Além disso, dados sobre a percepção e os hábitos de consumo com relação ao azeite de oliva entre consumidores brasileiros ainda são restritos. (AMBROSINI et al., 2017).

Destaca-se também que pesquisas em mercados em expansão mostram a relevância de estudos com consumidores para guiar ações de divulgação, ações educativas e de marketing visando incentivar o consumo. Além disso, estas pesquisas revelam que muitos consumidores se valem de critérios de escolha equivocados e que muitos mitos ainda guiam a compra e o consumo do azeite de oliva (NORTH AMERICAN OLIVE OIL ASSOCIATION, 2014; WANG, MOSCATELLO, FLYNN, 2013).

Portanto tem-se averiguado uma demanda crescente sobre informações ligadas ao uso do azeite de oliva e a arte da gastronomia. Os prazeres na arte do preparo dos alimentos em torno do propósito da descoberta de novos sabores e ressignificações das práticas culinárias, tem aglutinado desde renomados Master chefs até os chefes amadores de final de semana, bem como tem feito adeptos nas mais diferentes culturas e idades. Além disso, por ser considerado uma das bases de uma alimentação saudável, que contribui inclusive para a redução de doenças cardiovasculares (DUTRA, DUARTE, SOUZA, 2013), o azeite de oliva tem atraído a atenção dos consumidores, que também levam em consideração estas informações para a tomada de decisão e compra, para além dos fins culinários.

\section{METODOLOGIA}

O presente trabalho caracteriza-se como um levantamento do tipo survey de caráter exploratório realizado através da interrogação direta aos entrevistados a respeito de seu comportamento frente a determinadas situações, intenções, atitudes, percepções, etc. 0 protocolo desse tipo de pesquisa prevê que a coleta de dados primários seja feita através de entrevistas, que podem ser aplicadas de diferentes formas: pessoal, por telefone, correio, email, internet (GIL, 2002; MALHOTRA, 2001).

Para o desenvolvimento deste trabalho foi utilizada como ferramenta a plataforma de armazenamento de dados on-line do Google Drive que possibilita gerar formulários para a coleta de dados em diferentes formatos (questões fechadas, abertas, lickert, entre outras), apresentando a vantagem de, ao final, gerar uma planilha com todas as respostas.

A divulgação da pesquisa ocorreu de duas formas: i) através de mensagem de solicitação para preenchimento do questionário enviado via email, com o link da pesquisa sob a técnica "bola de neve", que repousa na solicitação de que os atingidos reenviem a seus contatos pessoais a mensagem e o link; ii) a mensagem de solicitação para preenchimento e o link para a pesquisa foram divulgados também em meios de comunicação e redes sociais, com apoio das assessorias de imprensa da Fundação Estadual de Pesquisa Agropecuária do Rio Grande do Sul - FEPAGRO, Secretaria da Agricultura Pecuária e Irrigação do Rio Grande do Sul - SEAPI e Colégio Politécnico da Universidade Federal de Santa Maria - UFSM.

0 questionário ficou disponível para preenchimento durante pouco menos de dois meses (entre 27 de junho e 20 de agosto de 2016). Destaca-se que as questões tinham como opção, resposta simples ou múltiplas escolhas visando captar as variações no comportamento de compra dos entrevistados. Durante o período, 343 pessoas acessaram o link e responderam às perguntas propostas. Em relação aos dados cabe fazer uma ressalva sobre a possibilidade de tendenciamento na composição da amostra pelo fato de se verificar a predominância de respondentes residentes no Rio Grande do Sul, com renda mais elevada e maior grau de instrução. Tal condição se deve ao método de aquisição dos dados, que ao se capilarizar pela rede acaba atingindo pessoas com perfis semelhantes e que se interessam pelo tema. 


\section{RESULTADOS E DISCUSSÃO}

Quanto ao perfil socioeconômico verificou-se que a maior parte dos respondentes tinha entre 26 a 45 anos. Já a composição por faixa etária, como também por gênero, apresentou equilíbrio com 55\% feminino e 45\% masculino. A renda familiar é acima da média da população brasileira, mais de $70 \%$ recebe entre 4 a 20 salários mínimos mensais. Mais de $90 \%$ da amostra tem curso superior, sendo que 29\% tem pósgraduação. A maior parte dos respondentes reside no Rio Grande do Sul, 85\% da amostra, sendo os demais de outros Estados da Federação.

Analisando o conhecimento dos consumidores sobre o produto verificou-se que os entrevistados mostraram que tem conhecimento sobre alguns aspectos que são considerados "mitos" em relação ao azeite de oliva. A maioria concorda como verdadeira a afirmação que o produto de melhor qualidade é o extravirgem (92\%), em detrimento do azeite virgem, onde 80\% consideram como falsa a afirmação de ser o de melhor qualidade. Tal consideração vai ao encontro do que a mídia e os experts revelem sobre qualidade, pois o extravirgem apresenta menor grau de acidez, sendo o mais recomendado para o consumo in natura.

Quanto a questão da data da fabricação, estes concordam que a qualidade está ligada diretamente com a sua data de fabricação onde o "novo" é percebido e avaliado como melhor - ao contrário da maioria dos vinhos, que poderia induzir a percepção pela associação direta com o outro produto de consumo diferenciado. Contudo, mais da metade da amostra julga que a cor é um bom indicador de qualidade para julgar o azeite de oliva, e como observaremos na sequencia tal critério não é parâmetro essencial para análise de qualidade. A Figura 1, apresenta as avaliações dos consumidores.

Figura 1 - Indicadores de Qualidade do Azeite de Oliva (\%)

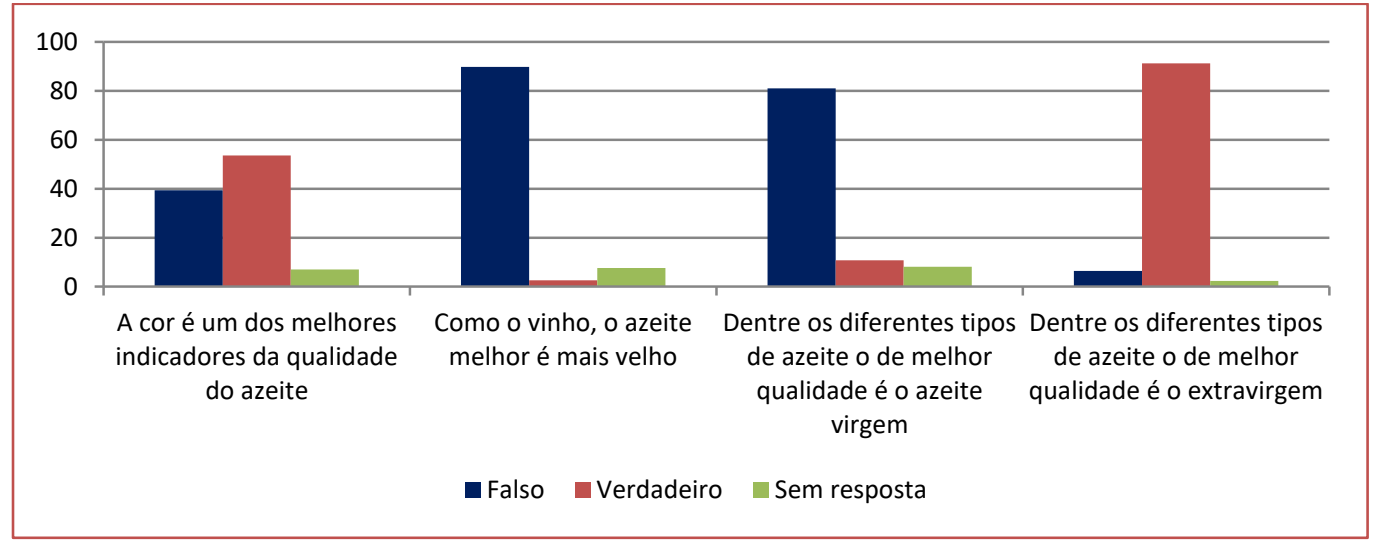

Fonte: dados da pesquisa (2017)

Contudo estas dúvidas também se refletem em outros estudos. Em estudo realizado pelo North American Olive Oil Association (2014), com consumidores americanos, este apresentou como resultado que $24 \%$ dos pesquisados responderam como falsa a afirmativa que o azeite seria um produto que melhoraria com a idade, e apenas $6 \%$ discordaram que a "cor" seria indicativo da qualidade do azeite (NORTH AMERICAN OLIVE OIL ASSOCIATION, 2014). Quanto a questão da "cor" é relevante salientar que os especialistas destacam que este é um atributo que não influencia na qualidade sensorial do azeite. A "cor" é o resultado da quantidade de clorofila presente no produto, da concentração de frutos verdes utilizados na prensagem, e das variedades de azeitona utilizadas. Quanto a questão da "idade", quanto mais novo for o azeite, decorrido menor tempo desde a sua elaboração, a tendência de ser um produto de melhor qualidade está ligada ao frescor dos ingredientes, pois as propriedades organolépticas poderão estar melhor conservadas. Destaca-se que a questão da "cor" pode ser mais um indicativo hedônico (beleza pela cor) do que um indicativo sensorial.

A maioria dos entrevistados mostrou que não acredita nos mitos mais comuns a respeito do azeite de oliva, entretanto, sua demanda por maiores informações e conhecimento é notável. Como se pode verificar na Figura 2, a maioria se sente insegura para julgar as informações disponíveis no rótulo, pois 78\% gostariam de maiores informações. 
Figura 2 - Sobre as Informações Contidas nos Rótulos das Embalagens

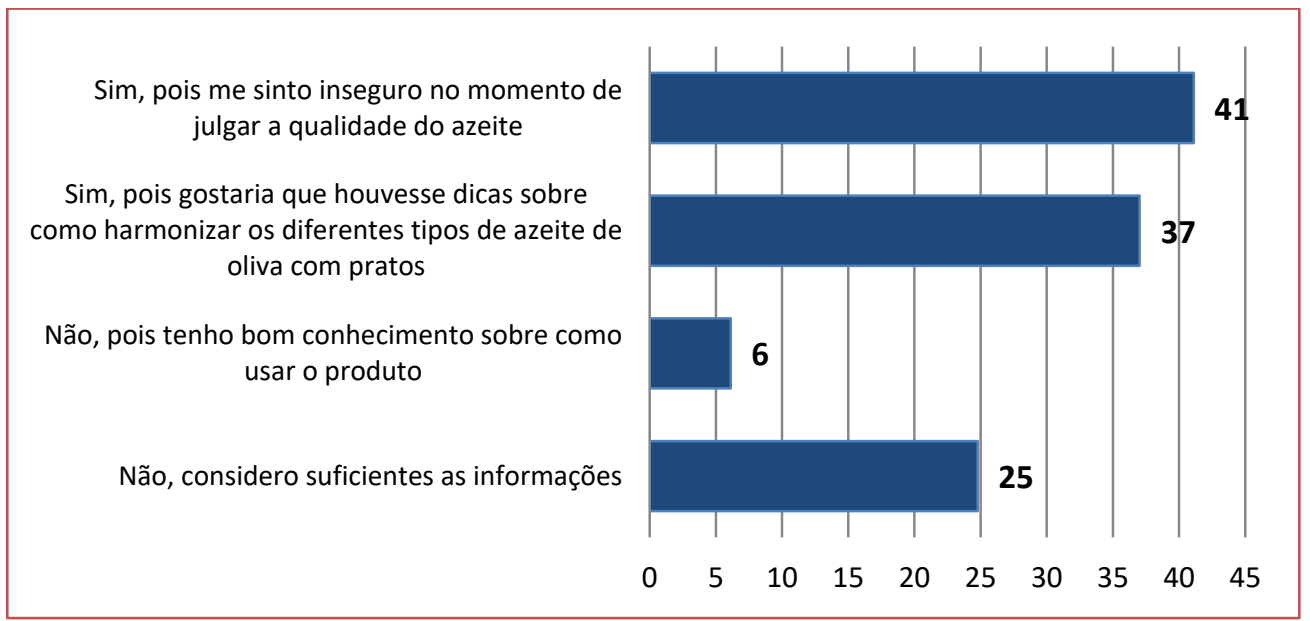

Fonte: dados da pesquisa (2017)

Além da necessidade de maiores informações que auxiliariam na decisão de compra, 37\% gostaria de maiores informações de como utilizá-lo: muitos gostariam que os rótulos contivessem dicas de como harmonizá-lo com diferentes pratos. Destaca-se que em termos culinários o azeite extravirgem não é recomendado para processos de cozimento, pois perde a suas propriedades, para estes casos se recomenda o azeite virgem. Mas como na enquete anterior, estas dúvidas também não são exclusivas dos consumidores desta pesquisa. Consumidores americanos em pergunta semelhante apresentaram um alto percentual de "sem resposta", que foi interpretado pelos autores como insegurança ao julgar parâmetros de qualidade do azeite (WANG, MOSCATELLO, FLYNN, 2013).

Outro resultado que reforça a relação do azeite de oliva com essa tendência de consumo é a análise das preferências sensoriais relacionadas com as práticas culinárias dos entrevistados. A Figura 3 destaca algumas destas preferências.

Figura 3 - Sobre as Preferências Sensoriais e as Práticas Culinárias

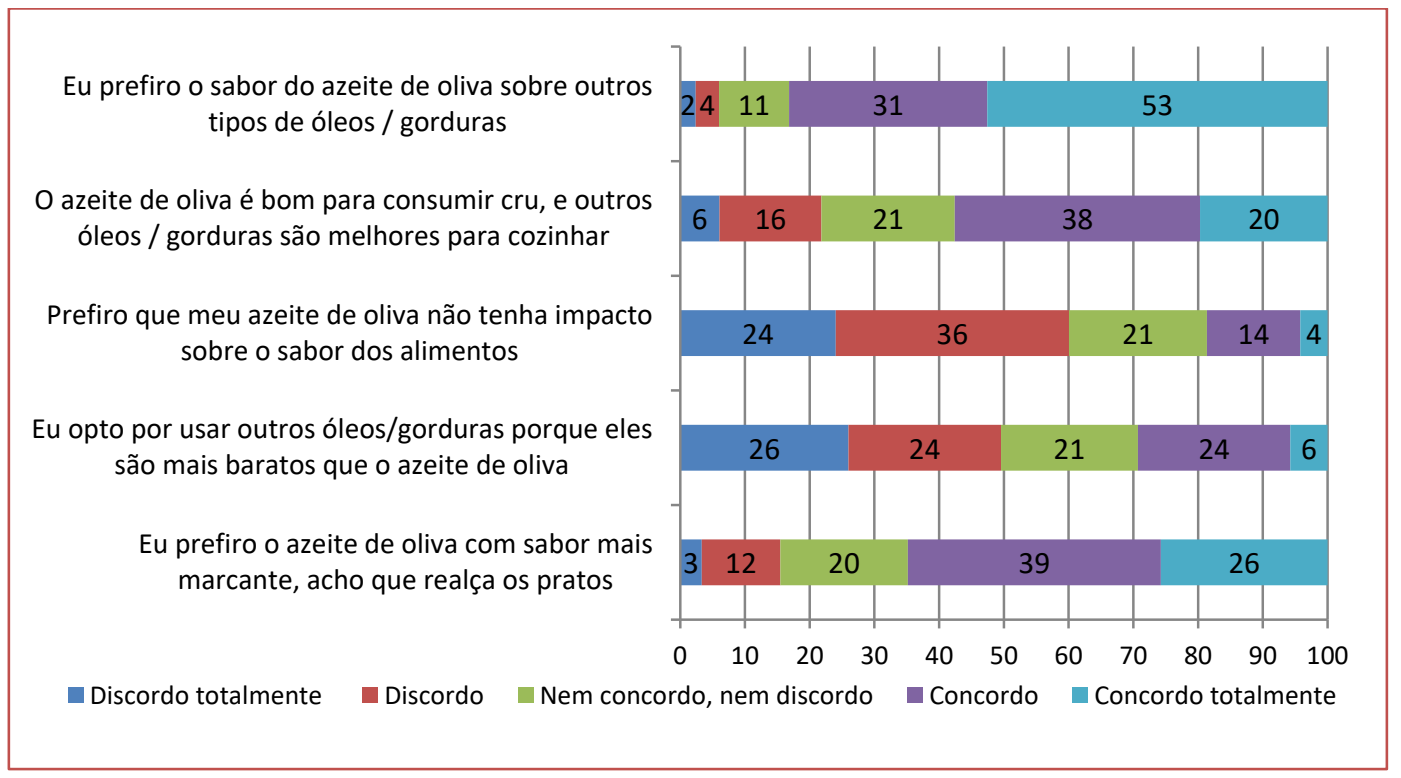


Destaca-se na avaliação que os entrevistados têm preferência por um azeite que apresente características marcantes, rejeitando em grande parte a opção por um azeite que teria sabor mais neutro. Para os entrevistados o sabor é importante, pois possuem a tendência de consumi-lo cru, agindo diretamente no sabor do prato preparado. Além disso, a preferência parece estar mais ligada ao tipo de preparo do que ao preço, pois para a metade da amostra o preço não é o principal fator de decisão para o uso.

Outro ponto que cabe uma ressalva quanto aos apresentados na Figura 3, é que estes contrastam com dados apresentados por Del Giudice et al. (2015), que analisaram o resultado de publicações entre 2000 a 2014, onde verificaram que a preferência dos consumidores seriam azeites de oliva com gosto neutro. Segundo os autores, a evolução da qualidade do azeite de oliva extravirgem deve-se ao desenvolvimento das análises sensoriais e o uso do Panel24 como ferramenta e guia na produção de azeite de qualidade. Além disso, muitas pesquisas têm contribuído para identificar aspectos de sabor e odor que são indicadores de qualidade, assim como técnicas de produção que influenciam em características do produto. Assim, os azeites de oliva de qualidade vêm apresentando perfil sensorial marcante. Entretanto, isso contrasta com o mercado, cujo paladar parece apreciar produtos com "pouca ou nenhuma personalidade". Essa é uma questão preocupante, segundo os pesquisadores, pois existem várias pesquisas e investimentos para melhorar a qualidade do produto, que é reconhecido por especialistas, mas pode ser "punido pelo mercado". Caberia ressaltar que, quanto mais amargo e picante for o azeite, maior o conteúdo de polifenóis, que proporcionam maiores benefícios à saúde, ou seja, características como amargor e picância são atributos positivos de um azeite (BERTONCINI e TESTA, 2014).

Para se avaliar o conhecimento dos consumidores, as questões sobre a motivação e contexto para o consumo são de importante relevância para este entendimento. Na Figura 4 são apresentadas algumas destas motivações e contextos que influenciam os hábitos de consumo dos entrevistados.

Figura 4 - Motivações e Contextos que Influenciam nos Hábitos de Consumo de Azeite de Oliva

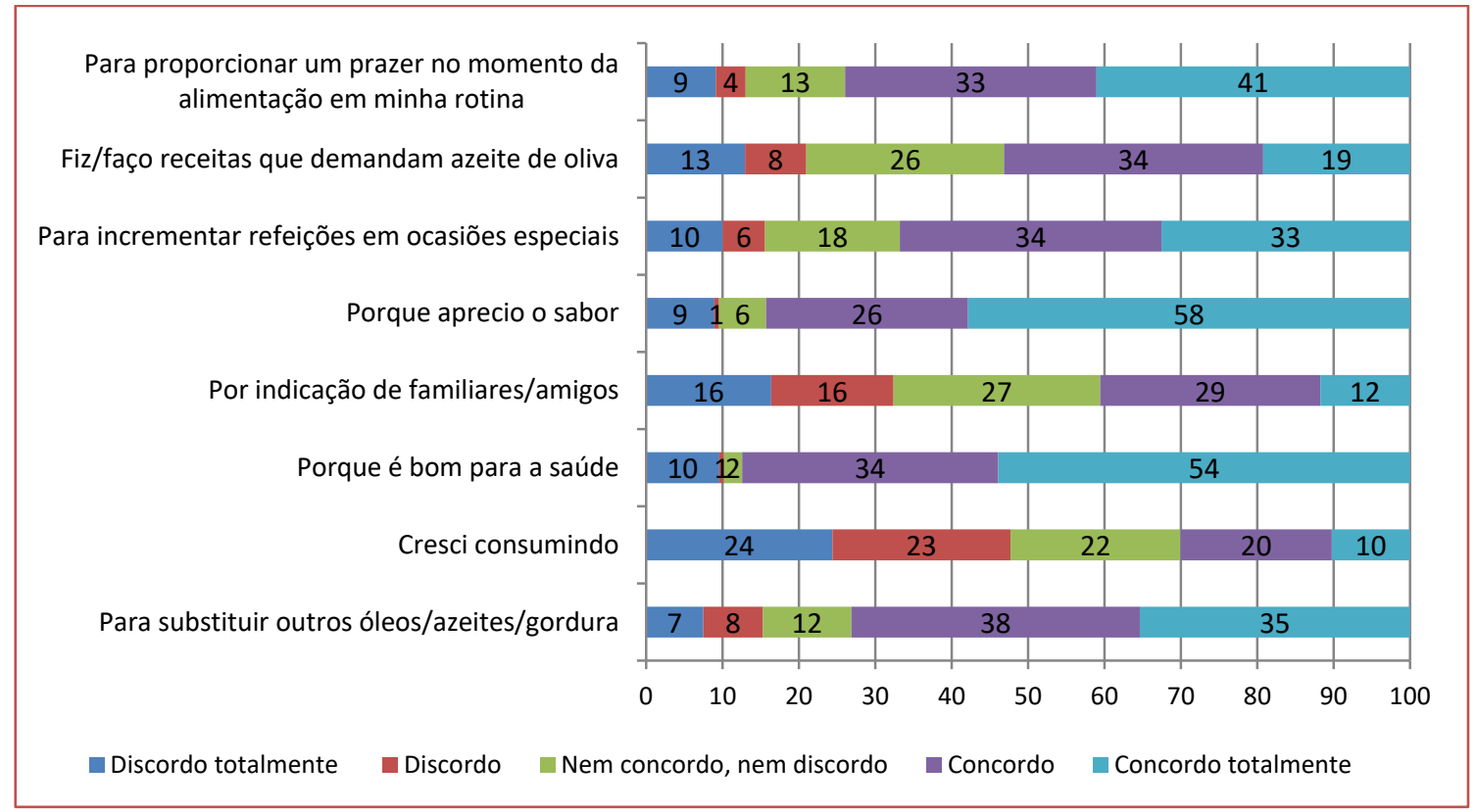

Fonte: dados da pesquisa (2017)

Entre as motivações e contextos destacados, a gratificação sensorial e relação com o bem-estar/saúde se destacam como as de maior concordância na pesquisa. A apreciação do sabor obteve $84 \%$ de concordância dos entrevistados e associação com o bem-estar/saúde obteve $88 \%$ em concordância. Em relação a associação do azeite de oliva e saúde, verifica-se que muito se tem falado sobre os benefícios da "dieta

\footnotetext{
${ }^{24}$ São análises realizadas por um grupo de 8 a 12 juízes, treinados e qualificados por órgãos reguladores que comprovam a qualidade do azeite de oliva por meio de análises organolépticas ou sensoriais. O certificado de análise do grupo é denominado Panel Test. De acordo com os resultados, o azeite pode ser classificado como: extravirgem, virgem ou lampante (BERTONCINI, TESTA, 2014).
} 
mediterrânea", ou seja, uma alimentação rica em oleaginosas e frutos do mar e que utiliza o azeite de oliva com principal gordura. Alguns estudos apontam que a preocupação com a saúde é fator impulsionador do consumo de azeite de oliva em mercados não tradicionalmente consumidores, como Estados Unidos, Japão, China e Brasil, pois como o azeite de oliva é rico em polifenóis antioxidantes, este auxilia no combate aos radicais livres (BERTONCINI, TESTA, 2014). Além disso, também podemos destacar que ações ligadas ao sabor e a busca pela saudabilidade estão relacionadas a valores de consumo chamados utilitários, pois cumprem uma função instrumental e são um segmento dentro de uma tendência de consumo mundial a qual se denomina Saudabilidade + Bem-Estar. A procura pela qualidade de vida revela-se nessa tendência, com a valorização de alimentos que trazem benefícios adicionais à saúde. Fatores como envelhecimento das populações, pesquisas científicas que vinculam determinadas dietas à prevenção ou ao aparecimento de doenças, e o estilo de vida nas grandes cidades influenciam a busca por hábitos mais saudáveis por parte dos consumidores. Dentre alguns segmentos de consumo dentro dessa tendência, poderíamos destacar o consumo de alimentos orgânicos, ou mais recentemente por alimentos funcionais, que seriam benéficos ao desempenho físico e mental (VIALTA et al, 2010). Destaca-se também nesta consideração sobre a motivação o fato de que o consumidor ainda estar se familiarizando com o produto. Os resultados indicam esta tendência, pois $60 \%$ dos entrevistados não adquiriram o hábito de consumir azeite de oliva na infância, e buscam por conhecimento em receitas que demandam o seu uso. Tal averiguação é salientada por 53\% dos entrevistados.

Além da gratificação sensorial a motivação social também se destaca como fator estimulante para o consumo. Os resultados apresentam que mais de dois terços dos entrevistados utilizam o produto para incrementar refeições especiais e para proporcionar prazer no momento das refeições, aliando assim, Sensorialidade + Prazer + Sociabilidade. 0 aumento do nível de educação e de renda, e o maior acesso à informação favoreceram o surgimento dessa tendência de consumo, que se revela na revalorização da culinária regional tradicional, mas também na busca por experiências gastronômicas em torno de novas combinações, novos sabores e texturas. A socialização em torno das refeições é um elemento que funciona como elo de ligação entre as pessoas. Também é crescente a busca pelos consumidores, de novos conhecimentos através da participação em circuitos e polos gastronômicos como forma de alinhar o conhecimento com o lazer e entretenimento. Para Vialta et al. (2010), o consumo de produtos de maior valor agregado (gourmet e premium), destinados à população com maior renda, tendem a continuar crescendo. Paralelamente, alimentos mais elaborados, com preço mais acessível, tendem a proporcionar novos mercados para a indústria alimentícia no futuro.

\section{CONCLUSÃO}

Ao se avaliar a percepção de sabor e o conhecimento dos consumidores de azeite de oliva verificou-se que a gratificação sensorial aliada a valorização do bem estar/saúde e a sociabilidade influenciam na decisão de compra dos entrevistados. Quanto a questão do conhecimento aliado a questão sensorial observou-se que os entrevistados sabem diferenciar alguns quesitos que são indicativos de qualidade, como a preferência pelo azeite extravirgem; contudo ainda tem dúvidas sobre a influência da questão da "cor". Outra questão relevante é que os consumidores entrevistados preferem azeites com sabor marcante que influencia no sabor do prato, não sendo um mero acompanhamento de gosto "neutro". 0 conjunto das respostas também indicaram que os consumidores gostariam de maiores informações sobre "novas" experiências gastronômicas, pois julgam os rótulos carentes de informações. Como sugestão para esta demanda seria o investimento em ações educativas e promocionais. Também poderiam ser idealizadas campanhas publicitárias em meios de comunicação, material informativo disponibilizado em pontos de comércio ou ainda, o uso de novas ferramentas, como aplicativos de telefone celular para auxiliar os consumidores na decisão de compra. Um aplicativo para celular poderia disponibilizar dicas de como harmonizar o produto com diferentes pratos, curiosidades sobre o azeite de oliva e receitas.

Cabe também realizar uma ressalva quanto as limitações deste trabalho, pela possível limitação da amostragem, que pode ter influenciado nos resultados. Sugere-se a ampliação desta amostragem utilizando outros canais de pesquisa.

Portanto, verifica-se que se fosse empreendido um esforço conjunto entre os promotores da cadeia produtiva e os profissionais ligados a gastronomia, este poderia proporcionar novos indicadores a serem explorados para o aprimoramento da qualidade e desenvolvimento da cadeia produtiva. 


\section{REFERÊNCIAS}

[1] AMBRosinI, L. B; BLUME, R; SPECHT, S; JOÃO, P. L: Comportamento de Compra dos Consumidores de Azeite de Oliva no Brasil: um estudo exploratório. In: 55 CONGRESSO DA SOCIEDADE BRASILEIRA DE ECONOMIA, ADMINISTRAÇÃO E SOCIOLOGIA E RURAL (SOBER), 2017, Santa Maria. Anais.... Santa Maria: Editora da UFSM, 2017.

[2] BERTONCINI, E. I.; TESTA, U. Análise Sensorial de Azeites de Oliva. Informe Agropecuário, v. 35, n. 282, 2014, pp. 58-65

[3] DEL GIUDICE, T.; CAVALLO, C.; CARACCIOLO, F.; CICIA, G. What Attributes of Extra Virgin Olive Oil are Really Important for Consumers: a metaanalysis of consumers' stated preferences. Agricultural and Food Economics, v.3, n. 20, 2015, pp. 1-15.

[4] DUTRA, L. B.; DUARTE, M. S. L.; SOUZA, E. C. G. Tendência do Perfil de Consumidores de Azeite de Oliva. Revista Instituto Adolfo Lutz, v. 72, n. 4, 2013, pp. 322-326.

[5] GIL, A. C. Como Elaborar Projetos de Pesquisa. 4 ed. São Paulo: Atlas, 2002.

[6] MAlhotRA, N. K. Pesquisa em Marketing: uma orientação aplicada. 3 ed. Porto Alegre: Bookman, 2001.

[7] NORTH AMERICAN OLIVE OIL ASSOCIATION. What the American Consumer Really Thinks of Olive Oil. 2014. Disponível em: http://c1.oliveoiltim.es/library/naooa-survey.pdf. Acesso em dezembro de 2015.

[8] VIALTA, A.; COSTA, A.; SARANTÓPOULOS, C.; LOPES, E.; RIBEIRO, E.; DONNA, E. Brasil Food Trends, 2020. In: FIESP, ITAL, $\quad$ editores. São $\quad$ Paulo; $2010 . \quad$ Disponível http://www.brasilfoodtrends.com.br/Brasil_Food_Trends/index.html. Acesso em fevereiro de 2017.

[9] WANG, S.; MOSCATELLO, B.; FLYNN, D. Survey: consumer attitudes on olive oil. University of California, Campus Davis. 2013. Disponível em: http://olivecenter.ucdavis.edu/research/files/surveyfinal052913reduced.pdf. Acesso em dezembro de 2016. 


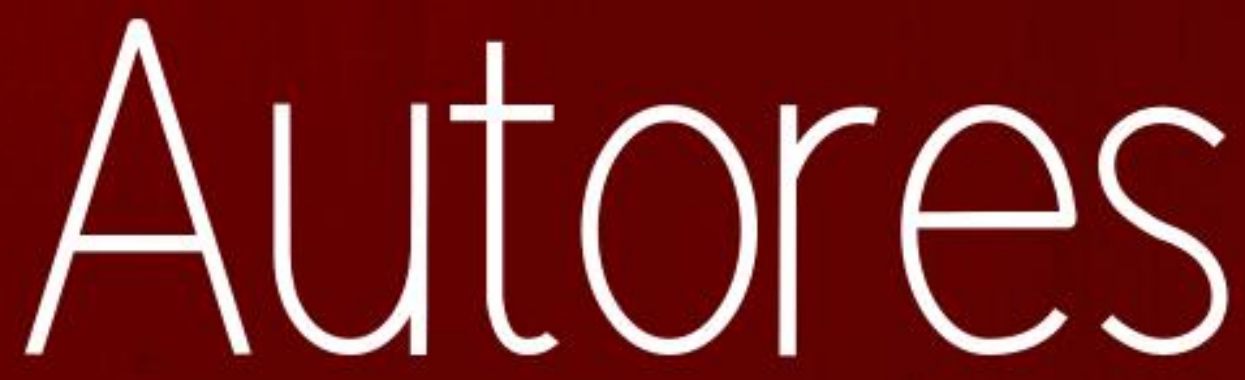




\section{ADRIANO LAGO}

Agrônomo, Professor Associado I no Departamento de Administração e no Programa de Pós Graduação em Agronegócio e Vice-Diretor do Campus de Palmeira das Missões da Universidade Federal de Santa Maria.

\section{ALCINETE APARECIDA BASSO FAVERO DA SILVA}

Bacharel em Ciências Contábeis pela Faculdade DOCTUM (unidade Guarapari).

\section{ANA CAROLINA JÚLIO}

Mestre em Administração pela UFES e Doutoranda em Administração pela UFES.

\section{ANTONIO SÉRGIO EDUARDO}

Possui graduação em Ciências Contábeis - Faculdades de Ciências Contábeis e Atuariais da Alta Noroeste - SALESIANO (1986). Especialização em Administração Financeiras - Centro Universitário Toledo (1991). Especialização em Controladoria, Gerência Contábil e Financeira, Auditoria - Universidade Federal de Mato Grosso do Sul (2002). Mestrado em Geociência - Recursos Naturais - Universidade Estadual de Campinas UNICAMP (2008). Professor Assistente I da Universidade Federal de Mato Grosso do Sul Campus Nova Andradina-MS. Doutorando em Meio Ambiente e Desenvolvimento Regional - Universidade Anhanguera - Uniderp.

\section{ARIANA MARCHEZI DE SOUZA}

Mestre em Administração pela FUCAPE e Doutoranda em Administração pela UFES.

\section{BÁRBARA ÁDRIA OLIVEIRA FARIAS FERNANDES}

Doutoranda em Administração pela Universidade da Amazônia- Unama. Mestre em Administração pela Universidade de São Caetano do Sul- SP. Formada em Ciências Contábeis pela Universidade da Amazônia. Professora de Ensino a Distância- EAD da Universidade Norte do Paraná - Unopar.

\section{CAUÊ BONGIOVANNI SOBRAL SOUSA}

Analista de Sistemas, graduado em Sistemas para Internet pela Fatec Rubens Lara. Estudando na escola de inglês The English Studio e trabalhando como Deliver Driver em Dublin,

\section{CEZAR EDUARDO SOARES CORDEIRO}

Contador, sendo graduado em Ciências Contábeis pela Universidade Federal da Grande Dourados/UFGD, Dourados-MS. Durante a graduação participou de programas voltados à pesquisa, docência e extensão, como PIBIC/PIVIC, monitoria e projetos de extensão. Atualmente é mestrando do programa de pós-graduação em Agronegócios da Universidade Federal da Grande Dourados/UFGD, Dourados-MS. 


\section{CLAYTON DOUGLAS CHAGAS DE OLIVEIRA}

Possui Mestrado em Economia com ênfase em Desenvolvimento Regional (2012) pelo Programa de Pós-Graduação em Economia - PPGE da Universidade Federal do Pará UFPA, Bacharelado em Estatística (2007) pela Universidade Federal do Pará - UFPA. Atualmente é Professor de Métodos Quantitativos da Universidade Federal do Sul e Sudeste do Pará (UNIFESSPA), ministrando aulas de Cálculo, Estatística e Econometria para as graduações de Economia e Agronomia. Tem conhecimento nas áreas de Matemática, Estatística e Economia com ênfase em Cálculo, Estatística e Econometria.

\section{CRISTIANE MALLMANN HUPPES}

Mestre em Contabilidade pela Universidade Federal do Paraná - UFPR, Especialista em Contabilidade Gerencial e Ensino Superior, Graduada em Ciências Contábeis pela Universidade Regional do Noroeste do Estado do Rio Grande do Sul - UNIJUÍ.

\section{DAVID COSTA CORREIA SILVA}

Possui Graduação em Ciências Econômicas pela Univesidade Federal do Pará - UFPA (2007), Mestrado em Economia com Ênfase em Desenvolvimento Econômico Regional Pelo Programa de Pós-Graduação em Economia - PPGE da Universidade Federal do Pará UFPA (2011). Doutorado em Desenvolvimento Sustentável pelo Núcleo de Altos Estudos Amazônicos - NAEA da Universidade Federal do Pará - UFPA (2018). Atualmente é Professor Assistente A na Universidade Federal Rural da Amazônia - UFRA. Estuda Economia, Instituições e Recursos Naturais.

\section{DAYAN RIOS PEREIRA}

Possui Graduação em Ciências Econômicas pela Universidade Federal de Rondônia (1997), Mestrado em Engenharia de Produção pela Universidade Federal de Santa Catarina (2001) e Doutorado em Ciências com ênfase em Desenvolvimento Socioambiental. Ocupa o cargo efetivo de Professor no Insttituto Federal de Educação, Ciência e Tecnologia do Pará. Atua como docente, consultor e pesquisador nas áreas de modelagem econômica, avaliação de desempenho organizacional, pesquisa operacional, análise de dados multivariada e georreferenciadas, análise espacial de dados, administração da produção e sistemas, Políticas Públicas e Desenvolvimento Regional.

\section{EDUARDO GELINSKI JÚNIOR}

Doutor em Desenvolvimento Econômico pela UFPR (2015), Mestre em Economia Rural pela UFRGS (1994), Médico Veterinário pela UFPR (1988), Bacharel em Ciências Econômicas pela Faculdade Católica de Administração e Economia de Curitiba - FAE (1986), Pró-Reitor de Pesquisa, Extensão e Pós-Graduação da UNOESC (de 1994 a 2004), Diretor Técnico Cientifico da Fundação de Ciência e Tecnologia do Estado de Santa Catarina - FAPESC (2002) e Professor da UNOESC nas áreas de Economia e Economia Aplicada (de 1990 a 2018). Pesquisador de Desenvolvimento Econômico, Economia e Desenvolvimento Regional e Agrário. Professor do Mestrado em Ciência e Biotecnologia Competitividade em Bionegócio e Empreendedorismo e Inovação até abril de 2018. Elabora Projetos de Desenvolvimento e de Investimentos (projetos de cursos, de captação de recursos, de informação, de mapeamentos), e assessoramento a entidades privadas e públicas. 


\section{ELSON AVALLONE}

Professor do Instituto Federal de Educação, Ciência e Tecnologia de São Paulo - câmpus Catanduva. Doutor em engenharia mecânica pela UNESP/FEB (Equipamentos e Processos Térmicos), Mestre pela Universidade Estadual Paulista - UNESP/FEB em Engenharia Mecânica (Fenômenos de Transporte), graduação em Engenharia Mecânica pela Universidade Estadual Paulista UNESP/FEB, Especialização em Engenharia de Segurança do Trabalho pela Universidade Estadual Paulista UNESP/FEB e graduação em Tecnologia Mecânica UNESP/FEB. Tem experiência nas áreas de Engenharia Aeroespacial, com ênfase em Engenharia Mecânica, construção de aeronaves leves na empresa Glaser-Dirks Flugzeugbau na Alemanha - manutenção aeronáutica - energia solar e coletores solares.

\section{EVA CARINA MARTINS ALDRIGUE}

Mestranda em Direcion e Administracion de Empresas - Universidad de la Empresa-UDEMontevideo-UY. Pós graduada em Docência do Ensino Superior pelo Instituto ISEIB-Belo Horizonte-MG. Graduada em Administração pela Universidade Anhanguera Uniderp-Polo Ivinhema-Ms. Professora tutora da Universidade Anhanguera-UNIDERP - Polo IvinhemaMs. Atua nos cursos de Administração, Ciências Contábeis e Logística. Conselheira Regional Suplente e membro da Comissão de Ensino Superior do Conselho Regional de Administração do Estado de Mato Grosso do Sul - CRA-MS.

\section{FERNANDO ZOCCHE}

Possui graduação em Medicina Veterinária pela Universidade Federal do Paraná - Campus Palotina, mestrado e Doutorado em Ciência e Tecnologia Agroindustrial pela Universidade Federal de Pelotas. Atualmente é Professor na Universidade Federal do Pampa - campus Dom Pedrito atuando na área de Agroindústrias, higiene agroindustrial e microbiologia básica e de alimentos.

\section{FRANCISCO GELINSKI NETO}

Doutor em Inteligência de Negócios do Programa de Engenharia de Produção e Sistemas da UFSC (2007). Mestre em Economia Rural do Programa de Economia Rural da URGS (1992). Engenheiro Agrônomo pela UFPR (1985) e em Administração de Empresas na Faculdade Católica de Administração e Economia (1984). Professor efetivo da UFSC no Departamento de Economia e Relações Internacionais. Atua no ensino de economia agroindustrial e de Teoria Econômica. Possui pesquisas nas áreas de economia rural e economia do meio ambiente e segurança pública. Mais recentemente, a sua preocupação tem se voltado às questões relativas à economia do meio ambiente: efeitos climáticos extremos, o uso de biodigestores na área agrícola e o impacto das Estações de Tratamento de Esgotos nas áreas urbanas.

\section{GELLENA TAYNÁ SILVA SOUZA}

Formação em Administração pela Universidade Federal do Sul e Sudeste do ParáUNIFESSPA

\section{GENECI DA SILVA RIBEIRO ROCHA}

Administradora, Especialista em Administração Pública, Mestranda no Programa de Pós Graduação em Agronegócios - Universidade Federal do Rio Grande do Sul. 


\section{GISELE ALVES SOARES ROCHA}

Mestre em Agronegócios e Desenvolvimento - Universidade Federal da Grande DouradosUFGD

\section{GISELLE GIOVANNA DO COUTO DE OLIVEIRA}

Possui graduação e mestrado em Química pela Universidade Federal do Paraná e o doutorado pela UNESP/Campus Araraquara. Foi professora Colaboradora na Universidade Estadual de Maringá, Campus Regional de Umuarama, na qual desenvolveu projetos com cunho ambiental, fazendo o estudo de substratos para o tratamento de águas contaminadas. Atualmente é professora efetiva no Instituto Federal de Educação de Mato Grosso do Sul, Campus Naviraí no qual tem desenvolvido pesquisa sobre educação química, com ênfase em aplicação de novas metodologias para auxiliar no ensino de Química.

\section{HAYATAHANDESON BORGES DE CALDAS}

Bacharel em Ciências Econômicas pela Universidade Federal de Campina Grande (2008). Especialista em Economia Política Regional pela Universidade Federal de Campina Grande (2010). Mestre em Economia pela Universidade Federal de Pernambuco - CAA. Atualmente professor do curso de Ciências Econômicas na UNIFESSPA (Marabá-PA). Atuando principalmente nos seguintes temas: Microeconomia Aplicada e Economia Regional.

\section{HENRY HIRAKI}

Analista de Sistemas, graduado em Sistemas para Internet pela instituição Fatec Rubens Lara.

Atuo na área de TI como desenvolvedor há três anos, atualmente estou na empresa BEXS. Banco de câmbio e inovações localizado em SP.

\section{JANAINA WOHLENBERG}

Possui Graduação em Administração de Empresas, pela Universidade de Passo Fundo (2009), Mestrado em Tecnologia Ambiental, pela Universidade de Santa Cruz do Sul (2012) e, atualmente, é Doutoranda em Tecnologia Ambiental, pela UNISC. Atua como Professora Assistente na Universidade Federal do Pampa - UNIPAMPA, campus Dom Pedrito, no Programa de Graduação de Tecnologia em Agronegócio e no Programa de Pós Graduação em Agronegócio.

\section{JOAB CAVALCANTE DA SILVA}

Graduado em Análise de Sistemas pela UFMS (2003), Mestre em Matemática pelo PROFMAT UEMS (2014), doutorando em Ciência da Computação e Matemática Computacional pelo ICMC - USP / São Carlos. Servidor administrativo da UEMS desde 2005

\section{JORGE EDUARDO MACEDO SIMÕES}

Possui Graduação em Ciências Econômicas pela Universidade da Amazônia - UNAMA (2009), Mestrado em Economia com Ênfase em Desenvolvimento Econômico Regional Pelo Programa de Pós-Graduação em Economia - PPGE da Universidade Federal do Pará UFPA (2012), Doutorado no Curso de Pós-Graduação em Economia - CAEN pela 
Universidade Federal do Ceará - UFC, com concentração em Setor Público. Atualmente é Professor Adjunto A no Instituto de Estudos em Desenvolvimento Regional e Agrário IEDAR, Faculdade de Ciências Econômicas - FACE da Universidade Federal do Sul e Sudeste do Pará - UNIFESSPA. Tem experiência em Macroeconomia, Microeconomia, Métodos quantitativos e Setor Público.

\section{JOSÉ CARLOS DE SOUZA}

Coronel QOR (Quadro de Oficiais da Reserva) / PMMG, Bacharel em Administração, Bacharel em Direito, Especialista em Gestão pela Qualidade Total, Especialista em Ciências Jurídicas, Mestre em Administração, Professor Universitário e Coordenador do Curso de Administração do Centro Universitário UNIFACIG / Manhuaçu-MG

\section{JOSÉ PAULO ALVES FUSCO}

Orientador de doutorado. Possui graduação em Engenharia Mecânica pela Universidade Estadual Paulista Júlio de Mesquita Filho (1977), mestrado em Engenharia (Engenharia de Produção) pela Universidade de São Paulo (1993), doutorado em Engenharia (Engenharia de Produção) pela Universidade de São Paulo (1996), desenvolveu projeto de pesquisa no exterior em SCM-Supply Chain Management pela UMIST School of Management (Manchester-UK, 2000), livre-docente em Logística e Cadeias de Fornecimentos pela Universidade de São Paulo (2002). Atualmente é Professor Adjunto Livre Docente da Universidade Estadual Paulista Júlio de Mesquita Filho. Tem experiência e é autor/organizador de vários livros na área de Engenharia de Produção, com ênfase em Administração da Cadeia de Fornecimentos, atuando principalmente nos seguintes temas: competitividade, supply chain, redes de empresas, estratégia de operações e gestão de operações.

\section{KELY DA SILVA RODRIGUES}

Especialista em Auditoria e Controladoria Contábil - Centro Universitário da Grande Dourados - UNIGRAN

\section{KEZIA SOUZA SILVA}

Formação em Administração pela Universidade Federal do Sul e Sudeste do ParáUNIFESSPA

\section{LARISSA BUENO AMBROSINI}

Possui graduação em Medicina Veterinária (2003), mestrado em Desenvolvimento Rural (2007), ambos pela Universidade Federal do Rio Grande do Sul, e doutorado em Gestão (2014), pela Université de Bourgogne (França). Trabalhou, em Porto Alegre, com ensino à distância na área de Gestão em Agronegócios, com rastreabilidade e certificação bovina; na França, trabalhou como pesquisadora ligada à VetAGro Sup em Clermont-Ferrand. Atualmente trabalha como pesquisadora no Departamento de Diagnóstico e Pesquisa (extinta Fepagro) na Secretaria da Agricultura, Pecuária e Desenvolvimento Rural do Rio Grande do Sul. 


\section{LAURENTINO AUGUSTO DANTAS}

Graduação em Processamento de Dados pela Universidade Norte do Paraná (1993), graduação em Direito pela Universidade Paranaense (2007) e mestrado em Ciências da Computação pela Universidade Federal de Santa Catarina (2001). Doutorando em Ciência da Computação e Matemática Computacional pelo ICMC - USP / São Carlos. Professor EBTT do Instituto Federal de Educação, Ciência e Tecnologia de Mato Grosso do Sul. Áreas de interesse: Educação, TIC na Educação, Ambientes Virtuais de Aprendizagem, Jogos Educacionais, Empreendedorismo, Inovação Tecnológica, Desenvolvimento WEB, Comércio Eletrônico e IHC.

\section{LILIAN ALDINA MENDONÇA}

Possui graduação em Ciências Econômicas pela Universidade Federal de Pernambuco (2017). Mestrado em Administração e Desenvolvimento Rural com ênfase em Gestão, Mercados e Agronegócios pelo Programa de Pós-graduação em Administração e Desenvolvimento Rural da Universidade Federal Rural de Pernambuco (2019). Tem experiência na área de Economia com ênfase em Economia Internacional; Economia Agrícola; Estatística, atuando principalmente no seguinte tema: africa; competitividade e produtividade da castanha de caju no mercado mundial. Tem experiência também na areá de Empreendedorismo. É uma das Coordenadoras da rede de Afroempreendedores de Pernambuco - RAEPE.

\section{LUIZ FERNANDO DE ORIANI E PAULILLO}

Professor Titular do Departamento de Engenharia de Produção da Universidade Federal de São Carlos. Diretor do Centro de Ciências Exatas e de Tecnologia da Universidade Federal de São Carlos (2019/2022). Pós-Doutorado na FAO-ONU (2007). Doutor em Economia pelo Instituto de Economia da UNICAMP (2000). Pesquisador Visitante no "Instituto de Estudios Sociales Avanzados de España" (1999), na Universidade de Cordoba e na Universidade Complutense de Madri - Espanha. Mestre em Engenharia de Produção pela Universidade Federal de São Carlos (1994). Economista graduado pela Universidade Estadual Paulista (1991). Professor e orientador de doutorado e mestrado no Programa de Pós-Graduação em Gestão da Produção da UFSCar e no Programa de Pós-Graduação em Desenvolvimento Territorial e Meio Ambiente na Universidade de Araraquara.

\section{MAIELEN LAMBRECHT KUCHAK}

Administradora, Mestranda no Programa de Pós Graduação em Agronegócios Universidade Federal do Rio Grande do Sul.

\section{MARIA VALDILENE DOS SANTOS SCHOTTEN}

Formada em Letras pela Faculdade Estadual de Educação, Ciências e Letras de Paranavaí, atua no ensino fundamental a 25 anos. Professora concursada no município de Nova Londrina/PR.

\section{MARK MIRANDA DE MENDONÇA}

Mestre em Ciências Contábeis pela FUCAPE e Professor do Centro Universitário Projeção. 


\section{MARLUCI MORAES PEREIRA}

Licenciatura Plena em Pedagogia, Bacharel em Economia, Mestre em Economia, Professora Universitária.

\section{MAXWELL PACELLI DE SOUSA MARCIAL}

Bacharel em Administração pela FACIG, Produtor Rural e Consultor Independente em Gestão do Agronegócio.

\section{MIGUEL CARLOS RAMOS DUMER}

Mestre em Ciências Contábeis pela FUCAPE e Doutorando em Administração pela UFES.

\section{MÔNICA RIBEIRO GAMA}

Formação em Administração pela Universidade Federal do Sul e Sudeste do ParáUNIFESSPA

\section{MURILO SECCHIERI DE CARVALHO}

Professor do Instituto Federal de Educação, Ciência e Tecnologia de São Paulo, câmpus Catanduva. Possui graduação em Ciências Econômicas pela Universidade Estadual Paulista Júlio de Mesquita Filho (1999), fez mestrado (2005) e doutorado (2015) em Engenharia de Produção na Universidade Federal de São Carlos (UFSCar). Tem experiência na área de Economia, com ênfase em Organização Industrial e Estudos Industriais, atuando principalmente nos seguintes temas: instituições, governança, comercialização e contratos.

\section{NÉDIO RICARDO ROGOSKI}

Mestrando em Ciências e Biotecnologia, Universidade do Oeste do Estado de Santa Catarina, UNOESC Campus de Videira SC, (2018). Pós Graduado em Microbiologia Ambiental e Industrial, Universidade do Oeste do Estado de Santa Catarina, UNOESC Campus de Videira SC. (2010) Bacharel em Ciências Biológicas Universidade do Oeste do Estado de Santa Catarina, UNOESC Campus de Videira SC. (2006). Consultor em Tecnologias Ambientais para Resíduos da Agropecuária. Responsável Técnico de Empresas de Gestão de Resíduos e Agroindústria.

\section{NORAH PATRICIA PANOZO RIVERO}

Possui graduação em Engenharia de Sistemas pela Universidade Católica Boliviana - UCB San Pablo, La Paz (2007), mestrado em Administração e Direção de Empresas Internacionais - MBA Internacional (2010) pela Escuela Europea de Negócios La Paz e mestrado em Engenharia de Produção pela Universidade Federal de Pernambuco - UFPE, Recife (2018).

\section{ODUVALDO VEDRAMETTO}

Possui graduação em Física pela Universidade de São Paulo (1970), mestrado em Física pela Universidade de São Paulo (1987) e doutorado em Engenharia (Engenharia de Produção) pela Universidade de São Paulo (1994). Assessorou a Reitoria da UNESP em assuntos referentes à Gestão de Planejamento e Orçamento de 1983 a 1987. Foi Diretor Superintendente do Centro Estadual de Educação Tecnológica ?Paula Souza?(CEETEPS), 
de 1987 a 1991. Atuou no Departamento de Engenharia de Produção da Escola Politécnica - USP como representante da parceria para qualificar docentes para as FATECs, de 1994 a 1997. Desenvolveu o projeto para criação e aprovação pela CAPES do Mestrado Profissional em Habitação do IPT - Instituto de Pesquisas Tecnológicas do Estado de São Paulo, em 1995/96. Organizou o projeto para criação do Mestrado stricto sensu em Engenharia de Produção da Universidade Paulista, em 1997 e de do Doutorado 2006. Programas de que é coordenador e professor titular. Líder do Grupo de Pesquisa da Cadeia Produtiva da Carne, Couto e Calçados sob a ótica da Cadeia de Fornecimento, de 2000 a 2010, Atuou em pesquisas sobre APLs, Arranjos Produtivos Locais (calçados, couro, leite, hidropônicos, cerâmicos, metal mecânico, transportes, etc.). Atualmente, pesquisa a contribuição dos APLs e Redes de Empresas para melhoria da competitividade das empresas.

\section{OTÁVIO JOSÉ DE OLIVEIRA}

Livre Docente em Sistemas Integrados de Gestão (2012) na área de Engenharia de Produção pela UNESP, Pós-doutor (2006) e Doutor (2005) em Engenharia Civil pela Escola Politécnica da USP, Mestre em Administração (2001) pela PUC-SP e Engenheiro Civil (1997) pela USJT. É Professor Adjunto III (Associate Professor) do Departamento de Produção da FEG/UNESP atuando principalmente com Sistemas Integrados de Gestão (Qualidade, Meio Ambiente, Saúde e Segurança e Responsabilidade Social) e Sustentabilidade/Gestão Ambiental Empresarial. Está no segundo mandato de coordenador do Programa de Mestrado Acadêmico em Engenharia de Produção da FEG/UNESP, foi Coordenador e Vice-coordenador do Curso de Graduação em Engenharia de Produção da FEB/UNESP. Foi coordenador do Curso de Graduação em Engenharia Mecânica da FEG/UNESP em 2018 e Presidente da Comissão Permanente de Ensino (CPE) da FEG/UNESP em 2019. Bolsista Produtividade em Pesquisa do CNPq na área de Engenharia de Produção.

\section{PATRÍCIO DUARTE ROCHA}

Técnico em Agropecuária, Matemático - Universidade Federal de Pelotas

\section{PAULO CESAR MIORALLI}

Professor do Instituto Federal de São Paulo, câmpus Catanduva. Graduado em Engenharia Mecânica pela Universidade Estadual Paulista Júlio de Mesquita Filho - UNESP/FEIS (2002) e em Formação de Docentes para a Educação Básica pelo Instituto Federal de São Paulo - IFSP (2012). Mestre (2005) e Doutor (2009) em Engenharia Mecânica pela Universidade Estadual de Campinas - FEM/UNICAMP. Possui Pós-doutorado em engenharia mecânica pela Universidade Estadual Paulista Júlio de Mesquita Filho UNESP/FEB (2017). Tem experiência na área de Ciências Térmicas, atuando principalmente nos seguintes temas: convecção térmica, simulação numérica, trocadores de calor e dutos com geometria não-convencional.

\section{PAULO CESAR SCHOTTEN}

Doutorando em Engenharia de Produção pela Universidade Federal de Pernambuco; Mestre em Administração pela Fundação Pedro Leopoldo de Minas Gerais. Professor do Ensino Superior desde 2001, com experiência profissional em cargos de gestão em empresas de médio e grande porte. Autor do livro 0 pré-adolescente na decisão de compra: Influenciado e Influenciador, lançado em 2015 pela editora Novas Edições Acadêmicas. 


\section{PAULO HENRIQUE PALOTA}

Professor do Instituto Federal de Educação, Ciência e Tecnologia de São Paulo - câmpus Catanduva. Graduação em Engenharia Mecânica pelo Centro Universitário da FEI (1994) e mestrado em Engenharia Mecânica pela Universidade de São Paulo (2005). Doutorado em Engenharia de Produção em Gestão da Qualidade em Cadeias de Suprimentos na Ufscar (2017). Tem experiência na área de Engenharia Mecânica e Gestão da Qualidade em Cadeia de Suprimentos.

\section{PAULO LIPP JOÃO}

Possui graduação em Programa Especial de Formação de Docente pelo Centro Universitário Univates (1988), graduação em Engenharia Agronômica pela Universidade Federal do Rio Grande do Sul (1978) e mestrado em Citricultura pela Universitat Politècnica de València (1999). Atualmente é Coordenador da Câmara Setorial da Citricultura da Secretaria da Agricultura e Pecuária do Rio Grande do Sul e Coordenador Câmara Setorial das Oliveiras da Secretaria da Agricultura, Pecuária e Desenvolvimento Rural do Rio Grande do Sul.

\section{RAFAELA ESMORGES ASSAD}

Graduada em Administração pela UFMS Campus Pantanal, pós graduanda em MBA em Gestão Pública pela FMU. Atualmente, atua como Administradora na prefeitura do município de Ladário-MS. Interessa-se por Administração pública.

\section{RAÍSSA DE MELO MORINIGO}

Bacharel em administração pela Universidade Federal de Mato Grosso do Sul - Campus do Pantanal.

\section{REGINA FERREIRA DA ROCHA}

Doutoranda em Ciências de Informação (UNESP de Marília). Mestre em Engenharia de Produção pela Universidade Estadual Paulista Júlio de Mesquita Filho, Bauru. Tecnóloga em Processamento de Dados (UNESP - Bauru), licenciada pelo Instituto Americano de Lins da Igreja Metodista e pós-graduada em Sistemas de Informação pela Universidade Federal de São Carlos. É docente na Faculdade de Tecnologia de Garça, nos cursos de graduação em Análise e Desenvolvimento de Sistemas e em Gestão Empresarial. Focos de interesse: Sistemas de informação, redes de empresas e sociais, inovação, gestão do conhecimento e bibliometria.

\section{REGINALDO JOSÉ DA SILVA}

Mestre em produção e Gestão Agroindustrial - Centro Universitário da Grande Dourados UNIGRAN

\section{ROCK KLEIBER SILVA BRANDÃO}

Bacharel em Administração, Especialista em Gestão Financeira e Controladoria, Mestre em Administração, Professor Universitário e Consultor em Recuperação Fiscal e Tributária. 


\section{RODRIGO RIBEIRO DA COSTA}

Cursando o $6^{0}$ Ciclo de Sistemas para Internet na Faculdade de Tecnologia da Baixada Santista (FATEC RUBENS LARA). Domínio intermediário do inglês, Concluí o curso de Informática na Escola Técnica Microcamp Internacional-Santos/SP reconhecida pelo MEC com certificado de Qualificação Profissional.

\section{RODRIGO SANTOLINI SOARES}

Possui graduação em Administração pela Universidade Federal de Mato Grosso do Sul (2013) e mestrado em Programa de Pós-Graduação em Desenvolvimento Rural Sustentável pela Universidade Estadual do Oeste do Paraná (2017). Especialista em Docência para Educação Profissional e Tecnológica (2018), atuando principalmente nos seguintes temas: inovação e Tecnologia, Meio Ambiente e Desenvolvimento sustentável, Empreendedorismo, Gestão de Projetos, Marketing, Metodologias ativas de Ensino e Aprendizagem, Currículo. Além de conhecimento na área empresarial, em logística, vendas e gerenciamento.

\section{RONI BLUME}

Possui graduação em: Bacharelado em Geografia pela Universidade Federal do Rio Grande do Sul (2000) e Licenciatura em Geografia pela Universidade Federal do Rio Grande do Sul (2003); Mestrado em Desenvolvimento Rural pela Universidade Federal do Rio Grande do Sul (2004); e Doutorado em Agronegócios pela Universidade Federal do Rio Grande do Sul (2008). É Professor Associado da Universidade Federal de Santa Maria, do Colégio Politécnico da UFSM. Vice-Coordenador do Curso Superior Tecnológico em Gestão Ambiental. Atua em ensino, pesquisa e extensão principalmente nos seguintes temas: empreendedorismo e empreendedorismo social, gestão ambiental empresarial, gestão intraempreendedora em organizações cooperativas.

\section{ROOSILEY DOS SANTOS SOUZA}

Doutora em Administração pela Universidade Nove de Julho, com período de estágio doutoral na Universidade de Lisboa - Instituto de Economia e Gestão - Lisbon School of Economics and Management (ISEG), Professora Adjunta na Universidade Federal de Mato Grosso do Sul/ Campus do Pantanal. Professora permanente do Programa de Pósgraduação Mestrado Profissional em Administração Pública (PROFIAP) da Escola de Negócios - ESAN/UFMS.

\section{ROSANE APARECIDA MOREIRA}

Licenciatura Plena em Pedagogia, Bacharel em Administração, Mestre em Administração, Professora Universitária.

\section{ROSANGELA SARMENTO SILVA}

Doutora em Administração pela Universidade Municipal de São Caetano do Sul -USCS e Mestre em Administração -USCS, linha de pesquisa Redes Organizacionais e Inovação, graduada em Administração de Empresas pela Faculdade Atual da Amazônia, especialista em Recursos Humanos pela FACINTER - Faculdade Internacional de Curitiba. Professora Dra no Instituto de Ciências Sociais Aplicadas da Universidade Federal do Sul e Sudeste do Pará-UNIFESSPA. Foi professora da Faculdade Metropolitas Unidas -FMU, Anhaguera Educacional, Senac Vila Prudente-SP e Universidade Estadual de Roraima - UERR. 


\section{ROSE KELLY I. S'TOS DA C. MELICIO}

Mestranda em Engenharia da Produção - UNIP/SP. Programa Especial de Formação Pedagógica de Docentes para Educação Profissional de Nível Médio - FATEC/SP. MBAComércio Exterior/ Perícia Aduaneira - UNIP/SANTOS. Bacharel em Administração de Empresa-UNISANTOS.

\section{SILVANA RIBEIRO COBÉ}

Carreira com desenvolvimento ascendente na área de Produtividade e Qualidade, desenvolvimento organizacional, prestação de serviços com foco nos resultados e na melhoria contínua. Experiência na implementação da norma NBR ISO 9001:2008 e nova versão 2015, com amplo conhecimento das ferramentas de gestão. Líder em projetos empresariais e acadêmicos com resultados concretos. Graduada em Engenharia Química pela Universidade Federal Rural do Rio de Janeiro.

\section{SOLANGE FACHIN}

Doutora em Administração/UNINOVE, Mestre em Administração/FURB, Graduada em Administração e Serviço Social pela Universidade Estadual do Oeste do Paraná. Especialista em Empreendedorismo e Gestão de Pessoas. Professora da Universidade Federal do Mato Grosso do Sul, Campus de Nova Andradina. Atua nas áreas de: Inovação, Empreendedorismo, Gestão de Pessoas, e Pesquisa Operacional.

\section{SOUROU GAUTIER GOUSSI}

Possui Graduação em Ciências Econômicas pela Universidade Federal Pernambuco. Mestrando em Administração e Desenvolvimento Rural pela Universidade Rural de Pernambuco. Tem experiência na área de Economia e Administração, com ênfase em Economia Internacional, Economia Agrícola, Comercio exterior, Estratégia Empresarial, interesse na área de estatística

\section{SUZIMARY SPECHT}

Possui graduação em Licenciatura em Geografia pela Universidade do Vale do Rio dos Sinos (1997), especialização em Educação Ambiental pelo Centro Universitário La Salle (1999), mestrado em Geografia pela Universidade Federal do Rio Grande do Sul (2001) e doutorado em Desenvolvimento Rural pela Universidade Federal do Rio Grande do Sul (2009). É Professora Adjunta, no Curso Superior de Tecnologia em Gestão Ambiental, da Universidade Federal de Santa Maria / Colégio Politécnico. Atua em ensino, pesquisa e extensão, na área das Ciências Ambientais, nas linhas de Educação Ambiental, Sistemas de Gestão Ambiental (ênfase em SGA na agropecuária) e Consumo Consciente.

\section{TATIELLE BELEM LANGBECKER}

Possui graduação em Tecnologia em Agronegócio pela Universidade Federal do Pampa Campus Dom Pedrito, mestrado em Desenvolvimento Rural pela Universidade Federal do Rio Grande do Sul. Atualmente é doutoranda, bolsista CAPES, pelo Programa de PósGraduação em Extensão Rural pela Universidade Federal de Santa Maria na linha de pesquisa Dinâmicas Econômicas e Organizacionais na Agricultura. 


\section{THAIS ARRUÉ MELO GONCALVES}

Possui graduação em Tecnologia em Agronegócio pela Universidade Federal do Pampa Campus Dom Pedrito, mestrado em Extensão Rural pela Universidade Federal de Santa Maria na linha de pesquisa Dinâmicas Econômicas e Organizacionais na Agricultura.

\section{THAÍS NOGUEIRA DA SILVA}

Graduação: Tecnologia em Gestão Financeira. UFMS - Universidade Federal de Mato Grosso do Sul, 2016. Profissão: Funcionária Pública Municipal

\section{VALDIR DA COSTA PEREIRA}

Graduado em Administração pelo Centro Universitário da Grande Dourados - UNIGRAN, Mestre em Produção e Gestão Agroindustrial. Coordenador e professor do Curso de Administração, docente na pós-graduação e no Ensino à distância da UNIGRAN. Conselheiro efetivo do conselho Regional de Administração de Mato Grosso do Sul CRA/MS (2019-2022). Possui mais de 10 anos de experiência em Gestão de empresas. Avaliador no banco de avaliadores do INEP/MEC.

\section{VANINA CARRARA SIGRIST}

Professora de Ensino Superior Nível III C na Faculdade de Tecnologia da Baixada Santista, membro da Comissão de Iniciação Científica nessa instituição, Doutora em Teoria e História Literária pela Unicamp.

\section{WANDO BELFFI DA COSTA}

Mestre em Ciências Contábeis pela UFES e Professor da Faculdade DOCTUM (unidade Guarapari).

\section{WILLER RODRIGUES DA COSTA}

Graduação: Tecnologia em Gestão Financeira. UFMS Universidade Federal de Mato Grosso do Sul 2016. Profissão: Líder de Manutenção Automotiva. 


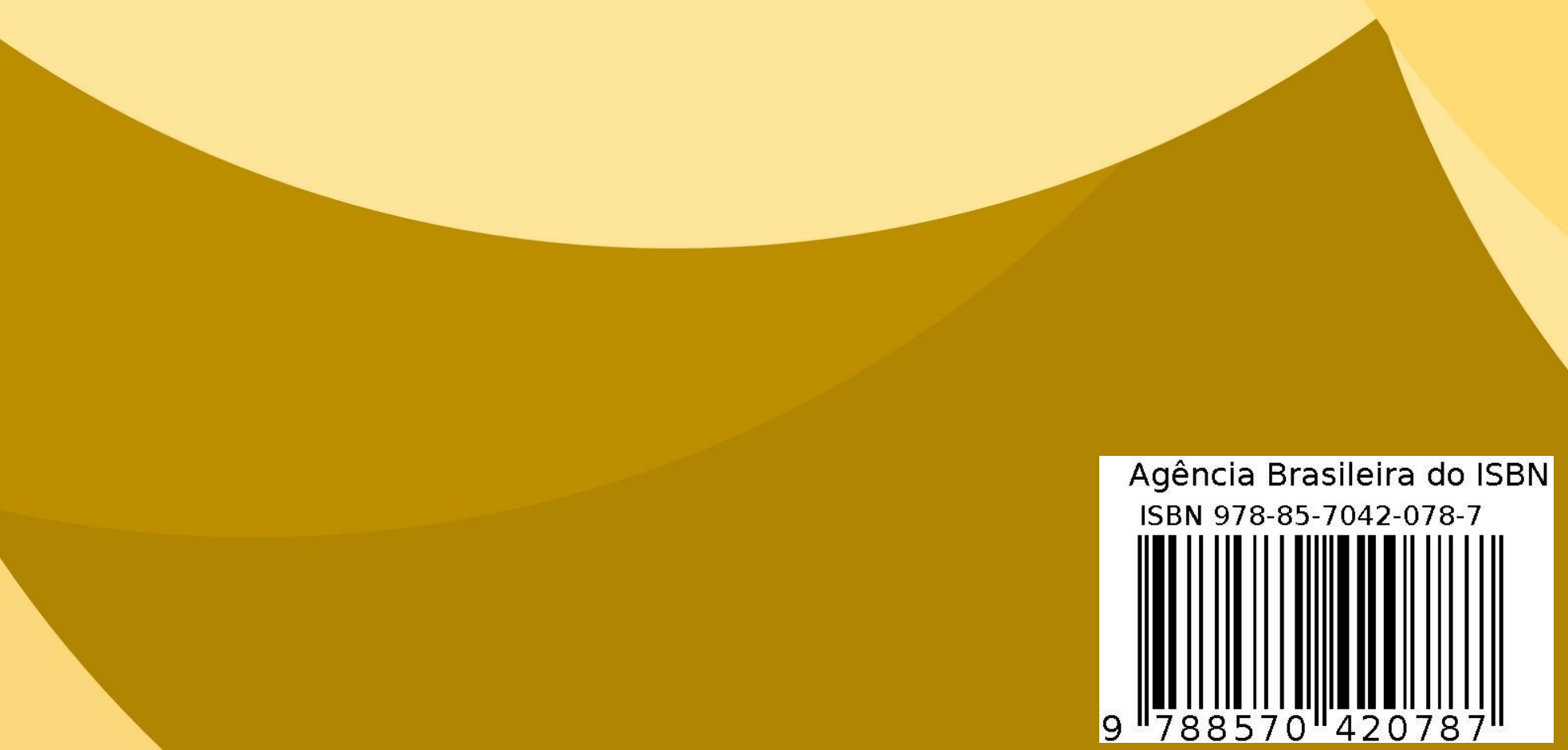

